LXXXIII Zjazd Naukowy

Polskiego Towarzystwa Zootechnicznego

Wyzwania zootechniki

w warunkach rolnictwa zrównoważonego

Streszczenia 


\section{Patronat}

Wiceprezes Rady Ministrów, Minister Nauki i Szkolnictwa Wyższego

Minister Rolnictwa i Rozwoju Wsi

Minister Środowiska

Dyrektor Generalny Krajowego Ośrodka Wsparcia Rolnictwa

Wojewoda Lubelski

Marszałek Województwa Lubelskiego

Prezydent Miasta Lublin

Rektor Uniwersytetu Przyrodniczego w Lublinie

Roztoczański Park Narodowy

Poleski Park Narodowy

Polska Federacja Hodowców Bydła i Producentów Mleka

Polski Związek Hodowców Koni

Polski Związek Hodowców Zwierząt Futerkowych

Polski Związek Hodowców i Producentów Bydła Mięsnego

Polski Związek Owczarski

Polski Związek Hodowców i Producentów Trzody Chlewnej POLSUS

Związek Hodowców Psów Rasowych

Polski Związek Felinologiczny 
Uniwersytet Przyrodniczy w Lublinie

Wydział Biologii, Nauk o Zwierzętach i Biogospodarki

\author{
LXXXIII Zjazd Naukowy \\ Polskiego Towarzystwa Zootechnicznego
}

\title{
Wyzwania zootechniki \\ w warunkach rolnictwa zrównoważonego
}

Streszczenia

Konferencja Międzynarodowa

Lublin, 19-21 września 2018 r. 
Opracowanie redakcyjne

Zespół

Redakcja merytoryczna

Marek Babicz

(C) Copyright by Polskie Towarzystwo Zootechniczne im. Michała Oczapowskiego - Koło w Lublinie, Lublin 2018

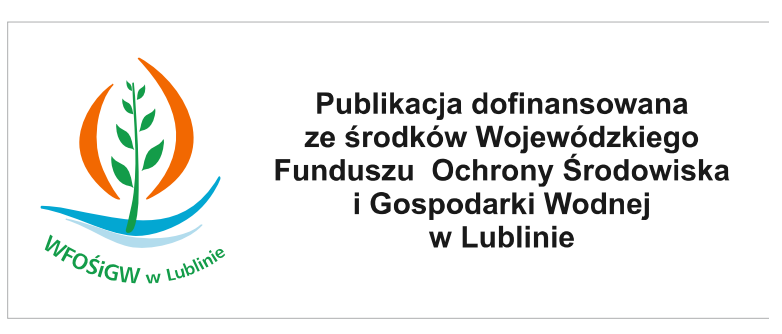

ISBN 978-83-7259-279-8 on-line

DOI: $10.24326 /$ ptz.2018.1

WYDAWNICTWO UNIWERSYTETU PRZYRODNICZEGO W LUBLINIE

ul. Akademicka 15, 20-950 Lublin, http://wydawnictwo.up.lublin.pl/

Nr zam. 252/201 


\section{KOMITET NAUKOWY}

Prof. dr hab. Piotr Guliński - Sekcja Chowu i Hodowli Bydła Prof. dr hab. Anna Rekiel - Sekcja Chowu i Hodowli Trzody Chlewnej

Prof. dr hab. Anna Wójcik - Sekcja Chowu i Hodowli Drobiu

Prof. dr hab. Tomasz Gruszecki - Sekcja Chowu i Hodowli Owiec i Kóz Dr hab. prof. nadzw. UP Iwona Janczarek- Sekcja Chowu i Hodowli Koni

Prof. dr hab. Grażyna Jeżewska-Witkowska - Sekcja Chowu i Hodowli Zwierząt Futerkowych

Prof. dr hab. Leszek Drozd - Sekcja Chowu i Hodowli Zwierząt Towarzyszących i Dzikich

Dr hab. Henryk Malec - Sekcja Praktyki Hodowlanej

\section{KOMITET ORGANIZACYJNY}

Dr hab. prof. nadzw. UP Iwona Janczarek - przewodnicząca

Dr hab. prof. nadzw. UP Jolanta Król - wiceprzewodnicząca Dr hab. prof. nadzw. UP Marek Babicz - sekretarz ds. finansowych Dr inż. Wioletta Sawicka-Zugaj - sekretarz ds. organizacyjnych

Dr inż. Krzysztof Patkowski - sekretarz ds. wydawnictwa Dr inż. Piotr Stanek - sekretarz ds. promocji

\section{Członkowie}

Dr hab. Witold Chabuz - opiekun Sekcji Chowu i Hodowli Bydła Dr hab. Anna Kasprzyk - opiekun Sekcji Chowu i Hodowli Trzody Chlewnej

Dr hab. Justyna Batkowska - opiekun Sekcji Chowu i Hodowli Drobiu Dr inż. Monika Greguła-Kania - opiekun Sekcji Chowu i Hodowli Owiec i Kóz

Dr inż. Izabela Wilk - opiekun Sekcji Chowu i Hodowli Koni

Dr hab. Andrzej Jakubczak - opiekun Sekcji Chowu i Hodowli Zwierząt Futerkowych

Dr hab. Mirosław Karpiński - opiekun Sekcji Chowu i Hodowli Zwierząt

Towarzyszących i Dzikich

Dr hab. Ewa Januś - opiekun Sekcji Praktyki Hodowlanej

Dr hab. prof. nadzw. UP Anna Chmielowiec-Korzeniowska opiekun Sesji Młodych Naukowców 


\title{
Spis treści
}

\author{
Sesja plenarna
}

TRENDY W PRODUKCJI ŻYWNOŚCI.

MAŁE PRZEŻUWACZE W ŚRODOWISKU PRZYRODNICZYM I W KULTURZE

Tomasz M. Gruszecki, Andrzej Junkuszew

EKOLOGIA WYZWANIEM POLSKIEJ WSI NOWEGO TYSIĄCLECIA

Jacek Janiszewski

WYPAS KONIKÓW POLSKICH NA TERENACH CENNYCH PRZYRODNICZO - KSZTAŁTOWANIE KRAJOBRAZU

I ZACHOWANIE BIORÓŻNORODNOŚCI

Zbigniew Jaworski, Aleksandra Górecka-Bruzda, Ewa Jastrzębska

CYWILIZACYJNE PROBLEMY ZWIERZĄT.

Tadeusz Kaleta

OCHRONA ZASOBÓW GENETYCZNYCH ZWIERZĄT GOSPODARSKICH W WARUNKACH ZRÓWNOWAŻONEGO ROLNICTWA ..... 7 Jędrzej Krupiński, Grażyna Maria Polak

PROBLEM UTYLIZACJI ODPADÓW I ELIMINACJI ZAGROŻEŃ W PRODUKCJI ZWIERZĘCEJ 


\section{Sekcja Chowu i Hodowli Bydła}

PORÓWNANIE EFEKTÓW ODCHOWU CIELATT UTRZYMYWANYCH W SYSTEMIE TRADYCYJNYM I KOMBINOWANYM....

Urszula Borowska, Marta Wysocka, Adrian Założyk, Małgorzata Szewczuk

PRZEWODNOŚĆ ELEKTRYCZNA MLEKA A WYDAJNOŚĆ DOBOWA ĆWIARTEK GRUCZOŁU MLECZNEGO KRÓW DOJONYCH AUTOMATYCZNIE.

Mariusz Bogucki

ZAWARTOŚĆ WITAMIN LIPOFILNYCH W MLEKU POZYSKANYM OD KRÓW RASY POLSKIEJ CZERWONEJ I SERACH

WYTWORZONYCH NA JEGO BAZIE. Aneta Brodziak, Jolanta Król ${ }^{2}$, Joanna Barłowska ${ }^{2}$, Barbara Topyła ${ }^{2}$, Anna Wolanciuk ${ }^{2}$

WPŁYW SPOSOBU UŻYTKOWANIA GÓRSKICH TRWAŁYCH UŻYTKÓW ZIELONYCH NA RÓŻNORODNOŚĆ FLORYSTYCZNĄ SIEDLISK I DOBROSTAN ZWIERZATT.

Witold Chabuz, Mariusz Kulik, Wioletta Sawicka-Zugaj, Paweł Żółkiewski, Marianna Warda, Michał Pluta, Antoni Lipiec, Andrzej Bochniak

BRAKOWANIE I DŁUGOWIECZNOŚĆ KRÓW MLECZNYCH W POLSCE.. Rachela Formella, Marta Kaliciak, Maciej Adamski

PRÓBA OPRACOWANIA POPRAWEK NA WYDAJNOŚĆ MLEKA DLA PODSTAWOWEGO SKŁADU CHEMICZNEGO MLEKA KRÓW RASY POLSKIEJ HOLSZTYŃSKO-FRYZYJSKIEJ Piotr Guliński, Ewa Salamończyk, Anna Kłopotowska

WPŁYW DAWKI WZBOGACONEJ W RÓŻNE ŹRÓDŁA B-KAROTENU NA WYNIKI PRODUKCYJNE KRÓW, WYNIKI ROZRODU ORAZ WYBRANE WSKAŹNIKI ZDROWIA.

Gabriela Halik, Andrzej Lozicki, Mateusz Makarski

KORELACJE GENETYCZNE MIEDZY PRZEBIEGIEM PORODÓW A CECHAMI PRODUKCYJNYMI I POKROJU BYDEA RASY POLSKIEJ HOLSZTYŃSKO-FRYZYJSKIEJ..... Magdalena Jakiel

ZWIĄZEK POMIĘDZY DŁUGOŚCIĄ OKRESU ZASUSZENIA A WYBRANYMI CECHAMI UŻYTKOWOŚCI MLECZNEJ KRÓW SIMENTALSKICH

Ewa Januś, Piotr Stanek, Paweł Żółkiewski, Krystian Rokosz

GENETYCZNA ANALIZA CECH POKROJU NÓG I RACIC BYDŁA SIMENTALSKIEGO W POLSCE Olga Jarnecka, Wojciech Jagusiak

EFEKTYWNOŚĆ ŻYWIENIA KRÓW MLECZNYCH W WYBRANYCH GOSPODARSTWACH INDYWIDUALNYCH ŚRODKOWO-WSCHODNIEJ POLSKI Renata Klebaniuk, Bożena Kiczorowska, Edyta Kowalczuk-Vasilev, Wioleta Samolińska, Maciej Bąkowski, Eugeniusz R. Grela, Anna Danek-Majewska, Małgorzata Kwiecień, Anna Winiarska-Mieczan, Magdalena Olcha, Robert Krusiński, Antoni Lipiec, Bogdan Szostak, Justyna Widz, Stanisław Pecka

DEPENDENCE OF THE LONGEVITY OF COWS UKRAINIAN BROWN DAIRY BREED FROM ESTIMATION OF LINEAR TRAITS OF CONFORMATION TYPE.

Volodymyr Ladyka, Leontyi Hmelnychyi, Serhii Hmelnychyi

HISTORICAL ASPECTS OF THE CREATION, DEVELOPMENT AND PRESERVATION OF LEBEDINSKA BREED AT THE PRESENT STAGE. Volodymyr Ladyka, Leontyi Hmelnychyi, Yuliya Pavlenko, Yuri Skliarenko

AKWAPORYNY (AQPS) W NERKACH BYDŁA Katarzyna Michałek, Marta Grabowska

ZMIANY W SKŁADZIE I JAKOŚCI MLEKA POZYSKANEGO W DWÓCH SYSTEMACH UTRZYMANIA KRÓW...

Jan Miciński, Janina Pogorzelska, Kinga Grabowska

ANALIZA ZAWARTOŚCI WYBRANYCH PIERWIASTKÓW W KULINARNEJ WOŁOWINIE POCHODZACEJ Z ZAKŁADÓW MIĘSNYCH ,ŁUNIEWSCY”. Grażyna Niedziałek, Ewa Salamończyk, Marzena Redosz 
WPŁYW STOSOWANIA KISZONKI ZE ŚLAZOWCA PENSYLWAŃSKIEGO NA ZAWARTOŚĆ SKŁADNIKÓW MINERALNYCH W WOEOWINIE

Zenon Nogalski, Cezary Purwin, Martyna Momot, Monika Sobczuk-Szul

ZNACZENIE ZIÓł W ŻYWIENIU BYDłA

Aleksandra Paskudska, Dorota Kołodziejczyk, Stanisław Socha

ZMIENNOŚĆ PROCESÓW MIKROBIOLOGICZNYCH ZACHODZACYCH W PRZEDŻOŁADKACH POD WPŁYWEM RÓŻNYCH

Ewa Pecka-Kiełb, Klaudia Fuks, Andrzej Zachwieja, Dorota Miśta, Bożena Króliczewska, Maja Słupczyńska, Barbara Król, Edyta Wojtas

DYNAMIKA PROCESÓW FIZJOLOGICZNYCH W ŻWACZU KRÓW W ZALEŻNOŚCI OD CZASU FERMENTACJI MIKROBIOLOGICZNEJ - BADANIA IN VITRO.

Ewa Pecka-Kiełb, Karolina Dyk, Andrzej Zachwieja, Dorota Miśta, Bożena Króliczewska, Maja Słupczyńska, Barbara Król, Edyta Wojtas

BADANIA POPULACYJNE NA PODSTAWIE MARKERÓW STR W KONTROLI RODOWODÓW BYDŁA Anna Radko, Dominika Rubiś, Agnieszka Szumiec, Grzegorz Smołucha, Anna Koseniuk, Angelika Podbielska

ANALIZA DYNAMIKI LAKTACJI ORAZ JAKOŚCI MLEKA KRÓW Małgorzata Roszak, Marzena Kęsek, Ewa Pecka-Kiełb, Edyta Wojtas, Andrzej Zachwieja, Anna Zielak-Steciwko

PROBLEM INBREDU I SPOKREWNIENIA W POPULACJI BYDŁA RASY CHAROLAISE OBJĘTEJ OCENĄ WARTOŚCI

UŻYTKOWEJ W POLSCE

Jolanta Różańska-Zawieja, Joanna Kania-Gierdziewicz, Maciej Gierdziewicz, Zbigniew Sobek, Anna Nienartowicz-Zdrojewska, I. Wenda

ANALIZA UDZIAŁU ZAŁOŻYCIELI I PRZODKÓW W POPULACJI BYDŁA RASY CHAROLAISE OBJĘTEJ OCENĄ WARTOŚCI

UŻYTKOWEJ W POLSCE

Jolanta Różańska-Zawieja, Joanna Kania-Gierdziewicz, Maciej Gierdziewicz Zbigniew Sobek, Anna Nienartowicz-Zdrojewska, I. Wenda

OCENA STOSUNKU TŁUSZCZOWO-BIAŁKOWEGO W MLEKU KRÓW RASY POLSKIEJ HOLSZTYŃSKO-FRYZYJSKIEJ.... Ewa Salamończyk, Piotr Guliński, Ewelina Bierkat

WPŁYW WIEKU I WYCIELENIA NA DŁUGOŚĆ LAKTACJI I WYDAJNOSĆ MLEKA KRÓW Ewa Salamończyk, Piotr Guliński, Grażyna Niedziałek

ZMIANY W STRUKTURZE GENETYCZNEJ BYDŁA BIAŁOGRZBIETEGO PO 15 LATACH HODOWLI. Wioletta Sawicka-Zugaj, Witold M. Chabuz, Karolina Kasprzak-Filipek, Zygmunt A. Litwińczuk

ZMIANY CECH UŻYTKOWOŚCI MLECZNEJ KRÓW RASY PHF BEDACCYCH W RÓŻNYCH LAKTACJACH..... Piotr Stanek, Ewa Januś, Paweł Żółkiewski, Karol Jadczak

KORELACJE GENETYCZNE I FENOTYPOWE POMIEDZY CECHAMI ZDOLNOŚCI UDOJOWEJ A LICZBA KOMÓREK

SOMATYCZNYCH W MLEKU I CECHAMI PŁODNOŚCI Bartosz Szymik, Piotr Topolski, Wojciech Jagusiak

ODZIEDZICZALNOŚĆ CECH PRODUKCYJNYCH W OBJĘTEJ PROGRAMEM OCHRONY ZASOBÓW GENETYCZNYCH POPULACJI KRÓW RASY POLSKIEJ CZERWONO-BIAŁEJ Piotr Topolski, Bartosz Szymik

THE LIFESPAN OF UKRAINIAN BLACK-AND-WHITE AND RED-AND-WHITE DAIRY BREEDS, DEPENDING ON THE ASSESSMENT OF UDDER LINEAR TRAITS Viktoriia Vechorka

ROBOTYZACJA DOJU KRÓW W WIELKOPOLSCE Stanisław Winnicki, Zbigniew Sobek, Jolanta Różańska-Zawieja'

KORELACJE MIEDZY ZAWARTOŚCIĄ SKłADNIKÓW SUCHEJ MASY A PARAMETRAMI KRZEPLIWOŚCI MLEKA 47 Anna Wolanciuk, Joanna Barłowska, Jolanta Król, Monika Kędzierska-Matysek, Aneta Brodziak, Barbara Topyła, Patrycja Dopieralska

ZAWARTOŚĆ IMMUNOGLOBULIN W SUROWICY CIELĄT W ZALEŻNOŚCI OD SPOSOBU POJENIA SIARĄ 48 Andrzej Zachwieja, Szymon Kopalak, Ewa Pecka, Edyta Wojtas, Anna Zielak-Steciwko 


\section{Sekcja Chowu i Hodowli Drobiu}

ANALIZA CECH MORFOLOGICZNYCH JAJ I WSKAŹNIKÓW LĘGU WYBRANYCH RAS KUR OZDOBNYCH..............................50 Dorota Banaszewska, Barbara Biesiada-Drzazga, Dominik Ostrowski, Małgorzata Długołęcka, Aleksandra Smarzewska

MORFOMETRIA KRĘGÓW SZYJNYCH EMU Z ZASTOSOWANIEM METODY HYDROSTATYCZNEJ ............................................. 52 Piotr Baranowski, Jerzy Nowacki, Sławomir Krajewski, Piotr Nowak

Zachowania zakupowe i wiedza konsumentów jaj na rynku Lubelszczyzny..... Justyna Batkowska, Kamil Drabik, Antoni Brodacki, Magdalena Panfil

Wyniki produkcyjne i jakość mięsa perlic typu mięsnego 54 Justyna Batkowska, Kamil Drabik, Ahsan Umair ${ }^{4}$, Małgorzata Karwowska, Anna Kabacińska, Patrycja Chabroszewska

CHARAKTERYSTYKA GOSPODARSTW EKOLOGICZNYCH ZAJMUJACYCH SIE PRODUKCJA JAJ KONSUMPCYJNYCH NA TERENIE WOJEWÓDZTWA MAZOWIECKIEGO Elżbieta Bombik, Gabriel Maliszewski, Katarzyna Pietrzkiewicz, Emilia Wierzbicka, Anna Korzeniewska

RASY/RODY KUR NIEŚNYCH OBJĘTE PROGRAMEM OCHRONY ZASOBÓW GENETYCZNYCH ZWIERZĄT UTRZYMYWANE W INSTYTUCIE ZOOTECHNIKI - Państwowym Instytucie Badawczym Jolanta Calik

PRODUKCJA KAPŁONÓW W OPARCIU O RODZIME RASY KUR Jolanta Calik, Joanna Obrzut

EFEKTYWNOŚĆ STOSOWANIA PRODUKTÓW SOJOWYCH W ŻYWIENIU KURCZAT BROJLERÓW Alina Janocha, Daria Pietrusiak, Anna Milczarek, Kamil Laski

WPŁYW DODATKU DO ŚCIÓŁKI NADTLENKU WAPNIA $\left(\mathrm{CaO}_{2}\right)$ NA WARUNKI MIKROKLIMATYCZNE W BUDYNKACH DLA KURCZATT BROJLERÓW Tomasz Mituniewicz, Joanna Piotrowska, Sara Dzik, Anna Wójcik

MOŻLIWOŚCI WYKORZYSTANIA KUR RODZIMEJ RASY ŻÓŁTONÓŻKA KUROPATWIANA (Ż-33) DO PRODUKCJI PULARD... 61 Joanna Obrzut, Józefa Krawczyk

JAKOŚĆ TOKSYKOLOGICZNA PODROBÓW KURCZAT

Janusz Franciszek Pomianowski, Anna Wójcik, Tomasz Żmijewski

MEAT PRODUCTIVITY OF DUCKS OF THE NATIVE GENE POOL AND INTER-SPECIFIC HYBRIDS (MULARDS) 63 Maryna Shkurko

ZAWARTOŚĆ W JAJACH WYBRANYCH CZYNNIKÓW REGULUJĄCYCH EKSPRESJĘ GENÓW Edyta Szymanek, Kamil Drabik, Katarzyna Andraszek, Dorota Banaszewska

Wpływ rodzaju światła na produkcyjność kurcząt brojlerów Anna Wolska, Sara Dzik, Tomasz Mituniewicz, Marcin Jankowski

WPŁYW FITOBIOTYKÓW NA ŁAGODZENIE STRESU TRANSPORTOWEGO U INDORÓW RZEŹNYCH W OKRESIE ZIMY ......... 66 Anna Wójcik, Tomasz Mituniewicz, Janina Sowińska, Dorota Witkowska, Janusz Franciszek Pomianowski 


\section{Sekcja Chowu i Hodowli Zwierząt Futerkowych}

ZMIENNOŚĆ KSZTAŁTU CZASZKI SZYNSZYLI MAŁEJ. KĄTY CZASZKI

Piotr Baranowski, Magdalena Wróblewska, Katarzyna Pęzińska-Kijak

ZMIENNOŚĆ KSZTAŁTU CZASZKI SZYNSZYLI MAŁEJ. WZGLEDNA SZYBKOŚĆ WZROSTU WYBRANYCH OBSZARÓW CZASZKI

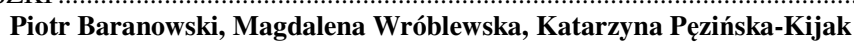

KRAJOWA HODOWLA NUTRII OBJĘTYCH PROGRAMEM OCHRONY ZASOBÓW GENETYCZNYCH (2017) Paweł Bielański

KRAJOWA HODOWLA SZYNSZYLI BEŻOWEJ OBJĘTEJ PROGRAMEM OCHRONY ZASOBÓW GENETYCZNYCH (2017) ............ 71 Paweł Bielański

WPŁYW IMMUNOMODULATORA NA WYNIKI UŻYTKOWANIA KRÓLIKÓW RZEŹNYCH.

Marian Brzozowski

KONDYCJA SAMIC NORKI HODOWLANEJ (NEOVISON VISON) A WYNIKI ICH ROZRODU I ZACHOWANIE W OKRESIE

CIAZŻY I LAKTACJI Lidia Felska-Błaszczyk, Natalia Lawrów, Beata Seremak, Małgorzata Dziadosz-Styś, Olga Rząsik

ANALIZA RODOWODOWA POPULACJI LISA POSPOLITEGO (VULPES VULPES) Patrycja Grzybek, Piotr Przysiecki, Andrzej Filistowicz, Jan Dobrzański, Tomasz Szwaczkowski

WPŁYW DODATKU ALTERNATYWNYCH ŹRÓDEŁ BIAŁKA ZWIERZĘCEGO DO DIETY NA STRAWNOŚĆ SKŁADNIKÓW POKARMOWYCH U SZYNSZYLI.... Andrzej Gugołek, Janusz Strychalski, Małgorzata Konstantynowicz, Barbara Jędrzycka

MOŻLIWOŚĆ ZASTOSOWANIA MARKERÓW GENETYCZNYCH W OCENIE TEMPERAMENTU LISÓW POSPOLITYCH Beata Horecka, Grażyna Jeżewska-Witkowska

WYKORZYSTANIE TECHNIK MOLEKULARNYCH W USTALANIU OJCOSTWA NOREK HODOWLANYCH (NEOVISON VISON)...... 77 Andrzej Jakubczak, Marek Kowalczyk, Beata Horecka, Grażyna Jeżewska-Witkowska

WSTEPNE BADANIA NAD MOŻLIWOŚCIĄ WYKORZYSTANIA SUSZONYCH LARW OWADÓW W ŻYWIENIU KRÓLIKÓW....... 78 Dorota Kowalska, Andrzej Gugołek

KRÓLIKI POPIELNIAŃSKIE BIAŁE - STAN HODOWLI W POLSCE Dorota Kowalska

WPŁYW CYTOCHALAZYNY B NA KOMÓRKI SOMATYCZNE KOTA DOMOWEGO FELIS CATUS Marta Kuchta-Gładysz, Olga Szeleszczuk, Przemysław Baran, Anna Grzesiakowska

SEZONOWOŚĆ ROZRODU SZYNSZYLI (CHINCHILLA LANIGERA) NA FERMIE ZLOKALIZOWANEJ W WIELKOPOLSCE.............. 82 Agnieszka Ludwiczak, Lukasz Sikora, Marek Stanisz

Zastosowanie paszy z dodatkiem L-tyrozyny i L-fenyloalaniny w żywieniu szynszyli. Stanisław Lapiński, Sylwia Pałka, Weronika Pudło, Lukasz Migdał, Piotr Niedbała

POZIOM GLUKOZY WE KRWI U CIEŻ̇ARYCH ORAZ JAŁOWYCH SAMIC NORKI HODOWLANEJ (NEOVISON VISON). 84 Natalia Lawrów, Lidia Felska-Błaszczyk

RELATYWNA MASA SERCA LISA POSPOLITEGO (Vulpes vulpes). Maria Nabzdyk, Hieronim Frąckowiak, Marcin Komosa

WSTEPNE OKREŚLENIE WPŁYWU MELATONINY NA PROFIL KWASÓW TŁUSZCZOWYCH W TKANCE TŁUSZCZOWEJ JENOTÓW HODOWLANYCH Piotr Niedbała, Andrzej Zoń, Dorota Maj, Stanisław Lapiński, Olga Szeleszczuk, Marta Kuchta-Gładysz

WSTĘPNE OKREŚLENIE PROFILU KWASÓW TŁUSZCZOWYCH W TKANCE TŁUSZCZOWEJ MIĘSOŻERNYCH ZWIERZĄT FUTERKOWYCH Z RODZINY ŁASICOWATYCH Piotr Niedbała, Andrzej Zoń, Dorota Maj, Stanisław Lapiński, Olga Szeleszczuk, Marta Kuchta-Gładysz

PARAMETRY GENETYCZNE CECH JAKOŚCI MIESA KRÓLIKÓW TERMONDZKICH BIAŁYCH.... 
ANALIZA PRACY HODOWLANEJ W FERMIE REPRODUKCYJNEJ SZYNSZYLI

Aleksandra Paskudska, Dorota Kołodziejczyk, Dorota Weremczuk, Stanisław Socha

ASYMETRIA WYBRANYCH CECH BILATERALNYCH SZKIELETU GŁOWY SZYNSZYLI MAŁEJ Z MIOTÓW

POJEDYNCZYCH I MNOGICH

Katarzyna Pęzińska-Kijak, Piotr Baranowski

WSPÓŁZALEŻNOŚĆ POMIEDZY WYBRANYMI CECHAMI METRYCZNYMI SZKIELETU GŁOWY ORAZ ELEMENTAMI

KOŃCZYNY PIERSIOWEJ I KOŃCZYNY MIEDNICZNEJ A PŁCIĄ I WIELKOŚCIĄ MIOTU SZYNSZYLI MAŁEJ.....

Katarzyna Pęzińska-Kijak, Piotr Baranowski

IDENTYFIKACJA MIKROSKOPOWA GRZYBÓW W TREŚCI ŻOłĄDKA I JELIT NOREK

Małgorzata Piórkowska

ŚRODOWISKO A JAKOŚĆ OKRYWY WŁOSOWEJ SKÓR JENOCICH

Małgorzata Piórkowska

KRAJOWA HODOWLA LISÓW POSPOLITYCH BIAŁOSZYJNYCH OBJĘTYCH PROGRAMEM OCHRONY ZASOBÓW

GENETYCZNTCH Małgorzata Piórkowska, Andrzej Zoń

ZALEŻNOŚCI POMIĘDZY ZASTOSOWANYM SYSTEMEM KRYĆ A UZYSKIWANYMI PARAMETRAMI ROZRODCZYMI SAMIC NOREK AMERYKANSKICH Beata Seremak, Marta Dworecka, Lidia Felska-Błaszczyk, Aleksandra Wojciechowska

WSKAŹNIKI ROZRODU SAMIC SZYNSZYLI (CHINCHILLA LANIGERA) NA WYBRANEJ FERMIE Lukasz Sikora, Agnieszka Ludwiczak, Marek Stanisz

OCENA PODSTAWOWYCH CECH JAKOŚCI MIĘSA KRÓLIKÓW POCHODZĄCYCH Z KRZYŻOWANIA HYBRYD KRÓLICZYCH Joanna Składanowska-Baryza

WARTOŚĆ RZEŹNA KRÓLIKÓW POCHODZACYCH Z KRZYŻOWANIA HYBRYD MARTINI I HYLA Marek Stanisz, Agnieszka Ludwiczak, Joanna Składanowska-Baryza, Marta Bykowska, Lukasz Sikora, Klaudia Robakowska

ZAWARTOŚĆ KSANTOFILI, BETA-KAROTENU, RETINOLU I ALFA-TOKOFEROLU W TKANCE TŁUSZCZOWEJ I MLEKU SAMIC KRÓLIKÓW Janusz Strychalski, Andrzej Gugołek, Zofia Antoszkiewicz, Paweł Brym

ZAWARTOŚĆ TŁUSZCZU I KWASÓW TŁUSZCZOWYCH W MLEKU SAMIC JENOTA FINNRACCOON W OKRESIE LAKTACJI Olga Szeleszczuk, Paulina Kilar, Dorota Maj, Piotr Niedbała

ANALIZA HODOWLANA CECH POKROJU U KRÓLIKÓW W FERMIE REPRODUKCYJNEJ Dorota Weremczuk, Dorota Kołodziejczyk, Lukasz Baran, Leszek Gacek, Aleksandra Paskudska, Stanisław Socha

TENDENCJE W HODOWLI SZYNSZYLI W POLSCE Jacek Zawiślak 


\section{Sekcja Chowu i Hodowli Koni}

CHARAKTERYSTYKA KONI PODDAWANYCH UBOJOWI

Romana Augustyn, Szymon Adamek, Bogusława Długosz, Magdalena Pieszka, Jarosław Luszczyński, Zenon Podstawski, Monika Stefaniuk-Szmukier

REALIZACJA PAKIETU 7. ZACHOWANIE LOKALNYCH RAS KONI Agnieszka Chełmińska, Iwona Tomczyk-Wrona

DZIAŁALNOŚĆ ORGANIZACJI POZARZĄDOWYCH NA RZECZ LOKALNYCH RAS KONI Agnieszka Chełmińska, Iwona Tomczyk-Wrona

PORÓWNANIE ORGANIZACJI TURYSTYCZNYCH RAJDÓW KONNYCH W POLSCE I GRUZJI. Bogusława Długosz, Anna Klich, Romana Augustyn, Magdalena Pieszka, Jarosław Luszczyński, Zenon Podstawski, Monika Stefaniuk-Szmukier

HODOWLA OSŁÓW W POLSCE

Danuta Dziurka, Bogusława Długosz, Agnieszka Szymańska

ZMIENNOŚĆ GENETYCZNA WYBRANYCH RAS KONI NA PODSTAWIE MARKERÓW SNP Agnieszka Fornal, Agata Piestrzyńska-Kajtoch, Anna Radko, Katarzyna Kowalska

ANALIZA WYNIKÓW UŻYTKOWOŚCI KONI RASY MAŁOPOLSKIEJ Marta Jarosławska, Alicja Borowska

OCENA SZYBKOŚCI UCZENIA SIE KONI W OPARCIU O TEST ROZWIAZZYWANIA PROBLEMU Ewa Jastrzębska, Kateryna Slivinska, Aleksandra Górecka-Bruzda

STAN WIEDZY UŻYTKOWNIKÓW KONI W POLSCE NA TEMAT FIZJOTERAPII TYCH ZWIERZACT.... Ewa Jastrzębska, Ewa Wadas, Adriana Bartkowicz, Zbigniew Jaworski

ZACHOWANIE KONI REKREACYJNYCH Ewa Jastrzębska, Ewa Wadas, Yuliia Sitchenko, Zbigniew Jaworski

SUPLEMENTACJA PYŁKIEM PSZCZELIM WPŁYWA NA WYBRANE WSKAŹNIKI KRWI KONI GERIATRYCZNYCH.... Witold Kędzierski, Iwona Janczarek, Sylwester Kowalik, Monika Franczyk, Lukasz Chrobak, Grzegorz Borsuk

TECHNIKA ODBICIA KONI STARTUJĄCYCH W KONKURENCJI SKOKÓW PRZEZ PRZESZKODY W ŚWIETLE ANATOMII FUNKCJONALNEJ Marcin Komosa, Gabriela Biedka

MOŻLIWOŚĆ WYKORZYSTANIA NOWEGO BODŹCA WECHOWEGO W ŁAGODZENIU STRESU U KONI Wanda Krupa, Jadwiga Topczewska

CZESTOŚĆ WYSTĘPOWANIA RÓŻNEGO RODZAJU MORZYSK U KONI NA TERENIE AGLOMERACJI LUBELSKIEJ...... Marta Liss, Izabela Wilk

Weryfikacja metod określenia masy ciała na podstawie wymiarów biometrycznych źrebiąt islandzkich..... Jarosław Łuszczyński, Weronika Pisarczyk, Anna Furtak, Magdalena Pieszka, Bogusława Długosz, Romana Augustyn, Zenon Podstawski

Zależność między składem mleka klaczy a tempem wzrostu źrebiąt islandzkich Jarosław Łuszczyński, Weronika Pisarczyk, Magdalena Pieszka, Bogusława Długosz, Romana Augustyn, Zenon Podstawski, Sylwia Siwiec

RONIENIA U KLACZY W WYNIKU ZAKAŻEŃ EHV-1 - MOŻLIWOŚĆ IMMUNOPROFILAKTYKI Angelika Orlewicz, Anna Nienartowicz-Zdrojewska

Preparat Escherichia Coli linia Nissle 1917 w profilaktyce biegunek rujowych u źrebiąt

Magdalena Pieszka, Monika Gołdyn, Jarosław Luszczyński, Bogusława Długosz, Romana Augustyn, Monika Stefaniuk-Szmukier, Zenon Podstawski

UŻYTKOWANIE ROZPŁODOWE OGIERÓW KONIKA POLSKIEGO W STADZIE REZERWATOWYM ROZTOCZAŃSKIEGO

PARKU NARODOWEGO W LATACH 1982-2017. Michał Pluta, Angelika Cieśla, Zbigniew Osiński, Mariusz Wójcik

UŻYTKOWANIE I DOBROSTAN KONI W WYBRANYCH OŚRODKACH JEŹDZIECKICH ŚWIADCZACYCH USŁUGI HIPOTERAPII Zenon Podstawski, Ewelina Horabik, Monika Stefaniuk-Szmukier, Bogusława Długosz, Magdalena Pieszka, Romana Augustyn, Jarosław Luszczyński, Weronika Petrych 
ANALIZA DZIAŁALNOŚCI MAŁOPOLSKIEGO ZWIĄZKU HODOWCÓW KONI W KRAKOWIE

Zenon Podstawski, Teresa Pracuch, Monika Stefaniuk-Szmukier, Bogusława Długosz, Magdalena Pieszka,

Romana Augustyn, Jarosław Luszczyński, Weronika Petrych, Przemysław Podstawski

ALTERNATYWNE WYKORZYSTANIE MLEKA KLACZY

Karolina Romaniuk, Katarzyna Kryszak, Agata Danielewicz

ANALIZA WYNIKÓW MISTRZOSTW POLSKI MŁODYCH KONI W UJEŻDŻENIU Sylwia Skoczyńska, Alicja Borowska

KONIE HUCULSKIE - ICH ROLA I ZNACZENIE W POLSCE Magda Socik, Stanisław Socha

STRUKTURA GENETYCZNA POPULACJI POLSKICH KONI ZIMNOKRWISTYCH POD WZGLĘDEM GENÓW UMASZCZENIA .. 133 Anna Stachurska, Antoni Brodacki, Marta Liss

Nieprawidłowości budowy i zmiany patomorfologiczne płaszczyzny karkowej koni i ich wpływ na biomechanikę ruchu 134 Monika Tołkacz-Paszkiewicz, Marcin Komosa, Małgorzata Dzierzęcka

REALIZACJA PROGRAMÓW OCHRONY ZASOBÓW GENETYCZNYCH LOKALNYCH RAS KONI PRYMITYWNYCH I PÓŁKRWI Iwona Tomczyk-Wrona, Agnieszka Chelmińska

ANALIZA RODOWODOWA KLACZY MAŁOPOLSKICH OBJĘTYCH PROGRAMEM OCHRONY ZASOBÓW GENETYCZNYCH .. 136 Iwona Tomczyk-Wrona

ZMIANY DOBOWEJ AKTYWNOŚCI AUTONOMICZNEGO UKŁADU NERWOWEGO KONI MAŁOPOLSKICH I KUCÓW FELIŃSKICH

Izabela Wilk, Marta Liss, Sylwester Tkaczyk

NAJCZESTSZE PROBLEMY ZDROWOTNE KONI GERIATRYCZNYCH Marcjanna Małgorzata Wiśniewska, Iwona Janczarek 


\section{Sekcja Chowu i Hodowli Owiec i Kóz}

ZALEŻNOŚCI MIĘDZY STĘŻENIEM BIAŁEK OSTREJ FAZY W SUROWICY KRWI KÓZ MLECZNYCH WOLNYCH

OD ZAKAŻENIA I ZAKAŻONYCH WIRUSEM MAEYCH PRZEŻUWACZY ...

Emilia Bagnicka, Daria Reczyńska, Magdalena Zalewska, Ewelina Kawecka', Paulina Brodowska, Danuta Słoniewska, Karina Horbańczuk, Sławomir Petrykowski, Lech Zwierzchowski

WPEYW PREPARATU SELENOWEGO O DŁUGIM OKRESIE DZIAŁANIA NA MECHANIZMY OBRONNE U JAGNIĄT Justyna Błażejak, Stanisław Milewski, Katarzyna Ząbek

WPEYW RÓŻNYCH SYSTEMÓW UTRZYMANIA NA MIKROSTRUKTURĘ MIĘŚNIA LONGISSIMUS LUMBORUM OWIEC RASY WRZOSÓWKA

Joanna Bogucka, Bronisław Borys, Julita Pabian, Jan Knapik

ZAKAŻENIA SRLV U RÓŻNYCH RAS OWIEC

Wiktor Bojar, Andrzej Junkuszew, Monika Olech, Jacek Kuźmak, Tomasz M. Gruszecki, Czesława Lipecka

PORÓWNANIE WYNIKÓW TUCZU PÓŁINTENSYWNEGO TRYCZKÓW SZEŚCIU RAS Z REZERWY GENETYCZNEJ Bronisław Borys, Jan Knapik, Anna Jarzynowska, Eugeniusz Kłopotek

ANALIZA POZIOMU WYBRANYCH BIAŁEK OSTREJ FAZY W OKRESIE OKOŁOPORODOWYM U OWIEC Monika Greguła-Kania, Urszula Kosior-Korzecka, Krzysztof Patkowski, Tomasz M. Gruszecki

PORÓWNANIE SKŁADU CHEMICZNEGO ORAZ PROFILU KWASÓW TŁUSZCZOWYCH W MIĘSIE OWIEC DOROSŁYCH ORAZ JAGNIACT...... Monika Greguła-Kania, Paulina Dudko, Andrzej Junkuszew, Wiktor Bojar

ANALIZA ROZRODU MACIOREK LINII SYNTETYCZNYCH BCP I SCP

Tomasz M. Gruszecki, Czesława Lipecka, Katarzyna Krzeszewska, Anna Szymanowska, Marek Szymanowski, Krzysztof Patkowski, Andrzej Junkuszew

BEHAWIOR PASTWISKOWY OWIEC WYPASANYCH NA TERENIE ZACHODNOWOŁYŃSKIEJ DOLINY BUGU Tomasz M. Gruszecki, Krzysztof Patkowski, Anna Szymanowska, Monika Greguła-Kania, Sylwia Bodzak, Katarzyna Wiercińska, Marek Szymanowski, Mariusz Kulik

OCENA PARAMETRÓW TECHNOLOGICZNYCH MLEKA KOZIEGO PRZEZNACZONEGO DO PRODUKCJI EKOLOGICZNYCH

SERÓW TWAROGOWYCH. Elżbieta Horoszewicz, Roman Niedziółka, Klaudia Bednarek

WSTĘPNA OCENA WARTOŚCI RZEŹNEJ ORAZ MOŻLIWOŚCIZAGOSPODAROWANIA JAGNIĘCINY Z PERSPEKTYWĄ SPRZEDAŻY BEZPOŚREDNIEJ.

Elżbieta Horoszewicz, Roman Niedziółka, Anna Tywoniuk

OCENA WARTOŚCI RZEŹNEJ JAGNIĄT ŻYWIONYCH Z WYKORZYSTANIEM PREPARATU O DZIAŁANIU Andrzej Junkuszew, Paulina Dudko, Klaudiusz Szczepaniak, Wiktor Bojar, Joël Le Scouarnec, Michał Milerski

DYNAMIKA ROZWOJU HODOWLI RODZIMYCH RAS OWIEC NA PRZESTRZENI OSTATNIEJ DEKADY

Aldona Kawęcka, Jacek Sikora, Marta Pasternak, Michał Puchała

PORÓWNANIE WZROSTU TRYCZKÓW 6 RAS Z REZERWY GENETYCZNEJ W OKRESIE ICH TUCZU W GOSPODARSTWIE MACIERZYSTYM Jan Knapik, Bronisław Borys

PORÓWNANIE PROFILU KWASÓW TŁUSZCZOWYCH MIĘSA TRYCZKÓW RASY UHRUSKIEJ TUCZONYCH DWOMA SYSTEMAMI

Dawid Kuźnicki, Bronisław Borys, Martyna Kozłowska, Jan Knapik Małgorzata Szumacher-Strabel, Adam Cieślak

RESEARCH OF CONTENT OF SOMATIC CELLS IN MILK OF DAIRY GOATS IN THE DIFERENT SEASONS

OF THE YEAR IN THE EASTERN REGION OF UKRAINE Lyubov Ladyka, Oleksandr Kyselov

DOBROSTAN ŻYWIENIOWY OWIEC W CZYNNEJ OCHRONIE SIEDLISK „NATURA 2000”..... Antonii Lipiec, Mariusz Kulik, Krzysztof Patkowski, Katarzyna Wiercińska, Tomasz M. Gruszecki

ROLA ULTRASONOGRAFII W NIEINWAZYJNEJ OCENIE MARMURKOWATOŚCI JAGNIECINY Agnieszka Ludwiczak, Piotr Ślósarz

ZMIANY SKŁADU CHEMICZNEGO MLEKA U POLSKICH OWIEC GÓRSKICH I RASY CAKIEL PODHALAŃSKI Edyta Molik, Krystyna Stękała, Karolina Nahajło 
OCENA WARTOŚCI HODOWLANEJ ALPAK NA PODSTAWIE MASY CIAŁA Anna Morales Villavicencio, Roman Niżnikowski

OCENA WARTOŚCI HODOWLANEJ ALPAK NA PODSTAWIE PARAMETRÓW JAKOŚCI WŁÓKNA Anna Morales Villavicencio, Roman Niżnikowski

IDENTYFIKACJA KOLORU RUNA ALPAK Z WYKORZYSTANIEM KOLORYMETRU..... Anna Morales Villavicencio, Roman Niżnikowski, Magdalena Ślęzak

CHARAKTERYSTYKA WEŁNY ALPAK UTRZYMYWANYCH W NIEKTÓRYCH GOSPODARSTWACH HODOWLANYCH

POŁUDNIOWEJ POLSKI Maciej Murawski, Agata Urban, Anna Kosiek

STUDY OF PHYSICO-CHEMICAL COMPOSITION AND TECHNOLOGICAL PROPERTIES OF GOAT'S MILK AS RAW MATERIALS FOR THE PRODUCTION OF SOFT CHEESES Julia Nazarenko, Lubov Ladyka

ZACHOWANIE OWIEC WYPASANYCH NA TERENIE REZERWATU PRZYRODY STAWSKA GÓRA Krzysztof Patkowski, Ewa Krawczyk, Tomasz M. Gruszecki, Anna Szymanowska, Monika Greguła-Kania, Marek Szymanowski, Mariusz Kulik

GENETYCZNA WRAŻLIWOŚĆ NA TRZĘSAWKĘ OWIEC RAS ZACHOWAWCZYCH..... 166 Agata Piestrzyńska-Kajtoch, Aldona Kawęcka, Grzegorz Smołucha

POLIMORFIZM GENU PRNP U OWIEC ZE ZDIAGNOZOWANA ATYPOWA TRZESAWKA ..... Agata Piestrzyńska-Kajtoch, Mirosław P. Polak, Grzegorz Smołucha, Jan F. Żmudziński

WPŁYW OBRÓBKI KULINARNEJ NA CECHY FIZYKO-CHEMICZNE I PROFIL KWASÓW TŁUSZCZOWYCH

W MIĘSIE JAGNIĘCYM Witold Rant, Aurelia Radzik-Rant, Magdalena Ślęzak, Marcin Świątek, Roman Niżnikowski, Żaneta Szymańska, Anna Morales-Villavicencio

KSZTAŁTOWANIE SIE TRENDÓW CECH UŻYTKOWYCH WYBRANYCH RAS OWIEC OBJETYCH PROGRAMEM OCHRONY ZASOBÓW GENETYCZNYCH Jacek Sikora, Aldona Kawęcka, Michał Puchała, Marta Pasternak

ANALIZA GENÓW MARKEROWYCH WARUNKUJĄCYCH WYSOKĄ PLENNOŚĆ U OWIEC. 170 Grzegorz Smołucha, Agata Piestrzyńska-Kajtoch

WYPAS SPOSOBEM POPRAWY BIORÓŻNORODNOŚCI ŁĄK PODKARPACIA Marian Szewczyk, Aldona Kawęcka, Iwona Radkowska, Jacek Sikora, Tomasz M. Gruszecki, Anna Miksza-Cybulska

PAKIET „ZACHOWANIE ZAGROŻONYCH ZASOBÓW GENETYCZNYCH ZWIERZATT W ROLNICTWIE” JAKO CZYNNIK STYMULUJĄCY CHÓW OWIEC NA OBSZARZE ŚRODKOWO-WSCHODNIEJ POLSKI Anna Szymanowska, Marek Szymanowski, Marlena Mirosław 


\section{Sekcja Chowu i Hodowli Zwierząt Towarzyszących i Dzikich}

ZASTOSOWANIE TESTU KOMETOWEGO DO OCENY STABILNOŚCI GENOMU KOTÓW Z FeLV......

Agnieszka Abramowska, Maria Dmitruk, Bartosz Jania, Ewa Wójcik, Katarzyna Andraszek

CECHY OSTEOMETRYCZNE WYBRANYCH ELEMENTÓW SZKIELETU KOTA DOMOWEGO (FELIS SILVESTRIS F. CATUS)

ZE STANOWISK ARCHEOLOGICZNYCH: WOLIN-MIASTO I RYNEK WARZYWNY W SZCZECINIE ............................................. 176 Piotr Baranowski, Piotr Nowak, Katarzyna Pęzińska, Agnieszka Talaga

ANALIZA MORFOMETRYCZNA CZASZEK PSÓW ŚREDNIOWIECZNYCH Z UWZGLĘDNIENIEM WSKAŹNIKA POŁOŻENIA

CZOŁA I WCIECIA DOGRZBIETOWEGO W OTWORZE WIELKIM. Piotr Baranowski

WPŁYW INTENSYWNEGO ŻYWIENIA ZIMOWEGO NA MASĘ CIAŁA CIELATT DANIELA EUROPEJSKIEGO (DAMA DAMA) ..... 179 Paweł Bogdaszewski, Żaneta Steiner-Bogdaszewska

MINIMALNY POZIOM NATĘŻENIA ŚWIATŁA KONIECZNY DO WYWOŁANIA REAKCJI FOTOPERIODYCZNEJ

U DANIELI (DAMA DAMA) UTRZYMYWANYCH W WARUNKACH FERMOWYCH. Marek Bogdaszewski, Katarzyna Tajchman, Zofia Bogdaszewska

OCENA WYBRANYCH CECH JAKOŚCIOWYCH MIĘSA DZIKO ŻYJACCEGO DANIELA EUROPEJSKIEGO (DAMA DAMA)..... Marta Bykowska

MORFOMETRIA PSA TYPU GREYSTER W ASPEKCIE PRZYSTOSOWANIA DO UŻYTKOWANIA SPORTOWGO Hieronim Frąckowiak, Mateusz Brylewski, Marcin Komosa, Maria Nabzdyk

OCHRONA DZIKICH GATUNKÓW ZWIERZĄT NA PRZYKŁADZIE ŻBIKA I RYSIA Paulina Gawryś, Dorota Kołodziejczyk, Stanisław Socha

WEGAŃSKA DIETA PSÓW? Andrzej Gugołek, Tomasz Wyczling, Janusz Strychalski, Anna Czarnecka

HISTORIA I WSPÓŁCZESNE PROBLEMY Z GOSPODAROWANIEM JELENIA SIKA CERVUS NIPPON W REPUBLICE CZESKIEJ Vladimir Hanzal, Paweł Janiszewski

ALERGIE U PSÓW Z TRZECH OBSZARÓW POLSKI BADANE ZA POMOCĄ TESTÓW ALERGICZNYCH IN VITRO Bartosz Jania', Marta Dopierała, Katarzyna Andraszek, Ewa Wójcik

WARTOŚĆ ODŻYWCZA WYBRANYCH PODROBÓW UZYSKANYCH OD JELENIA SZLACHETNEGO (CERVUS EPLAPHUS)

UTRZYMYWANEGO W WARUNKACH FERMOWYCH Paweł Janiszewski, Agnieszka Dziedzic, Tomasz Daszkiewicz, Marek Bogdaszewski, Żaneta Steiner-Bogdaszewska

DYNAMIKA SZKÓD WYRZĄDZANYCH PRZEZ BOBRA EUROPEJSKIEGO CASTOR FIBER NA TERENIE WOJEWÓDZTWA WARMINSKO-MAZURSKIEGO Paweł Janiszewski, Zuzanna Hermanowska, Andrzej Gugołek, Paweł Janczyk

JAKOŚĆ MIĘSA BYKÓW DANIELA EUROPEJSKIEGO (DAMA DAMA) Z OBWODU ŁOWIECKIEGO W ZACHODNIEJ

POLSCE Agnieszka Ludwiczak, Maciej Skorupski, Piotr Ślósarz, Marta Bykowska, Joanna Składanowska-Baryza, Łukasz Stańczak, Małgorzata Krokowska-Paluszak, Lukasz Sikora, Marek Stanisz

MIKO CZARNY (CALLIMICO GOELDII) - BEHAWIOR OKRESU OKOŁOPORODOWEGO Jacek Nowicki, Olga Szeleszczuk, Karolina Palka

CHARAKTERYSTYKA PRZYPADKÓW ZWIERZĄT TRAFIAJĄCYCH DO OŚRODKA REHABILITACJI ZWIERZĄT

„MARYSIEŃKA”, LASY MIEJSKIE - WARSZAWA...... Ewa Pacholik, Krzysztof Głowacz, Alicja Abramowicz

Analiza tempa wzrostu szczeniąt ras spanieli Magdalena Pieszka, Patrycja Kuś, Jarosław Łuszczyński, Bogusława Długosz, Romana Augustyn, Monika Stefaniuk-Szmukier, Zenon Podstawski

PORÓWNANIE EFEKTYWNOŚCI ZESTAWU 18 STR I 21 STR W CELU PRZEPROWADZANIA BADAŃ RYMINALISTYCZNYCH Z UDZIAŁEM PSÓW.... Anna Radko, Angelika Podbielska, Małgorzata Miszczak

WIELKOŚĆ „KOŚCI ŚW. HUBERTA” W SERCACH JELENI I DANIELI FERMOWYCH - WYNIKI WSTĘPNE Joanna Sadowska, Jagoda Czajkowska, Izabella Czaplejewicz, Anna Baranowska, Paweł Pietuszko 
SEZONOWE ZMIANY STĘŻENIA KORTYZOLU WE KRWI DANIELIEUROPEJSKICH (DAMA DAMA) UTRZYMYWANYCH

W WARUNKACH FERMOWYCH

Żaneta Steiner-Bogdaszewska, Katarzyna Tajchman, Paweł Bogdaszewski, Marek Bogdaszewski

ZASTOSOWANIE METODY RZUCANIA PIEKI PRZED PSEM W NAUCE BIEGANIA NA KOMENDE Janusz Strychalski, Andrzej Gugołek, Aleksandra Reksa, Aleksandra Kujtkowska, Aleksandra Felke, Piotr Dworak

SKUTECZNA METODA NAUKI PSA ,SIADU W MARSZU”

Janusz Strychalski, Magdalena Łęczycka, Marta Dulis, Marta Borowska, Agata Pazyra

WPEYW DODATKÓW MINERALNYCH NA ZAWARTOŚĆ MAKROELEMENTÓW W WYBRANYCH TKANKACH DANIELI FERMOWYCH

Katarzyna Tajchman, Marek Bogdaszewski, Edyta Kowalczuk-Vasilev, Leszek Drozd, Żaneta Steiner-Bogdaszewska

WPŁYW PRZESIEDLEŃ NA STRUKTURE GENETYCZNA POPULACJI JELENIA SZLACHETNEGO (CERVUS ELAPHUS)

W POLSCE

Katarzyna Tajchman, Monika Król, Wioletta Sawicka-Zugaj, Monika Greguła-Kania, Leszek Drozd, Piotr Czyżowski

CZESTOTLIWOŚĆ WYSTĘPOWANIA DYSPLAZJI STAWU BIODROWEGO U PSÓW RASOWYCH

Jacek Zawiślak, Natalia Chełmowska

DYSPLAZJA STAWÓW BIODROWYCH U PSÓW.

Aleksandra Zienkiewicz, Piotr Baranowski, Katarzyna Pęzińska-Kijak 


\section{Sekcja Chowu i Hodowli Trzody Chlewnej}

JAKOŚĆ EJAKULATÓW KNURÓW W ZALEŻNOŚCI OD WARTOŚCI HODOWLANEJ KNURA

Agnieszka Adamiak, Stanisław Kondracki, Anna Wysokińska

PORÓWNANIE WARTOŚCI UŻYTKOWEJ I HODOWLANEJ LOSZEK PBZ i WBP ORAZ MIESZAŃCÓW F1

Marta Borsuk, Wanda Milewska

ANALIZA UŻYTKOWOŚCI ROZPŁODOWEJ LOCH PIERWIASTEK I WIELORÓDEK PIC W ZALEŻNOŚCI OD KOLEJNEGO

CYKLU ROZPŁODOWEGO

Dorota Bugnacka, Martyna Zarzecka

PORÓWNANIE WYNIKÓW UŻYTKOWOŚCI ROZPŁODOWEJ LOCH PIERWIASTEK I WIELORÓDEK PIC

Dorota Bugnacka, Martyna Zarzecka

WPEYW CZASU PRZECHOWYWANIA W WARUNKACH CHŁODNICZYCH NA STABILNOŚĆ OKSYDACYJNĄ MIĘSA TUCZNIKÓW RASY PUŁAWSKIEJ

Piotr Domaradzki, Anna Litwińczuk, Marek Babicz, Piotr Skałecki, Małgorzata Dmoch, Michał Prasow, Małgorzata Ryszkowska-Siwko, Beata Ciupak

ZMIANY SKŁADU CHEMICZNEGO MLEKA W KOLEJNYCH DNIACH LAKTACJI U LOCH RAS MATECZNYCH Robert Eckert, Magdalena Szyndler-Nędza

WPŁYW CZASU PRZECHOWYWANIA NA RUCHLIWOŚĆ, INTEGRALNOŚĆ BŁONY KOMÓRKOWEJ I AKROSOMU ORAZ AKTYWNOŚĆ MITOCHONDRIÓW PLEMNIKÓW KNURA KONSERWOWANYCH W STANIE PŁYNNYM.....

Dariusz Gączarzewicz, Ewa Kwita, Jan Udała, Tomasz Stankiewicz, Barbara Błaszczyk, Bogumiła Pilarczyk, Agnieszka Tomza-Marciniak, Małgorzata Bąkowska

PARAMETRY FIZYCZNE EJAKULATU I MORFOLOGIA PLEMNIKÓW ORAZ ZALEŻNOŚCI POMIĘDZY CECHAMI NASIENIA U KNURÓW HYPOR W POSZCZEGÓLNYCH SEZONACH ROKU Krzysztof Górski, Stanisław Kondracki, Anna Wysokińska

OCENA SKALI STRAT SPOWODOWANYCH NISKĄ MASĄ CIAEA PROSIĄT PRZY URODZENIU W STADACH ŚWIŃ RASY WBP I PBZ Aleksandra Hajn, Anna Rekiel, Tadeusz Blicharski, Justyna Więcek, Martyna Snopkiewicz

ANALIZA WARTOŚCI RZEŹNEJ TUCZNIKÓW RASY PUŁAWSKIEJ Z UWZGLEDNIENIEM ICH POCHODZENIA Marcin Hałabis, Marek Babicz

ZNACZENIE ODSETKA PLEMNIKÓW O RUCHU POSTEPOWYM DLA FREKWENCII ZMIAN MORFOLOGICZNYCH

I WYMIARÓW PLEMNIKÓW W EJAKULATACH KNURÓW Maria Iwanina, Stanisław Kondracki, Marcin Mackiewicz

WPEYW MASY URODZENIOWEJ PROSIĄT NA WYNIKI PRODUKCYJNE

Paweł Jaroś, Justyna Więcek, Anna Rekiel, Martyna Batorska, Arkadiusz Biernacki

WPŁYW CZĘŚCIOWEGO ZASTĄPIENIA BIAŁKA POEKSTRAKCYJNEJ ŚRUTY SOJOWEJ BIAŁKIEM POCHODZĄCYM ZE ŚRUTY GUAR (CYAMOPSIS TETRAGONOLOBA) NA EFEKTYWNOŚĆ TUCZU ŚWIŃ

Krzysztof Karpiesiuk, Wojciech Kozera, Dorota Bugnacka, Anna Woźniakowska, Barbara Jarocka

KSZTAŁTOWANIE SIĘ DOCHODU Z GOSPODARSTWA UTRZYMUJĄCEGO TRZODĘ CHLEWNĄ PO WEJŚCIU POLSKI DO UNI EUROPEJSKIEJ - NA PODSTAWIE DANYCH Z FADN.

Krzysztof Karpiesiuk, Wojciech Kozera, Dorota Bugnacka, Anna Woźniakowska, Barbara Jarocka

PODSTAWOWE PARAMETRY JAKOŚCI MIESA TUCZNIKÓW DANBRED NAIMA I RASY PUŁAWSKIEJ..... Anna Kasprzyk, Marek Babicz

CHARAKTERYSTYKA PARAMETRÓW FIZYCZNYCH I CHEMICZNYCH NEREK ŚWIŃ RASY POLSKIEJ BIAŁEJ ZWISEOUCHEJ Kinga Kropiwiec-Domańska, Marek Babicz

ZALEŻNOŚĆ POMIĘDZY ECHOTEKSTURĄ PRZEKROJU POPRZECZNEGO MIĘŚNIA NAJDEUŻSZEGO GRZBIETU W PRZYŻYCIOWEJ ORAZ POUBOJOWEJ DIAGNOSTYCE ULTRASONOGRAFICZNEJ ŚWIŃ. Michał Marszałek, Martyna Małopolska, Tomasz Schwarz, Maciej Murawski, Mariola Pabiańczyk, Ryszard Tuz, Jacek Nowicki 
PORÓWNANIE WYNIKÓW UŻYTKOWOŚCI ROZPŁODOWEJ LOCH CZYSTORASOWYCH Z UŻYTKOWOŚCIĄ ROZPŁODOWĄ LOCH MIESZAŃCÓW

Beata Matysiak, Anna Sosnowska, Maria Kawęcka, Anita Kołodziej-Skalska, Anna Dorosińska

EFEKTYWNOŚĆ PRODUKCJI WARCHLAKÓW NA PRZYKŁADZIE FERMY UTRZYMUJACEJ STADO 175 LOCH Wanda Milewska, Damian Jasiński

PORÓWNANIE UŻYTKOWOŚCI ROZPŁODOWEJ LOCH PIC I WBP $\times$ PBZ

Wanda Milewska, Sandra Szepietowska

WYNIKI ODCHOWU PROSIĄT ODSADZONYCH ŻYWIONYCH MIESZANKAMI O SKŁADZIE PROSTYM (SIMPLE)

LUB ZŁOŻONYM (SEMI-COMPLEX).

Wanda Milewska, Patrycja Palińska, Dorota Bugnacka

EFEKTYWNOŚĆ STOSOWANIA FITOBIOTYKÓW W ŻYWIENIU TUCZNIKÓW

Piotr Mordaka, Martyna Batorska, Justyna Więcek, Anna Rekiel, Arkadiusz Biernacki

STEREOTYPIE BEHAWIORALNE I ZACHOWANIA AGONISTYCZNE TUCZNIKÓW ŻYWIONYCH MIESZANKAMI

Z RÓŻNYM UDZIAŁEM ŻYTA. Jacek Nowicki, Mariola Pabiańczyk, Tomasz Schwarz, Ryszard Tuz, Martyna Małopolska

ZNACZENIE ZIÓŁ W ŻYWIENIU TRZODY CHLEWNEJ

Aleksandra Paskudska, Dorota Kołodziejczyk, Stanisław Socha

OPRACOWANIE OPTYMALNEGO INDEKSU SELEKCYJNEGO STOSOWANEGO W OCENIE PRZYŻYCIOWEJ KNURÓW

I LOSZEK HODOWLANYCH Piotr Polok, Grzegorz Żak, Aurelia Mucha

JAKOŚĆ MIĘSA TUCZNIKÓW PO KNURACH RAS DanAvl DUROC I PUŁAWSKA. Artur Rybarczyk, Robert Moroch, Daniel Polasik, Krzysztof Sameluk

EFEKTYWNOŚĆ PRODUKCYJNA ZWIĘKSZONEGO UROZMAICENIA ŹRÓDEŁ ENERGII PASZOWEJ DLA ŚWIŃ ROSNACYCH Tomasz Schwarz, Ryszard Tuz, Artur Turek, Karol Włodarczyk, Jan Wujczak, Jacek Nowicki

WYKORZYSTANIE MIESA ŚWIŃ RASY PUŁAWSKIEJ DO PRODUKCJI WĘZZONEK WYSOKIEJ JAKOŚCI. Piotr Skałecki, Marek Babicz, Piotr Domaradzki, Anna Litwińczuk, Michał Prasow, Marcin Hałabis

DŁUGOWIECZNOŚĆ LOCH RASY RODZIMEJ.

Ewa Skrzypczak, Karolina Szulc, Piotr Luciński, Karolina Popiela

WPŁYW ŹRÓDŁA BIAŁKA ROŚLINNEGO I DODATKU ENZYMÓW PASZOWYCH DO MIESZANEK NA METABOLIZM AZOTU U TUCZNIKÓW.

Wiesław Sobotka, Elwira Fiedorowicz-Szatkowska

ANALIZA ZMIAN STRUKTURY POLIMORFIZMU GENÓW W ZALEŻNOŚCI OD ZINBREDOWANIA LOCH RAS RODZIMY Magdalena Szyndler-Nędza, Robert Eckert, Katarzyna Ropka-Molik, Karolina Szulc, Ewa Skrzypczak, Marek Babicz

EFEKTYWNOŚĆ EKONOMICZNA ZWIĘKSZONEGO UROZMAICENIA ŹRÓDEŁ ENERGII PASZOWEJ

DLA ŚWIŃ ROSNACYCH

Ryszard Tuz, Tomasz Schwarz, Artur Turek, Karol Włodarczyk, Jan Wujczak, Jacek Nowicki

WPŁYW KONSYSTENCJI PASZY NA DOBOWE PRZYROSTY MASY CIAŁA PROSIAT Ryszard Tuz, Paweł Sztafiński, Martyna Małopolska, Tomasz Schwarz, Jacek Nowicki

RUCH PLEMNIKÓW OCENIANY METODĄ TRADYCYJNĄ I SYSTEMEM CASA W CZASIE PRZECHOWYWANIA NASIENIA

KNURÓW W STANIE PŁYNNYM .......................................................................................................... Agnieszka Tomza-Marciniak, Małgorzata Bąkowska, Aleksandra Balicka-Ramisz, Karolina Procak

\section{Referaty}

HODOWLA ŚWIŃ RASY PUŁAWSKIEJ W WARUNKACH ROLNICTWA ZRÓWNOWAŻONEGO 


\section{Sesja Młodych Naukowców}

BARWA SKORUPY JAKO CZYNNIK DETERMINUJĄCY JAKOŚĆ JAJ PRZEPIÓRKI JAPOŃSKIEJ

THE IMPACT OF THE USE OF BIOCIDAL PAINT ON THE MICROBIOLOGICAL QUALITY OF POULTRY LITTER Sara Dzik, Tomasz Mituniewicz, Bogumił Torłop

THE INBREEDING LEVEL IN POPULATION OF HORSE FAMILY KEPT IN ZOOLOGICAL GARDENS

Patrycja Grzybek, Piotr Ćwiertnia, Tomasz Szwaczkowski

WPEYW ZAKAŻENIA WYMIENIA KRÓW MLECZNYCH GRONKOWCAMI KOAGULAZODODATNIMI

LUB KOAGULAZOUJEMNYMI NA EKSPRESJE GENÓW ALFA-S-KAZEINY I KAPPA-KAZEINY ORAZ NA ZAWARTOŚĆ

SKŁADNIKÓW MLEKA

Ewelina Kawecka, Magdalena Zalewska, Daria Reczyńska, Paulina Brodowska, Danuta Słoniewska,

Sławomir Petrykowski, Sylwester Marczak, Emilia Bagnicka

WYKORZYSTANIE WIELORASOWEGO KRZYŻOWANIA KRÓLIKÓW RAS ŚREDNICH DO PRODUKCJI BROJLERÓW TOWAROWYCH W CHOWIE TRADYCYJNYM.

Michał Kmiecik, Sylwia Pałka, Konrad Kozioł, Łukasz Migdał, Józef Bieniek

WPŁYW HYDROTERAPII NA POWIERZCHNIOWĄ TEMPERATURĘ KONI PO WYSIŁKU PODCZAS CIEPŁEJ I CHŁODNEJ POGODY W PORZE LETNIEJ

Marta Liss, Kostiantyn Vasiukov, Iwona Janczarek, Izabela Wilk, Sylwester Tkaczyk

PREFERENCJE SMAKOWE WARCHLAKÓW ŻYWIONYCH MIESZANKAMI Z RÓŻNYM UDZIAŁEM ŻYTA HYBRYDOWEGO I POPULACYJNEGO

Mariola Pabiańczyk, Jacek Nowicki, Tomasz Schwarz, Ryszard Tuz, Michał Marszałek, Martyna Małopolska

WPŁYW SUPLEMENTACJI MIESZANINĄ EKSTRAKTU ROZMARYNU I KURKUMY NA EKSPRESJĘ GENÓW UKŁADU IMMUNOLOGICZNEGO W WATROBIE KOZIOŁKÓW RASY POLSKIEJ BIAŁEJ USZLACHETNIONEJ

Daria Reczyńska, Ewelina Kawecka, Paulina Brodowska, Magdalena Zalewska, Danuta Słoniewska, Sławomir Petrykowski, Karina Horbańczuk, Emilia Bagnicka

PROJEKT OCENY STOPNIA NATEZŻENIA WYSIŁKU KONI WYŚCIGOWYCH NA PODSTAWIE PARAMETRÓW HRV Sylwester Tkaczyk, Marta Liss, Izabela Wilk

COMPARISON OF POTENTIAL EFFECTS ON THE PROFITABILITY OF THE US MPP APPLICATION ON DAIRY STABLES IN VENETO AND WIELKOPOLSKA Federico Vaona, Cristian Bolzonella, Martino Cassandro, Tomasz Szwaczkowski

WHEN DO HORSES DIE?

Izabela Wilk, Marcjanna Wiśniewska 
Sesja plenarna 
LXXXIII Zjazd Naukowy PTZ, Lublin 2018

Wyzwania zootechniki w warunkach rolnictwa zrównoważonego. Streszczenia

Sesja plenarna

\title{
TRENDY W PRODUKCJI ŻYWNOŚCI
}

Trends in food production

\author{
Joanna Barłowska
}

\author{
Uniwersytet Przyrodniczy w Lublinie \\ Katedra Towaroznawstwa i Przetwórstwa Surowców Zwierzęcych
}

Populacja ludzi na świecie w ciągu prawie 60 lat powiększyła się ponad 2,5-krotnie. Na przestrzeni ostatnich 50 lat kilkakrotnie zwiększyła się produkcja żywności, w tym podstawowych zbóż (ryżu, pszenicy i kukurydzy) przeciętnie 4-krotnie, mleka i wołowiny 2-krotnie, wieprzowiny i jaj 4-krotnie, a mięsa drobiowego aż 12-krotnie. Gwałtowny wzrost produkcji żywności na świecie w tym okresie był możliwy dzięki wykorzystaniu w produkcji roślinnej nawozów mineralnych, środków ochrony roślin i roślin GM, a w zwierzęcej wynikał z osiągnięć z zakresu genetyki cech ilościowych, nauk o żywieniu zwierząt oraz biotechnik rozrodu. Większość światowej produkcji zwierzęcej odbywa się obecnie w systemach intensywnych (przemysłowych), wywierających jednak silną presję na środowisko naturalne. Mając na względzie dalszy wzrost liczby ludzi na świecie (obecnie jest ich 7,6 mld, a prognozy ONZ przewidują, że w 2056 r. liczba ta wzrośnie do 10 mld) i jednocześnie dramatyczny problem głodu i niedożywienia nadal dla wielu z nich, wymagany będzie dalszy wyraźny progres w produkcji żywności. Dotyczy to również tej, która dostarcza pełnowartościowego białka, czyli pochodzenia zwierzęcego. W ostatnim czasie coraz większą uwagę zwraca się na żywność produkowaną z zastosowaniem metod nowoczesnej biotechnologii. Pozwala to na uzyskanie roślin uodpornionych na stres biotyczny, tzn. działanie wirusów, bakterii i owadów, które uszkadzają zbiory, ponadto na zwiększenie poziomu witamin w roślinach (witaminy E w soi, kukurydzy i rzepaku; beta-karotenu w ryżu), wzrost biodostępności np. żelaza w ryżu czy obniżenie zawartości alergenów w żywności. Obecnie niezbędnym i trwałym elementem $\mathrm{w}$ procesie produkcji żywności metodami konwencjonalnymi stało się stosowanie substancji dodatkowych. Ich obecność w żywności wzbudza na ogół negatywne emocje u konsumentów, jednak mogą one być stosowane wyłącznie w dozwolonej ilości i nie stanowić zagrożenia dla zdrowia lub życia człowieka. Głównym celem polityki rolnej Unii Europejskiej ostatnich lat stało się zapewnienie bezpieczeństwa żywności. Zgodnie z założeniami prawa europejskiego i krajowego wymaga to kompleksowego ujęcia całego łańcucha żywnościowego, określanego mianem „from farm to table” -z pola do stołu. Równocześnie w państwach wysoko rozwiniętych narasta problem chorób cywilizacyjnych i jednocześnie zwiększa się świadomość żywieniowa konsumentów poszukujących żywności, której spożywanie może w pewnym stopniu hamować występowanie i rozwój tych chorób. Na pierwszy plan wysuwa się obecnie jakość żywności, ze szczególnym uwzględnieniem jej kaloryczności i właściwości prozdrowotnych. Gwałtownie zatem rośnie zainteresowanie żywnością funkcjonalną, tradycyjną i ekologiczną. Duże znaczenie ma tutaj powrót do tradycyjnego, bardziej kosztownego modelu rolnictwa, tzn. takiego, w którym cała produkcja spełnia bardzo restrykcyjne kryteria: bezpieczeństwa żywności, środowiskowe, dobrostanu zwierząt, bioróżnorodności itp. Wielu producentów żywności inwestuje również w badania związane z nanotechnologią, uważając, że może ona przyczynić się do powstania produktów spożywczych o pożądanych cechach, tzn. produktów bezpieczniejszych, zdrowszych, o większej wartości odżywczej i smaczniejszych. Duże nadzieje wiąże się z badaniami w zakresie nowoczesnych technologii bioanalitycznych, tzw. omik (genomiki, proteomiki, metabolomiki). Dzięki wykorzystaniu nutrigenomiki i metabolomiki będzie możliwe na większą skalę spersonalizowane odżywianie ludzi. 


\title{
MAŁE PRZEŻUWACZE W ŚRODOWISKU PRZYRODNICZYM I W KULTURZE
}

\author{
Small ruminants in the natural environment and in culture
}

\author{
Tomasz M. Gruszecki, Andrzej Junkuszew \\ Uniwersytet Przyrodniczy w Lublinie \\ Instytut Hodowli Zwierząt i Ochrony Bioróżnorodności
}

Zaniechanie użytkowania rolniczego znacznych obszarów naszego kraju wpłynęło na przeobrażenia środowiska przyrodniczego, wyrażające się odmiennym kierunkiem i intensywnością przebiegu wielu specyficznych procesów biologicznych. Następstwa są wieloaspektowe, przy czym na czoło wysuwa się problem zubożenia różnorodności biologicznej. Należy podkreślić, że głównym zagrożeniem dla wspomnianych siedlisk, a w związku z tym dla występujących tam rzadkich gatunków flory i fauny, są naturalne procesy sukcesji wtórnej. Szata roślinna a co za tym idzie całe tereny przekształcają się w bardziej złożone układy roślinne, takie jak zarośla czy lasy.

Przeciwdziałając tym niekorzystnym zmianom, propagować należy zrównoważony rozwój umożliwiający zachowanie zróżnicowania na poziomie genotypów, gatunków i ekosystemów, określanego mianem bioróżnorodności. Osiągnięcie tego celu wymaga połączenia wiedzy z wielu dziedzin, począwszy od genetyki, gleboznawstwa, botaniki, zoologii, poprzez m.in. zootechnikę czy też gospodarkę przestrzenną.

Jest to możliwe poprzez stworzenie podstaw właściwego zarządzania wspomnianymi obszarami. Istnieje zatem potrzeba poszukiwań coraz doskonalszych rozwiązań, łączących zarówno szeroko rozumianą ochronę przyrody, jak i mechanizmy jej finansowania, szczególnie że dotychczasowe poczynania w tym zakresie wiążą się z dużymi nakładami i krótkotrwałym efektem. Autorzy niniejszego opracowania uważają, że obniżenie kosztów ponoszonych na ochronę jest możliwe poprzez powrót do wypasu na tych obszarach zwierząt gospodarskich, takich jak owce, kozy, bydło czy konie.

W strategii Unii Europejskiej rozwój obszarów wiejskich uwzględnia tzw. tożsamość regionalną, co jest ściśle powiązane z promowaniem tych terenów. Tradycje oraz zwyczaje ludowe związane szczególnie z kulturą pasterską pozwalają kultywować dziedzictwo kulturowe regionu, mające znaczenie nie tylko sentymentalne, ale stanowiące także istotny czynnik napędowy lokalnej gospodarki. Zatem połączenie działań ochronnych z wypasem oraz aktywizacją mieszkańców może odgrywać istotną rolę w promowaniu zrównoważonego rozwoju obszarów wiejskich. 


\title{
EKOLOGIA WYZWANIEM POLSKIEJ WSI NOWEGO TYSIĄCLECIA
}

\author{
Ecology - challenge of the new millennium
}

\section{Jacek Janiszewski}

Wyższa Szkoła Bankowa w Toruniu

Wejście Polski w 2004 r. do Unii Europejskiej nie tylko doprowadziło do zmian prawnych, organizacyjnych państwa, ale także zmieniło obyczaje i poglądy Polaków w wielu sprawach. Jednym z fundamentalnych elementów tych zmian jest ekologia, także jako element walki biznesowej, politycznej i społecznej. Nowe tysiąclecie zmusza zatem do tworzenia nieznanych wcześniej na taką skalę połączeń „wody z ogniem”, tzn. zachowania wielkości produkcji rolnej potrzebnej dla bezpieczeństwa żywnościowego kraju i do zatrzymania biodegradacji oraz zachowania tradycji.

Ta niewątpliwa ścieżka ryzyka tzw. poprawnej Europy w kontekście reszty świata może okazać się zgubna. Nie chodzi tylko o coraz mniejszą akceptację wizji wspólnotowej kontynentu na rzecz Europy państw niezależnych. Trzeba także wziąć pod uwagę konkurencję między poszczególnymi państwami wewnątrz UE oraz między UE a zewnętrznymi podmiotami.

Ktoś może zapytać: co to ma wspólnego z ekologią i nowymi wyzwaniami polskiej wsi? Ze wszystkich dostępnych danych wynika, że jesteśmy jedynym krajem Unii Europejskiej, w którym zwiększa się ilość mieszkańców wsi, a jednocześnie zmniejsza się ilość rolników. Takie fakty muszą nieść za sobą pewne konsekwencje. Coraz modniejsza wieś zamieszkana przez ludzi z miast wytworzy ogromny nacisk na marginalizowanie produkcji rolnej i nie wykluczam, że w dalszej konsekwencji doprowadzi to do wykluczenia społecznego rolników.

Dziś wydaje się to abstrakcyjne, ale pamiętamy, że mówimy o wyzwaniu nowego tysiąclecia. Obecnie już obserwujemy, że miejscowości wiejskie, w których sołtysem lub radnym zostaje aktor, pisarz czy przedsiębiorca, zmieniają się w kontekście społecznym, tym samym zmianie ulega dotychczasowa pozycja rolnika. Stąd też w niektórych przypadkach niejako przez wymuszenie otoczenia rolnik może być zmuszony do produkcji bez zapachów i innych uciążliwości dla sąsiadów.

Oczywiście, że pierwszoplanowe okaże się rolnictwo ekologiczne, mimo że nie spełni wszystkich wymagań, to jednak trudno przeciw niemu występować. Ekologia będzie więc warunkowała rodzaj produkcji, zakres jej uciążliwości, a nawet kształtowała działy produkcji rolnej, które są dopuszczone lub nie w Polsce. Najwyraźniej mogliśmy to zaobserwować w ostatnim czasie na przykładzie sporu dotyczącego zakazu hodowli zwierząt futerkowych.

Specjalistyczne branże rolnicze zawsze korelowały z wykształceniem, tradycją i wielopokoleniowością. To najmądrzejsi, najbardziej pracowici rolnicy tworzyli specjalizacje, a sąsiedzi i przyjaciele podglądali i naśladowali. Nic więc dziwnego, że enklawy hodowców świń, producentów kwiatów, warzyw, owoców itp. bardzo łatwo dostrzec w różnych miejscach Polski jako wyraźne skupiska.

Ekologia jest więc kluczem, a może nawet wytrychem do walki o wielkie pieniądze, a prawdziwie ideowi ekolodzy pewnie nigdy nie zdają sobie sprawy, że są narzędziem w wielkim biznesie lub polityce. Politycy z kolei często nieświadomie uczestniczą w grze biznesowej, co w rezultacie zostanie opisane i przedstawione dokładnie w referacie.

Musimy zdawać sobie sprawę, że nie tylko gaz i ropa będą polem walki o wpływy na świecie. Walka ta dotyczyć będzie także rolnictwa, szczególnie w obliczu zmniejszającej się ilości ziemi uprawnej i zwiększającej się ilości ludzi na świecie.

Starzejąca się Europa ze swoją poprawnością oraz chęcią przypodobania się biznesowi i wyborcom może wpaść w ciemny zaułek, a ekologia i doktrynalne poglądy jedności człowieka z naturą zostaną jej przewodnikiem do ogromnych problemów w przyszłości. 


\title{
WYPAS KONIKÓW POLSKICH NA TERENACH CENNYCH PRZYRODNICZO - KSZTAŁTOWANIE KRAJOBRAZU I ZACHOWANIE BIORÓŻNORODNOŚCI
}

The grazing of Konik Polski horses on valuable landscapes - maintaining the landscape and the biodiversity

\author{
Zbigniew Jaworski ${ }^{1}$, Aleksandra Górecka-Bruzda ${ }^{2}$, Ewa Jastrzębska ${ }^{1}$ \\ ${ }^{1}$ Uniwersytet Warmińsko-Mazurski w Olsztynie, Katedra Hodowli Koni i Jeździectwa \\ ${ }^{2}$ Instytut Genetyki i Hodowli Zwierząt PAN w Jastrzębcu, Zakład Zachowania się Zwierząt
}

Realizowany od 1999 r. „Program hodowli zachowawczej koników polskich” ma na celu zachowanie rasy konik polski, w szczególności cech odziedziczonych po tarpanach, doskonalenie cech związanych z użytkowaniem wierzchowym, rekreacyjnym, sportowym, hipoterapeutycznym oraz związanych z kształtowaniem krajobrazu.

Cel polegający na doskonaleniu cech związanych z kształtowaniem krajobrazu dotyczy wykorzystania koników polskich w działaniach związanych m.in. z ochroną terenów przyrodniczo cennych. Specyfiką ww. programu są trzy odrębne systemy hodowli (systemy utrzymania), a mianowicie: hodowla stajenna (konie w okresie pastwiskowym przebywają na pastwiskach, a w okresie zimowym w stajni, korzystając w ciągu dnia z wybiegów), hodowla bezstajenna (konie utrzymywane są przez cały rok na dużych pastwiskach, gdzie w przypadku niekorzystnych warunków pogodowych mają za schronienie wiatę lub naturalne zadrzewienia) i hodowla rezerwatowa (konie utrzymywane są przez cały rok w naturalnym środowisku leśnym lub łąkowoleśnym, na dużych obszarach, w otoczeniu innych dziko żyjących zwierząt, w grupach haremowych - tabunach, w warunkach zbliżonych do tych, w jakich bytowała leśna odmiana tarpana). Należy podkreślić, iż jest to jedyna rasa koni w Polsce, której program hodowlany przewiduje hodowlę rezerwatową, gdzie kluczową rolę odgrywa selekcja naturalna. Aby dany ośrodek uzyskał status hodowli rezerwatowej musi spełniać dodatkowe warunki poza tymi, jakie obowiązują w dwóch pozostałych systemach utrzymania. Obecnie, wg Komisji Księgi Stadnej, tylko 6 ośrodków odpowiada tym wymogom. Z badań przeprowadzonych w $2011 \mathrm{r}$. wynika, iż w systemie hodowli stajennej utrzymywanych jest ok. $42 \%$ koni tej rasy, natomiast w bezstajennej 54\% i rezerwatowej 4\%. W ostatnich latach w Polsce można zaobserwować stały, ale nie gwałtowny, wzrost populacji koników polskich i głównie dotyczy on koni utrzymywanych w hodowli bezstajennej. Zainteresowanie hodowlą rezerwatową i bezstajenną obserwowane jest nie tylko w Polsce, ale także poza jej granicami. W tym systemie utrzymania konik polski postrzegany jest jako duży roślinożerca, którego obecność jest niezbędna do utrzymania bioróżnorodności rozmaitego typu środowisk, zwłaszcza łąkowych i stepowych. Zaniechanie wypasu na terenach otwartych może powodować niekontrolowany wzrost roślinności, zachwaszczenie i zakrzaczenie, co w konsekwencji powoduje ich zmniejszenie oraz zanik flory i fauny. Wypas zwierząt jest bardzo istotny ze względu na wzrost biomasy, jej urozmaicenie i wzbogacenie składu gatunkowego oraz odtwarzanie zbiorowisk roślinnych. Obłamywanie i kruszenie suchych liści traw zapobiega tworzeniu się zwartej ściółki, a zgryzanie siewek drzew i krzewów powstrzymuje ich rozwój. Tym samym wypasanie trawożerców decyduje o zachowaniu zbiorowisk roślinnych, stanowiących siedliska lęgowe dla wielu gatunków ptaków. Dlatego koniki polskie wypasane na dużych przestrzeniach mogą spełniać pożyteczną funkcję środowiskotwórczą, wspomagając jednocześnie proces renaturalizacji zakłóconych ekosystemów. 


\title{
CYWILIZACYJNE PROBLEMY ZWIERZĄT
}

\author{
Animals' problem with civilization \\ Tadeusz Kaleta \\ Szkoła Główna Gospodarstwa Wiejskiego w Warszawie \\ Katedra Genetyki i Ogólnej Hodowli Zwierząt
}

Cywilizacja ludzka jest złożonym i przekazywanym z pokolenia na pokolenie zespołem zjawisk o charakterze religijnym, moralnym, estetycznym, technicznym i naukowym. Cywilizacja jest rozwiniętą formą kultury ludzkiej, a u jej podstawy leży powstanie rolnictwa i udomowienie zwierząt. Dziś wszystkie zwierzęta są w jakiś sposób związane ze światem człowieka, mogą mu służyć lub też być mniej czy bardziej pożądanymi sąsiadami. Podczas gdy ludzie wciąż nasilają i poszerzają swoją eksploatację świata naturalnego, część zwierząt domowych podlega procesowi feralizacji (wraca do środowiska naturalnego), a niektóre zwierzęta dzikie zbliżają się lub wręcz wchodzą do osiedli człowieka (synantropizacja i synurbizacja). Wszystko to rodzi dla zwierząt dzikich specyficzne sytuacje, w których muszą się odnaleźć. Przykładowe problemy to lęk przed człowiekiem i adaptacja do zmian antropogenicznych (zanieczyszczenie chemiczne, hałas, światło itp.). Zwierzęta domowe z kolei muszą zaspokajać rosnące zapotrzebowanie ludzi na żywność. Stąd stresogenny, intensywny chów, będący nieraz poważną przeszkodą do adaptacji. 


\title{
OCHRONA ZASOBÓW GENETYCZNYCH ZWIERZĄT GOSPODARSKICH W WARUNKACH ZRÓWNOWAŻONEGO ROLNICTWA
}

The livestock genetic resources conservation in condition of sustainable agriculture

\author{
Jędrzej Krupiński, Grażyna Maria Polak
}

Instytut Zootechniki - PIB

Wzrost zapotrzebowania na produkty pochodzenia zwierzęcego sprzyja ekspansji przemysłowych metod produkcji, co stanowi główny powód marginalizacji ras lokalnych i związanych z nimi tradycyjnych systemów. Podjęte przez FAO działania dotyczące ochrony zasobów genetycznych zwierząt gospodarskich zaowocowały rozwojem badań naukowych i nowym spojrzeniem na tę problematykę. Stworzono nowe definicje, klasyfikacje i kryteria dotyczące populacji zwierząt gospodarskich. Istniejące niebezpieczeństwo koncentrowania się tylko na liczbie osobników jako kryterium zagrożenia populacji, z pominięciem innych ważnych czynników (np. efektywnej wielkości populacji czy rozmieszczenia geograficznego), było przesłanką do opracowywania krajowych metod szacowania statusu zagrożenia.

Aktualnie koordynowane przez Instytut Zootechniki - PIB programy ochrony obejmują 83 rodzime rasy, odmiany, rody i linie zwierząt gospodarskich. Populacje te łącznie obejmują ponad 103 tys. samic populacji aktywnej, które utrzymywane są w około 3300 stadach, głównie w małych gospodarstwach rodzinnych. Przeprowadzone symulacje, mające na celu określenie statusu zagrożenia wg reguł stosowanych przez FAO i niektóre kraje europejskie, wskazują na dość dużą rozbieżność wyników. Interesujące rezultaty otrzymano również w badaniach przeprowadzonych przez Instytut Zootechniki - PIB w ramach projektu Biostrateg II na populacjach bydła, koni, świń i owiec, w których oszacowano dystans genetyczny pomiędzy rasami oraz stopień homozygotyczności tych populacji.

Biorąc pod uwagę różny stopień zagrożenia ras rodzimych w Polsce, należy przyjąć krajowy system weryfikacji, w którym oprócz stanu liczbowego uwzględniono inne czynniki. Dodatkowo efektywna realizacja programów ochrony wymaga włączenia metod ex situ, a zwłaszcza informacji dotyczących ilości i rodzaju przechowywanego materiału biologicznego. O powodzeniu działań ochronnych decyduje także wykorzystanie potencjału rodzimych i lokalnych ras do pozyskiwania wysokiej jakości surowców, produktów oraz w ochronie przyrody, na co wskazują badania Uniwersytetu Przyrodniczego w Lublinie, przeprowadzane w ramach ww. projektu Biostrateg II.

Produkty pochodzące od ras rodzimych mogą być szansą poprawy efektywności ekonomicznej w małych, rodzinnych gospodarstwach w warunkach zrównoważonego rolnictwa w Polsce. Na rolę zrównoważonej produkcji zwierzęcej już zwracają uwagę raporty światowe. 


\title{
PROBLEM UTYLIZACJI ODPADÓW I ELIMINACJI ZAGROŻEŃ W PRODUKCJI ZWIERZĘCEJ
}

The problem of waste disposal and elimination in animal production

\author{
Leszek Tymczyna
}

Uniwersytet Przyrodniczy w Lublinie, Katedra Higieny Zwierząt i Zagrożeń Środowiska

Od drugiej połowy XX w. obserwujemy proces uprzemysławiania produkcji zwierzęcej. Liczba ferm przemysłowych w Polsce wzrasta, przyczyniając się do znacznego zwiększenia działalności wytwórczej artykułów żywnościowych pochodzenia zwierzęcego. Działalność wielkotowarowych ferm zwierząt gospodarskich oprócz tego, że przynosi niewątpliwe korzyści o charakterze ekonomicznym, przyczynia się do powstawania wielu zagrożeń związanych z emisją gazów czy zagospodarowaniem odchodów. Wytwarzanie znacznych ilości zwierzęcych odchodów (gnojowica, gnojówka, obornik) stanowi najistotniejszą przyczynę zagrożenia dla środowiska, związanego z intensywnym chowem zwierząt gospodarskich. W wyniku nieprawidłowej gospodarki tymi pozostałościami poprodukcyjnymi powstaje ryzyko przedostania się zanieczyszczeń do gleby czy wód, zwiększenia emisji gazów cieplarnianych, niszczenia walorów rekreacyjnoturystycznych środowiska czy też emisji związków zapachowych. Całkowita emisja głównych zanieczyszczeń powietrza w Polsce należy do największych spośród krajów europejskich.

Produkcja zwierzęca do niedawna postrzegana jako proekologiczna stała się jednym z głównych powodów zanieczyszczenia. Szczególne zagrożenia występują w produkcji zwierzęcej, gdzie na stosunkowo małej powierzchni kumulowana jest znaczna ilość materii organicznej. Koncentracja dużej liczby zwierząt na relatywnie niewielkich przestrzeniach powoduje wysoki stopień zanieczyszczenia powietrza wewnątrz pomieszczeń hodowlanych, m.in. bioaerozolami zawierającymi głównie pył organiczny, drobnoustroje, endotoksyny i glukany oraz gazami drażniącymi, co stanowi istotny czynnik szkodliwy dla zdrowia pracowników zatrudnionych przy obsłudze (chowie) zwierząt.

Nieprzyjemne zapachy pochodzące z produkcji zwierzęcej nie są tolerowane również przez mieszkańców obszarów wiejskich. Przez urządzenia wentylacyjne pomieszczeń dla zwierząt emituje się wraz z usuwanym zużytym powietrzem ogromne ilości dwutlenku węgla, amoniaku, siarkowodoru, metanu, tlenków azotu, pyłów i związków odorowych. Dlatego konieczne staje się minimalizowanie ujemnego wpływu na atmosferę, a przede na zdrowie ludzi i zwierząt.

W chowie zwierząt nie można pominąć tematu osobników padłych, których śmierć nastąpiła w wyniku chorób, wad rozwojowych, jak również starości. Zagospodarowanie padłych zwierząt musi być natychmiastowe z uwagi na rozwijające się procesy gnilne tkanek, rozwój bakterii chorobotwórczych z jednoczesnym wydzielaniem się odorów. Produkty uboczne pochodzenia zwierzęcego, pochodzące ze zwierząt uznanych ze niezdatne do spożycia przez ludzi stanowią potencjalne zagrożenie dla zdrowia ludzi i zwierząt i nie powinny być wprowadzane do łańcucha pokarmowego. Zagrożenie to powinno być odpowiednio kontrolowane poprzez kierowanie takich produktów do zakładów utylizacji i usuwanie ich z zachowaniem ściśle określonych warunków. 
Sekcja Chowu i Hodowli Bydła 


\title{
PORÓWNANIE EFEKTÓW ODCHOWU CIELĄT UTRZYMYWANYCH W SYSTEMIE TRADYCYJNYM I KOMBINOWANYM
}

\author{
Comparison of effects calf rearing held in a traditional and combined system
}

\author{
Urszula Borowska, Marta Wysocka, Adrian Założyk, Małgorzata Szewczuk
}

\author{
Zachodniopomorski Uniwersytet Technologiczny w Szczecinie, Katedra Nauk o Zwierzętach Przeżuwających, \\ ul. Klemensa Janickiego 29, 71-270 Szczecin \\ e-mail: martawysocka98@interia.pl
}

Utrzymanie jak największej ilości młodego bydła w dobrym stanie zdrowia i kondycji fizycznej jest istotnym celem hodowców. Cielęta w pierwszym okresie życia wymagają szczególnej uwagi i opieki. Powinny mieć zapewnione optymalne żywienie oraz właściwe warunki zoohigieniczne. Celem badań było porównanie wyników odchowu cieląt $\mathrm{z}$ uwzględnieniem ich systemu utrzymania. Badania przeprowadzono na cielętach rasy holsztyńsko-fryzyjskiej odmiany czarno-białej utrzymywanych w województwie zachodniopomorskim. Zwierzęta podzielono na dwie grupy w zależności od systemu odchowu. Pierwszą grupę utrzymywano w tradycyjnym cielętniku na ściółce ze słomy (system tradycyjny; 53 osobniki), natomiast drugą w cielętniku w boksach zbiorowych po 2-3 cielęta (system kombinowany; łącznie 61 osobników), z możliwością wyjścia na utwardzony wybieg. Żywienie obu grup było zbliżone (wspólna baza paszowa), początkowo oparte na siarze, następnie preparatach mlekozastępczych, paszy treściwej CJ i sianie. W okresie odpajania cielęta otrzymywały w mleku dodatek Polfamiksu C oraz miały stały dostęp do wody. Od około 4. miesiąca przyzwyczajano je do kiszonki z kukurydzy i do sianokiszonki. Latem kiszonkę z kukurydzy i sianokiszonkę zastępowano trawą i lucerną. Ocenę odchowu oparto na wynikach ważenia po urodzeniu, w 30., 60., 90. i 180. dniu życia oraz na analizie przyrostów dobowych za cały okres odchowu. Oceniono przebieg porodów krów pierwiastek oraz żywotność cieląt. W całym analizowanym okresie odchowu młode zwierzęta podlegały ocenie zdrowotności. Stwierdzono, że najczęściej porody były łatwe i nie wymagały pomocy człowieka, a cielęta rodziły się żywe, normalne. Brak cieląt z wadami budowy oraz potworkowatych, a także stosunkowo niewielki odsetek $(0,88 \%)$ porodów, w których cielę urodziło się martwe lub padło w ciągu 24 godzin, świadczą o prawidłowej opiece zootechnicznej i weterynaryjnej oraz dobrym przygotowaniu jałówek do rozrodu. Cielęta utrzymywane w systemie kombinowanym charakteryzowały się największą średnią masą ciała od urodzenia do 6. miesiąca odchowu oraz większymi średnimi przyrostami dobowymi w wyznaczonych okresach ważenia w porównaniu z rówieśnikami utrzymywanymi w cielętniku w kojcach zbiorowych. Największą średnią masę w 180. dniu życia osiągały cielęta odchowywane w systemie kombinowanym $(199,9 \mathrm{~kg})$. Osiągały również największe przyrosty dobowe $(888 \mathrm{~g}) \mathrm{w}$ całym okresie odchowu. Prowadzone obserwacje zdrowotności cieląt w obu grupach wykazały typowe jednostki chorobowe dla tej grupy wiekowej. Najczęściej występowały choroby układu oddechowego oraz biegunki, przy czym na schorzenia układu pokarmowego chorowały częściej cielęta utrzymywane w systemie kombinowanym $(6,55 \%)$ niż utrzymywanie tradycyjnie (1,8\%). W systemie kombinowanym cieląt zdrowych było 93,5\%, co jest lepszym wynikiem niż w przypadku cieląt utrzymywanych tradycyjnie, gdzie zdrowotność kształtowała się na poziomie 90,6\%. Zmniejszenie obsady zwierząt w kojcu zbiorowym, wnikliwsza obserwacja zwierząt szczególnie w pierwszych 3 miesiącach życia oraz izolacja osobników podejrzanych o chorobę mogłyby przyczynić się do zmniejszenia zachorowalności, a w konsekwencji do większych przyrostów dobowych. Niekorzystnie na zdrowotność cieląt mógł wpłynąć system ich utrzymania w zamkniętych pomieszczeniach, bez możliwości dostępu do wybiegu i korzystania ze świeżego powietrza oraz promieni słonecznych. 


\title{
PRZEWODNOŚĆ ELEKTRYCZNA MLEKA A WYDAJNOŚĆ DOBOWA ĆWIARTEK GRUCZOŁU MLECZNEGO KRÓW DOJONYCH AUTOMATYCZNIE
}

Electrical conductivity of milk as related to daily milk yield of udder quarters in automatically milked cows

\author{
Mariusz Bogucki
}

\author{
Uniwersytet Technologiczno-Przyrodniczy w Bydgoszczy, Katedra Nauk o Zwierzętach, \\ ul. Mazowiecka 28, 85-084 Bydgoszcz \\ e-mail: bogucki@utp.edu.pl
}

Celem pracy było określenie częstotliwości występowania u pierwiastek i wieloródek ćwiartek wymion o określonym poziomie: 1) przewodności elektrycznej mleka, 2) wydajności mleka. Analizie poddano również zależności między zdrowotnością a wydajnością poszczególnych ćwiartek wymienia pierwiastek i wieloródek. Analizy przeprowadzono na podstawie wyników 360 tysięcy dojów automatycznych 240 krów rasy polskiej holsztyńsko-fryzyjskiej.

Ćwiartki przednie, lewe i prawe, stanowiły odpowiednio 67,39 i 67,90\% ćwiartek, z których dojono mleko o przewodności elektrycznej $\leq 5,50 \mathrm{mS} / \mathrm{cm}$. W klasie przewodności $>7,00 \mathrm{mS} / \mathrm{cm}$ największy udział stanowiły ćwiartki tylne - prawe 9,59 i lewe 7,13\%. Poszczególne ćwiartki wymion krów najczęściej produkowały do $7,00 \mathrm{~kg}$ (przednie) lub powyżej 10,00 kg (tylne) mleka na dobę. W pierwszych dwóch klasach przewodności elektrycznej mleka stwierdzono wyrównaną częstotliwość występowania poszczególnych ćwiartek wymienia u pierwiastek i wieloródek. W przypadku mleka o najmniejszej przewodności elektrycznej u pierwiastek kształtowała się ona od 50,38\% (przednie lewe) do 52,62\% (tylne lewe), natomiast u wieloródek od 47,38\% (tylne lewe) do 49,62\% (przednie lewe). Wraz z pogarszającym się stanem zdrowotnym gruczołu mlecznego krów obserwowano stopniowy spadek dobowej produkcji wszystkich jego ćwiartek. Wyraźniejszą reakcję na taki stan odnotowano w obrębie ćwiartek przednich. Ich wydajność uległa obniżeniu o 3,40 kg (lewe) i o 3,02 kg (prawe). Ćwiartki tylne lewe miały mniejszą wydajność o 2,85 kg na dobę, natomiast prawe o $2,18 \mathrm{~kg}$. Wyższy poziom produkcyjny w obrębie wszystkich ćwiartek wymienia, w każdej klasie przewodności elektrycznej, odnotowano u wieloródek. Wraz ze wzrostem przewodności elektrycznej mleka stwierdzono niższą dobową wydajność ćwiartek wymienia, zarówno u pierwiastek, jak i wieloródek. W przypadku ćwiartek przednich lewych i prawych krów najmłodszych spadek ten wyniósł 2,77 i 2,41 kg, natomiast u starszych 4,27 i 4,26 kg. Spadek produkcji mleka ćwiartek tylnych lewych wyniósł u pierwiastek 2,67, a u wieloródek 3,76 kg na dobę, natomiast ćwiartek tylnych prawych odpowiednio 2,01 i 3,86 kg mleka na dobę. 


\title{
ZAWARTOŚĆ WITAMIN LIPOFILNYCH W MLEKU POZYSKANYM OD KRÓW RASY POLSKIEJ CZERWONEJ I SERACH WYTWORZONYCH NA JEGO BAZIE
}

Content of lipophilic vitamins in milk obtained from Polish Red cows and manufactured cheeses

\author{
Aneta Brodziak ${ }^{1}$, Jolanta Król ${ }^{2}$, Joanna Barłowska ${ }^{2}$, Barbara Topyła ${ }^{2}$, Anna Wolanciuk ${ }^{2}$ \\ ${ }^{1}$ Uniwersytet Przyrodniczy w Lublinie, Pracownia Ekologicznej Produkcji Żywności Pochodzenia Zwierzęcego, \\ Instytut Hodowli Zwierząt i Ochrony Bioróżnorodności, ul. Akademicka 13, 20-950 Lublin \\ ${ }^{2}$ Uniwersytet Przyrodniczy w Lublinie, Katedra Towaroznawstwa i Przetwórstwa Surowców Zwierzęcych, \\ ul. Akademicka 13, 20-950 Lublin, e-mail: aneta.brodziak@up.lublin.pl
}

Wysokim statusem bioaktywnym, tj. zawartością substancji bioaktywnych wpływających pozytywnie na funkcjonowanie organizmu człowieka, cechuje się surowiec pozyskiwany zwłaszcza od krów ras lokalnych utrzymywanych w gospodarstwach tradycyjnych. W gospodarstwach tego typu żywienie zwierząt w sezonie wiosenno-letnim oparte jest głównie na pastwiskach z dodatkiem siana i śruty zbożowej, natomiast w sezonie jesienno-zimowym na sianokiszonce, uzupełnianej sianem i śrutą zbożową. Jakość surowca, w tym status bioaktywny, bezpośrednio wpływa na zawartość związków biologicznie czynnych w wytwarzanych produktach. W Polsce większym zainteresowaniem zaczynają się cieszyć produkty wytworzone przez lokalne społeczności, z surowca pozyskiwanego od krów utrzymywanych tradycyjnie. Dotyczy to głównie serów, które są naszą narodową specjalnością. W związku z tym celem pracy było określenie zawartości wybranych witamin lipofilnych, tj. witaminy A (retinolu), $\mathrm{D}_{3}$ (cholekalciferolu) i E (tokoferolu) oraz $\beta$-karotenu (prowitaminy A) w mleku pozyskanym od krów rasy polskiej czerwonej i serach z niego wytworzonych. Materiał do badań stanowiły próbki mleka zbiorczego pobrane z czterech gospodarstwach tradycyjnych usytuowanych w Polsce Południowej, utrzymujących krowy rasy polskiej czerwonej. Próbki mleka pobierano dwukrotnie w ciągu roku. Sery z mleka krów rasy polskiej czerwonej były pozyskane z lokalnej mleczarni specjalizującej się w produkcji serów. Do badań były wytypowane sery podpuszczkowe, dojrzewające. W każdej próbce mleka i serów określono zawartość ww. witamin metodą chromatografii cieczowej w odwróconym układzie faz. Próbki przygotowano w oparciu o ekstrakcję tłuszczu metodą Röse-Gottlieb zmodyfikowaną przez Hewavitharana i in. (1996). Wszystkie badania zostały wykonane w trzykrotnym powtórzeniu. Uzyskane wyniki opracowano statystycznie przy wykorzystaniu programu StatSoft Inc. Statistica ver. 13.1 (Statsoft Inc., 2016). Uzyskano statystycznie istotne $(\mathrm{p} \leq 0,01)$ różnice $\mathrm{w}$ zawartości analizowanych witamin w serach w porównaniu do surowca przerobowego. Mleko zawierało średnio 0,258 mg/l $\beta$-karotenu, $0,525 \mathrm{mg} / \mathrm{l}$ witaminy A, $0,704 \mu \mathrm{g} / \mathrm{l}$ witaminy $\mathrm{D}_{3}$ i $1,530 \mathrm{mg} / \mathrm{l}$ witaminy $\mathrm{E}$. Największe różnice w zawartości witamin lipofilnych w produkcie w stosunku do surowca uzyskano w przypadku witaminy A, której pięciokrotnie więcej było w serach. Ponadto wytworzone sery charakteryzowały się prawie czterokrotnie większą ilością $\beta$-karotenu oraz trzykrotnie - witaminy $\mathrm{D}_{3}$ i E. Można zatem stwierdzić, że zarówno surowiec, jak i produkty mleczne (sery) na bazie mleka pozyskanego od krów rasy polskiej czerwonej, rasy lokalnej utrzymywanej systemem tradycyjnym stanowią cenne źródło składników bioaktywnych występujących we frakcji tłuszczowej - witamin lipofilnych.

Badania wykonano w ramach projektu „Kierunki wykorzystania oraz ochrona zasobów genetycznych zwierząt gospodarskich w warunkach zrównoważonego rozwoju”, współfinansowanego przez Narodowe Centrum Badań i Rozwoju w ramach Strategicznego programu badań naukowych i prac rozwojowych „Środowisko naturalne, rolnictwo i leśnictwo” - Biostrateg, nr umowy: BIOSTRATEG2/297267/14/NCBR/2016. 


\title{
WPEYW SPOSOBU UŻYTKOWANIA GÓRSKICH TRWAŁYCH UŻYTKÓW ZIELONYCH NA RÓŻNORODNOŚĆ FLORYSTYCZNĄ SIEDLISK I DOBROSTAN ZWIERZĄT
}

Impact of the mountain permanent grassland use on floristic diversity of habitats and animal welfare

\author{
Witold Chabuz, Mariusz Kulik, Wioletta Sawicka-Zugaj, Paweł Żółkiewski, Marianna Warda, \\ Michał Pluta, Antoni Lipiec, Andrzej Bochniak
}

\author{
Uniwersytet Przyrodniczy w Lublinie, Instytut Hodowli Zwierząt i Ochrony Bioróżnorodności, \\ Zakład Hodowli i Ochrony Zasobów Genetycznych Bydła, ul. Akademicka 13, 20-950 Lublin \\ e-mail: witold.chabuz@up.lublin.pl
}

Celem badań było określenie wpływu sposobu i intensywności użytkowania trwałych użytków zielonych na szatę roślinną oraz ich wartość pokarmową w kontekście dobrostanu zwierząt. Badania przeprowadzono w 2016 r. w rejonie górskim (500-600 m n.p.m.), bezpośrednio przylegającym do Magurskiego PN i stanowiącym jego otulinę.

Szczegółówej analizie poddano obszary trwałych użytków zielonych (TUZ) zróżnicowane ze względu na sposób użytkowania. 1. Ekstensywny wypas owiec (rasa: polska owca górska) i bydła (rasa: polska czerwona). Na terenie 380 ha prowadzono sezonowy wypas 1400 sztuk owiec oraz 60 sztuk jałowic, trwający od maja do października. Na tym obszarze nie wykonywano żadnych zabiegów agrotechnicznych. 2. Wypas koni (rasa: hucuł) i bydła (rasa: polska czerwono-biała). Na terenie 13,5 ha prowadzono całoroczny wypas 20 jałówek i 10 koni. Stosowano tylko nawozy organiczne, z włókowaniem raz do roku. 3. Użytkowanie przemienne - wypas bydła (rasa: limousine) i koszenie. Na terenie 182 ha prowadzono wypas 120 sztuk krów i jałowic oraz 80 cieląt. Przynajmniej raz w roku wykonywano koszenie, pastwisko było nawożone organicznie i systematycznie podsiewane. 4. Użytkowanie kośne. Badana powierzchnia wynosiła 3,1 ha. Łąkę koszono w zależności od warunków pogodowych 2-3 razy w roku. 5. Brak użytkowania - próba kontrolna.

Wykono łącznie 26 zdjęć fitosocjologicznych metodą Braun-Blanqueta (1964) na powierzchni $25 \mathrm{~m}^{2}$. Analizie fitosocjologicznej poddano 15 zdjęć. Z każdej analizowanej powierzchni pobrano próby roślinności do określenia wartości pokarmowej, podając zawartość białka ogólnego, tłuszczu surowego, włókna surowego, popiołu surowego oraz związków bezazotowych wyciągowych. Określono obsadę oraz maksymalne możliwości pokarmowe badanych użytków zielonych.

Lokalne rasy stanowią szansę rozwoju obszarów wiejskich na terenach chronionych. W oparciu o nie wytwarzane są cenne produkty tradycyjne i regionalne, budzące zainteresowanie konsumentów, a przede wszystkim promujące region i jego kulturę. Rasy rodzime powinny być szeroko promowane ze szczególnym uwzględnieniem obszarów przyrodniczo cennych, gdzie żywe są tradycje ich hodowli i chowu. Wykazano, że ekstensywny wypas zwierząt gospodarskich (owiec, bydła) korzystnie wpłynął na różnorodność biologiczną ekosystemów trawiastych, zapobiegając wtórnej sukcesji lasu i może być wykorzystywany na obszarach przyrodniczo cennych do czynnej ochrony przyrody. 


\title{
BRAKOWANIE I DŁUGOWIECZNOŚĆ KRÓW MLECZNYCH W POLSCE
}

\author{
Culling reasons and longevity of dairy cows in Poland
}

\author{
Rachela Formella, Marta Kaliciak, Maciej Adamski \\ Uniwersytet Przyrodniczy we Wrocławiu, Instytut Hodowli Zwierząt, Zakład Hodowli Bydła i Produkcji Mleka, \\ ul. Chełmońskiego 38C, 50-630 Wrocław \\ e-mail: rachela.formella@up.wroc.pl
}

Długość użytkowania krów mlecznych jest ważnym czynnikiem zarówno pod względem hodowlanym, jak i ekonomicznym. W zrównoważonym rolnictwie, pozwalającym na pokrycie kosztów odchowu jałówek, krowa mleczna powinna być użytkowana przynajmniej przez 5 laktacji. W ostatnich latach większość krów w Polsce użytkowana jest przez zaledwie przez 2-3 laktacje. Obserwowano również wzrost liczby brakowań krów po lub w trakcie pierwszej laktacji. Poprawa cech, takich jak długowieczność poprzez selekcję jest trudna ze względu na niską odziedziczalność oraz negatywną korelację z poziomem wydajności mlecznej.

Brakowanie krów ze stada stanowi jedną z najistotniejszych decyzji w pracy hodowlanej. Procent zwierząt brakowanych w stadzie może być traktowany jako wyznacznik ostrości selekcji oraz warunków zoohigienicznych. Od lat 70. XX w. problemy z zapładnialnością stanowią poważny problem w polskich oborach. Uznawane są za główny powód brakowania krów ze stada. W latach 70 . z powodu problemów z rozrodem brakowane było od 15 do 32\% krów, od lat 80 . współczynnik ten wzrósł do $19-42 \%$.

Choroby wymienia stanowią kolejny bardzo ważny czynnik powodujący brakowanie krów ze stada. Od początku lat 80 . współczynnik ten plasuje się na wysokości od 4,5 do $23 \%$. Kolejnym czynnikiem, który może spowodować decyzje o brakowaniu zwierzęcia ze stada, jest niska wydajność mleczna. Na początku lat 70. brakowano $7,5 \%$ krów z tego powodu. W latach 80 . było to już $10,9-45 \%$. Ten poziom utrzymuje się do dzisiejszych czasów.

Poprawę widać przede wszystkim w kwestii chorób metabolicznych. Poziom brakowania krów z tych względów od lat osiemdziesiątych do 2000 r. plasował się na poziomie 1-14\%, a w niektórych oborach dochodził nawet do 41\%. Jednak od 2000 r. współczynnik ten nie przekracza $10 \%$. Następnym powodem brakowania są schorzenia układu ruchu, w szczególności kończyn. Do niedawna brakowanie krów z tych względów było na poziomie do $12 \%$, jednakże w ostatnich latach wzrosło aż do 30\%. Zmalał natomiast procent brakowania krów z powodów chorób zakaźnych z 54,5\% w latach 70. do około 3\% w chwili obecnej.

Obecnie główną przyczyną brakowania krów mlecznych z polskich stad są problemy z rozrodem. Martwi również wzrost brakowań związanych z problemami układu ruchu, przede wszystkim kulawizną tylnych kończyn. Problem ten zwiększa się wraz ze wzrostem wydajności mlecznej w stadzie. Lata selekcji nakierowanej na wzrost wydajności mlecznej skutkują pogorszeniem innych cech, w tym długowieczności. Długość użytkowania krów ma znaczący wpływ na ekonomikę produkcji mleka. W związku z tym hodowla krów mlecznych w dzisiejszych czasach powinna kierować się w stronę poprawy długowieczności. 


\title{
PRÓBA OPRACOWANIA POPRAWEK NA WYDAJNOŚĆ MLEKA DLA PODSTAWOWEGO SKŁADU CHEMICZNEGO MLEKA KRÓW RASY POLSKIEJ HOLSZTYŃSKO-FRYZYJSKIEJ
}

\author{
An attempt to develop corrections for milk yield for the basic milk chemical composition of cows \\ of Polish Holstein-Friesian breeds
}

\author{
Piotr Guliński, Ewa Salamończyk, Anna Kłopotowska
}

Uniwersytet Przyrodniczo-Humanistyczny w Siedlcach, Katedra Hodowli Bydła, Owiec i Oceny Mleka, ul. Prusa 14, 08-110 Siedlce, e-mail: ewa.salamonczyk@uph.edu.pl

Skład chemiczny mleka krów nie jest stały. Modyfikacja składu chemicznego mleka krów jest efektem występowania szeregu czynników, które na poziomie produkcyjnym konsekwentnie różnicują poziom jego poszczególnych składników. W warunkach krajowych należą do nich: pora roku, wiek krowy, stadium laktacji i ciąża, kondycja w okresie produkcji mleka, choroby (głównie metaboliczne i wymion) oraz stosowane technologie żywienia.

Celem pracy było poszukiwanie odpowiedzi, jaki skład mleka jest typowy dla rasy polskiej holsztyńskofryzyjskiej oraz próba opracowania poprawek na poziom produkcyjny dla podstawowego składu chemicznego. Oceniono dane dotyczące 1329 obserwacji dobowych krów utrzymywanych w 20 stadach bydła mlecznego na terenie powiatu sokołowskiego z lat 2009-2015. W pracy wyodrębniono następujące źródła zmienności dla podstawowego składu chemicznego i wydajności dobowej mleka: okres laktacji (tj. 15 miesięcy laktacji); wiek krów (długość użytkowania krów rozumianą jako ukończoną kolejną laktację określono w granicach 1-7); genotyp (udział krwi rasy polskiej holsztyńsko-fryzyjskiej w genotypach krów); jakość cytologiczna mleka (liczbę komórek somatycznych w tysiącach w $1 \mathrm{ml}$ mleka); poziom żywienia (wykorzystano ocenę stosunku tłuszczowobiałkowego w mleku); sezon wycielenia (jesienno-zimowy i wiosenno-letni); poziom produkcyjny (dobowa wydajność mleka). W obliczeniach statystycznych wykorzystano jednoczynnikową analizę wariancji wykonaną metodą najmniejszych kwadratów. Istotność różnic między średnimi szacowano testem Duncana przy poziomie istotności $\mathrm{P} \leq 0,05$. Do oceny współzależności pomiędzy wydajnością mleka a jego składem chemicznym wykorzystano współczynniki korelacji prostej Pearsona i regresji, określając ich poziom istotności przy $\mathrm{P} \leq 0,01$.

Przeciętna wydajność dobowa w 1329 obserwacjach dobowych wynosiła 22,6 kg. Najwyższą wydajnością dobową charakteryzowały się krowy w 1 miesiącu laktacji $(30,7 \mathrm{~kg})$. Średnia zawartość tłuszczu, białka, laktozy i suchej masy wyniosła odpowiednio: 4,48\%, 3,57\%, 4,74\% i 13,6\%. Zaobserwowano, że najniższy poziom tłuszczu, białka i suchej masy był w 2. miesiącu laktacji, tj. w okresie tzw. szczytu laktacyjnego. Podkreślić należy, że otrzymano dla wydajności mleka i procentowej zawartości tłuszczu, białka i suchej masy wysokie i negatywne współczynniki korelacji $r$, które ukształtowały się odpowiednio: $-0,47,-0,49$ i-0,49. Wyliczone następnie współczynniki regresji wykazały, że w ocenianej populacji bydła mlecznego wzrost wydajności dobowej mleka o $1 \mathrm{~kg}$ związany był ze spadkiem procentowej zawartości tłuszczu, białka i suchej masy o odpowiednio: $-0,03,-0,02$ i $-0,05$. Uzyskane dane prowadzą do jednoznacznego wniosku o nieistotnym oddziaływaniu wieku krowy, jej genotypu i sezonu wycielenia na procentową zawartość tłuszczu, białka i suchej masy w mleku.

Wyniki analiz dotyczące poszukiwania odpowiedzi, który z czynników w populacji kompleksowej bydła rasy polskiej holsztyńsko-fryzyjskiej prowadzi do szczególnie istotnego zróżnicowania składu chemicznego mleka, wykazały, że stan zdrowotny gruczołu mlekowego określany liczbą komórek somatycznych w $1 \mathrm{ml}$ oraz zbilansowanie dawek pokarmowych, interpretowane wielkością stosunku tłuszczowo- białkowego, należą do głównych czynników prowadzących do zmian w podstawowym składzie chemicznym mleka krów rasy phf. Stwierdzono także, że oddziaływanie poziomu produkcyjnego na podstawowy skład chemiczny mleka jest bardzo istotne. 


\title{
WPŁYW DAWKI WZBOGACONEJ W RÓŻNE ŹRÓDŁA B-KAROTENU NA WYNIKI PRODUKCYJNE KRÓW, WYNIKI ROZRODU ORAZ WYBRANE WSKAŹNIKI ZDROWIA
}

\begin{abstract}
The effect of the diets enriched in different sources of $\beta$-carotene on milk production, reproduction results
\end{abstract} and selected health indicators of the cows

\author{
Gabriela Halik, Andrzej Łozicki, Mateusz Makarski
}

\begin{abstract}
Szkoła Główna Gospodarstwa Wiejskiego w Warszawie, Katedra Żywienia i Biotechnologii Zwierząt, Zakład Żywienia Zwierząt, e-mail: gabrysiahalik@wp.pl
\end{abstract}

Badania przeprowadzono na 30 krowach rasy simental, podzielonych na trzy grupy. Zwierzęta wybierano do grup wg analogów: wiek, kolejność laktacji, produkcja mleka i masa ciała. Na cztery tygodnie przed przewidywanym wycieleniem krowy otrzymywały dawki doświadczalne dla krów zasuszonych na okres przejściowy. Po wycieleniu modyfikowano skład i wartość pokarmową dawek, dostosowując je do potrzeb pokarmowych krów w laktacji. W grupie I (kontrolnej) w okresie zasuszenia i laktacji podstawą dawki były kiszonki z traw i kukurydzy uzupełnione paszą treściwą. W grupie II do dawek analogicznych jak w grupie I wprowadzano $400 \mathrm{mg} /$ dzień /krowę syntetycznego $\beta$-karotenu. Do dawki pokarmowej w grupie III, zarówno w okresie zasuszenia, jak i laktacji, wprowadzano kiszonkę z dyni, która zastępowała $40 \%$ s.m. kiszonki z kukurydzy, tak aby w dawce uzyskać zawartość $\beta$-karotenu o 400 mg wyższą względem grupy kontrolnej.

Materiał badawczy stanowiła krew oraz mleko. Krew pobierano trzy razy: w pierwszym dniu po wycieleniu oraz w 4. i 12. tygodniu laktacji. Produkcję mleka i jego skład badano w 4., 8. i 12. tygodniu laktacji. Próbki mleka pobierano również w 23. dniu po inseminacji. Określono podstawowy skład mleka oraz zawartość w nim komórek somatycznych. We krwi oznaczano parametry morfologiczne, w surowicy - stężenie kwasu $\beta$-hydroksymasłowego (BHM). Analizowano także wybrane wskaźniki rozrodu krów: wystąpienie pierwszej rui, długość okresu międzyciążowego oraz stężenie progesteronu w mleku w 23. dniu po inseminacji.

W kolejnych pomiarach nie stwierdzono wpływu dawek na produkcję mleka oraz zawartość w nim białka, tłuszczu i laktozy. Podczas wszystkich pomiarów w grupie I zaznaczała się większa zawartość komórek somatycznych niż w grupie II i III, a w 8. tygodniu laktacji różnica pomiędzy grupą I a III była istotna statystycznie. Tuż po wycieleniu we krwi krów z grupy I stwierdzono istotnie niższą liczbę krwinek czerwonych (RBC) niż we krwi krów z grupy II. W 4. tygodniu laktacji u krów z grupy I stwierdzono niższy hematokryt (HCT) i mniejszą średnią zawartość hemoglobiny w krwince czerwonej (MCH) niż w grupie II i III.

Również w 12. tygodniu laktacji w grupie I w porównaniu z II i III była istotnie mniejsza liczba RBC (czerwone krwinki), a także niższy HCT (hematokryt). W grupie II w porównaniu z I i III stwierdzono zaś istotnie wyższe MCH (średnia masa hemoglobiny w krwince czerwonej) i MCHC (średnie stężenie hemoglobiny w krwince czerwonej).

Również w 12. tygodniu laktacji w grupie I w porównaniu z II i III był istotnie mniejszy RBC oraz HCT. W grupie II w porównaniu z I i III stwierdzono zaś istotnie wyższy MCH. Podczas wszystkich pomiarów najwyższe stężenie BHM w surowicy występowało w grupie kontrolnej, ale tylko tuż po wycieleniu różnica była istotna statystycznie w stosunku do grupy II. U krów z grupy II i III w porównaniu z krowami z grupy I stwierdzono istotnie lepsze badane wskaźniki rozrodu - wcześniejsze wystąpienie 1. rui, krótszy okres międzyciążowy, a także wyższe stężenie progesteronu w 23. dniu po inseminacji. 


\title{
KORELACJE GENETYCZNE MIĘDZY PRZEBIEGIEM PORODÓW A CECHAMI PRODUKCYJNYMI I POKROJU BYDŁA RASY POLSKIEJ HOLSZTYNSSKO-FRYZYJSKIEJ
}

\begin{abstract}
Genetic correlations between calving ease and production and type traits in Polish Holstein-Friesian cattle
\end{abstract}

\author{
Magdalena Jakiel
}

\author{
Zakład Hodowli Bydła, Instytut Zootechniki - Państwowy Instytut Badawczy, ul. Krakowska 1, 32-083 Balice \\ e-mail: magdalena.jakiel@izoo.krakow.pl
}

\begin{abstract}
Celem pracy było oszacowanie korelacji genetycznych między przebiegiem porodów a wydajnością mleka, tłuszczu i białka, wysokością w krzyżu, głębokością tułowia, szerokością i ustawieniem zadu u pierwiastek rasy polskiej holsztyńsko-fryzyjskiej odmiany czarno-białej. Materiał do badań stanowiły wartości hodowlane buhajów - ojców cieląt i ojców krów - dla przebiegu porodów oraz wartości hodowlane buhajów dla cech produkcyjnych i pokroju. Ojcami cieląt było 585 buhajów, a ojcami krów - 641. Wartość hodowlana buhajów była oceniona na podstawie przynajmniej 50 pierwszych ocieleń ich córek lub unasiennionych przez nie krów. Przebieg porodów klasyfikowano wg trzech kategorii: 3) samodzielny $(28,97 \%)$, 2) łatwy $(65,93 \%)$ i 1$)$ trudny $(5,10 \%)$. Częstości występowania poszczególnych kategorii przebiegu ocieleń są zbliżone do frekwencji notowanych w populacjach bydła holsztyńsko-fryzyjskiego w Europie i Stanach Zjednoczonych. Dane pochodziły z systemu SYMLEK (PFHBiPM). Przybliżone korelacje genetyczne oszacowano za pomocą metody Calo i in. (1973), obliczając korelacje między wartościami hodowlanymi buhajów dla przebiegu porodów a wartościami hodowlanymi dla cech produkcyjnych i pokroju. Wartości hodowlane buhajów dla efektu bezpośredniego i matczynego przebiegu porodów oszacowano za pomocą metody BLUP, według modelu progowego ojca i ojca matki (sire - maternal grandsire model), uwzględniającego stałe efekty: roku-sezonu ocielenia, płci cielęcia, wieku ocielenia, roku urodzenia ojca cielęcia i ojca krowy - matki cielęcia. Wartości hodowlane buhajów dla cech produkcyjnych i pokroju pochodziły z rutynowej oceny 2015/1 (http://wycena.izoo.krakow.pl/). Współczynniki korelacji genetycznej między bezpośrednimi wartościami hodowlanymi (ojców cieląt) dla przebiegu porodów a cechami wydajności były dodatnie i mieściły się w zakresie od 0,073 do 0,128 . W przypadku cech pokroju korelacje przebiegu porodu z wysokością w krzyżu i szerokością zadu były zbliżone do zera, nieco wyższe i ujemne były korelacje z głębokością tułowia $(-0,105)$ i ustawieniem zadu $(-0,189)$. Korelacje genetyczne dla efektów matczynych (na podstawie wartości hodowlanych ojców krów-matek) obliczone dla zbadania zależności między przebiegiem ocielenia a cechami produkcji były niskie: 0,187 dla wydajności tłuszczu i 0,155 dla wydajności białka. Wszystkie korelacje między efektami matczynymi dla przebiegu porodów a cechami pokroju okazały się bliskie zera (wysokość w krzyżu 0,074, głębokość tułowia 0,009, szerokość zadu 0,093 i ustawienie zadu 0,030). Przybliżone dodatnie korelacje genetyczne dla efektów matczynych między przebiegiem ocieleń a cechami wydajności tłuszczu i białka mieszczące się w granicach między 0,12 a 0,18 wskazują na brak wyraźnego związku trudnych ocieleń z większą wartością hodowlaną ojców krów matek pod względem cech produkcyjnych. W zakresie cech pokroju stwierdzono niewielką zależność ujemną między wartościami hodowlanymi ojców cieląt dla przebiegu porodu a głębokością tułowia i ustawieniem zadu.
\end{abstract}




\title{
ZWIĄZEK POMIĘDZY DŁUGOŚCIĄ OKRESU ZASUSZENIA A WYBRANYMI CECHAMI UŻYTKOWOŚCI MLECZNEJ KRÓW SIMENTALSKICH
}

Relationship between the dry period length and some milking performance traits of Simmental cows

\author{
Ewa Januś ${ }^{1}$, Piotr Stanek ${ }^{1}$, Paweł Żółkiewski ${ }^{2}$, Krystian Rokosz $^{1}$ \\ ${ }^{1}$ Uniwersytet Przyrodniczy w Lublinie, Instytut Hodowli Zwierząt i Ochrony Bioróżnorodności, \\ Pracownia Ekologicznej Produkcji Żywności Pochodzenia Zwierzęcego, ul. Akademicka 13, 20-950 Lublin \\ ${ }^{2}$ Uniwersytet Przyrodniczy w Lublinie, Instytut Hodowli Zwierząt i Ochrony Bioróżnorodności, \\ Zakład Hodowli i Ochrony Zasobów Genetycznych Bydła, ul. Akademicka 13, 20-950 Lublin \\ e-mail: ewa.janus@up.lublin.pl
}

W okresie zasuszenia w gruczole mlekowym następuje wymiana komórek nabłonkowych, które mają związek z wydajnością mleka w następnej laktacji. Jest to jeden z powodów poszukiwania związku pomiędzy długością okresu zasuszenia krów a ich wydajnością w kolejnej laktacji. O randze ważności okresu zasuszenia w całym życiu produkcyjnym krowy może świadczyć fakt, że niektórzy badacze i praktycy stoją na stanowisku, że pierwszy dzień zasuszania powinien być traktowany nie jako zakończenie bieżącej laktacji, ale jako pierwszy dzień nowej laktacji. Wiele badań przeprowadzonych w populacjach krów jednostronnie mlecznych sugeruje, że ze względu na wydajność w następnej laktacji najkorzystniejszy jest 40-60-dniowy okres zasuszenia. Wskazywano także na negatywne konsekwencje zarówno skracania i wydłużania, jak i pomijania okresu zasuszenia. Istnieją również badania, które dowodzą, że skrócenie okresu zasuszenia do 30 dni nie zmniejszyło produkcji mleka w następnej laktacji.

Celem pracy była analiza wpływu długości okresu zasuszenia na wydajność i skład mleka w standardowych i pełnych laktacjach krów simentalskich. W pracy wykorzystano wyniki oceny wartości użytkowej prowadzonej w stadzie krów rasy simentalskiej. Stado utrzymywano w oborze wolnostanowiskowej i żywiono mieszankami pełnoporcjowymi TMR. Analizą objęto 85 cykli (okresów zasuszenia i laktacji). W zakresie długości zasuszenia wyszczególniono 3 grupy: do 50 dni, 51-60 i powyżej 60 dni. Wyniki opracowano statystycznie przy użyciu programu Statistica ver. 9.0 w oparciu o jednoczynnikową analizę wariancji. Istotność różnic pomiędzy średnimi wartościami analizowanych cech oceniono testem Duncana.

Stwierdzono, że przeszło połowa krów $(54,12 \%)$ zasuszana była na ponad 60 dni. Zbliżony odsetek krów (22,35 i 23,53\%) charakteryzował się okresem zasuszenia długości odpowiednio do 50 i 51-60 dni. Długość tego okresu miała istotny wpływ na długość laktacji oraz wydajność mleka. Krowy zasuszane na nie dłużej niż 50 dni miały dłuższe laktacje w porównaniu z pozostałymi krowami. Nie znalazło to odzwierciedlenia w wydajności za 305 dni doju oraz w laktacji pełnej. Najkorzystniej pod tym względem wypadły krowy, u których długość przerwy międzylaktacyjnej przekraczała 60 dni. W ciągu 305 dni doju pozyskiwano od nich niemal $6594 \mathrm{~kg}$ mleka. W laktacjach pełnych ich przeciętna wydajność przekraczała $7912 \mathrm{~kg}$ mleka. Wyraźne różnice $\mathrm{w}$ zależności od długości okresu zasuszenia obserwowano również w wydajności i zawartości podstawowych składników mleka. Stwierdzono, że wraz z wydłużaniem okresu zasuszenia zwiększała się zawartość tłuszczu i białka w mleku. Zanotowano również wzrost zawartości suchej masy w mleku towarzyszący wydłużaniu okresu zasuszenia krów. Zwiększała się od 12,7\% u krów zasuszonych na nie więcej niż 50 dni do 13,7\% u krów z najdłuższym (>60 dni) okresem zasuszenia. 


\title{
GENETYCZNA ANALIZA CECH POKROJU NÓG I RACIC BYDŁA SIMENTALSKIEGO W POLSCE
}

Genetic analysis feet and legs conformation traits for Simmental cattle in Poland

\author{
Olga Jarnecka, Wojciech Jagusiak
}

\author{
Uniwersytet Rolniczy im. Hugona Kołłątaja w Krakowie, Katedra Genetyki i Metod Doskonalenia Zwierząt \\ e-mail: o.jarnecka@gmail.com
}

Bydło simentalskie hodowane w Polsce jest rasą o podwójnym typie użytkowania i od wielu lat nieprzerwanie doskonaloną w kierunku poprawy zarówno cech mlecznych, jak i mięsnych. Jednostronna selekcja prowadzona wyłącznie w kierunku doskonalenia cech produkcyjnych skutkuje pogorszeniem płodności, odporności na choroby i żywotności zwierząt, a w konsekwencji przedwczesnym brakowaniem i zmniejszeniem opłacalności hodowli. Obecnie doskonalenie genetyczne bydła tej rasy wiąże się więc ze zwiększaniem wydajności i z równoczesną poprawą cech funkcjonalnych. Cechy te nie są bezpośrednio związane z produkcyjnością, ale w znacznej mierze współdecydują o opłacalności hodowli zwierząt. Do grupy cech funkcjonalnych zalicza się cechy pokroju, płodności, długowieczności. Liczne badania naukowe i spostrzeżenia hodowców wskazują, że ważnym czynnikiem wpływającym na użytkowość produkcyjną krów jest prawidłowa budowa nóg i racic. Choroby nóg i racic są jednym z najczęstszych powodów brakowania krów.

Cechy pokroju są na ogół nisko lub umiarkowanie odziedziczalne: współczynniki odziedziczalności cech budowy nóg i racic wahają się w polskiej populacji bydła holsztyńsko-fryzyjskiego od 0,09 do 0,11, jednak liczne badania na krowach tej rasy potwierdzają korzystne korelacje fenotypowe i genetyczne pomiędzy cechami związanymi z budową nóg i racic a innymi cechami funkcjonalnymi oraz produkcyjnymi. Według badań autorów odziedziczalności cech budowy nóg i racic u rasy simentalskiej są wyższe i wynoszą od 0,07 do 0,26 .

Celem pracy było oszacowanie parametrów genetycznych cech budowy nóg i racic dla populacji polskiego bydła simentalskiego. Badania zostały przeprowadzone na danych przekazanych z Polskiej Federacji Hodowców Bydła i Producentów Mleka, wyodrębnione z Systemu Automatycznej Oceny Hodowlanej Krów SYMLEK z lat 1996-2013. W analizie uwzględnione zostały cechy opisowe nóg i racic oraz cztery cechy liniowe: postawa nóg tylnych widok z tyłu, postawa nóg tylnych widok z boku, racice i lokomocja.

Trendy genetyczne dla cech pokroju nóg i racic dla populacji były niekorzystne. Korzystne trendy odnotowano jedynie w przypadku racic i postawy nóg tylnych widok z tyłu. Korelacje genetyczne między cechami pokroju nóg i racic były ogólnie duże. 


\title{
EFEKTYWNOŚĆ ŻYWIENIA KRÓW MLECZNYCH W WYBRANYCH GOSPODARSTWACH INDYWIDUALNYCH ŚRODKOWO-WSCHODNIEJ POLSKI
}

The efficiency of dairy cows nutrition in chosen individual farms of central-eastern Poland

Renata Klebaniuk, Bożena Kiczorowska, Edyta Kowalczuk-Vasilev, Wioleta Samolińska, Maciej Bąkowski, Eugeniusz R. Grela, Anna Danek-Majewska, Małgorzata Kwiecień, Anna Winiarska-Mieczan, Magdalena Olcha, Robert Krusiński, Antoni Lipiec, Bogdan Szostak, Justyna Widz, Stanisław Pecka

\begin{abstract}
Uniwersytet Przyrodniczy w Lublinie, Instytut Żywienia Zwierząt i Bromatologii, ul. Akademicka 13, 20-950 Lublin e-mail: bozena.kiczorowska@up.lublin.pl; renata.klebaniuk@up.lublin.pl
\end{abstract}

W żywieniu krów jednym z najważniejszych czynników gwarantujących optymalną produkcyjność jest ilość i jakość pasz pobieranych przez krowy w dawkach pokarmowych, które pokrywają ich zapotrzebowanie warunkujące wydajność i skład mleka. Za cel pracy przyjęto analizę efektywności żywienia krów mlecznych w okresie laktacji, oceniając jakość pasz w dawkach pokarmowych oraz wydajność i skład mleka krów.

Badania przeprowadzono w 8 prywatnych gospodarstwach rolnych, położonych na terenie województwa lubelskiego i podlaskiego. Obserwacje prowadzono w okresie od września 2017 do stycznia $2018 \mathrm{r}$. W analizowanych gospodarstwach krowy rasy holsztyńsko-fryzyjskiej odmiany czarno-białej utrzymywane były w oborach wolnostanowiskowych. Średnia liczebność stad wynosiła 110 sztuk bydła, w tym średnio 55 krów mlecznych. Powierzchnia gospodarstw wahała się w granicach $45-80$ ha, z czego średnio około 30\% powierzchni przeznaczone było pod uprawę kukurydzy na kiszonkę, do $40 \%$ stanowiły użytki zielone, a na około $30 \%$ uprawiano zboża.

Krowy w gospodarstwach objętych badaniami żywione były w systemie TMR, wspomaganym komputerową stacją żywienia zwierząt. Żywienie oparte było na modelu całorocznym z wykorzystaniem takich samych pasz w okresie całego roku. TMR podawany był raz dziennie i bydło miało do niego stały dostęp. Skład TMR-u opierał się na kiszonce z całych roślin kukurydzy, wysłodków buraczanych mokrych, kiszonych (opcjonalnie) oraz sianokiszonce. Skład chemiczny pasz skarmianych w gospodarstwach oraz ich wartość pokarmowa były charakterystyczne dla ich rodzaju i zbliżone do danych z literatury. Stada krów w gospodarstwach, w których przeprowadzono badania, zwykle podzielone były na 5 grup produkcyjnych na podstawie dni laktacji, zgodnie z tabulogramem oceny użytkowości mlecznej (tab. 1).

Tabela 1. Średnie wskaźniki produkcyjne

\begin{tabular}{|l|c|c|c|c|}
\hline \multicolumn{1}{|c|}{ Stadium laktacji } & Liczba krów [szt.] & Wydajność mleka [kg] & Zawartość tłuszczu [\%] & Zawartość białka [\%] \\
\hline $1-40 \mathrm{dni}$ & 6,5 & 32,1 & 4,32 & 3,31 \\
\hline $41-100 \mathrm{dni}$ & 18 & 32,2 & 4,10 & 3,28 \\
\hline 101-200 dni & 14,5 & 26,6 & 4,59 & 3,56 \\
\hline Powyżej 200 dni & 16,0 & 24,2 & 4,57 & 3,86 \\
\hline Stado, średnio & 55 & 27,5 & 4,45 & 3,60 \\
\hline
\end{tabular}

W przeprowadzonych badaniach stwierdzono, że skład oraz jakość pasz były prawidłowe i charakterystyczne dla ich rodzaju. Wydajność krów mlecznych w analizowanych gospodarstwach, skład i jakość mleka nie odbiegały zasadniczo od wartości średnich dla krów rasy polskiej holsztyńsko-fryzyjskiej, odmiany czarno-białej w dobrej kondycji fizycznej. 


\title{
DEPENDENCE OF THE LONGEVITY OF COWS UKRAINIAN BROWN DAIRY BREED FROM ESTIMATION OF LINEAR TRAITS OF CONFORMATION TYPE
}

\author{
Uzależnienie czasu życia krów ukraińskiej brązowej rasy mlecznej od oceny cech liniowych \\ typu zewnętrznego
}

\author{
Volodymyr Ladyka, Leontyi Hmelnychyi, Serhii Hmelnychyi
}

\author{
Sumy National Agrarian University, Biological Technological Faculty, 160 Herasym Kondratiev, Sumy, 40021, Ukraine \\ e-mail: khmelnychy@ukr.net
}

The practice of zootechnics has shown that longevity of dairy cattle under conditions of industrial maintenance largely depending on the strength of limbs. Due to the existence of a positive correlation between linear type traits and longevity indicators, a sufficient level of heritability of conformation traits and the ability to estimate animals in the first lactation, linear type traits can be used as predictors of life expectancy (Zavadilová et al. 2009, Wiggans et al. 2006, Vukasinovic et al. 2002, Esteves et al. 2004, Getu and Misganaw 2015). The purpose of research was to study the relationship between estimation of linear traits of the conformation, characterizing the condition of limbs, and the longevity of cows of Ukrainian Brown dairy breed. A linear assessment was performed on a 9-point scale in accordance with ICAR's recommendations. In this study 4 linear type traits: rear legs side view (RLSV), rear legs rear view (RLRV), foot angle (FA), and locomotion (L) were considered. The list of experimental data included indicators about productive and linear traits of 489 cows collected from January 1, 2006 to December 31, 2016 on the farms of Sumy region. The longevity of cows was calculated as the number of days between the date of birth and the date of withdrawal.

According to the research results, the desired condition of the hock joint angle with an estimate in 5 scores varied within the range of $146-148^{\circ}$, with optimal development for cows. According to results of research, was found that the angle of pelvic limbs significantly affected on the longevity of cows. The highest longevity had animals with an estimate for optimal development of trait in 5 scores. Animals with 1-4 scores had a higher risk of culling, than with an assessment in 6-9 scores. Cows with optimal development of the trait were used in the herd, compared to groups of animals with 1-4 scores on 126-831 days longer (P $<0,01-0,001)$ and with an assessment in 7-9 scores on 286-505 days longer $(\mathrm{P}<0,001)$.

The results of studies of posture of pelvic limbs (rear view) also showed their impact on longevity of cows. The longest were used in the herd animals with an assessment of the trait in 7-9 scores (2672-2718 days). With a decrease from 6 (2,574 days) to 1 score (1,969 days), an adequate decrease in the longevity was observed.

The health and life of dairy cows essentially depending on the strength of hoof horn. Animals with the highest 9 score lived 2,659 days, or on 605 days longer than animals with 1 score $(\mathrm{P}<0,001)$.

According to the assessment of locomotion trait, cows with a 9 score were used 2,712 days or on 777 days $(\mathrm{P}<0,001)$ longer, compared to animals with 1 score. In general, assessing the average longevity of cows depending on the score level for locomotion trait, was found that more resilient cows with estimate in 5 scores $-2,448$ (days) and above.

The phenotypic association between linear traits of limbs and life expectancy of cows Ukrainian Brown dairy breed was a predictor of longevity, allowing use of indirect selection cows by type. 


\section{HISTORICAL ASPECTS OF THE CREATION, DEVELOPMENT AND PRESERVATION OF LEBEDINSKA BREED AT THE PRESENT STAGE}

Historyczne aspekty tworzenia, rozwoju i zachowania rasy lebedyńskiej w okresie współczesnym

Volodymyr Ladyka, Leontyi Hmelnychyi, Yuliya Pavlenko, Yuri Skliarenko

Sumy National Agrarian University, Biological Technological Faculty, 160 Herasym Kondratiev, Sumy, 40021, Ukraine

e-mail: jasjulia@ukr.net

Lebedinska breed of cattle of Ukraine was created by the method of prolonged mass interbreeding crossing of Algau bulls and Swiss breeds of Switzerland with animals of local gray Ukrainian cattle. At the time of approval (1950) the number of animals was 49 thousand heads. Lebedins' combined sufficient milk production at that time $(5000 \mathrm{~kg})$, fatty milk $(3.80-4.00 \%)$, protein content $(3.4-3.5 \%)$, good meat quality of the Swiss breed and adaptation to the local conditions of the gray Ukrainian breed. In addition, the animals were adapted to local conditions, endurance and good resistance.

Then the breeding work with Lebedinska breed was aimed at improving the exterior type while preserving fatty and protein-rich milk. The method of introductory cross-breeding with jersey was used partially to create a fat-milk line. In the 80 years of the last century, Lebedinska breed was turn out not competitive in the conditions of industrial technology of milk production, which required the improvement of the technological qualities of the udder. Therefore, from this period, Lebedinska breed were began be crossed with Swiss breed of German and Austrian breeding. In 1995, there were 250 thousand of domestic animals, including 140 thousand cows. And in 2009, the Ukrainian brown milk breed was approved. Lebedinska breed was preserved only in separate herds.

At present, 806 heads of cattle of Lebedinska breed, including 400 cows, are counted in basic farms of Ukraine. The milk yield is $4279-7946 \mathrm{~kg}$, the fat content is $3.76-3.91 \%$ depending on lactation and herds. The yield of calves per 100 cows is $85-88$ heads, the average service-period is $130-150$ days. The live weight of the first-born is within 489-495 kg. Periodically, an assessment of the exterior characteristics of animals is carried out. The degree of phenotypic consolidation cows of different lines for signs of milk production. Studied connectivity most common line Elegant 148551 other structural units of the breed. The genealogical structure of uterine livestock included representatives of nine lines of Lebedinska origin, descendants of thirteen bulls-inseminators. A characteristic feature is the presence of a significant number of livestock belonging to Swiss breed lines - within the range of 53.0-57.0\%.

A small number of bulls-inseminators of Lebedinska breed, whose semen is stored in breeding centers, does not allow completely prevent inbreeding, which can lead to undesirable breeding consequences.

As it was mentioned, the gray Ukrainian breeds and various kinds of the Swiss breed were the starting breeds during the creation of Lebedinska breed. Therefore, in our opinion, the use of bulls-inseminators of these kinds will allow to widen the genealogical structure of Lebedinska breed and to avoid unwanted inbreeding in the further work with pedigrees, whose semen is stored in the breeding enterprises of Ukraine.

Therefore, we have proposed a fundamentally new scheme for reproduction of the genealogical structure of Lebedinska breed herds, namely, the work by the method of population of reciprocal reproduction. Swiss breed, which participated in the creation of Lebedinska, including its original OBV kinds, can be added to the process of preserving Lebedinska breed. 


\title{
AKWAPORYNY (AQPS) W NERKACH BYDEA
}

\author{
Aquaporins (AQPS) in the bovine kidney \\ Katarzyna Michałek ${ }^{1}$, Marta Grabowska ${ }^{2}$ \\ ${ }^{1}$ Zachodniopomorski Uniwersytet Technologiczny w Szczecinie, Katedra Fizjologii, Cytobiologii i Proteomiki \\ ${ }^{2}$ Pomorski Uniwersytet Medyczny, Katedra Histologii i Biologii Rozwoju \\ e-mail: kmichalek@zut.edu.pl
}

Utrzymanie wewnętrznej homeostazy organizmu, w tym właściwego bilansu wodno-elektrolitowego i gospodarki kwasowo-zasadowej jest warunkiem zachowania zdrowia i dobrej kondycji zarówno ludzi, jak i zwierząt. U podstaw tych procesów leży efektywny transport wody i innych małych cząsteczek poprzez dwuwarstwowa błonę lipidową. Dwukierunkowy przepływ wody i innych substancji, tj. glicerolu, amoniaku i mocznika umożliwiają zlokalizowane w błonach komórkowych akwaporyny (AQPs). U ssaków zidentyfikowano 13 izoform tego białka (AQP0 - AQP12), z czego aż 9 (AQP1, AQP2, AQP3, AQP4, AQP5, AQP6, AQP7, AQP8 i AQP11) zlokalizowanych jest w poszczególnych odcinkach kanalików nerkowych. Z dotychczasowych badań przeprowadzonych u ludzi i zwierząt laboratoryjnych jednoznacznie wynika, że akwaporyny są zaangażowane w nerkową regulację bilansu wodno-elektrolitowego i gospodarki kwasowozasadowej, a każde nieprawidłowości związane z dystrybucją oraz ekspresją tych białek często są przyczyną zaburzeń czynności nerek. Niestety, pomimo dynamicznie rozwijającej się nauki i pojawiających się ciągle nowych informacji w tym zakresie, wciąż niewiele wiadomo na ten temat u zwierząt gospodarskich, $\mathrm{w}$ tym bydła. W związku z tym podjęto się badań, których celem było z zastosowaniem immunohistochemii (IHC) oraz western blot (WB) precyzyjne zlokalizowanie i określenie ekspresji AQPs w nabłonku kanalików nerkowych bydła. Badania przeprowadzono na 8 cielętach buhajkach rasy polskiej holsztyńsko-fryzyjskiej odmiany czarno-białej, w wieku 5-7 miesięcy. Na podstawie dotychczas uzyskanych wyników w nerkach badanych zwierząt potwierdzono obecność oraz precyzyjnie określono lokalizacje i ekspresje 8 akwaporyn (AQP1, AQP2, AQP3, AQP4, AQP5, AQP7, AQP8 i AQP11). Uzyskane wyniki pozwalają na stwierdzenie, że pomimo nieco odmiennej lokalizacji i ekspresji określonych izoform AQPs białka te również u tego gatunku zwierząt będą odgrywały istotną rolę w regulacje bilansu wodno-elektrolitowego i gospodarki kwasowo-zasadowej. 


\title{
ZMIANY W SKŁADZIE I JAKOŚCI MLEKA POZYSKANEGO W DWÓCH SYSTEMACH UTRZYMANIA KRÓW
}

The changes in the composition and quality of milk obtained in two cow keeping conditions

\author{
Jan Miciński, Janina Pogorzelska, Kinga Grabowska
}

Uniwersytet Warmińsko-Mazurski w Olsztynie, Katedra Hodowli Bydła i Oceny Mleka, ul. Oczapowskiego 5, 10-719 Olsztyn e-mail: micinsk@uwm.edu.pl

Do najważniejszych kwasów tłuszczowych o pożądanym działaniu prozdrowotnym zalicza się m.in. kwas oleinowy (z rodziny n-9), który blokuje wchłanianie cholesterolu pokarmowego, obniża zawartość LDL cholesterolu oraz zmniejsza lepkość krwi i wpływa na obniżenie ciśnienia krwi (Carriquiry i in. 2009). Kwas linolowy (z rodziny n-6) jest prekursorem niektórych kwasów z rodziny n-3, które są niezbędne do normalnego wzrostu i rozwoju organizmu, zapobiegają niewydolności wieńcowej serca, zwiększają odporność organizmu, uczestniczą w transporcie lipidów, w tym cholesterolu, a także obniżają poziom cholesterolu we krwi obwodowej.

W badaniach dokonano porównania składu jakości mleka z uwzględnieniem kwasów tłuszczowych w mleku 2 grup krów rasy polskiej holsztyńsko-fryzyjskiej utrzymywanych w alkierzu (A) i na pastwisku (P).

Tabela 1. Skład i cechy fizykochemiczne mleka

\begin{tabular}{|l|c|c|c|c|}
\hline \multirow{2}{*}{ Cechy } & \multicolumn{2}{c|}{ A } & \multicolumn{2}{c|}{ P } \\
\cline { 2 - 5 } & LSM & Sd & LSM & 0,38 \\
\hline Sucha masa [\%] & 13,09 & 0,66 & 12,92 & 0,14 \\
\hline Białko [\%] & 3,08 & 0,06 & $3,41^{\mathrm{x}}$ & 0,29 \\
\hline Tłuszcz [\%] & $4,42^{\mathrm{x}}$ & 0,57 & 3,96 & 0,46 \\
\hline WKT [g/100 g mleka] & $5,52^{\mathrm{x}}$ & 0,92 & 4,63 & 0,001 \\
\hline Gęstość [g/cm ${ }^{3}$ ] & 1,032 & 0,002 & 1,032 & 0,04 \\
\hline pH & 6,74 & 0,06 & 6,73 & \\
\hline
\end{tabular}

Istotność różnic: ${ }^{\mathrm{x}} \mathrm{p} \leq 0,05$

Tabela 2. Zawartość kwasów tłuszczowych mleka [g/100 g tłuszczu]

\begin{tabular}{|c|c|c|c|c|}
\hline \multirow{2}{*}{ Cechy } & \multicolumn{2}{|c|}{ A } & \multicolumn{2}{|c|}{$\mathrm{P}$} \\
\hline & LSM & $\mathrm{Sd}$ & LSM & $\mathrm{Sd}$ \\
\hline SFA & $71,20^{x}$ & 12,34 & 61,78 & 11,30 \\
\hline MUFA & 25,48 & 2,44 & 33,03 & 2,89 \\
\hline PUFA & 3,32 & 0,89 & $5,19^{x}$ & 0,78 \\
\hline \multicolumn{5}{|c|}{ Wybrane kwasy } \\
\hline Linolowy & 1.39 & 0,10 & $1,92^{x}$ & 0,02 \\
\hline Linolenowy & 0,34 & 0,03 & $0,70^{x}$ & 0,03 \\
\hline CLA & 0,72 & 0,04 & $1,61^{\mathrm{xx}}$ & 0,14 \\
\hline Wakcenowy & 1,44 & 0,06 & $3,37^{x}$ & 0,29 \\
\hline Oleinowy & 18,68 & 2,14 & $24,45^{x}$ & 0,43 \\
\hline
\end{tabular}

Istotność różnic: ${ }^{\mathrm{xx}} \mathrm{p} \leq 0,01,{ }^{\mathrm{x}} \mathrm{p} \leq 0,05$

Wykazano, że mleko krów utrzymywanych w alkierzu odznaczało się większą zawartością suchej masy $(13,09 \%)$ i tłuszczu $(4,42 \%)$. Zawartość kwasów tłuszczowych (WKT) w mleku tych krów przewyższała o 0,89 g/100g tłuszczu ich zawartość w mleku krów żywionych pastwiskowo, co potwierdzono statystycznie $(\mathrm{p} \leq 0,05)$. Wykazano korzystny wpływ żywienia pastwiskowego krów na zawartość pożądanych kwasów 
tłuszczowych nienasyconych (MUFA i PUFA). Statystycznie istotna różnica $(\mathrm{p} \leq 0,05)$ dotyczyła kwasów PUFA. W przeprowadzonych badaniach mleko krów żywionych na pastwisku charakteryzowało się istotnie statystycznie większym udziałem wymienionych wyżej kwasów w porównaniu do mleka krów utrzymywanych alkierzowo. Powyższe wyniki pozwalają na stwierdzenie, że istotnym czynnikiem oddziałującym na właściwości mleka jest zastosowany system żywienia krów. 


\section{ANALIZA ZAWARTOŚCI WYBRANYCH PIERWIASTKÓW W KULINARNEJ WOŁOWINIE POCHODZĄCEJ Z ZAKŁADÓW MIĘSNYCH „,EUNIEWSCY”}

Analysis of the content of selected elements in culinary beef from meat plants „, Łuniewscy”

Grażyna Niedziałek, Ewa Salamończyk, Marzena Redosz

Uniwersytet Przyrodniczo-Humanistyczny w Siedlcach, Katedra Hodowli Bydła, Owiec i Oceny Mleka, ul. Prusa 14, 08-110 Siedlce, e-mail: grazyna.niedzialek@uph.edu.pl

Mięso jest jednym z ważniejszych źródeł składników mineralnych. Dostarcza do organizmu człowieka niezbędnych pierwiastków, takich jak wapń, żelazo, cynk, magnez i selen. Żelazo i cynk znajdujące się w mięsie wołowym wykazują dużo większą absorpcję niż te same pierwiastki spożyte w produktach roślinnych (Florek i in. 2016). Dodatkowo mięso wołowe bogate jest w witaminy z grupy B. Uważane jest za główne źródło witaminy $\mathrm{B}_{12}$, która naturalnie nie występuje $\mathrm{w}$ produktach pochodzenia roślinnego (Zymon 2012). Jakość mięsa wołowego uzależniona jest m.in. od rasy, płci, żywienia czy wieku ubijanych zwierząt. Najlepszą jakościowo wołowinę uzyskuje się od ras mięsnych bądź mieszańców towarowych pozyskanych przy użyciu ras mięsnych.

Celem badań była analiza zawartości wybranych składników mineralnych w kulinarnym mięsie wołowym pochodzących z Zakładów Mięsnych ,„Łuniewscy”. Materiał do badań stanowiły próbki mięsa pochodzące z polędwicy wołowej 10 jałówek i 10 buhajków poddanych ubojowi w zakładach mięsnych. Średni wiek ubijanych jałówek wynosił 24 miesiące, a buhajków 25 miesięcy. Pobrane próbki zostały przekazane do Centralnego Laboratorium Analitycznego UMCS w Lublinie. Zawartość składników mineralnych oznaczono metodą spektrofotometrii absorpcyjnej według normy PN-EN 14084/2004.

Analizując uzyskane wyniki, stwierdzono, iż w polędwicy wołowej pochodzącej od jałówek średnia zawartość wapnia wynosiła $33,5 \mathrm{mg} / \mathrm{kg}$, od buhajków zaś $34,6 \mathrm{mg} / \mathrm{kg}$. Średnia zawartość żelaza u jałówek wynosiła $21,3 \mathrm{mg} / \mathrm{kg}$, u buhajków zaś $21,9 \mathrm{mg} / \mathrm{kg}$. Największą ilość magnezu odnotowano w polędwicy wołowej pochodzącej od buhajków - wynosiła $285,9 \mathrm{mg} / \mathrm{kg}$, od jałówek zaś $278,1 \mathrm{mg} / \mathrm{kg}$. W polędwicy wołowej pochodzącej od jałówek zawartość cynku była znacznie niższa i wynosiła 34,4 mg/kg, od buhajków zaś $36,1 \mathrm{mg} / \mathrm{kg}$. Stwierdzono zatem, że średnia zawartość wapnia i cynku jest wyższa u jałówek niż u buhajków, natomiast średnia zawartość żelaza i magnezu jest wyższa u buhajków.

Wyniki badań dowiodły również wpływu wieku ubijanych zwierząt na zawartość składników mineralnych w kulinarnym mięsie wołowym. Zwierzęta ubijane w wieku 24 miesięcy charakteryzowały się wyższą zawartością mikroelementów i makroelementów.

We wszystkich badanych próbkach zawartość składników mineralnych mieściła się w normach stosowanych do oceny kulinarnego mięsa wołowego. 


\title{
ANTYBIOTYKOTERAPIA MIEJSCOWA W LECZENIU MASTITIS
}

\author{
Local antibiotic therapy for the treatment of mastitis
}

Anna Nienartowicz-Zdrojewska, Angelika Orlewicz

Bioveta Polska, ul. Prosta 51, 00-838 Warszawa

e-mail: nienartowicz_zdrojewska.anna@bioveta.eu

Zapalenie gruczołu mlekowego krów rozpatrywać można wielowątkowo. Choroba ta wpływa nie tylko na obniżenie ekonomiki produkcji, ale również działa negatywnie na dobrostan zwierzęcia. Krowy cierpią z powodu bólu, świądu i podwyższonej temperatury. Dolegliwości powodują zmiany behawioralne.

Zapalenie gruczołu mlekowego wpływa na ilość i jakość siary oraz mleka, a co za tym idzie również na zdrowie cieląt. W mleku wzrasta poziom komórek somatycznych i toksyn, a w przypadku zwierząt leczonych znaleźć można pozostałości leków. Istnieją również doniesienia o mastitis jako czynniku wpływającym na zaburzenia płodności.

Zapalenie gruczołu mlekowego na 2-3 tygodnie przed wycieleniem często spowodowane jest spadkiem odporności na skutek stresu fizjologicznego i metabolicznego. Dodatkowo zbiega się z siarogenezą, obniżając jakość i ilości siary, co wpływa na zdrowie cielęcia. Siara zawiera mniejsze stężenie immunoglobulin, wzrasta jej pH i SCS. Uwolnienie mediatorów stanu zapalnego w organizmie cielnej krowy może predysponować dodatkowo do wcześniejszych porodów. Często zakażenia w obrębie wymienia spowodowane są gronkowcami oraz bakteriami coliform, w tym Klebsiella pneumoniae i Escherichia coli.

Z najczęstszymi sprawcami infekcyjnego zapalenia gruczołu mlekowego u bydła, czyli Staphylococcus aureus oraz Escherichia coli, można walczyć, stosując leczenie ogólne (iniekcyjne) albo miejscowe - dowymieniowe. Dużą skuteczność w leczeniu miejscowym wykazuje kombinacja linkomycyny i neomycyny (np. Lineomam). Na te dwa antybiotyki wrażliwość wykazują bakterie z rodzaju Staphylococcus spp. włącznie z $S$. aureus, $S$. agalactiae, $S$. dysgalactiae i $S$. uberis oraz bakterie z grupy coli wraz z E. coli.

Jak w przypadku każdego antybiotyku, ideałem byłoby, aby decyzja o zastosowaniu danej substancji czynnej była poprzedzona badaniami wrażliwości mikroorganizmów występujących u danego osobnika. Oczywiście w sytuacji chowu wielkotowarowego nie jest to możliwe, jednak okresowo powinno się pobierać wymazy od osobników z kliniczną lub podkliniczną formą mastitis, gdyż na danej fermie konkretne patogeny będą się powtarzać u większej liczby jednostek.

Dowymieniową kombinację linkomycyny i neomycyny można zastosować w przypadku osobników ciężarnych i w okresie laktacji, preparat tego typu nie powinien być stosowany równolegle z makrolidami (np. erytromycyna), gdyż substancje te działają antagonistycznie, synergicznie natomiast działa z antybiotykami beta-laktamowymi, które uszkadzają ścianę komórkową bakterii i ułatwiają przenikanie aminoglikozydu do rybosomu bakteryjnego. Kombinację linkomycyny i neomycyny (np. Lineomam) aplikuje się do każdej ćwiartki zmienionej chorobowo 3-krotnie w odstępie 12-godzinnym. Przed podaniem leku każdą ćwiartkę należy zdoić, a strzyki umyć i zdezynfekować chusteczką nasączoną np. 65\% roztworem izopropanolu. Środki dezynfekcyjne zwykle dołączane są do aplikatora. Po zaaplikowaniu można krótko rozmasować strzyk w kierunku wymienia.

Należy pamiętać o wymaganej karencji na mleko - wynosi ona 84 godziny. Jeżeli konieczny byłby ubój, na tkanki jadalne karencja wynosi 3 dni. 


\title{
WPŁYW STOSOWANIA KISZONKI ZE ŚLAZOWCA PENSYLWAŃSKIEGO NA ZAWARTOŚĆ SKŁADNIKÓW MINERALNYCH W WOŁOWINIE
}

The effect of Virginia fanpetals silage on the mineral content in beef

\author{
Zenon Nogalski ${ }^{1}$, Cezary Purwin ${ }^{2}$, Martyna Momot $^{1}$, Monika Sobczuk-Szul $^{1}$ \\ ${ }^{1}$ Uniwersytet Warmińsko-Mazurski w Olsztynie, Katedra Hodowli Bydła i Oceny Mleka, ul. Oczapowskiego 5, 10-719 Olsztyn \\ ${ }^{2}$ Uniwersytet Warmińsko-Mazurski w Olsztynie, Katedra Żywienia Zwierząt i Paszoznawstwa, \\ ul. Oczapowskiego 5, 10-179 Olsztyn, \\ e-mail: zena@uwm.edu.pl
}

Zwiększanie efektywności produkcji wołowiny to głównie obniżanie kosztów żywienia. W grupie roślin, które mogą mieć znaczenie pastewne, jest ślazowiec pensylwański (Sida hermaphrodita Rusby L.). Ma on niewielkie wymagania glebowe, jest rośliną wieloletnią i może dawać plon w wysokości około 10 t suchej masy rocznie. Jest to głównie roślina energetyczna, a wykorzystanie w żywieniu zwierząt może być jej alternatywnym zastosowaniem. Zakładamy, że kiszonka uzyskana z zielonej masy ślazowca pensylwańskiego może zastąpić w opasie inne rodzaje kiszonek. Żywienie jest głównym czynnikiem decydującym o jakości wołowiny, w tym również o zawartości składników mineralnych w mięśniach. Celem doniesienia jest ocena wpływu stosowania kiszonki ze ślazowca oraz rodzaju mięśnia na zawartość składników mineralnych w mięsie buhajków rasy polskiej holsztyńsko-fryzyjskiej.

Kiszonkę wyprodukowano $\mathrm{z}$ zielonej masy ślazowca pensylwańskiego zbieranej $\mathrm{w}$ fazie pąkowania roślin, sieczkarnią dokładnego cięcia i zakiszono w pryzmie. Przeprowadzono opas doświadczalny 40 buhajków rasy polskiej holsztyńsko-fryzyjskiej odmiany czarno-białej przez 7 końcowych miesięcy życia (14-21 miesięcy). Zastosowano 4 warianty żywieniowe, w których podstawową paszą były kiszonki: 1 . kiszonka ze ślazowca, 2. kiszonka ( $1 / 2$ ślazowiec $+1 / 2$ trawa), 3. kiszonka ( $1 / 2$ ślazowiec $+1 / 2$ kukurydza), 4. kiszonka z traw. Kiszonki uzupełniał dodatek paszy $3 \mathrm{~kg} / \mathrm{szt}$./doba paszy treściwej. W wieku około 21 miesięcy i masie około $700 \mathrm{~kg}$ buhajki ubijano. Próby mięśni m. longissimus thoracis (LT) i semimembranosus (SM) pobierano z prawych półtusz 96 godzin po uboju. Po zmineralizowaniu prób w obecności kwasu azotowego, oznaczono zawartość składników m mineralny: magnezu $(\mathrm{Mg})$, sodu $(\mathrm{Na})$, potasu $(\mathrm{K})$, cynku $(\mathrm{Zn})$ i żelaza (Fe) metodą atomowej spektrometrii absorpcyjnej. W obliczeniach wykonanych w programie Statistica 12.0, uwzględniono rodzaj mięśnia i skład dawki żywieniowej.

Próby mięśni pobrane z udźca $(\mathrm{SM})$ zawierały więcej $(\mathrm{P}<0,01)$ potasu i żelaza oraz więcej $(\mathrm{P}<0,05)$ magnezu i sodu, w porównaniu z próbami mięśni pobranymi z grzbietu (LT). Średnia różnica pomiędzy mięśniami w koncentracji Fe wyniosła 2,79 mg $\mathrm{kg}^{-1}$ świeżego mięsa, co stanowiło 14,25\%. Rodzaj diety stosowanej w opasie zróżnicował zawartość potasu w mięśniach buhajków. Mięśnie zwierząt żywionych kiszonką ze ślazowca zawierały istotnie więcej $\mathrm{K}$ w porównaniu z mięśniami opasów żywionych kiszonką ze ślazowca i traw. Różnica dla prób LT była wysoko istotna, a dla prób SM istotna.

Podsumowując, kiszonka sporządzona ze ślazowca pensylwańskiego wykorzystana w opasie nie zróżnicowała istotnie zawartości składników mineralnych w mięśniach buhajków. Wykazano istotny wpływ rodzaju mięśnia na koncentrację Mg, $\mathrm{Na}, \mathrm{K}$ i Fe.

Badania realizowane w ramach projektu pt. „Potencjał paszowy, energetyczny i ekonomiczny upraw ślazowca pensylwańskiego na glebach lekkich, odłogowanych i rekultywowanych” zostały sfinansowane przez NCBR w ramach programu ,Środowisko naturalne, rolnictwo i leśnictwo - Biostrateg" (umowa nr 1/270745/2/NCBR/2015). 


\title{
ZNACZENIE ZIÓŁ W ŻYWIENIU BYDŁA
}

The importance of herbs in cattle nutrition

\author{
Aleksandra Paskudska, Dorota Kołodziejczyk, Stanisław Socha \\ Uniwersytet Przyrodniczo-Humanistyczny w Siedlcach, Instytut Bioinżynierii i Hodowli Zwierząt, \\ Katedra Metod Hodowlanych i Hodowli Drobiu, ul. B. Prusa 12/14, 08-110 Siedlce \\ e-mail: socha@uph.edu.pl,dormark1@wp.pl
}

Jakość artykułów spożywczych spożywanych przez człowieka wpływa na jego samopoczucie oraz zdrowie, analogicznie pasze wpływają na zdrowie bydła. Zioła w widoczny sposób poprawiają jakość produktów od nich otrzymywanych, czyli mleka i mięsa, a także zdrowotność. Efekt pożądany pojawia się przy regularnym i dłuższym stosowaniu. Rośliny lecznicze zawierają bardzo cenne składniki, mające istotny wpływ na cały proces związany z trawieniem i stanem zdrowia zwierząt, ze względu na obecność substancji biologicznie czynnych. W czasie oceny wartości paszy pod uwagę najczęściej bierzemy przyrosty masy ciała i wydajność mleczną bądź mięsną. U wysoko wydajnych krów skutkiem jest obniżona odporność i co za tym idzie większa podatność na choroby [Maksymiec, 2012]. Na podstawie badań i publikacji autorów zajmujących się problematyką żywienia zwierząt można przedstawić zalety stosowania ziół u bydła.

Podawanie mieszanki ziołowej 2\%, zawierającej krwawnik pospolity, rumianek, pokrzywę zwyczajną, rzepik, przywrotnik czy babkę lancetowatą w sposób pozytywny wpływa na mleko (obraz cytologicznomikrobiologiczny). Badania wykazały, że to mleko w porównaniu z mlekiem od krów z grupy kontrolnej charakteryzuje się znacznie niższą liczba komórek somatycznych, niższą liczbą bakterii ciepłoopornych, pleśni i drożdży. Istotnie niższa w tym mleku była także częstotliwość występowania bakterii patogenicznych, które powodują skażenie mleka. Zauważono zmniejszenie ilości Staphylococcus ureus z 57\% do 3\% oraz Steptococcus agalactiae z 14\% do 2\%. Zatem zdrowotność wymion bydła oraz odżywcze wartości pozyskiwanego mleka uległy polepszeniu (Kraszewski i in. 2002).

Zioła zwiększają apetyt bydła, a zwiększone pobranie paszy powoduje jej lepsze wykorzystanie. Badania przeprowadzone po dodaniu do paszy 2,0\% i 1,0\% ziół (kozieradki, bratka, kopru, szałwii, tymianku, rumianku, pokrzywy, mięty) wykazały zwiększenie pobrania pasz stałych, uzyskanie większej masy ciała, większych przyrostów dziennych i lepsze wykorzystanie pokarmu. Podczas stosowania paszy z 2\% udziałem ziół uzyskano u buhajków i cieliczek najlepsze efekty. W czasie badań nie stwierdzono u zwierząt żadnych schorzeń (Kraszewski i in. 2008).

Inne badania świadczące o pozytywnych efektach uzyskano po zastosowaniu mieszanki mineralno- ziołowej w 2,5\% do $6 \%$, gdzie zioła stanowiły od 1,0\% do 4,0\%. Mieszanka zawierała kwiat krwawnika, ziele skrzypu, babkę lancetowatą, dziurawiec, melisę i pokrzywę. Jako dodatki mineralne zostały użyte: fosforan dwuwapniowy, dolomit paszowy, sole J, Co, Se, Zn, Cu i kreda pastewna. Uzyskano największe przyrosty między 127. a 190. dniem, kiedy zwierzęta otrzymywały dwukrotnie więcej roślin leczniczych (Stenzel i in. 1999).

Przeprowadzono badania na 3-miesięcznych cielakach, które podzielono na 2 grupy. Grupa doświadczalna dostawała wywar $10 \%$ sporządzony z bzu czarnego, nagietka lekarskiego, melisy lekarskiej. Średnie przyrosty dobowe $\mathrm{w}$ tej grupie wykazały, że zwierzęta miały znacznie lepszy przyrost w porównaniu z grupą kontrolną. Badania wykazały także, że zastosowanie w pierwszych 6 miesiącach życia cieląt dodatków mineralno-ziołowych, które zawierały dziurawiec, pokrzywę, szałwię i rumianek, spowodowało wzrost poziomu fosforu nieorganicznego, magnezu i wapnia w surowicy krwi (Saba i in. 2000). Zaobserwowano również, że stosowanie wyciągu ziołowego u cieląt wpływa korzystnie na koncentrację żelaza, cynku i miedzi w surowicy krwi (Bombik i in. 2002). 
Wykazano także, iż u bydła mlecznego skarmianego mieszankami ziołowymi następuje polepszenie składu chemicznego mleka i zwiększenie wydajności mlecznej krów. Mleko z grup, które dostawały mieszanki ziołowe, miało lepszą przydatność technologiczną w czasie przerobu niż z grupy kontrolnej. Przeprowadzono również badania wskaźników hematologicznych cieląt. Podawane im mieszanki z udziałem lukrecji, melisy, krwawnika, bobiku trójlistnego, majeranku, rumianku, szałwii, dziurawca i pokrzywy spowodowały zwiększenie liczby krwinek czerwonych oraz poziomu hemoglobiny. Świadczy to o bardzo dobrym oddziaływaniu metabolicznym ziół (Saba i in. 2000). 


\title{
ZMIENNOŚĆ PROCESÓW MIKROBIOLOGICZNYCH ZACHODZACYCH W PRZEDŻOŁĄDKACH POD WPŁYWEM RÓŻNYCH SUBSTRATÓW ROŚLINNYCH
}

Variability of microbiological process occurring in forestomach under influence of various plant substrate

\author{
Ewa Pecka-Kiełb ${ }^{1}$, Klaudia Fuks ${ }^{1}$, Andrzej Zachwieja ${ }^{2}$, Dorota Miśta ${ }^{1}$, Bożena Króliczewska ${ }^{1}$, \\ Maja Słupczyńska ${ }^{3}$, Barbara Król $^{3}$, Edyta Wojtas ${ }^{2}$
}

\footnotetext{
${ }^{1}$ Uniwersytet Przyrodniczy we Wrocławiu, Zakład Fizjologii Zwierząt, ul. Norwida 31, 50-375 Wrocław

${ }^{2}$ Uniwersytet Przyrodniczy we Wrocławiu, Zakład Hodowli Bydła i Produkcji Mleka, ul. Chełmońskiego 38c, 51-630 Wrocław

${ }^{3}$ Uniwersytet Przyrodniczy we Wrocławiu, Katedra Żywienia Zwierząt i Paszoznawstwa, ul. Chełmońskiego 38c, 51-630 Wrocław e-mail: ewa.pecka@upwr.edu.pl
}

Celem pracy była analiza wpływu kiszonek z kukurydzy oraz traw na poziom oraz profil lotnych kwasów tłuszczowych $\mathrm{w}$ treści żwacza krów - badania in vitro. Badania przeprowadzono w stadzie bydła rasy polskiej holsztyńsko-fryzyjskiej odmiany czarno-białej. Treść żwacza została pobrana od 6 krów, 2 godziny po porannym żywieniu TMR, przy użyciu sondy. Po pobraniu treść żwacza wymieszano z buforem (McDougall 1948) w stosunku 1: 3 i poddano homogenizacji. Celem przygotowania próbek do fermentacji odmierzono po $80 \mathrm{ml}$ zhomogenizowanej treści do buteleczek ,,serum bottles” o pojemności $125 \mathrm{ml}$ (Sigma Aldrich) i dodano $1 \mathrm{~g}$ uzyskanych substratów: K1 - kiszonka z kukurydzy, K2 - kiszonka z traw I pokos. Buteleczki wysycono $\mathrm{CO}_{2}$ i poddano 24-godzinnej fermentacji in vitro w wytrząsarce $\mathrm{z}$ łaźnią wodną w temperaturze $39^{\circ} \mathrm{C}$. Próbki płynnej treści poddano analizie przy użyciu chromatografu gazowego (Agilent Technologies 7890A GC System) z detektorem FID celem oznaczenia w nich ogólnego stężenia lotnych kwasów tłuszczowych (LKT) oraz udziału procentowego poszczególnych kwasów. Wyniki badań opracowano statystycznie przy zastosowaniu jednoczynnikowej analizy wariancji ANOVA w programie Statistica 10.0 (StatSoft Polska, Kraków, Polska) przy użyciu testu Duncana.

Po dodaniu substratów do inkubowanego płynu żwacza nie stwierdzono zmian w poziomie produkcji LKT. Odnotowano obniżenie $(P<0,01)$ udziału procentowego kwasu octowego w próbach treści żwacza inkubowanych z kiszonką z kukurydzy (K1) w odniesieniu do prób z dodatkiem kiszonki z traw (K2). Nie zaobserwowano wpływu zastosowanych kiszonek na udziału procentowy kwasu propionowego. Ponadto stwierdzono obniżenie $(P<0,01)$ udziału kwasu masłowego i kwasu heksanowego w ogólnej puli LKT przy inkubacji kiszonki z traw (K2) w porównaniu z kiszonką z kukurydzy (K1). Podsumowując uzyskane rezultaty, można stwierdzić, że zastosowanie kiszonki z kukurydzy oraz kiszonki z traw w fermentacji in vitro treści żwacza skutkuje produkcją lotnych kwasów tłuszczowych na zbliżonym poziomie, natomiast zastosowanie kiszonki z kukurydzy powoduje obniżenie udziału kwasu octowego oraz wzrost udziału kwasu masłowego, izo-walerianowego oraz heksanowego.

Zastosowanie różnych kiszonek $\mathrm{z}$ roślin skutkuje zmianami profilu fermentacji w treści żwacza krów. Uzyskane wyniki określające zmienność procesów mikrobiologicznych zachodzących w przedżołądkach pod wpływem substratów roślinnych, takich jak kiszonka z kukurydzy oraz kiszonka $\mathrm{z}$ traw, mogą być pomocne w dalszych badaniach nad mieszankami paszowymi w celu uzyskania produktów pochodzenia zwierzęcego o lepszej jakości technologicznej. 


\title{
DYNAMIKA PROCESÓW FIZJOLOGICZNYCH W ŻWACZU KRÓW W ZALEŻNOŚCI OD CZASU FERMENTACJI MIKROBIOLOGICZNEJ - BADANIA IN VITRO
}

Dynamics of processes in the rumen of cows depending on the time of microbial fermentation in vitro studies

\author{
Ewa Pecka-Kiełb ${ }^{1}$, Karolina Dyk $^{1}$, Andrzej Zachwieja ${ }^{2}$, Dorota Miśta ${ }^{1}$, Bożena Króliczewska ${ }^{1}$, \\ Maja Słupczyńska ${ }^{3}$, Barbara Król ${ }^{3}$, Edyta Wojtas ${ }^{2}$
}

\footnotetext{
${ }^{1}$ Uniwersytet Przyrodniczy we Wrocławiu, Zakład Fizjologii Zwierząt, ul. Norwida 31, 50-375 Wrocław

${ }^{2}$ Uniwersytet Przyrodniczy we Wrocławiu, Zakład Hodowli Bydła i Produkcji Mleka, ul. Chełmońskiego 38c, 51-630 Wrocław

${ }^{3}$ Uniwersytet Przyrodniczy we Wrocławiu, Katedra Żywienia Zwierząt i Paszoznawstwa, ul. Chełmońskiego 38c, 51-630 Wrocław e-mail: ewa.pecka@upwr.edu.pl
}

Celem pracy było określenie wpływu czasu fermentacji treści żwacza krów w warunkach in vitro na poziom i profil lotnych kwasów tłuszczowych. Materiał do badań stanowiła treść żwacza pobrana przy użyciu sondy od 6 krów rasy polskiej holsztyńsko-fryzyjskiej odmiany czarno-białej. Zwierzęta utrzymywane były w systemie wolnostanowiskowym i żywione TMR. Po pobraniu treść żwacza przesączono a następnie wymieszano $\mathrm{z}$ buforem $\mathrm{w}$ stosunku 1: 3 . Otrzymany roztwór poddano homogenizacji $(0 \mathrm{~h}$ fermentacji). Dodatkowo w celu przygotowania próbek do fermentacji odmierzono po $20 \mathrm{ml}$ filtratu żwacza do buteleczek ,serum bottles" o pojemności $125 \mathrm{ml}$ (Sigma-Aldrich), a następnie rozcieńczono 4-krotnie buforem i dodano $1 \mathrm{~g}$ kiszonki z kukurydzy. Buteleczki wysycono $\mathrm{CO}_{2} \mathrm{i}$ poddano 8- i 24-godzinnej fermentacji in vitro w wytrząsarce z łaźnią wodną w temperaturze $39^{\circ} \mathrm{C}$. Sporządzone roztwory z 0 - oraz 8 - i 24-godzinnej fermentacji odwirowano, a do uzyskanej cieczy dodano kwas mrówkowy $0,1 \mathrm{ml} / 2 \mathrm{ml}$ roztworu w celu zahamowania procesów fermentacyjnych. W próbkach płynnej treści oznaczono całkowite stężenie lotnych kwasów tłuszczowych (LKT) oraz udziału procentowego poszczególnych kwasów: octowego, propionowego, izomasłowego, masłowego, izowalerianowego, walerianowego oraz heksanowego. Analizy dokonano przy użyciu chromatografu gazowego (Agilent Technologies 7890A GC System) z detektorem FID. Wyniki badań opracowano statystycznie przy zastosowaniu jednoczynnikowej analizy wariancji ANOVA w programie Statistica 10.0 (StatSoft Polska, Kraków, Polska) przy użyciu testu Duncana.

W czasie trwania fermentacji treści żwacza krów uległa zwiększeniu produkcja lotnych kwasów tłuszczowych $(P<0,01)$. Zaobserwowano wzrost $(P<0,01)$ produkcji LKT $\mathrm{w} 24 \mathrm{~h}$ fermentacji $\mathrm{w}$ odniesieniu do $8 \mathrm{~h}$ inkubacji. Czas inkubowanych prób wpłynął na poziom produkcji kwasu octowego. Odnotowano wyższy $(P<0,01)$ udział procentowy kwasu octowego w ogólnej puli LKT w 8 i 24 h fermentacji w odniesieniu do $0 \mathrm{~h}$. Jednak różnic w poziomie tego kwasu pomiędzy 8 a 24 godziną fermentacji nie stwierdzono. W badaniach własnych zaobserwowano również wpływ $(P<0,05)$ czasu fermentacji na produkcję kwasu propionowego. Jego zwiększoną $(P<0,01)$ ilość wykazano w 8 i 24 godzinie fermentacji w odniesieniu do zerowej godziny. Analizując uzyskane wyniki, można stwierdzić, że wraz z upływem czasu inkubacji profil fermentacji w treści żwacza pomiędzy 8 a 24 h zmienia się nieznacznie, rośnie jedynie poziom lotnych kwasów tłuszczowych.

Uzyskane rezultaty pozwalają na stwierdzenie, że doświadczalna fermentacja treści żwacza może odbywać się w czasie $8 \mathrm{~h}$ przy zastosowaniu pasz standardowych używanych w żywieniu krów. Jednak zastosowanie pasz o zwiększonej zawartości włókna w roślinie wymaga zweryfikowania w badaniach in vitro. 


\title{
BADANIA POPULACYJNE NA PODSTAWIE MARKERÓW STR W KONTROLI RODOWODÓW BYDŁA
}

Population studies of STR markers for parentage control in cattle

\author{
Anna Radko, Dominika Rubiś, Agnieszka Szumiec, Grzegorz Smołucha, Anna Koseniuk, \\ Angelika Podbielska
}

Instytut Zootechniki - Państwowy Instytut Badawczy, Zakład Biologii Molekularnej Zwierząt, ul. Krakowska 32-083, Balice e-mail: anna.radko@izoo.krakow.pl

Prowadzenie kontroli rodowodów bydła zgodnie z zaleceniami PCA i ICAR wymaga wykonywania analiz zgodnie $\mathrm{z}$ wymogami normy ISO17025, udziału $\mathrm{w}$ testach biegłości organizowanych przez ISAG/ICAR oraz systematycznych badań populacyjnych.

Badania populacyjne są niezbędne do określenia przydatności markerów mikrosatelitarnych DNA - STR do kontroli pochodzenia oraz do interpretacji wyników i opracowywania ekspertyz pochodzenia. W Laboratorium Genetyki Molekularnej (LGM) Instytutu Zootechniki - PIB badania populacyjne w ramach kontroli rodowodów wykonywane są nie rzadziej niż co 3 lata. Badania przeprowadza się na podstawie analizy polimorfizmu alleli ustalonych w 12 STR oraz 9 STR w przypadku, gdy analiza porównawcza DNA wykonywana jest dla osobników, których rodzice posiadają zewnętrzne certyfikaty DNA z ustalonym profilem jedynie w 9 loci.

Analiza statystyczna obejmuje głównie wyliczenie parametrów prawdopodobieństwa wykluczenia $\mathrm{CPE}_{1}$ i $\mathrm{CPE}_{2}$ (łączne prawdopodobieństwo wykluczenia, odpowiednio w przypadku, gdy znany jest genotyp jednego z rodziców i obu rodziców), wyliczanych na podstawie częstości alleli ustalonych w badanej populacji

Badania w 2017 r. przeprowadzono na podstawie danych pochodzących od 85042 osobników bydła ras: HO (69 274), RW (4079), RP (1827), LM (7721), SM (2141). Prawdopodobieństwo wykluczenia dla zestawu 9 STR dały $\mathrm{CPE}_{1}$ od 0,9792 do 0,9912 i $\mathrm{CPE}_{2}$ od 0,9988 do 0,9996, odpowiednio najniższe wartości dla rasy SM i najwyższe dla RP. Wartości $\mathrm{CPE}_{1} \mathrm{i} \mathrm{CPE}_{2}$ wyliczone dla $12 \mathrm{STR}$ mieściły się odpowiednio w granicach od 0,9962 (HO) do 0,9981 (RP) i od 0,99993 (HO) do 0,99997 (RP). Otrzymane wyniki wskazują, że w przypadku, gdy znany jest genotyp jednego z rodziców, możemy potwierdzić pochodzenie bydła z co najmniej 97\% prawdopodobieństwem, natomiast w przypadku znajomości genotypów obu rodziców z prawdopodobieństwem większym niż 99\%. 


\title{
ANALIZA DYNAMIKI LAKTACJI ORAZ JAKOŚCI MLEKA KRÓW
}

Analysis of lactation dynamics and cows' milk quality

\author{
Małgorzata Roszak ${ }^{1}$, Marzena Kęsek ${ }^{1}$, Ewa Pecka-Kiełb ${ }^{2}$, Edyta Wojtas ${ }^{1}$, Andrzej Zachwieja ${ }^{1}$, \\ Anna Zielak-Steciwko ${ }^{1}$ \\ ${ }^{1}$ Uniwersytet Przyrodniczy we Wrocławiu, Zakład Hodowli Bydła i Produkcji Mleka \\ ${ }^{2}$ Uniwersytet Przyrodniczy we Wrocławiu, Zakład Fizjologii Zwierząt \\ e-mail: anna.zielak-steciwko@upwr.edu.pl
}

Celem pracy była analiza dynamiki laktacji oraz określenie wpływu stadium laktacji i wybranych czynników środowiskowo-produkcyjnych na wydajność, skład chemiczny oraz parametry mikrobiologiczne i cytologiczne mleka krów. Badania przeprowadzono od stycznia do grudnia 2017 r. w gospodarstwie indywidualnym utrzymującym krowy rasy polskiej holsztyńsko-fryzyjskiej, odmiany czarno-białej $(\mathrm{n}=31)$ w systemie uwięziowym. Krowy były w laktacji od pierwszej do czwartej. Podstawą żywienia zwierząt była mieszanka pełnoporcjowa TMR. Bazę paszową stanowiła głównie kiszonka z kukurydzy, sianokiszonka z trwałych użytków zielonych i lucerny, a także młóto browarniane mokre i pasza treściwa zawierająca $21 \%$ białka. Ze względu na wymagania odbiorcy mleka w czerwcu 2017 r. zaprzestano stosowania w gospodarstwie pasz zawierających produkty genetycznie modyfikowane (GMO). Do analizy wykorzystano dane z raportów wynikowych z próbnych udojów przeprowadzanych metodą AT4. Dodatkowo pozyskano dane dotyczące ogólnej liczby drobnoustrojów w mleku z internetowego serwisu eMik.

Na podstawie przeprowadzonych analiz zaobserwowano: 1) wpływ wieku krów na wydajność i skład chemiczny mleka - spośród wszystkich grup krowy będące w II laktacji produkowały najwięcej mleka, natomiast surowiec o najbardziej pożądanym składzie (największa koncentracja tłuszczu i białka) produkowany był przez krowy w III laktacji; 2) wpływ pory roku na analizowane parametry mleka - najwyższą ilość mleka o wysokim poziomie tłuszczu i białka, w tym kazeiny, uzyskały krowy w okresie jesienno-zimowym, w tym sezonie zaobserwowano również najwyższą jakość pozyskanego surowca; 3) brak wpływu żywienia paszami zawierającymi składniki modyfikowane genetycznie oraz paszami ich niezawierającymi na wydajność i skład mleka krów.

Skład i jakość mleka są czynnikami decydującymi o przydatności mleka do przetwórstwa oraz do spożycia. Szczegółowa analiza dynamiki laktacji i określenie wpływu stadiów laktacji, a także czynników środowiskowo-produkcyjnych na ilość uzyskanego mleka oraz na fizykochemiczne i mikrobiologiczne cechy surowca jest pomocna w uzyskaniu wysokiej jakości surowca dla przetwórstwa mleczarskiego. 


\title{
PROBLEM INBREDU I SPOKREWNIENIA W POPULACJI BYDEA RASY CHAROLAISE OBJĘTEJ OCENĄ WARTOŚCI UŻYTKOWEJ W POLSCE
}

The problem of inbreeding and relatedness in Charolaise cattle with estimated meat productive value in Poland

\author{
Jolanta Różańska-Zawieja ${ }^{1}$, Joanna Kania-Gierdziewicz ${ }^{2}$, Maciej Gierdziewicz ${ }^{3}$, \\ Zbigniew Sobek ${ }^{1}$, Anna Nienartowicz-Zdrojewska ${ }^{1}$, I. Wenda ${ }^{1}$
}

\footnotetext{
${ }^{1}$ Uniwersytet Przyrodniczy w Poznaniu, Katedra Genetyki i Podstaw Hodowli Zwierząt, ul. Wołyńska 33, 60-633 Poznań ${ }^{2}$ Uniwersytet Rolniczy w Krakowie, Katedra Genetyki i Metod Doskonalenia Zwierząt, al. Mickiewicza 24/28, 30-059 Kraków ${ }^{3}$ Akademia Górniczo-Hutnicza w Krakowie, Katedra Informatyki Stosowanej, al. Mickiewicza 30, 30-059 Kraków e-mail: jolek@up.poznan.pl
}

Ważnym elementem pracy hodowlanej jest monitoring poziomu inbredu oraz spokrewnienia zwierząt. Współczynniki inbredu i spokrewnienia są dobrymi wskaźnikami różnorodności genetycznej, a ich wzrost prowadzi przeważnie do wielu niekorzystnych zmian w populacjach. Celem niniejszej pracy było zbadanie stopnia zinbredowania i spokrewnienia aktywnej populacji bydła rasy charolaise. Materiał do badań stanowiła baza danych pozyskana z programu BOS, obejmująca 32550 osobników rasy charolaise, poddanych ocenie wartości użytkowej w Polsce. Obliczenia wykonano z wykorzystaniem pakietu SAS (2010). W tabeli 1 przedstawiono współczynniki inbredu oszacowane dla ocenianej populacji osobników rasy charolaise.

Tabela 1. Współczynniki inbredu oszacowane dla populacji rasy charolaise

\begin{tabular}{|c|c|c|c|c|c|c|c|}
\hline \multirow{3}{*}{ Płeć } & \multicolumn{3}{|c|}{ Wszystkie osobniki } & \multicolumn{3}{|c|}{ Osobniki zinbredowane } & \multirow{3}{*}{$\begin{array}{l}\text { Udział osobników } \\
\text { zinbredowanych } \\
\text { w populacji [\%] }\end{array}$} \\
\hline & \multirow{2}{*}{$\mathrm{N}$} & \multicolumn{2}{|c|}{$\mathrm{F}_{\mathrm{X}}$} & \multirow{2}{*}{$\mathrm{N}$} & \multicolumn{2}{|c|}{$\mathrm{F}_{\mathrm{X}}$} & \\
\hline & & średnia & zakres & & średnia & zakres & \\
\hline Buhaj & 12087 & 0,0072 & $0-0,50$ & 2806 & 0,0312 & $0,000015-0,50$ & 23,22 \\
\hline Krowa & 20471 & 0,0055 & $0-0,50$ & 3340 & 0,0334 & $0,000008-0,50$ & 16,32 \\
\hline Ogółem & 32558 & 0,0061 & $0-0,50$ & 6146 & 0,0324 & $0,000008-0,50$ & 18,88 \\
\hline
\end{tabular}

Stwierdzono, że udział osobników zinbredowanych w badanej populacji wynosił 18,88\%. Średni współczynnik inbredu w analizowanej populacji był bardzo niski i wynosił 0,061, natomiast średni współczynnik inbredu w obrębie płci wynosił odpowiednio: 0,0072 u buhajów i 0,0055 u krów. Maksymalną wartość współczynnika inbredu dla obu płci oszacowano na poziomie 0,5 .

Procentowy udział par spokrewnionych w ogólnej liczbie porównań wynosił 19,52\%. W obrębie par buhaj $\times$ krowa i krowa $\times$ krowa udział par spokrewnionych wynosił odpowiednio 20,43\% i 16,35\%, natomiast najwięcej, 25,56\%, było spokrewnionych par buhaj $\times$ buhaj. Średni współczynnik spokrewnienia w analizowanej populacji oszacowano na poziomie 0,023 , natomiast maksymalna wartość tego współczynnika była bardzo wysoka i wynosiła 0,81 (tab. 2). 
LXXXIII Zjazd Naukowy PTZ im. Michała Oczapowskiego, Lublin 2018 Wyzwania zootechniki w warunkach rolnictwa zrównoważonego. Streszczenia

Sekcja Chowu i Hodowli Bydła

Tabela 2. Współczynniki spokrewnienia oszacowane dla populacji rasy charolaise

\begin{tabular}{|c|c|c|c|c|c|c|c|}
\hline \multirow{3}{*}{ Porównania } & \multicolumn{3}{|c|}{ Wszystkie pary } & \multicolumn{3}{|c|}{ Pary spokrewnione } & \multirow{3}{*}{$\begin{array}{c}\text { Udział par } \\
\text { spokrewnionych } \\
\text { w ogólnej liczbie } \\
\text { porównań [\%] }\end{array}$} \\
\hline & \multirow{2}{*}{$\mathrm{N}$} & \multicolumn{2}{|r|}{$\mathrm{R}_{\mathrm{XY}}$} & \multirow{2}{*}{$\mathrm{N}$} & \multicolumn{2}{|r|}{$\mathrm{R}_{\mathrm{XY}}$} & \\
\hline & & średnia & zakres & & średnia & zakres & \\
\hline Buhaj $\times$ buhaj & 73041741 & 0,0059 & $0-0,8164966$ & 18666042 & 0,0230 & $0,00000064-0,8164966$ & 25,56 \\
\hline Krowa $\times$ krowa & 209520685 & 0,0039 & $0-0,8164966$ & 34248575 & 0,0238 & $0,00000043-0,8164966$ & 16,35 \\
\hline Buhaj $\times$ krowa & 247432977 & 0,0047 & $0-0,8164966$ & 50562491 & 0,0231 & $0,00000043-0,8164966$ & 20,43 \\
\hline Ogółem & 529995403 & 0,0045 & $0-0,8164966$ & 103477108 & 0,0233 & $0,00000043-0,8164966$ & 19,52 \\
\hline
\end{tabular}

Podsumowując, można stwierdzić, że uzyskane średnie współczynniki inbredu i spokrewnienia dla osobników rasy charolaise, która stanowi najliczniejszą grupę rasową objętą oceną wartości użytkowej w Polsce, są stosunkowo niskie. Niemniej należałoby zwrócić uwagę na występowanie spokrewnienia u 1/5 par buhaj $\times$ krowa. Utrzymanie takiej tendencji może prowadzić w przyszłości do wzrostu zinbredowania i jego niekorzystnych skutków, czyli np. obniżenia płodności i zdrowotności zwierząt. 


\section{ANALIZA UDZIAŁU ZAŁOŻYCIELI I PRZODKÓW W POPULACJI BYDŁA RASY CHAROLAISE OBJĘTEJ OCENĄ WARTOŚCI UŻYTKOWEJ W POLSCE}

Founder and ancestor contribution analysis of Charolaise cattle with estimated meat productive value in Poland

Jolanta Różańska-Zawieja ${ }^{1}$, Joanna Kania-Gierdziewicz ${ }^{2}$, Maciej Gierdziewicz ${ }^{3}$ Zbigniew Sobek $^{1}$, Anna Nienartowicz-Zdrojewska ${ }^{1}$, I. Wenda ${ }^{1}$

\footnotetext{
${ }^{1}$ Uniwersytet Przyrodniczy w Poznaniu, Katedra Genetyki i Podstaw Hodowli Zwierząt, ul. Wołyńska 33, 60-633 Poznań,

${ }^{2}$ Uniwersytet Rolniczy w Krakowie, Katedra Genetyki i Metod Doskonalenia Zwierząt, al. Mickiewicza 24/28, 30-059 Kraków

${ }^{3}$ Akademia Górniczo-Hutnicza w Krakowie, Katedra Informatyki Stosowanej, al. Mickiewicza 30, 30-059 Kraków e-mail: jolek@up.poznan.pl
}

Efektywna liczebność populacji oraz efektywna liczba założycieli i efektywna liczba przodków uznawane są za dobre wskaźniki różnorodności genetycznej badanych populacji. Celem pracy było zbadanie udziału założycieli i przodków populacji rasy charolaise, objętej oceną wartości użytkowej w Polsce. Materiał do badań stanowiła baza danych pozyskana z programu BOS, obejmująca 32550 osobników rasy charolaise, poddanych ocenie wartości użytkowej w Polsce.

Na podstawie danych rodowodowych wykonano analizę udziału genów założycieli i przodków w populacji, oszacowano ogólną i efektywną liczbę założycieli i przodków według metodyki Lacy’ego, z modyfikacją Boicharda. Obliczenia przeprowadzono dla 3 populacji referencyjnych obejmujących okres 5-, 10- i 15-letni, tj. zwierzęta urodzone w latach 2007-2011, następnie w latach 2002-2011, oraz zwierzęta urodzone w latach 1997-2011. Wyniki przedstawiono w tabeli 1.

Tabela 1. Wyniki analizy udziału genów założycieli i przodków populacji rasy charolaise z uwzględnieniem różnych przedziałów czasowych

\begin{tabular}{|c|c|c|c|}
\hline \multirow[b]{2}{*}{ Liczebności } & \multicolumn{3}{|c|}{ Analizowany okres } \\
\hline & $\begin{array}{c}5 \text { lat } \\
(2007-2011)\end{array}$ & $\begin{array}{c}10 \text { lat } \\
(2002-2011)\end{array}$ & $\begin{array}{c}15 \text { lat } \\
(1997-2011)\end{array}$ \\
\hline Liczba zwierząt w populacji referencyjnej & 12613 & 12663 & 12713 \\
\hline Liczba wszystkich zwierząt w rodowodach & 33315 & 33315 & 33315 \\
\hline Ogólna liczba założycieli & 7545 & 7545 & 7545 \\
\hline Efektywna liczba założycieli $f_{e}$ & 721 & 720 & 720 \\
\hline Ogólna liczba przodków & 4271 & 4284 & 4293 \\
\hline Efektywna liczba przodków $f_{a}$ & 217 & 216 & 217 \\
\hline $\begin{array}{l}\text { Wyjaśniająca 50\% zmienności puli genów } \\
\text { populacji referencyjnej: } \\
\text { liczba założycieli } \\
\text { liczba przodków }\end{array}$ & $\begin{array}{l}299 \\
101\end{array}$ & $\begin{array}{l}298 \\
101\end{array}$ & $\begin{array}{l}298 \\
101\end{array}$ \\
\hline $\begin{array}{l}\text { Wyjaśniająca 90\% zmienności puli genów } \\
\text { populacji referencyjnej: } \\
\qquad \begin{array}{l}\text { liczba założycieli } \\
\text { liczba przodków }\end{array}\end{array}$ & $\begin{array}{l}2361 \\
2134\end{array}$ & $\begin{array}{l}2366 \\
2144\end{array}$ & $\begin{array}{l}2372 \\
2151\end{array}$ \\
\hline
\end{tabular}

Liczebność osobników w populacji referencyjnej zależna była od analizowanego przedziału czasowego i wynosiła 12613 dla okresu 5-letniego, 12663 dla okresu 10-cio letniego i 12713 dla okresu 15-letniego. Ogólna liczba założycieli, czyli osobników bez udokumentowanego pochodzenia, dla wszystkich analizowanych populacji referencyjnych wyniosła 7545 , natomiast efektywna liczba założycieli $\left(f_{e}\right)$ nie zmieniała się 
w zależności od analizowanego przedziału czasowego i wynosiła 720-721 osobników dla wszystkich analizowanych lat. Ogólna liczba przodków związana była z wielkością populacji referencyjnej i wynosiła odpowiednio 4271, 4284 i 4293, odpowiednio dla 5, 10 i 15 badanych lat, przy czym efektywna liczba przodków $\left(f_{a}\right)$ nie zmieniała się wraz z wydłużaniem przedziału czasowego. Taka samą tendencję zaobserwowano, gdy wyznaczano liczby założycieli i przodków, których suma udziałów wyjaśniała 50\% zmienności puli genów danej populacji referencyjnej. Natomiast liczba przodków i założycieli, których suma udziałów wyjaśnia 90\% zmienności puli genowej danej populacji referencyjnej zmniejszała się nieznacznie w miarę skracania analizowanego przedziału czasowego.

Podsumowując, można stwierdzić, że w populacji bydła rasy charolaise poddanego ocenie wartości użytkowej w Polsce nie obserwuje się spadku zróżnicowania genetycznego. 


\title{
OCENA STOSUNKU TŁUSZCZOWO-BIAŁKOWEGO W MLEKU KRÓW RASY POLSKIEJ HOLSZTYŃSKO-FRYZYJSKIEJ
}

\author{
Evaluation of fat-protein ratio in milk of cows of Polish Holstein-Friesian breeds
}

\author{
Ewa Salamończyk, Piotr Guliński, Ewelina Bierkat
}

\begin{abstract}
Uniwersytet Przyrodniczo-Humanistyczny w Siedlcach, Katedra Hodowli Bydła, Owiec i Oceny Mleka, ul. Prusa 14, 08-110 Siedlce e-mail: ewa.salamonczyk@uph.edu.pl
\end{abstract}

Zawartość składników w mleku krów jest uwarunkowana czynnikami genetycznymi oraz środowiskowymi. $Z$ warunków środowiskowych najważniejsze jest żywienie oraz zdrowotność. Celem pracy była próba określenia wpływu kilku wybranych czynników na kształtowanie się stosunku tłuszczowo-białkowego (STB) w mleku oraz określenie liczby prób mleka z określoną wielkością tego wskaźnika w mleku krów rasy polskiej holsztyńsko-fryzyjskiej.

Materiał badawczy stanowiło mleko pochodzące z 15822 próbnych udojów od krów rasy polskiej holsztyńsko-fryzyjskiej, utrzymywanych w 22 oborach położonych na terenie powiatu węgrowskiego. Ze względu na ukończoną laktację 305-dniową zwierzęta pogrupowano w 5 klasach wiekowych (laktacje I, laktacje II, laktacje III i IV, laktacje V i VI oraz laktacje od VII do XII). Poziom produkcyjny krów ustalono w oparciu o wydajność rzeczywistą mleka w laktacji 305-dniowej ( $\leq 6000 \mathrm{~kg}$ mleka, 6001-8000 kg mleka, $>8000 \mathrm{~kg}$ mleka). Ze względu na wielkość stosunku tłuszczowo-białkowego mleka zwierzęta pogrupowano do 4 kategorii, u których STB wynosił: $\leq 1 ; 1,1-1,4 ; 1,41-1,7 ;>1,7$.

W pracy stwierdzono, że średnia dobowa wydajność mleka w 15822 obserwacjach wyniosła 20,8 kg. Dobowa wydajność mleka była największa w 1. (57,4 kg) i 2. (54,6 kg) miesiącu laktacji. Miesiąc laktacji miał decydujący wpływ na procentową zawartość tłuszczu i białka w mleku krów. Najniższą zawartość tłuszczu stwierdzono w 3. (3,91\%), a białka w 2. miesiącu laktacji (2,92\%). Poziom tych 2 podstawowych składników mleka w miarę wydłużania czasu laktacji systematycznie wzrastał, przyjmując maksymalne wartości w 15. miesiącu laktacji. W pracy zaobserwowano, że największą wartością stosunku tłuszczowobiałkowego (STB) charakteryzowało się mleko pozyskiwane w 1. miesiącu laktacji $(1,37)$, najmniejszą zaś w 15. miesiącu $(1,22)$. Na podstawie otrzymanych wyników stwierdzono, że miesiąc laktacji miał istotny statystycznie wpływ na wielkość stosunku tłuszczowo-białkowego w mleku krów rasy phf.

Oceniając udział prób mleka z różnym STB, wykazano, że w badanej populacji udział prób mleka ze stosunkiem tłuszczu do białka wynoszącym $\leq 1 ; 1,1-1,4 ; 1,41-1,7$ i $>1,7$ wynosił odpowiednio: 7,3\%, 68,8\%, $20,1 \%$ i $3,8 \%$. Wyniki te oznaczają, iż u analizowanej grupy krów $68,8 \%$ prób mleka wskazywało na optymalne, zbilansowane pod względem poziomu białka i energii żywienie. 7,3\% prób wskazywało na tzw. depresję mleka, czyli sytuację, w której poziom białka w mleku był wyższy aniżeli poziom tłuszczu. 20,1\% wskazywało na podkliniczna ketozę - objawiającą się podwyższonym poziomem tłuszczu w mleku, natomiast 3,8\% prób mleka pochodziło od krów dotkniętych kliniczną ketozą.

$\mathrm{W}$ podsumowaniu należy stwierdzić, iż STB $w$ mleku jest bardzo przydatnym narzędziem do oceny poziomu zawartości białka i tłuszczu w mleku oraz poprawności żywienia krów. Odchylenia w wartościach stosunku tłuszczu do białka uznawane za optymalne (czyli $1,1-1,4)$ wskazują na problemy związane z występowaniem chorób metabolicznych. 


\title{
WPŁYW WIEKU I WYCIELENIA NA DŁUGOŚĆ LAKTACJI I WYDAJNOSĆ MLEKA KRÓW
}

Effect of age at first calving on lactation length and milk yield

\author{
Ewa Salamończyk, Piotr Guliński, Grażyna Niedziałek
}

\begin{abstract}
Uniwersytet Przyrodniczo-Humanistyczny w Siedlcach, Katedra Hodowli Bydła, Owiec i Oceny Mleka, ul. Prusa 14, 08-110 Siedlce e-mail: ewa.salamonczyk@uph.edu.pl
\end{abstract}

Ważnym elementem wpływającym na płodność, długość użytkowania i wydajność krowy jest wiek jej pierwszego wycielenia (Litwińczuk i Barłowska 1987, Brzozowski i in. 2001, Sitkowska i in. 2009, Salamończyk i Guliński 2010). Za optymalny przedział wiekowy uznaje się 26-29 miesięcy, który ogranicza straty w produkcyjności oraz obniża koszty odchowu (Litwińczuk i Borkowska 1987, Juszczak i in. 2001, Piech i Tarkowski 2003).

Celem badań była ocena wpływu wieku pierwszego wycielenia na długość laktacji oraz wydajność mleka ECM $(\mathrm{kg})$ w pierwszych czterech laktacjach wybranej populacji krów mlecznych. Badaniami objęto użytkowość mleczną krów rasy polskiej holsztyńsko-fryzyjskiej odmian czarno- i czerwono-białej, wycielonych w latach 2005-2008. Analizowano łącznie 37394 laktacji krów, wyłącznie od laktacji I do IV (w tym: 14772 laktacje I; 10420 laktacje II; 7386 laktacji III oraz 4816 laktacji IV). Oceniane zwierzęta podzielono ze względu na wiek 1 . wycielenia na następujące grupy: 1) $\leq 750 \mathrm{dni}$; 2) 751-800 dni; 3) 801-850 dni; 4) 851-900 dni; 5) $\geq 901$ dni. W celu analizy wpływu wieku 1. wycielenia na wydajność mleka rzeczywistą produkcję mleka o rzeczywistej zawartości tłuszczu i białka przeliczono na wydajność mleka ECM (kg) zawierające $3,5 \%$ tłuszczu i 3,2\% białka, wg formuły: $(0,3246 \times \mathrm{kg}$ mleka $)+(12,86 \times \mathrm{kg}$ tłuszczu $)+(7,04 \times$ $\mathrm{kg}$ białka) [Bernard 1997]. W analizie statystycznej zastosowano dwuczynnikową analizę wariancji metodą najmniejszych kwadratów. Istotność różnic szacowano testem Duncana przy $\mathrm{P} \leq 0,05$.

Średnie wyniki badanej populacji to: wiek pierwszego wycielenia - 786 dni (26,2 miesiąca); długość laktacji pełnej - 382 dni; ECM za laktację pełną - $8072 \mathrm{~kg}$ mleka. W pracy wykazano, że wiek pierwszego ocielenia miał istotny wpływ na długość i wydajność mleka w pierwszych czterech laktacjach u ocenianych zwierząt. Krowy wycielone po raz pierwszy w wieku pomiędzy 801 a 900 dni charakteryzowały się najdłuższymi laktacjami i najwyższą wydajnością mleka ECM. Wyniki tych wskaźników kształtowały się w następujących przedziałach, odpowiednio 384-393 dni oraz 7743-8776 kg mleka ECM. 


\title{
ZMIANY W STRUKTURZE GENETYCZNEJ BYDŁA BIAŁOGRZBIETEGO PO 15 LATACH HODOWLI
}

Changes in the genetic structure of Whitebacked cattle after 15 years of breeding

\author{
Wioletta Sawicka-Zugaj, Witold M. Chabuz, Karolina Kasprzak-Filipek, Zygmunt A. Litwińczuk \\ Uniwersytet Przyrodniczy w Lublinie, Instytut Hodowli Zwierząt i Ochrony Bioróżnorodności, Zakład Hodowli i Ochrony Zasobów \\ Genetycznych Bydła, ul. Akademicka 13, 20-950 Lublin \\ e-mail: wioletta.sawicka@up.lublin.pl
}

Bydło białogrzbiete jest jedną z najstarszych ras bydła w Polsce. Chociaż występowało na tym terenie od niepamiętnych czasów, to w okresie powojennym zostało uznane za wymarłe. Na przełomie XX i XXI w. rozpoczęto proces restytucji rasy, a w roku 2004 objęta została programem ochrony zasobów genetycznych. Dynamiczny rozwój rasy doprowadził do sytuacji, w której występuje ona na terenie 9 województw w 56 stadach, przy czym jej największe natężenie występuje w województwach: lubelskim, mazowieckim, warmińsko-mazurskim i podlaskim. Na koniec 2017 r. w księdze hodowlanej bydła białogrzbietego znajdowało się 570 żywych krów oraz 10 żywych buhajów. Pierwsze badania, mające na celu określenie stopnia zmienności genetycznej w obrębie rasy białogrzbietej zostały przeprowadzone w $2003 \mathrm{r}$. Były to badania pilotażowe, obejmujące 50 zwierząt odpowiadających wzorcowi umaszczenia dla tej rasy, jednakże nieposiadające udokumentowanego pochodzenia.

Aktualne badania zostały przeprowadzone na populacji 100 krów i jałowic, posiadających pełne pochodzenie do dwóch pokoleń wstecz. W obrębie 25 analizowanych loci mikrosatelitarnych (TGLA227, BM2113, TGLA53, ETH10, SPS115, TGLA126, TGLA122, INRA23, ETH3, ETH225, BM1824, CSSM66, CSRM60, TGLA52, ILSTS005, ILSTS006, INRA037, INRA035, HEL13, HEL9, HEL5, HEL1, INRA005, INRA063 oraz BM1818) zidentyfikowano łącznie 257 różnych alleli (średnio 10,28 allela/locus). Określono wskaźniki zmienności genetycznej, które uzyskały wysokie wartości (średnia heterozygotyczność obserwowana $-0,684$, średnia heterozygotyczność oczekiwana - 0,7431 oraz polymorphism information content (PIC) - 0,7053). Średnia wartość fixation index dla analizowanej populacji była niska i wyniosła 0,068.

Podstawowym celem programów ochrony zasobów genetycznych jest zachowanie wysokiej zmienności genetycznej chronionej populacji. Uzyskane wysokie wskaźniki heterozygotyczności, PIC oraz niski stopień spokrewnienia w obrębie analizowanej populacji wyraźnie wskazują na spełnienie założeń programu. 


\title{
ZMIANY CECH UŻYTKOWOŚCI MLECZNEJ KRÓW RASY PHF BĘDĄCYCH W RÓŻNYCH LAKTACJACH
}

Changes in milk performance traits of PHF cows in various lactations

\author{
Piotr Stanek $^{1}$, Ewa Januś ${ }^{1}$, Paweł Żółkiewski ${ }^{2}$, Karol Jadczak ${ }^{1}$ \\ ${ }^{1}$ Uniwersytet Przyrodniczy w Lublinie, Instytut Hodowli Zwierząt i Ochrony Bioróżnorodności, \\ Pracownia Ekologicznej Produkcji Żywności Pochodzenia Zwierzęcego, ul. Akademicka 13, 20-950 Lublin \\ ${ }^{2}$ Uniwersytet Przyrodniczy w Lublinie, Zakład Hodowli i Ochrony Zasobów Genetycznych Bydła, \\ ul. Akademicka 13, 20-950 Lublin, \\ e-mail: piotr.stanek@up.lublin.pl
}

Długość życia i użytkowania bydła mlecznego ma najważniejszy wpływ na jego życiową efektywność produkcji. Zdaniem Czaplickiej i in. (2004), Sobka i in. (2005) oraz Gnypa i in. (2006) od dawna utrzymuje się tendencja skracania długości życia i użytkowania krów mlecznych szczególnie o wysokiej wydajności. Miciński (2006) i Sawa (2011) zwracają uwagę na fakt, że długość użytkowania krów mlecznych powinna wynosić 6-7 laktacji, co wpływa na poprawę efektywności produkcji, a tym samym na lepszy wynik finansowy. Przy dłuższym użytkowaniu krów dochody można czerpać nie tylko z mleka, ale również ze sprzedaży cieląt i jałowic hodowlanych, na co zwracają uwagę Sawa i Bogucki (2009) oraz Gnyp (2014).

Materiał do pracy pochodził z kontroli użytkowości mlecznej za lata 2013-2018 prowadzonej metodą AT4. W badaniach uwzględniono 118 krów mlecznych rasy polskiej holsztyńsko-fryzyjskiej odmiany czarno-białej będących w różnych laktacjach. Analiza dotyczyła wydajności krów w laktacjach 305-dniowych i rocznych. Pod uwagę wzięto również zawartość i wydajność składników mleka. Wyniki opracowano z wykorzystaniem pakietu statystycznego Statistica ver. $13.0 \mathrm{w}$ oparciu o jednoczynnikową analizę wariancji, podając średnie wartości dla poszczególnych cech oraz odchylenie standardowe. Istotności różnic między średnimi wartościami dla ocenianych grup wyznaczono testem Duncana.

Na podstawie przeprowadzonej analizy stwierdzono, że wraz z kolejną laktacją zwiększała się wydajność mleka i suchej masy, a dotyczyło to głównie krów będących w 2. i 3. oraz 4. laktacji. Krowy będące w 1. laktacji produkowały o ponad $850 \mathrm{~kg}$ mniej (różnica istotna przy $\mathrm{P} \leq 0,05)$ mleka $(7628,2 \mathrm{~kg}$ ) w porównaniu z krowami będącymi w laktacji 4. i starszych $(8486,0 \mathrm{~kg})$. Zależność tę zauważono również, analizując wydajność tych krów w laktacjach rocznych, gdzie różnica w wydajności pomiędzy tymi grupami laktacyjnymi wynosiła ponad $1000 \mathrm{~kg}$ mleka. Kolejność laktacji miała również wpływ na produkcję składników mleka, a ich wydajność zmieniała się podobnie jak w przypadku wydajności mleka. Zarówno w laktacji 305-dniowej, jak i rocznej wydajność składników mleka zwiększała się do laktacji 4., natomiast w następnych, tj. w 5. i 6., obserwowano nieznaczny spadek ich wydajności. Zanotowano, że w laktacji 305-dniowej procentowa zawartość tłuszczu w mleku oscylowała w przedziale 4,0-4,3, białka 3,3-3,6, a suchej masy 13,7-14,0.

Podsumowując uzyskane wyniki, należy stwierdzić, że oceniane krowy wpisują się w obecne trendy związane z użytkowaniem krów mlecznych. Najniższą wydajnością charakteryzowały się pierwiastki. Wzrost wydajności następował do laktacji 4., a w kolejnych następował jej nieznaczny spadek. 


\section{KORELACJE GENETYCZNE I FENOTYPOWE POMIĘDZY CECHAMI ZDOLNOŚCI UDOJOWEJ A LICZBĄ KOMÓREK SOMATYCZNYCH W MLEKU I CECHAMI PŁODNOŚCI}

Genetic and phenotypic correlations between workability traits and somatic cells count and fertility traits

Bartosz Szymik $^{1}$, Piotr Topolski ${ }^{1}$, Wojciech Jagusiak ${ }^{2}$

\footnotetext{
${ }^{1}$ Instytut Zootechniki - Państwowy Instytut Badawczy, Dział Genetyki i Hodowli Zwierząt, 32-083 Balice k. Krakowa

${ }^{2}$ Uniwersytet Rolniczy w Krakowie, Katedra Genetyki i Metod Doskonalenia Zwierząt, al. Mickiewicza 24/28, 30-059, Kraków e-mail: bartosz.szymik@izoo.krakow.pl
}

Celem badań było oszacowanie korelacji genetycznych i fenotypowych w trzech następujących po sobie laktacjach pomiędzy cechami zdolności udojowej bydła rasy polskiej holsztyńsko-fryzyjskiej: szybkością oddawania mleka (SOM) i temperamentem (TEM) a liczbą komórek somatycznych w mleku (LKS) w trzech następujących po sobie laktacjach oraz cechami płodności ocenianymi w Polsce, tj. wskaźnikiem niepowtarzalności unasienniania jałówek (NRJ), wskaźnikiem niepowtarzalności unasienniania krów (NRC), długością przestoju poporodowego (PP), długością okresu międzyciążowego (OMC). Dane obejmowały wyniki rutynowej oceny cech zdolności udojowej 13280 krów, które zgromadzono w systemie SYMLEK należącym do Polskiej Federacji Hodowców Bydła i Producentów Mleka. Cechy zdolności udojowej były oceniane podczas drugiego próbnego udoju, w latach od 2007 do 2014. Komponenty (ko) wariancji genetycznych i fenotypowych cech zdolności udojowej i liczby komórek somatycznych w mleku oraz cech płodności oszacowano za pomocą metody próbkowania Gibbsa, która został zaimplementowana w oprogramowaniu GIBBSF90 (Misztal 2008). W badaniach zastosowano dwucechowy model obserwacji. Jako efekty stałe uwzględniono efekt podklasy stado-rok-sezon, fazy laktacji, udziału genów rasy holsztyńsko-fryzyjskiej oraz wieku ocielenia. Oszacowania korelacji genetycznych i fenotypowych cech zdolności udojowej z cechami płodności oraz LKS przeprowadzano wielokrotnie, wykorzystując dwie cechy zdolności udojowej oraz jedną z cech płodności lub LKS.

Uzyskane współczynniki korelacji genetycznych $\left(\mathrm{r}_{\mathrm{G}}\right)$ pomiędzy SOM a badanymi cechami płodności mieściły się $\mathrm{w}$ przedziale od $-0,21\left(\mathrm{r}_{\mathrm{G}}\right)$ dla NRK do 0,41 dla PP. Współczynniki korelacji genetycznych pomiędzy TEM a badanymi cechami płodności znajdowały się w przedziale od $-0,15$ dla OMC do 0,42 dla NRK. Z kolei współczynniki korelacji fenotypowych między SOM wynosiły od 0,03 $\left(\mathrm{r}_{\mathrm{P}}\right)$ dla PP do 0,01 dla NRJ, a fenotypowe skorelowanie TEM z cechami pokroju wynosiło od $-0,01$ dla PP do 0,01 dla NRK.

Współczynniki korelacji genetycznych $\left(\mathrm{r}_{\mathrm{G}}\right)$ pomiędzy SOM a liczbą komórek somatycznych w mleku $\mathrm{w}$ trzech następujących po sobie laktacjach malały od $0,72 \mathrm{w}$ pierwszej laktacji do $0,36 \mathrm{w}$ trzeciej laktacji. Natomiast korelacje genetyczne pomiędzy TEM a liczbą komórek somatycznych w mleku wzrastały od $0,07 \mathrm{w}$ laktacji pierwszej do $0,23 \mathrm{w}$ laktacji trzeciej Z kolei współczynniki korelacji fenotypowych pomiędzy SOM a liczbą komórek somatycznych rosły w przedziale od 0,01 w laktacji pierwszej do $0,03 \mathrm{w}$ laktacji trzeciej, a pomiędzy TEM a liczbą komórek somatycznych malały od 0,04 w laktacji pierwszej do 0,02 w laktacji trzeciej.

Uzyskane parametry genetyczne w krajowej populacji krów rasy polskiej holsztyńsko-fryzyjskiej są na ogół umiarkowane i mieszczą się w zakresie opublikowanych w literaturze wartości dla tej grupy cech. Otrzymany rząd wielkości współczynników korelacji genetycznych pozwala na ich wykorzystanie do opracowywania optymalnej strategii selekcji w zakresie doskonalenia cech zdolności udojowej. 


\title{
ODZIEDZICZALNOŚĆ CECH PRODUKCYJNYCH W OBJĘTEJ PROGRAMEM OCHRONY ZASOBÓW GENETYCZNYCH POPULACJI KRÓW RASY POLSKIEJ CZERWONO-BIAEEJ
}

\begin{abstract}
Heritability of production traits in a population of polish red and white cows included in the genetic resources conservation programme
\end{abstract}

Piotr Topolski, Bartosz Szymik

Zakład Hodowli Bydła, Instytut Zootechniki - Państwowy Instytut Badawczy, ul. Krakowska 1, 32-083 Balice e-mail: piotr.topolski@izoo.krakow.pl

W ramach pracy oszacowano odziedziczalność cech produkcyjnych w zachowawczej populacji krów rasy polskiej czerwono-białej. Materiał do badań (populacja podstawowa) pochodził z systemu SYMLEK należącego do Polskiej Federacji Hodowców Bydła i Producentów Mleka i obejmował wyniki oceny pięciu cech produkcyjnych: standardowe 305-dniowe wydajności mleka, tłuszczu i białka $(\mathrm{kg})$ oraz zawartości tłuszczu i białka (\%).

Do analiz wybrano rekordy krów z wartościami cech produkcyjnych zarejestrowanymi dla pierwszej laktacji. Optymalizację struktury danych oraz kombinacji efektów stałych i losowych uwzględnionych w modelach obserwacji przeprowadzono za pomocą własnego oprogramowania napisanego w języku R, z wykorzystaniem pakietów, w których są zaimplementowane metoda maximum likelihood oraz procedury ANOVA i GLM.

Ostatecznie zbiór do szacowania parametrów genetycznych obejmował rekordy 1672 krów, dla których standardowe 305-dniowe wydajności/zawartości cech produkcyjnych mieściły się $\mathrm{w}$ zakresie $\pm 2,50 \mathrm{SD}$ w populacji podstawowej dla wydajności mleka, $\pm 2,60 \mathrm{SD}$ w populacji podstawowej dla wydajności białka i tłuszczu oraz $\pm 2,40$ SD w populacji podstawowej dla pozostałych cech. Krowy pochodziły od 103 ojców i 957 matek i zostały zaklasyfikowane do 717 poziomów HYS (stado-rok-sezon ocielenia) oraz 24 podklas YLA (poziom produkcji-wiek ocielenia).

Komponenty wariancji i kowariancji cech produkcyjnych oszacowano metoda największej wiarogodności z ograniczeniami (REML) na podstawie wielocechowego modelu liniowego mieszanego obserwacji, w którym uwzględniono: efekt losowy addytywny genetyczny zwierzęcia, efekty stałe HYS i YLA, efekty losowe interakcji ojciec-obora oraz błędu.

Otrzymane współczynniki odziedziczalności $\left(\mathrm{h}^{2}\right)$ cech produkcyjnych w zachowawczej populacji krów rasy polskiej czerwono-białej charakteryzują się na ogół średnim poziomem wielkości. Największą odziedziczalnością cechuje się zawartość białka $\left(h^{2}=0,44\right)$, a najmniejszą - wydajność tłuszczu $\left(h^{2}=0,19\right)$. Oszacowany w pracy współczynnik odziedziczalności dla wydajności mleka wynosi 0,32.

Badania finansowane w ramach projektu NCBiR - Biostrateg (nr 297267). 


\title{
THE LIFESPAN OF UKRAINIAN BLACK-AND-WHITE AND RED-AND-WHITE DAIRY BREEDS, DEPENDING ON THE ASSESSMENT OF UDDER LINEAR TRAITS
}

\author{
Czas życia ukraińskich krów czerwono-łaciatej i czarno-łaciatej rasy mlecznej \\ w zależności od oceny cech liniowych wymienia
}

\author{
Viktoriia Vechorka \\ Sumy National Agrarian University, Biological Technological Faculty, 160 Herasym Kondratiev, Sumy, 40021, Ukraine \\ e-mail:vvvechorka@gmail.com
}

Taking into account the importance method of linear classification in determining the breeding value of dairy cattle, selection and economic importance duration of use animals, studies have been carried out in the aspect of defining the relationship between the assessment of udder linear traits and lifespan of cows. Experiments in the herd of breeding farm AF „Mayak” in Zolotonosha district of Cherkasy region have been conducted on the number of livestock of Ukrainian Red-and-White and Black-and-White Dairy breeds. Estimation of cows-heifers according to the exterior type has been carried out to the linear classification method according to the latest ICAR recommendations at the age of 2-4 months after calving. Cows with higher scores for the development of udder morphological traits have a longer lifespan in comparison with animals assessed by the lower score.

Indicators of assessment for the front udder attachment have been showed the existence of a link between the development of this trait and lifespan of cows evaluated breeds. The difference between cows, estimated in 1 and 9 scores, is quite significant and has been amounted 939 (Ukrainian Red-and-White Dairy, $\mathrm{P}<0.001$ ) and 710 (Ukrainian Black-and-White Dairy, $\mathrm{P}<0.001$ ) days.

The difference between the lowest and the highest estimates based on the height of rear udder part attachment, obtained from our research in cows of the experimental breeds, is 687 (Ukrainian Red-and-White Dairy, $\mathrm{P}<0.001$ ) and 878 (Ukrainian Black-and-White Dairy, $\mathrm{P}<0.001$ ) days.

Animals with an estimate for the development of central ligament lower than average (1-4 scores) have been used from 1675 to 1832 (Ukrainian Red-and-White Dairy) and from 1535 to 1810 (Ukrainian Blackand-White Dairy) days according to estimated breeds. Cows with an estimate 9 scores have a higher lifespan in 2377 days, exceeding cows with the lowest estimate on 702 days (Ukrainian Red-and-White, $\mathrm{P}<0.001$ ) and 2322 days with a reliable increasing on 785 days (Ukrainian Black-and-White, $\mathrm{P}<0.001$ ).

The difference between the average life expectancy of cows with 9 and 1 scores of the udder depth is 618 days in Ukrainian Red-and-White Dairy cows $(\mathrm{P}<0.001)$, in cows of Ukrainian Black-and-White Dairy 762 days $(\mathrm{P}<0.001)$.

The longest have been used cows in the herd with an estimate of the front teats location from 5 to 9 scores, and a significant decrease of the longevity index in cows begins with an estimate for this trait from 3 to 1 scores.

Thus, assessment cows of Ukrainian Red-and-White and Black-and-White Dairy breeds by the method of linear classification has been confirmed that the desirable development of the udder morphological traits is a guarantee of a long life of cows in modern technological conditions of milk production. 


\title{
ROBOTYZACJA DOJU KRÓW W WIELKOPOLSCE
}

\author{
Robotic milking of cows in Wielkopolska
}

\author{
Stanisław Winnicki ${ }^{1}$, Zbigniew Sobek ${ }^{2}$, Jolanta Różańska-Zawieja ${ }^{1,2}$ \\ ${ }^{1}$ Instytut Technologiczno-Przyrodniczy w Falentach \\ ${ }^{2}$ Uniwersytet Przyrodniczy w Poznaniu, Katedra Genetyki i Podstaw Hodowli Zwierząt \\ e-mail: zbigniew@up.poznan.pl
}

Mija 10 lat od uruchomienia pierwszego robota udojowego w Polsce. W województwie wielkopolskim pierwszy taki robot (firmy Lely) został uruchomiony w 2010 r., natomiast ostatnio zainstalowany dwustanowiskowy robot (firmy DeLaval) rozpoczął pracę w oborze w drugim półroczu $2018 \mathrm{r}$.

W niniejszych badaniach analizowano aktualny stan robotyzacji w Wielkopolsce oraz wyniki produkcyjne w stadach, w których minimum przez rok krowy dojono robotem udojowym. Na koniec 2017 r. warunek ten spełniło 25 stad, które wykorzystywały roboty dwóch firm: Lely (19 stad) i DeLaval (6 stad). Robotami dojono około 4 tys. krów, co stanowi około 2\% pogłowia w Wielkopolsce. W 6 stadach są to roboty jednostanowiskowe, w 9 dwustanowiskowe i w 10 stadach mające od 3 do 7 stanowisk. Rozkład wydajności mleka w 2008 i 2017 r. przedstawiono w tabeli 1, a wydajności tłuszczu i białka w tabeli 2.

Tabela 1. Rozkład stad pod względem wydajności mleka

\begin{tabular}{|l|c|c|}
\hline \multirow{2}{*}{$\begin{array}{c}\text { Średnia wydajność } \\
\text { [tys. kg] }\end{array}$} & \multicolumn{2}{|c|}{ Liczba stad w roku } \\
\cline { 2 - 3 } & 2008 & 2017 \\
\hline Do 7 & 3 & - \\
$7-8$ & 9 & 1 \\
$8-9$ & 11 & 4 \\
$9-10$ & 2 & 6 \\
$10-11$ & - & 8 \\
$11-12$ & - & 4 \\
$12-13$ & - & 2 \\
\hline Razem & 25 & 25 \\
\hline
\end{tabular}

Tabela 2. Rozkład stad pod względem wydajności tłuszczu i białka

\begin{tabular}{|c|c|c|}
\hline $\begin{array}{c}\text { Wydajność } \\
\text { tłuszczu i białka } \\
{[\mathrm{kg}]}\end{array}$ & \multicolumn{2}{|c|}{ Liczba stad w roku } \\
\cline { 2 - 3 } & 2008 & 2017 \\
\hline Do 500 & 2 & - \\
$501-600$ & 11 & 1 \\
$601-700$ & 10 & 9 \\
$701-800$ & 2 & 11 \\
$\geq 801$ & - & 4 \\
\hline Razem & 25 & 25 \\
\hline
\end{tabular}

W większych stadach po wprowadzeniu robotów udojowych nastąpił znaczny wzrost wydajności mleka, tłuszczu oraz białka, przewyższający wzrost wydajności mleka oraz jego składników w populacji. W $2017 \mathrm{r}$. w 20 analizowanych stadach wydajność mleka przekroczyła średnią wydajność krów rasy polskiej holsztyńsko-fryzyjskiej odmiany czarno-białej. 


\title{
KORELACJE MIĘDZY ZAWARTOŚCIĄ SKŁADNIKÓW SUCHEJ MASY A PARAMETRAMI KRZEPLIWOŚCI MLEKA
}

Correlations between the content of dry matter compounds and milk coagulation parameters

\author{
Anna Wolanciuk, Joanna Barłowska, Jolanta Król, Monika Kędzierska-Matysek, Aneta Brodziak,
} Barbara Topyła, Patrycja Dopieralska

\author{
Uniwersytet Przyrodniczy w Lublinie, Katedra Towaroznawstwa i Przetwórstwa Surowców Zwierzęcych, \\ ul. Akademicka 13, 20-950 Lublin \\ e-mail: anna.wolanciuk@up.lublin.pl
}

W technologii serów jednym z najważniejszych etapów procesu produkcyjnego jest koagulacja białek mleka. Przebieg tego procesu zależy m.in. od zawartości składników suchej masy w mleku przerobowym. Celem badań było określenie korelacji między zawartością składników suchej masy a parametrami krzepliwości mleka.

Materiał do badań stanowiło 630 próbek mleka pobranych od krów trzech ras: polskiej czerwonej (215), białogrzbietej (226) i simentalskiej (189). Próbki mleka pobierano indywidualnie od każdej krowy w czasie próbnych udojów, w dwóch sezonach, tj. wiosenno-letnim (V-VII) i jesienno-zimowym (XII-II). W badaniach uwzględniono próbki mleka, w których liczba komórek somatycznych nie przekraczała 400 tys. $/ \mathrm{ml}$. Krowy były w II-VI laktacji, w środkowym jej stadium (tj. między 120. a 200. dniem laktacji). W pobranych próbkach mleka oznaczono skład chemiczny, tj. zawartość tłuszczu, białka i laktozy (na podstawie których wyliczono zawartość suchej masy oraz proporcję białka i tłuszczu) aparatem Infrared Milk Analyzer firmy Bentley. Właściwości koagulujące mleka oceniono na podstawie parametrów: RCT - czasu krzepnięcia pod wpływem podpuszczki, a30 - zwięzłości skrzepu po $30 \mathrm{~min}$ od dodania enzymu koagulującego, $\mathrm{k}_{20}$ wskazującym szybkość osiągnięcia przez żel określonej zwięzłości przy wykorzystaniu laktodynamografu V2 (Foss, Italia). Obliczono współczynniki korelacji Pearsona (r).

Wykazano, że zawartość suchej masy w mleku była dodatnio skorelowana ze zwięzłością skrzepu po $30 \min (\mathrm{r}=0,28, \mathrm{p}=0,000)$. Większa zawartość suchej masy skracała również czas niezbędny do osiągnięcia określonej zwięzłości skrzepu $(\mathrm{r}=-0,31, \mathrm{p}=0,000)$. Nie wykazano zależności między zawartością suchej masy a czasem krzepnięcia mleka. Zawartość białka i tłuszczu była dodatnio skorelowana ze zwięzłością skrzepu po 30 min (odpowiednio $r=0,28, p=0,000$ i $r=0,14, p=0,004$ ) oraz ujemnie $\mathrm{z}$ czasem osiągania określonej zwięzłości (odpowiednio $r=-0,34, p=0,000$ i $r=-0,24, p=0,000$ ). Nie wykazano istotnych statystycznie współczynników korelacji między parametrami krzepliwości mleka a zawartością laktozy oraz proporcją białka i tłuszczu.

Praca wykonana w ramach projektu „Kierunki wykorzystania oraz ochrona zasobów genetycznych zwierząt gospodarskich w warunkach zrównoważonego rozwoju" współfinansowanego przez Narodowe Centrum Badań i Rozwoju w ramach Strategicznego programu badań naukowych i prac rozwojowych „Środowisko naturalne, rolnictwo i leśnictwo” - Biostrateg, nr umowy: BIOSTRATEG2/297267/14/NCBR/2016. 


\title{
ZAWARTOŚĆ IMMUNOGLOBULIN W SUROWICY CIELĄT W ZALEŻNOŚCI OD SPOSOBU POJENIA SIARĄ
}

The level of immunoglobulins in calves serum according to method of colostrum feeding

\author{
Andrzej Zachwieja ${ }^{1}$, Szymon Kopalak $^{1}$, Ewa Pecka ${ }^{2}$, Edyta Wojtas $^{1}$, Anna Zielak-Steciwko ${ }^{1}$ \\ ${ }^{1}$ Uniwersytet Przyrodniczy we Wrocławiu, Zakład Hodowli Bydła i Produkcji Mleka, ul. Chełmońskiego 38c, 51-630 Wrocław, \\ ${ }^{2}$ Uniwersytet Przyrodniczy we Wrocławiu, Zakład Fizjologii Zwierząt, ul. Norwida 31, 50-375 Wrocław \\ e-mail: andrzej.zachwieja@upwr.edu.pl
}

Celem badań było porównanie dwóch sposobów odpajania cieląt siarą w pierwszej dobie życia - sondą oraz z wiadra ze smoczkiem - w aspekcie wykorzystania i poziomu immunoglobulin siarowych w ich surowicy. Badania przeprowadzono w gospodarstwie rodzinnym specjalizującym się w produkcji mleka. Objęto nimi grupę 18 krów i ich cielęta. Zwierzęta przydzielono do dwóch grup, biorąc pod uwagę wiek krów oraz płeć cieląt. 9 cieląt pojono z wiadra ze smoczkiem (I grupa), a 9 - sondą (II grupa). Krowy w okresie laktacji utrzymywane były w oborze uwięziowej płytkościołowej, żywione w systemie PMR, ustalona dawka żywieniowa na produkcję 25 litrów mleka; zwierzęta produkujące powyżej tej wartości otrzymywały dodatkową paszę treściwą indywidualnie. Okres zasuszenia trwał w zależności od kondycji zwierzęcia 6-8 tygodni, krowy przeprowadzane były do oddzielnego budynku, gdzie przebywały do 2 tygodni przed planowanym terminem ocielenia, w tym czasie żywione były kiszonką z kukurydzy, prefiksem mineralno-witaminowym oraz słomą i sianokiszonką do woli. Na 2 tygodnie przed ocieleniem krowy przeprowadzano do obory, poród odbywał się na stanowisku legowiskowym. Cielęta było pojone świeżo zdojoną siarą (z pierwszego pełnego doju po porodzie) w zależności od zastosowanego sposobu pojenia: $2 \times 21 \mathrm{z}$ wiadra ze smoczkiem, w odstępie 6-8 godzin, lub 41 sondą jednorazowo i umieszczane w kojcach indywidualnych w oborze. Do badań pobrano próby siary z pierwszego pełnego doju, bezpośrednio po wycieleniu. Od cieląt pobierano próby krwi po 48 godzinach od pierwszego podania siary. W siarze określano skład podstawowy, liczbę komórek somatycznych oraz ogólną liczbę drobnoustrojów. Metodą elektroforezy pionowej w żelu poliakryloamidowym, w obecności SDS, określono udział frakcji białkowych w siarze. W surowicy cieląt oznaczono zawartość immunoglobulin klasy G metodą ELISA. Wyniki wskazują na brak zmienności pomiędzy grupami w składzie podstawowym, poziomie frakcji białkowych oraz immunoglobulin w siarze. W surowicy cieląt pojonych jednorazowo sondą stwierdzono stężenie IgG na poziomie $23,33 \mathrm{mg} / \mathrm{ml}$, w grupie cieląt zaś pojonych tradycyjnie z wiadra ze smoczkiem w ilości $41 \mathrm{w}$ dwóch $(2 \times 2)$ odpasach wykazano zawartość $23,5 \mathrm{mg} / \mathrm{ml}$ immunoglobulin surowicy. Można zatem stwierdzić, że sposób pojenia cieląt nie miał wpływu na stężenie immunoglobulin w ich surowicy, a zatem na poziom odporności biernej. Można wnioskować, że większy wpływ na uzyskanie odpowiedniego poziomu biernej odporności przeciwzakaźnej przez cielęta mogą mieć inne czynniki, takie jak termin podania siary po porodzie oraz jej ilość, liczba odpasów. Uzyskane wyniki wskazują, że oba sposoby pojenia cieląt są właściwe i przynoszą oczekiwane efekty w zakresie ich statusu immunologicznego. Nadrzędnym celem powinien być zawsze stan zdrowia cieląt. Wybór sposobu pojenia powinien być warunkowany jego skutecznością oraz własnymi możliwościami. Sonda może być stosowana w przypadku braku odruchu ssania czy wystąpienia syndromu słabego cielęcia, a nie rutynowo. Ważny jest bowiem aspekt fizjologiczny procesu trawienia. Właściwe odpojenie siarą oraz dbałość o cielęta pozwoli uchronić je przed schorzeniami, które mogą negatywnie oddziaływać na ich cechy użytkowe, a w konsekwencji pogarszać opłacalność produkcji. 
Sekcja Chowu i Hodowli Drobiu 


\title{
ANALIZA CECH MORFOLOGICZNYCH JAJ I WSKAŹNIKÓW LĘGU WYBRANYCH RAS KUR OZDOBNYCH
}

Analysis of morphological egg characteristics and hatching results of selected breeds of ornamental chickens

\section{Dorota Banaszewska, Barbara Biesiada-Drzazga, Dominik Ostrowski, Małgorzata Długołęcka, Aleksandra Smarzewska}

\author{
Uniwersytet Przyrodniczo-Humanistyczny w Siedlcach, Instytut Bioinżynierii i Hodowli Zwierząt, \\ Katedra Metod Hodowlanych i Hodowli Drobiu, 08-110 Siedlce, ul. Prusa 14 \\ e-mail: dorota.banaszewska@uph.edu.pl
}

Rozwój wielkotowarowych metod chowu ptaków nie doprowadził do ograniczenia ilości hodowanych ras drobiu ozdobnego. W chwili obecnej wiele ras kur ozdobnych jest na nowo odkrywanych i utrzymywanych w małych amatorskich hodowlach. Stąd celem pracy była analiza cech jaj oraz wskaźników lęgu wybranych ras kur ozdobnych w hodowli amatorskiej. Badania przeprowadzono w gospodarstwie indywidualnym zajmującym się hodowlą amatorską kur. Oceną objęto sześć stadek kur ozdobnych: czubatka miniaturowa, czubatka duża, czubatka padewska, cochin, onagadori i chabo. W momencie rozpoczęcia badań ptaki ukończyły 36-37 tygodni życia.

Przeprowadzone badania obejmowały wybrane cechy zewnętrzne i wewnętrzne jaj. Od wszystkich stadek łącznie badaniami objęto 180 jaj. Parametry jakości jaj podzielono na oceniane niedestrukcyjnie oraz wymagające rozbicia jaja. Analizą objęto również wyniki lęgów. Do lęgu przeznaczano jaja złożone przez kury w czerwcu, po 30 jaj z każdego stadka (łącznie 180 jaj). Analiza jaj wylęgowych ze względu na pochodzenie obejmowała wskaźniki inkubacji jaj, na podstawie których obliczono wyniki wylęgu.

Uzyskane dane wskazują na różnice w masie, wielkości, kształcie jaj oraz grubości skorupy w zależności od genotypu kur. Jaja o największej masie, przekraczającej $53 \mathrm{~g}$, uzyskano od kur rasy czubatka duża i padewska. Jaja kur tych ras były o $15-21 \mathrm{~g}$ cięższe niż jaja kur pozostałych ras $(\mathrm{P} \leq 0,05)$. Kury pozostałych ras znosiły jaja o masie nieprzekraczającej $40 \mathrm{~g}$. Bardziej wydłużone jaja obserwowano u kur rasy onagadori i u czubatek w porównaniu z cochinami i chabo, na co wskazuje mniejszy indeks kształtu jaja. Barwa skorupy była zróżnicowana, co jest cechą rasową kur. Zaobserwowano, że najgrubszą skorupą bez względu na miejsce jej pomiaru charakteryzowały się jaja kur chabo. Warto zwrócić uwagę, że przy zbliżonej masie jaj czubatek dużej i padewskiej, mimo braku istotnych różnic w masie poszczególnych składników jaja, udział skorupy w jajach był różny. W jajach czubatki dużej przekroczył 14\% i był o ponad $2 \%$ większy niż w jajach czubatki padewskiej. W jajach czubatki dużej stwierdzono również większy udział żółtka (ponad 41\%) i mniejszy białka (ponad 44\%) w porównaniu z jajami czubatki padewskiej, w których stwierdzono zależność odwrotną. Udział żółtka w jajach kur tej rasy wynosił ponad 37\%, a udział białka ponad 51\%. W jajach kur rasy chabo, od których pozyskiwano jaja o najmniejszej masie, stwierdzono stosunkowo duży udział białka, wynoszący niemal 53\%, przy niewielkim udziale żółtka (około 35\%). Wskazano również na różnice w wynikach lęgu kur poszczególnych ras. Bardzo dobre wyniki lęgu miały kury ras czubatka padewska i onagadori. U kur tych ras procent zapłodnionych jaj przekraczał 90, natomiast procent wylęgu piskląt $\mathrm{z}$ jaj zapłodnionych również był większy niż u kur pozostałych ras $(\mathrm{P} \leq 0,05)$. Warto zwrócić uwagę, że u rasy onagadori z jaj zapłodnionych wylęgły się wszystkie pisklęta. Najmniejszą skuteczność zapłodnień stwierdzono u kur chabo (72,30\%), jednak z jaj zapłodnionych wylęgło się prawie $90 \%$. Z kolei niezadowalające wyniki wylęgu piskląt $\mathrm{z}$ jaj zapłodnionych uzyskano w przypadku czubatki dużej, gdzie kształtował się on na poziomie około $60 \%$ i był o $28-40 \%$ mniejszy niż w przypadku kur pozostałych ras $(\mathrm{P} \leq 0,05)$. 
Zajmując się hodowlą drobiu ozdobnego, można mieć również satysfakcję z dobrej jakości uzyskiwanych jaj i dobrych wskaźników lęgu. Najlepsze wyniki wylęgu otrzymano z jaj kur onagadori i czubatki padewskiej. Bardzo ważne jest, aby nie utracić ras drobiu ozdobnego, gdyż miłośnicy tych ptaków, którzy prowadzą hodowle amatorskie, przyczyniają się do utrzymania ogromnej bioróżnorodności, a ich ptaki są prawdziwym dziedzictwem kulturowym. Ponadto ptaki tych ras mogą $\mathrm{w}$ przyszłości stanowić $\mathrm{w}$ hodowli cenną pulę genetyczną, a w gospodarstwach agroturystycznych dużą atrakcję, dostarczając przy okazji jaj. 


\title{
MORFOMETRIA KRĘGÓW SZYJNYCH EMU Z ZASTOSOWANIEM METODY HYDROSTATYCZNEJ
}

Morphometry of the cervical spine of emu using the hydrostatic method

\author{
Piotr Baranowski ${ }^{1}$, Jerzy Nowacki $^{2}$, Sławomir Krajewski $^{2}$, Piotr Nowak $^{1}$ \\ ${ }^{1}$ Zachodniopomorski Uniwersytet Technologiczny w Szczecinie, Pracownia Anatomii Zwierząt \\ ${ }^{2}$ Zachodniopomorski Uniwersytet Technologiczny w Szczecinie, Instytut Inżynierii Materiałowej \\ e-mail: Piotr.Baranowski@ zut.edu.pl
}

U tych ptaków, u których szyja jest elastyczną, długą strukturą, liczba kręgów charakteryzuje się dużą zmiennością. Zasadniczo kręgów u ptaków może być od 9, jak u niektórych śpiewających, do 25 - jak u łabędzi. Kręgi szyjne u tych zwierząt są drobnymi jednostkami kostnymi, co sprawia, że kanał kręgowy nie jest łatwym obiektem w badaniach morfologicznych ich szkieletów, a metody pomiaru mało precyzyjne. Pomimo prowadzonych wielu badań szkieletów ptaków zaliczanych do nadrzędu Ratiatae w podgromadzie Palaeognathae, takich jak struś czy emu, o dokładnych pomiarach ich kręgów i kanału kręgowego nie wspomina się wcale lub są to tylko mało znaczące i niezbyt precyzyjne wzmianki. U ssaków badania kręgów ograniczają się do oszacowania wartości pomiarów liniowych w morfometrycznych badaniach porównawczych z innymi gatunkami. Nie odpowiadają one na pytanie, na który z odcinków kręgosłupa przypada najwięcej masy kostnej na jednostkę długości.

Celem badań było oszacowanie wartości podstawowych cech metrycznych kręgów szyjnych emu oraz objętości ich masy kostnej i pojemności kanału kręgowego, a ponadto uzyskanie informacji przydatnych w badaniach nad dymorfizmem szkieletu emu oraz wprowadzenie metod pomiaru do badań osteometrycznych, pozwalających ustalić wartości referencyjne dla oceny dojrzewania i stopnia jego rozwoju u ptaków.

Badania przeprowadzono na kręgach szyjnych kręgosłupa samców $(n=6)$ i samic $(n=10)$ emu w wieku 14 lat, użytkowanych rozpłodowo, pochodzących z hodowli Zakładu Hodowli Ptaków Użytkowych i Ozdobnych Wydziału Biotechnologii i Hodowli Zwierząt ZUT w Szczecinie. Średnia masa ciała samców wynosiła 33,87 kg $\pm 4,67(28,21-40,11 \mathrm{~kg})$, a samic 40,94 $\mathrm{kg} \pm 5,35(33,63-51,01 \mathrm{~kg})$. Pomiary osteometryczne wykonano trzykrotnie suwmiarką elektroniczną, mierząc wysokość, szerokość i największą długość każdego kręgu (ich suma wyznaczyła długość odcinka szyjnego), jego szerokość dogłowową i szerokość doogonową, szerokość powierzchni stawowej dogłowowej i doogonowej każdego kręgu. Suwmiarką wykonano również pomiar długości otworu kanału kręgu, a pole powierzchni światła kręgu oszacowano za pomocą programu MultiScan. Pojemność kanału każdego kręgu określono, mnożąc długość kanału kręgu przez pole powierzchni światła kręgu. Metodą hydrostatyczną oszacowano pomiar gęstości i objętości każdego kręgu. Oszacowano średnią wartość objętości masy kostnej kręgów, średnią pojemność kanału kręgu, współzależności pomiędzy pojemnością kanału kręgu a długością kręgu. W obliczeniach przyjęto za źródło zmienności płeć ptaków. W związku z brakiem rozkładu normalnego oraz niejednorodności wariancji cech różnice między grupami oszacowano, posługując się testem U Manna-Whitneya (Statistica 13.1 v.PL). Odcinek szyjny kręgosłupa liczył 17 kręgów.

Stwierdzono dymorfizm w zakresie podstawowych cech metrycznych między analogicznymi kręgami emu obojga płci. Kręgi samic charakteryzowały się istotnie $(\mathrm{P} \leq 0,05$ i $\mathrm{P} \leq 0,01)$ większą długością, szerokością i wysokością niż kręgi samców. Nie stwierdzono różnic dymorficznych w zakresie objętości masy kostnej kręgów od 1 do 8 , natomiast kręgi samic od 9 do 17 miały większą $(P \leq 0,05)$ objętość w porównaniu z kręgami samców. Wartości współczynników korelacji dla masy ciała, objętości kręgów i pojemności kanałów kręgów były słabe. Suma długości trzonów kręgów wyznaczająca długość szyi wykazała istotnie $(\mathrm{P} \leq 0.01)$ dłuższe szyje samic emu. Stwierdzono w całym przebiegu odcinka szyjnego kręgosłupa emu brak zwężeń i rozszerzeń kanału kręgowego dla przebiegającego w nim rdzenia kręgowego. 


\title{
ZACHOWANIA ZAKUPOWE I WIEDZA KONSUMENTÓW JAJ NA RYNKU LUBELSZCZYZNY
}

Buying behavior and knowledge of eggs' consumers on the market of Lublin region

\author{
Justyna Batkowska $^{1}$, Kamil Drabik $^{2}$, Antoni Brodacki ${ }^{1}$, Magdalena Panfil ${ }^{2}$ \\ ${ }^{1}$ Uniwersytet Przyrodniczy w Lublinie, Instytut Biologicznych Podstaw Produkcji Zwierzęcej \\ ${ }^{2}$ Uniwersytet Przyrodniczy w Lublinie, Sekcja Hodowli Drobiu SKN Biologów i Hodowców Zwierząt \\ e-mail: justyna.batkowska@up.lublin.pl
}

Zachowania konsumenckie w znacznym stopniu kształtują rynek surowców drobiarskich. Należy zwrócić uwagę na uwarunkowania lokalne, ściśle związane z kulturą regionu, które wpływają na późniejsze wybory zakupowe. Lubelszczyzna, z uwagi na znaczny udział rolnictwa, rozdrobnienie agrarne oraz relatywnie niewiele dużych miast stanowi specyficzny region w ujęciu konsumenckim.

Celem pracy była ocena zachowań zakupowych oraz wiedzy konsumentów na temat surowców drobiarskich w regionie Lubelszczyzny. Jako materiał do badań wykorzystano dane ankietowe w liczbie 744 poprawnie wypełnionych formularzy. Ankiety zawierały pytania dotyczące zarówno charakterystyki badanej grupy respondentów, jak i ich preferencji w zakresie zakupu i spożywania jaj konsumpcyjnych. Uzyskane dane poddano analizie statystycznej.

Uzyskane wyniki wskazują, że specyfika Lubelszczyzny wpływa znacząco na zachowania zakupowe konsumentów. Cechami demograficznymi najbardziej różnicującymi badaną grupę były wiek, liczba osób w gospodarstwie domowym oraz dochód.

Starsi ludzie kupują zazwyczaj wyłącznie tradycyjne jaja kurze, ale za to niższej klasy wagowej, pakowane w większej liczbie sztuk. Większe liczbowo opakowania wybierają też osoby lepiej wykształcone. Konsumenci wychowywani w większych miastach chętniej spożywają jaja od innych gatunków drobiu niż kury, preferują także bardziej ekstensywne systemy utrzymania drobiu oraz jaja większych klas wagowych. $\mathrm{Na}$ wiele wyborów rodzicielskich wpływa wiek dzieci w rodzinie. Rodziny ze starszymi dziećmi częściej kupują jaja w plastikowych opakowaniach, preferują ciemniejszą barwę żółtka i skorupy, ale mniejsze klasy wagowe. Wybór systemu chowu, z którego pochodzą jaja konsumpcyjne, wyraźnie pozostaje pod wpływem lokalizacji prowadzonych badań. Lubelszczyzna to region rolniczy, dodatkowo w badanej próbie dominowały osoby deklarujące wieś jako miejsce zamieszkania, stąd też prawdopodobnie dominujący wybór jaj z własnego gospodarstwa. 


\title{
WYNIKI PRODUKCYJNE I JAKOŚĆ MIĘSA PERLIC TYPU MIĘSNEGO
}

Production effects and meat quality of meat type guinea fowl

\author{
Justyna Batkowska ${ }^{1}$, Kamil Drabik $^{2}$, Ahsan Umair ${ }^{4}$, Małgorzata Karwowska ${ }^{3}$, Anna Kabacińska ${ }^{2}$, \\ Patrycja Chabroszewska ${ }^{2}$

\footnotetext{
${ }^{1}$ Uniwersytet Przyrodniczy w Lublinie, Instytut Biologicznych Podstaw Produkcji Zwierzęcej

${ }^{3}$ Uniwersytet Przyrodniczy w Lublinie, Katedra Technologii Surowców Pochodzenia Zwierzęcego

${ }^{4}$ Department of Animal Nutrition and Nutritional Diseases, Faculty of Veterinary Medicine, Adnam Menderes University, Isikli, Aydin 09016, Turkey

e-mail: justyna.batkowska@up.lublin.pl
} \\ ${ }^{2}$ Uniwersytet Przyrodniczy w Lublinie, Sekcja Hodowli Drobiu SKN Biologów i Hodowców Zwierząt
}

Perlice pozostają w Polsce raczej atrakcją turystyczną niż gatunkiem chętnie utrzymywanym przez producentów drobiu. Ptaki te są natomiast bardzo popularne na zachodzie Europy, przede wszystkim we Francji, z uwagi na walory smakowe ich mięsa. Spotykane w Polsce perlice to przede wszystkim ptaki typu nieśnego lub ogólnoużytkowego, charakteryzujące się wolnym przyrostem masy ciała i niewielką masą końcową, są zatem mało atrakcyjne w aspekcie pozyskiwania mięsa. W przypadku ptaków w typie mięsnym można uzyskać wysokiej jakości tuszki o masie przekraczającej $2 \mathrm{~kg}$, co podnosi atrakcyjność tego gatunku w ujęciu konsumenckim. Dodatkowym problemem w chowie perlic może być także brak na polskim rynku mieszanek paszowych przeznaczonych wyłącznie dla tego gatunku ptaków i pokrywających ich zapotrzebowanie na składniki pokarmowe.

Celem pracy była ocena możliwości wykorzystania komercyjnych pasz dla drobiu rzeźnego (indyków, kurcząt) w chowie perlic typu mięsnego.

Materiał do badań stanowiło 40 perlic typu mięsnego komercyjnego zestawu „Mr. Green”. Ptaki zakupiono w wieku 4 tygodni, podzielono losowo na dwie grupy (po 4 podgrupy każda) różniące się rodzajem zadawanej paszy (mieszanka pełnoporcjowa dla indyków rzeźnych vs dla kurcząt brojlerów) i odchowywano w głębokiej ściółce przez okres 12 tygodni. Rejestrowano przyrosty masy ciała ptaków, pobranie paszy oraz wykorzystanie paszy. Po zakończonym odchowie po 8 ptaków z każdej grupy poddano ubojowi. Oceniano ich wydajność rzeźną, a także parametry jakościowe mięsa, takie jak: kwasowość, barwa, kruchość, wodochłonność, wyciek naturalny i termiczny.

Stwierdzono brak statystycznych różnic w końcowej masie ciała perlic niezależnie od rodzaju zastosowanej paszy. Również wydajność rzeźna oraz proporcje poszczególnych elementów w tuszkach były zbliżone w obu grupach, chociaż nieznacznie lepsze u ptaków żywionych paszą dla kurcząt. Nie odnotowano wpływu zróżnicowanego żywienia na jakość pozyskanego mięsa.

Uzyskane wyniki wskazują na możliwość stosowania zarówno paszy dla kurcząt brojlerów, jak i indyków rzeźnych, w chowie perlic w typie mięsnym. $Z$ uwagi na niższą cenę pasz dla kurcząt oraz braku istotnego zróżnicowania cech jakości mięsa ich zastosowanie wydaje się być bardziej uzasadnione z ekonomicznego punktu widzenia. 


\title{
CHARAKTERYSTYKA GOSPODARSTW EKOLOGICZNYCH ZAJMUJĄCYCH SIE CRODUKCJĄ JAJ KONSUMPCYJNYCH NA TERENIE WOJEWÓDZTWA MAZOWIECKIEGO
}

\author{
Organic farms producing table eggs in Mazovian voivodeship, a case study
}

\author{
Elżbieta Bombik, Gabriel Maliszewski, Katarzyna Pietrzkiewicz, Emilia Wierzbicka, \\ Anna Korzeniewska
}

\author{
Uniwersytet Przyrodniczo-Humanistyczny w Siedlcach, Katedra Rozrodu i Higieny Zwierząt \\ e-mail: gabriel.malisz@gmail.com
}

W obecnych czasach coraz więcej osób interesuje się zdrowym trybem życia, zdrową żywnością. Konsumenci żywności coraz częściej przywiązują większą uwagę do pochodzenia produktu i jego składu niż do jego ceny czy opakowania. Dlatego też wartość zarówno międzynarodowego rynku produktów ekologicznych, jak i produkcji ekologicznej stale rośnie.

Celem badania było scharakteryzowanie gospodarstw ekologicznych zajmujących się produkcją jaj konsumpcyjnych na terenie województwa mazowieckiego.

Badania ankietowe przeprowadzono w lutym 2016 r. w 9 gospodarstwach ekologicznych położonych w powiatach województwa mazowieckiego: siedleckim, łosickim, sokołowskim, mińskim, węgrowskim. Kryterium wyboru badanych gospodarstw stanowiły: działalność gospodarstwa ekologicznego oraz jego lokalizacja. Badani respondenci byli certyfikowanymi producentami żywności ekologicznej i odpowiadali na pytania zawarte w dwóch ankietach, z których pierwsza, zawierająca 45 pytań, dotyczyła ogólnej charakterystyki gospodarstwa, natomiast druga, zawierająca 10 pytań, skupiała się jedynie na produkcji drobiarskiej. Pytania z obu ankiet obejmowały uwarunkowania sprzyjające rozwojowi produkcji ekologicznej na terenie wybranych powiatów województwa mazowieckiego, powierzchni gospodarstwa, struktury zasobów ziemi, struktury upraw, okresu prowadzenia produkcji ekologicznej, wieku właściciela gospodarstwa, poziomu osiąganych dochodów, kosztów poniesionych na przekształcenie gospodarstwa na produkcję ekologiczną, charakterystyki produkcji roślinnej i zwierzęcej oraz promocji produktów ekologicznych.

Z uzyskanych danych wynika, że gospodarstwa ekologiczne najczęściej prowadzone są przez mężczyzn o średniej wieku powyżej 40 lat, z wykształceniem średnim, którzy konwersję do certyfikowanego gospodarstwa ekologicznego rozpoczęli nawet 20 lat temu. Średnia wielkość gospodarstwa przewyższa 15 hektarów. Większość respondentów swoją działalność opiera na produkcji więcej niż jednego produktu ekologicznego, z czego najczęściej z produkcją drobiarską łączona była produkcja roślinna. Z drobiu najpopularniejsze wśród ankietowanych były kury rasy zielononóżka kuropatwiana. Niewielu z ankietowanych posiada więcej niż dwie rasy drobiu na swoim utrzymaniu - wśród utrzymywanych ras drobiu znalazły się kury rhode island red, kochin olbrzymi, polbary oraz kaczki rasy pekin. Najmniejsze stado liczyło 15 sztuk ptactwa, a największe 2500. Większość stad nie przekraczała 200 sztuk. Średnia nieśność zielononóżki kuropatwianej wynosiła 160-180 sztuk. Głównym powodem wyboru ras drobiu przez ankietowanych była wysoka produkcyjność w warunkach produkcji ekologicznej, jakość produktu i jego marka u konsumentów, niskie wymagania środowiskowe czy też odporność na choroby. Ankietowani sprzedaż swoich produktów ekologicznych prowadzili bezpośrednio $\mathrm{w}$ gospodarstwie, gdzie można nabyć jaja, mięso, warzywa czy mleko. W większości przypadków podjęcie produkcji drobiarskiej przez ankietowanych spowodowane było popularnością produktu wśród klientów oraz łatwością adaptacji budynków i wybiegów. 


\title{
RASY/RODY KUR NIEŚNYCH OBJĘTE PROGRAMEM OCHRONY ZASOBÓW GENETYCZNYCH ZWIERZĄT UTRZYMYWANE W INSTYTUCIE ZOOTECHNIKI - PAŃSTWOWYM INSTYTUCIE BADAWCZYM
}

Conserved breeds/lines of laying hens maintained by the National Research Institute of Animal Production

\author{
Jolanta Calik
}

\begin{abstract}
Instytut Zootechniki - Państwowy Instytut Badawczy, Zakład Hodowli Drobiu, ul. Krakowska 1, 32-083 Balice e-mail: jolanta.calik@izoo.krakow.pl
\end{abstract}

Instytut Zootechniki - PIB ma duże zasługi w ochronie zasobów genetycznych zwierząt w Polsce a na jego fermach - w Zakładzie Doświadczalnym w Chorzelowie i w Aleksandrowicach - utrzymywanych jest ponad 70\% krajowych zasobów genetycznych drobiu, tj. zielononóżka kuropatwiana (Z-11), żółtonóżka kuropatwiana (Ż-33), rhode island red (R-11, K-22), rhode island white (A-33), sussex (S-66), leghorn (G-99, H-22). Liczebność poszczególnych populacji waha się od 800 do 1150 sztuk. Większość ww. ras kur została zaliczona przez FAO do światowych zasobów podlegających ochronie (Word Watch List, FAO 2000).

Rodzime rasy kur nieśnych są ściśle związane z rolniczym krajobrazem, tradycją i kulturą miejscowych społeczności. Populacje te charakteryzuje dobra zdrowotność, odporność na niekorzystne warunki klimatyczne, a także niekontrolowane warunki chowu drobnostadkowego. Bardzo dobrze wykorzystują ubogie w ruń łąki i pastwiska oraz nieużytki, produkując jaja i mięso o dobrych walorach smakowych. Zasoby genetyczne drobiu mogą być wykorzystane w przyszłości w programach genetycznego doskonalenia komercyjnych stad, a obecnie są świadectwem wielowiekowej polskiej myśli hodowlanej. Stanowią także cenny pod względem genetycznym, fizjologicznym i biochemicznym materiał badawczy, który może być wykorzystywany do badań nad historią ewolucji zwierząt gospodarskich, ontogenezy ptaków, jak również nad ich zachowaniem się w zmiennych warunkach środowiskowych. Ponadto bioróżnorodność powinna być utrzymana nie tylko ze względów praktycznych, lecz także kulturowych. Zwierzęta domowe urozmaicają środowisko jako żywy element ekosystemu i dzięki temu wpływają korzystnie na poprawę jakości ludzkiego życia. Zagrożone wyginięciem populacje kur chroni się metodą in situ - polegającą na ochronie żywych zwierząt $\mathrm{w}$ ich naturalnym środowisku. Podstawowym celem programu ochrony zasobów genetycznych kur nieśnych jest zachowanie poszczególnych populacji i ochrona przed wyginięciem, przez utrzymanie w każdym chronionym stadzie (rodzie) równowagi genetycznej na niezmieniającym się poziomie, przy jednoczesnym zachowaniu charakterystycznych cech fenotypowych ptaków obu płci. Programem ochrony zasobów genetycznych objęte są ptaki (stada) danego rodu poddane w każdym pokoleniu ocenie wartości użytkowej, za którą odpowiedzialna jest Krajowa Rada Drobiarstwa IG.

Koordynację działań w zakresie ochrony zasobów genetycznych zwierząt gospodarskich w Polsce sprawuje Instytut Zootechniki - PIB. Szczegółowe informacje dotyczące wzorców rasowych poszczególnych populacji, ich liczebności oraz programy ochrony są dostępne na stronie internetowej Instytutu Zootechniki PIB (www.bioroznorodnosc.izoo.krakow.pl/drob).

Praca wykonana w ramach realizacji programu wieloletniego, zadanie nr 03-17-11-09, finansowanego przez MRiRW. 


\title{
PRODUKCJA KAPŁONÓW W OPARCIU O RODZIME RASY KUR
}

\author{
Capon production based on native chicken breeds \\ Jolanta Calik, Joanna Obrzut \\ Instytut Zootechniki - Państwowy Instytut Badawczy, Zakład Hodowli Drobiu, \\ ul. Krakowska 1, 32-083 Balice \\ e-mail: jolanta.calik@izoo.krakow.pl
}

W ostatnim dziesięcioleciu obserwuje się wzrost liczby konsumentów poszukujących produktów żywnościowych bogatych w składniki odżywcze, wolnych od skażenia mikrobiologicznego oraz wyróżniających się specyficznymi cechami sensorycznymi. Przy rosnącym zapotrzebowaniu na produkty drobiarskie wyższej jakości pojawia się szansa na zwiększenie znaczenia chowu rodzimych ras kur i wykorzystaniu ich m.in. do produkcji kapłonów.

Celem badań było określenie wpływu zabiegu kapłonowania kogutów rasy zielononóżka kuropatwiana (Z-11), żółtonóżka kuropatwiana (Ż-33) na masę ciała i wybrane parametry jakości mięsa.

Badaniami objęto po 80 kogutków Z-11 i Ż-33, które przydzielono losowo do dwóch grup, po 40 sztuk w każdej. Zabieg kastracji przeprowadził lekarz weterynarii w 9. tygodniu życia, przy masie ciała ok. $500 \mathrm{~g}$. Ptaki utrzymywano do 24. tygodnia życia i żywiono ad libitum jednakowymi mieszankami paszowymi w systemie ściołowym. Po uboju określono wydajność rzeźną, udział mięśni piersiowych i mięśni nóg, podrobów i tłuszczu sadełkowego. Oceniono cechy jakości mięsa, tj. pH, barwę CIE L*a*b*, wodochłonność, wyciek swobodny, straty termiczne, kruchość, oraz przeprowadzono ocenę sensoryczną mięśni piersiowych i nóg. Wyniki zweryfikowano statystycznie, przy użyciu analizy wariancji, stosując pakiet statystyczny Statgraphic plus 5.1.

Na podstawie uzyskanych wyników stwierdzono, że zabieg kastracji kogutków rasy Z-11 i Ż-33 wpłynął korzystnie na zwiększenie masy ciała, wydajność rzeźną i umięśnienie tuszki. Mięśnie kapłonów, a zwłaszcza Ż-33 charakteryzowały się lepszą wodochłonnością i kruchością oraz traciły mniej wody w stosunku do niekastrowanych ptaków. Ponadto mięśnie kastrowanych ptaków, a szczególnie mięśnie nóg, wyróżniały się wyższymi notami w ocenie sensorycznej w porównaniu z niekastrowanymi kogutami. 


\title{
EFEKTYWNOŚĆ STOSOWANIA PRODUKTÓW SOJOWYCH W ŻYWIENIU KURCZĄT BROJLERÓW
}

The effectiveness of the use of soy products in the nutrition of broiler chickens

\author{
Alina Janocha, Daria Pietrusiak, Anna Milczarek, Kamil Łaski \\ Uniwersytet Przyrodniczo-Humanistyczny w Siedlcach, Katedra Żywienia Zwierząt i Gospodarki Paszowej, \\ ul. B. Prusa 14, 08-110 Siedlce \\ e-mail: alina.janocha@uph.edu.pl
}

Krajowi producenci pasz oraz hodowcy są zainteresowani badaniami jakości produktów sojowych i oceną wyników uzyskanych $w$ doświadczeniach żywieniowych na różnych gatunkach zwierząt. Celem badań było określenie wpływu mieszanek zawierających produkty sojowe (śruta poekstrakcyjna sojowa zmodyfikowana genetycznie, makuch sojowy i ekstruderat sojowy z nasion bez GMO) na wyniki produkcyjne, wskaźniki poubojowe oraz walory smakowe mięsa kurcząt brojlerów.

Doświadczenie żywieniowe wykonano na 96 seksowanych kurczętach brojlerach Ross 308 podzielonych na 3 grupy (I, II, III), liczące po 32 ptaki obu płci (50\% kurki i 50\% kogutki). W każdej grupie wyodrębniono 4 podgrupy po 8 kurcząt. Kurczęta odchowywano przez 42 dni w metalowych klatkach, w standardowych warunkach mikroklimatycznych ze stałym dostępem do wody. Do 21. dnia życia ptaki żywiono systemem ad libitum sypkimi mieszankami starter, a od 22. do 42. dnia mieszankami grower, wyprodukowanymi na bazie pszenicy oraz dodatków mineralno-witaminowych. Czynnikiem różnicującym grupy był rodzaj produktów sojowych: I - śruta poekstrakcyjna sojowa $\mathrm{z}$ nasion genetycznie modyfikowanych, II - makuch sojowy z nasion bez GMO, III - ekstruderat sojowy z nasion soi bez GMO. Nasiona soi niemodyfikowanej genetycznie zostały importowane z Ukrainy. Badania na GMO potwierdzają stosowne certyfikaty (badania laboratoryjne potwierdzone przez J.S. Hamilton Poland SA Gdynia). Po zakończeniu doświadczenia żywieniowego z każdej grupy wybrano po 4 kurki i 4 kogutki, o masie ciała zbliżonej do średniej dla płci w każdej z grup, które ubito przez dekapitację w celu przeprowadzenia analizy rzeźnej i walorów smakowych mięsa piersiowego i udowego.

Zastosowanie produktów sojowych (śruta poekstrakcyjna sojowa, makuch sojowy, ekstruderat sojowy) w mieszankach miało istotny wpływ na końcową masę ciała kurcząt, jak również na ilość zużytej paszy i składników pokarmowych na $1 \mathrm{~kg}$ przyrostu masy ciała. Istotnie lepsze wskaźniki odnotowano dla ptaków otrzymujących mieszanki, w których źródłem białka był makuch sojowy (36\% starter $33 \%$ grower). Odnotowano istotny wpływ zastosowanego żywienia na wydajność rzeźną, która była najwyższa u kurcząt otrzymujących mieszanki z makuchem sojowym (77,86\% vs. 75,96-75,63\%). Kurczęta żywione mieszankami zawierającymi surowiec białkowy w postaci makuchu sojowego były istotnie lepiej umięśnione, o czym świadczy udział mięśni ogółem $(52,77$ \%) oraz mięśni piersiowych $(32,59 \%)$ w tuszce. Wprowadzenie do mieszanek ekstruderatu sojowego wpłynęło na zwiększenie otłuszczenia tuszek, o czym świadczy istotnie wyższy udział tłuszczu sadełkowego i skóry z tłuszczem podskórnym w stosunku do tuszek ptaków z pozostałych grup. Pod względem walorów smakowych najlepsze okazało się mięso piersiowe i udowe kurcząt żywionych mieszankami z udziałem makuchu sojowego. Uzyskane wyniki produkcyjne, wskaźniki poubojowe oraz walory smakowe mięsa kurcząt brojlerów, dają podstawę do zalecania stosowania makuchu sojowego z nasion niemodyfikowanych genetycznie w mieszankach starter (36\%) i grower (33\%) dla kurcząt rzeźnych 


\title{
WPŁYW DODATKU DO ŚCIÓŁKI NADTLENKU WAPNIA $\left(\mathrm{CaO}_{2}\right)$ NA WARUNKI MIKROKLIMATYCZNE W BUDYNKACH DLA KURCZĄT BROJLERÓW
}

\author{
The effect of the addition to the calcium peroxide $\left(\mathrm{CaO}_{2}\right)$ for microclimatic conditions \\ in the buildings for broiler chicken
}

\author{
Tomasz Mituniewicz, Joanna Piotrowska, Sara Dzik, Anna Wójcik \\ Uniwersytet Warmińsko-Mazurski w Olsztynie, Katedra Higieny Zwierząt i Środowiska, \\ ul. M. Oczapowskiego 5/107, 10-719 Olsztyn \\ e-mail: awojcik@uwm.edu.pl
}

Ściółka drobiowa jest ważnym czynnikiem kształtującym mikroklimat w kurniku, a w konsekwencji wpływa również na drób i uzyskiwane wyniki produkcyjne. Celem badań było określenie, czy dodatek nadtlenku wapnia $\left(\mathrm{CaO}_{2}\right)$ do ściółki wpływa na mikroklimat w kurnikach dla kurcząt brojlerów.

Badania prowadzono w dwóch kurnikach (każdy o pow. $1300 \mathrm{~m}^{2}$ i obsadzie $15 \mathrm{szt} . / \mathrm{m}^{2}$ ). Kurczęta brojlery Ross 308 odchowywane były na ściółce ze słomy żytniej (grubość warstwy ściółki około $15 \mathrm{~cm}$ ) bez dościelania, przez 6 tygodni. W grupie doświadczalnej przed wstawieniem ptaków posypano na ściółkę nadtlenek wapnia $\left(\mathrm{CaO}_{2}\right)$ w ilości $2 \mathrm{~g} / \mathrm{m}^{2}$. Ocenę parametrów fizykochemicznych ściółki i warunków mikroklimatycznych w badanych kurnikach wykonano w oparciu o przeprowadzone pomiary: temperatury i wilgotności względnej powietrza (pomiar ciągły - termohigrometry elektroniczne LB-520, pomiary momentalne - termohigroanenometr Kestrel 4000); ochładzania i prędkości ruchu powietrza (katatermometr suchy Hilla); stężenia w powietrzu $\mathrm{NH}_{3}, \mathrm{CO}_{2}$, i $\mathrm{O}_{2}$ (przenośny wielogazowy miernik GASDATA); poziomu frakcji respirabilnej zanieczyszczeń pyłowych (pyły $\leq 5 \mu \mathrm{m}$, miernik zapylenia powietrza Dust Scout Lite 3000); poziomu zanieczyszczenia mikrobiologicznego powietrza metodą sedymentacyjną Kocha. Podstawowe parametry powierzchniowej warstwy ściółki słomiastej (do głębokości $3 \mathrm{~cm}$ - temperaturę i wilgotność względną) mierzono termohigrometrem typu HAY-METER HM 1625/02; zanieczyszczenia mikrobiologiczne ściółki w kierunku ogólnej liczby bakterii tlenowych mezofilnych wykonywano zgodnie z PN-EN ISO 4833: 2004 oraz ogólnej liczby drożdży i pleśni, zgodnie z PN-ISO 21527-1: 200; oznaczenie odczynu (pH) ściółki wykonano zgodnie z PN-ISO 10390: 1997.

Na podstawie uzyskanych wyników stwierdzono, że dodatek nadtlenku wapnia do ściółki drobiowej wpłynął na mikroklimat kurników dla kurcząt brojlerów, głównie poprzez poprawę parametrów fizykochemicznych ściółki drobiowej. Stwierdzono statystycznie istotne obniżenie temperatury ściółki w trakcie trwania całego odchowu, co jest zjawiskiem pożądanym z punktu widzenia dobrostanu zwierząt. Na zakończenie odchowu stwierdzono również obniżenie wilgotności względnej ściółki w grupie z zastosowanym dodatkiem $\mathrm{CaO}_{2}$. Średnia liczebność bakterii tlenowych mezofilnych w ściółce w trakcie całego odchowu była niższa niż w grupie kontrolnej. Świadczy to o właściwościach dezynfekcyjnych nadtlenku wapnia. Rozpatrując wpływ dodatku nadtlenku wapnia na parametry mikroklimatu brojlerni stwierdzono jego istotny wpływ na wilgotność względną powietrza - od początku do końca odchowu niższą wilgotność względną powietrza notowano w kurniku, w którym do ściółki zastosowano dodatek $\mathrm{CaO}_{2}$. Zastosowanie nadtlenku wapnia $\mathrm{w}$ odchowie kurcząt brojlerów w istotny sposób wpłynęło również na zawartości amoniaku i dwutlenku węgla w powietrzu budynków. W kurniku z dodatkiem $\mathrm{CaO}_{2}$ stężenie amoniaku w powietrzu w żadnym tygodniu badań nie przekroczyło poziomu $10 \mathrm{ppm}$. Podkreślić należy jednak, że także w grupie kontrolnej średnie stężenie NH3 nie przekroczyło dopuszczalnych wartości. Rozpatrując wpływ dodatku nadtlenku wapnia na stężenie w powietrzu dwutlenku węgla, zauważono, iż już od trzeciego ty- 
godnia badań jego poziom w powietrzu był istotnie niższy niż w grupie kontrolnej. Pomimo właściwości natleniających nadtlenku wapnia istotny wpływ zastosowanej w przeprowadzonym doświadczeniu dawki $\mathrm{CaO}_{2}$ na zawartość tlenu w powietrzu kurnika doświadczalnego stwierdzono tylko $\mathrm{w}$ drugim tygodniu badań. Tendencja kształtowania się poziomu zanieczyszczenia mikrobiologicznego powietrza w poszczególnych tygodniach badań była podobna w obu budynkach. Rozpatrując jednak średnią liczebność mikroorganizmów w powietrzu kurników w całym okresie trwania doświadczenia, potwierdzono efekt dezynfekcyjny nadtlenku wapnia zarówno liczbą bakterii tlenowych mezofilnych, jak i drożdży i pleśni w powietrzu kurnika doświadczalnego. 


\section{MOŻLIWOŚCI WYKORZYSTANIA KUR RODZIMEJ RASY ŻÓŁTONÓŻKA KUROPATWIANA (Ż-33) DO PRODUKCJI PULARD}

Possibilities for the use of native Yellowleg Partridge hens (Ż-33) for poulard production

Joanna Obrzut, Józefa Krawczyk

Instytut Zootechniki - Instytut Badawczy, Zakład Hodowli Drobiu, ul. Krakowska 1, 32-83 Balice

e-mail: joanna.obrzut@izoo.krakow.pl

Pulardy to młode kurki, utuczone i ubite przed osiągnięciem dojrzałości płciowej. Produkcja pulard przebiega podobnie jak kapłonów, a jej celem jest pozyskanie mięsa od kurek lokalnych ras poddawanych zabiegowi sterylizacji, który zapobiega dojrzewaniu ptaków i umożliwia pozyskiwanie mięsa kruchego i smacznego, stanowiącego przysmak kuchni regionalnych. Przeprowadzone wcześniej w Instytucie badania nad wykorzystaniem czystych rodów kur ras zachowawczych, ze względu na wolne tempo przyrostu masy ciała ptaków i długi okres odchowu, nie były efektywne ekonomicznie. Dlatego podjęto próbę wykorzystania do produkcji pulard mieszańców uzyskanych ze skrzyżowania kur z kogutami mięsnymi Ross 308.

Celem badań była ocena możliwości produkcji pulard z wykorzystaniem mieszańców kurek rodzimej rasy żółtonóżka kuropatwiana z kogutami mięsnymi Ross 308. Zabieg sterylizacji został przeprowadzony w znieczuleniu miejscowym przez lekarza weterynarii w 8. tygodniu życia kurek. Po zakończeniu odchowu (18. tydzień) z każdej grupy wybrano do uboju po 8 ptaków o masie ciała zbliżonej do średniej w grupie, których mięso poddano szczegółowej analizie.

Pulardy uzyskały nieznacznie większą masę ciała oraz istotnie większy udział mięśni piersiowych i tłuszczu sadełkowego w tuszce w porównaniu z kurkami. Tuszki pulard wyróżniały się większym wysyceniem barwy w kierunku żółci, a mięśnie piersiowe były jaśniejsze niż u kurek. Mięso pulard było bardziej kruche i uzyskało lepszą ocenę sensoryczną. Wykorzystanie kogutów mięsnych do uzyskania pulard poprawiło wiele cech jakości mięsa oraz efektywność ekonomiczną produkcji głównie poprzez skrócenie okresu tuczu.

Praca wykonana w ramach realizacji programu wieloletniego, zadanie nr 03-17-11-09 finansowanego przez MRiRW. 


\title{
JAKOŚĆ TOKSYKOLOGICZNA PODROBÓW KURCZĄT
}

Toxicological quality of chicken offal giblets

\author{
Janusz Franciszek Pomianowski ${ }^{1}$, Anna Wójcik ${ }^{2}$, Tomasz Żmijewski ${ }^{1}$ \\ ${ }^{1}$ Uniwersytet Warmińsko-Mazurski w Olsztynie, Katedra Technologii i Chemii Mięsa, pl. Cieszyński 1, 10-718 Olsztyn \\ ${ }^{2}$ Uniwersytet Warmińsko-Mazurski w Olsztynie, Katedra Higieny Zwierząt i Środowiska, \\ 10-719 Olsztyn, ul. M. Oczapowskiego 5/107 \\ e-mail: janusz.pomianowski@uwm.edu.pl
}

Węglowodory chloroorganiczne $(\gamma-\mathrm{HCH}$ i DDT) oraz polichlorowane bifenyle (PCB) to grupa ksenobiotyków o szczególnym znaczeniu toksykologicznym, która ze względu na kumulację w tkankach zwierząt i ludzi oraz ze względu na znaczną trwałość w środowisku stanowi duże zagrożenie dla zdrowia ludzi i zwierząt. Celem podjętych badań było oznaczenie ilości pozostałości węglowodorów chloroorganicznych oraz polichlorowanych bifenyli w podrobach kurcząt.

Materiał badawczy stanowiły podroby (serca, żołądki, wątroby) pozyskane od kurcząt brojlerów ROSS $308(\mathrm{n}=30)$. Przedmiotem analiz był tłuszcz wyekstrahowany metodą Soxhleta z badanych podrobów, w którym określano zawartości węglowodorów chloroorganicznych (DDT, DDD, DDE, $\gamma$-HCH) [Amarowicz i in., 1989] oraz polichlorowanych bifenyli (PCB) (Ludwicki i in. 1996). Do identyfikacji związków wykorzystano chromatograf gazowy. Zebrany materiał liczbowy opracowano statystycznie jednoczynnikową analizą wariancji i testem Duncana, przy użyciu programu statystycznego Statistica 13.1.

Wśród badanych podrobów najmniejsze ilości $\gamma$-HCH oznaczono w wątrobach $(0,0002 \mathrm{mg} / \mathrm{g}$ thuszczu), kolejno w żołądkach $(0,0021 \mathrm{mg} / \mathrm{g}$ tłuszczu) i najwięcej w sercach $(0,0037 \mathrm{mg} / \mathrm{g}$ tłuszczu $)$. Analiza statystyczna wykazała jedynie różnice istotne statystycznie $(\mathrm{P} \leq 0,05)$ pomiędzy wątrobami i sercami. Podobną tendencję zaobserwowano w przypadku zawartości $\sum$ DDT, na którą składają się DDT oraz pochodzące z jego przemian metabolity DDD i DDE. Wątroby zawierały najmniejsze ilości tego składnika $(0,0021 \mathrm{mg} / \mathrm{g}$ tłuszczu), następne były żołądki oraz serca (odpowiednio 0,0112 i $0,0128 \mathrm{mg} / \mathrm{g}$ tłuszczu). Jednak w tym przypadku nie stwierdzono różnic istotnych statystycznie $(\mathrm{P} \leq 0,05)$.

We wszystkich badanych rodzajach podrobów stwierdzono 6 różnych kongenerów polichlorowanych bifenyli (PCB): 28, 52, 101, 118, 153, 180. Ich oznaczone ilości cechowało znaczne zróżnicowanie. Zawartość $\sum$ PCB wśród badanych podrobów największa była w sercach $(0,0018 \mathrm{mg} / \mathrm{g}$ tłuszczu $)$, mniejsza w żołądkach $(0,0012 \mathrm{mg} / \mathrm{g}$ tłuszczu), najmniejsza zaś w wątrobach $(0,0009 \mathrm{mg} / \mathrm{g}$ thuszczu). W analizie statystycznej nie stwierdzono, by zróżnicowanie to było istotne statystycznie $(\mathrm{P} \leq 0,05)$. Dodatkowo wątroba wyróżnia się szczególnie, ponieważ nie oznaczono w niej kongenerów PCB 52 i 180. 


\title{
MEAT PRODUCTIVITY OF DUCKS OF THE NATIVE GENE POOL AND INTER-SPECIFIC HYBRIDS (MULARDS)
}

Użytkowanie mięsne kaczek krajowej puli genowej i niepłodnych mieszańców (mulardów)

\author{
Maryna Shkurko \\ Sumy National Agrarian University, Biological Technological Faculty, \\ 160 Herasym Kondratiev, Sumy, 40021, Ukraine \\ e-mail: m.skurko@ukr.net
}

To meet the demand for lean duck meat a lot of amateur farmers breed moscovy ducks. Muscovy duck meat contains less than $55 \%$ of water and about $18 \%$ of fat, with the content of protein within $21.0-21.4 \%$. The chemical composition of meat doesn't inferior to broilers, and its taste is much greater than the taste of wildfowl. The most widespread breeds in Ukraine are Muscovy ducks, (white, brown, black). In addition, some farmers breed local ducks of four feather colouring phenotypes (gray, white, clay-coloured, black white-chested). There is no tribal base for breeding mulards in Ukraine. The country imports French mulards in the form of incubation eggs and daily ducklings.

The article presents the results of experimental studies on the slaughter and productive qualities of young ducks of different genotypes under conditions of farming household.

To obtain intergeneric hybrids during natural parasification of muscle spleen with ducks of the domestic gene pool, the following search crossings were performed:

T muscovy brown 9 steppe gray (cross № 1);

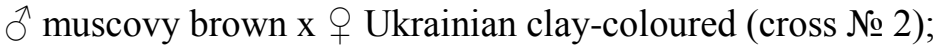

ô muscovy white $\mathrm{x} q$ Ukrainian white (cross № 3).

By degree of reduction of pre-slaughter live weight studied in FY "Povit-Agro" bird groups were placed in the following sequence: intergeneric hybrid № $3(4150 \pm 31 \mathrm{~g})$ intergeneric hybrid № $2(4122 \pm 43 \mathrm{~g})$, intergeneric hybrid № 1 (4073 $\pm 45 \mathrm{~g})$, muscovy white (3823 $\pm 45 \mathrm{~g})$, muscovy brown (3750 $\pm 49 \mathrm{~g})$, steppe gray (3381 $\pm 31 \mathrm{~g})$, Ukrainian clay-coloured $(3370 \pm 44 \mathrm{~g})$ and Ukrainian white $(3325 \pm 27 \mathrm{~g})$.

We also conducted comparative characteristics of native and foreign mulards. During breeding (120 days), French mulards overwhelmingly dominated over native ones and this difference became probable starting from the 20th day of breeding. At the end of breeding, average weight of Ukrainian mulards was $3710 \pm 22,0 \mathrm{~g}$, French mulards weighted $4005 \pm 30,2 \mathrm{~g}$. This difference is statistically significant and is $295 \mathrm{~g}$ ( $\mathrm{P}>0.999)$. This, above all, is caused by the fact that for selection of French mulards more speedy Pekin duck was used as a maternal form.

The yield of non-gutted $(91.15 \%)$, semi-gutted $(76.72,96 \%)$ and gutted $(67.10 \%)$ carcasses was also higher than the yield of French mulards, compared to Ukrainian ones $(90.89 \%, 74.90 \%, 66.28 \%$ respectively). This is due to the intensive selection of source lines of French cross for slaughter qualities. Although Ukrainian mulards are inferior to the French ones in live weight and pre-slaughter qualities, they showed significantly lower level of cannibalism during mewing.

Studies have shown that the French mulard ( ${ }^{\lambda}$ moscovy white $\times$ P Pekin white) and Ukrainian mulard ( $\delta$ moscovy white $\times$ + Ukrainian white) are characterized by the speedy growth, good safety and slaughter qualities and therefore they are suitable for the efficient production of organic meat under the conditions of both farms and adjoining farming household. 


\title{
ZAWARTOŚĆ W JAJACH WYBRANYCH CZYNNIKÓW REGULUJĄCYCH EKSPRESJĘ GENÓW
}

\author{
Content in eggs of selected factors regulating gene expression
}

\author{
Edyta Szymanek ${ }^{1}$, Kamil Drabik ${ }^{2}$, Katarzyna Andraszek ${ }^{1}$, Dorota Banaszewska ${ }^{1}$ \\ ${ }^{1}$ Uniwersytet Przyrodniczo-Humanistyczny w Siedlcach, Instytut Bioinżynierii i Hodowli Zwierząt, ul. Prusa 14, 08-110 Siedlce \\ ${ }^{2}$ Uniwersytet Przyrodniczy w Lublinie, Katedra Biologicznych Podstaw Produkcji Zwierzęcej, ul. Akademicka 13, 20-950 Lublin \\ e-mail: katarzyna.andraszek@uph.edu.pl
}

Nutrigenomika bada wpływ bioaktywnych składników diety na ekspresję genów, analizuje związki pomiędzy dietą i genetycznymi predyspozycjami do tzw. chorób cywilizacyjnych, w tym chorób nowotworowych, metabolicznych i chorób układu krążenia, a także identyfikuje mechanizmy decydujące o tym, w jaki sposób żywność i żywienie wpływają na stan zdrowia. Jajka są traktowane jako nutraceutyki, czyli żywność prozdrowotna i lecznicza, która jest żywnością naturalną. Wielką zaletą jaj jako źródła składników odżywczych jest ich wysoka przyswajalność biologiczna. Jaja przyczyniają się do obniżenia ryzyka występowania wielu chorób, wspomagają ogólną kondycję organizmu i działają jako naturalna suplementacja w przypadku diety ubogiej w składniki odżywcze lub monodiety. Celem pracy było określenie zawartości w jajach wybranych czynników wpływających na ekspresję genów w zależności od systemu użytkowania kur.

Materiał badawczy stanowiły jaja kur utrzymywanych w dwóch różnych systemach - ekologicznym (kury rasy zielononóżka kuropatwiana) i klatkowym (jaja zakupione w markecie należącym do jednej z lokalnych sieci handlowych). Z każdej grupy do analiz przeznaczono 20 jaj. W treści jaja, oddzielnie w żółtku i białku, oznaczono zawartość wapnia, magnezu i cynku. Ponadto obliczono zawartość wymienionych pierwiastków w jednorodnej mieszaninie (określonej jako mix) na podstawie procentowego udziału żółtka i białka w jaju. Oznaczanie zawartości pierwiastków przeprowadzono metodą spektrometrii absorbcji atomowej (AAS), przy użyciu spektrometru absorpcji atomowej z atomizacją w płomieniu SpectrAA 280-FS (Varian, Australia), z zastosowaniem automatycznego rozcieńczalnika standardów i próbek. Na podstawie oznaczonej zawartości $\mathrm{Ca}, \mathrm{Mg}$ i $\mathrm{Zn}$ w żółtku i białku obliczono zawartość tych pierwiastków w treści jaja ogółem. Do obliczeń wykorzystano dane dotyczące średniej, procentowej zawartości białka i żółtka w jaju.

Zawartość Ca, Mg i Zn zarówno w żółtku, jak i w białku jaj pochodzących z systemu klatkowego i ekologicznego różniła się statystycznie istotnie na poziomie $\mathrm{P} \leq 0,05$. Wyższe zawartości każdego $\mathrm{z}$ badanych pierwiastków stwierdzono w żółtku jaj kur utrzymywanych w systemie ekologicznym, przy czym w przypadku Ca są to wartości niewiele większe, a w przypadku Mg i $\mathrm{Zn}$ - w przybliżeniu dwa razy większe. W białku jaja kurzego obserwowano znacznie mniejsze zawartości badanych pierwiastków niż w żółtku. Jednak i w białku średnia zawartość Ca, Mg i Zn była większa w przypadku systemu ekologicznego utrzymania kur w porównaniu z systemem klatkowym. W przypadku Ca i Mg nie są to bardzo duże różnice, zawartość zaś Zn jest aż trzykrotnie większa.

Podsumowując, można stwierdzić, że jaja z chowu ekologicznego mają bogatszy skład chemiczny pod względem zawartości składników odżywczych, takich jak wapń, magnez czy cynk, od jaj otrzymanych od kur z chowu klatkowego. Na zawartość pierwiastków w jaju, poza systemem utrzymania i związanym z nim sposobem żywienia, duży wpływ może mieć również genotyp zwierząt. 


\title{
WPŁYW RODZAJU ŚWIATŁA NA PRODUKCYJNOŚĆ KURCZĄT BROJLERÓW
}

Effect of the type of light on the productivity of broiler chickens

\author{
Anna Wolska ${ }^{1}$, Sara Dzik $^{1}$, Tomasz Mituniewicz ${ }^{1}$, Marcin Jankowski ${ }^{2}$ \\ ${ }^{1}$ Uniwersytet Warmińsko-Mazurski w Olsztynie, Katedra Higieny Zwierząt i Środowiska, \\ 10-719 Olsztyn, ul. M. Oczapowskiego 5/107 \\ ${ }^{2}$ Agropian System, ul. Szeroka 29, 06-860 Płochocin \\ e-mail: annawolska26@gmail.com
}

Wybór metody oświetlenia kurników jest problemem od wielu dziesięcioleci, który wzbudza duże zainteresowanie nowymi, dostępnymi systemami. Hodowcy drobiu coraz częściej używają diod LED w systemie oświetlenia kurników. Diody LED zapewniają monochromatyczne światło o różnych długościach fali i mają wiele zalet $\mathrm{w}$ porównaniu z konwencjonalnymi źródłami światła, w tym wysoką energooszczędność, długą żywotność, wysoką niezawodność i niskie koszty konserwacji.

Celem przeprowadzonych badań było określenie wpływu światła LED na produkcyjność kurcząt brojlerów oraz na stan ich zdrowia. Dzięki światłu LED można uzyskać lepsze wyniki produkcyjne przy mniejszych kosztach zużycia energii elektrycznej. Badania przeprowadzono w warunkach produkcyjnych na fermie drobiu zlokalizowanej w województwie pomorskim. W przeprowadzonych doświadczeniach utworzono 2 grupy badawcze (kontrolną i doświadczalną), każdą z nich stanowił kurnik z obsadą 22000 ptaków. Nie dokonywano podziału ptaków ze względu na płeć. Kurczęta odchowywano na ściółce ze słomy żytniej, bez dościelania przez cały okres odchowu (41 dni). W kurnikach zastosowano wentylację mechaniczną z możliwością regulacji wydajności pracy wentylatorów. Ptaki w obu grupach żywiono standardowymi paszami przemysłowymi wg zaleceń producenta. W kurniku nr 1 zainstalowano lampy LED firmy Agropian System, o barwie światła białej i niebieskiej, natomiast w kurniku nr 2 (kontrolnym) zainstalowano oświetlenie żarowe. W obu kurnikach istniała możliwość regulacji natężenia światła. Harmonogram dnia i nocy w kurniku 1 i 2 był stały podczas całego doświadczenia i składał się z 18 godzin światła oraz 6 godzin nocy. Ocenę stanu zdrowia ptaków szacowano na podstawie liczby upadków i brakowań. Ocenę wyników odchowu kurcząt brojlerów prowadzono w oparciu o przyrosty masy ciała. W czasie trwania badań losowo wybrane ptaki z każdej grupy badawczej (50 sztuk) ważono po przywiezieniu ich z wylęgarni (waga elektroniczna Axis B3000). Następne ważenia odbywały się w odstępach tygodniowych do końca odchowu (42. dzień). W trakcie ważenia zwracano uwagę na stan zdrowia ptaków oraz ich kondycję.

Na podstawie przeprowadzonych badań stwierdzono, że zastosowanie oświetlenia LED nie skutkowało zmianami masy ciała kurcząt i spożycia paszy w kurniku badawczym. Stwierdzono jednak znacznie większą ilość upadków i brakowań w kurniku kontrolnym (1011 szt.) w porównaniu z ilością upadków w kurniku z oświetleniem LED (871 szt.). Dzięki uzyskanym wynikom można stwierdzić, że oświetlenie LED jest dobrą alternatywą dla lamp żarowych. Nie powoduje obniżenia wyników produkcyjnych, a jednocześnie zmniejsza koszty oświetlenia oraz konserwacji lamp. 


\title{
WPŁYW FITOBIOTYKÓW NA ŁAGODZENIE STRESU TRANSPORTOWEGO U INDORÓW RZEŹNYCH W OKRESIE ZIMY
}

The influence of phytobiotics on relieving transportation stress in turkeys during the winter period

\author{
Anna Wójcik ${ }^{1}$, Tomasz Mituniewicz ${ }^{1}$, Janina Sowińska ${ }^{1}$, Dorota Witkowska ${ }^{1}$, \\ Janusz Franciszek Pomianowski ${ }^{2}$ \\ ${ }^{1}$ Uniwersytet Warmińsko-Mazurski w Olsztynie, Katedra Higieny Zwierząt i Środowiska, \\ ul. M. Oczapowskiego 5/107, 10-719 Olsztyn \\ ${ }^{2}$ Uniwersytet Warmińsko-Mazurski w Olsztynie, Katedra Technologii i Chemii Mięsa, pl. Cieszyński, 110-718 Olsztyn \\ e-mail: awojcik@uwm.edu.pl
}

Efektem stresu występującego w okresie obrotu przedubojowego są zmiany fizjologiczne i morfologiczne objawiające się m.in. zmianami w składzie krwi. Niekorzystny wpływ obrotu przedubojowego można ograniczyć, podając indykom preparaty mineralne, witaminowe czy preparaty ziołowe. Celem pracy było określenie wpływu fitobiotyków na łagodzenie stresu transportowego u indorów rzeźnych transportowanych w okresie zimy.

Materiał doświadczalny stanowiły indory hybryd w wieku 20 tygodni (120 szt.). Indory otrzymywały w paszy $(\mathrm{F}+\mathrm{P})$ lub w wodzie do picia $(\mathrm{F}+\mathrm{W})$ przez ostatnie 7 dni przed planowanym transportem fitobiotyk, w skład którego wchodziły: rutwica lekarska (Herb. Galegae), pokrzywa zwyczajna (Herb. Utricae), melisa lekarska (Fol. Melissae), szałwia lekarska (Fol. Salviae) [P. 224605]. Przed ubojem u indorów ze wszystkich grup zastosowano różne warianty obrotu przedubojowego: bez transportu (B-T), z transportem na odległość 100 km (T-100; 1,5 godz.), 200 km (T-200; 3 godz.) i 300 km (T-300; 5 godz.). Krew od ptaków pobierano z żyły skrzydłowej. W celu stwierdzenia stopnia stresowrażliwości indorów obliczono liczbowy stosunek heterofilii do limfocytów (H : L), oznaczono zawartość białka całkowitego, trójglicerydów, glukozy i poziom kortykosteronu.

Tabela 1. Kształtowanie się parametrów krwi indorów w okresie zimy

\begin{tabular}{|l|c|c|c|c|c|c|c|}
\hline \multirow{2}{*}{ Wskaźniki } & \multicolumn{3}{|c|}{ Fitobiotyk } & \multicolumn{5}{c|}{ Transport } \\
\cline { 2 - 8 } & $\mathrm{K}$ & $\mathrm{F}+\mathrm{P}$ & $\mathrm{F}+\mathrm{W}$ & $\mathrm{BT}$ & $\begin{array}{c}\mathrm{T}-100 \\
(\sim 1,5 \mathrm{~h})\end{array}$ & $\begin{array}{c}\mathrm{T}-200 \\
(\sim 3 \mathrm{~h})\end{array}$ & $\begin{array}{c}\mathrm{T}-300 \\
(\sim 5 \mathrm{~h})\end{array}$ \\
\hline $\mathrm{H}: \mathrm{L}[1 / 1]$ & $\mathrm{cd}$ & 2,09 & 2,07 & $1,17^{\mathrm{A}}$ & $1,31^{\mathrm{A}}$ & $3,04^{\mathrm{B}}$ & $3,15^{\mathrm{B}}$ \\
\hline Białko ogólne [g/l] & 33,30 & 34,25 & 34,60 & $40,47^{\mathrm{A}}$ & $32,40^{\mathrm{B}}$ & $31,53^{\mathrm{B}}$ & $31,80^{\mathrm{B}}$ \\
\hline Trójglicerydy [mmol/1] & 0,659 & $0,599^{\mathrm{A}}$ & $0,738^{\mathrm{B}}$ & $0,774^{\mathrm{A}}$ & $0,779^{\mathrm{A}}$ & $0,565^{\mathrm{B}}$ & $0,543^{\mathrm{B}}$ \\
\hline Glukoza [mmol/l] & 10,98 & 11,70 & 12,70 & $14,68^{\mathrm{A}}$ & $12,00^{\mathrm{BC}}$ & $10,92^{\mathrm{B}}$ & $9,56^{\mathrm{BD}}$ \\
\hline Kortykosteron [ng/ml] & $8,25^{\mathrm{b}}$ & $6,89^{\mathrm{B}}$ & $10,25^{\mathrm{Aa}}$ & $3,22^{\mathrm{A}}$ & $7,87^{\mathrm{B}}$ & $9,67^{\mathrm{B}}$ & $13,29^{\mathrm{C}}$ \\
\hline
\end{tabular}

$\mathrm{A}, \mathrm{B}$ oraz $\mathrm{C}, \mathrm{D}-\mathrm{P} \leq 0,01 ; \mathrm{a}, \mathrm{b}-\mathrm{P} \leq 0,05$

Przeprowadzone badania wykazały, że wraz ze wzrastającą odległością i wzrastającym czasem transportu wzrastał stosunek H : L oraz poziom kortykosteronu, natomiast obniżeniu uległa zawartość białka ogólnego, trójglicerydów i poziom glukozy. Zmieniające się parametry krwi wraz z długością i czasem transportu wskazują na narastające obciążenie organizmu indorów czynnikami występującymi w czasie obrotu przedubojowego.

Zastosowanie fitobiotyku podanego z wodą wpłynęło na wzrost zawartości trójglicerydów i poziomu kortykosteronu w surowicy krwi. Podanie fitobiotyku w paszy nie miało wpływu na badane wskaźniki krwi a tym samym na złagodzenie reakcji stresowej u indorów. 
Sekcja Chowu i Hodowli Zwierząt Futerkowych 


\title{
ZMIENNOŚĆ KSZTAŁTU CZASZKI SZYNSZYLI MAŁEJ. KĄTY CZASZKI
}

Shape variability in the skull of long-tailed chinchilla. Cranial angles

\author{
Piotr Baranowski, Magdalena Wróblewska, \\ Katarzyna Pęzińska-Kijak
}

\author{
Zachodniopomorski Uniwersytet Technologiczny w Szczecinie, Pracownia Anatomii Zwierząt \\ ul. Doktora Judyma 14, 71-466 Szczecin \\ e-mail: piotr.baranowski@zut.edu.pl
}

Dotychczasowe badania nad morfologią szkieletu głowy szynszyli zmierzały do wyjaśnienia przyczyn nienaturalnego zgrubienia tkanki kostnej okolic szczęki i żuchwy, przerostu siekaczy, nienaturalnie szerokiej powierzchni zębów przedtrzonowych i trzonowych, aż do występowania form patologicznych włącznie. Skutkiem tego są zmiany wielkości cech metrycznych czaszek i żuchw oraz lokalizacji i symetrii cech epigenetycznych na nich występujących. Szkielety głowy zwierząt są znakomitym przedmiotem do badań nad zmiennością morfologiczną i odzwierciedlają przebieg ewolucji gatunku, na który mogą również wpływać czynniki niegenetyczne. Jak dotąd w odniesieniu do gryzoni nie stosowano techniki pomiaru polegającej na badaniu geometrycznych współzależności cech metrycznych czaszki, której poszczególne części ulegają przebudowaniu wraz z osiąganiem kolejnych etapów rozwoju. Nie opisano więc zmian kształtu czaszki szynszyli małej, którą od czaszek innych przedstawicieli Rodentia odróżnia charakterystyczna budowa. Czaszkę tych zwierząt charakteryzują dwa bardzo duże otwory oczodołowe, pod którymi lokalizują się przyczepy mięśni żwaczowych, specyficzna budowa kości żuchwy, specyficzne ułożenie kości łzowych, odmienne połączenie kości ciemieniowej, skroniowych i potylicznej. Szkielet głowy jest strukturą plastyczną, a pobierany pokarm wpływa na biomechanikę zespołu czaszki-żuchwy i przyczynia się do jego rozwoju, wzrostu i ogólnej morfologii. Warunki życia w niewoli i na wolności są czynnikiem determinującym budowę szkieletu. Odpowiedź na pytanie, czy pochodzenie może być źródłem zmienności niektórych cech czaszek szynszyli małej, stała się zasadniczym celem pracy. Cel ten postanowiono osiągnąć przez oszacowanie wielkości zmian wartości kątów wyznaczonych przez punkty kraniometryczne, zachodzących w czasie, i ustalenie współzależności między tymi kątami a wybranymi cechami metrycznymi czaszek szynszyli małej w wybranych okresach wzrostu i rozwoju, a następnie porównanie tych wartości z wynikami badań czaszek zwierząt bytujących w warunkach naturalnych. Badania przeprowadzono na 319 czaszkach samców i samic szynszyli małej, w 6 okresach, obejmujących wiek od 1 do ponad 800 dni życia (1-18 dni, $\mathrm{n}=29 ; 30-58 \mathrm{dni}, \mathrm{n}=9 ; 258-360 \mathrm{dni}, \mathrm{n}=126 ; 366-399 \mathrm{dni}, \mathrm{n}=65 ; 400-507$ dni, $\mathrm{n}=52$; ponad $800 \mathrm{dni}, \mathrm{n}=38$ ). Czaszki te pozyskano ze skórowanych na fermie hodowlanej $\left(53^{\circ} 40^{\prime} \mathrm{N}\right.$; $\left.15^{\circ} 08^{\prime} \mathrm{E}\right)$ tusz tych zwierząt. Przebadano także 32 czaszki szynszyli znajdujących się w Muzeum Historii Naturalnej w Londynie. Na podstawie analizy obliteracji szwów czaszkowych i porównania z czaszkami zwierząt hodowlanych z Polski o znanym wieku ustalono, że egzemplarze muzealne szkieletów głowy szynszyli małej należały do zwierząt dojrzałych (subadult). Wiek szynszyli z hodowli w chwili uboju ustalono na podstawie kart hodowlanych tych zwierząt. Oszacowano wartości kątów wyznaczonych liniami łączącymi następujące punkty kraniometryczne czaszki: ZPZ, SmPSm, EuPEu, ZNZ, SmNSm, EuNEu, AZP, AZN, EuAEu, ZAZ, AEuP, NSmP, gdzie: A - akrokranion, Eu - euryon, $\mathrm{N}$ - nasion, $\mathrm{P}$ - prosthion, Sm - supramolare, Zyg - zygion. Wykazano brak statystycznie istotnego wpływu płci na wielkość kątów czaszek szynszyli. Szkielety czaszek szynszyli małej populacji hodowlanej, pomimo istotnych zmian zachodzących w relacjach między częściami trzewną i mózgową w okresie wzrostu i rozwoju, zachowują współzależności zbliżone do czaszek pochodzących od osobników bytujących w warunkach naturalnych.

Pomimo diametralnie innych warunków życia, co zwykło przyjmować się za czynnik determinujący rozwój i ukształtowanie szkieletu, w tym czaszki, okres około stuletniej hodowli nie wykreował nowego morfotypu dla tego gatunku gryzoni. 


\title{
ZMIENNOŚĆ KSZTAŁTU CZASZKI SZYNSZYLI MAŁEJ. WZGLĘDNA SZYBKOŚĆ WZROSTU WYBRANYCH OBSZARÓW CZASZKI
}

\author{
Shape variability in the skull of long-tailed chinchilla. Relative growth rate of some skull regions
}

\author{
Piotr Baranowski, Magdalena Wróblewska, Katarzyna Pęzińska-Kijak \\ Zachodniopomorski Uniwersytet Technologiczny w Szczecinie, Pracownia Anatomii Zwierząt \\ ul. Doktora Judyma 14, 71-466 Szczecin \\ e-mail: piotr.baranowski@zut.edu.pl
}

\begin{abstract}
Ważnym źródłem wiedzy służącym poznaniu i zrozumieniu wielu biologicznych zjawisk są dane morfometryczne. Wykorzystywane są $w$ badaniach nad filogenezą organizmów, zmianami ewolucyjnymi, w badaniach historii i struktury minionych i współczesnych populacji, a także dymorfizmu płciowego, kondycji i wzrostu, dziedziczenia czy asymetrii cech populacji występujących w różnych warunkach ekologicznych. Celem pracy było przedstawienie względnej szybkości wzrostu poszczególnych obszarów czaszki i żuchwy szynszyli małej oraz uchwycenie zmian morfometrycznych w różnych okresach rozwoju tych zwierząt. Materiałem do badań było 299 czaszek szynszyli małej obojga płci. Oszacowanie względnej szybkości wzrostu parametrów czaszek i żuchw szynszyli hodowlanych przeprowadzono metodą SzmalhauzenaBrodiego polegającą na zlogarytmowaniu wartości empirycznych cech metrycznych czaszek i żuchw z uwzględnieniem okresu rozwoju morfologicznego. Analizę danych prowadzono na podstawie daty urodzenia i śmierci (tj. uboju lub padnięcia) osobnika. Materiał podzielono na 6 grup wiekowych: pierwsza 1-30 dni życia $-\mathrm{n}=29$ (12 samców i 17 samic), druga 31-58 d.ż. - n = 9 (5 samców i 4 samic), trzecia 258-360 d.ż. $-\mathrm{n}=135$ (78 samców i 57 samic), czwarta 366-399 d.ż. $-\mathrm{n}=72$ (60 samców i 12 samic), piąta $-400-507$ d.ż. $-\mathrm{n}=54$ (44 samce i 10 samic). Czaszki pozyskano ze zwierząt utrzymywanych w tych samych warunkach pielęgnacji i żywienia. Uzyskane dane empiryczne opracowano statystycznie za pomocą pakietu Statistica v. 9Pl. W pierwszym okresie oceny względnej szybkości wzrostu stwierdzono, że parametr ten był dodatni dla wszystkich badanych cech. Zwrócił uwagę fakt, że większa względna szybkość wzrostu dotyczyła większej liczby cech czaszki i żuchwy samic. W drugim okresie względna szybkość wzrostu większości cech długości czaszki malała w podobny sposób u obu płci, przy czym względna szybkość wzrostu długości mózgowioczaszki samic była większa $(\mathrm{P} \leq 0,01)$ niż samców. Od trzeciego okresu zauważono wstrzymanie tempa względnej szybkości wzrostu takich cech, jak długości kości nosowej u samców, trzewioczaszki u samic, szerokości mózgowioczaszki, największej szerokości czaszki i kości potylicznej u samic oraz wszystkich cech $\mathrm{z}$ nią powiązanych, tj. wysokości czaszki, pola powierzchni trójkąta potylicznego i otworu wielkiego oraz pojemności jamy czaszkowej. Wśród cech charakteryzujących podstawę czaszki w trzecim okresie ujemne wartości względnej szybkości wzrostu odnotowano dla cech długości i szerokości podniebienia u samców. Z kolei dodatnie wartości tych cech w czwartym okresie mogą wskazywać na kontynuację wzrostu podstawy czaszki u tej płci. Badania potwierdziły, że łączenie czaszek samców i samic podczas porównywania populacji prowadzi do utraty wielu cennych informacji biologicznych. $Z$ reguły czaszki samców, jako osobników somatycznie większych, charakteryzują się silniej wykształconymi przyczepami mięśni i powięzi, a także pola przyczepów tych mięśni są adekwatnie większe u samców niż u samic. Jednak prac opisujących morfologiczną zmienność wiekową obszarów czaszki jest niewiele, a wobec stwierdzonego rzadkiego u ssaków zjawiska niewielkiego odwróconego dymorfizmu płciowego szynszyli przeprowadzone badania dostarczają interesujących danych wskazujących na różnice we wzroście poszczególnych elementów szkieletu głowy w progresywnej fazie wzrostu tego gatunku gryzoni.
\end{abstract}




\title{
KRAJOWA HODOWLA NUTRII OBJEQTYCH PROGRAMEM OCHRONY ZASOBÓW GENETYCZNYCH (2017)
}

\author{
State of breeding nutrias included in the conservation programme in Poland (2017)
}

\author{
Paweł Bielański
}

\begin{abstract}
Instytut Zootechniki - Państwowy Instytut Badawczy, Dział Ochrony Zasobów Genetycznych Zwierząt e-mail: pawel.bielanski@izoo.krakow.pl
\end{abstract}

Badania prowadzono na trzech fermach nutrii zlokalizowanych w następujących miejscowościach: 1 - Dobrzyniewo Duże (woj. podlaskie), 2 - Kraków (woj. małopolskie) i 3 -Pniewy (woj. wielkopolskie).

Średnio dla wszystkich samic stada podstawowego najliczniejsze mioty zarówno urodzonych (3,94 szt.), jak i odsadzonych $(3,76)$ były na fermie w Pniewach. Na fermie w Dobrzyniewie na 232 samice urodziło się średnio 1,30 nutrii w miocie, a odsadzono średnio 1,18 szt. Ferma w Krakowie uzyskała jeszcze niższe wskaźniki. Na 29 samic stada podstawowego uzyskano średnio po 0,48 młodych i 0,41 odsadzonych. Na dwóch fermach - w Pniewach i Dobrzyniewie - uzyskano bardzo małą liczbę upadków w czasie od urodzenia do odsadzenia, które wahały się od 4,7 do 9,27\%. Na fermie w Krakowie upadkowość była najwyższa i wynosiła 14,3\%. Omówione wyniki nie w pełni odzwierciedlają wskaźniki użytkowości rozpłodowej, gdyż odnoszą się do wszystkich samic stada podstawowego. Hodowcy w związku z brakiem zbytu nie wszystkie samice użytkowali rozpłodowo.

Tabela 1. Wyniki użytkowości rozpłodowej samic nutrii w poszczególnych fermach

\begin{tabular}{|c|c|c|c|c|c|c|c|c|}
\hline \multirow{2}{*}{ Ferma } & \multicolumn{2}{|c|}{$\begin{array}{c}\text { Ocena } \\
\text { pokroju }\end{array}$} & $\begin{array}{c}\text { Wiek przy } \\
\text { przeznaczeniu } \\
\text { do rozrodu } \\
\text { (dni) }\end{array}$ & \multicolumn{2}{c|}{$\begin{array}{c}\text { Urodzone żywo } \\
\text { w miocie }\end{array}$} & \multicolumn{2}{c|}{$\begin{array}{c}\text { Odsadzone } \\
\text { w miocie }\end{array}$} & Upadki \\
\cline { 2 - 10 } & $\mathrm{n}$ & $\bar{X}$ & $\bar{X}$ & $\mathrm{n}$ & $\bar{X}$ & $\mathrm{n}$ & $\bar{X}$ & $\%$ \\
\hline 1 & 232 & 18,35 & 336 & 232 & 1,30 & 232 & 1,18 & 9,27 \\
\hline 2 & 29 & 17,74 & 385 & 29 & 0,48 & 29 & 0,41 & 14,3 \\
\hline 3 & 70 & 18,25 & 379 & 70 & 3,94 & 70 & 3,76 & 4,7 \\
\hline Łącznie & 331 & 18,19 & - & 331 & 1,79 & 331 & 1,66 & 7,3 \\
\hline
\end{tabular}

Największą populację badanych nutrii odmian barwnych stanowiły nutrie standardowe - 92 samice. Średnia ocena pokroju przebadanych zwierząt na trzech fermach wyniosła 18,37 pkt. Ogółem urodziło się 25 miotów, w każdym średnio 5,48 młodych. Odsadzono 4,95 sztuk w miocie. Wśród nutrii standardowych upadki były na niskim poziomie i wyniosły $9,45 \%$. Wyższą ocenę pokroju niż nutrie standardowe uzyskały białe niealbinotyczne (18,54 pkt). Nieco niższe oceny fenotypu uzyskały nutrie sobolowe (18,36 pkt), nutrie grenlandzkie $(18,25 \mathrm{pkt})$ i perłowe $(18,17 \mathrm{pkt})$. Najniższe wartości oceny fenotypowej uzyskały samice odmiany pastelowej $(17,93 \mathrm{pkt})$.

Oceny pokroju młodych nutrii na fermach w Dobrzyniewie i Krakowie były nieznacznie wyższe w stosunku do oceny fenotypu matek. Na fermie w Krakowie wartości oceny fenotypowej były nieznacznie niższe od wartości, które uzyskały samice matki. 


\title{
KRAJOWA HODOWLA SZYNSZYLI BEŻOWEJ OBJĘTEJ PROGRAMEM OCHRONY ZASOBÓW GENETYCZNYCH (2017)
}

State of breeding beige chinchilla included in the conservation programme in Poland (2017)

\author{
Paweł Bielański
}

\begin{abstract}
Instytut Zootechniki - Państwowy Instytut Badawczy, Dział Ochrony Zasobów Genetycznych Zwierząt e-mail: pawel.bielanski@izoo.krakow.pl
\end{abstract}

Władysław i Elwira Rżewscy w roku 1956 sprowadzili do Polski pierwsze szynszyle. Na przełomie lat 50. i 60. ubiegłego wieku na ich fermie pojawiła się nowa mutacja szynszyli, określona jako szynszyla beżowa. Na początku odmiana ta wzbudziła duże zainteresowanie wśród hodowców. Ze względu na nie najlepszą w tym okresie koniunkturę dla skór szynszylowych zainteresowanie to szybko minęło. Wpłynęła na to również zbyt mała liczba zwierząt tej odmiany barwnej (beżowej). Na szczęście odmiana beżowa została utrzymana przez kilku hodowców - obecnie zwierzęta tej odmiany barwnej można spotkać na nielicznych fermach w naszym kraju, najliczniejsza populacja utrzymywana jest w woj. małopolskim.

Badania były przeprowadzone w siedmiu stadach hodowlanych szynszyli beżowych, utrzymywanych w województwie małopolskim (Kraków, Limanowa, Zakopane, Myślenice, Radwanowice), w województwie łódzkim (Łódź) oraz województwie śląskim (Częstochowa). Łącznie badania przeprowadzono w populacji hodowlanej nie większej niż 200 samic stada podstawowego szynszyli beżowych, tj. samic użytkowanych rozpłodowo w $2017 \mathrm{r}$.

Cechy reprodukcyjne były badane w stadzie podstawowym samic szynszyli beżowych w okresie kryć, rozrodu i odchowu młodych, a cechy fenotypowe w stadzie podstawowym i u młodych osobników urodzonych z ww. kryć.

Średnie oceny pokroju samic wahały się w kolejnych latach od 24,00 pkt w 2006 r. do 25,7 pkt w 2014 i 2015 r. Wydały one potomstwo w ciągu 2017 r., uzyskując średnią dla pierwszego miotu 1,67, dla drugiego miotu 0,86 , a dla trzeciego 0,07 . Średnia liczba szynszyli odsadzonych w kolejnych miotach wynosiła odpowiednio $0,82,0,86$ i 0,07 .

Największą liczbą urodzonych i odsadzonych szynszyli uzyskanych od jednej samicy w ciągu roku charakteryzowały się fermy w Radwanowicach (odpowiednio 4,1 i 3,7) oraz ferma w Krakowie (odpowiednio 3,87 i 3,54 sztuki) i Łodzi (odpowiednio 2,38 i 2,38). Najmniejszy procent upadków młodych szynszyli w okresie od urodzenia do odsadzenia były na fermach w Myślenicach - 5,8\% i Częstochowie - 6,7\%.

$\mathrm{Na}$ podstawie przeprowadzonych badań należy stwierdzić, że występują rozbieżności pomiędzy badanymi fermami we wskaźnikach użytkowości rozpłodowej. Wydaje się niezbędne kontynuowanie badań w celu określenia przyczyn tych różnic i znalezienia sposobu ich wyrównania. Z kolei badania dotyczące młodych osobników wykazały, że stosowany fachowy system żywienia wpłynął pozytywnie na wyrównanie materiału hodowlanego młodzieży na fermach. 


\title{
WPEYW IMMUNOMODULATORA NA WYNIKI UŻYTKOWANIA KRÓLIKÓW RZEŹNYCH
}

The influence of ImmunoModulator on slaughtering rabbits' results

\author{
Marian Brzozowski \\ Szkoła Główna Gospodarstwa Wiejskiego w Warszawie, Katedra Szczegółowej Hodowli Zwierząt, \\ ul. Ciszewskiego 8, 02-786 Warszawa \\ e-mail: marian_brzozowski@sggw.pl
}

ImmunoModulator to mieszanka paszowa uzupełniająca (m.p.u.), dlatego jego stosowanie nie wymaga recepty i może być długoterminowe.

W skład ImmunoModulatora wchodzą dwa aktywne składniki pochodzenia roślinnego: wyciąg z rumianku (Matricaria recutita), który jest źródłem apigeniny, oraz wyciąg z gorzkiej pomarańczy (Citrus aurantium), źródła naringiny. Apigenina oraz naringina należą do grupy flawonoidów mających bardzo szerokie spektrum pozytywnego oddziaływania na funkcje organizmów. Dzięki swoim właściwościom ImmunoModulator jest efektywnym środkiem do poprawy wydajności i wyników produkcji zwierząt.

Celem doświadczenia było określenie efektywności zastosowania ImmunoModulatora w odchowie królików rzeźnych. Oceniano następujące wskaźniki: zdrowotność, przeżywalność, zmiany masy ciała, wydajność rzeźną, spożycie paszy. Wyniki dotyczyły okresu od urodzenia do uboju.

Samice z grupy doświadczalnej w okresie okołoporodowym otrzymywały ImmunoModulator w ilości $1 \%$ dziennej dawki pokarmowej. Preparat łączono z wodą w proporcjach $1: 4$, a następnie tak uzyskany żel mieszano z granulatem. Codziennie sporządzano nową partię granulatu zmieszanego z preparatem. Żywienie preparatem stosowano od 23. dnia po pokryciu do 8. dnia po porodzie. Samice z grupy kontrolnej były żywione granulatem bez jakichkolwiek domieszek.

Stwierdzono, że już w okresie odchowu przy samicach młode króliki z grupy doświadczalnej odznaczały się lepszymi parametrami badanych cech, przy czym różnice między grupami nie były istotne statystycznie. W okresie po odsadzeniu króliki z grupy doświadczalnej cechowały się lepszą zdrowotnością (nie zaobserwowano objawów biegunki), większa także była w tej grupie średnia masa końcowa oraz lepsza wydajność rzeźna.

Zastosowanie preparatu okazało się korzystne dla uzyskania lepszych wyników użytkowania rzeźnego królików, przede wszystkim z racji ograniczenia występowania problemów zdrowotnych, co przełożyło się na wyższe wartości pozostałych wskaźników. 


\title{
KONDYCJA SAMIC NORKI HODOWLANEJ (NEOVISON VISON) A WYNIKI ICH ROZRODU I ZACHOWANIE W OKRESIE CIĄŻY I LAKTACJI
}

Body condition of breeding mink (Neovison vison) and their result of the reproduction and behavior in the current and lactation period

\author{
Lidia Felska-Błaszczyk ${ }^{1}$, Natalia Ławrów ${ }^{1}$, Beata Seremak $^{2}$, Małgorzata Dziadosz-Styśs ${ }^{3}$, \\ Olga Rząsik ${ }^{1}$
}

\author{
${ }^{1}$ Zachodniopomorski Uniwersytet Technologiczny w Szczecinie, Pracownia Anatomii Zwierząt \\ ul. Doktora Judyma 14, 71-466 Szczecin \\ ${ }^{2}$ Zachodniopomorski Uniwersytet Technologiczny w Szczecinie, \\ Katedra Biotechnologii Rozrodu Zwierząt i Higieny Środowiska \\ ${ }^{3}$ Gospodarstwo Rolne Maciej Buczek \\ e-mail: lidia.felska-blaszczyk@zut.edu.pl
}

Żywienie norek hodowlanych na fermach w okresie jesiennym jest bardzo intensywne i energetyczne. Takie żywienie, często $\mathrm{z}$ dodatkiem wolnego tłuszczu w dawce powoduje, że norki w okresie przedubojowym są maksymalnie otłuszczone. Wybrane do stada podstawowego zwierzęta hodowlane po okresie tak intensywnego żywienia należy doprowadzić do tzw. kondycji rozrodczej, co związane jest z krótkotrwałym żywieniem ograniczonymi dawkami i jednoczesnym zmniejszeniem energetyczności dawki, przede wszystkim poprzez usunięcie z żywienia pasz tłustych i wolnego tłuszczu oraz żywieniem pełną dawką o zwiększonej energetyczności na 4-5 dni przed okresem kryć. Odpowiednia kondycja zwierząt stada podstawowego jest jednym w najważniejszych czynników decydujących o sukcesie rozrodczym zwierząt. Kondycja ciała norek stada podstawowego może mieć również wpływ na występowanie zachowań stereotypowych.

Celem pracy była ocena wpływu kondycji samic stada podstawowego na wyniki rozrodu, takie jak procent samic jałowych, wielkość miotu i liczba odchowanych młodych z jednego miotu oraz na zachowanie samic w okresie ciąży i laktacji.

Badania prowadzono na wielkotowarowej fermie norek położonej w północno-zachodniej Polsce. Samice odmiany perła w łącznej liczbie 601 (311 samic jednorocznych i 290 samic dwuletnich) podzielono na grupy ze względu na kondycję. Zwierzęta utrzymywano w standardowych klatkach do chowu norek i żywiono jednakową paszą na bazie produktów odpadowych z kurczaka i ryby. Na kilka dni przed kryciem samice podzielono na następujące grupy: 1 - norki bardzo chude, 2 - norki chude, 3 - idealna kondycja, 4 - norki o wyglądzie ciężkim, 5 - norki otyłe. Analizowano następujące wskaźniki rozrodu i zachowania: wielkość miotu, liczbę żywo urodzonych młodych w miocie, liczbę odchowanych młodych z miotu, procent samic jałowych, procent samic padłych w okresie ciąży, procent samic, które wygryzały okrywę.

Wpływ kondycji ciała na wyniki rozrodu był wyraźniejszy u samic jednorocznych. Najwyższe wskaźniki wielkości miotu, liczby żywo urodzonych młodych w miocie oraz liczby odchowanych norek z miotu u samic jednorocznych zanotowano u samic o optymalnej kondycji ciała (grupa 3). Zachowanie stereotypowe wygryzanie okrywy włosowej - występowało częściej u samic najchudszych i bardzo otyłych (grupy kondycyjne 1 i 5), zarówno u samic jednorocznych, jak i dwuletnich. Najwięcej samic jałowych zanotowano wśród samic najchudszych (1 grupa kondycyjna), zarówno jednorocznych, jak i dwuletnich, oraz wśród samic najgrubszych (5 grupa kondycyjna), również w obu latach użytkowania rozrodczego. Najniższe natomiast wartości tego wskaźnika wystąpiły u samic o optymalnej kondycji (3 grupa kondycyjna). Najniższy procent samic padłych w okresie ciąży stwierdzono u samic o optymalnej kondycji (3 grupa kondycyjna). 


\title{
ANALIZA RODOWODOWA POPULACJI LISA POSPOLITEGO (VULPES VULPES)
}

\author{
Pedigree analysis of the fox (Vulpes vulpes) population
}

\author{
Patrycja Grzybek ${ }^{1}$, Piotr Przysiecki ${ }^{2}$, Andrzej Filistowicz ${ }^{3}$, Jan Dobrzański ${ }^{1}$, \\ Tomasz Szwaczkowski ${ }^{1}$ \\ ${ }^{1}$ Uniwersytet Przyrodniczy w Poznaniu, Katedra Genetyki i Podstaw Hodowli Zwierząt, \\ ${ }^{2}$ Zespół Szkół Rolniczo-Budowlanych w Lesznie \\ ${ }^{3}$ Uniwersytet Przyrodniczy we Wrocławiu, Instytut Hodowli Zwierząt \\ e-mail: patrycja.grzybek92@gmail.com
}

Analiza rodowodowa jest bardzo ważnym elementem pracy hodowlanej, gdyż dostarcza informacji o strukturze genetycznej populacji, poziomie inbredu i jego zmianach, a także ocenie zmienności genetycznej w populacjach zwierząt gospodarskich. Dla hodowców jest integralną częścią strategii hodowlanej, przyczyniającą się do optymalizacji doboru par do kojarzeń.

Celem pracy była ocena kompletności danych rodowodowych, oszacowanie poziomu inbredu oraz analiza zmienności genetycznej w populacji lisów pospolitych z fermy zarodowej.

Materiał badawczy stanowią dane rodowodowe i produkcyjne 39434 osobników utrzymywanych w fermie zarodowej lisa pospolitego „Batorówka” w latach 1956-2016, z czego 751 z nich stanowili założyciele populacji. Stado podstawowe składało się łącznie z 4465 lisów. Oszacowano następujące parametry: ekwiwalent kompletnych pokoleń, współczynnik inbredu, wskaźnik różnorodności genetycznej oraz współczynnik utraty zmienności genetycznej (wynikający z dryfu genetycznego i nierównego udziału założycieli). Obliczenia wykonano, stosując pakiet komputerowy CFC.

Wykazano bardzo dobrą kompletność rodowodów. Średni ekwiwalent kompletnych generacji dla całej populacji wyniósł 10,56, a maksymalna jego wartość osiągnęła 18,24. To warunkuje wysoką precyzję oszacowań parametrów rodowodowych. Średni poziom inbredu całej populacji równy był 5,34\%, a w populacji zinbredowanej - 6,04\% (mimo że tylko $10 \%$ osobników było niezinbredowanych). W pierwszych dekadach (do lat $80 . \mathrm{XX}$ w.) zanotowano wzrost inbredu, co jest naturalną konsekwencją wzrostu liczby danych rodowodowych. Z kolei od połowy lat 90. obserwowane są tendencje spadkowe. Oszacowano wysokie wskaźniki różnorodności genetycznej i ich fluktuacji, przekraczające $90 \%$. Natomiast strata zmienności genetycznej w badanym okresie oscylowała w granicach $1-6 \%$.

Generalnie oszacowane parametry rodowodowe populacji są korzystne zarówno z punktu widzenia programu doskonalenia populacji, jak i ochrony zasobów genetycznych. 


\title{
WPŁYW DODATKU ALTERNATYWNYCH ŹRÓDEŁ BIAŁKA ZWIERZEYCEGO DO DIETY NA STRAWNOŚĆ SKŁADNIKÓW POKARMOWYCH U SZYNSZYLI
}

The effect of addition of alternative animal protein sources to diet on nutrient digestibility in chinchillas

\author{
Andrzej Gugołek ${ }^{1}$, Janusz Strychalski ${ }^{1}$, Małgorzata Konstantynowicz ${ }^{1}$, Barbara Jędrzycka ${ }^{2}$ \\ ${ }^{1}$ Uniwersytet Warmińsko-Mazurski, Katedra Hodowli Zwierząt Futerkowych i Łowiectwa, ul. Oczapowskiego 5, 10-719 Olsztyn \\ ${ }^{2}$ Uniwersytet Warmińsko-Mazurski, Studenckie Koło Naukowe Hodowców Zwierząt Amatorskich \\ e-mail: gugolek@uwm.edu.pl
}

Szynszyle to gryzonie zaliczane do grupy zwierząt roślinożernych. Większość współczesnych źródeł podaje, że nie należy im podawać pasz pochodzenia zwierzęcego pod żadną postacią, a nawet że ich stosowanie powoduje zaburzenia funkcjonowania przewodu pokarmowego. Są jednak także opinie przeciwne, szczególnie w starszych publikacjach i opracowaniach naukowych, wskazujące, że dzikie szynszyle, żyjące w ubogim w pokarm wysokogórskim środowisku, obok roślin pobierają także owady i ptasie jaja. Ponadto w wielu zagranicznych mieszankach paszowych stosowany jest dodatek mączki rybnej, a w krajowych wykorzystywano mleko w proszku.

Celem przeprowadzonego eksperymentu było wykazanie wpływu dodatku mączki z larw mącznika młynarka (Tenebrio molitor) oraz mączki rybnej do mieszanek paszowych pełnodawkowych granulowanych na strawność składników pokarmowych u szynszyli.

Badania wykonano na 18 samcach szynszyli w wieku ok. 250 dni, podzielonych na trzy grupy. Zwierzęta grupy kontrolnej (K) żywiono dietą standardową z udziałem śruty sojowej poekstrakcyjnej (10\%), w grupie doświadczalnej pierwszej (I) zastosowano dodatek mączki rybnej (3\%) o zawartości białka ogólnego 60\%, a w drugiej (II) suszonej mączki z larw mącznika (4\%) o zawartości białka ogólnego 50\%. Wszystkie diety były izobiałkowe, zawierały ponad $18 \%$ białka ogólnego oraz ok. $14 \%$ włókna surowego.

Wyniki uzyskane podczas badań strawnościowych przedstawiono w tabeli 1.

Tabela 1. Współczynniki strawności składników pokarmowych u szynszyli [\%]

\begin{tabular}{|l|c|c|c|}
\hline \multirow{2}{*}{\multicolumn{1}{c|}{ Składnik pokarmowy }} & \multicolumn{3}{|c|}{ Grupa } \\
\cline { 2 - 4 } & K & I & II \\
\hline Białko ogólne & 78,60 & 74,98 & 77,17 \\
Tłuszcz surowy & $89,56^{\mathrm{b}, \mathrm{c}}$ & $87,36^{\mathrm{B}, \mathrm{d}}$ & $92,17^{\mathrm{Aa}}$ \\
Włókno surowe & 44,85 & 45,80 & 47,42 \\
Związki bezazotowe wyciągowe & 72,04 & 71,29 & 70,58 \\
\hline
\end{tabular}

A, $B-p \leq 0,01, a-d-p \leq 0,05$

Diety doświadczalnie nie spowodowały zaburzeń w funkcjonowaniu przewodów pokarmowych szynszyli. Na podstawie opisanego eksperymentu można stwierdzić, że w żywieniu szynszyli można stosować niewielkie ilości białka zwierzęcego: mączki rybnej i suszonych larw mącznika, bez negatywnego wpływu na strawność składników pokarmowych. Ponadto wykazano, że dodatek mączki z larw mącznika wpłynął korzystnie na strawność tłuszczu surowego. 


\title{
MOŻLIWOŚĆ ZASTOSOWANIA MARKERÓW GENETYCZNYCH W OCENIE TEMPERAMENTU LISÓW POSPOLITYCH (VULPES VULPES)
}

Possibility of use of genetic markers in the assessment of silver foxes (Vulpes vulpes) temperament

\author{
Beata Horecka, Grażyna Jeżewska-Witkowska
} Uniwersytet Przyrodniczy w Lublinie, Instytut Biologicznych Podstaw Produkcji Zwierzęcej, ul. Akademicka 13, 20-950 Lublin
e-mail: beata.horecka@up.lublin.pl

W ostatnich latach w pracach dotyczących zwierząt futerkowych kładzie się na świecie duży nacisk na badania behawioralne, które, jak się okazuje, mają duży wpływ na ekonomikę tej gałęzi produkcji. Pomimo wieloletniej hodowli zwierząt futerkowych nie można jednoznacznie stwierdzić, że proces ich udomowienia został zakończony. Występowanie zachowań bojaźliwych, agresywnych, nieufności w stosunku do człowieka nie jest sporadyczne na fermach zwierząt futerkowych i może być zależne zarówno od czynników środowiskowych (system utrzymania, organizacja życia stadnego, relacje zwierzę - człowiek), jak i genetycznych. Markery genetyczne mogą być wykorzystywane jako narzędzie wspomagające dla testów behawioralnych, które stanowią obecnie jedno z kryteriów oceny dobrostanu zwierząt fermowych. Lis pospolity (Vulpes vulpes) charakteryzuje się bliskim pokrewieństwem filogenetycznym z psem domowym, będącym jednym z najlepiej poznanych gatunków modelowych. Daje to większe możliwości poznawcze poprzez zastosowanie analogicznych metod i sprawdzonych markerów. Jednym z genów o potwierdzonym wpływie na zachowanie ludzi i zwierząt jest gen $D R D 4$, kodujący receptor dopaminy D4. Wykazano m.in. zależność pomiędzy polimorfizmem VNTR (variable number of tandem repeats) $\mathrm{w}$ regionach kodujących i niekodujących tego genu a pobudliwością i agresją u psów. Celem badań była optymalizacja warunków PCR z wykorzystaniem starterów stosowanych uprzednio w badaniach psów do amplifikacji homologicznych regionów genu DRD4 lisów pospolitych. Jako materiał do ekstrakcji DNA wykorzystano próby włosów wraz z cebulkami, pobrane od 10 losowo wybranych lisów pospolitych srebrzystych. Zarówno izolację, jak i amplifikację DNA przeprowadzono z użyciem komercyjnych zestawów. Zastosowano startery DRD4F: GCCTCCATCTTCAACCTGTG i DRD4R: CTGGCGGTTGTAACTCAGC (Proskura i in. 2013), flankujące intron 2, oraz D1c: CGCGCGTCGGGCCAAGCTG i D2c: GCGGGGGGCAGGGGGCG (Hejjas i in. 2007), flankujące ekson 3 genu $D R D 4$. Temperatura przyłączania wynosiła dla obu par starterów $59^{\circ} \mathrm{C}$. $\mathrm{W}$ obu przypadkach uzyskano produkty odpowiadające długością fragmentom identyfikowanym u psów (intron 2 - ok. 200 pz, ekson 3 - ok. 280-430 pz). Pozytywne wyniki amplifikacji stwarzają możliwość dalszych badań. Należałoby przeprowadzić testy behawioralne w celu utworzenia grup referencyjnych zwierząt o różnych typach temperamentu, a następnie przeprowadzić testy genetyczne $\mathrm{z}$ wykorzystaniem markerów DRD4. Umożliwiłoby to obliczenie frekwencji poszczególnych alleli i genotypów oraz określenie ich związku z temperamentem osobnika. 


\title{
WYKORZYSTANIE TECHNIK MOLEKULARNYCH W USTALANIU OJCOSTWA NOREK HODOWLANYCH (NEOVISON VISON)
}

Use of molecular techniques in paternity determination of farm mink (Neovison vison)

\author{
Andrzej Jakubczak, Marek Kowalczyk, Beata Horecka, Grażyna Jeżewska-Witkowska \\ Uniwersytet Przyrodniczy w Lublinie, Instytut Biologicznych Podstaw Produkcji Zwierzęcej, ul. Akademicka 13, 20-950 Lublin \\ e-mail: andrzej.jakubczak@up.lublin.pl
}

Precyzyjną kontrolę pochodzenia zwierząt umożliwiają metody biologii molekularnej, które opierają się na wykorzystaniu markerów molekularnych wraz z nowoczesnymi metodami ich analizy. W badaniach przynależności zarówno gatunkowej, jak i osobniczej wykorzystuje się sekwencje STR, które ze względu na wysoki polimorfizm, dość częste występowanie w genomie oraz szybką i łatwą identyfikację są dobrymi markerami genetycznymi. U norek występuje owulacja indukowana, tzn. uwalnianie pęcherzyków następuje po ok. 36-48 h w odpowiedzi na stymulację szyjki macicy przez samca. W ciągu trwającego ok. 3 tygodni okresu rozrodczego owulacja następuje co ok. 7-8 dni, a z jej pojawieniem wiąże się wzrost gotowości samic do krycia. Występowanie cyklicznej owulacji umożliwia zastosowanie kryć wielokrotnych z udziałem różnych samców. Z perspektywy hodowców interesujące jest ustalenie efektywnego systemu i terminu krycia. Ponadto w przypadku norek występuje zjawisko wieloojcostwa (występowanie w miocie potomstwa po kilku samcach użytych do krycia), które może wpływać na liczebność i strukturę genetyczną potomstwa. W doborze optymalnych strategii reprodukcyjnych dla norek mogą pomóc metody molekularne oparte na analizie sekwencji mikrosatelitarnych. Ustalenie profilu genetycznego potomstwa i skonfrontowanie go z profilami samców użytych do krycia mogą pozwolić na wskazanie nie tylko najkorzystniejszego systemu krycia, ale również na wykonanie krycia samcem o najlepszych cechach fenotypowych. Celem pracy było zaprojektowanie panelu mikrosatelitarnego przeznaczonego do identyfikacji i ustalania pokrewieństwa norek amerykańskich (Neovison vison). Uzyskane wyniki zwalidowano na podstawie badań populacyjnych tego gatunku. W rezultacie przeprowadzonych badań otrzymano panel mikrosatelitarny zawierający 13 loci mikrosatelitarnych: Mvi020, Mvi075, Mvi099, Mvi111, Mvi1016, Mvi1273, Mvi1341, Mvi2623, Mvi2624, Mvi4025, Mvi4031, Mvi4066 oraz Mvi5001. Analiza poziomu polimorfizmu badanych 13 sekwencji mikrosatelitarnych wykazała, że panel ten może być przydatny w badaniach identyfikacji osobniczej. Dla poszczególnych loci określano indeks stopnia polimorfizmu. Najwyższe wartości, przekraczające wartość 0,5 , otrzymano dla loci Mvi099, Mvi1016, Mvi2623, Mvi2624 oraz Mvi4025, dlatego należy uznać je za najbardziej informatywne. Współczynnik wykluczenia ojcostwa (PE) oraz siłę dyskryminacji (PD) określono na podstawie badań przeprowadzonych zarówno na całej populacji, jak i osobno - na zwierzętach hodowlanych oraz dzikich. Dla większości analizowanych loci uzyskano wskaźniki o wysokich wartościach potwierdzające przydatność do analiz. Wykorzystywanie panelu zawierającego 13 sekwencji mikrosatelitarnych potwierdziło jego przydatność zarówno do identyfikacji osobniczej zwierząt w populacji norek hodowlanych, jak i dziko żyjących. 


\title{
WSTĘPNE BADANIA NAD MOŻLIWOŚCIĄ WYKORZYSTANIA SUSZONYCH LARW OWADÓW W ŻYWIENIU KRÓLIKÓW
}

Preliminary study on the possibility of using dried insect larvae in rabbit nutrition

\author{
Dorota Kowalska ${ }^{1}$, Andrzej Gugołek ${ }^{2}$ \\ ${ }^{1}$ Instytut Zootechniki - Państwowy Instytut Badawczy, Zakład Hodowli Drobnego Inwentarza \\ ul. Krakowska 1, 32-083 Balice \\ ${ }^{2}$ Uniwersytet Warmińsko-Mazurski, Katedra Hodowli Zwierząt Futerkowych i Łowiectwa \\ ul. M. Oczapowskiego 5/366, 10-719 Olsztyn \\ e-mail: dorota.kowalska@izoo.krakow.pl
}

W żywieniu królików od momentu wprowadzenia zakazu stosowania mączek mięsno-kostnych głównym źródłem białka stała się importowana poekstrakcyjna śruta sojowa, a także, choć w mniejszym stopniu, śruty: rzepakowa i słonecznikowa. Jak wiadomo, wartość odżywcza komponentów białkowych pochodzenia roślinnego jest mniejsza w porównaniu $\mathrm{z}$ białkiem pochodzenia zwierzęcego, stąd też $\mathrm{w}$ przemyśle paszowym zaczyna poszukiwać się nowych materiałów paszowych, mogących ograniczyć ich wykorzystanie. W ostatnim czasie coraz częściej poruszany jest temat zastosowania różnych gatunków owadów jako źródła białka i tłuszczu. W wielu krajach azjatyckich, afrykańskich i krajach Ameryki Łacińskiej to właśnie bezkręgowce stanowią powszechne źródło białka w mieszankach paszowych dla zwierząt gospodarskich.

Celem niniejszej pracy jest wskazanie na możliwość wykorzystania w żywieniu królików larw jedwabnika morwowego i mącznika młynarka jako źródeł najwyższej jakości białka.

Materiał doświadczalny stanowiły króliki rasy nowozelandzkiej białej pochodzące z fermy należącej do Instytutu Zootechniki PIB w Aleksandrowicach, w ilości 60 szt., podzielone na 3 grupy (po 20 szt. w każdej), kontrolną (K) i dwie doświadczalne (A i B). Badania prowadzono w okresie od odsadzenia młodych królicząt od matek w 35. d.ż. do 90. d.ż. Na potrzeby doświadczenia sporządzono 3 mieszanki paszowe kontrolną (K) i 2 doświadczalne: pierwszą z dodatkiem 4\% suszonych larw jedwabnika morwowego (A), a drugą z dodatkiem $4 \%$ suszonych larw mącznika młynarka (B). Króliczęta w okresie doświadczalnym żywiono mieszankami paszowymi ad libitum.

W celu oceny wyników produkcyjnych zostały określone: indywidualne masy ciała królików w wieku 35, 56, 70 i 90 dni. Po zakończeniu odchowu doświadczalnego ubito po 12 królików z każdej grupy. Przeprowadzono analizę rzeźną i obliczono wydajność rzeźną jako stosunek masy tuszki ciepłej z głową i podrobami do masy zwierzęcia przed ubojem. Badania wykazały, że przy wyrównanej początkowej masie ciała (773,3-782,5 g) już w 56. d.ż. królicząt w grupie B stwierdzono statystycznie istotnie potwierdzony wzrost masy ciała $\mathrm{w}$ stosunku do pozostałych grup. W 90. d.ż. zwierząt istotne różnice $(\mathrm{p} \leq 0,05)$ stwierdzono pomiędzy grupą $\mathrm{K}$ a obydwiema grupami doświadczalnymi. Średnia masa ciała królików $\mathrm{z}$ grupy A była o 222,9 g, a z grupy B o 211,6 g większa niż w grupie kontrolnej (2352 g). Wyniki analizy rzeźnej wykazały istotne różnice w masie tuszki ciepłej z głową i masie części jadalnych na korzyść grup doświadczalnych. Z punktu widzenia hodowcy i konsumenta za istotne należy uznać, że do wieku 90 d.ż., u królików w grupach doświadczalnych otrzymujących paszę z dodatkiem suszonych larw jedwabnika morwowego i mącznika młynarka nie stwierdzono wzrostu otłuszczenia tuszek. Najwyższą wydajność rzeźną stwierdzono w grupie A $(59,88 \%)$. Pomiędzy nią a pozostałymi ( $\mathrm{K}-57,67 \%$, B - 57,49\%) wykazano potwierdzone statystycznie różnice na poziomie $\mathrm{p} \leq 0,05$. Obecnie trwają dalsze badania mające na celu określenie jakości pozyskanego mięsa króliczego. 


\title{
KRÓLIKI POPIELNIAŃSKIE BIAŁE - STAN HODOWLI W POLSCE
}

\author{
Popielno White rabbits - state of breeding in Poland
}

\section{Dorota Kowalska}

\begin{abstract}
Instytut Zootechniki - Państwowy Instytut Badawczy, Zakład Hodowli Drobnego Inwentarza, ul. Krakowska 1, $32-083$ Balice e-mail: dorota.kowalska@izoo.krakow.pl
\end{abstract}

Króliki popielniańskie białe są jedyną zachowaną w Polsce rodzimą rasą królików. Utrzymanie jej wydaje się celowe ze względu na wysoką płodność i plenność oraz bardzo dobre cechy adaptacyjne do mniej korzystnych warunków środowiskowych, jak również ze względu na ogromny trud wielu naukowców i hodowców włożony w jej wytworzenie. Materiał wyjściowy, nad którym rozpoczęto prace hodowlane, stanowiły króliki polskie albinotyczne zakupione na targu w Myślenicach (20 szt.) oraz przejęte ze zlikwidowanego Zakładu Doświadczalnego w Brzeziu (20 szt.). Średnia masa ciała tych zwierząt wynosiła ok. 2,5 kg, toteż w celu jej powiększenia przekrzyżowano je jednorazowo królikami rasy belgijski olbrzym szary. Krzyżowano samice białe polskie z samcami rasy belgijski olbrzym szary, a samice rasy belgijski olbrzym szary z samcami białymi polskimi. Stosowano heterospermię, kryjąc samicę kolejno dwoma samcami. W wyniku tego uzyskano pokolenie mieszańców o szarej barwie okrywy włosowej, które kojarzono między sobą. W pokoleniu drugim mieszańców oprócz osobników szaro umaszczonych uzyskano także króliki o albinotycznej barwie okrywy włosowej, na których oparto dalsze prace hodowlane. Rozpoczęto krzyżowanie mieszańców albinotycznych między sobą. Mioty ograniczano do 2 szt., aby zapewnić lepszy wzrost i rozwój młodych. Przez kilka lat stosowano też tzw. zimny chów ciężarnych matek, mający na celu poprawę okrywy włosowej u potomstwa. Zwierzęta utrzymywano w klatkach drewnianych na wolnym powietrzu, co w warunkach zimowych zapewniało surowe warunki chowu. W efekcie prowadzonych prac w $1964 \mathrm{r}$. udało się uzyskać w Popielnie całe stado zwierząt o jednolitej, albinotycznej barwie okrywy włosowej. Królice rodziły liczebne mioty (8-12 szt.) i stosunkowo dobrze je odchowywały. Młode króliczęta miały bardzo dobre tempo wzrostu - w wieku 90 dni uzyskiwały masę ciała 2,7 kg przy wysokiej wydajności rzeźnej, sięgającej do 60\%. W 2017 r. na terenie naszego kraju króliki popielniańskie białe utrzymywano w 6 stadach wpisanych do ksiąg prowadzonych przez KCHZ. Przeprowadzono w nich badania dotyczące: oceny fenotypowej w skali od 1 do 100 pkt, wieku samic w dniu wykotu, długości ciąży, liczby miotów w roku, liczby królicząt urodzonych żywo i martwo, liczby królicząt odsadzonych od samicy, procentu padnięć oraz masy ciała królicząt w dniu odsadzenia (w 90. i 120. d.ż., w zależności od systemu żywienia). Podczas badań sprawdzano warunki utrzymania zwierząt oraz ogólną kondycję stada należącego do danego hodowcy. Stada różniły się między sobą: wielkością stada podstawowego - od 13 do 220 samic, systemem utrzymania budynki inwentarskie dogrzewane (3), budynki inwentarskie nieogrzewane (1), klatki stojące na wolnym powietrzu (2), systemem żywienia - pełnoporcjowa mieszanka granulowana (3), pasze gospodarskie (zielonka, siano, marchew, mieszanki zbożowe, śruty, pieczywo) (2), mieszane: pełnoporcjowa mieszanka granulowana + pasze gospodarskie (1), co zostało uwzględnione w opracowaniu końcowym uzyskanych wyników. Zwierzęta były utrzymywane w różnego typu klatkach: kojcach ściołowych, kojcach rusztowych bezściołowych, kojcach betonowych wkopanych do $1 \frac{1}{2}$ wysokości w ziemię, klatkach z siatki metalowej jednopoziomowych, klatkach z siatki metalowej dwupoziomowych, klatkach z prętów metalowych rusztowych, klatkach drewnianych ściołowych, jedno- i dwukondygnacyjnych, zadaszonych, kojcach betonowych z ogrodzonym wybiegiem. Średnia ocena pokroju samic przeprowadzona w poszczególnych stadach w 2017 r. mieściła się w granicach od 94,4 do 95,7 pkt. Najwyżej oceniono zwierzęta utrzymywane (w budynkach inwentarskich nieogrzewanych w systemie żywienia mieszanym (95,7 pkt). Wyniki oceny wskazują na konieczność dalszej pracy hodowlanej nad poprawą cech pokroju tych zwierząt. Najczęstsze zastrzeżenia dotyczyły zbyt niskiej masy ciała, małej gęstości, sprężystości i zażółceń okrywy włosowej oraz budowy ciała. Z 336 ocenianych 
samic 326 wykociło się przynajmniej raz w roku, 10 pozostało jałowych. W sumie we wszystkich stadach urodziło się 2648 królicząt, z czego $2336 \mathrm{w}$ pierwszym miocie, a $312 \mathrm{w}$ drugim miocie samic. Odchowano łącznie 2444 sztuki potomstwa, z czego 2154 z pierwszego miotu samic i 290 z drugiego miotu.

Średni wiek samic w dniu pierwszego pokrycia w $2017 \mathrm{r}$. wahał się w badanych stadach od 10,8 do 18,6 miesiąca życia. W przedziale wiekowym od 10 do 13 miesięcy mieściło się 50 samic, od 14 do 16 miesięcy - 267, a powyżej 16 miesięcy - 9 .

Długość ciąży była zbliżona we wszystkich stadach i wynosiła średnio 31,2 dni. Różnice pomiędzy badanymi stadami dotyczyły liczby królicząt urodzonych i odchowanych, procentu padnięć oraz masy ciała. Największą średnią liczbę królicząt urodzonych $(7,7)$ i odchowanych $(6,5)$ od 1 samicy w 1 miocie stwierdzono w stadzie utrzymywanym w dogrzewanych budynkach inwentarskich i żywionym pełnoporcjową mieszanką granulowaną. Najmniej padnięć $(1,75 \%)$ stwierdzono w stadzie utrzymywanym w kojcach rusztowych, bezściołowych w budynku nieogrzewanym i żywionych systemem mieszanym, w pozostałych stadach padnięcia wynosiły od 14,6 do $48,0 \%$. W dwóch badanych stadach stwierdzony wysoki procent padnięć, powyżej 20, wskazuje na konieczność monitorowania warunków utrzymania, żywienia i zdrowotności. Najczęstszymi przyczynami padnięć były schorzenia przewodu pokarmowego (biegunki) oraz kokcydioza. Średnia masa ciała młodych królików w wieku 90 dni wahała się od 2386,2 do 2470,5 g. Pochodziły one z gospodarstw, gdzie zwierzęta żywione były paszami granulowanymi lub systemem mieszanym. W pozostałych dwóch średnią masę ciała, 2403,6 i 2230,4 g, zwierzęta uzyskały w wieku 120 dni.

Masa ciała młodych królicząt w 35. d.ż. (średnia z 2 miotów samic) kształtowała się w granicach od 550 do $660 \mathrm{~g}$, najwyższe wartości uzyskano dla stad utrzymywanych w budynkach inwentarskich ogrzewanych, żywionych pełnoporcjową mieszanką granulowaną. W 90. d.ż. królicząt masa ciała wahała się od 2391,7 do $2470,5 \mathrm{~g}$, a w 120. dniu w gospodarstwach utrzymujących zwierzęta w klatkach lub kojcach na powietrzu, przy systemie żywienia paszami gospodarskimi - od 2219,6 do 2414,9 g. Średnia ocena pokroju młodych królicząt dla wszystkich stad wyniosła 95,0 pkt.

Uzyskane w 2017 r. wyniki badań prowadzonych w 6 stadach królików popielniańskich białych wskazują, że rasa ta jest dobrze przystosowana zarówno do chowu w klatkach na wolnym powietrzu (chów przydomowy), a więc do mniej korzystnych warunków środowiskowych, jak i w pomieszczeniach zamkniętych. Samice wydają duże liczebnie mioty, są dobrymi matkami, stąd w odpowiednich warunkach utrzymania i żywienia mogą odchować wysoki procent królicząt. Uzyskane wyniki wskazują jednak, że możliwa jest dalsza poprawa zarówno cech fenotypowych, jak i reprodukcyjnych. 


\title{
WPEYW CYTOCHALAZYNY B NA KOMÓRKI SOMATYCZNE KOTA DOMOWEGO FELIS CATUS
}

The influence of cytochalasin B on cat's somatic cells Felis catus

\author{
Marta Kuchta-Gładysz ${ }^{1}$, Olga Szeleszczuk ${ }^{1}$, Przemysław Baran ${ }^{2}$, Anna Grzesiakowska $^{1}$ \\ ${ }^{1}$ Uniwersytet Rolniczy im. Hugona Kołłątaja w Krakowie, Zakład Anatomii Zwierząt, Instytut Nauk Weterynaryjnych \\ ${ }^{2}$ Przychodnia Weterynaryjna Salamandra, Kraków \\ e-mail: rzszeles@cuf-kr.edu.pl
}

Mikrojądra (micronucleus, MN) powstają w czasie mitotycznego podziału komórki i występują w cytoplazmie komórki potomnej w pobliżu jądra komórkowego. Głównymi mechanizmami przyczyniającymi się do ich tworzenia są złamania chromosomów i dysfunkcja aparatu mitotycznego pod wpływem różnych czynników o charakterze cytotoksyn. Mikrojądra mogą zawierać całe chromosomy lub chromatydy, fragmenty acentryczne lub fragmenty chromatyd. Na częstość występowania, liczbę oraz zawartość MN mają wpływ różne czynniki osobniczo specyficzne: jednostki chorobowe, proces starzenia (wiek), płeć, różnorodne czynniki środowiskowe o charakterze fizycznym lub chemicznym. Do tych ostatnich należy cytochalazyna $\mathrm{B}$, która jest alkaloidem $\mathrm{z}$ toksyny grzybów pleśniowych hamującym polimeryzację aktyny $\mathrm{F}$ tworzącej mikrofilamenty cytoszkieletu. W ten sposób powstają komórki dwujądrzaste (BNC), ponieważ cytostatyk ten zatrzymuje podział cytoplazmy, natomiast nie zatrzymuje podziału jądra. Mechanizm ten wykorzystywany jest w teście mikrojądrowym, który stanowi jedną z metod cytogenetycznych służących do oceny niestabilności chromosomowych pod wpływem działania różnych biotoksyn.

Celem badań była ocena wpływu różnych stężeń cytochalazyny B na komórki somatyczne u kota domowego, ze szczególnym uwzględnieniem parametryzacji warunków testu MN dla badanego gatunku. Badania wykonano na 10 osobnikach kota domowego (Felis catus). Wszystkie zwierzęta pochodziły z Polski Południowej, osiągnęły dojrzałość somatyczną i były w dobrej kondycji zdrowotnej. Materiał do badań stanowiły limfocyty pełnej krwi obwodowej, pozyskanej podczas rutynowych badań weterynaryjnych z żyły v. cephalica antebrachi. Hodowle in vitro prowadzono w standardowych warunkach i 4 powtórzeniach dla danego osobnika. W 44. h do hodowli komórkowych dodawano cytochalazynę B w 4 różnych stężeniach: 2,5, 5, 7,5, $10 \mu \mathrm{g} / \mathrm{ml}$. Preparaty zawiesinowe barwiono odczynnikiem Giemsa w buforze fosforanowym.

Na podstawie przeprowadzonych badań stwierdzono, że poziom spontanicznych uszkodzeń endogennych u kota domowego występuje przy stężeniu $5 \mu \mathrm{g} / \mathrm{ml}$. Wyższe stężenia (7 i $10 \mu \mathrm{g} / \mathrm{ml}$ ) tej substancji działają genotoksycznie, uszkadzając strukturę chromosomów kota. 


\title{
SEZONOWOŚĆ ROZRODU SZYNSZYLI (CHINCHILLA LANIGERA) NA FERMIE ZLOKALIZOWANEJ W WIELKOPOLSCE
}

\author{
Seasonality of breeding on a chinchilla (Chinchilla lanigera) farm located in Wielkopolska
}

\author{
Agnieszka Ludwiczak, Łukasz Sikora, Marek Stanisz
}

Uniwersytet Przyrodniczy w Poznaniu, Katedra Hodowli Zwierząt i Oceny Surowców e-mail: agnieszka.ludwiczak@up.poznan.pl

Szynszyle małe (Chinchilla lanigera) są zwierzętami poliestralnymi, powtarzającymi cykl płciowy wielokrotnie w ciągu roku. Pomimo utrzymywania tych gryzoni w hodowli klatkowej, w kontrolowanych warunkach mikroklimatu oraz selekcji w kierunku intensyfikacji rozrodu szynszyle wykazują wyraźną sezonowość aktywności płciowej. Według danych literaturowych pora roku ma wpływ na długość i regularność cykli płciowych samic szynszyli oraz na czas trwania okresu międzyporodowego, jak również na aktywność płciową samców. Długość okresu międzyporodowego jest ważnym czynnikiem decydującym o opłacalności hodowli fermowej szynszyli. Okres ten jest dość zróżnicowany, od 190 do ponad 300 dni, przy czym nadmierne jego wydłużenie może negatywnie wpłynąć na liczebność miotu. Na długość okresu międzyporodowego ma wpływ wiele czynników, w tym genotyp oraz wiek samicy. Okres międzyporodowy wydłuża się wraz z wiekiem samic szynszyli, a najkrótszym charakteryzują się samice pomiędzy 1. a 5. r.ż.

Celem przeprowadzonego badania była ocena sezonowości wykotów na fermie szynszyli zlokalizowanej w województwie wielkopolskim. W okresie objętym oceną (lata 2015-2017) stado podstawowe liczyło 80 samic i 20 samców utrzymywanych w systemie haremowym, przy stopniu poligamii 1 samiec na 4 samice. Daty wykotów pozwoliły na obliczenie przybliżonych dat pokrycia. Przeanalizowano w sumie 409 miotów. Średnia liczba urodzonych i odsadzonych młodych na samicę w stadzie kształtowała się na poziomie 2,13 i 1,66. Zwiększoną liczbę wykotów stwierdzono w 3 sezonach roku: I - na przełomie wiosny i lata, w maju, czerwcu i lipcu (11,1, 9,0 i 8,9\% wykotów w roku), II - jesienią, we wrześniu i październiku (7,5 i 10,9\%) oraz w III - zimą, w grudniu (10,0\%). Powyższe wyniki sugerują więc zwiększoną liczbę pokryć w styczniu, w maju oraz we wrześniu. Najmniejsza liczba wykotów była charakterystyczna dla: stycznia $(6,6 \%)$, lutego $(6,6 \%)$, sierpnia $(4,9 \%)$ oraz listopada $(6,8 \%)$.

Podsumowując, można stwierdzić, że pomimo starań ukierunkowanych na wyeliminowanie sezonowości rozrodu u szynszyli hodowlanej cecha ta wyraźnie zaznaczyła się w badanym stadzie. 


\title{
ZASTOSOWANIE PASZY Z DODATKIEM L-TYROZYNY I L-FENYLOALANINY W ŻYWIENIU SZYNSZYLI
}

The use of fodder with the addition of L-tyrosine and L-phenylalanine in chinchilla feeding

\author{
Stanisław Łapiński, Sylwia Pałka, Weronika Pudło, Łukasz Migdał, Piotr Niedbała
}

Uniwersytet Rolniczy im. H. Kołłątaja w Krakowie, Wydział Hodowli i Biologii Zwierząt

e-mail: s.lapinski@ur.krakow.pl

Wśród hodowców kotów, psów czy szynszyli pojawiają się informacje, że kolor sierści zmienia się z czarnego na czerwonawo-brązowy po zastosowaniu niektórych pasz pełnoporcjowych. Badania naukowe dowiodły, że większa zawartość tyrozyny (Tyr) i fenyloalaniny (Phe) potrzebna jest do osiągnięcia maksymalnego poziomu syntezy melaniny np. u kotów. Tyrozyna jest też prekursorem ważnych neuroprzekaźników, takich jak dopamina i noradrenalina. Dlatego celem podjętych badań było określenie wpływu dodatku Tyr i Phe w paszy granulowanej na wybarwienie okrywy włosowej szynszyli oraz ich temperament. Badania przeprowadzono na fermie hodowlanej. Czteromiesięczne zwierzęta podzielono na 3 grupy po 18 osobników. Grupa kontrolna otrzymywała komercyjny granulat pełnoporcjowy, grupa I - granulat komercyjny zmieszany w proporcji $1: 1$ z granulatem z dodatkiem Tyr i Phe, grupa II - granulat z dodatkiem Tyr i Phe. Pasza wzbogacona o Tyr i Phe została wyprodukowana ze $150 \mathrm{~kg}$ komercyjnego granulatu, do którego dodano $2 \mathrm{~kg}$ L-Phe FCC (Sigma) oraz $1 \mathrm{~kg}$ L-Tyrosine FG (Sigma). Badania prowadzono przez 4 miesiące. Co dwa tygodnie oceniano temperament zwierząt z wykorzystaniem ,testu ręki” (9 pomiarów). Przyjęto pięciostopniową skalę temperamentu, gdzie 1 oznaczało zwierzę łagodne, a 5 - zwierzę agresywne. Na koniec eksperymentu przeprowadzono ocenę fenotypową. Co miesiąc określana była barwa okrywy włosowej szynszyli z wykorzystaniem kolorymetru CR-410 (Konica Minolta), pozwalającego na wyznaczenie koordynat systemu barw: L*, a*, $b^{*}$. Uzyskane dane poddano analizie statystycznej z wykorzystaniem programu Statistica 13.1 (StatSoft 2014). Analiza statystyczna nie wykazała istotnych różnic między grupami w badaniach behawioralnych w żadnym $\mathrm{z}$ pomiarów. Zaobserwowano, że $\mathrm{w}$ trakcie prowadzenia badań średnia ocena temperamentu wszystkich zwierząt miała tendencję zniżkową $(\mathrm{R}=-0,67, \mathrm{P}<0,05)$ i wahała się od 2,94 $\pm 0,49$ (pomiar II) do 2,49 $\pm 0,85$ (pomiar VIII). Może to świadczyć o przyzwyczajaniu się zwierząt do eksperymentatora lub o zmianach związanych z wiekiem zwierząt, co było stwierdzane np. u jenotów. W ocenie fenotypu szynszyli stwierdzono statystycznie istotne różnice pomiędzy grupami dla cechy „wielkość i budowa”. Średnia tej cechy dla gr. kontrolnej wyniosła $3,56 \pm 0,86$, dla gr. I 3,88 $\pm 0,33$ a dla gr. II 4,0 $\pm 0,00$. Mogło to być związane z zastosowaniem w paszy eksperymentalnej zwiększonej ilości aminokwasów, co przełożyło się na większe przyrosty. Zarówno dla pozostałych cech (typ barwny, czystość barwy, jakość okrywy włosowej, pas brzuszny), jak i łącznej oceny nie wykazano statystycznie istotnych różnic pomiędzy grupami. Analiza statystyczna wyników pomiarów kolorymetrycznych nie wykazała różnic w jasności barwy $\left(\mathrm{L}^{*}\right)$, która w poszczególnych grupach przyjęła wartości: gr. kontrolna $25,38 \pm 5,21$, gr. I $28,05 \pm 4,26$, gr. II $27,64 \pm 4,15$. Dla składowej a* statystycznie istotne różnice stwierdzono pomiędzy gr. II $(0,15 \pm 0,10)$ a kontrolą $(0,28 \pm 0,16)$ i gr. I $(0,27 \pm 0,11)$. Dla składowej b* nie odnotowano statystycznie istotnych różnic. W przeciwieństwie do rezultatów badań przeprowadzanych na psach i kotach w przypadku szynszyli nie stwierdzono wpływu dodatku Tyr i Phe na intensywność barwy okrywy włosowej. Może wynikać to z faktu, że zastosowany komercyjny granulat był właściwie zbilansowany i zawierał wystarczającą ilość aminokwasów będących prekursorami barwnika (Tyr 6,91 mg/g SM, Phe 7,45 mg/g SM). Znane są jednak doniesienia z praktyki o nabieraniu przez szynszyle brunatnego odcienia. Może być to konsekwencją niedoborów tych aminokwasów, a zastosowanie suplementowanej paszy pomaga poprawić pigmentację włosów szynszyli. 


\title{
POZIOM GLUKOZY WE KRWI U CIĘŻARNYCH ORAZ JAŁOWYCH SAMIC NORKI HODOWLANEJ (NEOVISON VISON)
}

\author{
Level of glucose in blood of pregnant and unfertilized females farm mink (Neovison vison)
}

\author{
Natalia Ławrów, Lidia Felska-Błaszczyk \\ Zachodniopomorski Uniwersytet Technologiczny w Szczecinie, \\ Pracownia Anatomii Zwierząt, ul. Doktora Judyma 14, 71-466 Szczecin \\ e-mail: natalia.lawrow@zut.edu.pl
}

Najbardziej wycieńczającym okresem hodowlanym dla samic norek jest laktacja. Dla hodowców jest to również trudny czas, ponieważ wymaga odpowiedniego żywienia energetycznymi i wysokobiałkowymi paszami. Większość ferm zwierząt futerkowych oparta jest na produkcji wielkotowarowej, co powoduje duże zagęszczenie samic oraz trudności w utrzymaniu prawidłowego żywienia. U samic wysokoplennych może to prowadzić to schorzenia zwanego polaktacyjnym wycieńczeniem samic lub anemią polaktacyjną (Nursing sickness). W stadzie samic zachorowalność wynosi aż 15\%, przy $8 \%$ śmiertelności.

Monitorowanie poziomu glukozy u skutecznie pokrytych samic norki jest stosowane w celu wczesnego wykrycia anemii polaktacynej. Taka analiza dowodzi, jak istotnym elementem jest właściwy poziom glukozy we krwi u samic na fermie, a co za tym idzie utrzymanie prawidłowego żywienia podczas całego cyklu produkcyjnego.

Badania były przeprowadzone w 2017 r., na jednej z największych ferm w Polsce, zlokalizowanej w województwie zachodniopomorskim. Pobrano krew od dwóch grup jednorocznych samic odmiany silverblue, w każdej grupie było po 50 samic. Grupę pierwszą stanowiły nieskutecznie pokryte samice, drugą samice ciężarne. Badania wykonywano, gdy samice $\mathrm{z}$ drugiej grupy były w połowie ciąży. Analizę poziomu glukozy we krwi wykonano na miejscu za pomocą glukometru, poprzez nałożenie kropli krwi na pasek testowy urządzenia. Krew została pobrana $\mathrm{z}$ naciętego pazura tylnej łapy, jest to standardowa metoda stosowana na fermach przy testach na obecność wirusa choroby aleuckiej. Stężenie glukozy we krwi oznaczano w mg/dl.

Średnie stężenie glukozy we krwi jałowych samic w pierwszej grupie wynosiło 141, przy odchyleniu standardowym 82,93 mg/dl. Były jednak samice, u których stężenie glukozy we krwi wynosiło aż 431 lub $504 \mathrm{mg} / \mathrm{dl}$. Świadczy to o istotnym problemie, ponieważ za poziom krytyczny uznaje się $126 \mathrm{mg} / \mathrm{dl}$. Większość przebadanych samic w grupie pierwszej miała więc hiperglikemię lub była jej bliska. Dla samic skutecznie pokrytych średnie stężenie glukozy we krwi wyniosło $82,9 \mathrm{mg} / \mathrm{dl}$, z odchyleniem standardowym 43,65 mg/dl. W tej grupie wartość krytyczna została przekroczona jedynie u jednej samicy.

Aby utrzymać prawidłowy poziom glukozy we krwi oraz odpowiednio przygotować zwierzęta do okresu rozrodczego, należy przez cały cykl produkcyjny utrzymywać prawidłowe żywienie oraz w każdym okresie monitorować jej poziom. Takie badania mają więc charakter prewencyjny i mogą przyczynić się do odpowiednio szybkich reakcji w zagrażających sytuacjach. 


\title{
RELATYWNA MASA SERCA LISA POSPOLITEGO (VULPES VULPES)
}

\author{
Heart to body mass index (HBMI) in red fox \\ Maria Nabzdyk, Hieronim Frąckowiak, Marcin Komosa \\ Uniwersytet Przyrodniczy w Poznaniu, Instytut Zoologii, Zakład Anatomii Zwierząt \\ e-mail: maria.nabzdyk@up.poznan.pl
}

Lis pospolity rudy bytuje $\mathrm{w}$ środowisku naturalnym, mając nieograniczone możliwości poruszania się. W skład jego diety wchodzi pokarm, który w danym momencie jest najłatwiejszy do zdobycia. Stanowią go gryzonie, zajęczaki, drób domowy. Natomiast lis pospolity srebrzysty jest najczęściej utrzymywaną, w warunkach hodowli zamkniętej, odmianą barwną. Powstała ona w wyniku krzyżowania czarnego mutanta wywodzącego się z Kanady z lisem rudym (Schackelford 1980). Lis pospolity srebrzysty utrzymywany jest w klatkach pawilonowych i żywiony zbilansowaną dawką pokarmową w stałych odstępach czasu. Jego możliwości poruszania się są ograniczone do minimum.

Warunki bytowania i tryb życia mogą przyczyniać się do modyfikowania udziału masy serca w masie ciała zwierząt, tym samym wpływając na zmianę współczynnika relatywnej masy serca (HBMI). Współczynnik relatywnej masy serca zmienia się w zależności od rasy, wytrenowania zwierząt oraz płci (Northup 1975). Wartość tego współczynnika u psów jest wykorzystywana w badaniach nad kardiomiopatią przerostową (Evans, de Lahunta 2010).

W badaniach wykorzystano 120 zwierząt jednorocznych pozyskanych w sezonie 2011/2012 z ferm zwierząt futerkowych (lis pospolity srebrzysty - 60 osobników: 30 samic, 30 samców) i łowisk (lis pospolity rudy - 60 osobników: 30 samic, 30 samców). Osobniki ważono w skórze (dokładność 10 g), następnie nadawano im numer, oznaczano płeć i wypreparowano serca. Po usunięciu osierdzia i skróceniu naczyń uchodzących z serca każde serce ważono na wadze elektronicznej (dokładność 0,01g).

Wyliczona wartość współczynnika relatywnej masy serca (HBMI) wynosiła średnio dla samic lisa pospolitego rudego $1,18 \%$, natomiast dla samców $-1,17 \%$. W przypadku lisów srebrzystych wartość ta była mniejsza i wynosiła $0,62 \%$ oraz $0,68 \%$ odpowiednio dla samic i samców. Wykazano, że nie ma istotnych różnic wartości współczynnika wewnątrz odmiany, natomiast lisy pospolite różnią się statystycznie wysoce istotnie pod względem wielkości parametru od lisów pospolitych srebrzystych.

\section{Piśmiennictwo}

Evans H.E., de Lahunta 2010. Guide to the dissection of the dog. 7th edition. Elsevier Saunders, Ithaca.

Northup D.W., Van Liere E.J., Stickney J.C. 1957: The effect of age, sex and body size on the heart weight-body weight ratio in the dog. Anat. Rec., 128. 411-417.

Schackelford R.M. 1980. Domestic production of mink and foxes. Department of Meat and Animal Science University of Wisconsin, Madison, 142-159. 


\title{
WSTĘPNE OKREŚLENIE WPŁYWU MELATONINY NA PROFIL KWASÓW TŁUSZCZOWYCH W TKANCE TŁUSZCZOWEJ JENOTÓW HODOWLANYCH
}

\author{
Preliminary determination of the melatonin effect on the fatty acid profile in of finnraccoon
}

\author{
Piotr Niedbała ${ }^{1}$, Andrzej Zoń ${ }^{2}$, Dorota Maj $^{3}$, Stanisław Łapiński ${ }^{1}$, Olga Szeleszczuk ${ }^{4}$, \\ Marta Kuchta-Gładysz ${ }^{4}$
}

\author{
${ }^{1}$ Uniwersytet Rolniczy im. H. Kołłątaja w Krakowie, Instytut Nauk o Zwierzętach, Zakład Hodowli Trzody Chlewnej \\ i Drobnego Inwentarza, al. Mickiewicza 24/28, 30-059 Kraków \\ ${ }^{2}$ Zakład Doświadczalny Instytutu Zootechniki - Państwowy Instytut Badawczy Chorzelów Sp. z o.o., 39-331 Chorzelów \\ ${ }^{3}$ Uniwersytet Rolniczy im. H. Kołłątaja w Krakowie, Instytut Nauk o Zwierzętach, Katedra Genetyki i Metod Doskonalenia Zwierząt, \\ ${ }^{4}$ Uniwersytet Rolniczy im. H. Kołłątaja w Krakowie, Instytut Nauk Weterynaryjnych, Zakład Anatomii Zwierząt \\ e-mail: p.niedbala@ur.krakow.pl
}

Jenoty ze względu na swoją fizjologię mają tendencję do gromadzenia w okresie jesiennym materiału zapasowego w postaci podskórnej tkanki tłuszczowej. Ma to ogromne znaczenie dla ich fizjologii i umożliwia im przetrwanie ciężkich okresów w czasie zimy. Z kolei melatonina ma istotny wpływ na procesy związane z rozrodem i na kształtowanie futra, szczególnie przyspieszenie wzrostu okrywy zimowej. Interesujące jest, czy podana podskórnie melatonina wpłynie również na zmianę profilu kwasów tłuszczowych (TK) $\mathrm{w}$ tkance zapasowej. Implanty melatoniny podano jenotom hodowlanym (Nyctereutes procyonoides) w czerwcu. Przed ubojem dokonano pomiarów masy ciała zwierząt, a po zdjęciu skóry zważono odebraną z tuszek tkankę tłuszczową. Profil kwasów tłuszczowych w tłuszczu podskórnym oznaczono w laboratorium KŻiDZ UR w Krakowie metodą chromatografii gazowej na aparacie VARIAN 450GC. Wyniki opracowano za pomocą pakietu SAS (2014), z zastosowaniem procedury GLM. Uwzględniono grupę zwierząt i płeć oraz interakcje. Dla masy i udziału tkanki tłuszczowej w tuszce zastosowano regresję liniową badanej cechy na masę ciała przy uboju. Ponieważ nie stwierdzono istotnych interakcji dla wszystkich badanych cech, średnich dla interakcji nie zamieszczono $\mathrm{w}$ tabeli. Istotność różnic między średnimi badanych grup określano testem Tukeya. Stwierdzono istotnie większe MC, MTT w grupie zwierząt po implantach melatoniny niż $\mathrm{w}$ grupie kontrolnej. Uzyskane wyniki własne są analogiczne do podawanych w literaturze. Jenoty bowiem po podaniu melatoniny wykazują większy apetyt i pobierają więcej karmy. Udział tkanki tłuszczowej w ich masie ciała stanowił od 38 do $42 \%$ (tab. 1). Nie obserwowano jednak różnic dla UTT w MC. W profilu kwasów tłuszczowych obu grup zwierząt dominowały kwasy: oleinowy (C-18:1), palmitynowy (C-16:0), linolowy (C-18:2), palmitooleinowy (C-16:1), stearynowy (C-18:0), eikozenowy (C-20:1), erukowy (C-22:1) i mirystynowy (C-14:0). Tylko ostatniego kwasu było istotnie więcej w tłuszczu zwierząt kontrolnych. Stwierdzono też u nich istotnie większe udziały kwasów: linolenowego (C-18:3), dokozaheksaenowego (C-22:6), eikozapentatenowego (C-20:5), dokozapentatenowego (C-22:5) i sprzężonego kwasu linolowego 18:2 (CLA). W profilu, w grupie doświadczalnej istotnie mniej było wielonienasyconych kwasów tłuszczowych n-3 (PUFA-3), natomiast stosunek ilościowy kwasów wielonienasyconych n-6 do n-3 (PUFA-6/PUFA-3) był istotnie wyższy. Zaobserwowano także istotną interakcję między grupą zwierząt a płcią dla: kwasu arachidowego (C-20:0) i dokozapentatenowego (C22:5). Stwierdzono istotne różnice w ilościach nasyconych (SFA), nienasyconych (UFA) i jednonienasyconych (MUFA) kwasów tłuszczowych pomiędzy samcami a samicami. Zgodnie ze wzorcem oceny pokroju KCHZ jenoty hodowlane szczególnie po implantach melatoniny oceniono jako zwierzęta bardzo duże. Pod względem profilu kwasów tłuszczowych jenoty różnią się jednak od lisów polarnych i pospolitych.

W tkance tłuszczowej jenotów jest mniej kwasów C-16:0, C-16:1, C-18:0 i C-18:3. Natomiast jest więcej kwasów C-14:0, C18:2 i łącznie kwasów z grupy C-20 i C-22. Należy zauważyć, że podanie melatoniny niekorzystnie wpłynęło na ilość CLA i kwasów wielonienasyconych n-3. 
LXXXIII Zjazd Naukowy PTZ im. Michała Oczapowskiego, Lublin 2018

Wyzwania zootechniki w warunkach rolnictwa zrównoważonego. Streszczenia

Sekcja Chowu i Hodowli Zwierząt Futerkowych

Tabela 1. Profil kwasów tłuszczowych w tkance tłuszczowej jenotów hodowlanych [\%]

\begin{tabular}{|c|c|c|c|c|}
\hline \multirow{2}{*}{ Wyszczególnienie } & \multicolumn{2}{|c|}{ Grupa kontrolna $(\mathrm{n}=10)$} & \multicolumn{2}{|c|}{ Grupa z melatoniną $(\mathrm{n}=10)$} \\
\hline & $\bar{x}$ & SD & $\bar{x}$ & SD \\
\hline $\mathrm{MC}[\mathrm{kg}]$ & $10,020^{b}$ & 1,034 & $13,030^{a}$ & 1,075 \\
\hline MTT $[\mathrm{kg}]$ & $3,815^{b}$ & 0,574 & $5,559^{\mathrm{a}}$ & 1,071 \\
\hline UTT w MC [\%] & 38,078 & 3,894 & 42,483 & 6,355 \\
\hline $\mathrm{C}-12: 0$ & 0,903 & 0,176 & 0,823 & 0,140 \\
\hline C-14:0 & $3,400^{\mathrm{a}}$ & 0,272 & $3,108^{b}$ & 0,277 \\
\hline C-14:1 & 0,278 & 0,036 & 0,272 & 0,034 \\
\hline C-15:0 & 0,195 & 0,022 & 0,204 & 0,012 \\
\hline C-16:0 & 14,948 & 2,140 & 14,451 & 2,545 \\
\hline C-16:1 & 6,086 & 0,488 & 5,792 & 1,153 \\
\hline C-18:0 & 5,197 & 1,779 & 4,653 & 1,624 \\
\hline C-18:1 & 43,979 & 2,655 & 45,731 & 3,179 \\
\hline C-18:2 & 13,340 & 1,065 & 13,801 & 0,762 \\
\hline CLA & $0,272^{\mathrm{a}}$ & 0,052 & $0,139^{b}$ & 0,063 \\
\hline C-18:3 & $1,204^{\mathrm{a}}$ & 0,188 & $0,993^{b}$ & 0,067 \\
\hline C-20:0 & 0,129 & 0,039 & 0,145 & 0,019 \\
\hline C-20:1 & 3,219 & 0,257 & 3,305 & 0,484 \\
\hline C-20:2 & 0,195 & 0,012 & 0,209 & 0,022 \\
\hline C-20:3 & 0,136 & 0,011 & 0,153 & 0,018 \\
\hline C-20:4 & 0,293 & 0,032 & 0,272 & 0,040 \\
\hline C-20:5 & $0,575^{\mathrm{a}}$ & 0,172 & $\mathbf{0 , 3 1 9 ^ { b }}$ & 0,093 \\
\hline C-22:1 & 2,359 & 0,253 & 2,284 & 0,288 \\
\hline C-22:5 & $0,320^{\mathrm{a}}$ & 0,054 & $0,266^{b}$ & 0,042 \\
\hline C-22:6 & $0,859^{\mathrm{a}}$ & 0,206 & $0,596^{b}$ & 0,104 \\
\hline SFA & 24,772 & 3,507 & 23,384 & 4,232 \\
\hline UFA & 73,115 & 4,094 & 74,132 & 5,348 \\
\hline MUFA & 55,921 & 3,185 & 57,384 & 4,552 \\
\hline PUFA & 17,194 & 1,156 & 16,748 & 0,957 \\
\hline PUFA-3 & $1,340^{\mathrm{a}}$ & 0,194 & $1,146^{b}$ & 0,070 \\
\hline PUFA-6 & 14,199 & 1,007 & 14,397 & 0,792 \\
\hline UFA/SFA & 3,021 & 0,547 & 3,281 & 0,687 \\
\hline MUFA/SFA & 2,311 & 0,419 & 2,542 & 0,548 \\
\hline PUFA/SFA & 0,710 & 0,131 & 0,739 & 0,142 \\
\hline PUFA-6/PUFA-3 & $10,761^{b}$ & 1,464 & $12,593^{a}$ & 0,877 \\
\hline
\end{tabular}

Średnie oznaczone różnymi literami $(\mathrm{a}, \mathrm{b})$ różnią się istotnie $(\mathrm{P} \leq 0,05)$

MC - masa ciała; MTT - masa tkanki tłuszczowej, UTT w MC - udział tkanki tłuszczowej w masie ciała, SFA - ilość nasyconych KT, UFA - ilość nienasyconych KT, MUFA - ilość jednonienasyconych KT, PUFA - ilość wielonienasyconych KT, PUFA-3 - ilość wielonienasyconych KT n-3, PUFA-6 - ilość wielonienasyconych KT n-6

\section{Piśmiennictwo}

Matysiak-Żurowska D., Zalewski K., Kamieniarz R. 2009. Unusual odd-chin and trans-octadecenoic fatty acids in tissue of feral European beaver (Castor fiber), Euroasian badger (Meles meles) and raccoon dog (Nyctereutes procyonoides). CB and P, Part B, $153,145-148$.

Przysiecki P. 2000. Wpływ fotoperiodyzmu na użytkowość lisa polarnego i pospolitego. Zesz. Nauk. AR Wroc., Rozprawy 371.

Przysiecki P., Nowicki S., Potkański A., Nawrocki Z., Filistowicz A., Filistowicz A. 2013. Wpływ płci na profil kwasów tłuszczowych w tuszach lisów pospolitych (Alopex lagopus). ABiD 1, 87-92.

Praca wykonana w ramach tematu badawczego: DS-3266/ZHTCHiDI/2017. 


\title{
WSTĘPNE OKREŚLENIE PROFILU KWASÓW TŁUSZCZOWYCH W TKANCE TŁUSZCZOWEJ MIĘSOŻERNYCH ZWIERZĄT FUTERKOWYCH Z RODZINY ŁASICOWATYCH
}

\author{
Preliminary determination of fatty acid profile in fat tissue of carnivorous fur animals of carnivorous \\ fur animals from the Mustelidae family
}

\section{Piotr Niedbała ${ }^{1}$, Andrzej Zoń ${ }^{2}$, Dorota Maj $^{3}$, Stanisław Łapiński ${ }^{1}$, Olga Szeleszczuk ${ }^{4}$, Marta Kuchta-Gładysz ${ }^{4}$}

\author{
${ }^{1}$ Uniwersytet Rolniczy im. H. Kołłątaja w Krakowie, Instytut Nauk o Zwierzętach, Zakład Hodowli Trzody Chlewnej \\ i Drobnego Inwentarza, al. Mickiewicza 24/28, 30-059 Kraków \\ ${ }^{2}$ Zakład Doświadczalny Instytutu Zootechniki - Państwowy Instytut Badawczy Chorzelów Sp. z o.o., 39-331 Chorzelów \\ ${ }^{3}$ Uniwersytet Rolniczy im. H. Kołłątaja w Krakowie, Instytut Nauk o Zwierzętach, Katedra Genetyki i Metod Doskonalenia Zwierząt \\ ${ }^{4}$ Uniwersytet Rolniczy im. H. Kołłątaja w Krakowie, Instytut Nauk Weterynaryjnych, Zakład Anatomii Zwierząt \\ e-mail: p.niedbala@ur.krakow.pl
}

Wiadomo, że tkanka tłuszczowa norek pozyskana po uboju skórkowym może być wykorzystywana w przemyśle kosmetycznym. Zastanawiające było, czy podobne właściwości może mieć tkanka tłuszczowa tchórzy hodowlanych. Celem badań było określenie profili kwasów tłuszczowych u obu gatunków zwierząt, a szczególnie w tkance tłuszczowej tchórzy hodowlanych. Przed ubojem wybrakowanych zwierząt dokonano pomiarów ich masy ciała, a po zdjęciu skóry zważono odebraną z tuszek tkankę tłuszczową. Profil kwasów tłuszczowych w tłuszczu podskórnym oznaczono w laboratorium Katedry Żywienia i Dietetyki Zwierząt UR w Krakowie metodą chromatografii gazowej, wykorzystując aparat VARIAN 450 GC. Wyniki opracowano za pomocą pakietu SAS [2014], z zastosowanem procedury GLM. Uwzględniono gatunek i płeć oraz interakcje. Dla masy i udziału tkanki tłuszczowej w tuszce zastosowano regresję liniową badanej cechy na masę ciała przy uboju. Ponieważ nie stwierdzono istotnych interakcji dla wszystkich badanych cech, średnich dla interakcji nie zamieszczono w tabeli. Istotność różnic między średnimi badanych grup określano testem Tukeya. Stwierdzono istotnie wyższe wartości parametrów: MC, MTT i UTT w MC u norek, które są, zgodnie z literaturą i wzorcami oceny pokroju, wyraźnie większe niż u tchórzy hodowlanych (tab. 1). Natomiast UTT w MC (19,171\%) dla tchórzy był podobny do UTT w MC norek, ale ponad 40 lat temu. W profilu norek i tchórzy dominowały kwasy: oleinowy (C-18:1), linolowy (C-18:2), stearynowy (C-18:0), palmitynowy (C-16:0), palmitooleinowy (C-16:1) i mirystynowy (C-14:0). Trzy pierwsze u tchórzy, następne u norek. Nie obserwowano istotnych różnic tylko w ilościach kwasów: linolenowego (C-18:3), arachidowego (C20:0) i eikozenowego (C20:1) oraz łącznie kwasów jednonienasyconych (MUFA) i wielonienasyconych n-3 (PUFA-3). Podobnie nie stwierdzono różnic dla stosunku ilościowego kwasów wielonienasyconych n-6 do n-3 (PUFA-6/PUFA-3). Zaobserwowano także istotną interakcję między gatunkiem a płcią dla kwasu arachidowego (C-18:0), linolenowego (C-18:3), eikozenowego (C-20:1), eikozadienowego (C-20:2), eikozatrienowego (C-20:3), kwasów wielonienasyconych n-3 (PUFA-3) i stosunku ilościowego kwasów wielonienasyconych n-6 do n-3 (PUFA-6/PUFA-3). Stwierdzono istotne różnice w ilościach kwasów: mirystynowego (C14:0), tetradecenowego (C14:1), stearynowego (C-18:0), oleinowego (C-18:1) i eikozadienowego (C20:2) pomiędzy samcami a samicami. Profil KT w tkance tłuszczowej norek wyraźnie uległ zamianie. Zwiększył się udział kwasów: C12:0, C-18:0, C-18:1, C-18:2, a obniżyła się ilość kwasów: C14:1, C-16:0, C-16:1 i C-18:3. Ponadto stwierdzono obecność nienasyconych kwasów tłuszczowych C-20 na poziomie 1,236\%. Profil KT w tkance tłuszczowej tchórzy wyraźnie odbiega od profilu KT nie tylko norek, ale również lisów hodowlanych pospolitych czy 
polarnych. Odbiega również od profilu KT w tkance tłuszczowej borsuka, u którego np. kwasy C-18:1 i C-18:2 stanowią 31\%, podczas gdy u tchórza stanowią ponad 72\% wszystkich kwasów.

Tabela 1. Profil kwasów tłuszczowych w tkance tłuszczowej norek i tchórzy hodowlanych [\%]

\begin{tabular}{|c|c|c|c|c|}
\hline \multirow{2}{*}{ Wyszczególnienie } & \multicolumn{2}{|c|}{ Norki $(\mathrm{n}=10)$} & \multicolumn{2}{|c|}{ Tchórze $(\mathrm{n}=10)$} \\
\hline & $\bar{x}$ & $\mathrm{SD}$ & $\bar{x}$ & SD \\
\hline $\mathrm{MC}[\mathrm{kg}]$ & $2,070^{\mathrm{a}}$ & 0,760 & $1,483^{\mathrm{b}}$ & 0,548 \\
\hline MTT [kg] & $0,587^{\mathrm{a}}$ & 0,269 & $0,298^{\mathrm{b}}$ & 0,150 \\
\hline UTT w MC [\%] & $27,472^{\mathrm{a}}$ & 3,790 & $19,171^{\mathrm{b}}$ & 3,099 \\
\hline $\mathrm{C}-12: 0$ & $0,922^{\mathrm{a}}$ & 0,188 & $0,425^{\mathrm{b}}$ & 0,050 \\
\hline C-14:0 & $2,658^{\mathrm{a}}$ & 0,453 & $1,636^{\mathrm{b}}$ & 0,244 \\
\hline C-14:1 & $0,381^{\mathrm{a}}$ & 0,096 & $0,248^{\mathrm{b}}$ & 0,060 \\
\hline$C-15: 0$ & $0,091^{\mathrm{a}}$ & 0,006 & $0,070^{\mathrm{b}}$ & 0,013 \\
\hline$C-16: 0$ & $13,932^{\mathrm{a}}$ & 1,732 & $10,471^{\mathrm{b}}$ & 1,234 \\
\hline$C-16: 1$ & $10,752^{\mathrm{a}}$ & 2,609 & $6,984^{\mathrm{b}}$ & 1,570 \\
\hline C-18:0 & $2,631^{\mathrm{b}}$ & 0,602 & $4,367^{\mathrm{a}}$ & 1,502 \\
\hline C-18:1 & $49,996^{\mathrm{b}}$ & 3,223 & $53,710^{\mathrm{a}}$ & 1,354 \\
\hline C-18:2 & $15,245^{\mathrm{b}}$ & 1,016 & $18,484^{\mathrm{a}}$ & 0,476 \\
\hline C-18:3 & $\mathbf{0 , 9 3 3}$ & 0,374 & 1,008 & 0,277 \\
\hline C-20:0 & 0,081 & 0,017 & $\mathbf{0 , 0 7 7}$ & 0,015 \\
\hline C-20:1 & 0,800 & 0,164 & 0,719 & 0,102 \\
\hline C-20:2 & $0,102^{\mathrm{b}}$ & 0,019 & $0,153^{\mathrm{a}}$ & 0,012 \\
\hline C-20:3 & $0,090^{\mathrm{b}}$ & 0,022 & $0,115^{\mathrm{a}}$ & 0,018 \\
\hline C-20:4 & $0,244^{\mathrm{b}}$ & 0,047 & $0,334^{\mathrm{a}}$ & 0,050 \\
\hline SFA & $20,315^{\mathrm{a}}$ & 2,066 & $17,046^{\mathrm{b}}$ & 2,557 \\
\hline UFA & $78,543^{\mathrm{b}}$ & 2,297 & $81,755^{\mathrm{a}}$ & 2,642 \\
\hline MUFA & 61,929 & 1,840 & 61,661 & 2,399 \\
\hline PUFA & $16,614^{\mathrm{b}}$ & 1,232 & $20,094^{\mathrm{a}}$ & 0,573 \\
\hline PUFA-3 & 1,023 & 0,386 & 1,123 & 0,285 \\
\hline PUFA-6 & $15,245^{\mathrm{b}}$ & 1,016 & $18,484^{\mathrm{a}}$ & 0,476 \\
\hline UFA/SFA & $3,913^{\mathrm{b}}$ & 0,515 & $4,914^{\mathrm{a}}$ & 0,881 \\
\hline MUFA/SFA & $3,084^{\mathrm{b}}$ & 0,393 & $3,709^{\mathrm{a}}$ & 0,689 \\
\hline PUFA/SFA & $0,829^{\mathrm{b}}$ & 0,135 & $1,205^{\mathrm{a}}$ & 0,195 \\
\hline PUFA-6/PUFA-3 & 16,214 & 4,116 & 17,241 & 3,524 \\
\hline
\end{tabular}

Średnie oznaczone różnymi literami $(\mathrm{a}, \mathrm{b})$ różnią się istotnie $(\mathrm{P} \leq 0,05)$

MC - masa ciała; MTT - masa tkanki tłuszczowej; UTT w MC - udział tkanki tłuszczowej w masie ciała; SFA - ilość nasyconych kwasów tłuszczowych; UFA - ilość nienasyconych kwasów tłuszczowych; MUFA - ilość jednonienasyconych kwasów tłuszczowych; PUFA - ilość wielonienasyconych kwasów tłuszczowych; PUFA-3 - ilość wielonienasyconych kwasów tłuszczowych n-3; PUFA-6 - ilość wielonienasyconych kwasów tłuszczowych n-6

\section{Piśmiennictwo}

Kosko I. 1983 Badania nad przydatnością tłuszczu zapasowego lisa polarnego (Alopex lagopus), lisa pospolitego (Vulpes vulpes) i norki (Mustela visom Schreb.) dla celów kosmetycznych i farmaceutycznych. Cz. I. Zesz. Probl. Post. Nauk Rol. 302, $147-154$.

Przysiecki P. 2000. Wpływ fotoperiodyzmu na użytkowość lisa polarnego i pospolitego. Zesz. Nauk AR Wrocław, Rozprawy, 371.

Zalewski K., Martysiak-Żurowska D., Iwaniuk M., Nitkiewicz B., Stołyhwo A. 2007. Characterization of fatty acid composition in Euroasian bader (Males males). Pol. J. Environ. Stud. 16(4), 645-650.

Praca wykonana w ramach tematu badawczego: DS-3266/ZHTCHiDI/2017. 


\title{
PARAMETRY GENETYCZNE CECH JAKOŚCI MIĘSA KRÓLIKÓW TERMONDZKICH BIAŁYCH
}

Genetic parameters for meat quality traits of Thermond White rabbits

\author{
Sylwia Pałka, Michał Kmiecik, Łukasz Migdał, Dorota Maj, Konrad Kozioł, Olga Derewicka, \\ Józef Bieniek
}
Uniwersytet Rolniczy w Krakowie, Katedra Genetyki i Metod Doskonalenia Zwierząt, al. Mickiewicza 24/28, 30-059 Kraków e-mail: s.palka@ur.krakow.pl

Celem badań było oszacowanie parametrów genetycznych dla kwasowości, barwy mięsa oraz siły cięcia i profilowej analizy tekstury (TPA) mięsa królików termondzkich białych $(\mathrm{n}=206 ; 113 \hat{\jmath}, 93$ q $)$.

Króliki ubijano w 84. d.ż. Po 45 min i 24 h od uboju mierzono $\mathrm{pH}$ m. longissimus lumborum $\mathrm{pH}$-metrem HI-9024, a także barwę (L", a $\left.{ }^{*}, b^{*}\right)$ kolorymetrem Minolta CR-410. W czasie obróbki poubojowej pobierano próbkę z combra ( $m$. longissimus lumborum), którą pakowano próżniowo do opakowania foliowego. Próbki mrożono przez $72 \mathrm{~h}$, a następnie rozmrażano i gotowano w łaźni wodnej. Siłę cięcia mierzono teksturometrem TA.XT Plus wyposażonym w ostrze Warnera-Bratzlera z trójkątnym wycięciem. Profilową analizę tekstury (TPA) wykonywano tym samym urządzeniem wyposażonym w przystawkę, którą stanowi walec o średnicy $50 \mathrm{~mm}$. Mierzono twardość, sprężystość, spójność i żujność. Wszystkie parametry obliczono za pomocą programu Exponent ver. 6.1.10.0.

Parametry genetyczne oszacowano metodą największej wiarogodności z ograniczeniami (REML). Obliczenia wykonano za pomocą pakietu VCE6. Oszacowano następujące odziedziczalności $\left(\mathrm{h}^{2}\right): \mathrm{pH}_{45}=0,22$, $\mathrm{pH}_{24}=0,27, \mathrm{~L}_{45}=0,28, \mathrm{a}^{*}{ }_{45}=0,46, \mathrm{~b}_{45}=0,31, \mathrm{~L}_{24}=0,41, \mathrm{a}^{*}{ }_{24}=0,43, \mathrm{~b} *_{24}=0,33$, siła cięcia $=0,50$, twardość $=0,50$, sprężystość $=0,31$, spójność $=0,54$, żujność $=0,40$. Błąd standardowy dla oszacowanych odziedziczalności wahał się od 0,02 do 0,07 .

Współczynnik korelacji genetycznej między pH45 a pH24 był równy 0,31 , a między siłą cięcia a twardością i żujnością odpowiednio 0,25 i 0,39 . Twardość była także dodatnio skorelowana z żujnością $(\mathrm{rG}=0,88)$.

Odziedziczalności cech jakości mięsa króliczego oraz genetyczne zależności między nimi są wystarczająco duże i mogą być przydatne w wyborze odpowiedniej metody hodowlanej.

Badania zostały sfinansowane z dotacji przyznanej przez MNiSW na działalność statutową DS.3228 i BM.4270. 


\title{
PORÓWNANIE TEKSTURY GOTOWANEGO, PIECZONEGO I SUROWEGO MIĘSA KRÓLICZEGO
}

\author{
Analysis of the texture of boiled, roasted and raw rabbit meat
}

\author{
Sylwia Pałka, Zuzanna Siudak, Michał Kmiecik, Łukasz Migdał, Konrad Kozioł, Józef Bieniek \\ Uniwersytet Rolniczy w Krakowie, Katedra Genetyki i Metod Doskonalenia Zwierząt, Al. Mickiewicza 24/28, 30-059 Kraków \\ e-mail: s.palka@ur.krakow.pl
}

Celem doświadczenia było porównanie siły cięcia, twardości, spójności, sprężystości i żujności mięsa króliczego surowego, gotowanego i pieczonego.

Materiał doświadczalny stanowiły próbki mięsa pozyskane z 31 królików rasy termondzkiej białej $(12$ ㅇ $19 \AA)$. Zwierzęta do odsadzenia utrzymywano $\mathrm{z}$ matkami w drewnianych klatkach, a po odsadzeniu w 35. d.ż. były utrzymywane w systemie bateryjnym i żywione ad libitum komercyjną, pełnoporcjową paszą granulowaną. Króliki ubijano w wieku 84 dni. Pozyskane tuszki poddawano 24-godzinnemu chłodzeniu w $4^{\circ} \mathrm{C}$. Następnie z combra (m. longissimus lumborum) wycinano próbki w kształcie walców. Pierwszą grupę próbek pakowano próżniowo w opakowania foliowe i przechowywano przez $72 \mathrm{~h} \mathrm{w}-18^{\circ} \mathrm{C}$, następnie rozmrażano i gotowano w łaźni wodnej w temp. $80^{\circ} \mathrm{C}$ przez $40 \mathrm{~min}$. Drugą grupę próbek pakowano indywidualnie $\mathrm{w}$ foliowe opakowania, mrożono $\mathrm{w}-18^{\circ} \mathrm{C}$ przez $72 \mathrm{~h}$, a następnie rozmrażano i pieczono $\mathrm{w} 180^{\circ} \mathrm{C}$ do uzyskania wewnętrznej temperatury $78^{\circ} \mathrm{C}$. Trzecią grupę próbek pakowano w foliowe opakowania, mrożono $\mathrm{w}-18^{\circ} \mathrm{C}$ przez $72 \mathrm{~h}$, a następnie rozmrażano bez poddawania ich późniejszej obróbce termicznej. Siłę cięcia mierzono za pomocą teksturometru TA.XT Plus wyposażonego w ostrze Warnera-Bratzlera z trójkątnym wycięciem. Wartość siły cięcia próbek o przekroju $10 \times 10 \mathrm{~mm}$ mierzono przy prędkości ostrza $2 \mathrm{~mm} / \mathrm{s}$, poprzecznie do przebiegu włókien mięśniowych, aż do pełnego przecięcia próbki. Profilową analizę tekstury (TPA) wykonano za pomocą tego samego urządzenia wyposażonego w przystawkę, którą stanowił walec o średnicy $50 \mathrm{~mm}$. Mierzono twardość, sprężystość, spójność i żujność próbek w kształcie sześcianu o boku $10 \mathrm{~mm}$. Przeprowadzono test dwukrotnego ściskania do $70 \%$ ich wysokości przy prędkości walca $5 \mathrm{~mm} / \mathrm{s}$ i przerwie między naciskami wynoszącej $5 \mathrm{~s}$, wzdłuż przebiegu włókien mięśniowych. Wszystkie parametry były liczone automatycznie za pomocą programu Exponent ver. 6.1.10.0. Wyniki opracowano za pomocą pakietu statystycznego SAS. W modelu uwzględniono efekty stałe, takie jak płeć i sposób obróbki termicznej. Istotność różnic między średnimi zbadano testem Tukeya-Kramera.

Na podstawie analizy statystycznej stwierdzono istotne różnice w sile cięcia mięsa gotowanego $(1,31 \mathrm{~kg})$ i surowego $(1,69 \mathrm{~kg})$ oraz gotowanego i pieczonego $(1,83 \mathrm{~kg})$. Ponadto wykazano również istotne różnice w twardości mięsa surowego $(7,27 \mathrm{~kg})$, gotowanego $(12,32 \mathrm{~kg})$ i pieczonego $(15,52 \mathrm{~kg})$. Istotne różnice W sprężystości stwierdzono pomiędzy mięsem gotowanym $(0,50)$ a surowym $(0,37)$ oraz surowym i pieczonym $(0,51)$. W spójności istotne różnice stwierdzono między mięsem gotowanym $(0,41)$ a surowym $(0,33)$, gotowanym i pieczonym $(0,44)$ oraz surowym i pieczonym. Obróbka termiczna różnicowała istotnie także żujność. Stwierdzono istotne różnice w żujności mięsa gotowanego $(2,61 \mathrm{~kg})$ i surowego $(0,94 \mathrm{~kg})$, gotowanego i pieczonego $(3,55 \mathrm{~kg})$ oraz surowego i pieczonego. Nie stwierdzono istotnych różnic w sile cięcia oraz profilowej analizie tekstury (TPA) mięsa samców i samic. 


\title{
ANALIZA PRACY HODOWLANEJ W FERMIE REPRODUKCYJNEJ SZYNSZYLI
}

\author{
Analysis of breeding work in a chinchilla reproductive farm
}

\author{
Aleksandra Paskudska, Dorota Kołodziejczyk, Dorota Weremczuk, Stanisław Socha \\ Uniwersytet Przyrodniczo-Humanistyczny w Siedlcach, Katedra Metod Hodowlanych i Hodowli Drobiu \\ ul. B. Prusa 12/14, 08-110 Siedlce \\ e-mail: dormark1@wp.pl, socha@uph.edu.pl
}

Praca hodowlana na fermach szynszyli jest ukierunkowana na uzyskanie okrywy włosowej o jak najlepszym wyglądzie i jak najwyższej jakości. W selekcji szynszyli kładzie się nacisk na właściwe cechy okrywy włosowej, budowę zwierząt i ich wielkość. Najbardziej ukierunkowane są wymagania w kierunku odpowiedniej okrywy włosowej. Poza tym najlepsze są zwierzęta o budowie „zbitej”, szerokim tułowiu. Z kolei w zakresie cech strukturalnych należy zwrócić uwagę na dużą gęstość okrywy włosowej, którą można stwierdzić, gdy podczas badania skóra nie jest w ogóle widoczna lub widoczna tylko w minimalnym stopniu. Najlepsze jest futro, które ma odcień szaroniebieski na całej powierzchni, bez plam. Z kolei utworzony z końcówek włosów pokrywowych woal najlepiej żeby był dobrze widoczny i kontrastujący, w sposób równomierny rozłożony, niepowodujący zawirowań i plam w obszarze owłosienia na powierzchni ciała (Wzorzec oceny szynszyli).

Celem pracy była kontynuacja analizy pracy hodowlanej w fermie reprodukcyjnej szynszyli dotyczącej cech pokroju szynszyli wyrażonego jako cechy okrywy włosowej i budowy zwierząt. Oceniane były szynszyle odmiany standardowej i beżowej. Zasadniczą cechą u zwierząt futerkowych jest jakość okrywy włosowej, do której zaliczamy: gęstość okrywy, jej wyrównanie i długość włosów w poszczególnych częściach ciała zwierząt oraz pas brzuszny. Problemem jest utrzymanie wszystkich cech na wzorcowym wysokim poziomie, bez strat w pozostałych. W pracy przeprowadzono analizę cech pokrojowych szynszyli, uwzględniając takie cechy, jak: wielkość i budowa zwierząt, jakość okrywy włosowej, typ barwny, czystość barwy okrywy włosowej, barwa pasa brzusznego i łączna suma punktów za wszystkie cechy. W obliczeniach zastosowano program SAS (2000). Dla wszystkich wyżej wymienionych cech pokrojowych szynszyli została wykonana w pracy wieloczynnikowa analiza wariancji. W zastosowanym modelu uwzględniono następujące źródła zmienności: płeć, rok licencji i odmianę barwną.

Analiza wariancji wykazała statystyczny wysoko istotny wpływ płci na czystość barwy okrywy włosowej, na łączną sumę punktów otrzymanych przez zwierzęta podczas oceny, zarówno u szynszyli standardowych, jak i beżowych. Rok licencji statystycznie wysoko wpłynął na czystość okrywy włosowej oraz jej jakość. Podobne wyniki uzyskały zarówno szynszyle standardowe, jak i beżowe, większe odchylenia w analizie zaobserwowano w takich cechach, jak budowa zwierząt i pas brzuszny. Średnie arytmetyczne badanych cech odznaczały się niewielkim zróżnicowaniem u ocenianych szynszyli standardowych i beżowych.

Na podstawie przeprowadzonej oceny i analizy cech pokroju u szynszyli w fermie reprodukcyjnej należy stwierdzić, że zwierzęta charakteryzowały się bardzo dobrymi parametrami cech wielkości i budowy ciała oraz jakości okrywy włosowej. Uzyskane wyniki oceny wskazują, że w analizowanej fermie jest prowadzona w dalszym ciągu właściwa praca hodowlana. Szynszyle pochodzące z analizowanej fermy cieszą się dużą popularnością wśród hodowców. O wysokiej wartości hodowlanej zwierząt pochodzących z tej fermy świadczą uzyskiwane nagrody na różnego rodzaju wystawach i pokazach szynszyli organizowanych w naszym kraju, jak również poza granicami (Krajowe Centrum Hodowli Zwierząt 2015). 


\title{
ASYMETRIA WYBRANYCH CECH BILATERALNYCH SZKIELETU GŁOWY SZYNSZYLI MAŁEJ Z MIOTÓW POJEDYNCZYCH I MNOGICH
}

Asymmetry in some bilateral traits of the skull of long-tailed chinchilla from single and multiple litters

\author{
Katarzyna Pęzińska-Kijak, Piotr Baranowski \\ Zachodniopomorski Uniwersytet Technologiczny w Szczecinie, Pracownia Anatomii Zwierząt \\ ul. Doktora Judyma 14, 71-466 Szczecin \\ e-mail: katarzyna.pezinska@zut.edu.pl,piotr.baranowski@zut.edu.pl
}

$\mathrm{Na}$ każdym etapie rozwoju organizmu niezbędnym warunkiem prawidłowego funkcjonowania jest homeostaza ustrojowa. Odpowiada ona za zdolność organizmu do autoregulacji wszelkich procesów ontogenetycznych i zachowanie dynamicznej równowagi między czynnikami endogennymi organizmu a zmiennymi czynnikami środowiska. W modelu symetrii dwubocznej ciała kręgowców parzyste organy teoretycznie powinny rozwijać się jednakowo, za co odpowiadają istniejące już we wczesnym etapie rozwoju embrionalnego autoregulacyjne mechanizmy molekularne. W procesie filogenezy asymetria zwiększa się wraz ze wzrostem poziomu organizacji i najwyższa jest u człowieka, a najlepiej dostrzegana w zespole kostnym czaszki. W piśmiennictwie światowym pojawiają się coraz częściej prace poświęcone analizie wskaźnika asymetrii fluktuacyjnej jako wyznacznika stresu. W polskim piśmiennictwie problem asymetrii fluktuacyjnej jest tematem badawczym mało rozpowszechnionym, a prace z tego zakresu są nieliczne i dotyczą głównie człowieka. W świetle wyników badań nad asymetrią wydaje się interesujące rozważenie ewentualnego wpływu liczby płodów na wartość wskaźnika asymetrii. Dobrym materiałem do tego typu obserwacji są zwierzęta, które pochodzą z ciąży wielopłodowej. U szynszyli, które w warunkach naturalnych z reguły rodzą jednego osobnika, w wyniku intensywnej selekcji prowadzonej w hodowli można uzyskać dwoje, troje lub więcej zwierząt w miocie. Wykazano m.in., że większa liczba istotnie asymetrycznych bilateralnych cech epigenetycznych wystąpiła na czaszkach i żuchwach pozyskanych z osobników pochodzących z miotów wielopłodowych szynszyli małej. Celem obecnych badań było udzielenie odpowiedzi na pytanie, czy liczba osobników w miocie wpływa na wartości wskaźników asymetrii cech metrycznych szkieletu głowy szynszyli małej. Materiałem do badań było 70 czaszek i żuchw szynszyli, na których oszacowano wartości 13 bilateralnych cech metrycznych: 1. Wysokość pierścienia oczodołowego; 2. Punkt przecięcia Sutura zygomatica maxilliaris - Prosthion; 3. Processus temporalis ossis zygomatica - Sutura zygomatica maxiliaris; 4. Długość szeregu zębowego szczęki; 5. Długość szeregu zębowego żuchwy; 6. Ectorbilate - Entorbitale; 7. Protuberantia occipitalis externa - Processus paracondylaris; 8. Bregma - Ectorbitale; 9. Bregma Processus mastoideus; 10. Margo parietalis squmae temporalis - Processus mastoideus; 11. AkrokranionInfraorbitale; 12. Długość łuku jarzmowego; 13. Tylna krawędź puszki bębenkowej - Prosthion. Określono współczynniki asymetrii względnej (Aw) i asymetrii fluktuacyjnej (FA).Wśród 6 cech przyległych do osi czaszki współczynnik FA był istotny $(\mathrm{P} \leq 0,01$ i $\mathrm{P} \leq 0,05)$ w przypadku 2 cech, a wśród 7 cech odległych od osi czaszki - aż w przypadku 5. Stwierdzono wzrost wartości istotnych statystycznie współczynników FA cech bilateralnych wraz z rosnącą liczbą osobników w miocie. 


\title{
WSPÓŁZALEŻNOŚĆ POMIĘDZY WYBRANYMI CECHAMI METRYCZNYMI SZKIELETU GŁOWY ORAZ ELEMENTAMI KOŃCZYNY PIERSIOWEJ I KOŃCZYNY MIEDNICZNEJ A PŁCIĄ I WIELKOŚCIĄ MIOTU SZYNSZYLI MAEEJ
}

\begin{abstract}
Correlation between selected metric traits of head skeleton and the bone elements of the thoracic and pelvic limbs and sex and litter size in long-tailed chinchilla
\end{abstract}

\author{
Katarzyna Pęzińska-Kijak, Piotr Baranowski
}

\author{
Zachodniopomorski Uniwersytet Technologiczny w Szczecinie, Pracownia Anatomii Zwierząt \\ ul. Doktora Judyma 14, 71-466 Szczecin \\ e-mail: katarzyna.pezinska@zut.edu.pl
}

Podstawowymi komponentami szkieletu kończyny przedniej i tylnej są kości ramienna i udowa. Budowa obu tych kości dostarcza dużo informacji o lokomotorycznych preferencjach osobnika. O ile kość udowa jest masywną, najsilniejszą z kości długich organizmu ssaka i obok funkcji podporowych spełnia istotną rolę motoryczną, to kość ramienna, biernie obciążona masą ciała u niektórych gatunków zwierząt, ma różny kształt i masę, a interakcja obu tych cech z czynnikami środowiska i kontekstem filogenetycznym staje się, podobnie jak szkielet głowy, bardzo interesującym materiałem do badań adaptacyjnych. W warunkach naturalnych, w górach Ameryki Południowej, na skalistych zboczach żyją i organizują się w niewielkie kolonie zasiedlające rozpadliny górskie szynszyle małe. Poruszanie się po tym terenie wpływa na przystosowanie obu kończyn i elementów budujących obręcz kończyny piersiowej i miednicznej tych gryzoni. Ponieważ szkielet głowy ulega podczas ontogenezy znacznej modyfikacji i przebudowaniu, a takie czynniki, jak wiek i płeć, są istotnymi źródłami zmienności podczas jej przebiegu, zadano sobie pytanie, czy szkielet pozaczaszkowy samców i samic szynszyli różni się pod względem morfologiczno-osteometrycznym oraz czy w związku ze wzrostem liczby osobników w miocie szynszyli hodowlanych występują różnice w wielkości elementów obręczy piersiowej i obręczy miednicznej oraz podjęto się określenia wartości podstawowych cech osteometrycznych takich kości, jak łopatka, kość ramienna, miednica i kość udowa szynszyli małej, z uwzględnieniem płci i wielkość miotu jako źródeł zmienności, i ustalenia, czy istnieje statystyczna współzależność między cechami czaszki a cechami wybranych kości obręczy piersiowej i miednicznej. Badania przeprowadzono na pozyskanych w sposób losowy z tusz szkieletach szynszyli małej. Zwierzęta pochodziły z tych samych warunków pielęgnacji i utrzymania. Materiał obejmował ogółem 136 czaszek oraz 140 szkieletów pozaczaszkowych. Średni wiek samców wynosił $357 \pm 41$ dni, a samic $319 \pm 46$ dni. Suwmiarką elektroniczną zmierzono siedem odcinków płaszczyzny grzbietowej i podstawy czaszki. Na wybranych lewych i prawych największych elementach obręczy kończyny piersiowej i obręczy kończyny miednicznej pozostałych po oskórowaniu zwierząt wykonano odpowiednie pomiary: łopatki, kości ramiennej, miednicy, kości udowej. Ponadto wykonano pomiary pól powierzchni trzonu, nasady bliższej i dalszej oraz pola powierzchni całkowitej prawej i lewej kości udowej. Obliczono wskaźnik masywności ogólnej kości udowej, wskaźnik nasadowo-trzonowy kości udowej, wskaźnik nasady bliższej kości udowej, wskaźnik nasady dalszej kości udowej. Wyniki opracowano statystycznie z uwzględnieniem dwóch źródeł zmienności, płci i wielkości miotu. Stwierdzono, że w szkielecie szynszyli samic istnieje większa współzależność między kośćcem głowy a kośćcem obręczy piersiowej i obręczy miednicznej niż u samców oraz że płeć i wielkość miotu urodzenia nie są istotnymi źródłami zmienności dla wielkości takich kości, jak łopatka, kość ramienna, miednica i kość udowa szynszyli małej. 


\title{
IDENTYFIKACJA MIKROSKOPOWA GRZYBÓW W TREŚCI ŻOŁĄDKA I JELIT NOREK
}

Microscopic identification of fungi in stomach and intestinal contents of mink

\author{
Małgorzata Piórkowska
}

\begin{abstract}
Instytut Zootechniki - Państwowy Instytut Badawczy, Zakład Hodowli Drobnego Inwentarza, ul. Sarego 2, 31-047 Kraków e-mail: m.piorkowska@izoo.krakow.pl
\end{abstract}

Optymalizacja warunków zdrowotnych i żywieniowych w utrzymaniu mięsożernych zwierząt futerkowych ma zasadniczy wpływ na osiągane rezultaty produkcyjne i hodowlane. Norki są ważnym ogniwem w utylizacji odpadów pochodzenia zwierzęcego (głównie z przemysłu rybnego i drobiowego), a mięsożerne zwierzęta futerkowe należą do nielicznych, w żywieniu których dopuszcza się ich stosowanie. Dlatego ważny jest stan sanitarny podawanej paszy, w której obecność mikroorganizmów, toksyn lub innych zanieczyszczeń jest niedopuszczalna lub ich liczba winna być jak najniższa. Długotrwałe żywienie norek paszami o niskiej wartości biologicznej może odbijać się na ich rozwoju somatycznym (wzroście i dojrzałości płciowej), a także przyczynić się do obniżenia ogólnej odporności organizmu. Konsekwencją nieodpowiedniego żywienia są zatrucia i schorzenia związane z przemianą materii, które stanowią jedną z głównych przyczyn strat w hodowli. Warunkiem wysokiej produkcyjności norek jest ich dobry stan zdrowia, a poprzez żywienie można wpłynąć na funkcjonowanie całego układu pokarmowego, którego specyficzna budowa (krótki przewód o szybkiej perystaltyce) wymusza żywienie paszami zawierającymi dobrej jakości białko i o znacznej koncentracji energii. Celem podjętych badań było doskonalenie żywienia norek dawką o zróżnicowanym poziomie białka i probiotyku oddziałującego na rozwój flory bakteryjnej, popartego badaniami bakteriologicznymi ze szczególnym uwzględnieniem grzybów. Badania przeprowadzono na 49 norkach odmiany pastel oraz całości uzyskanego potomstwa. W grupie kontrolnej (I) zwierzęta żywiono karmą powszechnie stosowaną na fermie, bez udziału dodatków, w grupie II karmą z dodatkiem probiotyku ( $0,2 \mathrm{~g} / \mathrm{szt} . /$ dzień), a w grupie III - karmą ze zwiększonym udziałem EM z białka i dodatkiem probiotyku $(0,2 \mathrm{~g} / \mathrm{szt}$./dzień). $\mathrm{Na}$ przełomie listopada i grudnia pobrano materiał biologiczny do dalszych badań bakteriologicznych. W pobranej treści pokarmowej żołądka i jelit oznaczono: ogólną liczbę grzybów oraz przeprowadzono identyfikację makro- i mikroskopową grzybów za pomocą dostępnych testów API (bioMérieux Polska), z użyciem klucza do oznaczania grzybów Tsuneo Wantanabe. Badania wykazały, że średnia koncentracja ogólnej liczby grzybów w treści żołądka była najwyższa w grupie III - $9136 \mathrm{jtk} / \mathrm{g}$ i zdecydowanie niższa w grupie I i II - odpowiednio o 2772 oraz $2636 \mathrm{jtk} / \mathrm{g}$. W przypadku treści jelit ogólna liczba grzybów w grupie II i III była na podobnym poziomie (ok. 1,5 × $103 \mathrm{jtk} / \mathrm{g}$ ) i niższa niż w grupie I o połowę. Zarówno w treści żołądka, jak i jelit przeważały grzyby rodzaju Candida, z dominującym - Candida glabrata. Udział grzybów tego rodzaju we wszystkich grupach kształtował się w żołądku na poziomie 90-92\%, natomiast w jelitach był bardziej zróżnicowany i wahał się od 84,5 do 89,5\%. Pozostałe zidentyfikowane grzyby w treści pokarmowej to:

- Rhizopus sp. w ilości od 3,5 do 17,7\%,

- Aspergillus sp. w ilości od 3,0 do 6,1\%,

- Ulocladium sp. w ilości od 1,3 do 4,0\%,

- Rhizopus oryzae w ilości od 1,5 do 3,0\%,

- Penicillium sp. w ilości 3\%. 


\title{
ŚRODOWISKO A JAKOŚĆ OKRYWY WŁOSOWEJ SKÓR JENOCICH
}

The environment as related to hair coat quality of raccoon dog skins

\author{
Małgorzata Piórkowska
}

\footnotetext{
${ }^{1}$ Instytut Zootechniki - Państwowy Instytut Badawczy, Zakład Hodowli Drobnego Inwentarza, ul. Sarego 2, 31-047 Kraków e-mail: m.piorkowska@izoo.krakow.pl
}

Dotychczas przeprowadzono niewiele badań dotyczących kompleksowej oceny wpływu czynników genetycznych i środowiskowych na właściwości parametrów fizycznych, histologiczno-morfologicznych i jakość okrywy włosowej skór jenotów z uwzględnieniem pochodzenia zwierząt.

Pierwotnym terenem występowania jenota był Daleki Wschód (pd.-wsch. Syberia, Mandżuria, Korea i Japonia), a w szczególności obszar dorzecza Amuru i Ussuri. W latach 30. ubiegłego wieku zwierzęta te sprowadzono do europejskiej części Związku Radzieckiego celem rekonstrukcji fauny łownej. Jenoty doskonale zaaklimatyzowały się na obecnym terenie Ukrainy, Białorusi i Litwy, a stąd rozprzestrzeniły się po Europie. Na terenie Polski, w środowisku naturalnym, najliczniej jenoty występują w płn.-wsch. województwach, natomiast pierwsza ferma hodowlana tych zwierząt powstała w $1958 \mathrm{r}$.

Celem pracy było zbadanie wpływu pochodzenia zwierząt na jakość okrywy włosowej.

Badania przeprowadzono na 55 surowych skórach jenocich. Materiał biologiczny zostały podzielony na 3 grupy w zależności od środowiska, w jakim zwierzę żyło: grupa I - jenoty rosyjskie, niepoddane procesowi udomowienia; grupa II - jenoty dziko żyjące w środowisku naturalnym na terenie Polski, grupa III zwierzęta hodowlane. Pomiary cech użytkowych i wad okrywy włosowej zostały przeprowadzone w 6 miejscach topograficznych skóry (kark, pas barkowy, środek grzbietu, pas biodrowy, bok i brzuch).

Zwierzęta dzikie były odławiane w okresie zimowym, natomiast hodowlane pozyskiwano po osiągnięciu dojrzałości zimowej futra. W trakcie badań określono wielkość skór i parametry jakości okrywy włosowej, skupiając się na ocenie tkanki skórnej, określeniu wad okrywy, częstotliwości ich występowania i usytuowania. Przeprowadzono także pomiary wielkości tych uszkodzeń.

Analiza owłosienia jenotów wykazała występowanie wad w strukturze włosów pokrywowych, takich jak: rozdwojenie końcówek włosa, objawiające się pękaniem wzdłuż osi podłużnej, zbyt gruby szorstki włos oraz skręcenie włosa. Wszystkie te uszkodzenia włosów związane z ich budową stwierdzono w okrywie włosowej skór rosyjskich, natomiast u zwierząt krajowych (II i III grupa) występowało jedynie nietypowe skręcenie włosa pokrywowego w połowie długości.

U jenotów najczęstszą wadą okrywy jest sfilcowanie włosów, które stwierdzono we wszystkich badanych próbkach, z wyjątkiem partii brzucha. Wada ta jako sfilcowanie głębokie występowała w $60 \%$ skór rosyjskich w 2 miejscach - na grzbiecie i w pasie barkowym. U 36\% skór dzikich jenotów polskich uszkodzenie to zaobserwowano w 5 badanych miejscach topograficznych skóry. W tej grupie postać lekka spilśnienia występowała na boku i w pasie barkowym, średnia - na karku, a głęboka - na grzbiecie i w pasie biodrowym. Splątanie okrywy włosowej u zwierząt hodowlanych odnotowano u 30\% jenotów jako płytką postać uszkodzenia i u 10\% jako średnią. Stwierdzono, że w zależności od miejsca, z którego pobrano próbki do badań, wada ta występowała najczęściej w obrębie pasa biodrowego w $40 \%$ wszystkich skór jenotów oraz na boku i grzbiecie odpowiednio w ok. 11 i 9\% skór. Na karku sfilcowanie dotyczyło 5,5\% skór, a w pasie barkowym 3,6\%.

Kolejnymi wadami, zaobserwowanymi u jenotów były: niewykształcenie puchu oraz rozdwojenie włosów pokrywowych. Pierwsze uszkodzenie okrywy włosowej stwierdzono u wolno żyjących zwierząt na terenie kraju, drugie - tylko u osobników rosyjskich. Niewłaściwy stosunek długości włosów pokrywowych do puchowych występował na całej skórze w $28 \%$ skór grupy II, we wszystkich badanych miejscach topograficznych. Niedorozwój warstwy podszycia stwierdzano najczęściej na karku i w pasie barkowym - odpo- 
wiednio w ok. 9 i 11\% wszystkich skór. Rozdwajanie się końcówek włosów pokrywowych wystąpiło w 30\% skór rosyjskich w 3 miejscach grzbietu - próby 2, 3 i 4. Wady tej nie stwierdzono wcześniej podczas badań własnych.

U jenotów hodowlanych nie stwierdzono charakterystycznych dla skór dzikich zatłuszczeń okrywy włosowej, uszkodzeń przez pasożyty, nie w pełni wykształconego podszycia, kobuka, nierównomiernie rozłożonego woalu oraz odcieni obcych w okrywie. W tej grupie odnotowano natomiast $70 \%$ skór z kępiastą okrywą włosową. 


\title{
KRAJOWA HODOWLA LISÓW POSPOLITYCH BIAEOSZYJNYCH OBJĘTYCH PROGRAMEM OCHRONY ZASOBÓW GENETYCZNTCH
}

Domestic breeding of White Neck foxes included in the genetic resources conservation programme

\author{
Małgorzata Piórkowska ${ }^{1}$, Andrzej Zoń ${ }^{2}$ \\ ${ }^{1}$ Instytut Zootechniki - Państwowy Instytut Badawczy, Zakład Hodowli Drobnego Inwentarza, ul. Sarego 2, 31-047 Kraków \\ ${ }^{2}$ Zakład Doświadczalny Instytutu Zootechniki - Państwowy Instytut Badawczy Chorzelów Sp. z o.o. \\ e-mail: m.piorkowska@izoo.krakow.pl
}

Lisy pospolite białoszyjne jako mutacja lisa srebrzystego pojawiły się w latach 70 . ubiegłego wieku. Zwierzęta te wyróżniają się efektownym ciemnometalicznym, srebrzystym umaszczeniem z szerokim na 6-10 cm białym symetrycznym kołnierzem wokół szyi, przechodzącym pasmem bieli na podgardle i brzuch. Pysk jest czarny lub ciemnosrebrzysty z białą obwódką nosa przechodzącą w strzałkę wzdłuż pyska i czoła. Łapy są białe z czarnymi cętkami lub plamami. Gen białoszyjności (Wn), warunkujący charakterystyczne umaszczenie, jest odmianą alleliczną genu z locus „W”, a w układzie homozygotycznym jest genem letalnym. Okrywa włosowa, gęsta na grzbiecie, odznacza się jedwabistym, delikatnym i sprężystym włosem. W 2017 r. na terenie naszego kraju populacja lisów pospolitych białoszyjnych, objętych programem ochrony zasobów genetycznych zwierząt futerkowych, liczy łącznie 102 samice stada podstawowego i utrzymywana była w dwóch fermach zlokalizowanych w woj. podkarpackim (1) i w łódzkim (2). Prowadzone badania miały na celu zgromadzenie danych dotyczących cech użytkowych i reprodukcyjnych z uwzględnieniem czynników środowiskowych, takich jak sposób utrzymania i obsada klatek. Różnice między fermami dotyczyły: wielkości stada podstawowego (od 12 do 90 samic), struktury wiekowej samic (od roku do 9 lat), sposobu utrzymania - klatki w systemie pawilonowym oraz wolno stojące (pojedyncze dla $\widehat{\delta}$ i łączone po dwie dla +). Między fermami wystąpiły duże różnice długości okresu kryć i wykotów. Kojarzenia samic rozpoczęto w tym samym czasie, tj. w pierwszych dniach lutego, a zakończono odpowiednio - 14 i 26 marca. Także pierwsze wykoty na obu fermach przypadły równocześnie pod koniec marca i trwały do 6 maja (ferma 1) oraz 19 maja (ferma 2). W bieżącym roku na obu fermach odsetek samic rodzących kształtował się na poziomie $85,6-91,7 \%$. Na fermie 1 nie odnotowano samic niepokrytych i roniących. Na obu fermach procent samic jałowych był podobny i wahał się od 8,3 do 8,9\%. Z 88 samic wykoconych 9 zniszczyło swoje mioty. Ogółem na obu fermach uzyskano 381 szczeniąt żywo urodzonych, a średnia od samicy wynosiła 4,3 szt. Średnia liczba odchowanych młodych na samicę stada wynosiła 3,4 szt., na samicę wykoconą 3,9 szt., a na samicę wykoconą, która nie zniszczyła młodych, 4,3 szt. Największe mioty liczyły do 8 młodych. Śmiertelność szczeniąt w okresie odchowu przy matkach była zróżnicowana, wyższa w większej populacji tych zwierząt (ferma 2). Procent odchowu młodych dla fermy 1 i 2 kształtował się odpowiednio na poziomie ok. 95 i 90\%. W wyniku prowadzonych kojarzeń w bieżącym roku łącznie z dwóch ferm odsadzono 344 młodych lisów (160 samców i 184 samice), w tym 158 lisów białoszyjnych. Udział płci dla tej odmiany barwnej wyniósł 72 samce i 86 samic. Obecna populacja tej odmiany barwnej lisa charakteryzuje się znacznym zróżnicowaniem struktury wiekowej samic, od roku do 9 lat. Najwięcej szczeniąt urodzonych i odchowanych uzyskano od samic 2-letnich (ferma 1) i 1-rocznych (ferma 2). Upadki szczeniąt za okres odchowu przy matce wynosiły do $11 \%$ na fermie 1 i do $17,5 \%$ na fermie 2 . Na przełomie grudnia i stycznia ocenie fenotypu poddano jedynie 15 lisów białoszyjnych, w tym 2 szt. z fermy 1. Stanowiło to 9,5\% badanej populacji. Pięć osobników z fermy 2 uzyskało ocenę najwyższą. Najwięcej lisów otrzymało wycenę B+. 


\title{
ZALEŻNOŚCI POMIĘDZY ZASTOSOWANYM SYSTEMEM KRYĆ A UZYSKIWANYMI PARAMETRAMI ROZRODCZYMI SAMIC NOREK AMERYKAŃSKICH
}

\author{
Associations between applied mating system and reproductive parameters attained \\ by American mink females
}

\author{
Beata Seremak $^{1}$, Marta Dworecka ${ }^{1}$, Lidia Felska-Błaszczyk $^{2}$, Aleksandra Wojciechowska $^{1}$ \\ ${ }^{1}$ Zachodniopomorski Uniwersytet Technologiczny w Szczecinie, \\ Katedra Biotechnologii Rozrodu Zwierząt i Higieny Środowiska, ul. Janickiego 29, 71-270 Szczecin \\ ${ }^{2}$ Zachodniopomorski Uniwersytet Technologiczny w Szczecinie, Pracownia Anatomii Zwierząt \\ e-mail: beata.seremak@zut.edu.pl
}

Celem niniejszej pracy było zbadanie, czy ilość kojarzeń wpływa na płodność samicy oraz średnią liczbę urodzonych i żywo urodzonych młodych. Specyfika rozrodu samic norek, z cyklicznością dojrzewania i owulacji pęcherzyków jajnikowych, pozwala na ich wielokrotne krycie w ciągu sezonu rozrodczego. Na fermach stosuje się różne systemy kryć, w doświadczeniu zastosowano systemy: $1,1+2,1+2+8$, $1+2+8+9$, gdzie liczbami oznaczono kolejne dni. Z przeprowadzonych badań wynika, iż liczba kojarzeń miała znaczący wpływ na płodność samic norek oraz na średnią liczbę urodzonych i żywo urodzonych młodych. Analizując płodność samic, najwyższy procent wykoconych samic, na poziomie $94,8 \%$, zanotowano dla grupy samic skutecznie krytych czterokrotnie, 93,66\% dla krytych trzykrotnie, 84,1\% dla krytych dwukrotnie i $62,1 \%$ dla krytych tylko jeden raz. Wykazano, iż ilość kryć ma także znaczący wpływ na średnią liczbę urodzonych i żywo urodzonych młodych. I tak najwyższe wyniki odnotowano dla samic skutecznie krytych czterokrotnie, wyniki te kształtowały się na poziomie 6,78 urodzonych i 6,33 żywo urodzonych młodych, natomiast dla samic krytych jednokrotnie wyniki te były na poziomie odpowiednio 5,43 i 5,01. Dobór systemu i krotności kryć samic norek amerykańskich ma zasadniczy wpływ na uzyskiwane podstawowe parametry rozrodcze na fermie. 


\title{
WSKAŹNIKI ROZRODU SAMIC SZYNSZYLI (CHINCHILLA LANIGERA) NA WYBRANEJ FERMIE
}

\author{
Reproduction traits of chinchilla females (Chinchilla lanigera) from a selected farm \\ Łukasz Sikora, Agnieszka Ludwiczak, Marek Stanisz \\ Uniwersytet Przyrodniczy w Poznaniu, Katedra Hodowli Zwierząt i Oceny Surowców \\ e-mail: agnieszka.ludwiczak@up.poznan.pl
}

Szynszyla mała (Chinchilla lanigera) jest w Polsce popularnym zwierzęciem futerkowym, utrzymywanym głównie na niewielkich fermach towarowych, liczących średnio 200 matek stada podstawowego. Wskaźniki rozrodu szynszyli mają znaczący wpływ na opłacalność hodowli fermowej tych zwierząt. Jednym z ważniejszych celów hodowlanych jest poprawa takich parametrów rozrodu, jak liczba miotów na rok od samicy oraz średnia liczba urodzonych i odchowanych młodych od samicy w roku. Procent odchowu jest szczególnie istotny, ponieważ bezpośrednio przekłada się na liczbę pozyskanych skór. Czynnikiem ograniczającym wyniki reprodukcyjne na fermach szynszyli jest długi okres międzyporodowy, wynikający głównie z czasu trwania samej ciąży (średnio 111 dni). Możliwość skrócenia tego okresu i poprawy parametrów rozrodu daje występująca u tych zwierząt ruja poporodowa. Ponadto według danych literaturowych na odstęp między kolejnymi wykotami wpływa wiek pierwszego krycia samicy, który powinien mieścić się w zakresie 7-10 miesięcy, a także genotyp i wiek.

Celem badania była ocena wskaźników rozrodu w 3 kolejnych latach użytkowania szynszyli na fermie towarowej zlokalizowanej w województwie wielkopolskim. W okresie objętym badaniami liczebność stada podstawowego wynosiła 80 samic oraz 20 samców. Oceniono następujące parametry rozrodu: liczbę młodych urodzonych i odsadzonych oraz długość okresu międzyporodowego. Uwzględniono wskaźniki rozrodu z 5 kolejnych wykotów. Wybierając zwierzęta do rozrodu, kierowano się wzorcem oceny fenotypu szynszyli opracowanym przez Krajowe Centrum Hodowli Zwierząt. Średni wiek podczas pierwszego wykotu wynosił 462,1 dnia (min. 322, max. 776). Średnia długość okresu międzyporodowego kształtowała się na poziomie 165,3 dnia. Natomiast średnia liczba urodzonych i odchowanych młodych z wykotu na jedną samicę stada podstawowego wynosiła 2,12 i 1,66. Stwierdzono zróżnicowanie czasu trwania kolejnych okresów międzyporodowych (pierwszy 163,0, drugi 152,7, trzeci 167,4 i czwarty 173,3 dni), choć analiza statystyczna nie wykazała istotnych różnic. Najwięcej dni upłynęło pomiędzy 4. a 5. wykotem, a najmniej pomiędzy 2. a 3. wykotem. W 5 kolejnych wykotach liczba urodzonych i odchowanych młodych wynosiła: 2,09 i 1,53 w pierwszym, 2,27 i 1,80 w drugim, 2,08 i 1,64 w trzecim, 2,08 i 1,69 w czwartym oraz 2,08 i 1,65 w piątym. Drugi wykot charakteryzował się największą liczbą urodzonych i odchowanych młodych, natomiast w pierwszym wykocie stwierdzono najmniejszą liczbę młodych odchowanych. 


\title{
OCENA PODSTAWOWYCH CECH JAKOŚCI MIĘSA KRÓLIKÓW POCHODZĄCYCH Z KRZYŻOWANIA HYBRYD KRÓLICZYCH
}

Assessment of the basic quality traits of meat from rabbits derived from crossing rabbit hybrids

\author{
Joanna Składanowska-Baryza
}

\begin{abstract}
Uniwersytet Przyrodniczy w Poznaniu, Katedra Hodowli Zwierząt i Oceny Surowców, Złotniki, ul. Słoneczna 1, 62-002 Suchy Las e-mail: jskladanowska92@gmail.com
\end{abstract}

Pomimo wysokiego potencjału ras średnich coraz więcej uwagi poświęca się liniom hybrydowym, powstałe mieszańce (w zależności od celu ich wytworzenia) uzyskują wyższe wskaźniki niż rasy użyte do ich wytworzenia. Do intensywnej produkcji mięsa króliczego wytwarza się wyspecjalizowane linie hybrydowe mateczne i ojcowskie. Okres tuczu zaczyna się w wieku ok. 30 dni, badania na mięsie hybryd wykazały, iż najlepszą jakością charakteryzują się tuszki ubite między 77 a 90. d.ż. Celem przeprowadzonych badań była ocena jakości mięsa dwóch różnych krzyżówek hybryd króliczych. Materiał badawczy stanowiło 40 królików pochodzących z krycia samic PS19 samcami Hycol (grupa I) oraz samic (Jordan $\times$ Hycole) samcami Hyla (grupa II). Zwierzęta były utrzymywane w tej samej króliczarni oraz żywione taką samą dietą. Po zakończonym tuczu króliki poddano 24-godzinnej głodówce i zważono. Zwierzęta zostały ogłuszone, a następnie wykrwawione poprzez przecięcie tętnic szyjnych. Po $24 \mathrm{~h}$ od uboju pobrano z tuszki odcinek lędźwiowy $m$. longissimus. Analiza pH została wykonana elektrodą szklano-kalomelową (ERH-11X1, SCHOOT, Niemcy) podłączoną do przenośnego pH-metru (Handylab 2, SCHOOT, Niemcy). Kwasowość była analizowana $45 \min$ i $24 \mathrm{~h}$ po uboju. Analizę barwy $\left(\mathrm{L}^{*}, \mathrm{a}^{*}, \mathrm{~b}^{*}, \mathrm{C}^{*}, \mathrm{H}^{\circ}\right)$ aparatem Konica Minolta (The Netherlands) przeprowadzono $24 \mathrm{~h}$ po uboju. Wykonano analizę chemiczną: zawartość suchej masy (\%) (PN-ISO 1442 2000), białka ogólnego (\%), tłuszczu ekstrahowanego (\%) (PN-ISO 1444 2000), wyciek naturalny (\%), wyciek termiczny $(\%)$, zawartość wody wolnej $(\%)$ i plastyczność $\left(\mathrm{cm}^{2}\right)$. Analizę statystyczną wykonano z użyciem pakietu ANOVA oprogramowania SAS ver. 9.4. Analizowane mieszańce różniły się istotnie masą ciała (gr. I - 2,64 vs. gr. II $-2,91 \mathrm{~kg} ; \mathrm{P} \leq 0,01$ ). Nie stwierdzono wpływu genotypu na $\mathrm{pH}$ mięsa mierzonego $45 \min (\mathrm{pH}=$ gr I $-6,76$ vs. gr II $-6,71 ; \mathrm{P}>0,05)$ i 24 h po uboju $(\mathrm{pH}=$ gr I $-5,74$ vs. gr II $-5,71$; $\mathrm{P}>0,05)$. Nie stwierdzono istotnych różnic pod względem barwy badanych mięśni w zależności od genotypu królików (P > 0,05). Mięsień longissimus królików z grupy I charakteryzował się mniejszym wyciekiem naturalnym w porównaniu z mięśniem z grupy II $(0,58$ vs. 0,$84 ; \mathrm{P} \leq 0,01)$. Nie odnotowano istotnych różnic w ilości wycieku termicznego (gr. I - 23,42, gr. II - 24,29), ilości wody wolnej (gr. I - 28,80, gr. II - 29,51) oraz plastyczności (gr. I - 2,99, gr. II - 2,98), przy P > 0,05. Zawartość białka ogólnego (gr. I - 22,63; gr. II 22,11\%) oraz suchej masy (gr I - 24,24; gr. II - 24,36\%) w mięsie królików należących do różnych genotypów nie różniła się istotnie $(\mathrm{P}>0,05)$. Mięso pochodzące z mięśnia z grupy II charakteryzowało się większą zawartością tłuszczu w porównaniu z mięsem grupy I ( 0,43 vs. $0,59 \%$; $\mathrm{P} \leq 0,05)$. Podsumowując, zwierzęta pochodzące z krzyżowania różnych hybryd króliczych nie różniły się istotnie fizykochemicznymi wyznacznikami jakości mięsa, co pozwala wnioskować o jego podobnej przydatności technologicznej niezależnie od grupy genetycznej. Wpływ genotypu zaobserwowano jedynie w zawartości tłuszczu ekstrahowanego i wycieku naturalnego. 


\title{
WARTOŚĆ RZEŹNA KRÓLIKÓW POCHODZĄCYCH Z KRZYŻOWANIA HYBRYD MARTINI I HYLA
}

The slaughter value of rabbits bred by crossing Martini and Hyla hybrids

\author{
Marek Stanisz, Agnieszka Ludwiczak, Joanna Składanowska-Baryza, Marta Bykowska, \\ Łukasz Sikora, Klaudia Robakowska
}

Uniwersytet Przyrodniczy w Poznaniu, Katedra Hodowli Zwierząt i Oceny Surowców, Złotniki, ul. Słoneczna 1, 62-002 Suchy Las e-mail: stanisz@up.poznan.pl

Wiek jest jednym z wielu czynników mających wpływ na wartość rzeźną królików. Dlatego celem przeprowadzonych badań była ocena wpływu wieku królików pochodzących z krzyżowania dwóch hybryd Martini i Hyla na ich wartość rzeźną. Badaniami objęto 32 króliki, które ubito w wieku 90 (16 szt.) i 120 (16 szt.) dni. W okresie tuczu króliki żywiono do woli mieszanką granulowaną, zawierającą 16,0\% białka ogólnego, 14,0\% włókna surowego, o energii metabolicznej 10,4 MJ, zwierzętom zapewniono stały dostęp do wody pitnej. Po zakończonym tuczu króliki poddano 24-godzinnej głodówce i zważono. Zwierzęta przed ubojem ogłuszono, a następnie skrwawiono, oskórowano i wypatroszono. Po uboju tuszki i podroby jadalne (wątroba, nerki, serca i płuca) zważono i umieszczono w chłodni w temp. $+2^{\circ} \mathrm{C}$. Po $24 \mathrm{~h}$ tuszki zważono i podzielono na 3 podstawowe wyręby. Część przednią - cięcie za ostatnim kręgiem piersiowym a pierwszym lędźwiowym. Comber - cięcie między 6. a 7. kręgiem lędźwiowym. Część tylną - obejmującą nogi tylne wraz z 7. kręgiem lędźwiowym i częścią krzyżową. Każdą z części poddano dysekcji szczegółowej na tkankę mięśniową, tłuszczową i kostną. Poszczególne tkanki zważono z dokładnością do $1 \mathrm{~g}$ i obliczono ich udział procentowy w poszczególnych elementach i w całej tuszy. Wydajność rzeźną I obliczono na podstawie stosunku masy tuszki ciepłej bez głowy do masy ciała przed ubojem. Wydajność rzeźną II obliczono na podstawie stosunku masy tuszki ciepłej bez głowy i z podrobami jadalnymi do masy ciała przed ubojem. Wydajność rzeźną III obliczono na podstawie stosunku masy tuszki ciepłej z głową i z podrobami jadalnymi do masy ciała przed ubojem. Analizę statystyczną wykonano z użyciem pakietu ANOVA oprogramowania SAS ver. 9.4. Badane mieszańce Martini $\times$ Hyla w wieku 90 dni ważyły średnio 3,14 kg. Natomiast tuczone do wieku 120 dni miały o $14 \%$ ( $\leq 0,01)$ większą masę ciała $(3,59 \mathrm{~kg})$. U mieszańców ubijanych w wieku 120 dni uzyskano wyższą wydajność rzeźną ciepłą I (48,8 vs. 50,9\%, P $\leq 0,05)$ i II $(54,4$ vs. $56,0 \%, \mathrm{P} \leq 0,05)$ niż u mieszańców ubijanych w wieku 90 dni. Natomiast nie stwierdzono wpływu wieku uboju na wydajność rzeźną ciepłą III (59,7 vs. 60,6\%, P > 0,05). Tuszki mieszańców 90-dniowych po 24 h straciły na masie średnio 3,71\%, natomiast 120-dniowe 3,28\%. Udział części przedniej w tuszkach królików starszych był mniejszy niż u młodszych $(36,0$ vs. $34,5 \%, \mathrm{P} \leq 0,05)$. Udział combra, najcenniejszego elementu w tuszce królika, był bardzo podobny u obu grup wiekowych $(24,0$ vs. $24,3 \%$, P > 0,05). Natomiast udział części tylnej w tuszkach królików starszych był większy niż u młodszych (39,9 vs. $41,2 \%, \mathrm{P} \leq 0,01)$. W każdej z badanych części tuszki z uboju w wieku 120 dni stwierdzono zmniejszanie się udziału procentowego tkanki mięśniowej. $\mathrm{W}$ części przedniej o 2,5 jedn. proc. $(\mathrm{P} \leq 0,05)$, w części tylnej o 3,3 jedn. proc. $(\mathrm{P} \leq 0,05)$. $\mathrm{W}$ combrze udział procentowy tkanki mięśniowej był mniejszy o 0,6 jedn. proc. i nie został potwierdzony statystycznie $(\mathrm{P}>0,05)$. Udział procentowy tkanki tłuszczowej zwiększył się we wszystkich 3 częściach tuszki pochodzących z uboju w wieku 120 dni. W części przedniej o 2,9 jedn. proc. $(\mathrm{P} \leq 0,01)$, w combrze o 2,5 jedn. proc. $(\mathrm{P} \leq 0,01)$ i części tylnej o 2,4 jedn. proc. $(\mathrm{P} \leq 0,01)$. Udział procentowy tkanki kostnej w 3 częściach tuszki u obu grup wiekowych był podobny $(\mathrm{P}>0,05)$. W tuszkach królików 90-dniowych udział tkanki mięśniowej $(81,2 \%)$ był większy o 1,4 jedn. proc. $(\mathrm{P} \leq 0,05)$, a tkanki tłuszczowej $(3,1 \%)$ był mniejszy o $42,6 \%$ jedn. proc. niż w tuszkach królików 120-dniowych. Natomiast udział procentowy tkanki kostnej u obu grup wiekowych był bardzo podobny (15,7 vs. 15,8\%, P > 0,05). Podsumowując, można stwierdzić, że wiek uboju badanych królików ma wpływ na większość badanych cech. 


\title{
ZAWARTOŚĆ KSANTOFILI, BETA-KAROTENU, RETINOLU I ALFA-TOKOFEROLU W TKANCE TŁUSZCZOWEJ I MLEKU SAMIC KRÓLIKÓW
}

Content of xanthophylls, beta-carotene, retinol and alpha-tocopherol in adipose tissue and milk of rabbit does

\author{
Janusz Strychalski ${ }^{1}$, Andrzej Gugołek ${ }^{1}$, Zofia Antoszkiewicz ${ }^{2}$, Paweł Brym ${ }^{3}$ \\ ${ }^{1}$ Uniwersytet Warmińsko-Mazurski w Olsztynie, Katedra Hodowli Zwierząt Futerkowych i Łowiectwa \\ ul. Oczapowskiego 5, 10-719 Olsztyn \\ ${ }^{2}$ Uniwersytet Warmińsko-Mazurski w Olsztynie, Katedra Żywienia Zwierząt i Paszoznawstwa \\ ${ }^{3}$ Uniwersytet Warmińsko-Mazurski w Olsztynie, Katedra Genetyki Zwierząt \\ e-mail: janusz.strychalski@uwm.edu.pl
}

Karotenoidy są grupą związków organicznych rozpuszczalnych w tłuszczu. Pełnią one funkcję antyoksydacyjną. Są wytwarzane przez fotosyntetyzujące organizmy, algi oraz przez wiele gatunków bakterii i grzybów. Zwierzęta nie potrafią ich syntetyzować i dlatego muszą mieć je dostarczone w diecie. Karotenoidy dzielą się na dwie grupy. Pierwszą stanowią karoteny (np. beta-karoten), drugą grupą są ksantofile (np. luteina). Do nieenzymatycznych składników systemu obrony antyoksydacyjnej w tłuszczu zwierząt należą witaminy A i E, w tym ich najważniejsze formy: retinol i alfa-tokoferol. Celem pracy było zbadanie ilości ksantofili, beta-karotenu, retinolu i alfa-tokoferolu w tkance tłuszczowej i mleku samic królików.

Materiał do badań stanowiło 6 samic królików rasy nowozelandzkiej czerwonej. Samice razem z miotami były utrzymywane na głębokiej ściółce i żywione paszą granulowaną, zawierającą w $1 \mathrm{~kg}$ 32,70 mg ksantofili, 20,07 mg beta-karotenu, 9174 IU witaminy A oraz 32,36 mg witaminy E. Od 7. do 13. dnia laktacji pobierano mleko od samic, po $1,5 \mathrm{ml}$ dziennie, łącznie w ilości po $10,5 \mathrm{ml}$ od każdej samicy. Młode odsadzono od samic w wieku 35 dni. Po odsadzeniu młodych samice poddano ubojowi. Bezpośrednio po uboju pobrano od nich próbki tkanki tłuszczowej (tłuszcz okołonerkowy). Wyniki oznaczeń przedstawiono w tabeli 1.

Tabela 1. Zawartość wybranych mikrokomponentów ( $\mu \mathrm{g} / \mathrm{g})$ w tkance tłuszczowej i mleku samic królików

\begin{tabular}{|l|c|c|c|c|}
\hline \multicolumn{1}{|c|}{ Specyfikacja } & Ksantofile & Beta-karoten & Retinol & Alfa-tokoferol \\
\hline Tkanka tłuszczowa & 0,30 & 0,56 & 6,34 & 3,32 \\
Mleko & 0,01 & 0,31 & 1,32 & 0,50 \\
\hline
\end{tabular}

Uzyskane wyniki wskazują, że tkanka tłuszczowa samic królików zawiera pewne ilości badanych komponentów. Natomiast w mleku samic stwierdzono występowanie tylko bardzo niewielkich ilości ksantofili (ok. 30 razy mniej niż w tkance tłuszczowej). Koncentracje beta-karotenu, retinolu i alfa-tokoferolu były 1,8 razy, 4,8 razy i 6,6 razy niższe w mleku niż w tkance tłuszczowej. Dalsze badania przewidują określenie ilości karotenoidów oraz witamin A i E w różnych tkankach królików otrzymujących zróżnicowaną ilość tych składników w diecie. 


\title{
ZAWARTOŚĆ TŁUSZCZU I KWASÓW TŁUSZCZOWYCH W MLEKU SAMIC JENOTA FINNRACCOON W OKRESIE LAKTACJI
}

Variation in the composition of fat and fatty-acid of milk of finnraccoon throughout lactation

\author{
Olga Szeleszczuk, Paulina Kilar, Dorota Maj, Piotr Niedbała
}

\begin{abstract}
Uniwersytet Rolniczy im. Hugona Kołłątaja w Krakowie, Zakład Anatomii Zwierząt, al. Mickiewicza 24/28 30-150 Kraków Uniwersytet Rolniczy im. Hugona Kołłątaja w Krakowie, Zakład Hodowli Trzody Chlewnej i Drobnego Inwentarza Uniwersytet Rolniczy im. Hugona Kołłątaja w Krakowie, Katedra Genetyki i Metod Doskonalenia Zwierząt e-mail: rzszeles@cuf-kr.edu.pl
\end{abstract}

Celem pracy było określenie zawartości oraz składu kwasów tłuszczowych (KT) tłuszczu mleka hodowlanego przedstawiciela Canidae - jenota.

Materiał badawczy stanowiły próbki mleka pobrane w poszczególnych fazach laktacji od 52 samic jenota z 2 hodowli położonych w województwach świętokrzyskim i podkarpackim. W próbkach mleka zawartość substancji tłuszczowej oznaczono w analizatorach Milkoscanie FT 2 TYPE 79069 firmy FOSS - bliska podczerwień i EKOMILK - milk analizator MILKANA KAM 98-2A. Profil kwasów tłuszczowych określono metodą chromatografii gazowej na aparacie Varian 450-GC z detektorem FID, stosując kolumnę CP-SIL 88 (FAME) o długości $100 \mathrm{~m}$, średnicy $0,25 \mathrm{~mm}$.

Analiza zawartości tłuszczu w mleku wykazała znaczną ilość tego składnika w mleku samic jenota, średnio 12,46\%. Zawartość tłuszczu w mleku zwierząt charakteryzowała się zmiennością w zależności od pochodzenia samic i fazy laktacji. W badanych próbkach mleka stwierdzono obecność 18 kwasów tłuszczowych. Zidentyfikowano 10 nasyconych kwasów tłuszczowych, natomiast zarówno w grupie kwasów jednonienasyconych (MUFA), jak i wielonienasyconych (PUFA) stwierdzono obecność 4 kwasów tłuszczowych. Większa część kwasów występowała w niewielkich ilościach, poniżej 1\%. Natomiast zawartość 3 kwasów wyniosła ponad 20\%, były to kwasy: palmitynowy C16:0, cis-oleinowy C18:1 n9 cis, linolowy C18:2 n6.

Wnioski:

1. Mleko pozyskiwane od samic jenota charakteryzowało wysoką zawartością tłuszczu.

2. Faza laktacji miała istotny wpływ na podstawowy skład chemiczny pozyskiwanego mleka. Wraz z przebiegiem laktacji następował sukcesywny wzrost zawartości tłuszczu, natomiast zmniejszała się zawartość wolnych kwasów tłuszczowych, co zostało potwierdzone statystycznie.

3. Wykazano istotny wpływ fazy laktacji na zawartość tłuszczu i profil kwasów tłuszczowych w mleku.

Praca wykonana w ramach DS. 3552/ZAZ. 


\title{
ANALIZA HODOWLANA CECH POKROJU U KRÓLIKÓW W FERMIE REPRODUKCYJNEJ
}

\author{
Breeding analysis of conformation traits in rabbits in a reproductive farm
}

\author{
Dorota Weremczuk ${ }^{1}$, Dorota Kołodziejczyk ${ }^{1}$, Łukasz Baran $^{3}$, Leszek Gacek $^{2}$, \\ Aleksandra Paskudska ${ }^{1}$, Stanisław Socha ${ }^{1}$

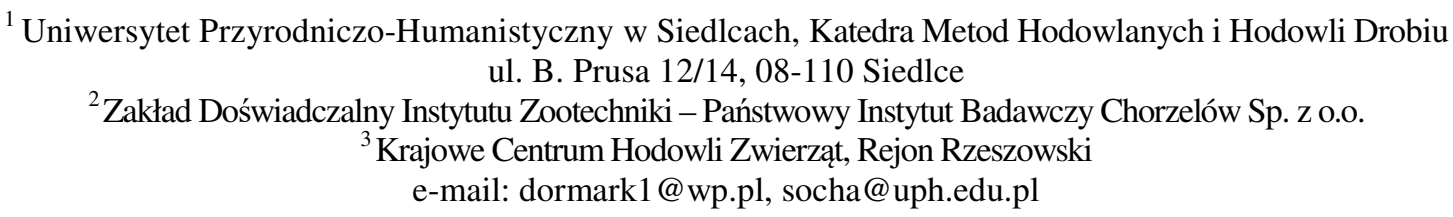

W pracy przedstawiono najistotniejsze zagadnienia związane z chowem i hodowlą królików. Obecnie wyhodowanych mamy ok. 150 ras królików. Wśród nich wyróżnia się osobniki o użytkowości mięsnej, charakteryzujące się szybkim przyrostem i dużą masą ciała w końcowym etapie chowu, futerkowe, odznaczające się dobrej jakości okrywą włosową, oraz osobniki o użytkowości mieszanej - futerkowo-mięsnej, charakteryzujące się zarówno dobrymi przyrostami masy, jak i dobrej jakości okrywą włosową. W Polsce istnieje kilka ferm specjalizujących się $\mathrm{w}$ produkcji żywca króliczego. Jedną z ras, jaką utrzymuje się na fermach, jest królik rasy popielniański biały. Jest to rodzima rasa powstała z królików polskich albinotycznych. Inną rasą utrzymywaną na fermach jest termondzki biały. Obie te rasy charakteryzują śnieżnobiała okrywa włosowa, czerwone oczy, a także wydajność rzeźna na poziomie $60 \%$. Ustalono na podstawie źródeł, iż optymalnym terminem odsadzenia młodych od matki na fermie reprodukcyjnej jest 35 . d.ż. Do podstawowych zadań na fermie zalicza się m.in. szczepienia ochronne oraz w miarę możliwości jak najczęstsze kontrole użytkowości stada. Jednak bez jednego ważnego elementu nie można mówić o dobrej hodowli. Mianowicie chodzi tutaj o pracę hodowlaną. Wiedza genetyczna dostarcza hodowcom potrzebnych informacji przy planowaniu okrywy włosowej w przypadku użytkowania futerkowego, z kolei w procesie uzyskania jak największej wydajności rzeźnej pomaga w planowaniu budowy ciała królików. Poprzez skuteczną pracę hodowlaną wywnioskować można, iż prawidłowa ocena wartości użytkowej i hodowlanej daje możliwość przeprowadzenia odpowiedniej selekcji. Dzięki temu do dalszej hodowli oraz do rozrodu wybiera się osobniki tylko o najlepszych cechach. Celem pracy jest też analiza cech pokroju królików na fermie reprodukcyjnej. Cechy pokroju królików są przedmiotem oceny wartości użytkowej, a następnie szacowania wartości hodowlanej królików. Przeprowadzona w pracy analiza dotyczyła cech pokroju zwierząt z uwzględnieniem: masy ciała, wielkości zwierząt (wyrażonej w punktach), budowy ciała, typu, jakości okrywy, barwy okrywy. Analizą objęto 2 rasy królików: popielniański biały i termondzki. Wykonano analizy statystyczne, w tym analizę wariancji z wykorzystaniem programu statystycznego SAS [2000]. W pracy oszacowano i przedstawiono też korelacje fenotypowe cech pokrojowych królików. Z oszacowanych wskaźników wynika, że korelacje fenotypowe pomiędzy łączną sumą punktów, a pozostałymi cechami są dodatnie i stosunkowo wysokie. Ujemne i bardzo niskie korelacje stwierdzono pomiędzy masą ciała a jakością okrywy włosowej. Na podstawie uzyskanych wyników można stwierdzić, że podczas selekcji w kierunku poprawy masy ciała pogarsza się jakość okrywy. Drugą korelacją ujemną pojawiającą się w tej pracy jest zależność wielkości względem typu i jakości okrywy włosowej. Tutaj również selekcja prowadzona pod względem poprawy wielkości powoduje pogorszenie parametrów okrywy. Pomiędzy typem a wielkością zwierząt (wyrażoną w punktach) korelacja jest ujemna. Ogólnie można stwierdzić, że korelacje pomiędzy poszczególnymi cechami wahały się od ok. $-0,08$ do ok. $+0,7$. 
Podsumowując wyniki analizy cech pokroju, należy stwierdzić, że króliki utrzymywane na fermie reprodukcyjnej uzyskały bardzo dobre oceny. Z oszacowanych średnich dla poszczególnych cech należy wnioskować, że praca hodowlana na analizowanej fermie hodowlanej jest właściwie prowadzona. Zwierzęta charakteryzują się bardzo dobrymi cechami pokroju. Dotyczy to wszystkich grup parametrów: płci królików, ras oraz poszczególnych lat oceny. Dlatego też ferma cieszy się dużą popularnością wśród hodowców i uzyskiwany na niej materiał hodowlany jest chętnie kupowany przez hodowców indywidualnych. 


\title{
TENDENCJE W HODOWLI SZYNSZYLI W POLSCE
}

Trends in chinchilla breeding in Poland

\author{
Jacek Zawiślak
}

\author{
Uniwersytet Technologiczno-Przyrodniczy, Zakład Hodowli Owiec, Kóz i Zwierząt Futerkowych \\ ul. Mazowiecka 28, 85-084 Bydgoszcz \\ e-mail: futerka@utp.edu.pl
}

Szynszyle w Polsce są hodowane od 1953 r., a hodowla tych zwierząt w naszym kraju ma charakter rodzinny. Są to bardzo cenne zwierzęta futerkowe, których skóry odznaczają się niespotykaną miękkością i oryginalnym kolorem, dlatego też są surowcem ciągle poszukiwanym przez producentów konfekcji futrzarskiej. Aktualna sytuacja w branży zwierząt futerkowych w Polsce nie jest najlepsza, gdyż propozycja wprowadzenia ustawy o całkowitym zakazie hodowli zwierząt futerkowych na futra, w tym także szynszyli (wyjątek w proponowanym projekcie ustawy stanowią tylko króliki), nie napawa optymizmem.

Celem pracy była analiza pogłowia szynszyli hodowanych w Polsce w latach 2010-2017, znajdującego się pod kontrolą Krajowego Centrum Hodowli Zwierząt (KCHZ).

Materiał badawczy stanowiły szynszyle (63 378 szt.) utrzymywane na polskich fermach. Dane pochodziły z raportów KCHZ w Warszawie. Analizowano liczbę samic stada podstawowego, a także liczbę stad, wyznaczając trendy dla tych parametrów, które obliczono w postaci funkcji pierwszego stopnia. Badano także wyniki rozrodu (liczbę zwierząt urodzonych i odchowanych, a także procent odchowu młodych) oraz wyniki oceny fenotypowej.

W analizowanym okresie liczba samic stada podstawowego miała tendencję spadkową (co potwierdza linia trendu: $y=-566,02 x+10469)$. W wartościach rzeczywistych zaobserwowano spadek z 10591 szt. (w 2010 r.) do 7758 szt. (w 2017 r.) i był on statystycznie istotny $\left(\mathrm{r}_{\mathrm{xy}}-0,822^{* *}\right)$. Ostatnie 3 lata (20152017) charakteryzowały się jednak lekkim wzrostem liczby samic stada podstawowego, co potwierdza nadal aktualne zainteresowanie tym gatunkiem zwierząt wśród hodowców. Także spadkową tendencję wykazano dla liczby stad, ponieważ w okresie od roku 2010 do 2017 rocznie likwidowano ok. 2 stad $(y=-2,392 x+73,393)$.

Analizując wyniki rozrodu, zaobserwowano, że średnia liczba młodych uzyskanych od jednej samicy w roku była na jednakowym poziomie w okresie od 2010 do 2016 r. (3,3 szt.), a najmniejsza była w 2017 r. (3,1 szt.). Liczba szczeniąt odchowanych od jednej samicy w ciągu roku w analogicznym okresie kształtowała się od 2,9 do 3,0 szt., a w 2017 r. była także najniższa (2,8 szt.). Procent odchowu młodych kształtował się na dość dobrym poziomie, bo wahał się od 88,7 do 91,2\%.

Ocena fenotypowa szynszyli wyrażona w punktach (max. 30 pkt) wypadała bardzo niekorzystnie, gdyż zaobserwowano bardzo niepożądaną tendencję, która polegała na tym, że im niższy przedział punktowy, tym większy udział procentowy niekorzystnie ocenionych zwierząt. Do najwyższego przedziału punktowego (29-30 pkt) zakwalifikowano w badanym okresie tylko od 0,9 do 2,8\% zwierząt, natomiast do najniższego przedziału (<24 pkt) zakwalifikowano aż od 46,9 do 53,2 \% zwierząt.

Podsumowując, należy stwierdzić, że dla całego analizowanego okresu (2010-2017) zaobserwowano tendencje spadkowe i to zarówno dla liczby samic stada podstawowego, jak i dla liczby stad. Jednak ostatnie 3 lata (2015-2017) wykazują pewną poprawę wyżej wymienionych parametrów, co wskazuje na pewien optymizm wśród polskich hodowców, czekających z nadzieją na dalszy rozwój sytuacji hodowlanej w naszym kraju. 
Sekcja Chowu i Hodowli Koni 


\title{
CHARAKTERYSTYKA KONI PODDAWANYCH UBOJOWI
}

\author{
Characteristic of slaughtered horses \\ Romana Augustyn, Szymon Adamek, Bogusława Długosz, Magdalena Pieszka, \\ Jarosław Łuszczyński, Zenon Podstawski, Monika Stefaniuk-Szmukier \\ Uniwersytet Rolniczy im. H. Kołłątaja w Krakowie, Instytut Nauk o Zwierzętach, Zakład Hodowli Koni \\ al. Mickiewicza 24/28 30-059 Kraków \\ e-mail: r.augustyn@ur.krakow.pl
}

Polska jest głównym eksporterem koniny wśród krajów Unii Europejskiej. Zakład ubojowy, z którego pochodziły informacje dotyczące populacji ubitych w nim koni, znajduje się w Małopolsce, w powiecie nowosądeckim i zajmuje się eksportem mięsa końskiego głównie do Włoch i w mniejszym stopniu do Francji. Konie, które trafiają do opisywanej ubojni, pochodzą głównie z małych gospodarstw. Należy podkreślić, że w województwie małopolskim hodowla koni ukierunkowana na produkcję mięsa nie jest popularna. Na południu województwa zlokalizowane są przede wszystkim niewielkie gospodarstwa, w których najczęściej jest jedna lub dwie klacze wykorzystywane do pracy na roli (w lesie), a dodatkowo stanowione w celu uzyskania źrebiąt, które po okresie opasu trafiają na rzeź. Z uzyskanych informacji o koniach poddanych ubojowi w okresie 6 miesięcy utworzono zestawienie, w którym uwzględniono wiek, płeć, maść i typ rasowy dla 1228 koni. $\mathrm{Z}$ analizy wynika, iż konie trafiające do badanej ubojni to w większości klacze ras zimnokrwistych, powyżej piątego roku życia, o ciemnym umaszczeniu. Umaszczenie siwe zdarzało się sporadycznie, co nie tylko odzwierciedla upodobania hodowców/właścicieli koni z tej części Polski, ale ma związek ze zwiększonym prawdopodobieństwem wystąpienia u koni tej maści czerniaków i czerniakomięsaków. Ponieważ mięso koni, u których badanie na melanoma/melanosarcoma wykaże ich obecność, jest uznawane za niezdatne do spożycia przez ludzi, właściciele nie chcą ryzykować finansowej straty. Maść kasztanowata występowała u niespełna $20 \%$ koni, z czego znaczna część pochodziła ze Słowacji i często były to konie huculskie. Jak wspomniano, ponad połowę koni stanowiły osobniki dorosłe, powyżej piątego roku życia. Źrebięta stanowiły $18 \%$, konie w przedziale wiekowym 1-2,5 roku 10\%, a konie młode, w wieku 3-5 lat jedynie 5\%. Udział poszczególnych typów koni kształtowany jest głównie przez rynek odbiorców, którzy jasno zaznaczają swoje preferencje. Na typ duży wpływ mają także rolnicy, gdyż to głównie od nich pochodzą konie poddawane ubojowi w tym zakładzie. Najwięcej było koni w typie zimnokrwistym (76\%). Na drugim miejscu znalazły się konie szlachetne $-20 \%$, pozostałe konie to osobniki ras prymitywnych. Produkcja mięsa końskiego oraz jego eksport w Polsce jest bardzo dobrze rozwinięty. Wynika to z jakości mięsa polskich koni oraz jego składu chemicznego. W dzisiejszych czasach polska konina stała się towarem luksusowym, który na rynkach światowych osiąga wysokie ceny. 


\title{
REALIZACJA PAKIETU 7. ZACHOWANIE LOKALNYCH RAS KONI
}

\author{
Realisation of package 7. Protection of local horses breeds \\ Agnieszka Chełmińska, Iwona Tomczyk-Wrona \\ Instytut Zootechniki - Państwowy Instytut Badawczy, Zakład Hodowli Koni \\ ul. Krakowska 1, 32-083 Balice \\ e-mail: agnieszka.chelminska@izoo.krakow.pl
}

Od roku 2005 chronione rasy zwierząt, w tym koni, objęte są płatnościami rolno-środowiskowymi/rolnośrodowiskowo-klimatycznymi. Początkowo płatności dotyczyły czterech ras koni - hucuła, konika polskiego, małopolskiej i śląskiej - a od 2008 r. także rasy wielkopolskiej oraz dwóch typów polskiego konia zimnokrwistego - sztumskiego i sokólskiego. Za płatności odpowiada Agencja Restrukturyzacji i Modernizacji Rolnictwa. Aktualnie realizowany jest już trzeci program rozwoju obszarów wiejskich, a w nim pakiet: „Zachowanie zagrożonych zasobów genetycznych zwierząt w rolnictwie". W ramach pakietu wyróżnia się warianty dla poszczególnych gatunków i ras zwierząt gospodarskich, w tym wariant 7.2 dla koni (tab. 1).

Tabela 1. Liczba stad, liczba klaczy oraz należności wypłacone przez ARiMR łącznie w ramach działania rolnośrodowiskowego oraz rolno-środowiskowo-klimatycznego wg danych ARiMR

\begin{tabular}{|l|c|c|c|}
\hline \multicolumn{1}{|c|}{ Wyszczególnienie } & 2015 & 2016 & $2017 *$ \\
\hline Liczba stad & 1270 & 1329 & 1373 \\
\hline Liczba klaczy & 5796 & 6372 & 6654 \\
\hline Płatności w zł & 8652975 & 9468729 & - \\
\hline
\end{tabular}

* Stada oraz sztuki zadeklarowane do płatności

W 2017 r. stawka płatności dla koni uległa zwiększeniu z 1500 zł dla wszystkich ras do 1900 zł dla klaczy wielkopolskich i małopolskich oraz 1700 zł dla pozostałych ras, co spowoduje wzrost kwot wypłaconych hodowcom w ramach wariantu 7.2. Ponadto biorąc pod uwagę rosnące zainteresowanie hodowców tym wariantem, należy już podjąć prace nad przyszłym programem rozwoju obszarów wiejskich. 


\title{
DZIAŁALNOŚĆ ORGANIZACJI POZARZĄDOWYCH NA RZECZ LOKALNYCH RAS KONI
}

\author{
Activities of non-governmental organizations for local horses breeds
}

\author{
Agnieszka Chełmińska, Iwona Tomczyk-Wrona
}

\author{
Instytut Zootechniki - Państwowy Instytut Badawczy, Zakład Hodowli Koni \\ ul. Krakowska 1, 32-083 Balice \\ e-mail: agnieszka.chelminska@izoo.krakow.pl
}

\begin{abstract}
W ramach prac związanych z monitorowaniem wdrażania Planu działań do „Krajowej strategii zrównoważonego użytkowania i ochrony zasobów genetycznych zwierząt gospodarskich" zidentyfikowano 20 organizacji pozarządowych (NGOs), których działalność jest związana w różny sposób z ochroną zasobów genetycznych zwierząt gospodarskich. NGOs przywiązują szczególną rolę do znaczenia wypasu, gdyż jego brak jest m.in. przyczyną sukcesji wtórnej, która objawia się wzrostem zakrzaczenia, zubożeniem różnorodności biologicznej i tym samym zachwianiem równowagi ekologicznej. Równie ważne są działania edukacyjne oraz popularyzacja wykorzystania ras rodzimych. Jednym z pierwszych NGOs działających w tym obszarze był Społeczny Instytut Ekologiczny, który w latach 2000-2010 zrealizował jeden z największych projektów reintrodukcji ras rodzimych do gospodarstw na Mazowszu. Rolnicy otrzymali zwierzęta ośmiu ras rodzimych, w tym dwie rasy koni: koniki polskie i hucuły. $\mathrm{W}$ ramach projektu przeprowadzono wiele szkoleń i wydano kilkadziesiąt publikacji, prowadzono także promocje w mediach na temat znaczenia bioróżnorodności. Efekty projektu są obecne do dziś, gdyż wielu hodowców utrzymuje konie i uczestniczy w programie ochrony. Na uwagę zasługuje aktualnie realizowany przez Lubelskie Towarzystwo Ornitologiczne projekt „Czynna ochrona rzadkich gatunków zwierząt w Puszczy Solskiej” (2016-2020). Głównym celem projektu jest zabezpieczenie i polepszenie warunków bytowych rzadkich gatunków ptaków, tj. orlika krzykliwego, bielika, bociana czarnego, głuszca, w Puszczy Solskiej m.in. z wykorzystaniem wypasu koników polskich.

Ogólnopolskie Towarzystwo Ochrony Ptaków (OTOP) chroni dzikie tereny poprzez zakładanie rezerwatów. Jednym z pierwszych jest rezerwat Karsiborska Kępa, położony na wyspie o tej samej nazwie. Pierwsze koniki polskie wprowadzono do tego rezerwatu w 2010 r.. Stado, które w 2017 r. liczyło 30 koników polskich, pomaga chronić otwarte tereny przed zarastaniem przez trzcinę. W ramach popularyzacji swoich działań OTOP zarządza też akcją „Adoptuj konika!”. Pozostałe organizacje, które prowadzą regularny wypas koni ras rodzimych, to: Polskie Towarzystwo Ochrony Ptaków i Towarzystwo Przyrodnicze „Alauda”. Dwa NGOs: Fundacja Ziemia i Ludzie oraz Fundacja im. Stanisława Karłowskiego zajmują się działaniami szkoleniowymi dla rolników, nauczycieli i doradców, również z wykorzystaniem nowoczesnych platform e-learningowych. Podejmują także próby prowadzenia zajęć edukacyjnych dla dzieci i młodzieży z wykorzystaniem zagrody edukacyjnej, w której utrzymywane są zwierzęta ras rodzimych, w tym koniki polskie.

Spośród 20 zidentyfikowanych organizacji pięć prowadzi działania dotyczące użytkowania i ochrony rodzimych ras koni, cztery wykorzystują rasy koni do ochrony siedlisk ptaków oraz ochrony przyrody specyficznej dla danego terenu i zachowania bogactwa bioróżnorodności, a dwa zajmują się edukacją, popularyzacją i promocją rodzimych ras koni.
\end{abstract}

Praca wykonana w ramach programu wieloletniego, zadania 03-17-14-09. 


\title{
PORÓWNANIE ORGANIZACJI TURYSTYCZNYCH RAJDÓW KONNYCH W POLSCE I GRUZJI
}

\author{
Comparison organization touristic equestrian rallies in Poland and Georgia
}

\section{Bogusława Długosz, Anna Klich, Romana Augustyn, Magdalena Pieszka, Jarosław Łuszczyński, Zenon Podstawski, Monika Stefaniuk-Szmukier}

\author{
Uniwersytet Rolniczy im. H. Kołłątaja w Krakowie, Instytut Nauk o Zwierzętach, Zakład Hodowli Koni \\ al. Mickiewicza 24/28, 30-059 Kraków \\ e-mail: boguslawa.dlugosz@urk.edu.pl
}

Turystyka jeździecka w Polsce rozwija się prężnie, mocnymi stronami są niewątpliwie wspaniałe krajobrazy oraz dobrze rozwinięta infrastruktura szlaków konnych, mających przebieg na najciekawszych terenach przyrodniczych w Polsce. W czasach, w których większość ludzi może podróżować bez trudu, otwierają się nowe możliwości spędzania aktywnego wypoczynku w siodle. Wielbiciele turystyki konnej nie muszą ograniczać się tylko do polskich szlaków konnych, mogą spróbować swoich sił przejazdu na końskim grzbiecie po terenach oddalonych o tysiące kilometrów od Polski. Turyści mają możliwość wyjazdu na Ukrainę, do Iranu, Mongolii, Maroka, Kirgistanu i Peru oraz do wielu innych ciekawych zakątków świata. Jednym z krajów, który zyskał dużą popularność wśród jeźdźców, jest Gruzja, a konkretnie masyw Kaukazu.

Celem pracy było porównanie organizacji i przebiegu rajdów konnych w Polsce i Gruzji na podstawie turystyki konnej prosperującej w rejonach górskich. Rajdy konne w Polsce zostały scharakteryzowane na podstawie Transjurajskiego Szlaku Konnego, natomiast w Gruzji - na podstawie konnego trampingu w Chewsuretii po górach Kaukazu.

Pomiędzy rajdem na Transjurajskim Szlaku Konnym i rajdem w gruzińskiej Chewsuretii uwidacznia się szereg zasadniczych różnic. Rajd po Wyżynie Krakowsko-Częstochowskiej jest rajdem, którego trasa pokonuje wzniesienia maksymalnie $400 \mathrm{~m}$ n.p.m., natomiast w Chewsuretii turyści mogą poczuć prawdziwy wysokogórski klimat, przekraczając 3000 m n.p.m. Przebieg Jurajskiego Szlaku Konnego nie powinien stanowić trudności dla jeźdźców amatorów, bieg szlaku łączy się często z drogami asfaltowymi, przechodzi przez wsie i obszary gęsto zaludnione. Na Kaukazie pokonuje się skaliste, wąskie ścieżki nad przepaścią, natrafiając rzadko na osady ludzkie. W razie problemów na rajdzie (wypadek, kulawizna) w Polsce z łatwością wzywa się pomoc, dzwoniąc pod numer alarmowy. Na Kaukazie natomiast zasięg sieci telefonicznych jest jedynie w większych osadach. Rajdy w Polsce z pewnością są szybsze, trzeba być bardzo uważnym ze względu na napotkanych ludzi, zwierzęta, samochody. W Chewsuretii turyści mogą poczuć prawdziwą dziką, dziewiczą naturę. Koszt 8-dniowego rajdu w Polsce to 1200 zł z wypożyczeniem konia, a w Gruzji (łącznie z przelotem) ok. $3000 \mathrm{zł}$. 


\title{
HODOWLA OSŁÓW W POLSCE
}

Donkey breeding in Poland

\author{
Danuta Dziurka $^{1}$, Bogusława Długosz ${ }^{2}$, Agnieszka Szymańska ${ }^{3}$ \\ ${ }^{1}$ Polskie Stowarzyszanie Hodowców Osłów na rzecz Rozwoju Hodowli i Onoterapii, 58-114 Lubachów 3 \\ ${ }^{2}$ Uniwersytet Rolniczy im. H. Kołłątaja w Krakowie, Instytut Nauk o Zwierzętach, Zakład Hodowli Koni, \\ al. Mickiewicza 24/28, 30-059 Kraków \\ ${ }^{3}$ Polski Związek Hodowców Koni, 00-673 Warszawa, ul. Koszykowa 60/62 m. 16 \\ e-mail: boguslawa.dlugosz@urk.edu.pl
}

Hodowla osłów w Polsce dopiero się rozwija. Instytucją zajmującą się rejestracją oraz identyfikacją osłów jest Polski Związek Hodowców Koni, Polskie Stowarzyszanie Hodowców Osłów na rzecz Rozwoju Hodowli i Onoterapii oraz ogrody zoologiczne. Celem pracy była charakterystyka hodowli osłów w Polsce, prowadzonej przez ogrody zoologiczne oraz prywatne hodowle w 2015 r. Uzyskane dane pochodziły od 12 hodowców, 13 ogrodów zoologicznych znajdujących się na terenie Polski, Polskiego Związku Hodowców Koni oraz 11 organizacji pozarządowych zajmujących się ratowaniem koniowatych w Polsce.

Według danych z PZHK z 2015 r. w Polsce znajdowało się 448 osłów posiadających paszporty. Z czego 323 było przypisane do poszczególnych województw, a 79 miało udokumentowane pochodzenie. Dane wskazywały na to, że najwięcej osłów posiadających paszporty znajdowało się w województwach dolnośląskim oraz pomorskim i spośród tych właśnie najwięcej miało udokumentowane pochodzenie (49\% w pomorskim i około 34\% w dolnośląskim). Według rejestrów w Polsce znajdowało się dokładnie tyle samo samców (202 ogiery i 22 wałachy) oraz samic (224 oślice). Aby można było sprzedać osła, musi mieć on wyrobiony paszport. W prowadzeniu hodowli normalnym zjawiskiem jest częstsze sprzedawanie osobników męskich to z tego właśnie powodu najprawdopodobniej w bazie PZHK było zarejestrowanych aż tyle ogierów. Bardzo wysoka liczba ogierów w stosunku do wałachów była spowodowana najprawdopodobniej tym, że niewielu właścicieli informowało PZHK o przeprowadzonym zabiegu kastracji.

Najdłużej hodowlą osłów w Polsce zajmowały się ogrody zoologiczne, średnio ponad 51 lat. W przypadku prywatnych hodowców średnia długość prowadzenia rozrodu osłów to 7 lat. W większości polskich hodowli osły są utrzymywane w systemie stajenno-pastwiskowym, z dostępem do padoków lub pastwisk, na których spędzają dzień, a w okresie letnim nawet całą dobę. Najczęściej wykorzystywanymi w żywieniu paszami są owies, siano i marchew. Poza użytkowaniem rozpłodowym jedynie 17\% ankietowanych hodowców użytkuje osły do jazdy wierzchem, onoterapii oraz jazdy zaprzęgowej. Powszechnie stosowanym systemem krycia jest harem, inseminacja nie jest stosowana, w większości hodowli rodzi się do dwóch źrebiąt rocznie. W 50\% przypadków oślice są kryte w trzecim roku życia, odsadzenie w 82\% następuje między 9. a 25. miesiącem życia. Hodowcy sprzedają od jednego do dwóch osobników rocznie. 


\title{
ZMIENNOŚĆ GENETYCZNA WYBRANYCH RAS KONI NA PODSTAWIE MARKERÓW SNP
}

Horse breeds genetic diversity on the basis of SNP markers

\author{
Agnieszka Fornal, Agata Piestrzyńska-Kajtoch, Anna Radko, Katarzyna Kowalska \\ Instytut Zootechniki - Państwowy Instytut Badawczy, Zakład Biologii Molekularnej Zwierząt \\ e-mail: agnieszka.fornal@izoo.krakow.pl
}

Markery SNP są powszechnie wykorzystywane w badaniach nad genetyczną zmiennością osobniczą i populacyjną zwierząt, w tym koni. W ostatnich latach znalazły również zastosowanie w kontroli rodowodów. Celem badań było określenie stopnia polimorfizmu wybranych markerów SNP w regionach niekodujących u koni. Materiał badawczy stanowiły losowo wybrane próbki DNA 23 koni trzech ras. Zaprojektowano zestawy specyficznych starterów i znakowanych fluorescencyjnie sond TaqMan MGB dla markerów SNP (221 SNP) zlokalizowanych na wszystkich chromosomach konia, częściowo wybranych z bazy dbSNP Short Genetic Variants. Analizę wykonano metodą dyskryminacji alleli na płytkach OpenArray w aparacie QuantStudio 12K Flex Real-time PCR System.

Zamplifikowano pełny zestaw SNP dla 21 prób, dla dwóch próbek nie uzyskano pełnych genotypów, prawdopodobnie z uwagi na jakość DNA. Określono genotypy badanych osobników. Uzyskane wyniki poddano analizie statystycznej (frekwencje rzadszego allelu - MAF). Mimo niewielkiej próby badawczej, przeważająca większość wybranych SNP okazała się polimorficzna. W dalszych etapach badań zestaw markerów SNP zostanie przetestowany dla większej liczby koni różnych ras. Zweryfikowana zostanie też zmienność SNP, które po pierwszych analizach wydają się być monomorficzne. Proponowany zestaw markerów będzie można w przyszłości wykorzystać nie tylko do analizy zmienności populacji, ale również do kontroli pochodzenia i identyfikacji osobniczej koni. 


\title{
ANALIZA WYNIKÓW UŻYTKOWOŚCI KONI RASY MAŁOPOLSKIEJ
}

\author{
Analysis of performance results for horses of Małopolska breed
}

\author{
Marta Jarosławska, Alicja Borowska
}

Uniwersytet Przyrodniczy w Poznaniu, Zakład Hodowli Koni

e-mail: aborek@up.poznan.pl

Hodowla koni na terenie Polski była od dawna znaczącym elementem w przemyśle gospodarskim. Ze względu na znakomite gleby, rozległe pastwiska i odpowiedni klimat, szczególnym miejscem do chowu koni były ziemie małopolskie. Rozpoczęta tam hodowla osobników w typie konia angloarabskiego ukształtowała następnie rasę koni małopolskich.

Celem pracy była analiza statystyczna wartości użytkowej potomstwa klaczy rasy małopolskiej wyhodowanych w Stadninie Koni (SK) Walewice z uwzględnieniem ich przynależności do rodzin żeńskich. Do analizy zaliczono dwie liczne rodziny: rodzinę $\mathrm{nr} 4$ klaczy 64 Szürk Szikra i rodzinę $\mathrm{nr} 22$ klaczy Zośka.

Przeprowadzono analizę rodowodową pod kątem przynależności rasowej ojca, która objęła 65 ogierów licencjonowanych i 223 klacze hodowlane. Analiza wykazała, że najczęściej używano do rozrodu ogiery rasy małopolskiej oraz pełnej krwi angielskiej.

Przeanalizowano wyniki prób dzielności po zakładzie treningowym 44 ogierów i 12 klaczy. Większość ogierów zakończyła próbę z oceną bardzo dobrą, natomiast większość klaczy z oceną dobrą. Lepszą średnią ocen otrzymały ogiery wywodzące się z rodziny klaczy 64 Szürk Szikra, natomiast średnia wartość bonitacji była minimalnie wyższa dla ogierów z rodziny klaczy Zośka. Różnice te nie były jednak istotne statystycznie. Niektóre ogiery małopolskie wyhodowane w Stadninie odznaczyły się wysoką wartością hodowlaną wśród ogierów półkrwi. Z rodziny klaczy 64 Szürk Szikra wyraźnie wyróżnił się ogier Browar 1998 (Sebastian $\mathrm{m}$ - Belisima m po Pick Wick AA), który zajął w rankingu 5. miejsce na 1578 pozycji. Kolejny ogier w stawce również należał do tej rodziny. Może to świadczyć o minimalnej wyższości rodziny klaczy 64 Szürk Szikra nad rodziną klaczy Zośka pod kątem wartości użytkowej W przeprowadzonym teście t-studenta nie zaobserwowano istotnych statystycznie różnic między średnimi wynikami wartości hodowlanej ogierów potomków klaczy z dwóch rodzin żeńskich.

Analiza wartości użytkowej objęła także wyniki Mistrzostw Polski Młodych Koni (24 konie), wyniki w sporcie jeździeckim (29 koni) oraz wyścigach (41 koni). Zebrane dane pozwoliły stwierdzić, iż konie małopolskie z SK Walewice odnosiły najwięcej sukcesów sportowych we Wszechstronnym Konkursie Konia Wierzchowego. Jednym z ogierów odnoszących sukcesy w WKKW jest ogier Huzar 2004 (Jalienny AA, Huanita po Toledo xx). Dodatkowo konie z rodziny klaczy 64 Szürk Szikra sprawdzały się bardzo dobrze w konkursach skoków przez przeszkody, czego przykładem może być klacz Bretania 1991 (Campetot AA, Belgiana po Amok xo) oraz ogier Burgund 1988 (Juriste AA, Blanka po Ułus xo). W wyścigach koni półkrwi zdecydowaną przewagę miały zarówno klacze, jak i ogiery z rodziny klaczy Zośka. Analiza statystyczna nie wykazała jednak statystycznie istotnych różnic między wynikami ogierów pochodzących z dwóch rodzin. Przeprowadzone analizy z uwzględnieniem przynależności do rodzin żeńskich wskazują na celowość takich badań w kontekście decyzji hodowlanych co do utrzymywania najlepszych rodzin klaczy w stadninach. Natomiast aby dokonać dokładniejszej oceny wartości hodowlanej koni należy zebrać większą liczbę obserwacji dotyczących oceny użytkowej koni w Stadninie Koni Walewice, co może być motywacją do podjęcia dalszych badań. 


\title{
OCENA SZYBKOŚCI UCZENIA SIE KONI W OPARCIU O TEST ROZWIĄZYWANIA PROBLEMU
}

\author{
Assessment of horses learning speed based on problem solving test
}

\author{
Ewa Jastrzębska ${ }^{1}$, Kateryna Slivinska ${ }^{2}$, Aleksandra Górecka-Bruzda ${ }^{3}$ \\ ${ }^{1}$ Uniwersytet Warmińsko-Mazurski w Olsztynie, Katedra Hodowli Koni i Jeździectwa \\ ${ }^{2}$ Schmalhausen Institute of Zoology, Kyiv, Ukraine, Department of Parasitology \\ ${ }^{3}$ Instytut Genetyki i Hodowli Zwierząt PAN w Jastrzębcu, Zakład Zachowania się Zwierząt \\ e-mail: e.jastrzebska@uwm.edu.pl
}

Zdolność uczenia się jest cechą odgrywającą ważną rolę w użytkowaniu i chowie koni. Szybciej uczące się zwierzęta lepiej radzą sobie podczas treningu i w trakcie obsługi. Celem niniejszej pracy była ocena indywidualnej szybkości uczenia się koni w oparciu o test rozwiązywania problemu.

Materiał badawczy stanowiło 39 koni (21 klaczy, 18 wałachów). Zwierzęta reprezentowały trzy typy rasowe: kuce i konie prymitywne, typ szlachetny oraz typ pogrubiony. Siedem z badanych osobników było użytkowanych sportowo w skokach przez przeszkody, a 32 rekreacyjnie w szkółkach jeździeckich. Zwierzęta poddano doświadczeniu mającemu na celu ocenę szybkości uczenia i zapamiętywania, które przeprowadzono na podstawie testu rozwiązywania problemu z użyciem motywatora pokarmowego (marchewka). Doświadczenie przeprowadzono w boksach, $\mathrm{z}$ minimum dwugodzinną przerwą przed i po jedzeniu. Test wykonano w pięciu etapach, różnicując stopień trudności. Podczas testu dokonano następujących pomiarów: liczby wskazań koniowi, gdzie leży marchewka; czasu, jakiego potrzebował koń, by zjeść marchewkę leżącą koło wiaderka; czasu, jakiego potrzebował koń, by zjeść marchewkę leżącą pod wiaderkiem; liczby prób przesunięcia wiaderka. W pięciostopniowej skali oceniano perfekcję, czyli sprawdzano, za którym podejściem koń dostał się do marchewki. Jeżeli koń nie wykonał danego etapu, wracano do poprzedniego. Jeśli w dalszym ciągu nie radził sobie z zadaniem, próbę uznawano za niezaliczoną.

Cały test wykonano dwa razy, $\mathrm{z}$ miesięczną przerwą między testem wstępnym a próbą pamięciową w celu sprawdzenia, jak koń zapamiętał zadanie.

Wstępna analiza wyników wykazała, że:

- czas wykonywanych czynności malał wraz z liczbą wykonanych prób,

- najszybciej uczyły się konie w typie pogrubionym, co uwidoczniło się w szybkości znajdywania marchewki schowanej pod wiaderkiem w próbie pamięciowej,

- konie sportowe lepiej rozwiązywały problem niż konie rekreacyjne, osiągając krótszy czas znalezienia schowanej pod wiaderkiem marchewki oraz mniejszej liczby prób przesunięcia wiaderka, by znaleźć smakołyk,

- wałachy osiągnęły lepsze wyniki niż klacze (potrzebowały mniej wskazówek, by znaleźć smakołyk w teście wstępnym, a następnie szybciej znajdowały marchewkę schowaną pod wiaderkiem w próbie pamięciowej).

W przeprowadzonym doświadczeniu strategią uczenia się koni była metoda prób i błędów, za pomocą której zapamiętywały one wykonywane czynności i utrwalały tylko te, które przynosiły pożądany efekt. 


\title{
STAN WIEDZY UŻYTKOWNIKÓW KONI W POLSCE NA TEMAT FIZJOTERAPII TYCH ZWIERZĄT
}

State of knowledge of horse users in Poland about physiotherapy of these animals

\author{
Ewa Jastrzębska, Ewa Wadas, Adriana Bartkowicz, Zbigniew Jaworski
}

Uniwersytet Warmińsko-Mazurski w Olsztynie, Katedra Hodowli Koni i Jeździectwa

e-mail: e.jastrzebska@uwm.edu.pl

Fizjoterapia zwierząt, zwana zoofizjoterapią, jest jedną z dziedzin weterynarii utworzoną po $1980 \mathrm{r}$. w USA. Główny jej cel stanowią działania przywracające organizmowi zdolność do prawidłowego ruchu i funkcjonowania. Działania fizjoterapeutyczne niosą pomoc osobnikom, u których wystąpiły problemy zdrowotne, niezależnie od ich wieku, a także obejmują profilaktykę i promocję zdrowia. Fizjoterapię, w zależności od stosowanych metod leczniczych, dzieli się na fizykoterapię, kinezyterapię i terapie manualne.

Celem niniejszej pracy była analiza wiedzy użytkowników koni o różnych metodach fizjoterapii koni. Badania przeprowadzono na próbie 98 użytkowników koni, w okresie wrzesień - październik 2017 r. Badania opinii jeźdźców na temat fizjoterapii koni przeprowadzono w oparciu o metodę anonimowej ankiety bezpośredniej. Zawierała ona pytania dotyczące: samooceny stanu wiedzy na temat fizjoterapii, powszechności stosowania zabiegów fizjoterapeutycznych, zainteresowania pogłębianiem wiedzy na ten temat, oceny przydatności zabiegów fizjoterapeutycznych u koni, ich skuteczności w zapobieganiu urazom, ceny w stosunku do zabiegów i częstości stosowania zabiegów. W kwestionariuszu ankietowym postawiono 8 pytań merytorycznych oraz pytania o dane respondentów - dane metryczkowe. Do wyliczeń korelacji pomiędzy zmiennymi mierzonymi na skali jakościowej zastosowano standardowy test chi-kwadrat. Różnice istotne statystycznie określone zostały na poziomie $\mathrm{p} \leq 0,05$.

Wśród respondentów kobiet było blisko ośmiokrotnie więcej $(88,8 \%)$ niż mężczyzn $(11,2 \%)$. Nieco ponad połowa respondentów $(57,1 \%)$ stosowała zabiegi fizjoterapeutyczne na koniach. Największy odsetek stosujących zabiegi stanowiły osoby z grupy wiekowej powyżej 41. roku życia, pomimo że grupa osób z przedziału wiekowego 21 lat i poniżej była najliczniejsza w badaniach. Wszyscy ankietowani stwierdzili, że zoofizjoterapia jest przydatną formą rehabilitacji koni, a 94,9\% uważa, iż powinna być bardziej rozpowszechniona w Polsce. Większość respondentów wykazała pozytywną postawę wobec przedstawionych w ankiecie form rehabilitacji $(87,8 \%)$, a ponad połowa respondentów oceniła swoją wiedzę na temat zoofizjoterapii dobrze i bardzo dobrze (51,6\%). Masaż, który nie wymaga zbyt wielkiego nakładu finansowego, był stosowany przez największy odsetek osób $(96,4 \%)$, co świadczy o tym, że użytkownicy koni szukają sposobów, aby odpowiednio zadbać o swoje zwierzęta, a jeśli jest to konieczne, są także w stanie przeznaczyć odpowiednią kwotę pieniędzy, żeby wyleczyć konia.

Wykonana analiza badawcza pozwoliła na potwierdzenie pozytywnej postawy użytkowników koni wobec fizjoterapii. Mając na uwadze dobro koni, zapobieganie negatywnym skutkom zbyt ciężkich treningów oraz zmniejszanie ich stresu, istnieje potrzeba kształcenia właścicieli i opiekunów w kierunku właściwej opieki nad końmi, przy jednoczesnej dbałości o ich dobrostan. Może temu służyć także wiedza z zakresu możliwości zastosowania fizjoterapii, za sprawą której można wspomóc proces leczenia zwierząt oraz zapobiegać urazom związanym z użytkowaniem koni. W Polsce fizjoterapia jest mniej znana i rzadziej stosowana niż w USA, Australii, Szwecji czy Finlandii, jednak Polacy coraz bardziej się nią interesują. 


\title{
ZACHOWANIE KONI REKREACYJNYCH
}

\author{
Behavior of recreational horses \\ Ewa Jastrzębska, Ewa Wadas, Yuliia Sitchenko, Zbigniew Jaworski \\ Uniwersytet Warmińsko-Mazurski w Olsztynie, Katedra Hodowli Koni i Jeździectwa \\ e-mail: e.jastrzebska@uwm.edu.pl
}

Konie rekreacyjne to grupa bardzo zróżnicowana pod względem płci, typu, pokroju i rasy. W ich przypadku zdecydowanie ważniejszą rolę od idealnej budowy czy cennego rodowodu pełnią cechy temperamentu i charakteru koni, m.in. niewielka reaktywność, przewidywalność reakcji, opanowanie, chęć współpracy z człowiekiem, brak narowów i problemów w obsłudze.

Celem niniejszej pracy było zbadanie zachowania się koni rekreacyjnych pod wpływem wybranych czynników środowiskowych: umiejętności jeźdźca, systemu utrzymania i intensywności pracy.

Materiał badawczy stanowiły 24 konie użytkowane rekreacyjnie w województwie warmińsko-mazurskim. Obserwacje i badania były przeprowadzone w dwóch stajniach (Kortowo, Popielno) różniących się pod względem ilości koni, ich typów i ras, systemu utrzymania, żywienia i intensywności pracy w roku kalendarzowym. Każdy koń był obserwowany pod jeźdźcami o różnym stopniu umiejętności: początkującym, średniozaawansowanym i zaawansowanym. Za jeźdźca początkującego uznano takiego, którego umiejętności pozwalały na samodzielny stęp, kłus oraz obejmowały początki nauki galopu. Osoba o średnim zaawansowaniu swobodnie poruszała się galopem, znała podstawy ujeżdżenia (praca na kołach) i zasady bezpiecznego poruszania się na ujeżdżalni. Instruktorzy i trenerzy jazdy konnej oraz osoby jeżdżące sportowo byli w niniejszych badaniach traktowani jako jeźdźcy zaawansowani. Każdy z uczestników wypełniał ankietę składającą się z dwóch części: I - „przed jazdą" - opisującą jeźdźców i ich preferencje wobec koni oraz II - ,po jeździe” - obejmującą ocenę dosiadanego konia. Wszystkie przygotowania do jazdy i treningi były obserwowane w celu późniejszej interpretacji zachowania koni.

Wyniki uzyskane podczas badań wskazują, iż najwięcej osób (81\%) wybierało jazdę konną w stadninach lub ośrodkach jeździeckich pod okiem instruktora, gdyż zwiększało to poczucia bezpieczeństwa jeźdźców w trakcie jazdy. Jeźdźcy preferowali konie o temperamencie sangwinicznym (60\%) - wierzchowce zachowujące spokój i opanowanie przy jednoczesnej chęci do ruchu. Przekładało się to na zadowolenie z jazdy ze strony osób jeżdżących. Badania wykazały bezpośredni wpływ zachowania jeźdźca i jego nastawienia na zachowanie konia podczas przygotowania i jazdy konnej. Doświadczenie, umiejętności jeździeckie i postawa osoby miały wpływ na porozumienie i współpracę z koniem. Wykazano także wpływ systemu utrzymania na zachowanie się koni. Utrzymywanie koni w warunkach bezstajenno-pastwiskowych w Popielnie było zgodne $\mathrm{z}$ behawiorem tych zwierząt. Towarzystwo innych koni i zapewniona przestrzeń do poruszania się pozwalały na odprężenie po jeździe i zmniejszenie występowania zachowań niepożądanych. Stosowany natomiast w Ośrodku Jeździeckim w Kortowie system utrzymania stajenno-pastwiskowy ułatwiał obsługę zwierząt, jednak krótki czas spędzany przez zwierzęta na wybiegach lub pastwiskach był niewystarczający i powodował występowanie zachowań niepożądanych podczas obsługi i jazdy konnej. Zaobserwowano także, iż regularność pracy koni wpłynęła na zmniejszenie występowania zachowań niepożądanych podczas jazdy konnej. Dlatego zarówno bezpieczeństwo jeźdźców, jak i dobrostan zwierząt będą zapewnione, jeśli konie zostaną poddane regularnemu treningowi z zachowaniem zasad odpowiedniego obciążenia pracą i właściwego dopasowania jeźdźców do koni. 


\title{
SUPLEMENTACJA PYŁKIEM PSZCZELIM WPŁYWA NA WYBRANE WSKAŹNIKI KRWI KONI GERIATRYCZNYCH
}

Bee pollen supplementation to geriatric horses seems to improve some blood parameters

\author{
Witold Kędzierski ${ }^{1}$, Iwona Janczarek ${ }^{2}$, Sylwester Kowalik ${ }^{3}$, Monika Franczyk ${ }^{1}$, Łukasz Chrobak $^{1}$, \\ Grzegorz Borsuk ${ }^{4}$ \\ ${ }^{1}$ Uniwersytet Przyrodniczy w Lublinie, Katedra Biochemii \\ ${ }^{2}$ Uniwersytet Przyrodniczy w Lublinie, Katedra Hodowli i Użytkowania Koni \\ ${ }^{3}$ Uniwersytet Przyrodniczy w Lublinie, Katedra Fizjologii Zwierząt \\ ${ }^{4}$ Uniwersytet Przyrodniczy w Lublinie, Instytut Biologicznych Podstaw Produkcji Zwierzęcej \\ e-mail: witold.kedzierski@up.lublin.pl
}

Potrzeba utrzymania w dobrej kondycji koni starzejących się i starych staje się coraz bardziej powszechna. Szczególnie trudnym okresem dla zwierząt jest przesilenie jesienne. W tym czasie odnotowuje się m.in. spadek odporności oraz obniżenie wartości wskaźników hematologicznych. Celem podjętych badań było określenie wpływu suplementacji pyłkiem pszczelim na wartość wybranych parametrów krwi koni geriatrycznych. Badania przeprowadzono w okresie wczesnojesiennym na grupie 16 koni w wieku 15-26 lat użytkowanych w rekreacji. Konie podzielono na 2 grupy po 8 osobników każda, po czym jednej z nich podawano $60 \mathrm{~g}$ pyłku pszczelego 2 razy dziennie przez 30 dni. Pyłek był nasączany wodą $12 \mathrm{~h}$ przed podaniem. Przed rozpoczęciem doświadczenia i po jego zakończeniu oceniono ogólny stan zdrowia koni i ich chęć do pracy oraz pobrano krew do badań. W uzyskanych próbkach krwi oznaczono szereg parametrów hematologicznych, takich jak liczbę krwinek czerwonych (RBC) i płytek krwi (PLT), hematokryt (Ht), stężenie hemoglobiny $(\mathrm{Hb})$ i wiele innych oraz parametry biochemiczne, w tym stężenie glukozy, triacylogliceroli, cholesterolu we frakcjach HDL i LDL, profil wątrobowy, nerkowy i mięśniowy, oraz parametry odpornościowe i antyoksydacyjne: poziom immunoglobulin, stężenie grup SH w białkach, aktywność peroksydazy glutationowej (GSH-Px) i całkowitą zdolność antyoksydacyjną osocza (FRAP). Otrzymane wyniki poddano jednoczynnikowej analizie wariancji (MANOVA) z zastosowaniem testu t-Studenta. W grupie kontrolnej stwierdzono w badanym okresie istotny spadek wartości RBC, Ht, Hb i FRAP, podczas gdy w grupie badanej wartości tych parametrów utrzymały się na niezmienionym poziomie. Nie odnotowano różnic w kondycji fizycznej i wartości użytkowej badanych koni. Podsumowując, suplementacja pyłkiem pszczelim w okresie przesilenia jesiennego miała pozytywny efekt, gdyż zapobiegła niekorzystnym spadkom wybranych parametrów krwi badanych koni geriatrycznych. W celu potwierdzenia pozytywnego wpływu suplementacji pyłkiem pszczelim na organizm konia należy wykonać dalsze badania na szerszej grupie koni, w różnych układach doświadczalnych. 


\title{
TECHNIKA ODBICIA KONI STARTUJACCYCH W KONKURENCJI SKOKÓW PRZEZ PRZESZKODY W ŚWIETLE ANATOMII FUNKCJONALNEJ
}

The technique of bounce of show jumping horses in view of functional anatomy

\author{
Marcin Komosa, Gabriela Biedka
}

Uniwersytet Przyrodniczy w Poznaniu, Zakład Anatomii Zwierząt
e-mail: marcin.komosa@up.poznan.pl

Celem badań było porównanie techniki stawiania tylnych kończyn koni podczas początkowej fazy skoku, jakim jest moment odbicia. Przeanalizowano technikę koni młodych, zaczynających dopiero karierę sportową oraz koni zaawansowanych. Poprawność fazy odbicia decyduje o jakości oraz skuteczności skoku, jak również może świadczyć o pewnych nieregularnościach ruchowych, a nawet o istnieniu dyskomfortu w pewnych partiach ciała konia. Należy również wziąć pod uwagę efekt nabywanego przez konie doświadczenia, skutkującego stopniowym polepszaniem się koordynacji pracy poszczególnych grup mięśni. Stąd hipoteza postawiona w niniejszych badaniach zakładała, że konie stojące u progu kariery sportowej cechują się gorszą koordynacją ruchową kończyn miednicznych podczas odbicia aniżeli konie zaawansowane.

Badania przeprowadzono na zawodach rangi ogólnopolskiej w trzech klasach wysokości przeszkód: pośredniej, normalnej i ciężkiej. Zdjęcia oraz nagrania w zwolnionym tempie zrobiono podczas pokonywania parkuru, koncentrując się na dwóch przeszkodach ustawionych w linii: stacjonacie oraz okserze. Wśród całej grupy 54 koni różnica w technice odbicia rozłożyła się następująco - 31 koni stawiało prawą i lewą kończynę miedniczną w znacznej odległości od siebie (jedna z nich wyraźnie bardziej podstawiona pod tułów niż druga), podczas gdy 23 konie stawiały kończyny obok siebie, co wskazuje na zbliżony stopień zgięcia zwłaszcza obustronnych stawów biodrowych. Wyraźne różnice frekwencji powyższych technik pojawiły się podczas analizy poszczególnych konkursów. W klasach P i N na 32 konie aż 23 stawiały kończyny w znacznej odległości od siebie, tylko zaś 9 w sposób synchroniczny. W najwyższym analizowanym konkursie klasie C, sytuacja była odwrotna. Na 22 startujące konie 16 osobników stawiało kończyny tylne synchronicznie, a tylko 6 nierówno.

Biorąc pod uwagę fakt, że w niższych klasach startowały głównie konie młode, wyniki sugerują znaczącą różnicę w technice odbicia wyżej wymienionych dwóch grup koni. Jednoczesne i bardziej skoordynowane stawianie kończyn u koni doświadczonych jest techniką ułatwiającą skok, z powodu równomiernej kumulacji energii w obu kończynach i optymalnego wykorzystania siły odbicia oraz zdolności oddania bardziej pionowych skoków. Lepsza synchronizacja stawiania kończyn w początkowej fazie skoku związana jest zwłaszcza z umiejętnością aktywizacji mięśni zginaczy stawu biodrowego, przy jednoczesnym wyprostowaniu stawu kolanowego (zwłaszcza m. najdłuższy uda, m. czworogłowy uda, m. pośladkowy powierzchowny, m. lędźwiowy większy). Galop jako chód trójtaktowy jest chodem asymetrycznym, stąd młode konie mają trudności w wyrównaniu pracy obu stawów biodrowych w ostatnim momencie przed odbiciem. Istotna jest wówczas także umiejętność rozluźnienia mięśni nadosiowych grzbietu i lędźwi (m. najdłuższy lędźwi i klatki piersiowej zintegrowany z m. biodrowo-żebrowym). Umożliwia to zgięcie kręgosłupa lędźwiowego podczas podstawienia kończyn miednicznych pod tułów. Zrozumienie odmienności w technice odbicia może przyczynić się do większej świadomości treningu koni młodych. W przypadku koni starszych o wypracowanej już indywidualnej technice odbicia utrata synchronizacji pracy tylnych kończyn może świadczyć o przeciążeniach bądź kontuzjach i oszczędzaniu przez zwierzę jednej z kończyn lub kręgosłupa. Newralgicznym miejscem, którego uszkodzenie wpływa na gorszą pracę kończyn miednicznych, jest staw krzyżowobiodrowy wraz $\mathrm{z}$ okolicznymi więzadłami, będący zasadniczym połączeniem integrującym kończynę ze szkieletem osiowym. 


\title{
MOŻLIWOŚĆ WYKORZYSTANIA NOWEGO BODŹCA WĘCHOWEGO W ŁAGODZENIU STRESU U KONI
}

The possibility of using a new olfactory stimulus in relieving stress in horses

\author{
Wanda Krupa ${ }^{1}$, Jadwiga Topczewska ${ }^{2}$
}

\footnotetext{
${ }^{1}$ Uniwersytet Przyrodniczy, Zakład Hodowli i Dobrostanu Zwierząt Towarzyszących, ul. Akademicka 13, 20-950 Lublin ${ }^{2}$ Uniwersytet Rzeszowski, Wydział Biologiczno-Rolniczy, Katedra Produkcji Zwierzęcej i Oceny Produktów Drobiarskich, ul. Zelwerowicza 4, 35-601 Rzeszów

e-mail:wanda.krupa@up.lublin.pl,jtopczewska@ur.edu.pl
}

W praktyce hodowlanej konieczność transportowania koni jest nieunikniona. Jednak dla wielu osobników, szczególnie tych, które są przewożone sporadycznie, już sam załadunek jest źródłem silnego stresu, a podejmowane przy tym czynności często utrwalają lęk konia przed wejściem do przyczepy. Stosowanie substancji trankwilizujących nie zawsze jest uzasadnione. Dlatego też poszukuje się alternatywnych metod, które obniżyłyby poziom stresu, a więc zapewniły optymalny poziom dobrostanu.

Celem pracy była próba oceny wpływu nowego bodźca węchowego na zachowanie koni i wartość wskaźnika pracy serca podczas załadunku do przyczepy transportowej.

Materiał badawczy stanowiło 12 sztuk koni własności prywatnej w typie rasy małopolskiej, w wieku od 7 do 14 lat, przewożonych sporadycznie i wykazujących strach i znaczny opór przed wchodzeniem do przyczepy transportowej. Konie poddane zostały próbie wprowadzenia (przez osobę znaną) do przyczepy transportowej. Test trwał 3 minuty i w tym czasie oceniano (w punktach) reaktywność behawioralną każdego osobnika według stereotypu opracowanego na podstawie pilotażowych badań. Przed testem (w stajni), podczas testu oraz po powrocie do boksu (przez okres 5 minut) u każdego konia rejestrowano pracę serca. Drugi etap badań przeprowadzono analogicznie, ale konie były wyeksponowane na działanie nowego bodźca węchowego w postaci olejku lawendowego.

$\mathrm{Na}$ podstawie przeprowadzonych badań stwierdzono, że czynności związane z załadunkiem do przyczepy transportowej są dla koni potencjalnym źródłem stresu, co znalazło odzwierciedlenie zarówno w reaktywności behawioralnej, jak i wartości wskaźnika pracy serca. Zastosowanie nowego bodźca węchowego (w postaci olejku lawendowego) wpłynęło znacząco na reaktywność behawioralną (obniżając intensywność reakcji niepożądanych) oraz istotnie obniżyło wartość wskaźnika pracy serca. Uzyskane wyniki wskazują, iż olejek lawendowy może być interesującą alternatywą dla tradycyjnych metod obniżania poziomu stresu podczas różnych czynności i zabiegów niezbędnych w praktyce hodowlanej. 


\title{
CZĘSTOŚĆ WYSTĘPOWANIA RÓŻNEGO RODZAJU MORZYSK U KONI NA TERENIE AGLOMERACJI LUBELSKIEJ
}

\author{
Prevalence of different colics in horses in Lublin area
}

\author{
Marta Liss, Izabela Wilk \\ Uniwersytet Przyrodniczy w Lublinie, Katedra Hodowli i Użytkowania Koni, ul. Akademicka 13, 20- 950 Lublin \\ marta.liss@up.lublin.pl
}

Badania dotyczyły częstości występowania różnego rodzaju morzysk u koni. Jest to zawsze aktualny temat, głównie ze względu na ewolucyjne niedostosowanie układu pokarmowego konia do obecnych warunków utrzymania. Opisywanych jest wiele klasyfikacji morzysk, wśród których jedna z definicji określa to zjawisko jako zaburzenia czynnościowo-trawienne, stany zapalne i zanikowo-rozrostowe, zatkania i zalegania kałowe, przemieszczenia mechaniczne bez zastoju krwi i niedrożności strangulacyjne, kolki nietypowe o złożonej etiologii, kolki chroniczne i nawrotowe oraz choroby kolkowe źrebiąt. W definicji tej wykorzystano prosty podział, z jakiego korzystają zootechnicy, a mianowicie: morzysko pokarmowe, piaskowe, powietrzne i glistnicze. Wszystkie one związane są z najczęściej występującymi przyczynami chorób kolkowych, możliwych do stwierdzenia przez właścicieli i opiekunów koni. Celem pracy była próba określenia częstości występowania różnego rodzaju morzysk u koni na terenie aglomeracji lubelskiej w okresie jednego roku. Przeprowadzono ustne wywiady w większości (22) ośrodków jazdy konnej na terenie aglomeracji lubelskiej. W badanych ośrodkach utrzymywano 467 koni, z których 21 (4,5\%) cierpiało na morzysko. W niektórych przypadkach morzyska powtarzały się, dlatego całkowita liczba morzysk wyniosła 28. Stwierdzono, ze morzyska trudno jest uniknąć nawet przy zachowaniu szczegółowych reguł dobrostanu w aglomeracji lubelskiej. Choroba ta wystąpiła w 45,5\% ośrodków jazdy konnej, chociaż odsetek chorujących koni był niewielki (4,5\%). Możliwość prawidłowego leczenia i zapobiegania nawrotom choroby jest uzależniona od poznania jej podłoża. W 53,6\% przypadków morzysk ich przyczyna nie została zdiagnozowana. Według lekarzy weterynarii większość to były morzyska o podłożu pokarmowym - żołądkowe i jelitowe. Wyniki wskazują, że konie w każdym wieku i każdej płci są w podobnym stopniu narażone na morzyska. Schorzenie to występuje najczęściej wieczorem. Liczba przypadków zwiększa się również wiosną. Czynnikami wpływającymi na występowanie morzysk jest sposób pojenia oraz rodzaj substancji aktywnej w środku odrobaczającym. Nie odnotowano natomiast wyraźnego związku częstości występowania morzysk z przebywaniem koni na pastwiskach, rodzajem zadawanych pasz i ich ilością, obecnością stereotypii, intensywnością i rodzajem użytkowania oraz narażeniem na stres. 


\title{
WERYFIKACJA METOD OKREŚLENIA MASY CIAŁA NA PODSTAWIE WYMIARÓW BIOMETRYCZNYCH ŹREBIĄT ISLANDZKICH
}

\author{
Verification of body weight determination methods based on the biometric measurements \\ of the Icelandic foals
}

\begin{abstract}
Jarosław Łuszczyński, Weronika Pisarczyk, Anna Furtak, Magdalena Pieszka, Bogusława Długosz, Romana Augustyn, Zenon Podstawski
\end{abstract} Uniwersytet Rolniczy w Krakowie, Instytut Nauk o Zwierzętach, Zakład Hodowli Koni, al. Mickiewicza 24/28, 30-059 Kraków
e-mail: jluszczynski@ar.krakow.pl

Prawidłowe szacowanie masy ciała koni pozwala na odpowiednie dopasowanie nie tylko dawek pokarmowych, ale także dawek leków lub innych preparatów zarówno podczas leczenia, jak i podczas zabiegów profilaktycznych, np. odrobaczania czy szczepienia. Najlepszym sposobem ustalenia masy ciała jest wykonanie pomiaru z wykorzystaniem specjalnie do tego celu przystosowanych wag platformowych, jednak nie zawsze jest dostępu do takich urządzeń. Alternatywne metody opracowane zostały przede wszystkim dla koni dorosłych. Brak natomiast sposobów wiarygodnego określenia masy ciała koni w okresie wzrostu i dojrzewania, gdy przyrost tego wskaźnika jest bardzo intensywny, a proporcje ciała źrebiąt różnią się zasadniczo od proporcji ciała koni dorosłych. Celem pracy była ocena przydatności wybranych metod określania masy ciała koni islandzkich w pierwszym roku życia na podstawie ich wymiarów biometrycznych. Materiał do badań stanowiły 24 konie islandzkie urodzone w Stadninie Koni Islandzkich Punktur. Od urodzenia do wieku jednego roku w miesięcznych odstępach wykonywano u źrebiąt pomiary obwodu klatki piersiowej i podłużnego obwodu tułowia. Na ich podstawie ustalono masę ciała źrebiąt w poszczególnych miesiącach życia, wykorzystując wzory: Marcenac i Aublet (MA) (Marcenac i Aublet 1964), Sasimowskiego, Budzyńskiego i Jelenia (S) (Sasimowski i Budzyński 1987) oraz wzór dla źrebiąt (Z) (Lewis 1996). W kolejnym etapie badań porównano rzeczywistą masę ciała ustaloną z wykorzystaniem wagi platformowej OHAUS T32XW z masą ciała określoną na podstawie analizowanych wzorów w czterech kwartałach pierwszego roku życia źrebiąt, podając procent popełnionych błędów. Wyniki opracowano statystycznie w programie Statistica for Windows 13.1, wykorzystując jednoczynnikową analizę wariancji i test Tukeya. Stwierdzono, że najbardziej wiarygodną metodą szacowania masy ciała okazało się wykorzystanie wzoru „Z”. Masa ciała określona na jego podstawie nie różniła się statystycznie istotnie od rzeczywistej masy ciała źrebiąt. W I kwartale życia była ona zawyżana średnio o 3,0 kg (6,1\%), a w kwartale II i III zaniżana odpowiednio o $1,3 \mathrm{~kg}(4,9 \%)$ i o $2,0 \mathrm{~kg}(5,2 \%)$. Tylko w IV kwartale zaniżanie masy ciała średnio o $12 \mathrm{~kg}(7,2 \%)$ okazało się wysoce istotne $\mathrm{w}$ stosunku do faktycznej masy ciała, ale i tak było najmniejsze $\mathrm{w}$ porównaniu $\mathrm{z}$ pozostałymi wzorami. W okresie pourodzeniowym najlepszym sposobem ustalania badanego wskaźnika okazała się metoda z wykorzystaniem wzoru „MA”, który pozwalał z dokładnością 87,6\% przewidywać masę ciała źrebiąt w tym okresie. Okazało się, że najmniej przydatnym wzorem był wzór „S”, którego użycie generowało wysoce istotny błąd przy szacowaniu masy ciała źrebiąt islandzkich, wynoszący w zależności od badanego okresu życia od 22,2\% do 87,0\%. Na podstawie przebiegu krzywej tempa wzrostu masy ciała w poszczególnych miesiącach życia wyznaczono nowe współczynniki, które wykorzystano do oszacowania masy ciała źrebiąt przy użyciu wzoru „S”. Okazało się, że błąd przy oszacowaniu w ten sposób masy ciała źrebiąt islandzkich w poszczególnych miesiącach nie był większy niż 5\%, co świadczy o tym, że zmodyfikowany wzór „S" może być wiarygodną metodą określania masy ciała źrebiąt pod warunkiem uwzględnienia w nim współczynników wyznaczonych w oparciu o tempo wzrostu tego wskaźnika.

Badania zostały sfinansowane z dotacji przyznanej przez MNiSW na działalność statutową DS 3257/ZHK/2018. 


\title{
ZALEŻNOŚĆ MIĘDZY SKŁADEM MLEKA KLACZY A TEMPEM WZROSTU ŹREBIĄT ISLANDZKICH
}

The relationship between the composition of mare milk and the growth rate of Icelandic foals

\author{
Jarosław Łuszczyński, Weronika Pisarczyk, Magdalena Pieszka, Bogusława Długosz, \\ Romana Augustyn, Zenon Podstawski, Sylwia Siwiec
}

\author{
Uniwersytet Rolniczy w Krakowie, Instytut Nauk o Zwierzętach, Zakład Hodowli Koni, al. Mickiewicza 24/28, 30-059 Kraków \\ e-mail: jluszczynski@ar.krakow.pl
}

Pierwsze miesiące życia źrebiąt są kluczowe do osiągnięcia właściwego stopnia rozwoju, który determinuje późniejsze szeroko pojęte użytkowanie koni. W tym okresie zachodzą ważne zmiany dotyczące morfologii organizmu, składu ciała, funkcji metabolicznych, fizjologicznych i odpornościowych, a tempo przemian jest tym szybsze, im organizm jest młodszy. Mleko klaczy, jego skład i ilość, jest jednym z najważniejszych czynników wpływających na rozwój źrebięcia w początkowym okresie jego życia. Nie ma wielu informacji, w porównaniu z innymi rasami, na temat hodowli koni islandzkich, w tym przebiegu procesów wzrostu i dojrzewania, w polskich warunkach klimatyczno-przyrodniczych. Celem pracy było określenie zależności między składem mleka klaczy a tempem wzrostu źrebiąt islandzkich w pierwszym półroczu życia. Analizą objęto 20 źrebiąt rasy islandzkiej ze Stadniny Koni Islandzkich Punktur. Od urodzenia do szóstego miesiąca życia w miesięcznych odstępach wykonywano u źrebiąt pomiary biometryczne i określano ich masę ciała na wadze pomostowej. Na ich podstawie wyliczono tempo wzrostu. Równocześnie, w miesięcznych odstępach, do momentu odsadzenia źrebiąt, od klaczy zostały pobrane próby mleka (około $60 \mathrm{ml}$ ) w celu określenia zawartości suchej masy, białka, tłuszczu i laktozy. Do analizy próbek mleka użyto aparatu Milco Scan FT120. Analizując zmiany średniej zawartości białka i tłuszczu w mleku klaczy, zaobserwowano, że w drugim miesiącu doszło do wysoce istotnego obniżenia ich poziomów w stosunku do miesiąca pierwszego, w którym koncentracja była największa. Od drugiego do czwartego miesiąca poziom badanych składników nie zmieniał się statystycznie istotnie, ale w piątym nastąpiło gwałtowne, wysoce istotne zwiększenie poziomu białka, ale zmniejszenie poziomu tłuszczu. Największą koncentrację laktozy i suchej masy stwierdzono w pierwszym miesiącu laktacji. Do czwartego miesiąca nie zaobserwowano istotnie statystycznych zmian zawartości zarówno laktozy, jak i suchej masy. W piątym miesiącu poziom obu składników uległ wysoce istotnemu obniżeniu w porównaniu z ich poziomem w czwartym miesiącu. Tempo wzrostu masy ciała, wysokości w kłębie i obwodu klatki piersiowej wysoce istotnie zmniejszało się od pierwszego do czwartego miesiąca życia źrebiąt, a potem nieistotnie wzrastało. Tempo wzrostu obwodu nadpęcia do czwartego miesiąca zmieniało się nieregularnie, by w piątym zanotować wysoce istotny spadek. Nie wykazano istotnych różnic między tempem wzrostu źrebiąt korzystających z mleka o większej i mniejszej zawartości badanych składników w poszczególnych miesiącach laktacji. Wykazano jednak na podstawie oszacowanych współczynników korelacji, że średnia zawartość suchej masy w mleku za całą laktację była istotnie dodatnio skorelowana ze średnim tempem wzrostu masy ciała, tempem wzrostu wysokości w kłębie, obwodu klatki piersiowej i obwodu nadpęcia w pierwszych pięciu miesiącach życia źrebiąt. Im więcej tłuszczu i białka zawierało mleko klaczy, tym intensywniej źrebięta zwiększały swoją masę ciała, wysokość w kłębie i obwód klatki piersiowej, o czym świadczą istotne, dodatnie współczynniki korelacji wyliczone dla tych parametrów. Zawartość laktozy okazała się istotnie, dodatnio skorelowana tylko z tempem wzrostu masy ciała i tempem wzrostu obwodu nadpęcia.

Badania zostały sfinansowane z dotacji przyznanej przez MNiSW na działalność statutową DS 3257/ZHK/2018. 


\title{
RONIENIA U KLACZY W WYNIKU ZAKAŻEŃ EHV-1 - MOŻLIWOŚĆ IMMUNOPROFILAKTYKI
}

\author{
Mare's abortion due to EHV-1 infections - possibility of immunoprophylaxis
}

Angelika Orlewicz, Anna Nienartowicz-Zdrojewska

Bioveta Polska Sp. z o.o., ul. Prosta 51, 00-838 Warszawa

e-mail: orlewicz.angelika@bioveta.eu

Infekcje herpeswirusowe u koni są bardzo powszechne. Największe znaczenie epidemiologiczne i ekonomiczne odgrywa EHV-1, należący do Alphaherpesvirinae. Wirus ten odpowiedzialny jest za infekcje górnych dróg oddechowych, zakażenia układu nerwowego, rodzenie się słabych źrebiąt oraz ronienia.

Do zakażenia może dochodzić poprzez kontakt bezpośredni z zakażonym osobnikiem (droga aerogenna), a także przez kontakt pośredni, np. zakażony sprzęt czy poronione płody. Wrotami infekcji jest błona śluzowa górnych dróg oddechowych, następnie wirus replikuje się w komórkach nabłonka, przedostaje się przez błonę podstawną i za pomocą komórek dendrytycznych i makrofagów dostaje się do węzłów chłonnych. Następuje trwająca kilka dni wiremia. Po przechorowaniu konie pozostają latentnie zakażone. W wyniku immunosupresji (stres, transport, krycie etc.) następuje aktywacja zakażenia latentnego i siewstwo wirusa.

U klaczy źrebnych wirus jest w stanie migrować do śródbłonka naczyń pępowinowych, gdzie namnażając się doprowadza do zapalenia naczyń krwionośnych płodu, zakrzepicy, niedokrwienia oraz w rezultacie do poronienia płodu. Ronienie w wyniku zakażeń EHV-1 przebiega bez wcześniejszych objawów zwiastujących, odsetek roniących $\mathrm{w}$ stadzie klaczy może dochodzić do $50 \%$. Klacze ronią zwykle pomiędzy 7-11 miesiącem ciąży, w terminie od 6 dni do 4 miesięcy po zakażeniu. Poronione płody wykazują charakterystyczne zmiany anatomopatologiczne. Aborcje u klaczy to spory problem ekonomiczny, spowodowany stratą źrebięcia oraz czasu (333 dni ciąży).

W celu ograniczenia strat spowodowanych zakażeniami herpeswirusowymi u koni już od drugiej połowy XX w. trwają ciągłe badania nad opracowaniem skutecznych szczepionek.

W latach 1943-1952 w Kentucky stosowano szczepionki inaktywowane, które produkowano z narządów pochodzących od poronionych, zakażonych płodów. Następnie do produkcji inaktywowanych szczepionek używano antygenu namnożonego na chomikach, poprzez dootrzewnowe zakażanie chomików szczepem EHV- 1 Kentucky B lub D. W wielu krajach równolegle prowadzono badania mające na celu udoskonalenie preparatów zawierających inaktywowany wirus.

Aktualnie na polskim rynku dostępne są szczepionki inaktywowane BioEquin $\mathrm{H}$, BioEquin $\mathrm{FH}$ oraz Equip EHV 1,4. Program szczepień klaczy źrebnych przy użyciu preparatów BioEquin obejmuje 3 szczepienia: w 2, 5-6 oraz 9 miesiącu ciąży. Utrzymywanie wysokiego poziomu przeciwciał przeciwko EHV-1 u klaczy źrebnych ma na celu ograniczenie występowania poronień. Szczepieniem ochronnym powinny być również objęte pozostałe osobniki w stadzie (szczepienia bazowe oraz regularna rewakcynacja co 6 miesięcy) - pozwala to w znacznym stopniu zmniejszyć cyrkulacje wirusa w grupie zwierząt.

W celu minimalizacji odsetka ronień wywołanych EHV oprócz immunoprofilaktyki ważne jest odpowiednie zarządzanie hodowlą i chowem. Idealną sytuacją byłaby możliwość przestrzegania 21-dniowej kwarantanny nowych osobników, dzielenie koni na grupy wiekowe, odizolowanie klaczy źrebnych od reszty stada. Nie zawsze istnieje techniczna możliwość takiej profilaktyki, jednak zawsze należy mieć na uwadze zwiększenie poziomu bioasekuracji w stadzie z ciężarnymi klaczami. Immunoprofilaktyka całego stada, połączona z odpowiednią zoohigieną i bioasekuracją, wymiernie wpłynie na profilaktykę aborcji w stadzie. 


\title{
PREPARAT ESCHERICHIA COLI LINIA NISSLE 1917 W PROFILAKTYCE BIEGUNEK RUJOWYCH U ŹREBIĄT
}

Escherichia coli line Nissle 1917 for the prevention of oestrous diarrhoea in foals

\author{
Magdalena Pieszka, Monika Gołdyn, Jarosław Łuszczyński, Bogusława Długosz, \\ Romana Augustyn, Monika Stefaniuk-Szmukier, Zenon Podstawski
}

Uniwersytet Rolniczy im. Hugona Kołłątaja w Krakowie, Instytut Nauk o Zwierzętach, Zakład Hodowli Koni e-mail:mieszka@ar.krakow.pl

Jednym z najważniejszych elementów w wychowie źrebiąt jest prawidłowe żywienie. Sysaki w początkowym okresie życia (ok. 3-4 tygodni) pobierają jedynie mleko matki. Ilość dostarczonych w nim składników pokarmowych oraz możliwości ich przyswajania wpływają na stan odżywienia młodych organizmów. Różnego rodzaju dolegliwości ze strony przewodu pokarmowego mogą zaburzyć proces trawienia i przyswajania substancji odżywczych. Ciekawym zjawiskiem obserwowanym u większości źrebiąt są tzw. biegunki rujowe, które pojawiają się najczęściej w 7-9 dniu po urodzeniu (mniej więcej w czasie wystąpienia pierwszej, po urodzeniu źrebięcia, rui u klaczy - stąd nazwa biegunki rujowe) i trwają średnio przez 5 dni. Towarzyszą im objawy zawilgotnienia lub zmoczenia okolic zadu. Rzadko te biegunki są intensywne, cuchnące i pieniste. W większości przypadków interwencja weterynaryjna nie jest konieczna. Jednak zdarzają się przypadki, w których biegunka uznana za fizjologiczną przechodzi w formę patologiczną (bardzo nasiloną lub przewlekłą). Do niedawna w zaburzeniach żołądkowo-jelitowych stosowano antybiotyki. Po wprowadzeniu zakazu stosowania ich jako suplementów diety dla zwierząt gospodarskich zaistniała konieczność poszukiwania ich skutecznych zamienników.

Zatem celem niniejszej pracy było określenie wpływu stosowania preparatu mikrobiologicznego opartego na linii Nissle 1917 Escherichia coli na przebieg biegunki rujowej u źrebiąt.

Badania zostały przeprowadzone w czterech stadninach i objęły łącznie 108 źrebiąt pełnej krwi angielskiej podzielonych na grupy: doświadczalną - otrzymującą w pierwszym dniu po urodzeniu preparat zawierający 108 CFU zdolnych do życia bakterii E. coli linii Nissle 1917 w postaci ciekłej zawiesiny w ilości $15 \mathrm{ml}$ oraz grupę kontrolną. W trakcie obserwacji brano pod uwagę takie parametry, jak termin wystąpienia pierwszej biegunki, długość jej trwania oraz stopień nasilenia określony skalą punktową 1-3.

Przeprowadzone analizy wykazały brak wpływu hodowcy, a co za tym idzie warunków środowiska, w jakich znajdowały się sysaki objęte doświadczeniem, a także ich płci, na parametry biegunek tzw. rujowych u badanych źrebiąt. Najważniejszym wnioskiem wyciągniętym z przeprowadzonej analizy jest stwierdzenie pozytywnego wpływu linii Nissle 1917 Escherichia coli na przebieg biegunki rujowej u źrebiąt. U sysaków w grupie doświadczalnej, otrzymującej preparat E. coli linii Nissle 1917, stwierdzono znacznie krótszy czas trwania biegunki oraz mniejszy stopień jej nasilenia. Podawanie preparatu nie wpłynęło natomiast istotnie na termin wystąpienia pierwszej biegunki u źrebiąt, chociaż źrebięta doświadczalne wykazywały jej objawy nieco wcześniej niż źrebięta w grupie kontrolnej. Takie działanie badanego preparatu zawierającego linię Escherichia coli może polepszyć warunki zoohigieniczne otoczenia, w jakim znajduje się sysak, oraz zmniejszyć ryzyko wystąpienia patologicznych biegunek wtórnych. 


\title{
UŻYTKOWANIE ROZPŁODOWE OGIERÓW KONIKA POLSKIEGO W STADZIE REZERWATOWYM ROZTOCZAŃSKIEGO PARKU NARODOWEGO W LATACH 1982-2017
}

Reproduction performance of polish konik stallions in Roztocze National Park reserve during 1982-2017

\author{
Michał Pluta ${ }^{1}$, Angelika Cieśla ${ }^{2}$, Zbigniew Osiński $^{3}$, Mariusz Wójcik ${ }^{4}$
}

\footnotetext{
${ }^{1}$ Uniwersytet Przyrodniczy w Lublinie, Katedra Hodowli i Użytkowania Koni, ul. Akademicka 13, 20-950 Lublin ${ }^{2}$ Zachodniopomorski Uniwersytet Technologiczny w Szczecinie, Pracownia Hodowli Koni i Animaloterapii

${ }^{3}$ Państwowy Instytut Weterynaryjny - Państwowy Instytut Badawczy w Puławach, Zakład Higieny Pasz

${ }^{4}$ Uniwersytet Przyrodniczy w Lublinie, Katedra Etologii i Dobrostanu Zwierząt, ul. Akademicka 13, 20-950 Lublin e-mail:michal.pluta@up.lublin.pl
}

Rasa konik polski charakteryzuje się korzystnymi cechami pozwalającymi na dostosowywanie się do trudnych i zmiennych warunków środowiska - niewybrednością i dobrym wykorzystaniem paszy, długowiecznością oraz dobrymi wynikami hodowlanymi. Głównie ostatnia właściwość zadecydowała o wyborze tych koni do tworzenia nowych ras (kuc feliński) oraz typów hodowlanych koni (arabofiord, arabokonik). Dlatego celem pracy było przeanalizowanie użytkowości rozpłodowej ogierów na podstawie wskaźników rozrodu klaczy w stadzie rezerwatowym na terenie Roztoczańskiego Parku Narodowego (RPN).

Materiał badawczy stanowiło 21 ogierów użytych do rozpłodu w sezonach od 1982 do 2017 r. Warunki środowiskowe, powierzchnia rezerwatu oraz związana z tym baza paszowa pozwalają na utrzymanie i zaspokojenie dostatecznego poziomu dobrostanu stadu zwierząt o liczebności nieprzekraczającej 10 sztuk klaczy-matek.

Średnia liczba klaczy w sezonie w stadzie wynosiła 5,89 $( \pm 1,06)$. Ogółem w 36 sezonach badawczych brało udział 31 klaczy. Czas przebywania klaczy w stadzie był różny i wynosił od 1 do 25 sezonów użytkowania rozpłodowego, co pozwoliło na otrzymanie od 1 do nawet 22 źrebiąt przez klacze rekordzistki: Trzmielina, Hurtnica i Hańcza - wszystkie hodowli RPN. Użytkowane do reprodukcji osobniki męskie w pierwszych latach pochodziły, podobnie jak wyjściowa grupa klaczy, ze SK w Racocie (4 sztuki), następnie od sezonu 1986 do rozrodu zaczęto wykorzystywać konie z własnej hodowli (w całym badanym okresie ogierów urodzonych w rezerwacie RPN było 10). Według założeń hodowlanych, mających zapobiegać bliskiej hodowli w pokrewieństwie, ogiery stadne przebywały w grupie klaczy od 1 do 3 sezonów (1 sezon 7 szt., 2 - 10 szt. i 3 - 4 szt.). Na przestrzeni 36 lat w omawianej hodowli wykorzystano także ogiery pochodzące z innych, obok już wymienionego Racotu, znaczących dla tej rasy ośrodków: Popielna (3 szt.) i Sierakowa (2 szt.). Struktura płci uzyskanego potomstwa dla badanego okresu ukształtowała się w proporcji 48,74\% ogierków i 51,26\% klaczek. Jednak ta proporcja różnie kształtowała się u poszczególnych ogierów, począwszy od otrzymania źrebiąt tylko jednej płci (5 klaczek po ogierze Test-Mech), poprzez nierówne proporcje, do idealnych równych wartości wynoszących po 50\% dla każdej z płci (dwa ogiery).

Reasumując, użytkowość rozpłodowa ogierów oceniana na podstawie rozrodu klaczy osiągnęła następujące wartości wskaźników: źrebność - 94,34\%, płodność - 91,04\%, plenność - 86,32\%, jałowość - 4,72\%, poronienia $-2,50 \%$, odchów źrebiąt $-91,96 \%$ oraz użytkowość rozpłodowa - 91,50\%. Uzyskane wartości potwierdzają słuszność tezy, że hodowla zachowawcza koników polskich w warunkach zbliżonych do naturalnych pozwala na wykorzystanie zdolności oraz potencjału rozrodczego przedstawicieli tej rasy. Powinna również pozwolić na utrzymanie i wykorzystanie tej cennej cechy do pracy hodowlanej nad końmi innych ras, np. w celu powstania lub przyśpieszenia zjawisk specjacji. 


\title{
UŻYTKOWANIE I DOBROSTAN KONI W WYBRANYCH OŚRODKACH JEŹDZIECKICH ŚWIADCZĄCYCH USŁUGI HIPOTERAPII
}

Usage and welfare of horses in selected equestrian centres providing hippotherapy services

\author{
Zenon Podstawski, Ewelina Horabik, Monika Stefaniuk-Szmukier, Bogusława Długosz, \\ Magdalena Pieszka, Romana Augustyn, Jarosław Łuszczyński, Weronika Petrych \\ Uniwersytet Rolniczy im. Hugona Kołłątaja w Krakowie, Instytut Nauk o Zwierzętach, Zakład Hodowli Koni, \\ al. A. Mickiewicza 24/28, 30-059 Kraków \\ e-mail: zpodstawski@ar.krakow.pl,z.podstawski@ur.krakow.pl
}

Od zarania dziejów człowiek użytkował konie. Oprócz przydatności do celów militarnych, przewożenia osób i ładunków czy pracy na roli bardzo wcześnie dostrzeżono również znaczenie terapeutyczne tego zwierzęcia. Hipoterapia obejmuje swym zakresem niemalże wszystkie działania mające na celu przywracanie zdrowia poprzez wykorzystanie kontaktu z koniem oraz jazdy konnej.

Materiał do pracy zebrano w pięciu ośrodkach świadczących usługi hipoterapii (łącznie 22 konie różnych ras) na terenie Małopolski, z których dwa posiadały patronat: Fundacji „Hipoterapia” i Polskiego Towarzystwa Hipoterapeutycznego. Wykorzystano także informacje pochodzące $\mathrm{z}$ ankiet skierowanych do hipoterapeutów prowadzących zajęcia $\mathrm{w}$ analizowanych ośrodkach.

Wykazano, że tylko $\mathrm{w}$ jednym $\mathrm{z}$ analizowanych ośrodków wszystkie konie były użytkowane wyłącznie do hipoterapii, natomiast $\mathrm{w}$ czterech pozostałych obiektach konie dodatkowo użytkowano poza zajęciami hipoterapii. Najczęściej pracowały w rekreacji (59,1\% koni terapeutycznych), a także były użytkowane do treningu sportowego, rajdów oraz pracy w zaprzęgu. W czterech ośrodkach (18 koni) czas pracy koni w zajęciach hipoterapii w ciągu dnia nie przekraczał czterech godzin, w piątym czasami konie pracowały ponad cztery godziny dzienne.

Stwierdzono, że ponad $60 \%$ koni w ciągu dnia, poza zajęciami hipoterapii miało od jednej do dwóch godzin innych zajęć: rekreacji czy treningu sportowego. Natomiast 35,8\% miało od dwóch do trzech godzin innych zajęć dziennie w zależności od tego, jak długo trwały zajęcia hipoterapii.

Do nietypowych zachowań koni zaliczono ciągnięcie do miejsca zsiadania pacjenta, strach przed wejściem do lasu, „wyrywanie się” do trawy znajdującej się na obrzeżach ujeżdżalni czy też brak reakcji na niektóre polecenia terapeuty. Wszystkie konie po zajęciach miały możliwość odpoczynku na okólnikach i pastwiskach. 


\title{
ANALIZA DZIAŁALNOŚCI MAŁOPOLSKIEGO ZWIĄZKU HODOWCÓW KONI W KRAKOWIE
}

\author{
Analysis of the activity of The Małopolski Horse Breeders Association in Kraków
}

\section{Zenon Podstawski ${ }^{1}$, Teresa Pracuch ${ }^{2}$, Monika Stefaniuk-Szmukier ${ }^{1}$, Bogusława Długosz ${ }^{1}$, Magdalena Pieszka ${ }^{1}$, Romana Augustyn ${ }^{1}$, Jarosław Łuszczyński ${ }^{1}$, Weronika Petrych ${ }^{1}$, Przemysław Podstawski ${ }^{3}$}

\footnotetext{
${ }^{1}$ Uniwersytet Rolniczy im. Hugona Kołłątaja w Krakowie, Instytut Nauk o Zwierzętach, Zakład Hodowli Koni, al. A. Mickiewicza 24/28, 30-059 Kraków

${ }^{2}$ Małopolski Związek Hodowców Koni, ul. Konrada Wallenroda 59/104, Kraków

${ }^{3}$ Instytut Zootechniki - Państwowy Instytut Badawczy, Samodzielna Pracownia Genomiki, ul. Krakowska 1, 32-083 Balice e-mail: zpodstawski@ar.krakow.pl,z.podstawski@ur.krakow.pl
}

Małopolski Związek Hodowców Koni (MZHK) zrzesza około 650 członków - hodowców koni z terenu województwa małopolskiego, a obsługą zootechniczną obejmuje ponad 11,5 tys. gospodarstw rolnych utrzymujących łącznie ponad 20,5 tys. koni różnych ras. Zachodzące zmiany polityczne i gospodarcze ostatnich lat wywarły również wpływ na działalność Małopolskiego Związku Hodowców Koni w Krakowie, dlatego celowe wydało się przeprowadzenie analizy działalności tego Związku. Materiał, który poddano analizie, zebrano w oparciu o dokumentację zgromadzoną w MZHK w Krakowie.

Wykazano, że w 1997 r. Związek liczył 890 członków zrzeszonych w 19 terenowych kołach hodowców koni (TKHK), a do roku 2002 liczba członków związku wzrosła i wynosiła 1063 w 18 TKHK. W okresie późniejszym liczba ta zmniejszała się, tak że w 2017 r. wyniosła 641 członków w 15 TKHK. Analizując odsetek osób uczestniczących w zebraniach TKHK, wykazano tendencję spadkową, od 42,1\% w $1997 \mathrm{r}$. poprzez 29,4\% w 2002 r. do 38,6\% w 2017 r. Wzrosła natomiast liczba organizowanych wystaw i liczba uczestniczących w nich koni od jednej wystawy w 1997 r. do dwóch w 2002 r. i 17 w 2017 r., przy czym 20 wystaw koni odnotowano w 2015 r. oraz odpowiednio: 32 konie w 1997 r., 67 w 2002 r., 791 w 2017 r. i 792 konie w 2015 r., co świadczy o dużej aktywności hodowców koni zainteresowanych zaprezentowaniem swojego dorobku hodowlanego. Analizując liczbę klaczy hodowlanych (starszych i młodych), wykazano, że w 1997 r. wynosiła ona 1201, w 2002 r. - 1424, a w 2017 r. obniżyła się do 1357. Analizując liczbę klaczy objętych Programem Ochrony Zasobów Genetycznych Koni, wykazano ciągły jej wzrost - od 214 klaczy w 2005 r. do 400 w 2010 r., 508 w 2015 r. i 565 w 2017 r. Dokonano również analizy aktywności Związku w poszukiwaniu środków finansowych, gdzie wykazano, że w 2012 r. Związek złożył cztery wnioski, pozytywnie rozpatrzono dwa z nich, w 2014 r. złożono osiem, z których pięć uzyskało wsparcie, w 2016 r. na 12 wniosków pięć pozytywnie rozpatrzono. Podsumowując, można stwierdzić, że Małopolski Związek Hodowców Koni w Krakowie prowadzi zarówno aktywną działalność hodowlaną, jak i organizacyjną, co można zaobserwować, analizując liczbę koni prezentowanych podczas licznych wystaw i czempionatów koni. Obserwowany spadek liczby klaczy hodowlanych w końcowym okresie objętym analizą jest tendencją ogólnokrajową, będącą wynikiem niekorzystnej sytuacji na rynku zbytu koni hodowlanych, zwłaszcza ras półkrwi. Właśnie z tym problemem Związek musi się zmierzyć w następnych latach działalności. 


\title{
ALTERNATYWNE WYKORZYSTANIE MLEKA KLACZY
}

\author{
Alternative use of mare milk \\ Karolina Romaniuk $^{1}$, Katarzyna Kryszak ${ }^{2}$, Agata Danielewicz ${ }^{1}$ \\ ${ }^{1}$ Uniwersytet Przyrodniczo-Humanistyczny w Siedlcach, Instytut Bioinżynierii i Hodowli Zwierząt, Katedra Genetyki i Hodowli \\ Koni, ul. B. Prusa 14, 08-110 Siedlce \\ ${ }^{2}$ Uniwersytet Przyrodniczo-Humanistyczny w Siedlcach, Instytut Bioinżynierii i Hodowli Zwierząt, \\ Katedra Żywienia Zwierząt i Gospodarki Paszowej, ul. B. Prusa 14, 08-110 Siedlce \\ e-mail: katarzyna.kryszak@wp.pl
}

W dzisiejszych czasach konie jako zwierzęta rzeźne są w niewielkim stopniu wykorzystywane w przemyśle spożywczym. Jeszcze rzadziej użytkowane są mlecznie, mimo iż właściwości odżywcze i terapeutyczne mleka klaczy zostały docenione już w V w p.n.e. Prozdrowotne właściwości mleka klaczy znajdowano głównie ze względu na podobny skład do mleka ludzkiego oraz pod kątem możliwości wykorzystania w produkcji fermentowanych napojów alkoholowych. Na przestrzeni dziejów na kontynencie euroazjatyckim, głównie w azjatyckiej jego części, mleko od klaczy było pozyskiwane powszechnie. Najczęściej spożywano je w postaci napoju fermentowanego, tzw. kumysu. W Centralnej Azji mleko klaczy jest nadal ważnym komponentem ludzkiej diety. Wyróżnia się ono też spośród mleka innych gatunków zwierząt użytkowanych mlecznie przez człowieka bogatym zestawem składników bioaktywnych, które czynią z niego produkt o właściwościach prozdrowotnych. Zawartość tłuszczu w tym mleku jest prawie trzykrotnie niższa niż w mleku krowim, efektem czego jest stosunkowa wysoka koncentracja witamin rozpuszczalnych w tłuszczach. Zawartość laktozy jest natomiast porównywalna z mlekiem ludzkim, ale znacznie wyższa niż w mleku krowim. W zestawieniu z mlekiem krowim mleko klaczy ma bardziej korzystny skład i strukturę białek. Wpływa ono korzystnie na poprawę zdrowia skóry, a ze względu na działanie bakteriobójcze przyspiesza proces gojenia się ran. Oddziałuje też pozytywnie na pacjentów z chorobami jelit. Do innych funkcji prozdrowotnych można zaliczyć pozytywną reakcję na organizm pacjentów z chorobami układu krążenia, chorobami oskrzeli i płuc, marskością wątroby, wrzodami żołądka, osteoporozą, anemią. Zawartość kwasów tłuszczowych, głównie linolenowego i linolowego, korzystnie wpływa na rozwój mózgu i komórek nerwowych. Alternatywą wykorzystania mleka klaczy jest też kosmetologia. Producenci łączą charakterystyczne dla kosmetyków działania z właściwościami antybakteryjnymi i terapeutycznymi mleka.

Celem badań ankietowych było zbadanie świadomości konsumentów z zakresu alternatywnego wykorzystywania mleka klaczy. Ankieta została przeprowadzona wśród studentów z czterech kierunków studiów (bioinżynieria produkcji żywności, dietetyka, rolnictwo i zootechnika) oraz ludzi niezwiązanych z rolnictwem. Łącznie zebrano odpowiedzi od 200 osób. Po analizie wyników okazało się, że 51\% osób nie zdaje sobie sprawy z mlecznego kierunku użytkowania koni, stąd tak mała popularność mleka klaczy wśród konsumentów oraz niska świadomość w zakresie zalet i możliwości wykorzystania tego produktu. Mleko klaczy najczęściej (60\%) kojarzone jest wyłącznie z pokarmem dla źrebiąt i takie zastosowanie jest mu przede wszystkim przypisywane. Świadomość respondentów na temat składu chemicznego mleka jest niska (37\%). Głównym produktem spożywczym wytworzonym z mleka klaczy, a kojarzonym przez respondentów (70\%), jest kumys. Podsumowując, można zatem stwierdzić, że społeczna świadomość na temat zastosowania mleka klaczy w medycynie i kosmetologii jest niska. Konieczna jest kampania promująca wszechstronne zastosowanie mleka klaczy i jego wykorzystanie w dietetyce, kosmetologii i medycynie. 


\title{
ANALIZA WYNIKÓW MISTRZOSTW POLSKI MŁODYCH KONI W UJEŻDŻENIU
}

\author{
Analysis of results in Polish championships for young horses \\ Sylwia Skoczyńska, Alicja Borowska \\ Uniwersytet Przyrodniczy w Poznaniu, Zakład Hodowli Koni \\ e-mail: aborek@up.poznan.pl
}

Obecnie hodowla koni koncentruje się na uzyskaniu osobników, które sprawdzą się w wyczynowym sporcie jeździeckim bądź rekreacji, stąd też poszczególne programy hodowlane skupione są głównie na selekcji koni skokowych i ujeżdżeniowych. Ważnym aspektem jest więc odpowiedni wybór metod oceny wartości hodowlanej i użytkowej zwierząt. W tym celu konie poddawane są różnego rodzaju próbom dzielności. Jedną z nich są Mistrzostwa Polski Młodych Koni (MPMK).

Celem pracy była analiza rodowodowa koni biorących udział w MPMK, określenie wpływu rasy, płci oraz ojca na wyniki osiągane podczas czempionatu oraz analiza wartości hodowlanej ogierów z największą ilością potomstwa.

Do badań wykorzystano dane pochodzące z bazy Polskiego Związku Hodowców Koni. Do ostatecznego zestawienia trafiło ponad 400 koni, które zostały pogrupowane według rasy i płci. Ponadto wyselekcjonowano potomstwo po 18 ogierach w celu określenia wartości hodowlanej ogierów-ojców.

Statystyka opisowa objęła następujące parametry: średnia, minimum, maksimum, odchylenie standardowe oraz współczynnik zmienności. Przeprowadzona została analiza wariancji dla analizowanych czynników. Ocena wpływu ojca na wyniki w MPMK została przeprowadzona na podstawie dwóch modeli liniowych: stałego i mieszanego. Do analiz użyto programu SAS 9.3.

Analiza wyników MPMK nie wykazała istotnie statystycznego wpływu płci i rasy na wyniki osiągane podczas czempionatów. Najwyższą średnią wśród płci odznaczały się klacze, następnie ogiery i wałachy. Dla większości ras średnie były na wysokim poziome, lecz wyraźnie pod tym względem różniła się rasa DSP. W modelu liniowym stałym wykazano istotny statystycznie efekt ojca. Najlepszy okazał się ogier Samba Hit I. Natomiast w modelu mieszanym wpływ ojców nie był istotny statystycznie. Pierwsze miejsce zajął Pegasus HB. Oszacowane wartości hodowlane ojców pozwoliły na stworzenie rankingu ogierów z największą liczba potomków. Wartości hodowlane w znacznym stopniu różnicowały ocenianą stawkę ogierówojców. Może to wynikać z różnej ilości ich potomstwa. Należy zwrócić uwagę na małą liczbę obserwacji poszczególnych ogierów, co skutkowało dużym błędem statystycznym. Dlatego należałoby kontynuować szacowanie wartości hodowlanej tych ogierów. 


\title{
KONIE HUCULSKIE - ICH ROLA I ZNACZENIE W POLSCE
}

\author{
Hucul horses: the role and importance in Poland
}

\author{
Magda Socik, Stanisław Socha
}

\author{
Uniwersytet Przyrodniczo-Humanistyczny w Siedlcach, Katedra Metod Hodowlanych i Hodowli Drobiu, \\ ul. B. Prusa 12/14, 08-110 Siedlce \\ e-mail: socikmagda@gmail.com, myszoskoczek16@gmail.com, socha@uph.edu.pl
}

Celem pracy jest zwrócenie uwagi na zalety koni rasy huculskiej, które powinny zostać otoczone szczególną ochroną i zainteresowaniem. Przedstawione informacje pozwolą zrozumieć, iż hodowla koni rasy huculskiej w Polsce jest sprawą niezwykle istotną. Do połowy XIX w. nie zanotowano większego zainteresowania końmi huculskimi poza autochtonicznymi terenami. Właściwy rozwój hodowli na polskich terenach został zanotowany od roku 1899, kiedy zainteresowało się tą rasą Krakowskie Towarzystwo Rolnicze oraz Galicyjskie Towarzystwo Gospodarcze. Zapoczątkowano również w Żabiem organizowanie regularnych wystaw hodowlanych wspólnie z premiowaniem koni. Odbudowa hodowli hucułów po II wojnie światowej była zadaniem trudnym, gdyż dostępny materiał był ograniczony do kilkunastu klaczy i zaledwie kilku ogierów. Właściwą hodowlę zorganizowano w 1950 r., stworzono stadninę w Jodłowniku, która została przeniesiona w 1955 r. do Tylicza, następnie do Siar, aż ostatecznie ulokowano ją w Gładyszowie. Na Huculszczyźnie, którą uznaje się za miejsce skonsolidowania rasy, wykorzystywano ją jako juczną i wierzchową na terenie, którego nie można było pokonać wozem. Ze względu na stopniowy zanik użytkowania jucznego nastąpiło zwiększanie się wzrostu i masy koni tej rasy, co było przystosowaniem do zaprzęgowego typu użytkowego. Biometryczna charakterystyka koni huculskich wykazała stopniowe zwiększanie się podstawowych wymiarów ogierów i klaczy huculskich. Zjawisko zmiany typu użytkowego czy też parametrów ruchu może być sumą wyników działań w przypadku wieloletniej selekcji, obfitego żywienia czy intensywnego użytkowania wierzchowego.

Rasa ta zdobywała coraz większą popularność dzięki swym charakterystycznym cechom, wśród których wymienia się chęć do pracy, spokojny temperament, łagodność, niewybredność na paszę i dużą wytrzymałość. Obecnie Polska posiada największą spośród wszystkich krajów świata populację koni huculskich, a przy tym może się pochwalić wzorcowym sposobem prowadzenia dokumentacji hodowlanej i kontroli rodowodu. Księga Pochodzenia dla Koni Rasy Huculskiej jest prowadzona przez Polski Związek Hodowców Koni, co wynika z nawiązania współpracy z Hucul Horse International Federation (HIF). W wielu europejskich krajach rekreacja konna zyskuje coraz większe zainteresowanie. W ostatnich latach można zanotować wzrost zainteresowania jeździectwem nie tylko rekreacyjnym, ale również sportowym. W Polsce sport z wykorzystaniem koni huculskich również zaczyna się odradzać, co skutkuje poszukiwaniem typu koni odpowiednich do sportu. Biorąc pod uwagę stan zdrowia i wytrzymałość, konie huculskie doskonale spełniają powyższe kryteria. Wraz z upływem lat można zaobserwować coraz intensywniejsze zainteresowanie rajdami konnymi. Konie mniejszego pokroju nadają się idealnie, ze względu na to, że świetnie sobie radzą w górskim terenie, są spokojne, rozważne, a przy tym łagodne, co jest wyjątkowo istotne w przypadku poszukiwań konia dla dziecka. Nie występuje problem przeprawy przez górski potok czy też powrotu do stajni dzięki doskonałej orientacji i instynktowi.

Wielu autorów prac nt. hucułów zwraca uwagę na wiele zalet, jakie posiadają te konie, które są znaczącym argumentem, by wciąż doskonalić hodowlę i dbać o odpowiednią selekcję, jak również rozród. Warto pamiętać o stadach zachowawczych, dzięki którym konie mają szanse na rozwój w warunkach zbliżonych do naturalnych dla nich. Turystyka konna cieszy się rosnącym zainteresowaniem i rozwija się w szybkim tempie. Wielu mieszkańców miast chętnie wyrusza na grzbietach koni huculskich zdobywać niedostępne dla ludzi górskie tereny, które stanowią doskonałe miejsce zarówno do wypoczynku, jak i rekreacji. Praca hodowlana nad końmi huculskimi stanowi obecnie znaczące wyzwanie dla hodowców, gdyż zachowanie pierwotnego pokroju i charakteru ras prymitywnych jest pracochłonnym i czasochłonnym zadaniem, wymagającym dużej wiedzy na ten temat. 


\title{
STRUKTURA GENETYCZNA POPULACJI POLSKICH KONI ZIMNOKRWISTYCH POD WZGLĘDEM GENÓW UMASZCZENIA
}

Genetic structure of Polish Coldblood population with regard to coat colour genes

\author{
Anna Stachurska, Antoni Brodacki, Marta Liss \\ Uniwersytet Przyrodniczy w Lublinie, Katedra Hodowli i Użytkowania Koni, u. Akademicka 13, 20-950 Lublin \\ e-mail: anna.stachurska@up.lublin.pl
}

Struktura genetyczna populacji może ulegać znacznym zmianom w kolejnych generacjach, co skutkuje zmienioną frekwencją alleli odpowiedzialnych za umaszczenie oraz zmienionym fenotypem rasy. Takie zjawiska wskazują na potrzebę badań nad genetyką populacji na podstawie ksiąg stadnych. Badania molekularne dotyczą zazwyczaj części żyjących populacji i nie mogą pokazać trendów, które w nich zachodzą od momentu powstania. Celem pracy było oszacowanie frekwencji alleli odpowiedzialnych za umaszczenie populacji polskich koni zimnokrwistych. Przeanalizowano maść niemal 36 tysięcy koni zapisanych do głównej księgi stadnej podzielonej na dziewięć subpopulacji. Frekwencja alleli została oszacowana w pięciu loci A, E, D, Rn i G w pokoleniu rodzicielskim i potomnym na podstawie dwóch metod - wyników kojarzeń testowych oraz pierwiastka z frekwencji fenotypów recesywnych. Stwierdzono, że maść nie jest całkowicie pomijana w selekcji tych koni. Populacja znajduje się w genetycznej równowadze jedynie w locus E. Konie kare są faworyzowane, a wyższa homozygotyczność w tym locus koni karych niż gniadych powoduje, że rodzi się stosunkowo więcej karych źrebiąt. Niepożądane w hodowli są natomiast maści rozjaśnione bułana i myszata, dereszowata i siwa. Niemal wszystkie konie są obecnie maści podstawowych - kasztanowatej, gniadej i karej. Frekwencja dominujących alleli A, E, D, Rn i G oszacowana na podstawie pierwiastka frekwencji fenotypów recesywnych wyniosła w ostatnim czasie odpowiednio $0,5842,0,3492,0,0006,0,0025$ i 0,0081 . 


\title{
NIEPRAWIDŁOWOŚCI BUDOWY I ZMIANY PATOMORFOLOGICZNE PŁASZCZYZNY KARKOWEJ KONI I ICH WPŁYW NA BIOMECHANIKE RUCHU
}

\author{
Anomalies and pathomorphological changes of the nuchal plane of horses and their influence \\ on biomechanics of movement \\ Monika Tołkacz-Paszkiewicz ${ }^{1}$, Marcin Komosa ${ }^{1}$, Małgorzata Dzierzęcka ${ }^{2}$ \\ ${ }^{1}$ Uniwersytet Przyrodniczy w Poznaniu, Zakład Anatomii Zwierząt, \\ ${ }^{2}$ Szkoła Główna Gospodarstwa Wiejskiego w Warszawie, Katedra Nauk Morfologicznych \\ e-mail: marcin.komosa@up.poznan.pl
}

Sport jeździecki cieszy się wciąż dużą popularnością, co skłania do prowadzenia szczegółowych badań nad funkcjonowaniem ciała konia w aspekcie biomechaniki ruchu. Coraz częściej słyszy się o problemach jeźdźców z tzw. kontaktem z pyskiem konia. Pojawiają się nawet kulawizny, zwane w środowisku jeździeckim kulawiznami pochodzącymi „od ręki jeźdźca”, nie zaś z przyczyn urazów kończyn. Pojęcie kontaktu oznacza oddziaływanie ręki jeźdźca poprzez wodzę i wędzidło na brzeg międzyzębodołowy żuchwy konia, a częściowo też na język i podniebienie twarde. Objawy, jakie konie wykazują przy problemach z kontaktem, są różnorakie. Istotą ich rozwiązania jest właściwe zdiagnozowanie czynników, które mogą być zarówno zewnętrzne, jak i mogą wynikać ze swoistych dla danego osobnika cech anatomicznych bądź zmian patomorfologicznych. Po wyeliminowaniu ewentualnych błędów ze strony jeźdźca, źle dobranego sprzętu, jak również czynników wewnątrz pyska konia (przerośnięte zęby, wilcze zęby, ropnie itp.) warto poświęcić uwagę płaszczyźnie karkowej (planum nuchale). W przypadku konia płaszczyzna ta jest reprezentowana przez jedną tylko kość, którą jest kość potyliczna, a konkretnie przez jej nieparzystą łuskę i parzyste części boczne. Część podstawna kości potylicznej nie wchodzi już w zakres płaszczyzny karkowej. Kość potyliczna razem z pierwszym kręgiem szyjnym tworzą staw szczytowo-potyliczny, jedno z ciekawszych połączeń w ciele konia. Jej stosunkowo mała powierzchnia jest miejscem przyczepu wielu mięśni działających na głowę i szyję. Na łusce kości potylicznej znajduje się także miejsce przyczepu powrózka karkowego w postaci guzowatości potylicznej zewnętrznej. Powrózek razem z blaszkami karkowymi tworzy obszerne więzadło karkowe, rozpościerające się powyżej kręgosłupa szyjnego. Więzadło to będąc w łączności z więzadłem nadkolcowym, stabilizuje niemal cały kręgosłup konia oraz wspomaga jego pracę w sposób pasywny. Zaburzenia w prawidłowym funkcjonowaniu tych miękkich struktur wynikające z anomlii, procesów zwyrodnieniowych i stanów zapalnych w obrębie kości potylicznej będą zaburzać biomechanikę ruchu konia i mogą znacząco wpływać na zachowanie konia podczas treningu.

Celem niniejszych badań było określenie zmienności budowy i wskazanie anomalii kości potylicznej oraz opisanie zmian patomorfologicznych, które mogą się na niej pojawiać. W analizach o charakterze anatomicznym wykorzystano 75 czaszek koni, przyporządkowanych do pięciu grup wiekowych. Metody zastosowane w badanich miały charakter zarówno opisowy, jak i metryczny, z wykorzystaniem analiz statystycznych.

Badania kraniologiczne wykazały występowanie różnorodnych zmian patomorfologicznych i szeregu anomalii w obrębie kości potylicznej. Zmiany patomorfologiczne objawiające się wzmożonym remodelingiem kostnym zaobserwowano na głównych strukturach płaszczyzny karkowej kości potylicznej - łusce potylicznej oraz częściach bocznych. Remodeling miał charakter kostnych nacieków (osteofity, entezofity). Pojawiały się także martwicze ubytki w pobliżu kłykci potylicznych i otworu wielkiego. Poza powyższymi zmianami zaobserwowano także anomalie, które trudno określić jako typowo patomorfologiczne, niemniej mogące się przyczyniać do odczuwania przez konie dyskomfortu w warunkach przyżyciowych. Były to:

- asymetria grzebienia karkowego bez widocznych zmian chorobowych,

- ponadnormatywne długości wyrostków przykłykciowych wpływające na ruchy w stawie szczytowo-potylicznym,

- różnice w długości prawego i lewego wyrostka przykłykciowgo,

- różnice w grubości prawego i lewego wyrostka przykłykciowego. 


\title{
REALIZACJA PROGRAMÓW OCHRONY ZASOBÓW GENETYCZNYCH LOKALNYCH RAS KONI PRYMITYWNYCH I PÓŁKRWI
}

\author{
Implementation of the genetic resources conservation programme of local primitive races \\ and halfbreed horses
}

\section{Iwona Tomczyk-Wrona, Agnieszka Chełmińska}

\author{
Instytut Zootechniki - Państwowy Instytut Badawczy, Zakład Hodowli Koni \\ 32-083 Balice, ul. Krakowska 1, \\ e-mail: iwona.wrona@izoo.krakow.pl
}

Ochrona lokalnych ras koni prowadzona jest przez Instytut Zootechniki - Państwowy Instytut Badawczy jako podmiot upoważniony przez Ministra Rolnictwa i Rozwoju Wsi do koordynacji lub realizacji programów ochrony zasobów genetycznych. Działania te prowadzone są już od wielu lat, zaczynając od 2000 r. dla koników polskich i koni huculskich, następnie od 2005 r. dla koni małopolskich i śląskich oraz od 2008 r. dla koni wielkopolskich. Od 2005 r. wszystkie klacze objęte programem ochrony mogą uczestniczyć w programach rolnośrodowiskowych, co łączy się z perspektywą uzyskania dopłat z tytułu realizacji pakietu zwierzęcego - konie. Mając na względzie długoletnie doświadczenie, należy stwierdzić, że największe znaczenie w hodowli ras zachowawczych mają hodowcy indywidualni, których tradycje, zamiłowanie i konsekwencja w działaniu daje możliwości uzyskania cennego materiału. Ochrona in situ, uważana za najbardziej preferowaną metodę ochrony bioróżnorodności populacji zwierząt gospodarskich, jednak najlepiej sprawdza się $\mathrm{w}$ tradycyjnych systemach produkcji. Pozwala na utrzymanie i adaptacyjne użytkowanie zasobów genetycznych zwierząt w krajobrazach produkcyjnych z zachowaniem ich wartości kulturowych. Programy ochrony zawierające informacje o historii powstania danej rasy oraz szczegółowe uzasadnienie konieczności jej ochrony określają harmonogram działań, zakres ochrony in situ i ex situ, zasady i metody pracy hodowlanej oraz wskazują organizacje odpowiedzialne za ich realizację. Prowadzona cykliczna szczegółowa charakterystyka pozwala na ocenę statusu zagrożenia. Obejmuje dane dotyczące liczebności, kierunku użytkowania, informacji o pochodzeniu i rozwoju danej populacji, cechach wyglądu i budowy zewnętrznej oraz określa obszary występowania (tab. 1).

Tabela 1. Liczebności lokalnych ras koni w działaniach rolnośrodowiskowych - stan na 30.05.2018 r.

\begin{tabular}{|l|c|c|c|}
\hline \multicolumn{1}{|c|}{ Rasa } & Liczba stad & Liczba klaczy & Liczba ogierów \\
\hline Konik polski & 225 & 1572 & $167(26)^{*}$ \\
\hline Koń huculski & 254 & 1168 & $176(17)$ \\
\hline Koń małopolski & 127 & 428 & $101(60)$ \\
\hline Koń śląski & 265 & 917 & $236(64)$ \\
\hline Koń wielkopolski & 27 & 125 & $34(19)$ \\
\hline Razem & 898 & 4210 & $714(186)$ \\
\hline
\end{tabular}

* Liczby w nawiasach - dodatkowe ogiery bez zgłoszonego punktu kopulacyjnego

Praca wykonana w ramach tematu wieloletniego, zadanie: 03-17-11-09. 


\title{
ANALIZA RODOWODOWA KLACZY MAŁOPOLSKICH OBJĘTYCH PROGRAMEM OCHRONY ZASOBÓW GENETYCZNYCH
}

\author{
Pedigree analysis of Malopolski mares covered of the genetic resources conservation programme
}

\author{
Iwona Tomczyk-Wrona \\ Instytut Zootechniki Państwowy Instytut Badawczy, Zakład Hodowli Koni \\ 32-083 Balice, ul. Krakowska 1 \\ e-mail: iwona.wrona@izoo.krakow.pl
}

Program ochrony rasy małopolskiej został w głównych celach oparty na tzw. „,właściwych koniach małopolskich”, czyli z dolewem przede wszystkim pełnej krwi angielskiej, półkrwi arabskiej, angloarabskiej, a także krwi rodów austro-węgierskich. Konie te posiadają wiele cech konia orientalnego, pod wpływem którego przez wiele lat rozwijała się polska hodowla, co pozwoliło na zachowanie wielu cech dawnych koni rodzimych. Znaczący wpływ koni pełnej krwi, zarówno w formie czystej, jak i poprzez różne szczepy półkrwi, zaznaczył się dopiero od drugiej połowy XIX w. Przenikanie się krwi arabskiej i angielskiej doprowadziło do powstania angloaraba półkrwi, który z czasem stał się dominującym typem konia na terenach Małopolski. Głównym warunkiem uczestnictwa w programie ochrony jest pochodzenie od co najmniej trzech pokoleń przodków wpisanych do działu głównego ksiąg stadnych rasy małopolskiej lub ras biorących udział $\mathrm{w}$ jej tworzeniu. Za rasy biorące udział w tworzeniu konia małopolskiego uznaje się przede wszystkim pełną krew angielską oraz czystą krew arabską, czystą krew angloarabską, angloaraby obcego pochodzenia, w tym również francuskie i pochodzące ze starych rodów austro-węgierskich. W trzecim pokoleniu wstecznym (8 przodków) łącznie dopuszcza się maks. 50\% udziału krwi ras uznanych za tworzące. Głównym celem realizacji programu ochrony jest uzyskanie potomstwa spełniającego jego warunki, co jest uzależnione od kojarzenia klaczy uczestniczących $\mathrm{w}$ programie ochrony $\mathrm{z}$ odpowiednio dobranymi ogierami. Z uwagi na specyfikę rasy małopolskiej, reprezentującej genetycznie angloaraba półkrwi, priorytetem jest zachowanie określonego genotypu tej populacji. Ze względu na znaczącą i udokumentowaną rolę przedstawicieli pełnej krwi angielskiej $(x x)$ w tworzeniu rasy małopolskiej przeprowadzono charakterystykę udziału koni pełnej krwi angielskiej w rodowodach klaczy uczestniczących w programie ochrony. Analizie poddano 446 klaczy małopolskich pod względem procentowego udziału w ich rodowodach do III pokolenia przodków rasy pełnej krwi angielskiej w odniesieniu do przodków rodzimych małopolskich i innych ras uznanych za tworzące. $\mathrm{Z}$ tej liczby do szczegółowych analiz wybrano 257 klaczy mających w swych rodowodach do III pokolenia udział przodków xx. Spośród ocenianych 257 klaczy 187 (72,8\%) miało przodków rodzimych małopolskich, $x x$ oraz innych ras, natomiast 70 klaczy $(27,2 \%)$ nie miało udziału przodków innych ras tworzących. Ponadto wśród 257 ocenianych klaczy małopolskich $237(92,2 \%)$ miało do trzeciego pokolenia wstecz co najmniej $50 \%$ udział rodzimych koni małopolskich, 5 klaczy $(1,9 \%)$ - 50\% udział $x x$ i 7 klaczy $(2,7 \%)$ - 50\% i więcej udziału innych ras. Następnie 141 (55\%) spośród charakteryzowanych klaczy małopolskich miało udział rasy $x x$ tylko od strony ojca, 77 (30\%) tylko od strony matki, a tylko 39 (15\%) od strony i ojca i matki. W przypadku 138 klaczy (53,7\%) był to udział tylko jednego przodka rasy $x x$ w III pokoleniu, 91 klaczy $(35,4 \%)$ miało dwóch przodków $x x, 23$ klacze $(9 \%)$ trzech, a 5 klaczy $(2 \%)$ czterech przodków rasy $x x$. Uzyskane wyniki wskazują, że największy udział ras uznanych za tworzące w rodowodach do trzeciego pokolenia wstecz w populacji badanych klaczy małopolskich stanowiły konie pełnej krwi angielskiej.

Praca wykonana w ramach tematu wieloletniego, zadanie: 03-17-11-09. 


\title{
ZMIANY DOBOWEJ AKTYWNOŚCI AUTONOMICZNEGO UKŁADU NERWOWEGO KONI MAŁOPOLSKICH I KUCÓW FELIŃSKICH
}

\author{
Changes in the daily activity of autonomic nervous system of Małopolski horses and Felin ponies
}

\author{
Izabela Wilk, Marta Liss, Sylwester Tkaczyk \\ Uniwersytet Przyrodniczy w Lublinie, Katedra Hodowli i Użytkowania Koni, \\ ul. Akademicka 13, 20-950 Lublin \\ e-mail: izabela.wilk@up.lublin.pl
}

Układ współczulny i przywspółczulny autonomicznego układu nerwowego (AUN) w sposób antagonistyczny wpływa na parametry pracy serca poprzez pobudzanie lub hamowanie aktywności węzła zatokowego generującego skurcze serca. Oddziaływanie AUN wywołuje cyklicznie występujące różnice w czasie trwania kolejnych odstępów między prawidłowymi zespołami QRS (RR) w zapisie EKG, czyli zmienność rytmu serca (HRV). Stąd też parametry HRV odzwierciedlają wzajemne relacje i stopień aktywności komponenty współczulnej i przywspółczulnej ANS, a tym samym są pomocne w opisie relacji między homeostazą a stanem pobudzenia emocjonalnego organizmu. Analiza zapisu HRV znajduje zastosowanie w medycynie (zaburzenia czynnościowe serca, jednostki psychiatryczne, etiologia bólu) i weterynarii (dysfunkcje behawioralne, stres). Mimo iż badania HRV koni są prowadzone od wielu lat, to jednak nie określono u nich dotychczas spoczynkowej aktywności dobowej. Dotychczas opisano HRV koni z objawami morzyska, ochwatu, migotania przedsionków oraz koni klinicznie zdrowych, ale poddanych testom behawioralnym i różnym sposobom treningu. Dlatego też celem badań stało się określenie dobowej aktywności AUN koni gorącokrwistych i kuców. Badaniami objętych zostało 8 koni małopolskich i 8 kuców felińskich w równej liczbie ogiery i klacze. Konie utrzymywane były w dwóch stajniach boksowych o takim samym standardzie i obsługiwane przez tę samą osobę. Boksy wyposażone były w żłób plastikowy, kosz na siano i poidło automatyczne. Karmienie odbywało się trzykrotnie o godzinie 6.00, 13.00 i 19.00. Podczas analizy brano pod uwagę sześć półgodzinnych zapisów, które rozpoczynały się w odstępach czterogodzinnych. Pozwoliło to na wyodrębnienie interwałów w sześciu różnych porach dnia (w godzinach: 8.00, 12.00, 16.00, 20.00, 24.00 i 4.00). Pod uwagę wzięto pięć parametrów częstości i zmienności rytmu serca: HR - częstość pracy serca, określana liczbą uderzeń serca na minutę [ud/min], RMSSD - opisujący zmienność krótkookresową, jako pierwiastek kwadratowy ze średniej sumy kwadratów różnic pomiędzy kolejnymi dwoma interwałami RR [ms], LF - moc widma w zakresie niskich częstotliwości [ms²], ukazująca aktywność układu współczulnego, HF - moc widma w zakresie wysokich częstotliwości [ $\left.\mathrm{ms}^{2}\right]$, obrazująca działanie układu przywspółczulnego, LF/HF - stosunek mocy widm w zakresie niskich częstotliwości do wysokich częstotliwości wyrażony w układzie procentowym, mówiący o zrównoważeniu układu autonomicznego. Uzyskane wyniki wskazały na związane z rasą różnice w aktywności układu współczulnego i przywspółczulnego w godzinach popołudniowych i nocnych. Silniejsze działanie układu przywspółczulnego, odpowiadającego za odprężenie organizmu, można zaobserwować w godzinach popołudniowych w przypadku koni małopolskich, a także w godzinach wieczornych w przypadku kuców felińskich. Obydwie grupy koni wykazywały najsilniejsze zrównoważenie układu autonomicznego we wczesnych godzinach porannych.

Badania w ramach projektu NCN Miniatura 1: Dobowa aktywność komponentów autonomicznego układu nerwowego koni: 2017/01/X/NZ9/00472. 


\title{
NAJCZESTSZE PROBLEMY ZDROWOTNE KONI GERIATRYCZNYCH
}

\author{
Commonly diseases of geriatric horses \\ Marcjanna Małgorzata Wiśniewska ${ }^{1}$, Iwona Janczarek ${ }^{2}$ \\ ${ }^{1}$ Uniwersytet Technologiczno-Przyrodniczy im. J.J. Śniadeckich w Bydgoszczy, Katedra Nauk o Zwierzętach, \\ Zakład Hodowli Trzody Chlewnej i Koni, ul. Mazowiecka 28, 85-084 Bydgoszcz \\ ${ }^{2}$ Uniwersytet Przyrodniczy w Lublinie, Katedra Hodowli i Użytkowania Koni, ul. Akademicka 13, 20-950 Lublin \\ e-mail: marcjannaw100@wp.pl
}

Utrzymywanie i użytkowanie starych (geriatrycznych) zwierząt jest z wielu powodów coraz częściej zasadne. W przypadku koni starych niezwykle cenne jest ich spokojne zachowanie się oraz doświadczenie wierzchowe, które jest wykorzystywane w szkółkach jeździeckich. Wspomniany fakt powoduje, że konie te uważane są za bezpieczne, a zatem mogą być świetnymi nauczycielami hipiki dla początkujących adeptów jeździectwa. Warto jednak zwrócić uwagę, że nierzadko geriatryczne zwierzęta z racji wieku oraz intensywnego użytkowania cierpią na liczne choroby związane z procesem starzenia się, co czasami niedostrzegalnie zaburza ich dobrostan. Tylko odpowiednia profilaktyka, diagnozowanie i leczenie jest w stanie zapewnić im dobrą kondycję zdrowotną i funkcjonowanie ich organizmu przez długie lata. W związku z powyższymi względami celem pracy było scharakteryzowanie problemów zdrowotnych geriatrycznych koni rekreacyjnych. Kolejną kwestią było omówienie ukierunkowania właścicieli na odpowiednią opiekę zdrowotną nad tego typu końmi. Na podstawie wypowiedzi ankietowych właścicieli 30 koni w wieku 17-25 lat utrzymywanych w 20 stajniach rekreacyjnych na terenie województwa kujawsko-pomorskiego zebrano informacje na temat rodzaju i częstotliwości chorób i dolegliwości występujących u tych koni oraz stosowanej profilaktyki i leczenia. Najczęściej odnotowano spadek masy ciała (18 koni), zwyrodnienia/zapalenia stawów (4 konie), COPD (3 konie), pogorszenie wzroku (2 konie), zespół Cushinga (1 koń). Każdą z tych jednostek zaliczono do typowych dla okresu geriatrii. Stwierdzono również, że użytkowanie koni starych jest możliwe, ale tylko dzięki odpowiedniemu wspomaganiu organizmu poprzez prawidłową profilaktykę lub zastosowane leczenie, przy czym rutynowe i regularne badania pomagają łagodzić objawy występujących chorób. Podsumowując, stwierdzono, że możliwość użytkowania koni geriatrycznych jest w dużym stopniu uzależniona od świadomości właścicieli na temat zdrowia posiadanych zwierząt i zagrożeń wiążących się $\mathrm{z}$ jego osłabieniem, a także szeroko rozumianej profilaktyki i specjalistycznego leczenia. Wszechstronna wiedza właścicieli na ten temat pozwala zapobiegać występowaniu poważnych dolegliwości, skutecznie leczyć choroby oraz wspomagać przewlekle cierpiące zwierzęta. Nieustanne poszerzanie wiedzy w aspekcie utrzymywania i opieki nad starymi końmi spowoduje przedłużenie ich sprawności fizycznej i ogólnej witalności, co idzie w parze z możliwością zachowania dobrostanu tych zwierząt w ostatnich latach życia. 
Sekcja Chowu i Hodowli Owiec i Kóz 


\title{
ZALEŻNOŚCI MIEDZY STEŻENIEM BIAŁEK OSTREJ FAZY W SUROWICY KRWI KÓZ MLECZNYCH WOLNYCH OD ZAKAŻENIA I ZAKAŻONYCH WIRUSEM MAŁYCH PRZEŻUWACZY
}

Relationship between acute phase protein concentrations in blood serum of small ruminant lentivirus infected and uninfected goats

\author{
Emilia Bagnicka ${ }^{1}$, Daria Reczyńska ${ }^{1}$, Magdalena Zalewska ${ }^{1}$, Ewelina Kawecka ${ }^{1,2}$, \\ Paulina Brodowska ${ }^{1}$, Danuta Słoniewska ${ }^{1}$, Karina Horbańczuk ${ }^{3}$, Sławomir Petrykowski $^{3}$, \\ Lech Zwierzchowski ${ }^{4}$ \\ ${ }^{1}$ Zakład Doskonalenia Zwierząt, Instytut Genetyki i Hodowli Zwierząt PAN w Jastrzębcu \\ ${ }^{2}$ Szkoła Główna Gospodarstwa Wiejskiego, w Warszawie, Katedra Genetyki i Ogólnej Hodowli Zwierząt, Warszawa \\ ${ }^{3}$ Zakład Doświadczalny, Instytut Genetyki i Hodowli Zwierząt PAN w Jastrzębcu \\ ${ }^{4}$ Zakład Biologii Molekularnej, Instytut Genetyki i Hodowli Zwierząt PAN w Jastrzębcu \\ e-mail: e.bagnicka@ighz.pl
}

Białka ostrej fazy (BOF) to duża, heterogenna grupa białek i polipeptydów, biorąca udział w odpowiedzi ostrej fazy na zakażenie bakteryjne czy wirusowe, zranienia, oparzenia oraz niedokrwienie tkanek. Są one zatem zaangażowane w mechanizmy obrony humoralnej. Stanowią pierwszą linię obrony, a ich głównym zadaniem jest przywrócenie homeostazy organizmu. Ich koncentracja w surowicy krwi jest wskaźnikiem stanu zdrowia organizmu. Białka te można podzielić na pozytywne, których stężenie wzrasta w odpowiedzi na zakażenie, oraz negatywne, których stężenie w stanach zapalnych maleje. U różnych gatunków różne białka uczestniczą w reakcji ostrej fazy. U kóz dotychczas zidentyfikowano pięć pozytywnych białek ostrej fazy: amyloid surowicy (SAA), alfa $a_{1}$-kwaśną glikoproteinę $\left(\mathrm{A}_{1} \mathrm{GP}\right)$, haptoglobinę $(\mathrm{Hp})$, ceruloplazminę $(\mathrm{Cp})$ i fibrynogen $(\mathrm{Fb})$ oraz jedno negatywne BOF - laktoalbuminę (LALBA). Białka C-reaktywne (CRP) nie jest zaliczane do BOF u kóz, jednak jest pierwszym białkiem ostrej fazy zidentyfikowanym u ludzi. Białka te produkowane są głównie w wątrobie, jednak komórki nabłonka, mięśni gładkich, komórki pęcherzykowate oraz limfocyty i makrofagi są również ich źródłem. Z drugiej strony, docelowymi komórkami krwi dla lentiwirusa małych przeżuwaczy (SRLV - small ruminant lentivirus) są monocyty, w których następuje namnażanie się wirusa, a uwalnianie jego kopii do krwi następuje w momencie dojrzewania monocytów do makrofagów.

Dotychczas niewiele jest informacji dotyczących zależności między stężeniem poszczególnych BOF w surowicy krwi kóz, dlatego celem pracy było określenie zależności między stężeniem BOF w komórkach krwi kóz mlecznych zakażonych SRLV i wolnych od zakażenia w oddzielnych analizach.

Badania prowadzono na 24 kozach rasy polskiej białej i barwnej uszlachetnionej, podzielonych na dwie analogiczne grupy pod względem stanu zdrowia (zakażone SRLV i wolne od zakażenia) określonego na podstawie dwóch kolejnych testów immunoenzymatycznych (ELISA), rasy oraz numeru laktacji (druga lub czwarta laktacja). Próby krwi pobierano pięciokrotnie w trakcie laktacji: tuż po wykocie, w 30. dniu (wczesna laktacja), 60. dniu (szczyt laktacji), 140. dniu (pełna laktacja) i 200. dniu (późna laktacja) do probówek bez antykoagulantu. Krew wirowano w $4^{\circ} \mathrm{C}$, przy prędkości 3 tys. rpm przez $20 \mathrm{~min}$. Surowicę do dalszych analiz przechowywano w temp. $-80^{\circ} \mathrm{C}$. Stężenie SAA, $\mathrm{A}_{1} \mathrm{GP}, \mathrm{Hp}, \mathrm{Cp}, \mathrm{Fb}, \mathrm{CRP}$ oraz laktoalbuminy LALBA w surowicy krwi określono za pomocą odpowiednich testów ELISA. Zależności między stężeniem BOF określono za pomocą korelacji Pearsona (procedura CORR, pakiet SAS).

W surowicy krwi kóz wolnych od SRLV stwierdzono średnie, dodatnie korelacje między SAA i Cp $(0,37 ; \mathrm{p}<0,01)$, LALBA i Hp $(0,33 ; \mathrm{p}<0,05)$ oraz LALBA i Cp $(0,47 ; \mathrm{p}<0,01)$. Natomiast ujemną korelację odnotowano między $\mathrm{A}_{1}$ GP i $\mathrm{Hp}(-0,31 ; \mathrm{p}<0,05)$. 
U kóz zakażonych również stwierdzono ujemną korelację między stężeniem AGP i Hp, jednak na dwukrotnie wyższym poziomie $(-0,66 ; \mathrm{p}<0,01)$. Ponadto ujemne korelacje odnotowano między $\mathrm{A}_{1} \mathrm{GP}$ i $\mathrm{Fb}$ oraz $\mathrm{A}_{1}$ GP i CRP (odpowiednio: $-0,23 \mathrm{i}-0,24 ; \mathrm{p}<0,05$ ). Dodatnie zależności stwierdzono jedynie pomiędzy $\mathrm{Fb}$ i $\mathrm{Hp}$ oraz $\mathrm{Fb}$ i $\mathrm{Cp}$ (odpowiednio: 0,32 i 0,23; p < 0,05). W zdrowym organizmie BOF pełnią różne funkcje, np. transportowe, czy antyoksydacyjne. Dodatnie korelacje pomiędzy niektórymi białkami wskazują na synergię ich działania. U zwierząt zakażonych SRLV, $\mathrm{A}_{1}$ GP działa antagonistycznie nie tylko w stosunku do $\mathrm{Hp}$, ale także w stosunku do Fb i CRP. Ujemna korelacja między $\mathrm{A}_{1}$ GP i Hp (dodatnia korelacja Hp z Fb), $\mathrm{A}_{1} \mathrm{GP}$ i $\mathrm{Fb}$ (Fb powoduje agregację płytek) oraz $\mathrm{A}_{1} \mathrm{GP}$ i CRP (CRP hamuje agregację płytek) wskazuje na ich antagonistyczne działanie, zatem zwiększone stężenie $\mathrm{A}_{1} \mathrm{GP}$ może wpływać na proces krzepnięcia krwi. Reumatoidalne zapalenie stawów u ludzi, dla którego zakażenie SRLV u kóz stanowi model zwierzęcy, oraz inne przewlekłe stany zapalne powodują zwiększoną koncentrację $\mathrm{A}_{1} \mathrm{GP}$ w surowicy.

Badania finansowano z grantu Opus NCN2013/09/B/N26/03514 oraz Preludium NCN2016/21/N/NZ9/01508. 


\title{
WPŁYW PREPARATU SELENOWEGO O DŁUGIM OKRESIE DZIAŁANIA NA MECHANIZMY OBRONNE U JAGNIĄT
}

The effect of long-acting selenium preparation on defence mechanisms in lambs

\author{
Justyna Błażejak, Stanisław Milewski, Katarzyna Ząbek \\ Uniwersytet Warmińsko-Mazurski w Olsztynie, Katedra Hodowli Owiec i Kóz \\ e-mail: stanislaw.milewski@uwm.edu.pl
}

Selen jest jednym z ważniejszych mikroelementów w organizmie, a równocześnie należy do pierwiastków deficytowych w środowisku. W organizmie występuje w ok. 35 selenoproteinach, a jego istotne funkcje to udział m.in. w eliminacji z ustroju wolnych rodników, zapobieganiu chorobom autoimmunologicznym oraz w procesach odpornościowych, a także przeciwdziałanie szkodliwym wpływom nitrozoamin czy promieniowania jonizującego. Selen hamuje glikolizę, jest też antagonistą kadmu, ołowiu, arsenu i rtęci. Hiposelenoza może prowadzić do zaburzeń procesów rozrodczych oraz wystąpienia pokarmowej dystrofii mięśni. Najbardziej efektywną drogą suplementacji niedoboru selenu jest iniekcja. Na ogół preparaty selenowe charakteryzują się krótkim okresem działania, co wpływa na częstotliwość suplementacji. Rozwiązaniem mogą być preparaty o przedłużonym działaniu. Zagadnienie to podjęto $\mathrm{w}$ badaniach przeprowadzonych na owcach. Porównano efekty iniekcyjnego podawania preparatu selenowego (Bvp Barium Selenate Injection) bezpośrednio jagniętom oraz ich matkom. Materiał badawczy stanowiło 36 jagniąt ssących, analogicznych pod względem płci i masy ciała w 2. dniu życia, podzielonych na trzy grupy po 12 sztuk: $\mathrm{K}$ - kontrolną oraz DI i DII - doświadczalne. W grupie DI matkom badanych jagniąt podano wyprzedzająco, w połowie 3. miesiąca ciąży, preparat selenowy o długim okresie działania, natomiast w grupie DII podano ten preparat jagniętom, między 3. a 7. dniem życia. Preparat selenowy wprowadzono podskórnie, w dawce $1 \mathrm{ml} / 10 \mathrm{~kg}$ masy ciała. Próby krwi do oznaczeń immunologicznych pobierano z żyły jarzmowej w dniu aplikacji preparatu selenowego - 4-7 dzień życia (termin 0), a następnie w 28., 70. i 100. dniu życia. Analizowano humoralne i komórkowe mechanizmy obronne u jagniąt. Badania odpowiedzi humoralnej dotyczyły oznaczenia: aktywności lizozymu i ceruloplazminy oraz poziomu białka ogólnego i frakcji gammaglobulin. Z kolei badania mechanizmów odporności komórkowej obejmowały: aktywność metaboliczną fagocytów krwi - RBA (respiratory burst activity) - określaną wybuchem tlenowym po stymulacji PMA (phorbol myristate acetate), wewnątrzkomórkową zdolność fagocytów do zabijania - PKA (potential killing activity) oraz określenie odpowiedzi proliferacyjnej limfocytów stymulowanych mitogenami - konkanawaliną A (MTT-ConA) i lipopolisacharydem (MTT-LPS). Stwierdzono, że preparat selenowy nie spowodował istotnych zmian w koncentracji białka ogólnego, natomiast wpłynął na wzrost parametrów odporności humoralnej - aktywności lizozymu i ceruloplazminy oraz koncentrację gammaglobulin. Istotny wpływ wykazano u jagniąt grupy DII. Parametry te były u tych jagniąt wyższe niż u kontrolnych i w kolejnych terminach badań utrzymywały się na wyższym poziomie w stosunku do terminu 0 , a szczególnie w 70. i 100. dniu życia $(\mathrm{p} \leq 0,01)$. Podobne tendencje wystąpiły w zakresie odporności komórkowej. Zarówno parametry odporności nieswoistej - RBA i PKA fagocytów, jak i odporności swoistej - MTT-ConA i MTT-LPS kształtowały się na wyższym poziomie u jagniąt grup doświadczalnych, przy czym wyższe były w grupie DII. Rozpatrując te wartości w układzie dynamicznym, stwierdzono silniejszą odpowiedź fagocytów w zakresie PKA u jagniąt grupy DI, natomiast w zakresie MTT-ConAu wszystkich jagniąt doświadczalnych. Rezultaty przeprowadzonych badań wskazują na wpływ iniekcyjnie podawanego preparatu selenowego o długim okresie działania na swoiste i nieswoiste mechanizmy obronne u jagniąt, przy czym skuteczniejsza jest bezpośrednia aplikacja jagniętom, w porównaniu z podawaniem wyprzedzającym matkom podczas ciąży. 


\title{
WPEYW RÓŻNYCH SYSTEMÓW UTRZYMANIA NA MIKROSTRUKTURĘ MIĘŚNIA LONGISSIMUS LUMBORUM OWIEC RASY WRZOSÓWKA
}

The impact of various maintenance systems on the microstructure of longissimus lumborum muscle of Wrzosówka breed

\author{
Joanna Bogucka $^{1}$, Bronisław Borys ${ }^{2}$, Julita Pabian ${ }^{1}$, Jan Knapik ${ }^{3}$ \\ ${ }^{1}$ Uniwersytet Technologiczno-Przyrodniczy w Bydgoszczy, Katedra Fizjologii, Zoofizjoterapii i Żywienia Zwierząt, ul. Mazowiecka \\ 28, 85-084 Bydgoszcz, e-mail: bogucka@utp.edu.pl \\ ${ }^{2}$ Instytut Zootechniki Państwowy Instytut Badawczy Zakład Doświadczalny Kołuda Wielka, ul. Parkowa 1, 88-160 Janikowo \\ ${ }^{3}$ Instytut Zootechniki - Państwowy Instytut Badawczy, ul. Krakowska 1, 32-083 Balice k. Krakowa
}

Celem badań była ocena wpływu różnych systemów utrzymania na mikrostrukturę mięśnia longissimus lumborum $(L L)$ owiec rasy wrzosówka. Materiał doświadczalny stanowiło 17 tryczków, które podzielono na dwie grupy: A (8 szt.) - utrzymywane w stadzie macierzystym (Naryjski Młyn k. Morąga, tucz ekstensywny) oraz B (9 szt.) - w IZ PIB ZD Kołuda Wielka (tucz półintensywny). Jagnięta z grupy A w okresie tuczu żywiono wyłącznie zielonką pastwiskową na kwaterze przyleśnej, a jagnięta z grupy B mieszanką treściwą zawierającą 35\% komponentów oleistych (po 15\% makuchu rzepakowego i suszonego wywaru kukurydzianego DDGS + 5\% nasion lnu) zadawaną w ilości 3\% masy ciała jagniąt oraz sianem z traw do woli. Jagnięta ubito po osiągnięciu średniej masy ciała: w gr. A - 28,3 kg i B - 36,4 kg. Próbki mięśnia longissimus lumborum (LL) do badań histologicznych pobrano bezpośrednio po uboju i zamrożono w ciekłym azocie, a następnie ścięto w kriostacie i sporządzono z nich preparaty mikroskopowe. Zastosowano dwie metody barwienia: NADH-TR i ATP-azę miofibrylarną dla określenia profilu enzymatycznego włókien (STO, FTO i FTG; fot. 1) oraz Oil Red (w celu określenia udziału tłuszczu śródmięśniowego; fot. 2). Ocenę preparatów histologicznych przeprowadzono w programie MultiScan. Określono: średnicę i liczbę włókien mięśniowych oraz udział tłuszczu śródmięśniowego. Ponadto dokonano obliczenia gęstości włókien mięśniowych, a także łącznej liczby włókien mięśniowych poprzez pomnożenie zagęszczenia włókien/1 $\mathrm{mm}^{2}$ i powierzchni „oka” polędwicy.

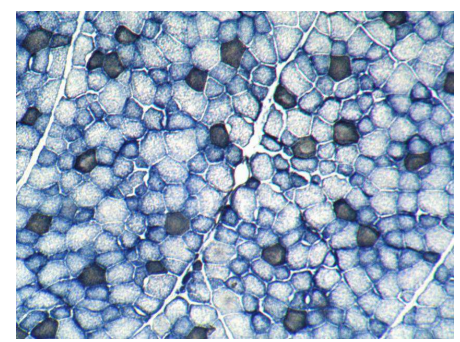

Fot. 1.

Przekrój poprzeczny

mięśnia $L L$

NADH-TR +ATP-aza

miofibrylarna.

Pow. 125x

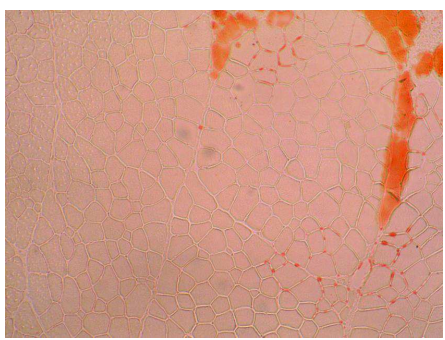

Fot. 2.

Przekrój poprzeczny

mięśnia $L L$.

Oil Red.

Pow. 125x

Przeprowadzone analizy histologiczne wykazały, że jagnięta tryczki tuczone półintensywnie w IZ PIB ZD Kołuda Wielka miały istotnie większą średnicę włókien białych (FTG $-31,11 \mu \mathrm{m}^{2}$ ), większą łączną liczbę włókien w mięśniu $(606 \times 1000)$ oraz większy udział tłuszczu śródmięśniowego $(1,63 \%)$ w porównaniu $\mathrm{z}$ jagniętami $\mathrm{z}$ gospodarstwa macierzystego utrzymywanymi w systemie ekstensywnym (odpowiednio: $26,18 \mu \mathrm{m}^{2}, 360 \times 1000$ i $\left.0,47 \%\right)$.

Badania zrealizowano w ramach programu Biostrateg II, podzadanie 5.5.
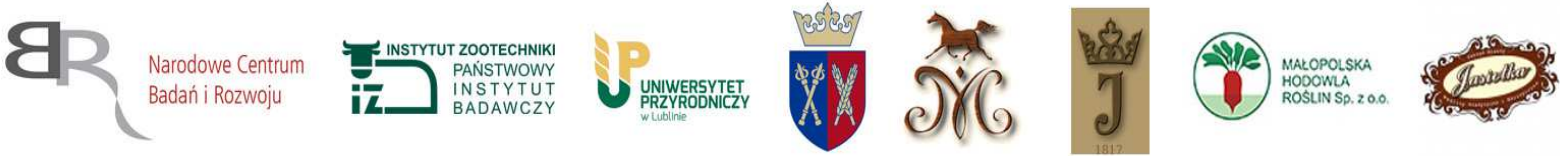


\title{
ZAKAŻENIA SRLV U RÓŻNYCH RAS OWIEC
}

SRLV infections in various sheep breeds

\author{
Wiktor Bojar ${ }^{1}$, Andrzej Junkuszew ${ }^{1}$, Monika Olech ${ }^{2}$, Jacek Kuźmak ${ }^{2}$, \\ Tomasz M. Gruszecki ${ }^{1}$, Czesława Lipecka ${ }^{1}$

\footnotetext{
${ }^{1}$ Uniwersytet Przyrodniczy w Lublinie, Instytut Hodowli Zwierząt i Ochrony Bioróżnorodności, ul. Akademicka 13, 20-950 Lublin ${ }^{2}$ Państwowy Instytut Weterynaryjny - Państwowy Instytut Badawczy, Zakład Biochemii, al. Partyzantów 57, 24-100 Puławy
}

Celem pracy było określenie prewalencji zakażeń SRLV ras owiec utrzymywanych na obszarze środkowo-wschodniej Polski. Przebadano próbki surowic pobrane od 15 ras owiec. Oznaczanie swoistych przeciwciał dla SRLV w surowicy krwi wykonano przy użyciu testu ELISA. W wyniku przeprowadzonych analiz wykazano duże zróżnicowanie prewalencji u poszczególnych ras owiec. Najniższą prewalencję odnotowano u owiec rasy uhruska, u której pomimo dużej ilości przebadanych osobników (1675 owiec matek) tylko $5,07 \%$ stanowiły osobniki o pozytywnym odczynie serologicznym. Wykazana prewalencja u tej rasy była ponad 5-7-krotnie niższa w stosunku do rasy wielkopolskiej (35\%), owcy pogórza $(22,73 \%)$ czy cakla podhalańskiego $(29,03 \%)$ i ponad 10-krotnie niższa niż u owiec rasy świniarka $(57,04 \%)$. Podsumowując, w konstruowaniu programów ochrony stad przed SRLV istotną rolę powinno odgrywać wykorzystanie ras wykazujących większą oporność na zakażenia. Nie należy jednak zapominać także o ograniczeniu występowania czynników zwiększających ryzyko zakażeń SRLV. Szczególnie należy zwrócić uwagę na wymianę materiału hodowlanego pomiędzy gospodarstwami. W związku z tym dużą uwagę powinno zwrócić się na badanie na obecność SRLV zwierząt wprowadzanych do obrotu. Uwzględnienie powyższych zaleceń powinno przyczynić się do zmniejszenia ryzyka zakażeń SRLV bez negatywnych skutków ekonomicznych dla hodowców owiec.

Projekt „Kierunki wykorzystania oraz ochrona zasobów genetycznych zwierząt gospodarskich w warunkach zrównoważonego rozwoju" współfinansowany przez Narodowe Centrum Badań i Rozwoju w ramach strategicznego programu badań naukowych i prac rozwojowych „Środowisko naturalne, rolnictwo i leśnictwo” - Biostrateg, nr umowy: BIOSTRATEG2/297267/14/NCBR/2016. 


\title{
PORÓWNANIE WYNIKÓW TUCZU PÓŁINTENSYWNEGO TRYCZKÓW SZEŚCIU RAS Z REZERWY GENETYCZNEJ
}

Comparison of the half-intensive fattening effects of the ram-lambs represented six breeds from the genetic reserve

\author{
Bronisław Borys $^{1}$, Jan Knapik ${ }^{2}$, Anna Jarzynowska ${ }^{1}$, Eugeniusz Kłopotek ${ }^{1}$ \\ ${ }^{1}$ Instytut Zootechniki - Państwowy Instytut Badawczy, ul. Krakowska 1, 32-083 Balice k. Krakowa \\ e-mail: bronislaw.borys@onet.eu \\ ${ }^{2}$ Instytut Zootechniki Państwowy Instytut Badawczy Zakład Doświadczalny Kołuda Wielka, ul. Parkowa 1, 88-16 Janikowo
}

W ramach komunikatu zaprezentowane zostaną wstępne wyniki tuczu półintensywnego tryczków 6 rodzimych ras owiec: uhruskiej (UHR), pomorskiej (POM), czarnogłówki (CZG), cakla podhalańskiego (CPH), wrzosówki (WRZ) i świniarki (ŚW). Tryczki tuczone były w 2017 r. grupowo (po 9 szt. z każdej rasy) w IZ PIB ZD Kołuda Wielka sukcesywnie po zakończeniu ich odchowu w gospodarstwach macierzystych. Tucz tryczków UHR, POM, CZG i CPH prowadzono do uzyskania w grupie średniej masy ciała $40 \mathrm{~kg}$, a WRZ i ŚW do masy $35 \mathrm{~kg}$. Jagnięta żywiono jednakowo mieszanką treściwą zawierającą 35\% komponentów oleistych (po 15\% makuchu rzepakowego i suszonego wywaru kukurydzianego DDGS + 5\% nasion lnu) zadawaną w ilości 3\% masy ciała jagniąt + siano z traw do woli. Prowadzono codzienną kontrolę ilości zadawanych pasz i okresową niewyjadów (dwa razy w tygodniu). W warunkach standardowych zarysowały się różnice w wynikach tuczu między rasami w typie ogólnoużytkowym i mięsnym (UHR, POM i CZG) a prymitywnymi (CPH, ŚW I WRZ). Tryczki UHR, POM i CZG uzyskały bardzo dobre przyrosty dzienne, powyżej $310 \mathrm{~g}$. Tryczki pozostałych trzech ras uznawanych za prymitywne uzyskały znacznie mniejsze przyrosty dzienne, co świadczy o ich znacznie mniejszym potencjale tempa wzrostu. W tej grupie ras największe przyrosty dzienne uzyskały cakle podhalańskie $(220 \mathrm{~g})$, a przyrosty ŚW i WRZ należy uznać za bardzo zbliżone ze względu na różnice w typie urodzenia - przyrosty odpowiednio 180 i 169 g (średni typ urodzenia odpowiednio 1,33 i 2,00). Przy stosunkowo mało zróżnicowanej średniej masie ciała jagniąt z poszczególnych ras na początku tuczu (od 22,1 kg u UHR do $25,2 \mathrm{~kg} \mathrm{u} \mathrm{CPH),} \mathrm{różnice} \mathrm{w} \mathrm{tempie} \mathrm{wzrostu} \mathrm{podczas} \mathrm{tuczu} \mathrm{przekła-}$ dają się na liczbę dni tuczu oraz zużycie pasz i składników pokarmowych na jednostkę przyrostu masy ciała. U ras w typie bardziej mięsnym tucz trwał od 46 dni u POM do 57 u UHR, a u ras prymitywnych od 64 dni u CPH do 71 dni u WRZ. Również w zakresie jednostkowego zużycia pasz i składników pokarmowych, rasy bardziej mięsne uzyskały zbliżone i znacznie lepsze wyniki niż rasy prymitywne. Średnio na $1 \mathrm{~kg}$ przyrostu masy ciała tryczki UHR, POM i CZG w porównaniu z CPH, ŚW i WRZ zużywały mniej mieszanki treściwej o 39,2\%, siana o 41,4\%, JPŻ o 39,8\% i białka ogólnego o 39,9\%. Bardziej pogłębiona analiza wyników uzyskanych w zakresie odchowu i tuczu tryczków w gospodarstwach macierzystych i tuczu standardowego będzie przeprowadzona po zakończeniu odchowu i tuczów wszystkich 8 ras owiec objętych badaniami.

Badania zrealizowano w ramach programu Biostrateg II, podzadanie 5.5. Projekt „Kierunki wykorzystania oraz ochrona zasobów genetycznych zwierząt gospodarskich w warunkach zrównoważonego rozwoju” finansowany przez Narodowe Centrum Badań i Rozwoju w ramach Strategicznego programu badań naukowych i prac rozwojowych „Środowisko naturalne, rolnictwo i leśnictwo”Biostrateg, nr umowy: BIOSTRATEG2/297267/14/NCBR/2016.
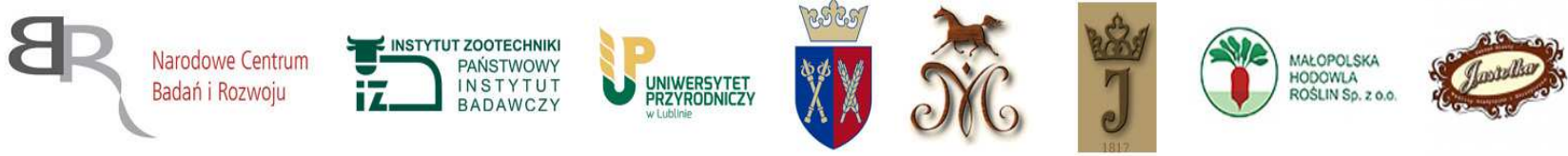


\title{
ANALIZA POZIOMU WYBRANYCH BIAŁEK OSTREJ FAZY W OKRESIE OKOLOPORODOWYM U OWIEC
}

Analysis of acute phase proteins level in perinatal period in ewes

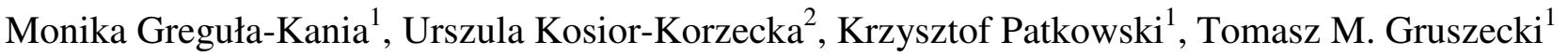 \\ ${ }^{1}$ Uniwersytet Przyrodniczy w Lublinie, Instytut Hodowli Zwierząt i Ochrony Bioróżnorodności, Akademicka 13, 20-950 Lublin \\ ${ }^{2}$ Uniwersytet Przyrodniczy w Lublinie, Katedra Przedklinicznych Nauk Weterynaryjnych, \\ Zakład Patofizjologii, Akademicka 13, 20-950 Lublin
}

Reakcja ostrej fazy oznacza zespół zjawisk lokalnych i ogólnoustrojowych pojawiających się w sytuacji zaburzenia homeostazy ustroju i zmierzających do jej przywrócenia. Reakcja ostrej fazy związanej z porodem stanowi przedmiot zainteresowania w kontekście porodu prawidłowego, przedwczesnego, a także ewentualnych powikłań ciąży i porodu. Biologiczna rola reakcji ostrej fazy w okresie porodu i w bezpośrednim okresie poporodowym sprowadza się do jak najszybszego powrotu matki do dobrej kondycji zdrowotnej, by móc opiekować się jagnięciem i karmić je. Celem pracy jest określenie przebiegu odpowiedzi białek ostrej fazy w okresie okołoporodowym u maciorek. Materiał badawczy stanowiły 34 owce matki syntetycznej linii BCP. U maciorek przeprowadzono synchronizację rui metodą Chronogest ${ }^{\circledR}$, zakładając samicom gąbki dopochwowe nasączone progestagenem na 16 dni, bezpośrednio po usunięciu gąbek dokonano domięśniowej iniekcji 500 j.m. serogonadotropiny. Inseminację laparoskopową przeprowadzono u wszystkich maciorek pomiędzy 56. a 58. godziną po usunięciu gąbek. Krew do analiz była pobierana sześciokrotnie: 3 tygodnie przed inseminacją, 2 tygodnie i 1 tydzień przed porodem, w terminie porodu, 1 tydzień oraz 2 tygodnie po porodzie. Stężenie surowiczego amyloidu A (SAA), fibrynogenu oraz haptoglobiny zbadano przy użyciu testu ELISA.

W wyniku analiz stwierdzono istotnie wyższe stężenia analizowanych białek w okresie okołoporodowym w porównaniu z okresem jałowości. W przypadku stężenia SAA oraz fibrynogenu obserwowano wzrost w okresie przedporodowym aż do dnia porodu, po czym ulegało obniżeniu. Natomiast stężenie haptoglobiny było najwyższe 2 tygodnie przed porodem, po czym ulegało obniżeniu. 


\title{
PORÓWNANIE SKŁADU CHEMICZNEGO ORAZ PROFILU KWASÓW TŁUSZCZOWYCH W MIĘSIE OWIEC DOROSŁYCH ORAZ JAGNIĄT
}

Chemical composition and fatty acid profile in meat of lambs and adult sheep

\author{
Monika Greguła-Kania, Paulina Dudko, Andrzej Junkuszew, Wiktor Bojar
}

Celem badań było porównanie składu chemicznego, profilu oraz zawartości kwasów tłuszczowych w tkance mięśniowej jagniąt oraz owiec dorosłych doskonalonych w kierunku mięsnym. Badania przeprowadzono w eksperymentalnej stacji Bezek należącej do Uniwersytetu Przyrodniczego w Lublinie, położonej w południowo-wschodniej Polsce. W gospodarstwie utrzymywanych jest 550 owiec matek w systemie alkierzowo-pastwiskowym. Wykoty odbywały się w styczniu. Jagnięta utrzymywane są z matkami przez cały okres odchowu odbywającego się w owczarniach. Badaniami objęto 30 sztuk zwierząt syntetycznej linii plenno-mięsnej SCP (15 owiec dorosłych oraz 15 pochodzących od nich jagniąt). Zwierzęta podczas całego doświadczenia utrzymywano $\mathrm{w}$ systemie alkierzowym $\mathrm{w}$ ujednoliconych warunkach środowiskowych. Po uboju w pobranych próbkach mięsa z mięśnia biceps femoris oznaczono podstawowy skład chemiczny oraz określono profil kwasów tłuszczowych w tłuszczu wewnątrzmięśniowym. Na podstawie uzyskanych wyników stwierdzono korzystniejszy stosunek zawartości kwasów tłuszczowych omega 6 do omega 3 w mięsie zwierząt dorosłych w porównaniu z jagnięciną. Baranina posiadała także korzystny niższy procentowy udział kwasów OFA. Uzyskane wyniki badań powinny stanowić podstawę do wprowadzenia baraniny jako mięsa zalecanego przez dietetyków w żywieniu człowieka. Powinno przyczynić się to do popularyzacji mięsa ze zwierząt dorosłych jako w pełni wartościowego produktu, a także do poprawy ekonomiki produkcji owczarskiej szczególnie w krajach, gdzie do tej pory ten gatunek mięsa nie cieszył się uznaniem klientów.

Projekt „Kierunki wykorzystania oraz ochrona zasobów genetycznych zwierząt gospodarskich w warunkach zrównoważonego rozwoju” współfinansowany przez Narodowe Centrum Badań i Rozwoju w ramach Strategicznego programu badań naukowych i prac rozwojowych „Środowisko naturalne, rolnictwo i leśnictwo” -Biostrateg, nr umowy: BIOSTRATEG2/297267/14/NCBR/2016. 


\section{ANALIZA ROZRODU MACIOREK LINII SYNTETYCZNYCH BCP I SCP}

Analysis of reproduction performance ewes of synthetic line BCP and SCP

\section{Tomasz M. Gruszecki, Czesława Lipecka, Katarzyna Krzeszewska, Anna Szymanowska, Marek Szymanowski, Krzysztof Patkowski, Andrzej Junkuszew}

Uniwersytet Przyrodniczy w Lublinie, Instytut Hodowli Zwierząt i Ochrony Bioróżnorodności, Akademicka 13, 20-950 Lublin e-mail: tomasz.gruszecki@up.lublin.pl

Celem niniejszej pracy była analiza użytkowości rozpłodowej owiec linii BCP i SCP utrzymywanych w Stacji Badawczej w Bezku należącej do Uniwersytetu Przyrodniczego w Lublinie.

Oceną i analizą objęto obie populacje w okresie od 2003 do 2017 r. Oceniane były parametry: plenność, płodność, użytkowość rozpłodowa oraz śmiertelność jagniąt w okresie okołoporodowym a także długość użytkowania rozpłodowego owiec matek. Wyniki pozwalają ocenić efektywność prowadzonej pracy hodowlanej, wskazać potrzeby ewentualnych zmian w tym zakresie i sformułować następujące konkluzje:

Wyniki rozrodu (płodność, plenność) owiec matek linii BCP i SCP w latach 2003-2017 w Stacji Badawczej w Bezku kształtowały się na dobrym poziomie, co wskazuje na prawidłowość pracy hodowlanej. W pracy hodowlanej należy większą uwagę zwrócić na poziom odchowu jagniąt.

Obserwowano wahania masy ciała jagniąt pomiędzy poszczególnymi latami, co wynikać może ze zmieniających się warunków środowiskowych, a w szczególności z różnej jakości pasz.

Analiza masy ciała jagniąt z poszczególnych lat wykazała, że w linii SCP u jedynaków przyrosty masy ciała są wyższe niż w linii BCP. 


\title{
BEHAWIOR PASTWISKOWY OWIEC WYPASANYCH NA TERENIE ZACHODNOWOEYŃSKIEJ DOLINY BUGU
}

\author{
Grazing behaviour of sheep in the Bug valley area
}

\author{
Tomasz M. Gruszecki ${ }^{1}$, Krzysztof Patkowski ${ }^{1}$, Anna Szymanowska ${ }^{1}$, Monika Greguła-Kania ${ }^{1}$, \\ Sylwia Bodzak ${ }^{1}$, Katarzyna Wiercińska ${ }^{1}$, Marek Szymanowski ${ }^{1}$, Mariusz Kulik ${ }^{2}$ \\ ${ }^{1}$ Uniwersytet Przyrodniczy w Lublinie, Instytut Hodowli Zwierząt i Ochrony Bioróżnorodności \\ e-mail: tomasz.gruszecki@up.lublin.pl \\ ${ }^{2}$ Uniwersytet Przyrodniczy w Lublinie, Katedra Łąkarstwa i Kształtowania Krajobrazu \\ ul. Akademicka 13, 20-950 Lublin, e-mail: mariusz.kulik@up.lublin.pl
}

W ostatnich latach znacząco zwiększono liczbę działań mających na celu wykorzystywanie zwierząt gospodarskich w czynnej ochronie przyrody poprzez prowadzenie kontrolowanych wypasów m.in. w parkach narodowych, parkach krajobrazowych, rezerwatach przyrody itp. Celem niniejszej pracy była analiza zachowywania się owiec podczas wypasu na terenie siedliska przyrodniczego murawy kserotermicznej, Zachodniowołyńskiej Doliny Bugu PLH060035 w miejscowości Gródek-Czumów. Miejscem wypasu był nasłoneczniony stok o powierzchni 1,7 ha. Wypasana powierzchnia była ograniczona specjalistyczną siatką ogrodzeniową podłączoną do pastucha elektrycznego. Przedmiotem badań było stado maciorek rasy świniarka i owca uhruska. Obserwacje behawiorystyczne wykonano podczas wypasu w dwu terminach 18-22 czerwca 2016 r. i 17-21 lipca 2017 r., szczegółowy monitoring prowadzono w godzinach od 7:00 do 19:00. Na noc zwierzęta były zamykane w namiocie ze względów bezpieczeństwa, w celu ochrony przed drapieżnikami oraz wałęsającymi się psami. Podczas wypasu obserwowano takie zachowania jak: pasienie, odpoczynek, ruch, częstotliwość korzystania z wody a ponadto zwracano uwagę na zachowanie się zwierząt względem siebie. W trakcie obserwacji kontrolowano temperaturę i wilgotność powietrza w odstępach co godzinę.

Podczas obserwacji zauważono, że owce w trakcie pasienia poruszały się całym stadem, najintensywniej pasąc się rano i wieczorem, w upalne i zimne (wietrzne) dni czas pasienia był krótszy, a w dni pochmurne, bezwietrzne, o zwiększonej wilgotności odnotowywano zwiększone pobieranie paszy. Wodę zwierzęta pobierały średnio 2-3 razy dziennie, głównie rano i wieczorem.

Owce rasy świniarka były bardziej aktywne, zazwyczaj pierwsze wychodziły na pastwisko, wysuwając się na czoło stawki i odważnie zbliżając do obrzeży pastwiska. Zwierzęta tej rasy przejawiały behawior zabawowy, biegając po pastwisku, nawiązując kontakt i wspinając się na skarpę, czego nie obserwowano u maciorek uhruskich.

Wyniki obserwacji behawioralnych pozwalają na uzyskanie informacji, które są niezbędne przy podejmowaniu decyzji o wyborze rasy owiec wykorzystywanych w specyficznych warunkach wypasu.

Projekt „Kierunki wykorzystania oraz ochrona zasobów genetycznych zwierząt gospodarskich w warunkach zrównoważonego rozwoju” współfinansowany przez Narodowe Centrum Badań i Rozwoju w ramach Strategicznego programu badań naukowych i prac rozwojowych „Środowisko naturalne, rolnictwo i leśnictwo” - Biostrateg, nr umowy: BIOSTRATEG2/297267/14/NCBR/2016. 


\title{
OCENA PARAMETRÓW TECHNOLOGICZNYCH MLEKA KOZIEGO PRZEZNACZONEGO DO PRODUKCJI EKOLOGICZNYCH SERÓW TWAROGOWYCH
}

Assessment of technological parameters of goat's milk for the production of ecological cottage cheese

\author{
Elżbieta Horoszewicz, Roman Niedziółka, Klaudia Bednarek
}

\author{
Uniwersytet Przyrodniczo-Humanistyczny w Siedlcach, Instytut Bioinżynierii i Hodowli Zwierząt \\ Katedra Hodowli Bydła, Owiec i Oceny Mleka, ul. Prusa 14, 08-110 Siedlce \\ e-mail: roman.niedziolka@uph.edu.pl
}

Produkty z mleka koziego postrzegane są przez konsumentów jako wysokowartościowe wyroby o dobrej jakości odżywczej i walorach prozdrowotnych, co sprawia, że popyt na te produkty stale rośnie. Mleko kozie oraz produkty z niego uzyskiwane są wysoko wartościowe dla człowieka ze względu na skład oraz wartość biologiczną, a szczególnie zawartość tłuszczu i białka. Dodatkowo niewielki udział albo całkowity brak bakterii chorobotwórczych wpływa na jakość zdrowotną czy łatwość trawienia i przyswajania składników, czyli na to, czego konsumenci obecnie poszukują na rynku żywności. Mleko kozie wykorzystywane jest najczęściej do produkcji serów, które niejednokrotnie są produktami chronionymi na rynku UE (1429 produktów) i są wytwarzane w całości z mleka koziego lub mieszane z mlekiem owczym i krowim. Również w Polsce wzrasta liczba produktów tradycyjnych, obecnie jest ich już ponad 1822. Serów kozich lub mieszanych jest jednak tylko 31, a w województwie mazowieckim tylko 5 - wszystkie z mleka koziego (ser twarogowy z Cegłowa, kozi ser twarogowy suszony, ser ziemny z Kornicy, ser z Jakubowa, kozi młodziak).

Celem niniejszej pracy była ocena parametrów technologicznych i ocena konsumencka mleka koziego przeznaczonego do produkcji ekologicznych serów twarogowych.

Badania zostały przeprowadzone w stadzie kóz utrzymywanych w woj. mazowieckim w warunkach ekologicznych (certyfikat Agro Bio Test). Ocenie poddane zostało mleko kóz rasy polskiej białej uszlachetnionej (pbu) i polskiej barwnej uszlachetnionej (pku). Zwierzęta przez cały czas były żywione paszami pochodzącymi z gospodarstwa, tylko niewielką ilość paszy treściwej dokupywano od producentów ekologicznych. W analizie mleka zostały uwzględnione następujące parametry składu mleka: OLB, LKS, tłuszcz, białko, laktoza, sucha masa, punkt zamarzania, mocznik. Ponadto analizowano parametry technologiczne oznaczone w mleku i serze: $\mathrm{pH}$, temperatura, zużycie mleka na $1 \mathrm{~kg}$ sera, masa i udział serwatki w produkcji $1 \mathrm{~kg}$ sera.

Wyniki analizy wydajności mlecznej wykazały, że kozy rasy białej uszlachetnionej dawały więcej mleka (w ciągu całej 240-dniowej laktacji - 73 l) o mniejszej zawartości OLB (poniżej 27 jkt w tys./1 ml) i mniejszej LKS (poniżej 369 tys./1 ml, p s 0,05). Poziom mocznika w mleku niższy był u kóz białych uszlachetnionych (poniżej $336 \mathrm{mg} / \mathrm{l}$ ), na który miały wpływ wahania bilansu białkowo-energetycznego paszy i co mogło pośrednio wpływać na podwyższony poziom LKS w grupie pku. Mleko kóz barwnych charakteryzowało się większą zawartością suchej masy $(11,57 \%)$, tłuszczu $(3,61 \%, \mathrm{p} \leq 0,5)$, białka $(2,82 \%, \mathrm{p} \leq 0,5)$. Pod względem kwasowości - pH wyniosło 6,59 (pbu) i 6,71 (pku), natomiast pH skrzepu było zbliżone na poziomie 4,23. Zużycie mleka na $1 \mathrm{~kg}$ sera większe było w grupie pbu i wyniosło $9937 \mathrm{ml}$, czyli w ciągu laktacji na taką samą masę sera potrzeba było o 37 litrów więcej niż w przypadku mleka kóz barwnych. Również uzysk serwatki przy produkcji $1 \mathrm{~kg}$ sera większy był u pbu o ok. $200 \mathrm{ml}$ i wyniósł $6242 \mathrm{ml}$.

Podsumowując, stwierdzono lepsze parametry składu mleka kóz białych uszlachetnionych, ale jednak potrzeba go było więcej na wyprodukowanie tej samej masy sera. 


\title{
WSTEPNA OCENA WARTOŚCI RZEŹNEJ ORAZ MOŻLIWOŚCI ZAGOSPODAROWANIA JAGNIĘCINY Z PERSPEKTYWĄ SPRZEDAŻY BEZPOŚREDNIEJ
}

\author{
Initial evaluation of the slaughter value and the possibility of managing lamb with the prospect \\ of direct sales
}

Elżbieta Horoszewicz, Roman Niedziółka, Anna Tywoniuk

\author{
Uniwersytet Przyrodniczo-Humanistyczny w Siedlcach, Instytut Bioinżynierii i Hodowli Zwierząt \\ Katedra Hodowli Bydła, Owiec i Oceny Mleka, ul. Prusa 14, 08-110 Siedlce \\ e-mail: roman.niedziolka@uph.edu.pl
}

Rynek jagnięciny jest ciągle rynkiem deficytowymi w Unii Europejskiej musi być pokrywany importem. Produkcja owczarska powinna się rozwijać, ponieważ konsument oczekuje na towar wysokiej jakości i zdrowotności. Jak szacują eksperci z FAO w 2016 r. do globalnego handlu trafiło 933 tys. ton mięsa, tj. 6,6\% światowej produkcji, a zatem o 3,2\% mniej niż w $2015 \mathrm{r}$. W globalnym handlu w tym gatunku mięsa dominującą rolę odgrywają Australia oraz Nowa Zelandia z $87 \%$ udziałem w światowym handlu. W Polsce $3 / 4$ jagniąt rzeźnych stanowią jagnięta w przedziałach wagowych $24,1-31,0 \mathrm{~kg}, 31,1-36,0 \mathrm{~kg}, 36,1-40,0 \mathrm{~kg}$. W krajach UE do produkcji owczarskiej w stadach zarodowych lub na obszarach ONW można liczyć na znaczące wsparcie finansowe z zewnątrz, co powinno zachęcić producentów jagnięciny pochodzącej od ras mięsnych.

Celem niniejszej pracy była ocena wartości rzeźnej, konsumenckiej oraz możliwość zagospodarowania jagnięciny w łańcuchu żywnościowym z uwzględnieniem wartości przychodu na przykładzie mięsnej rasy czarnogłówka.

Badania zostały przeprowadzone w stadzie zarodowym owiec rasy czarnogłówka utrzymywanych w systemie tradycyjnym z wykorzystaniem pasz własnych. Obserwacje przyżyciowe prowadzone były na 96 jagniętach. Do analizy wybrano losowo 6 tryczków i 6 jarek, które były tuczone do wieku $90( \pm 7)$ dni. W tym okresie prowadzona była analiza wzrostu jagniąt. Po uboju w grupie doświadczalnej oceniano wskaźniki wartości rzeźnej, tj. masę i procentowy udział tuszy, półtuszy, wyrębów (udziec, antrykot, comber, szyja, karkówka, łopatka, mostek, łata z żebrami, goleń przednia i tylna), masę podrobów i skóry. Oszacowano masę i udział mięsa i podrobów, które mogły mieć dalsze przeznaczenie kulinarne. Zaprojektowano produkty (m.in. kołduny, pasztety, wyroby wędzone) z poszczególnych partii wyrębów, co dało pogląd wykorzystania jagnięciny $\mathrm{w}$ łańcuchu żywnościowym, z oceną konsumencką przeprowadzoną wśród studentów i pracowników. Istotną częścią była ocena parametrów przychodu ze sprzedaży mięsa, wyrębów i gotowych produktów, w celu uświadomienia producentom jego skali i wartości.

W analizowanym stadzie plenność była na poziomie 141,9\%, co dało 132 jagnięta, w tym 96 jagniąt przeznaczonych na rzeź. W przeliczeniu na masę ubojową (średnia masa tuszy tryczków 15,7 kg i jarek $13,0 \mathrm{~kg}$ ) uzyskano $1325 \mathrm{~kg}$ tuszy o wartości rynkowej 35 tys. zł. Na podstawie średniej masy wyrębów wartościowych oszacowano, że ilość wyrębów wartościowych wyniosła $580 \mathrm{~kg}$, za które hodowca mógłby uzyskać 44 tys. zł. Tusze podzielone na wyręby miały średnio wartość ok. 669 zł (tryczki) i 555 zł (jarki), co globalnie dało wartość większą o ok. 29 tys. zł w porównaniu do wartości uzyskanej za żywe jagnięta. Kupno wyrobów z jagnięciny podyktowane było względami dietetycznymi $(63,6 \%)$, a nie trendem żywieniowym. Dlatego aż $80 \%$ badanych konsumentów w ciągu ostatniego roku nie jadło produktów z jagnięciny. Najczęściej były jedzone udziec $(28,5 \%)$ i antrykot $(26,5 \%)$, w restauracji $(66,67 \%)$, a nie przyrządzane w domu $(33,37 \%)$. Z przygotowanych produktów najbardziej akceptowalnym produktem był comber i antrykot wędzony, za który najwięcej konsumentów $(66,6 \%)$ było w stanie zapłacić ponad 47 zł/kg.

Podsumowując, zaobserwowano tendencję kupowania jagnięciny w postaci tusz lub wyrębów jednak barierą była jeszcze cena zarówno za wyręby, jak i produkty gotowe. 


\title{
OCENA WARTOŚCI RZEŹNEJ JAGNIĄT ŻYWIONYCH Z WYKORZYSTANIEM PREPARATU O DZIAŁANIU KOKCYDIOSTATYCZNYM
}

The effect of coccidiostatic treatment on slaughter value of lambs

\author{
Andrzej Junkuszew ${ }^{1}$, Paulina Dudko ${ }^{1}$, Klaudiusz Szczepaniak ${ }^{2}$, Wiktor Bojar ${ }^{1}$, Joël Le Scouarnec ${ }^{3}$, \\ Michał Milerski ${ }^{4}$ \\ ${ }^{1}$ Uniwersytet Przyrodniczy w Lublinie, Instytut Hodowli Zwierząt i Ochrony Bioróżnorodności, , Akademicka 13, 20-950 Lublin \\ ${ }^{2}$ Zakład Parazytologii i Chorób Inwazyjnych, Uniwersytet Przyrodniczy w Lublinie, Akademicka 12, 20-950 Lublin \\ ${ }^{3}$ NEOVIA Research and Development Division, BP 235, 56006 Vannes Cedex, France \\ ${ }^{4}$ Institute of Animal Science in Prague, Přátelství 815, 104 00, Prague 10 - Uhř́něves, Czech Republic
}

Celem pracy była ocena zastosowanych działań profilaktycznych z wykorzystaniem preparatu o działaniu kokcydiostatycznym zawierającego wyciąg z Origanum vulgare i Citrus spp na wartość rzeźną jagniąt utrzymywanych w systemie alkierzowym. Materiał do badań stanowiła grupa 222 matek oraz 276 jagniąt owiec rasy polska owca nizinna. Zwierzęta podczas całego doświadczenia utrzymywane były w systemie alkierzowym (indoors) w ujednoliconych warunkach środowiskowych. Na podstawie przeprowadzonej analizy parazytologicznej podzielono stado owiec na trzy grupy zbliżone do siebie pod względem zarówno intensywności, jak i ekstensywności zarażenia pasożytami: grupa 1 - grupa kontrolna, dieta nie była suplementowana (74 owce matki i 87 jagniąt); grupa 2 - dieta suplementowana preparatem Oilis Sd o działaniu kokcydiostatycznym w okresie od trzeciego miesiąca ciąży aż do wykotu, urodzone jagnięta żywione były jak grupa kontrolna (73 owce matki i 105 jagniąt); grupa 3 - dieta suplementowana preparatem Oilis Sd o działaniu kokcydiostatycznym w okresie od trzeciego miesiąca ciąży do odsadzenia jagniąt, urodzone jagnięta od 14. dnia życia otrzymywały paszę z dodatkiem Oilis Sd (75 owiec matek i 84 jagnięta). Z 276 jagniąt uczestniczących w doświadczeniu wybrano do uboju 18 tryczków oraz 18 maciorek, reprezentujących wszystkie obserwowane grupy. W ok. 100. dniu życia ( \pm 6 dni) jagnięta poddano ubojowi. W wyniku przeprowadzonych obserwacji stwierdzono, że zwierzęta z grupy 3., w której pasza zarówno matek, jak i jagniąt suplementowana była preparatem o działaniu kokcydiostatycznym, charakteryzowały się większą masą ubojową $(30,80 \mathrm{~kg})$ w porównaniu ze zwierzętami z grupy $1(27,80 \mathrm{~kg})$ i $2(26,90 \mathrm{~kg})$, co zostało potwierdzone statystycznie $(\mathrm{p} \leq 0,05)$. Konsekwencją tego były uzyskane masy tuszy. Najwięszą średnią masą tuszy ciepłej charakteryzowała się grupa $3(13,36 \mathrm{~kg})$, natomiast istotnie niższą $(\mathrm{p} \leq 0,05)$ grupa $1(11,88 \mathrm{~kg})$ oraz $2(11,28 \mathrm{~kg})$. Analiza poubojowa jednoznacznie wykazała, że zastosowana profilaktyka przeciw kokcydiozie z wykorzystaniem preparatu zawierającego kompozycję olejków eterycznych z Origanum vulgare (Lamiacea) i Citrus spp. (Citraceae) korzystnie wpływa na wartość rzeźną jagniąt, powodując zwiększenie zarówno masy tuszy, jak i poszczególnych wyrębów oraz tkanek.

Projekt „Kierunki wykorzystania oraz ochrona zasobów genetycznych zwierząt gospodarskich w warunkach zrównoważonego rozwoju" współfinansowany przez Narodowe Centrum Badań i Rozwoju w ramach Strategicznego programu badań naukowych i prac rozwojowych „Środowisko naturalne, rolnictwo i leśnictwo” - Biostrateg, nr umowy: BIOSTRATEG2/297267/14/NCBR/2016. 


\title{
DYNAMIKA ROZWOJU HODOWLI RODZIMYCH RAS OWIEC NA PRZESTRZENI OSTATNIEJ DEKADY
}

The dynamics of breeding of native sheep breeds over the last decade

\author{
Aldona Kawęcka, Jacek Sikora, Marta Pasternak, Michał Puchała
}

Instytut Zootechniki - Państwowy Instytut Badawczy, Zakład Hodowli Owiec, 32-083 Balice k. Krakowa

Program ochrony zasobów genetycznych owiec jest ważnym narzędziem ochrony bioróżnorodności tego gatunku. Rok 2018 to kolejny rok realizacji Pakietu 7. w ramach Programu rolno-środowiskowoklimatycznego PROW 2014-2020, wspomagającego programy ochrony zasobów genetycznych zwierząt, w tym owiec. Od początku ich realizacji obserwuje się stały wzrost populacji chronionej. W ciągu ostatnich 10 lat realizacji programu liczebność owiec zwiększyła się trzykrotnie: z 22275 maciorek w roku 2008 do 66735 w roku bieżącym, utrzymywanych w 884 stadach. Od momentu włączenia do programu ochrony merynosa polskiego w starym typie i cakla podhalańskiego, czyli od 2008 r., zanotowano znaczne, prawie dwukrotne zwiększenie liczby stad w stosunku do ich liczby w PROW 2004-2006. W 2015 r. do programu ochrony zostały włączone dwie kolejne rasy owiec: polska owca pogórza oraz czarnogłówka. Obecnie programem ochrony zasobów genetycznych owiec objętych jest 15 ras, do których oprócz wspomnianych wcześniej należą: polska owca górska odmiany barwnej, korideil, merynos barwny, owca kamieniecka, olkuska, pomorska, uhruska, świniarka, wielkopolska, wrzosówka, żelaźnieńska.

Dynamika działań związanych z realizacją programów ochrony miała i ma wpływ na hodowlę owiec w naszym kraju. $Z$ uwagi na możliwość uzyskania dofinasowania do hodowli zwierząt objętych programem ochrony, hodowcy chętniej utrzymują rasy rodzime owiec, do których przewidziano dopłaty, niż pozostałe rasy hodowlane owiec. W 2008 r. maciorki objęte programem ochrony zasobów genetycznych stanowiły $33 \%$ całkowitej populacji maciorek wpisanych do ksiąg, natomiast w 2017 r. stanowiły już 78\%. Zakres zwiększenia liczby stad w ostatniej dekadzie był szeroki i wynosił w zależności od rasy od 11,60\% (cakiel podhalański) do nawet $88,80 \%$ (merynos barwny). Najbardziej dynamiczny wzrost liczebności (ponad 80\%) zaobserwowano w przypadku ras: polska owca górska odmiany barwnej, merynos barwny, korideil, świniarka i kamieniecka. Jedynie w przypadku owiec pomorskich i wrzosówek odnotowano zmniejszenie liczby stad, niemające jednak wpływu na liczebność tych ras, która przez wspomniane lata zwiększyła się odpowiednio o $32,02 \%$ i 48,3\%.

Pozytywnym aspektem realizacji programu ochrony zasobów genetycznych owiec są działania towarzyszące, które opierają się na wykorzystaniu pozaprodukcyjnej roli tego gatunku. Ekstensywny wypas owiec jako forma ochrony przyrody służy zachowaniu krajobrazów cennych przyrodniczo, a także związanej z owczarstwem kultury lokalnych społeczności. Pozytywnym aspektem hodowli zachowawczej jest również rozwój działalności dotyczącej rynku produktów tradycyjnych i regionalnych, związanych bezpośrednio z lokalnymi rasami owiec.
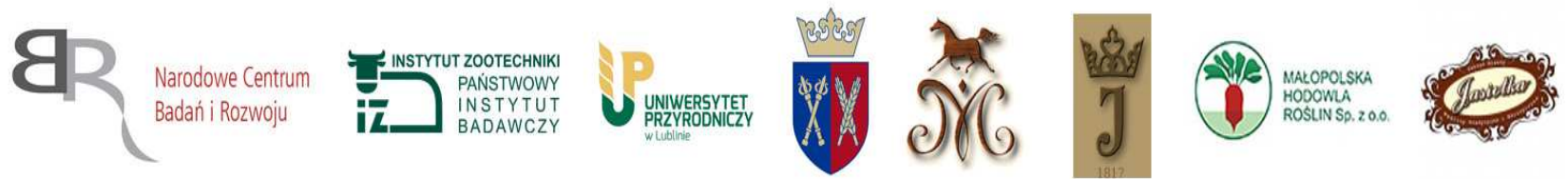


\title{
PORÓWNANIE WZROSTU TRYCZKÓW 6 RAS Z REZERWY GENETYCZNEJ W OKRESIE ICH TUCZU W GOSPODARSTWIE MACIERZYSTYM
}

Comparison of the ram-lambs growth represented 6 breeds from the genetic reserve during fateing period on their parental household

\author{
Jan Knapik ${ }^{1}$, Bronisław Borys ${ }^{2}$
}

\author{
${ }^{1}$ Instytut Zootechniki - Państwowy Instytut Badawczy, ul. Krakowska 1, 32-083 Balice k. Krakowa \\ ${ }^{2}$ Instytut Zootechniki - Państwowy Instytut Badawczy, Zakład Doświadczalny Kołuda Wielka, ul. Parkowa 1, 88-16 Janikowo \\ e-mail: Jan.knapik@izoo.krakow.pl
}

Celem badań jest ocena możliwości wykorzystania rodzimych ras owiec objętych programem ochrony zasobów genetycznych do produkcji regionalnych produktów mięsnych o zwiększonych walorach dietetycznych w warunkach systemów utrzymania stosowanych w regionach chowu oraz według nowoczesnych zasad żywienia ukierunkowanych na prozdrowotną modyfikację jakości produktów mięsnych. W ramach tego komunikatu zaprezentowane zostaną wyniki tuczu 6 przebadanych w 2017 r. ras owiec (po 9 sztuk z każdej rasy) utrzymywanych w ich gospodarstwach macierzystych w różnych regionach kraju; wrzosówka (WRZ) w woj. warmińsko-mazurskim, cakiel podhalański (CPH) w małopolskim, świniarka (ŚW) w świętokrzyskim, pomorska (POM) i czarnogłówka (CZG) w pomorskim i uhruska (UHR) w lubelskim. W gospodarstwach objętych badaniami stosowane są bardzo zróżnicowane systemy chowu, w tym tuczu jagniąt, od ekstensywnego w gospodarstwie utrzymującym wrzosówki do intensywnego w hodujących rasę uhruską i pomorską.

Tabela 1. Wyniki tuczu tryczków w gospodarstwach macierzystych

\begin{tabular}{|c|c|c|c|c|c|}
\hline \multirow{2}{*}{ Rasa } & \multirow{2}{*}{$\begin{array}{l}\text { Średni typ } \\
\text { urodzenia }\end{array}$} & \multicolumn{2}{|c|}{ Masa ciała $(\mathrm{kg})$ : } & \multirow{2}{*}{ Dni tuczu } & \multirow{2}{*}{ Przyrosty, g } \\
\hline & & początek tuczu & koniec tuczu & & \\
\hline WRZ & 2,11 & 21,8 & 28,3 & 157 & 41 \\
\hline $\mathrm{CPH}$ & 1,33 & 22,7 & 38,2 & 109 & 142 \\
\hline ŚW & 1,22 & 21,3 & 30,9 & 117 & 93 \\
\hline POM & 1,11 & 27,0 & 39,2 & 50 & 244 \\
\hline $\mathrm{CZG}$ & 1,00 & 28,0 & 41,9 & 78 & 178 \\
\hline UHR & 1,67 & 20,8 & 37,8 & 51 & 333 \\
\hline
\end{tabular}

Uzyskano zróżnicowane wyniki tuczu jagniąt, które wynikały z czynników genetycznych (rasa, typ urodzenia) oraz $\mathrm{z}$ różnych systemów utrzymania stada oraz tuczu jagniąt. Wśród ras ogólnoużytkowych i w typie mięsnym (UHR, POM i CZG) wyróżniające wyniki uzyskała rasa UHR, a najsłabsze CZG, co wynikało z ich ekstensywnego żywienia w okresie tuczu. Wśród ras prymitywnych (CPH, ŚW i WRZ) najlepsze wyniki uzyskały CPH, pośrednie ŚW, a wyraźnie najsłabsze WRZ. CPH tuczone wyłącznie przez wypas na pastwisku uzyskały zadawalające tempo wzrostu, lepsze niż ŚW przy utrzymywaniu pastwiskowym razem z matkami i dokarmianiu śrutami zbożowymi, natomiast najsłabsze były WRZ utrzymywane w okresie tuczu na pastwisku przyleśnym bez żadnego dokarmiania. Bardziej pogłębiona analiza wyników uzyskanych w zakresie odchowu i tuczu tryczków w gospodarstwach macierzystych i tuczu standardowego będzie przeprowadzona po zakończeniu odchowu i tuczów wszystkich 8 ras owiec objętych badaniami.

Badania zrealizowano w ramach programu Biostrateg II, podzadanie 5.5.
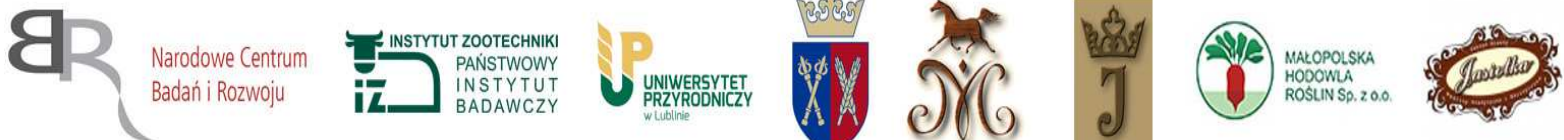


\title{
PORÓWNANIE PROFILU KWASÓW TŁUSZCZOWYCH MIĘSA TRYCZKÓW RASY UHRUSKIEJ TUCZONYCH DWOMA SYSTEMAMI
}

Comparison of meat fatty acid profile of the Uhurska lamb-rams fattening under two systems

\author{
Dawid Kuźnicki ${ }^{1}$, Bronisław Borys ${ }^{2}$, Martyna Kozłowska ${ }^{1}$, Jan Knapik ${ }^{3}$ \\ Małgorzata Szumacher-Strabel ${ }^{1}$, Adam Cieślak ${ }^{1}$
}

\author{
${ }^{1}$ Uniwersytet Przyrodniczy w Poznaniu, Katedra Żywienia Zwierząt, ul. Wołyńska 33, 60-637 Poznań \\ ${ }^{2}$ Instytut Zootechniki - Państwowy Instytut Badawczy, Zakład Doświadczalny Kołuda Wielka, ul. Parkowa 1, 88-16 Janikowo \\ ${ }^{3}$ Instytut Zootechniki - Państwowy Instytut Badawczy, ul. Krakowska 1, 32-083 Balice k. Krakowa
}

Celem badań była ocena możliwości wykorzystania owiec rodzimej rasy uhruskiej do produkcji produktów mięsnych w warunkach dwóch systemów utrzymania i żywienia: (i) stosowanym w gospodarstwie macierzystym oraz (ii) przy zastosowaniu standardowego żywienia ukierunkowanego na prozdrowotną modyfikację jakości mięsa. Jagnięta (17 sztuk) tuczono po odsadzeniu od matek do uzyskania ok. $40 \mathrm{~kg}$ masy ciała. Zwierzęta utrzymywano w 2 lokalizacjach: w IZ PIB ZD Kołuda Wielka oraz w gospodarstwie macierzystym w Chomęciskach Małych (pow. zamojski). W IZ PIB ZD Kołuda Wielka (KW; 9 szt.) jagnięta żywiono mieszanką treściwą zawierającą 35\% komponentów oleistych (po 15\% makuchu rzepakowego i suszonego wywaru kukurydzianego DDGS $+5 \%$ nasion lnu) zadawaną w ilości 3\% masy ciała jagniąt oraz sianem z traw do woli. W gospodarstwie macierzystym (grupa GM; 8 szt.) tryczki żywiono do woli mieszanką śrut zbożowych $\mathrm{z}$ własnych upraw $\mathrm{z}$ dodatkiem mineralno-witaminowym oraz sianokiszonką i sianem $\mathrm{z}$ traw i mieszanki traw z koniczyną. Jagnięta KW ubito przy średniej masie ciała $41,1 \mathrm{~kg}$, a jagnięta GM przy masie ciała 37,8 kg i pobrano próby mięśnia longissimus dorsi (LD) do analiz. Zawartość tłuszczu w mięśniach oznaczono metodą Soxleta wg Polskiej Normy PN-73/A-82111. Analizę profilu kwasów tłuszczowych wykonano na chromatografie gazowym Varian Star CP 3800 wyposażonym w detektor FID i kolumnę kapilarną o długości $100 \mathrm{~m}$ i średnicy wewnętrznej $0,25 \mathrm{~mm}$, przy użyciu $0.2 \mu \mathrm{m}$ CP-Sil 88 (Chrompack, Varian). Tłuszcz śródmięśniowy jagniąt z grup KW i GM zawierał zbliżoną zawartość kwasów nasyconych (odpowiednio 45,3 vs. 43,8 g/100 g). Grupa KW charakteryzowała się mniejszą zawartością kwasów jednonienasyconych (41,0 vs. 44,3 g/100 g), wynikającą z mniejszej koncentracji kwasów: C16:1 cis 9, C18:1 t10, C18:1 cis 9 i C18:1 c11. W grupie KW zanotowano jednak większą zawartość jednonienasyconego kwasu C18:1 $t 11$. Mięso jagniąt KW żywionych mieszanką z dużym udziałem komponentów oleistych zawierało więcej kwasów wielonienasyconych (14,3 vs. 12,8 g/100 g), co wynikało z większej zawartości kwasu C18:2 $c 9 c 12$ oraz C18:3 $c 9 c 12 c 15$. Stosowanie mieszanki z komponentami oleistymi zwiększyło zawartość CLA (C18:2 c9 t11) w analizowanych próbach ( 0,48 vs. $0,30 \mathrm{~g} / 100 \mathrm{~g}$, odpowiednio dla grupy $\mathrm{KW}$ i GW) oraz zawęziło stosunek kwasów wielonienasyconych n6/n3 (5,42 vs. 5,76). Tkanka mięśniowa jagniąt tuczonych mieszanką z dużym udziałem komponentów oleistych zawierała więcej tłuszczu, odpowiednio 2,83\% (KW) vs. 2,40\% (GM). Mięśnie longissimus dorsi jagniąt rasy uhruskiej tuczonych dwoma systemami (KW i GW) charakteryzowały się korzystnym profilem kwasów tłuszczowych. Stosowanie mieszanki z wysokim udziałem komponentów oleistych (35\%, grupa KW) pozwoliło uzyskać mięso o dodatkowych walorach prozdrowotnych; z wyższą zawartością CLA i o węższym stosunku kwasów PUFA n6/n3.

Badania zrealizowano w ramach programu Biostrateg II, podzadanie 5.5.
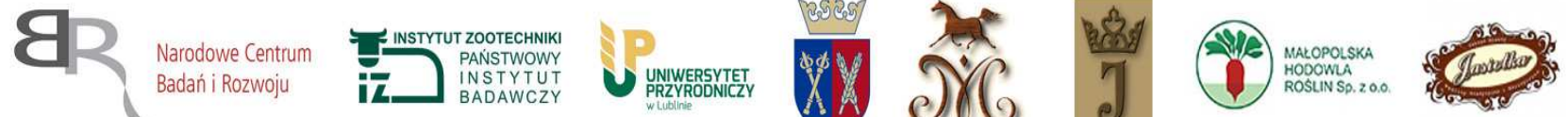


\title{
RESEARCH OF CONTENT OF SOMATIC CELLS IN MILK OF DAIRY GOATS IN THE DIFERENT SEASONS OF THE YEAR IN THE EASTERN REGION OF UKRAINE
}

\author{
Badanie zawartości komórek somatycznych w mleku kóz mlecznych według pory roku \\ we wschodnim regionie Ukrainy
}

Lyubov Ladyka, Oleksandr Kyselov Sumy National Agrarian University, 160 Herasym Kondratiev, Sumy, 40021, Ukraine
e-mail: Kyselov_snau@ukr.net, L_Ladyka@ukr.net

The very important indicator of characterizing the quality of the milk is the amount of somatic cells. The increased content of somatic cells indicates the morbidity of the animal, which leads to changes in the chemical composition of milk, and to the restriction or total unfitness of its further processing. The increase of somatic cells is connected with the reduction of milk amount and changes in its composition.

The presence of somatic cells is the most important indirect indicator of udder health, as in the inflammatory process in milk, the number of blood cells, in particular leukocytes and neutrophil granulocytes, which can absorb the cells of pathogenic microorganisms - pathogens of mastitis and in the mammary gland have a protective function. In addition, a number of somatic cells can be an excellent index in the monitoring programs of mastitis. In the all world, including in our country, the problem of mastitis is one of the first position determining the safety and health-hygienic index of milk. In dairy goat industry until last time this indicator has not been research. Consequently this research aimed at studying somatic cells of goat's milk is opportunely and actual.

For research we are choose clinically healthy goats Saanen breeds in accordance with the generally accepted methods of zootechnic research. The level of SC was studied on the greater amount of animals in different zones of the East of Ukraine.

The minimum percent of SC was in winter time. This research can become pre-condition in the analysis of goat milk rating in the Eastern region of Ukraine. Also we are discover a difference between the morning and evening yield of milk in individual samples was from 1 to 770 thousands. A middle difference of SC contents in goat milk between the morning and evening yield of milk was from 35 to 150 thousand cells. Such difference may be explained by influence of different factors: greater motion activity in the interval of light day and correspondingly the speed of metabolism, the interval of time from milking to milking - the bigger interval the more yield of milk and value of milk components concentrations. Thus, it is shown that this index is very variable even for one animal when milking in different time of the day.

On the next stage the level of SC at milk excretion was studied. From the different other researches we are knows that at milking the first streams differentiate on chemical composition: less high-fat than in the last streams. It is explained by complicated mechanisms and concerted reflex reactions of mioeliteliy and smooth musculature of udder, walls and sphincter of nipple.

The ratio of SC changes depending on individual distinctions of animals and stages of lactation, age of goats, interval and stereotype of milking, capacity of udder, cisternal pressure and other.

Research of SC concentration in goat milk in different breeds and also estimation of top concentration limit requires further study on more considerable portion of sampling. 


\title{
DOBROSTAN ŻYWIENIOWY OWIEC W CZYNNEJ OCHRONIE SIEDLISK „NATURA 2000”
}

\author{
Nutritional welfare of sheep in area „Natura 2000” \\ Antonii Lipiec ${ }^{1}$, Mariusz Kulik ${ }^{2}$, Krzysztof Patkowski ${ }^{3}$, Katarzyna Wiercińska ${ }^{3}$, \\ Tomasz M. Gruszecki ${ }^{3}$

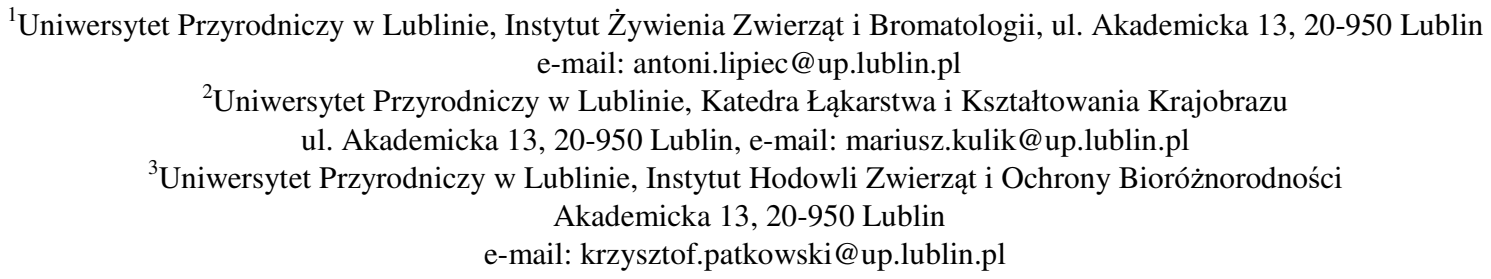

Badania przeprowadzone w latach 2016-2017 we wschodniej Polsce na trzech obszarach przyrodniczo cennych: suche wrzosowiska 4030, murawy kserotermiczne 6210 oraz ciepłolubne śródlądowe murawy napiaskowe 6120 . Celem pracy była weryfikacja hipotezy, że cenne siedliska przyrodnicze $\mathrm{z}$ roślinnością tam występującą mogą zapewnić odpowiedni dobrostan pasącym się zwierzętom (plon i wartość pokarmowa), które jednocześnie mogą przyczynić się do zachowania tych siedlisk. Dokonano oceny botanicznej roślinności tam występującej, plonu i wartości pokarmowej biomasy pod kątem dobrostanu żywieniowego owiec, które mogą być wykorzystane do zapobiegania wtórnej sukcesji tych siedlisk.

Uzyskane wyniki pozwoliły na sformułowanie następujących konkluzji:

- zważywszy na wysoką zawartość suchej masy w skarmianym poroście koniecznym jest zapewnienie zwierzętom stałego dostępu do wody w trakcie całego sezonu wegetacyjnego;

- do wypasu najlepiej nadają się owce ras rodzimych, np. świniarka. Maksymalna obsada w badanych obiektach - od początku sezonu do końca czerwca - nie powinna być większa aniżeli 1 SD na 1 ha pastwiska. Wyłączając ten okres pastwiskowania, dalsze użytkowanie badanych obiektów wiąże się ze stałym dokarmianiem zwierząt, a czas przebywania na spasanych kwaterach oraz obsada zwierząt powinny być ściśle monitorowane, aby uniknąć niedożywienia oraz nadmiernego niszczenia runi.

Projekt „Kierunki wykorzystania oraz ochrona zasobów genetycznych zwierząt gospodarskich w warunkach zrównoważonego rozwoju” współfinansowany przez Narodowe Centrum Badań i Rozwoju w ramach Strategicznego programu badań naukowych i prac rozwojowych „Środowisko naturalne, rolnictwo i leśnictwo” - Biostrateg, nr umowy: BIOSTRATEG2/297267/14/NCBR/2016. 


\title{
ROLA ULTRASONOGRAFII W NIEINWAZYJNEJ OCENIE MARMURKOWATOŚCI JAGNIĘCINY
}

\author{
The role of ultrasonography in non-invasive assessment of marbling in lamb
}

\author{
Agnieszka Ludwiczak, Piotr Ślósarz
}

\begin{abstract}
Uniwersytet Przyrodniczy w Poznaniu, Katedra Hodowli Zwierząt i Oceny Surowców, Złotniki, ul. Słoneczna 1, 62-002 Suchy Las e-mail: agnieszka.ludwiczak@up.poznan.pl
\end{abstract}

Zasadniczą trudnością ultrasonograficznej oceny marmurkowatości jagnięciny jest mała wyrazistość tej cechy. Jak dotąd brakuje szerzej akceptowanej metodyki nieinwazyjnej klasyfikacji tusz jagnięcych pod względem marmurkowatości mięsa. Celem badań była ocena wpływu grubości tłuszczu podskórnego, częstotliwości emisyjnej sondy USG oraz punktu pomiaru na tuszy na przydatność ultrasonogramów mięśni do oceny marmurkowatości jagnięciny. Materiał badawczy stanowiły obrazy USG pozyskane na 95 tuszach tryczków białogłowej owcy mięsnej (masa ciała przed ubojem $35 \mathrm{~kg}$ ). Porównano trzy częstotliwości emisyjne sondy $(5,0,7,5$ oraz 10,0 MHz), 6 punktów na tuszy (m. longissimus za 10. i 13. kręgiem piersiowym oraz za 3. kręgiem lędźwiowym, $m$. semimembranosus, $m$. semitendinosus i $m$. biceps femoris) oraz 3 . klasy otłuszczenia wyznaczone na podstawie średniej grubości podskórnej tkanki tłuszczowej w punkcie pomiaru. Wykonano także analizy laboratoryjne obejmujące ocenę zawartości tłuszczu ekstrahowanego oraz wzrokową ocenę marmurkowatości mięsa (1-5 pkt). Zebrane dane zostały przeanalizowane za pomocą pakietu statystycznego SAS. Zawartość tłuszczu ekstrahowanego nie różniła się pomiędzy badanymi punktami na tuszach jagnięcych i wynosiła 2,25-2,76\% (P > 0,05). Nie stwierdzono także wpływu punktu pomiaru na wzrokową ocenę marmurkowatości $(1,53-1,88 \mathrm{pkt}$; P > 0,05). Pozyskane ultrasonogramy mięśni zaklasyfikowano do dwóch kategorii jakości na bazie stopnia uszkodzenia przez artefakty: kategoria A (obrazy dobre) i kategoria B (obrazy uszkodzone). Spośród ultrasonogramów pozyskanych na $m$. longissimus jagniąt najwięcej obrazów kategorii A uzyskano za 13. kręgiem piersiowym za pomocą częstotliwości emisyjnej $5,0 \mathrm{MHz}(62,6 \% ; \mathrm{P} \leq 0,01)$. Na udźcu najwięcej obrazów dobrych uzyskano na m. semimembranosus $\mathrm{z}$ wykorzystaniem częstotliwości $5,0 \mathrm{MHz}(96,8 \%$; $\mathrm{P} \leq 0,01)$. Także grubość tłuszczu podskórnego nad m. longissimus za 13. kręgiem piersiowym miała wpływ na udział obrazów kategorii A, który był najwyższy dla tusz o najcieńszej warstwie tłuszczu $(65,63 \%$ przy częstotliwości $5,0 \mathrm{MHz}, \mathrm{P} \leq 0,01)$. W punktach tuszy o najwyższym udziale obrazów dobrych oceniono parametry komputerowe ultrasonogramów (średnia jasność oraz udział jasnych pikseli). Wykazano istotny wpływ grubości tłuszczu na jasność ultrasonogramów m. longissimus za 13. kręgiem piersiowym jagniąt. Ultrasonogramy o najwyższej jasności (125,1 piksela) uzyskano dla tusz z najcieńszą warstwą tłuszczu podskórnego. Otłuszczenie tusz jagnięcych nie miało wpływu na procentowy udział jasnych pikseli, mieszczący się w zakresie od 3,15 do 3,87\%. Najwyższe wartości współczynnika korelacji stwierdzono pomiędzy zawartością tłuszczu ekstrahowanego a udziałem jasnych pikseli w przypadku obrazów pozyskanych sondą o częstotliwości emisyjnej $5,0 \mathrm{MHz} \mathrm{w}$ punkcie m. longissimus za 13. kręgiem piersiowym $(\mathrm{r}=0,592 ; \mathrm{P} \leq 0,001)$ oraz sondą o częstotliwości $7,5 \mathrm{MHz}$ w punkcie m. semimembranosus $(\mathrm{r}=0,575 ; \mathrm{P} \leq 0,01)$. Współczynniki korelacji pomiędzy ocenianą wzrokowo marmurkowatością (pkt) a udziałem jasnych pikseli były niskie $(0,061 \leq \mathrm{r} \leq 0,367)$. Wyniki badań wykazały, że udział dobrych ultrasonogramów m. longissimus za 13. kręgiem piersiowym był zbyt niski, aby wykorzystać ten punkt pomiaru do oceny poziomu marmurkowatości mięsa. Z kolei punkt $m$. semimembranosus, mimo wysokiego udziału obrazów kategorii A, charakteryzował się niską wartością współczynnika korelacji pomiędzy zawartością tłuszczu ekstrahowanego a udziałem jasnych pikseli. Spośród analizowanych parametrów obrazów USG udział jasnych pikseli był bardziej skorelowany z zawartością tłuszczu ekstrahowanego niż średnia jasność obrazów, dlatego parametr ten można uznać za ultrasonograficzny wskaźnik zawartości tłuszczu ekstrahowanego. 


\title{
ZMIANY SKŁADU CHEMICZNEGO MLEKA U POLSKICH OWIEC GÓRSKICH I RASY CAKIEL PODHALAŃSKI
}

\author{
Changes in the chemical composition of milk in the Polish sheep and Cakiel Podhalański
}

Edyta Molik, Krystyna Stękała, Karolina Nahajło

Uniwersytet Rolniczy w Krakowie, Katedra Biotechnologii Zwierząt, e-mail: rzmolik@cyf-kr.edu.pl

Wykorzystanie potencjału rolniczego i przyrodniczego w Karpatach, a zwłaszcza przywrócenie wypasu kulturowego, może przyczynić się do tworzenia nowych miejsc pracy w tradycyjnych zawodach i turystyce, a także istotnie sprzyjać dynamicznemu rozwojowi produktów lokalnych. W ciągu ostatnich lat obserwuje się wzrost zainteresowania konsumentów żywnością wysokiej jakości o oryginalnych cechach sensorycznych. Przykładem tego typu żywności są sery wytwarzane z mleka owczego w warunkach wypasu wielkoobszarowego w Karpatach. Dlatego też celem przeprowadzonych badań było przeanalizowanie zmian składu chemicznego mleka polskich owiec górskich i rasy cakiel podhalański. Badania przeprowadzono w warunkach naturalnego wypasu na hali Jaworki. Do badań przeznaczono łącznie 530 sztuk owiec laktujących w tym: 230 sztuk matek polskich owiec górskich oraz 300 sztuk owiec rasy cakiel podhalański dojonych od maja do września. Zbiorcze próby mleka od każdej grupy rasowej pobierano dwa razy w miesiącu. Wykonano oznaczenia zawartości suchej masy, białka, tłuszczu i laktozy. Przeprowadzone badania nie wykazały istotnych różnic w wydajności mleka u obydwu ras owiec. Średnia dobowa wydajność mleka wynosiła 0,32 $\pm 0,01$ litra u polskich owiec górskich i $0,31 \pm 0,01$ litra u cakla podhalańskiego. Natomiast stwierdzono różnice w składzie chemicznym mleka. Istotnie $(\mathrm{P} \leq 0,05)$ więcej suchej masy w pierwszym tygodniu dojenia (maj) zawierało mleko cakla podhalańskiego $(17,64 \pm 2,6 \%)$ niż polskiej owcy górskiej $(16,71 \pm 2,1 \%)$. W czerwcu nadal mleko cakla podhalańskiego zawierało istotnie więcej suchej masy $(17,55 \pm 2,6 \%)$, w odniesieniu do mleka polskiej owcy górskiej $(16,19 \pm 2,1 \%)$. Wraz z upływem laktacji od lipca do września istotnie $(\mathrm{P} \leq 0,05)$ więcej suchej masy stwierdzono w mleku polskich owiec górskich (lipiec 19,2 $\pm 3,1 \%$, wrzesień $24,5 \pm 3,1 \%$ ) niż u cakla podhalańskiego (lipiec 17,77 $\pm 2,4 \%$, wrzesień 21,75 $\pm 2,8 \%$ ). Badania wykazały, że mleko owiec cakla podhalańskiego zawierało istotnie $(\mathrm{P} \leq 0,05)$ więcej białka (maj 6,28 $\pm 0,4 \%$, wrzesień 8,04 $\pm 0,6 \%$ ) niż polskich owiec górskich (maj 4,79 $\pm 0,1 \%$, wrzesień 7,7 $\pm 0,5 \%$ ). W pierwszych trzech miesiącach doju istotnie $(\mathrm{P} \leq 0,05)$ więcej tłuszczu zawierało mleko cakla podhalańskiego (maj 5,05 $\pm 0,3 \%$, czerwiec $6,1 \pm 0,4 \%$, lipiec 7,84 $\pm 0,3 \%$ ), niż mleko polskiej owcy górskiej (maj $3 \pm 0,1 \%$, czerwiec $5,55 \pm 0,2 \%$, lipiec $6,94 \pm 0,3 \%$ ). Istotne różnice w zawartości laktozy między rasami zanotowano pod koniec maja, na początku czerwca i pod koniec sierpnia. 


\title{
OCENA WARTOŚCI HODOWLANEJ ALPAK NA PODSTAWIE MASY CIAŁA
}

\author{
Evaluation of breeding value of alpacas based on body weight
}

\author{
Anna Morales Villavicencio, Roman Niżnikowski \\ Szkoła Główna Gospodarstwa Wiejskiego w Warszawie, Katedra Szczegółowej Hodowli Zwierząt \\ ul. Ciszewskiego 8, 02-787 Warszawa \\ e-mail: anna_morales_villavicencio@sggw.pl
}

\begin{abstract}
Możliwości produkcyjne alpak zależą od czynników genetycznych i środowiskowych. Do reprodukcji wybierane są takie osobniki, które przekażą potomstwu najlepsze cechy. Hodowca może oddziaływać na genotyp, selekcjonując zwierzęta charakteryzujące się wyższym poziomem pożądanej cechy. Ocena wartości hodowlanej alpak realizowana jest po ukończeniu pierwszego roku życia.

Masa ciała alpak w wieku jednego roku jest bardzo ważna z zootechnicznego i ekonomicznego punktu widzenia, ponieważ większe młode $\mathrm{w}$ przyszłości będzie miało większą masę ciała, co związane jest też z wcześniejszym okresem reprodukcji. Samice do rozpłodu przeznaczane są w wieku 1,5-2 lat lub po uzyskaniu 75\% masy ciała dorosłego osobnika, tj. $42 \mathrm{~kg}$, samce w wieku 3 lat.

W każdym kraju, w którym populacja alpak jest dość liczna, ocena wartości hodowlanej jest różna i dopasowana do istniejących możliwości i potencjału produkcyjnego zwierząt, z możliwością jej modyfikacji w przyszłości. Dokonano analizy porównawczej oceny wartości hodowlanej alpak w zakresie masy ciała z uwzględnieniem standardów obowiązujących w Peru, jako lidera w światowej hodowli (4 200000 sztuk), oraz Niemiec, które zajmują drugie miejsce w Europie pod względem liczebności populacji (ponad 20000 sztuk) oraz mają podobny system utrzymania tych zwierząt do występującego w Polsce. Standardy peruwiańskie i niemieckie różnią się między sobą parametrami poddawanymi ocenie.

W Peru ocena jest dokonywana na podstawie wskaźników produkcyjnych, zapisanych w standardach i rozporządzeniach ministerialnych (MINAG 2011), i ma dwie składowe w skali 100 pkt: runo 70 pkt i budowa ciała $30 \mathrm{pkt}$. W zakresie budowy istotną rolę odgrywa masa ciała i wymagania są następujące: masa urodzeniowa $\geq 6 \mathrm{~kg}$, w wieku odsadzenia $\geq 25 \mathrm{~kg}$, w wieku 1 roku $\geq 28 \mathrm{~kg}$, w wieku 2 lat $\geq 40 \mathrm{~kg}$.

W Niemczech standardy zostały opracowane przez zespół ekspercki Niemieckiego Związku Hodowców Alpak (AZVD) i jednym z kryterium jest masa ciała w wieku 1 roku wynosząca min. $32 \mathrm{~kg}$.

Badania przeprowadzono na grupie noworodków alpak huacaya $(n=53)$ hodowanych $w$ Polsce, których matki pochodziły z importu z Chile. Monitorowano wzrost masy ciała alpak od urodzenia do pierwszego roku życia. Po ocenie uzyskano następujące wyniki:

1. Spośród 53 alpak wg standardów peruwiańskich pozytywną ocenę wartości hodowlanej z uwzględnieniem kryterium masy ciała w wieku 1 roku (min. $28 \mathrm{~kg}$ ) uzyskało 45 alpak, natomiast wg standardów niemieckich (min. $32 \mathrm{~kg}$ ) pozytywną ocenę uzyskało 37 alpak.

2. Zbyt niska masa ciała samic $\mathrm{w}$ wieku jednego roku powoduje straty $\mathrm{w}$ hodowli wynikające $\mathrm{z}$ konieczności przesunięcia terminu ich krycia, które możliwe jest w wieku 18 miesięcy, a nawet wcześniej. Niska masa ciała sprawia, że masa runa jest mniejsza z uwagi na mniejsze pole powierzchni runa.

Mając na uwadze, że jak dotąd w Polsce nie ma standardów dotyczących oceny wartości hodowlanej alpak, niniejsze badania mogą być użyteczne i stanowić wkład w rozpoczęty w kraju proces legislacyjny, prowadzący do normowania oceny i unifikacji procedur klasyfikacji alpak.
\end{abstract}




\title{
OCENA WARTOŚCI HODOWLANEJ ALPAK NA PODSTAWIE PARAMETRÓW JAKOŚCI WŁÓKNA
}

\author{
Evaluation of breeding value of alpacas based on fiber quality parameters
}

\author{
Anna Morales Villavicencio, Roman Niżnikowski
}

\author{
Szkoła Główna Gospodarstwa Wiejskiego w Warszawie, Katedra Szczegółowej Hodowli Zwierząt \\ ul. Ciszewskiego 8, 02-787 Warszawa \\ e-mail: anna_morales_villavicencio@sggw.pl
}

Jest pewna liczba kryteriów, które muszą być spełnione i oszacowane, żeby właściciel alpak wiedział, jaką wartość ma jego zwierzę (wartość rzeczywista). Najważniejszym z nich jest grubość runa wyrażona w $\mu \mathrm{m}$ - jest to cecha wysoce odziedziczalna i powinna zostać doceniona w procesie hodowli. Informacja taka powinna być zawarta $\mathrm{w}$ rejestrze zwierząt i jeśli możemy dowiedzieć się, ile wynosiła grubość runa u rodzica, wtedy mamy punkt odniesienia dla oczekiwanej grubości runa u potomstwa.

Pracą hodowlaną w przypadku włókna czy wełny nie jest poszczególny włos ani dowolna wybrana masa runa. Elementem tym są konkretne zwierzęta, ich grupy i pokolenia wraz z okrywą włosową. Hodowca nie może z dnia na dzień ani z roku na rok przestawić produkcji, lecz może ją doskonalić w długofalowym, wieloletnim procesie i sprzyjających warunkach gospodarczych.

Potencjał produkcyjny alpak huacaya $\mathrm{w}$ zakresie włókna jest wysoki: masa runa 3-5 kg, grubość 14-30 $\mu \mathrm{m}$, długość 6-12 cm. Jednak nie każda alpaka może wyprodukować bardzo cienkie włókno, dlatego osobniki o niższej wartości hodowlanej mogą zostać wykorzystane w turystyce i rekreacji, alpakoterapi lub do produkcji mięsa. Mając to na uwadze, należy umiejętnie dobierać do kojarzeń samice i samce.

Kryteria jakości runa nie mogą być poddawane częstym zmianom, ponieważ oparte są na znajomości elementarnych cech włosów, cech zespołów włosowych jako naturalnej postaci związku włosów oraz cech całości okrywy włosowej.

Próbki runa z rocznego odrostu pobrano podczas strzyży od samic alpak huacaya $(n=30)$, w wieku 1 i 2 lat, masę runa zważono po strzyży. Zmierzono długość włókna na naturalnych zespołach włosowych, a grubość w laboratorium na lanametrze. Przeanalizowano najważniejsze parametry produkcyjne runa alpak huacaya, które brane są pod uwagę w pracy hodowlanej i selekcji zwierząt w Peru: masę runa, grubość i długość. Wymienione parametry mają wpływ na efekt ekonomiczny uzyskiwany przez hodowców, jakim jest przychód ze sprzedaży włókna.

Badaną grupę zwierząt oceniono na podstawie standardów obowiązujących w Peru, które jest światowym liderem w hodowli alpak (4,2 mln szt.) i produkcji włókna (4 $500 \mathrm{~kg}$ ). Standardy oceny zapisane są w rozporządzeniach Ministerstwa Rolnictwa (MINAG). Ocena wartości hodowlanej w zakresie włókna odnosi się do następujących wskaźników produkcyjnych: grubość runa jednorocznych alpak $\leq 22 \mu \mathrm{m}$; grubość runa dwuletnich alpak $\leq 24 \mu \mathrm{m}$; masa runa jednorocznych alpak $\geq 3$ funtom; masa runa dwuletnich alpak $\geq 3,5$ funta; długość rocznego odrostu runa $\geq 10 \mathrm{~cm}$.

Powyższe wskaźniki wykorzystano w ocenie grupy 30 samic alpak huacaya pochodzących z importu z Chile.

Średnia masa runa u jednorocznych alpak wynosiła $1,571 \mathrm{~kg}$, a dwuletnich 1,746 kg. Spośród 15 jednorocznych alpak pozytywną ocenę wartości hodowlanej na podstawie masy runa uzyskały wszystkie zwierzęta. W przypadku długości runa tylko 5 alpak uzyskało pozytywną ocenę, a w przypadku grubości 12 alpak miało runo poniżej $22 \mu \mathrm{m}$. U dwuletnich alpak: masę runa 3,5 funta miało tylko 8 alpak, wymaganą długość tylko 2 alpaki, 11 alpak miało grubość runa poniżej $24 \mu \mathrm{m}$.

W badanej grupie alpak jednorocznych i dwuletnich wykazano, że produkują mało runa, które jest krótkie, natomiast grubość była na satysfakcjonującym poziomie. Wyniki wskazują na pilną potrzebę poprawy jakości alpak w zakresie ilości i długości runa oraz prac selekcyjnych z tym związanych. 


\title{
IDENTYFIKACJA KOLORU RUNA ALPAK Z WYKORZYSTANIEM KOLORYMETRU
}

\author{
Identifying the color of alpaca fleece using colorimeter
}

\begin{abstract}
Anna Morales Villavicencio, Roman Niżnikowski, Magdalena Ślęzak
Szkoła Główna Gospodarstwa Wiejskiego w Warszawie, Katedra Szczegółowej Hodowli Zwierząt e-mail: anna_morales_villavicencio@sggw.pl
\end{abstract}

Włókno alpak występuje w szerokiej gamie kolorów, od białego do czarnego, ze wszystkimi możliwymi odcieniami beżu, brązu i szarego. Tak szeroki wachlarz kolorów sprawia, że nie wymaga farbowania i z tego powodu jest postrzegane jako włókno ekologiczne. Trudno jest obiektywnie ocenić kolor runa, ponieważ oko ludzkie różnie może postrzegać kolor.

$\mathrm{Na}$ świecie opracowanych zostało kilka wzorów kolorów, żeby zakwalifikować runo alpak po subiektywnej ocenie przez wyszkolonego sędziego lub klasyfikatora. Wg standardów australijskich (Australian Alpaca Association) każdy kolor jest oznaczony symbolem, np. biały - WT, jasnopłowy - LF, średnio płowy - MF, ciemnopłowy - DF, jasnobrązowy - LB, średni brąz - MB, ciemny brąz - DB, czarno-brązowy - BB, czarny - BK, jasnoszary - LG, średnio szary - MG, ciemnoszary - DG, szaro-wrzosowy - RG.

Symbolika kolorów jest wykorzystywana w ocenie wartości hodowlanej, podczas pokazu zwierząt na ringu podczas show, w rejestrze zwierząt do ksiąg, a także przez przedsiębiorstwa skupujące runo.

Celem badań było zweryfikowanie zakresu barw runa alpak na 40 próbkach. Kolor runa mierzono na zespołach włosowych, wykorzystując kolorymetr Konica Minolta cr-400 i standaryzowaną metodę międzynarodową (Commission Internationale de l'Eclairage) CIELab, wg której: L* opisuje jasność koloru w zakresie od białego (100) do czarnego, a* opisuje nasycenie kolorów od czerwonego do zielonego, b* nasycenie koloru żółtego do niebieskiego.

Jasność i nasycenie koloru runa alpak huacaya w różnych kolorach przedstawiono w tabeli 1.

Tabela 1. CIEL*a*b* wartości włókien poddanych badaniu

\begin{tabular}{|l|c|c|c|}
\hline \multicolumn{1}{|c|}{ Kolor } & $\mathrm{L}^{*}$ & $\mathrm{a}^{*}$ & $\mathrm{~b}^{*}$ \\
\hline Biały & $80,26-87,56$ & $-0,23-0,03$ & $5,1-9,06$ \\
Płowy & $70,83-79,95$ & $-0,23-1,33$ & $5,1-11,22$ \\
Jasny brąz & $57,35-63,27$ & $3,41-4,82$ & $13,05-16,51$ \\
Średni brąz & $41,51-51,67$ & $7,72-6,25$ & $18,01-16,77$ \\
Ciemny brąz & $36,97-35,04$ & $9,38-8,77$ & $18,60-16,47$ \\
Czekoladowy brąz & $23,21-28,46$ & $9,45-10,3$ & $9,92-13,99$ \\
Czarny & $14,09-22,54$ & $1,31-6,92$ & $-0,52-4,10$ \\
Szary & $24,39-31,82$ & $0,71-1,42$ & $-0,39-0,08$ \\
Szaro-wrzosowy & 33,78 & 4,63 & 6,88 \\
\hline
\end{tabular}

Niniejsze wyniki badań mogą zostać wykorzystane w praktyczny sposób przez związki hodowców alpak oraz przedsiębiorstwa skupujące włókno.

Badania będą kontynuowane na większej grupie alpak w celu znalezienia obiektywnej metody pomiaru, która mogłaby uwzględniać wszystkie klasy kolorów runa. 


\title{
CHARAKTERYSTYKA WEENY ALPAK UTRZYMYWANYCH W NIEKTÓRYCH GOSPODARSTWACH HODOWLANYCH POŁUDNIOWEJ POLSKI
}

\author{
Characteristic of wool of alpaca maintained in some breeding farms in south of Poland
}

\author{
Maciej Murawski, Agata Urban, Anna Kosiek
}

Uniwersytet Rolniczy w Krakowie, Katedra Biotechnologii Zwierząt e-mail: rzmmuraw@cyf-kr.edu.pl

Hodowla alpak w naszym kraju to stosunkowo młoda, szybko zyskująca na popularności i dynamicznie rozwijająca się gałąź hodowli. W Peru i Chile, skąd się wywodzą te egzotyczne zwierzęta, są hodowane na mięso i wełnę. W Polsce są głównie utrzymywane dla wełny, natomiast ze względu na wysoką cenę osobniczą nie są hodowane na mięso. Alpaki posiadają bardzo cienką i puszystą wełnę, przypominając swoim sympatycznym wyglądem duże przytulanki. Dzięki takiej prezencji są bardzo dobrze postrzegane przez dzieci i dorosłych i dlatego często wykorzystywane także w alpakoterapii.

Z uwagi na skromny zasób informacji źródłowej na temat wełny alpak hodowanych w naszym kraju podjęto badania, których celem było scharakteryzowanie parametrów jakościowych wełny alpak hodowanych w wybranych gospodarstwach południowej Polski.

Wełnę alpak pobrano w czterech gospodarstwach, dwóch posiadających po 200 szt. i kolejnych dwóch po 30 i 14 zwierząt. Łącznie pobrano 56 próbek wełny od alpak rasy suri (13 szt.) i huacaya (43 szt.) i określono ich barwę. Każdą próbkę wełny przed wykonaniem pomiarów wyprano w wodzie o temp. $35^{\circ} \mathrm{C}$ i wysuszono. Średnicę włókien określono pod lanametrem (MP3 Polskie Zakłady Optyczne) w powiększeniu 500x. W każdej próbce mierzono grubość 400 włosów i we włosach rdzeniowych oceniano rodzaj występującego rdzenia.

Średnia grubość przeanalizowanych próbek pobranych od 56 alpak w czterech gospodarstwach wynosi 22,30 $\mu \mathrm{m}$ i kwalifikuje się do klasy wełen cienkich. W odniesieniu do grubości wełny opisanej przez Czaplickiego [2012], wynoszącej 27,4 $\mu \mathrm{m}$ i klasyfikowanej jako gruba, jest ona znacznie delikatniejsza, co może wskazywać na znaczące zróżnicowanie grubości wełny alpak hodowanych w Polsce lub na polepszenie jej jakości u współcześnie hodowanych zwierząt. A ponadto można stwierdzić, że jest ona podobnej jakości do wełny pochodzącej z Peru, której średnica przebadana w Peru przez Montes i wsp. w 2008 r. wynosiła $22,70 \mu \mathrm{m}$. Wełna alpak suri charakteryzowała się większą grubością od wełny alpak huacaya wynoszącą odpowiednio 25,12 i $21,53 \mu \mathrm{m}$. Natomiast średnia grubość włókna bezrdzeniowego i rdzeniowego wynosiła odpowiednio 18,54 i 23,65 $\mu \mathrm{m}$ ( $\mathrm{p} \leq 0,005)$. Spośród 56 próbek wełny 18 pochodziło od samców i 28 od samic, jej średnia grubość wynosiła odpowiednio 22,62 i 22,15 $\mu \mathrm{m}(\mathrm{p}>0,05)$. W przebadanych próbkach dominowała wełna koloru białego, która była jednocześnie wełną najcieńszą wśród próbek o innej barwie. Wełna szpicówkowa pobrana od 18 młodych alpak była cieńsza od wełny alpak strzyżonych co najmniej jednokrotnie i posiadała grubość odpowiednio 17,9 i $24,38 \mu \mathrm{m}(\mathrm{p} \leq 0,05)$. Interesująca wydaje się zależność występująca w wełnie alpak o barwie szarej i srebrzystej. Włókna w takiej okrywie występują w dwóch frakcjach, ciemnej i jasnej, a ich kolor uzależniony jest od proporcji występowania włókien ciemnych do jasnych. Ponadto wykazano występowanie różnicy w grubości włókien ciemnych i jasnych, odpowiednio 22,13 i 31,81 $\mu \mathrm{m}(\mathrm{p} \leq 0,05)$.

Na podstawie przeprowadzonych badań można stwierdzić, że:

1. Wełna alpak w wybranych gospodarstwach południowej Polski zalicza się do klasy wełen cienkich i wskazuje na wysoką wartość hodowanych zwierząt.

2. Samice i samce alpak w badanych gospodarstwach posiadają wełnę tej samej grubości.

3. Wełna szpicówkowa charakteryzowała się mniejszą średnicą od wełny alpak strzyżonych wcześniej co najmniej jednokrotnie.

4. Na barwę szarą i srebrzystą wełny alpak ma wpływ proporcja liczby włosów jasnych do ciemnych. 


\title{
STUDY OF PHYSICO-CHEMICAL COMPOSITION AND TECHNOLOGICAL PROPERTIES OF GOAT'S MILK AS RAW MATERIALS FOR THE PRODUCTION OF SOFT CHEESES
}

\author{
Badanie struktury fizyko-chemicznej i właściwości technologicznych mleka koziego jako surowca \\ do produkcji serów miękkich
}

\author{
Julia Nazarenko, Lubov Ladyka
}

\author{
Sumy National Agrarian University, 160 Herasym Kondratiev, Sumy, 40021, Ukraine \\ e-mail: nazarenko.sumy@gmail.com
}

Recently, there has been a steady tendency towards the expansion of production of goat milk products, and the replacement of cow milk on goat milk in the pediatric and therapeutic diet is increasingly being due to its hypoallergenic properties. The production of goat milk, as well as processing it for cheese and other dairy products, is aimed at ensuring, first of all, the safety of people who have problems with the absorption of cow milk. Goose breeding is a new branch of developing livestock, so carrying out complex studies of qualitative indices and technological properties of milk of different breeds of goats of the breeding base of Ukraine and the development of technologies of new types of milk using goat milk are key issues of the present.

The aim of the research was to study the physico-chemical composition of milk of goats breeds, which are common in Sumy Oblast: the Lamancha, Toggenburg and Nubian, and the study of the technological properties of goat milk for the purpose of using it as raw material for the production of soft cheese as a product with hypoallergenic properties. In the article the technological process of production of soft cheese and comparatively basic technological parameters of milk production of goats of different breeds is examined. The features of the technological process of production of cheese from goat milk are determined: milk maturation, introduction of an increased dose of fertilising and calcium chloride, cutting and setting of large grains, reducing the processing time of cheese, self-pressing, pickles.

A comparative characteristic of the chemical parameters of milk of goats of different breeds - the Lamancha, Toggenburg and Nubian, on equal terms of maintenance and feeding, has been carried out. From the data obtained, it is evident that the mass fraction of protein in the milk of Nubian breeds of goats $-3.04 \%$ is significantly different from the same indicator in the milk of goats of the Toggenburg and Lamancha breeds, but the mass fraction of protein in the milk of the Toggenburg breed is the highest and is 3.5\% and exceeds this indicator in the milk of goats of the Lamancha breed for $0.11 \%$ and Nubian breed for $0.31 \%$.

The most valuable ingredient in milk is dry matter, because it includes all the components that determine its overall nutritional and technological properties. By mass fraction of dry matter, it is necessary to allocate milk of goats of the Toggenburg and Lamancha breeds, in which this index is 13.75 and $13.41 \%$, and exceeds the mass fraction of dry substances in milk of goats of the Nubian breed, respectively, by 0.87 and $0.52 \%$.

In the production of soft cheese using goat milk, according to the results of the evaluation of physicochemical and organoleptic parameters, there is a receipt of the finished product with high consumer properties and nutritional value.

In the production of cheese, one of the important indicators is the mass of milk spent on the production of $1 \mathrm{~kg}$ of product. If we analyze the norms of consumption of raw materials per $1 \mathrm{~kg}$ of soft cheese, then the obvious is the lowest norm - from the milk of Toggenburg breed goats, by $1.1 \%$ more than the milk of goats of the Lamancha breed, and by $1.4 \%$ more than the milk of goats of the Nubian breed.

Based on the analysis of the progress of the technological process of producing raw materials for $1 \mathrm{~kg}$ of cheese, the most suitable for the production of soft cheese is the milk of goats of the Toggenburg breed. 


\title{
ZACHOWANIE OWIEC WYPASANYCH NA TERENIE REZERWATU PRZYRODY STAWSKA GÓRA
}

\author{
Behaviour of grazing sheep in the Stawska Góra reserve
}

\author{
Krzysztof Patkowski ${ }^{1}$, Ewa Krawczyk ${ }^{1}$, Tomasz M. Gruszecki ${ }^{1}$, Anna Szymanowska ${ }^{1}$, \\ Monika Greguła-Kania ${ }^{1}$, Marek Szymanowski ${ }^{1}$, Mariusz Kulik ${ }^{2}$ \\ ${ }^{1}$ Uniwersytet Przyrodniczy w Lublinie, Instytut Hodowli Zwierząt i Ochrony Bioróżnorodności \\ email: krzysztof.patkowski@up.lublin.pl \\ ${ }^{2}$ Uniwersytet Przyrodniczy w Lublinie, Katedra Łąkarstwa i Kształtowania Krajobrazu, \\ ul. Akademicka 13, 20-950 Lublin, e-mail: mariusz.kulik@up.lublin.pl
}

Obserwacje behawiorystyczne przeprowadzone zostały w trakcie wypasu owiec na terenie rezerwatu przyrody Stawska Góra. Powierzchnia rezerwatu to 4,9 ha, z czego zwierzętom udostępniono do wypasu obszar 1,85 ha. Wypasana powierzchnia była ograniczona za pomocą specjalnej siatki ogrodzeniowej podłączonej do pastucha elektrycznego. Obszar ten zajmuje fragment górnej części jednego ze wzniesień zwanego Górą Czubatką (238,7 m n.p.m.). Największą sławę temu malowniczemu zakątkowi przyniósł występujący tu dziewięćsił popłocholistny (Carlina onopordifolia), mający zaledwie cztery stanowiska w Polsce. Rezerwat przyrody jest miejscem występowania również innych rzadkich gatunków roślin, ochronie podlegają dodatkowo inne ciepłolubne i wapieniolubne gatunki stepowe. Łącznie na terenie siedliska potwierdzono występowanie 210 gatunków roślin, z czego 30 należy do rzadkich, a 8 jest pod ochroną ścisłą. Są to: dziewięćsił popłocholistny i bezłodygowy, miłek wiosenny, zawilec wielkokwiatowy, aster gawędka, orlik pospolity, wiśnia karłowata, goryczka krzyżowa. Natomiast 3 gatunki objęte są ochroną częściową: pierwiosnek lekarski, kalina koralowa i kruszyna pospolita. Celem niniejszej pracy było przedstawienie zachowania owiec rasy świniarka i owiec uhruskich podczas wypasu w rezerwacie przyrody Stawska Góra. Wypasana grupa składała się z 8 owiec matek uhruskich i 8 owiec matek świniarek. Obserwacje behawiorystyczne prowadzono podczas wypasu w lipcu, w godzinach 7:30-19:30. Na czas nocy owce celowo zapędzane były do namiotu przez wzgląd na ich komfort i bezpieczeństwo. Zwierzęta miały możliwość schronienia się w owej wiacie również w ciągu dnia ze względu na ochronę przed wysokimi temperaturami, promieniami słonecznymi, wiatrem czy deszczem. Owce świniarki przebywające na wypasie kontrolowanym na terenie rezerwatu przyrody na zgryzanie trawy poświęcały średnio $310 \mathrm{~min}$, zaś owce uhruskie potrzebowały nieco więcej czasu na zaspokojenie swoich potrzeb żywieniowych (326 min). W trakcie 12-godzinnego wypasu zarówno świniarki, jak i owca uhruska na odpoczynek przeznaczyły zbliżoną ilość czasu, odpowiednio: 368 oraz $361 \mathrm{~min}$. Analizując dane pogodowe i czas przeznaczony na wypasanie i odpoczynek, stwierdzono, że owce podczas przelotnych i spokojnych opadów deszczu nie przerywały pobierania paszy, natomiast w sytuacji pojawienia się nagłej burzy przerywały pasienie i przemieszczały się do namiotu. Ruch podczas wypasu zajmował zwierzętom rasy świniarka i owca uhruska odpowiednio 31,6 oraz 41,6 min.

Projekt „Kierunki wykorzystania oraz ochrona zasobów genetycznych zwierząt gospodarskich w warunkach zrównoważonego rozwoju” współfinansowany przez Narodowe Centrum Badań i Rozwoju w ramach Strategicznego programu badań naukowych i prac rozwojowych „Środowisko naturalne, rolnictwo i leśnictwo” - Biostrateg, nr umowy: BIOSTRATEG2/297267/14/NCBR/2016. 


\section{GENETYCZNA WRAŻLIWOŚĆ NA TRZĘSAWKĘ OWIEC RAS ZACHOWAWCZYCH}

Scrapie susceptibility in sheep breeds enrolled in the genetic resources conservation programme

Agata Piestrzyńska-Kajtoch, Aldona Kawęcka, Grzegorz Smołucha

Instytut Zootechniki - Państwowy Instytut Badawczy, Zakład Biologii Molekularnej Zwierząt, ul. Krakowska 1, 32-083 Balice e-mail: agata.kajtoch@izoo.krakow.pl

Jednym z najważniejszych narzędzi do ochrony bioróżnorodności owiec w Polsce jest program ochrony zasobów genetycznych. Programem objęto 15 ras rodzimych, które z różnych przyczyn, głównie ekonomicznych, były zagrożone wyginięciem - ich liczebność była niska. W rasach o niskiej liczebności konieczne są m.in. działania umożliwiające zachowanie stabilności genetycznej i bioróżnorodności połączone z ograniczeniem potencjalnie niekorzystnych czynników genetycznych, np. powiązanych z różnymi chorobami, takimi jak trzęsawka owiec. Trzęsawka owiec to śmiertelna choroba prionowa, która ma dwie postacie: klasyczną i atypową. Podatność na trzęsawkę powiązana jest z polimorfizmem genu PRNP.

Celem badań było oznaczenie polimorfizmu genu $P R N P$ w siedmiu rasach zachowawczych owiec: cakiel podhalański (CKP; 99), czarnogłówka (CZGL; 53), merynos polski w starym typie (MST; 55), merynos polski barwny (MPB; 64), polska owca górska barwna (POGB; 85), świniarka (SWIN; 72) i wrzosówka (WRZOS; 54) oraz oszacowanie stopnia podatności tych zwierząt na zachorowanie na klasyczną i atypową trzęsawkę owiec. Analizę polimorfizmu genu PRNP przeprowadzono metodą dyskryminacji alleli z zastosowaniem fluorescencyjnie znakowanych sond TaqMan MGB w aparacie StepOnePlus Real-time PCR System (Applied Biosystems).

Uwzględniając cztery kodony genu $\operatorname{PRNP}(136,141,154$ i 171) w całej badanej grupie owiec (482 osobniki), stwierdzono występowanie 14 różnych genotypów i 6 różnych alleli. Najczęściej występującym genotypem był ALRR/ALRQ (36,51\%), a najrzadszymi (0,21\%) ALRR/ALRH, AFRQ/ALHQ i warunkujący podatność na klasyczną trzęsawkę VLRQ/VLRQ. Częstość allelu ALRR, warunkującego oporność na klasyczną trzęsawkę, wynosiła 55,08\%. Allel AFRQ, powiązany z atypową trzęsawką, znaleziono u zaledwie czterech osobników ras MST i POGB. Najwięcej różnych genotypów (11) stwierdzono u polskiej owcy górskiej barwnej, a najmniej (3) u czarnogłówki i merynosa polskiego barwnego. Najwyższą częstość korzystnego genotypu ALRR/ALRR zaobserwowano u owiec rasy świniarka $(69,44 \%)$, czarnogłówka (56,6\%) i wrzosówka $(42,59 \%)$. Niekorzystny allel VLRQ występował w rasach świniarka $(4,17 \%)$, cakiel podhalański $(2,53 \%)$ i polska owca górska barwna $(1,18 \%)$. Istnieje 5 grup ryzyka narażenia na klasyczną trzęsawkę owiec (G1-G5, gdzie G1 oznacza najniższe ryzyko, a G5 najwyższe). W badanej populacji najwięcej owiec należało do grupy G2 (42,53\%), a najmniej do grup G4 i G5 (po 1,24\%).

Na podstawie otrzymanych wyników stwierdzono, że rasami najbardziej opornymi na klasyczną trzęsawkę są czarnogłówka i wrzosówka, u których nie stwierdzono w ogóle obecności allelu VLRQ i u których ponad $90 \%$ badanych owiec należało do grup o najniższym ryzyku zarażenia się tą chorobą (G1 i G2). 


\title{
POLIMORFIZM GENU PRNP U OWIEC ZE ZDIAGNOZOWANĄ ATYPOWĄ TRZĘSAWKĄ
}

PRNP gene polymorphism in sheep with atypical scrapie

\author{
Agata Piestrzyńska-Kajtoch ${ }^{1}$, Mirosław P. Polak ${ }^{2}$, Grzegorz Smołucha ${ }^{1}$, Jan F. Żmudziński \\ ${ }^{1}$ Instytut Zootechniki - Państwowy Instytut Badawczy, Zakład Biologii Molekularnej Zwierząt, ul. Krakowska 1, 32-083 Balice \\ e-mail: agata.kajtoch@izoo.krakow.pl \\ ${ }^{2}$ Państwowy Instytut Weterynaryjny - Państwowy Instytut Badawczy, Zakład Wirusologii, al. Partyzantów 57, 24-100 Puławy
}

Trzęsawka owiec (scrapie) to śmiertelna choroba prionowa należąca do grupy pasażowalnych encefalopatii gąbczastych. Ma dwie postacie: klasyczną i atypową (NOR98). Wywoływana jest przez priony - patogenne białka prionowe $\left(\mathrm{PrP}^{\mathrm{Sc}}\right)$, które, akumulując się w mózgu, powodują zamieranie komórek. Priony powstają na skutek zmian w konformacji występującego w zdrowych komórkach prawidłowego białka $\operatorname{PrP}^{\mathrm{C}}$ (ang. cellular prion protein), produkowanego przez organizm gospodarza, kodowanego przez gen PRNP. Stwierdzono, że zmienność kodującej części genu $P R N P$, której wynikiem jest polimorfizm aminokwasów białka PrP, jest powiązana z występowaniem klasycznej trzęsawki (kodony 136, 154 i 171), a także prawdopodobnie atypowej (kodon 141).

W Polsce dotychczas (czerwiec 2018) zdiagnozowano 81 przypadków trzęsawki owiec, w tym 18 przypadków trzęsawki klasycznej (wyłącznie u owiec z importu) i 63 przypadki trzęsawki atypowej (50 przypadków rodzimych). U wszystkich zwierząt ze zdiagnozowaną trzęsawką (Western-blot) oznaczono genotypy genu PRNP. W tym celu wyizolowano DNA z próbek pnia mózgu, zsekwencjonowano kodujący fragment genu PRNP, używając BigDye ${ }^{\circledR}$ Terminator v3.1 Cycle Sequencing Kit (Applied Biosystems) i sekwenatorów kapilarnych.

U owiec ze zdiagnozowaną atypową trzęsawką znaleziono 11 różnych genotypów i pięć różnych alleli. Najczęściej obserwowano genotyp ALRR/ALHQ. U około 30\% owiec znaleziono allel F w kodonie 141 (częstość allelu 18,55\%), co znacząco przewyższa frekwencję tego allelu stwierdzoną wśród osobników zdrowych 2-6\% (wg rożnych autorów). Choroba rozwinęła się też aż u 12 owiec z genotypem ALRR/ALRR, który warunkuje oporność na klasyczną trzęsawkę, potwierdzając, że aspekty genetyczne dla atypowej i klasycznej postaci choroby są różne. 


\title{
WPŁYW OBRÓBKI KULINARNEJ NA CECHY FIZYKO-CHEMICZNE I PROFIL KWASÓW TŁUSZCZOWYCH W MIĘSIE JAGNIĘCYM
}

\author{
The effect of cooking method on the physico-chemical characteristics
} and fatty acid composition in lamb meat

\section{Witold Rant, Aurelia Radzik-Rant, Magdalena Ślęzak, Marcin Świątek, Roman Niżnikowski, Żaneta Szymańska, Anna Morales-Villavicencio}

\author{
Szkoła Główna Gospodarstwa Wiejskiego w Warszawie, Katedra Szczegółowej Hodowli Zwierząt, Zakład Hodowli Owiec i Kóz \\ 02-786 Warszawa, ul. Ciszewskiego 8 \\ e-mail: witold_rant@sggw.pl
}

Mięso, w tym mięso jagnięce, jako źródło wysokiej jakości białka, związków mineralnych i witamin jest podstawą zrównoważonej diety, a przed spożyciem wymaga odpowiedniego przygotowania. Obróbka termiczna poprzez niszczenie patogenów zapewnia bezpieczeństwo mikrobiologiczne i sprawia, że jest ono bardziej przyswajalne. Z drugiej strony obróbka mięsa może przyczyniać się do wystąpienia szeregu niekorzystnych zmian w jego wartości odżywczej. Stopień tych zmian zależy od sposobu obróbki termicznej. Toteż celem podjętych badań była ocena wpływu podgrzewania mikrofalowego i pieczenia mięsa na skład chemiczny, cechy fizyczne i profil kwasów tłuszczowych mięsa jagnięcego.

Badania przeprowadzono na 24 próbach mięsa (comber) jagniąt polskiej owcy nizinnej odmiany żelaźnieńskiej ubijanych w masie ciała $32 \pm 0,5 \mathrm{~kg}$. Wszystkie próby podzielono na dwie równe części, z których 12 poddano obróbce w mikrofalówce, 12 pieczeniu, a 24 posłużyły jako próby kontrolne (mięso surowe). Pieczenie prowadzono $\mathrm{w}$ piecu konwekcyjnym w temperaturze $100^{\circ} \mathrm{C}$, aż próbka osiągnęła temperaturę punktu końcowego $70^{\circ} \mathrm{C}$. Próbki poddane ogrzewaniu mikrofalowemu umieszczono w kuchence mikrofalowej (Amica, AMM 17M70; $2450 \mathrm{MHz}$ ), ustawionej na $700 \mathrm{~W}$. Zastosowano dwa 2-minutowe cykle ogrzewania z każdej strony. Oznaczono ubytek masy, barwę mięsa, zdolność zatrzymywania wody własnej, skład chemiczny i profil kwasów tłuszczowych.

Wyniki badań wykazały, że ubytek masy był większy w mięsie jagnięcym poddanym ogrzewaniu w mikrofali niż pieczeniu. Obydwie metody obróbki termicznej nie różniły się pod względem wpływu na wzrost zawartości tłuszczu, białka i kolagenu w porównaniu z mięsem surowym. Mięso poddane zarówno ogrzewaniu w mikrofali, jak i pieczeniu charakteryzowało się jaśniejszą barwą. Badane metody obróbki termicznej mięsa nie spowodowały istotnych zmian w zawartości SFA i MUFA. Obniżeniu uległy PUFA i stosunek PUFA/SFA w mięsie jagnięcym ogrzewanym w mikrofali. Zawartość niektórych kwasów, jak C20:3 i C22:5 (DPA), obniżyła się zarówno pod wpływem działania mikrofali, jak i pieczenia. Obydwie metody obróbki nie wpłynęły na istotną zmianę w zawartości ważnego w diecie człowieka składnika, jakim jest izomer C18:2 c9, t11.

Uzyskane rezultaty wskazują, iż obydwie badane metody obróbki mogą być polecane do stosowania w szybkim przygotowywaniu mięsa jagnięcego do spożycia, chociaż nieco lepsze okazało się pieczenie. 


\title{
KSZTAETOWANIE SIE TRENDÓW CECH UŻYTKOWYCH WYBRANYCH RAS OWIEC OBJĘTYCH PROGRAMEM OCHRONY ZASOBÓW GENETYCZNYCH
}

\author{
The evolution of trends in performance traits of selected sheep breeds included \\ in the genetic resources conservation program
}

\author{
Jacek Sikora, Aldona Kawęcka, Michał Puchała, Marta Pasternak
}

Stała analiza stanu populacji podlegających ochronie pozwala na ocenę efektywności działania programów ochrony. Celem opracowania było wyznaczenie trendów dla cech użytkowych wybranych ras owiec w trakcie funkcjonowania programów ochrony. Analiza została przeprowadzona na 3 rasach owiec (owca olkuska, wielkopolska, wrzosówka), objętych programem ochrony zasobów genetycznych w latach 2010-2016.

Wyznaczono trendy dla cech dotyczących wskaźników rozrodu (plenność, odchów jagniąt i użytkowość rozpłodowa), a także dla cech związanych z odchowem potomstwa (masa ciała jagniąt w 56. dniu życia).

Objęte badaniami rasy charakteryzowały się zróżnicowanym poziomem plenności. Rasa olkuska odznaczała się najwyższą plennością, kształtującą się w przedziale 194,6\%-214,0\%. Najniższą wartość współczynnika zaobserwowano u owiec rasy wielkopolskiej (113\% w 2016 r.). Analiza trendów plenności wskazuje na spadek tej cechy w odniesieniu do większości ras. Najbardziej znaczące obniżenie plenności obserwowano u owcy olkuskiej (13\%). Wysoka plenność owcy olkuskiej wiązała się ze znacznymi stratami jagniąt w trakcie odchowu (26,4\% w 2012). Lepiej odchowywały swoje potomstwo maciorki rasy wrzosówka (85\% jagniąt przeżywało do odsadzenia). Poziom odchowu jagniąt u rasy wielkopolskiej był najwyższy i wynosił 94,2\%. Największe straty wśród potomstwa owcy olkuskiej i wrzosówki mają prawdopodobnie źródło w ich wysokiej plenności, ponieważ jagnięta z licznych miotów mogą być słabiej rozwinięte, przez co mogą wykazywać się słabszą żywotnością po urodzeniu. Analizując zgromadzone dane dotyczące odchowu jagniąt u wszystkich ras, można stwierdzić, że wartość tej cechy utrzymywała się w ciągu badanych 7 lat na dość stabilnym poziomie i nie wykazywała tendencji spadkowych.

Użytkowość rozpłodowa jest cechą złożoną - jest wynikiem płodności i plenności, a także odchowu jagniąt. W badanej populacji wskaźnik użytkowości rozpłodowej odznaczał się największym zróżnicowaniem spośród wszystkich badanych cech. Najwyższą użytkowością rozpłodową w całym badanym okresie charakteryzowały się maciorki rasy olkuskiej. Na podstawie zgromadzonych danych można przyjąć, że wartość cech mięsnych jagniąt $w$ dużej mierze zależała od rasy owiec. Jagnięta wrzosówki charakteryzowały się małą masą ciała $(9,2 \mathrm{~kg})$, olkuskie $16,1 \mathrm{~kg}$, natomiast najcięższe były tryczki rasy wielkopolskiej $(20,1 \mathrm{~kg})$.

$\mathrm{Z}$ uwagi na niepokojąco obniżające się trendy wartości w niektórych cechach (plenność, masa ciała miotu w 56. dniu życia jagniąt) należy w dalszym ciągu prowadzić monitorowanie tych cech i podejmować kroki dążące do odwrócenia tej negatywnej dla hodowli tendencji.
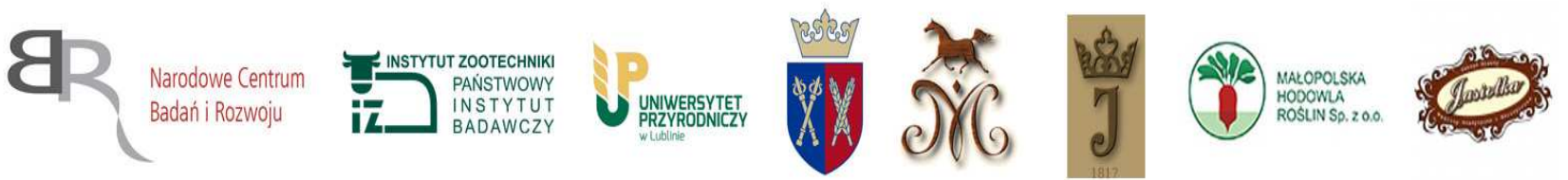


\title{
ANALIZA GENÓW MARKEROWYCH WARUNKUJĄCYCH WYSOKĄ PLENNOŚĆ U OWIEC
}

Analysis of marker genes determining high fertility in sheep

\author{
Grzegorz Smołucha, Agata Piestrzyńska-Kajtoch
}

\begin{abstract}
Instytut Zootechniki - Państwowy Instytut Badawczy, Zakład Biologii Molekularnej Zwierząt, ul. Krakowska 1, 32-083 Balice e-mail: grzegorz.smolucha@izoo.krakow.pl
\end{abstract}

Cechy reprodukcyjne zwykle charakteryzują się niską odziedziczalnością, a selekcja zwierząt oparta na fenotypie jest często powolna i nieskuteczna. W celu poprawy wskaźników cech płodności, takich jak liczba owulujących pęcherzyków jajnikowych i wielkość miotu owiec, skuteczniejsza wydaje się selekcja zwierząt hodowlanych oparta na ich genotypie. Wykazano, że różne mutacje w genach BMPR-1B, BMP-15 i GDF-9 należących do nadrodziny transformujących czynników wzrostu- $\beta$ (TGF- $\beta$ ) wpływają na liczbę owulujących pęcherzyków jajnikowych oraz wielkość miotu u owiec. Mutacje występujące w tych genach cechują się różnymi efektami oraz wzorcami dziedziczenia. Zidentyfikowane mutacje zwiększają liczbę owulujących pęcherzyków jajnikowych u osobników heterozygotycznych, lecz niektóre mutacje mogą powodować bezpłodność u osobników homozygotycznych, których jajniki nie rozwijają się prawidłowo. Wzrost wielkości miotu ma kluczowe znaczenie dla rentowności produkcji owczarskiej, ale koncentrowanie się na zwiększaniu liczby urodzonych jagniąt jest tylko jednym z wielu czynników wpływającym na opłacalność hodowli owiec. Badania przeprowadzone $\mathrm{w}$ niniejszej pracy obejmowały identyfikację polimorfizmu $\mathrm{w}$ genach $B M P R-1 B$ oraz BMP-15 u wybranych ras owiec objętych programem ochrony zasobów genetycznych. W tym celu wyizolowano DNA od 336 owiec ras: (55) polska owca górska, (55) merynos polski ST, (64) merynos polski barwny, (72) świniarka, (35) czarnogłówka, (55) polska owca górska barwna. W celu wykluczenia mutacji mającej wpływ na wysoką plenność owiec w genie BMPR-lB (receptor białka morfogenetycznego kości 15) (c.746 $\mathrm{A} \rightarrow \mathrm{G}$ ) przeprowadzono analizę polimorfizmu z zastosowaniem enzymu restrykcyjnego AvaII. Identyfikację polimorfizmu przeprowadzono dla 336 owiec wybranych ras. Analiza wyników wykazała, że wszystkie przebadane zwierzęta posiadały ten sam genotyp dziki FecB+/FecB+. W celu weryfikacji otrzymanych wyników PCR-RFLP przeprowadzono sekwencjonowanie dla losowo wybranych próbek. Sekwencjonowanie potwierdziło poprawność otrzymanych wyników. Dalsze analizy zostały przeprowadzone dla genu BMP-15 (exon 2 - zawiera fragment kodujący dojrzałe białko BMP-15). W przeprowadzonych analizach nie wykryto dotychczas znanych alleli: FecXG, FecXB, FecXI, FecXH, FecXL, FecXR, które $\mathrm{w}$ formie homozygotycznej powodują bezpłodność u owiec. Nie zidentyfikowano również mutacji FecXO, FecXGr, które w formie homozygotycznej nie powodują bezpłodności. W toku przeprowadzanych analiz zidentyfikowano polimorfizm SNP w genie BMP-15 c.755T >C u owiec ras: polska owca górska, czarnogłówka, merynos polski ST, merynos polski barwny. Mutacja ta zmienia kodujący aminokwas z leucyny na prolinę. Drugim zidentyfikowanym polimorfizmem SNP w tym genie jest c.747T>C. W tym przypadku mutacja nie powodowała zmiany kodującego aminokwasu. Analizy asocjacyjne pomiędzy wykrytym polimorfizmem SNP a plennością owiec są kontynuowane.

Badania finansowane z projektu BIOSTRATEG2/297267/14/NCBR/2016. 


\title{
WYPAS SPOSOBEM POPRAWY BIORÓŻNORODNOŚCI ŁĄK PODKARPACIA
}

\author{
Grazing as a method to increase meadows biodiversity in Subcarpathia Province, Poland
}

\author{
Marian Szewczyk ${ }^{1}$, Aldona Kawęcka ${ }^{3}$, Iwona Radkowska ${ }^{3}$, Jacek Sikora ${ }^{3}$, Tomasz M. Gruszecki ${ }^{2}$, \\ Anna Miksza-Cybulska ${ }^{3}$ \\ ${ }^{1}$ Państwowa Wyższa Szkoła Zawodowa w Sanoku, Instytut Gospodarki Rolnej i Leśnej \\ e-mail: marian.szewczyk@gmail.com \\ ${ }^{2}$ Uniwersytet Przyrodniczy w Lublinie, Instytut Hodowli Zwierząt i Ochrony Bioróżnorodności \\ e-mail: tomasz.gruszecki@up.lublin.pl \\ ${ }^{3}$ Instytut Zootechniki - Państwowy Instytut Badawczy, ul. Krakowska 1, 32-083 Balice
}

Historia wypasu łąk podkarpackich liczy już ponad 500 lat. Dochód z hodowli przeważał nad dochodem płynącym wprost z produkcji roślinnej. Stabilność oddziaływania zwierząt przez wiele wieków (XV-XX) była istotnym czynnikiem oddziaływującym na łąki i pastwiska. W tym czasie ukonstytuowały się bogate w gatunki roślin i zwierząt, różnorodne zespoły zbiorowisk łąkowych i pastwiskowych. Ilość gatunków roślin tu obecnych znacznie przewyższała gatunki lasów w otoczeniu. W okresie od II wojny światowej różnorodne zdarzenia w istotny sposób zubożyły zróżnicowanie roślin łąk podkarpackich, a co za tym idzie zmniejszyły różnorodność występujących na nich kręgowców i bezkręgowców. Łąki stały się miejscem zajmowanym przez gatunki inwazyjne roślin, w tym przez niebezpieczne barszcze kaukaskie (Heracleum sosnowskyi, H. mantegazzianum). Nastąpił znaczny spadek ilości hodowanych zwierząt. Szczególnie duży regres w produkcji zwierzęcej nastąpił w latach 2002-2010. O blisko 60\% spadła liczba gospodarstw prowadzących chów i hodowlę bydła.

Istnieje pilna potrzeba odwrócenia tych groźnych dla bioróżnorodności procesów.

Prowadzone od kilku lat obserwacje fitosocjologiczne na wypasanych łąkach pozwalają mieć nadzieję na istotną zmianę niekorzystnych tendencji. Prace prowadzono w Bieszczadach Zachodnich oraz w Beskidzie Niskim. Widoczny jest korzystny wpływ wypasu na bioróżnorodność łąk i pastwisk (zgryzanie, nawożenie i rozsiewanie roślin endo- i egzozoochoryczne). Wypas zmniejsza także obecność roślin inwazyjnych na łąkach i jest ważnym sposobem zwalczania barszczy kaukaskich.

Wniosek końcowy można wyrazić wielką potrzebą restytucji chowu i hodowli, nie tylko z uwagi na zapotrzebowanie na produkty i sytuację gospodarczą drobnych gospodarstw, ale i w celu ochrony różnorodności biologicznej na trwałych użytkach zielonych oraz ograniczenia występowania roślin inwazyjnych na łąkach. 


\section{PAKIET ,ZACHOWANIE ZAGROŻONYCH ZASOBÓW GENETYCZNYCH ZWIERZĄT W ROLNICTWIE" JAKO CZYNNIK STYMULUJĄCY CHÓW OWIEC NA OBSZARZE ŚRODKOWO-WSCHODNIEJ POLSKI}

„Preservation of endangered animal genetic resources in agriculture” package as a stimulant for sheep breeding in central-eastern Poland

Anna Szymanowska, Marek Szymanowski, Marlena Mirosław

Uniwersytet Przyrodniczy w Lublinie, Instytut Hodowli Zwierząt i Ochrony Bioróżnorodności, Pracownia Doradztwa Rolniczego e-mail: anna.szymanowska@up.lublin.pl

W połowie lat pięćdziesiątych ubiegłego wieku naukowcy z Wyższej Szkoły Rolniczej w Lublinie pod kierunkiem prof. Adama Domańskiego podjęli pracę hodowlaną nad wytworzeniem owcy uhruskiej. Wyhodowana populacja wywarła duży wpływ na hodowlę owiec na Lubelszczyźnie poprzez materiał hodowlany męski i żeński pochodzący z macierzystego stada. Od 1996 r. polska owca nizinna odmiany uhruskiej została objęta Programem Ochrony Zasobów Genetycznych. Obecnie programem ochrony objęto 15 ras owiec utrzymywanych na obszarze całego kraju, z czego 4 (owca uhruska, czarnogłówka, świniarka, wrzosówka) na Lubelszczyźnie. W niniejszym opracowaniu analizie poddano stan owiec ras zachowawczych w regionie środkowo-wschodniej Polski, które objęte są programem pomocowym w ramach unijnych pakietów. Analizując okres od 2014 do 2017 r., stwierdzono, że średnia ogólna liczba aktywnej populacji owiec wpisanych do ksiąg wynosi ok. 6700 i w omawianym okresie wykazywała tendencję wzrostową (ogółem o 5\%). Najbardziej liczną grupę stanowią owce uhruskie, których obecna populacja w stosunku do $2014 \mathrm{r}$. wzrosła o ok. 5\%. Znaczący liczebny wzrost populacji w badanym okresie odnotowano w rasie czarnogłówka (20\%). Wydaje się, że tendencja ta stała się wynikiem uznania rasy za zagrożoną i hodowcy mogli ubiegać się o wsparcie finansowe w wysokości 360 zł rocznie na jedną owcę-matkę. Stwierdzona ogólnie tendencja wzrostu liczby owiec wpisanych do ksiąg w każdej grupie genetycznej jest niewątpliwie wynikiem możliwości uruchamiania pakietów pomocowych dla beneficjentów utrzymujących rasy owiec zagrożonych wyginięciem. W badaniach przeanalizowano również rozmieszczenie stad utrzymujących owce. Stwierdzono, że wschodnia część województwa obejmująca powiaty: radzyński, włodawski, chełmski i bialski charakteryzuje się największą liczbą zwierząt. Jest to obszar szczególnie predysponowany do prowadzenia chowu i hodowli owiec z uwagi na występujące tam duże obszary trwałych użytków zielonych, ponadto należy dodać, że są to tereny o bogatych tradycjach w chowie tych zwierząt. 


\title{
ZAKAŻENIA CAEV U RÓŻNYCH RAS KÓZ
}

CAEV infections in various goat breeds

\author{
Marek Szymanowski ${ }^{1}$, Tomasz M. Gruszecki ${ }^{1}$, Monika Olech ${ }^{2}$, Jacek Kuźmak ${ }^{2}$, Emilia Bagnicka ${ }^{3}$, \\ Anna Szymanowska ${ }^{1}$

\footnotetext{
${ }^{1}$ Uniwersytet Przyrodniczy w Lublinie, Instytut Hodowli Zwierząt i Ochrony Bioróżnorodności, ul. Akademicka 13, 20-950 Lublin ${ }^{2}$ Państwowy Instytut Weterynaryjny - Państwowy Instytut Badawczy, Zakład Biochemii, al. Partyzantów 57, 24-100 Puławy

${ }^{3}$ Instytut Genetyki i Hodowli Zwierząt Polskiej Akademii Nauk, ul. Postępu 36A, Jastrzębiec, 05-552 Magdalenka
}

Celem pracy była analiza występowania wirusa CAEV u kóz rasy białej uszlachetnionej, barwnej uszlachetnionej, saaneńskiej, alpejskiej i burskiej, hodowanych w trzech rejonach Polski. Analizę poziomu zakażeń CAEV przeprowadzono w stadach kóz usytuowanych $w$ trzech województwach środkowo-wschodniej Polski. Badania przeprowadzono w 4 stadach kóz. Utrzymywane w nich było 251 kóz następujących ras: biała uszlachetniona, barwna uszlachetniona, saaneńska, alpejska oraz burska. Identyfikacja zakażonych zwierząt i ocena stanu epidemiologicznego w poszczególnych stadach została wykonana na podstawie badania serologicznego próbek surowicy krwi. Oznaczanie swoistych przeciwciał dla CAEV wykonano z użyciem testu ELISA. W wyniku przeprowadzonych obserwacji stwierdzono, że w zależności od województwa poziom stwierdzonej prewalencji kształtował się od 35,40\% w województwie mazowieckim do 81,10\% w województwie lubelskim, przy czym średni stan zakażenia zwierząt w badanym rejonie wyniósł 51,60\%. Natomiast w ujęciu rasowym stwierdzono, że obserwowane zakażenie populacji kóz saaneńskich $(\mathrm{P} \leq 0,05)$ było istotnie wyższe w porównaniu z kozami rasy białej uszlachetnionej $(48,90 \%)$ oraz alpejskiej $(50,00 \%)$, z kolei w stosunku do populacji kóz razy barwnej uszlachetnionej odnotowana różnica statystyczna była wyższa $(P \leq 0,01)$, a odsetek zakażanych zwierząt kształtował się na poziomie $32,10 \%$. W przypadku analizy poziomu zakażenia w stadzie kóz burskich stwierdzono 66,70\% osobników seropozytywnych, natomiast przeprowadzona analiza statystyczna nie wykazała istotnych różnic prewalencji z pozostałymi obserwowanymi rasami zwierząt. Podsumowując, należy stwierdzić, że poprawy zaistniałej sytuacji upatrywać można w konsekwentnym badaniu kóz oraz w stworzeniu programu uwalniania stad od CAEV. Przy tworzeniu programów zmierzających do eliminacji wirusa należy także pamiętać o podnoszeniu świadomości hodowców dotyczącej szkodliwości zakażeń CAEV. 
Sekcja Chowu i Hodowli Zwierząt Towarzyszących i Dzikich 


\title{
ZASTOSOWANIE TESTU KOMETOWEGO DO OCENY STABILNOŚCI GENOMU KOTÓW Z FELV
}

The use of the comet assay fot the assessment of genome stability in cats with FeLV disease

\author{
Agnieszka Abramowska ${ }^{1}$, Maria Dmitruk ${ }^{1}$, Bartosz Jania ${ }^{1,2}$, Ewa Wójcik ${ }^{1}$, Katarzyna Andraszek ${ }^{1}$ \\ ${ }^{1}$ Uniwersytet Przyrodniczo-Humanistyczny w Siedlcach, Instytut Bioinżynierii i Hodowli Zwierząt, Katedra Genetyki i Hodowli \\ Koni, ul. B. Prusa 14, 08-110 Siedlce \\ ${ }^{2}$ LAB-WET Weterynaryjne Laboratorium Diagnostyczne, ul. Wita Stwosza 30, 02-661 Warszawa \\ e-mail: ewa.wojcik@uph.edu.pl
}

Negatywnie wpływające na materiał genetyczny czynniki egzo- i endogenne o właściwościach mutagennych i genotoksycznych zaburzają prawidłowość działania mechanizmów utrzymujących stabilność genomu. Zaburzenia te mają wpływ na właściwy rozwój i zachowanie zdrowotności oraz predysponują komórkę np. do transformacji nowotworowej. Niestabilność genomu jest cechą charakterystyczną komórek nowotworowych, w których obserwuje się zwiększoną tendencję do różnorodnych uszkodzeń podczas podziału komórki. Elektroforeza pojedynczych komórek jest wiarygodną szybką metodą cytogenetyczną umożliwiającą ocenę stabilności chromatyny. Test ten daje możliwość detekcji uszkodzeń DNA na poziomie pojedynczej komórki. Uformowana kometa daje nam odpowiedź, w jakim stopniu DNA uległo degradacji. Jest to technika prosta, szybka w wykonaniu i nieinwazyjna o wysokiej czułości. Białaczka kotów wywoływana jest przez wirusa z rodziny Retroviridae. Retrowirus wywołujący FeLV replikuje się w specyficzny sposób za pomocą enzymu integrazy. Wirus powoduje patologiczne namnażanie się komórek układu krwionośnego i ma silne działanie immunosupresyjne na szpik kostny oraz układ immunologiczny. Wirus kociej białaczki wykazuje silne działanie chorobotwórcze, które może prowadzić do częstszych zachorowań na chłoniaki i niedokrwistość.

Celem badań była ocena poziomu uszkodzeń DNA limfocytów krwi obwodowej u kotów z FeLV.

Badaniami objęto bezdomne koty będące pod opieką wolontariuszy jednego z lokalnych stowarzyszeń zajmujących się ochroną zwierząt. U kotów określono ogólny stan zdrowia i wykonano testy płytkowe wykrywające antygeny wirusa białaczki kotów (FeLV). Następnie zbadano stabilność genomu zwierząt testem kometowym. W badaniach zastosowano procedurę według Singh i in. (1988). Komórki limfocytów zawieszano na szkiełkach przedmiotowych pokrytych warstwą 0,5\% żelu agarozowego NMP, zatopionych w dwuwarstwowym $0,5 \%$ żelu agarozowym LMP. Następnie preparaty poddano: lizie alkalicznej, denaturacji alkalicznej, elektroforezie, neutralizacji i barwieniu bromkiem etydyny. Integralność DNA komórek oceniano na podstawie procentowej zawartości DNA jądrowego w głowie i ogonie komety oraz wartości współczynnika Tail Moment. Testem kometowym potwierdzono zaburzoną integralność DNA występującą u kotów, u których testem płytkowym zdiagnozowano FeLV.

Wynik testu kometowego informuje nas o kondycji działania mechanizmów utrzymujących stabilność genomu. Test z powodzeniem można wykorzystać do oceny komórek z nagromadzonymi różnymi formami uszkodzeń materiału genetycznego jakie obserwuje się w komórkach nowotworowych. U zwierząt chorych obraz mknącej komety obserwowany był z większą częstością w porównaniu z osobnikami zdrowymi. Wirus kociej białaczki (FeLV) jest powszechnym patogenem wywołującym choroby w rodzinie kotowatych. Ze względu na specyfikę wbudowywania się wirusów w komórki gospodarza do ich wykrycia niezbędne są bardzo czułe badania. Rutynowo do badania stosuje się szybkie testy diagnostyczne.

Nie zawsze jednak wynik testu antygenowego jest wiążący i optymalne byłoby potwierdzenie skutków spowodowanych obecnością wirusa w postaci różnorakich uszkodzeń DNA. Test kometowy może być wykorzystywany w identyfikacji niestabilności w diagnostyce kociej białaczki (FeLV). 


\title{
CECHY OSTEOMETRYCZNE WYBRANYCH ELEMENTÓW SZKIELETU KOTA DOMOWEGO (FELIS SILVESTRIS F. CATUS) ZE STANOWISK ARCHEOLOGICZNYCH: WOLIN-MIASTO I RYNEK WARZYWNY W SZCZECINIE
}

\author{
Osteometric traits of the selected skeleton elements of domestic cat (Felis silvestris f. catus) \\ from archaeological sites Wolin-Town and Szczecin Vegetable Market
}

\author{
Piotr Baranowski, Piotr Nowak, Katarzyna Pęzińska, Agnieszka Talaga \\ Zachodniopomorski Uniwersytet Technologiczny w Szczecinie, Pracownia Anatomii Zwierząt \\ e-mail: Piotr.Baranowski@zut.edu.pl
}

Kot, jako zwierzę dość późno udomowione przez człowieka, do IV w. n.e. nie był w ogóle znany w Europie. Znana jest natomiast i wielokrotnie wspominana mała plastyczność kota, wyrażająca się stałością morfologiczną, połowiczną zależnością od człowieka, polegającą np. na zdolności podejmowania samodzielnych łowów, upodabniających tryb jego życia do życia dzikich przodków czy wymykający się ingerencji człowieka rozród. Wśród materiałów osteologicznych odkrytych na Pomorzu Zachodnim i zdeponowanych w zbiorach Pracowni Anatomii Zwierząt znajdują się szczątki kota. Ich liczba w stosunku do ogólnej liczby oznaczonych szczątków ssaków z Wolina i Szczecina jest niewielka, ponieważ waha się od 0,60 do 0,70\%. Przeprowadzone badania osteometryczne kilku większych fragmentów czaszek tych zwierząt pozwoliły zaliczyć szczątki z Wolina-Miasta do resztek kota domowego. Pochodzą one z miejsc, w których zakopywano je w całości lub takich jak śmietniska i nie noszą śladów po ostrych narzędziach, co wskazuje na to, że nie są odpadkami kuchennymi ani rzemieślniczymi. Druga grupa szczątków kota pochodzi ze stanowiska leżącego u podnóża Zamku Książąt Pomorskich w Szczecinie. Eksplorowane przez 10 lat dostarczyło materiału porównawczego z terenu samego zamku i okolicznych zabudowań miejskich i nie ma wśród nich takich, które wskazywałyby na wykorzystanie szczątków kota jako surowca do prac rzemieślniczych, co potwierdza ich pochodzenie jako pozostałości po zwierzętach padłych w różnym wieku. Celem podjętych badań było zweryfikowanie hipotezy o możliwości występowania na terenie średniowiecznego Szczecina kotów większych niż we współczesnym temu okresowi Wolinie. Materiałem do badań były szczątki kostne kotów domowych pochodzące ze stanowisk usytuowanych w miejscu wczesnośredniowiecznych ośrodków miejskich w Wolinie i Szczecinie. Do badań wykorzystano kości: żuchwy $(\mathrm{n}=50)$, łopatki $(\mathrm{n}=14)$, ramienne $(\mathrm{n}=28)$, promieniowe $(n=18)$, łokciowe $(n=11)$, udowe $(n=21)$ i piszczelowe $(n=20)$. Na podstawie stopnia zrośnięcia trzonu kości długich z nasadami określono wiek kotów i wyróżniono 3 grupy: młode - juvenil (do 6 miesiąca życia), dojrzałe - subadult (od 6 do 11,5 miesiąca życia), dorosłe - adult (powyżej 11,5 miesiąca życia). Dodatkowo oszacowano wartości pola powierzchni rzutów pionowych nasad końca bliższego i końca dalszego kości kończyny miednicznej oraz obliczono wskaźniki masywności ogólnej, nasadowo-trzonowy, nasady bliższej i nasady dalszej. Uzyskane dane opracowano statystycznie. Analiza osteometryczna większości cech kości żuchwy nie wykazała różnic statystycznie istotnych pomiędzy obiektami. Stwierdzono jedynie większą $(\mathrm{P} \leq 0,05)$ średnią szerokość zębów $\mathrm{M}_{1}$ żuchw pozyskanych $\mathrm{z}$ Wolina-Miasta w porównaniu do wartości tej cechy charakteryzującej obiekty ze stanowisk w Szczecinie. Stwierdzono, że długość całkowita, długość główkowa oraz największa szerokość nasady bliższej kości ramiennych odnalezionych w Szczecinie była większa $(\mathrm{P} \leq 0,01)$ w porównaniu do tych z Wolina-Miasta w grupie wieku subadult.

Wykazano również istotnie większą długość całkowitą i główkową kości udowej kotów ze Szczecina w grupie adult w porównaniu z egzemplarzami z Wolina-Miasta, długość całkowitą największą szerokość nasady bliższej i największą szerokość nasady dalszej kości piszczelowej w grupie subadult. Powyższą zależność potwierdzają pomiary pól powierzchni rzutów nasady bliższej i nasady dalszej oraz pole powierzchni całkowitej rzutu i pole powierzchni rzutu trzonu kości udowej i kości piszczelowej obiektów zaliczonych do 
grup wiekowych subadult i adult. Każda z tych cech dla kości obu rodzajów ze stanowisk ze Szczecina wykazuje wartości istotnie wyższe w porównaniu ze stanowiskiem z Wolina-Miasta. Wyniki nie są jednoznaczne. Obraz zaciemnia zdolność do wydawania hybryd będących efektem kojarzeń kotów dzikich i żbików.

Przeprowadzone badania wskazują na większą integrację morfologiczną kotów z Wolina-Miasta, ale nie można wykluczyć również tego, że wśród szczątków znalezionych na stanowisku w Szczecinie były i takie, które należały również do żbików lub ich potomstwa z kotami. Zebrany materiał obejmuje kilka stuleci, co powoduje, że w tak długim czasie mogła nastąpić zmiana w rozmiarach ciała o charakterze wewnątrzpopulacyjnym. Przyczyn można również upatrywać w migracji z terenów pozamiejskich lub w znalezieniu szczątków żbików upolowanych dla wartościowych i o wiele większych skór niż skóry kotów domowych. 


\title{
ANALIZA MORFOMETRYCZNA CZASZEK PSÓW ŚREDNIOWIECZNYCH Z UWZGLĘDNIENIEM WSKAŹNIKA POŁOŻENIA CZOŁA I WCIĘCIA DOGRZBIETOWEGO W OTWORZE WIELKIM
}

\author{
Morphometric analysis of early medieval dog skulls from Pomerania allowing for forehead position index \\ and dorsal notch of the foramen magnum
}

\section{Piotr Baranowski}

\author{
Zachodniopomorski Uniwersytet Technologiczny w Szczecinie, Pracownia Anatomii Zwierząt \\ e-mail: Piotr.Baranowski@zut.edu.pl
}

Osteologicznych dowodów na to, że polimorfizm psa w zakresie cech pokroju najsilniej uwidacznia się w obrębie cech głowy, zgromadzono już wiele. Potwierdzają one wyodrębnione w obrębie gatunku pies trzy zasadnicze morfotypy o czaszkach: brachycefalicznych, mesaticefalicznych oraz dolichocefalicznych. Poza tym podziałem stosuje się wyodrębnienie okazów czaszek psów na krótkopyskie, średniopyskie i długopyskie na podstawie wskaźnika położenia czoła. Porównawcze badania sklepienia czaszek psów trzech morfotypów wykazały dużą zmienność budowy i konsekwencje słabego wykształcenia zatoki czołowej u psów krótkogłowych. Zjawiskiem charakterystycznym dla czaszek typu brachycefalicznego jest obecność wcięcia dogrzbietowego o różnym kształcie i wielkości w otworze wielkim. Do niedawna wydawało się, że wcięcie to jest wynikiem hodowli, ale badania przeprowadzone na czaszkach datowanych na epokę żelaza, pochodzących z południowo-wschodniej Europy, wykazały jego obecność w otworze wielkim również tamtych form psów. Celem badań była analiza cech metrycznych czaszek psów historycznych z uwzględnieniem wartości wskaźnika położenia czoła oraz obecności lub braku wcięcia dogrzbietowego w otworze wielkim. Badaniami objęto 28 szczątków kostnych szkieletu głowy psów pochodzących ze stanowisk archeologicznych datowanych na okres od połowy IX do XIV w., które podzielono na dwie grupy - czaszki krótkopyskie i średniopyskie. Oszacowano wartości 48 cech metrycznych części mózgowiowej, trzewnej oraz powierzchni karkowej tych czaszek i ich pojemność. Oszacowano 11 indeksów czaszkowych, obliczono współczynniki korelacji między wybranymi cechami metrycznymi oraz wzajemne zależności wybranych niektórych indeksów czaszkowych i cech metrycznych w relacji do pola powierzchni otworu wielkiego, jego wysokości i szerokości oraz indeksu foramen magnum. Spośród 16 okazów czaszek 11 charakteryzowało się wartością wskaźnika położenia czoła mniejszą niż 125 (od 104,2 do 121,7) - czaszki krótkopyskie. Wartość tego wskaźnika dla pozostałych pięciu czaszek mieściła się w przedziale od 125,9 do 129,9 - czaszki średniopyskie. Okazów długopyskich w badanym materiale nie było. Dwanaście spośród 18 cech metrycznych charakteryzujących powierzchnię grzbietową czaszek krótkopyskich wykazało wartości wyższe niż u okazów średniopyskich, jednak test t-Studenta wykazał różnicę istotną $(\mathrm{P} \leq 0.01)$ między grupami tylko w zakresie długości odcinka frontal midpoint-opisthion oraz w wysokości oczodołu. Nie stwierdzono różnic statystycznie istotnych między grupami w zakresie cech charakteryzujących podstawę czaszki oraz powierzchnię karkową czaszki psów obu grup. Analiza statystyczna wartości wyprowadzonych indeksów czaszkowych wykazała jedynie różnice między grupami w odniesieniu do indeksu otworu wielkiego obliczanego bez wcięcia dogrzbietowego $(\mathrm{P} \leq 0.05)$ oraz dla indeksu $\mathrm{Pm}-\mathrm{Pd} / \mathrm{St}-\mathrm{P} \times 100(\mathrm{P} \leq 0.01)$. Wykazano, iż skala siły związku między badanymi cechami zawiera się w przedziale od nikłej do prawie pełnej. Analiza oszacowanych wartości charakteryzujących powierzchnię karkową badanych czaszek pozwoliła również na ustalenia stopnia dysplazji potylicznej w badanym materiale. Przeprowadzone badania wykazały brak wpływu wskaźnika położenia czoła na wartość badanych cech. 


\title{
WPŁYW INTENSYWNEGO ŻYWIENIA ZIMOWEGO NA MASĘ CIAŁA CIELĄT DANIELA EUROPEJSKIEGO (DAMA DAMA)
}

The influence of intensive winter feeding on the body weight of the European fallow deer (Dama dama)

\author{
Paweł Bogdaszewski, Żaneta Steiner-Bogdaszewska
}

\author{
Instytut Parazytologii im. Witolda Stefańskiego PAN, Stacja Badawcza w Kosewie Górnym 7, 11-700 Mrągowo \\ e-mail: kosewopan@kosewopan.pl
}

Daniel europejski (Dama dama) charakteryzuje się sezonową zmiennością przyrostów masy ciała. Ze względu na niekorzystne warunki pogodowe częściej dochodzi do upadków zwierząt młodych. Zimowanie cieląt pod zadaszeniem w specjalistycznych budynkach inwentarskich ogranicza upadki zwierząt związane z niekorzystnymi warunkami środowiskowymi oraz czasowym brakiem pokarmu.

Celem pracy było określenie wpływu intensywnego żywienia cieląt daniela europejskiego płci męskiej na ich masę ciała w czasie zimowania w specjalistycznych budynkach inwentarskich.

Doświadczenie przeprowadzono w okresie od 16.12.2015 r. do 16.05.2016 r. na terenie fermy jeleniowatych Stacji Badawczej Instytutu Parazytologii Polskiej Akademii Nauk w Kosewie Górnym, w woj. warmińsko-mazurskim. Grupą badawczą było 36 cieląt płci męskiej, które zważono i umieszczono w przestronnym pomieszczeniu inwentarskim na okres 5 miesięcy. W trakcie trwania doświadczenia zwierzęta miały stały dostęp do siana i wody oraz lizawki mineralno-witaminowej. Raz dziennie otrzymywały $260 \mathrm{~g}$ paszy treściwej, która składała się w 70\% z gniecionego owsa, w 15\% z koncentratu rzepakowego o poziomie białka surowego $33 \%$ oraz w $15 \%$ z koncentratu sojowego o poziomie białka surowego $45 \%$ łączonych rozwodnioną melasą. Dodatkowo do dawki pokarmowej dodawano mineralną mieszankę uzupełniającą. Monitoring w pomieszczeniu inwentarskim wskazał brak negatywnych interakcji między cielętami w trakcie pobierania pokarmu. W dniu zakończenia doświadczenia zwierzęta zostały ponownie zważone oraz zmierzono długość ich rosnącego poroża od podstawy czaszki do wierzchołka tyki.

Zaobserwowano istotne statystycznie różnice mas ciała cieląt przed i po okresie zimowania $(\mathrm{t}=13,75$, df $=35, \mathrm{p}=0,00000, \alpha=0,05$ ). Średnia masa cieląt przed zimowaniem wynosiła 27,38 kg (współczynnik zmienności $\mathrm{V}=15 \%$ ) i zwiększyła się w czasie trwania eksperymentu do 32,69 kg (współczynnik zmienności $\mathrm{V}=12 \%$ ). Przyrost masy ciała wyniósł średnio $20 \%$. Biorąc pod uwagę istniejące różnice w początkowej masie ciała poszczególnych zwierząt, do celów analizy uzyskanych wyników dokonano podziału grupy doświadczalnej na 3 podgrupy wagowe. Wyniki przedstawiały się następująco: zwierzęta o masie przed zimowaniem mniejszej niż $25 \mathrm{~kg}$ przyrosły o $30 \%$, zwierzęta o masie 25-30 kg przyrosły o $20 \%$, natomiast zwierzęta o masie ciała powyżej $30 \mathrm{~kg}$ przyrosły średnio o $14 \%$.

Obliczono korelację pomiędzy początkową masą ciała cieląt a długością ich poroża, końcową masą ciała a długością poroża oraz przyrostem masy ciała w okresie zimowym a długością poroża. Określono wysoce istotną statystycznie korelację pomiędzy początkową i końcową masą ciała a długością poroża $\left(\mathrm{R}_{\mathrm{p}}=0,7\right.$, $\left.\mathrm{p}=0,000002 ; \mathrm{R}_{\mathrm{k}}=0,69, \mathrm{p}=0,000002\right)$. Nie stwierdzono istotnej statystycznie korelacji pomiędzy przyrostem masy ciała a długością poroża $\left(\mathrm{R}=-0,18, \mathrm{r}^{2}=0,03, \mathrm{p}=0,29\right)$.

Podsumowując, można stwierdzić, że zimowanie w pomieszczeniach inwentarskich oraz intensywne żywienie cieląt zbilansowaną paszą o wysokiej zawartości białka jest skuteczną metodą na uniknięcie zimowego zatrzymania wzrostu osobniczego. Koniec eksperymentu nastąpił w okresie przed intensywnym wiosennym wzrostem cieląt, a mimo to u cieląt nastąpił znaczny przyrost masy ciała. Szczegółowa analiza wykazała, że największe przyrosty masy ciała uzyskały zwierzęta najmniejsze, co sugeruje, że nastąpiła kompensacja omawianej cechy. Długość pierwszego poroża, jakie zostało wytworzone w okresie zimowym, zależna jest przede wszystkim od masy ciała zwierzęcia. Nie stwierdzono związku pomiędzy tempem wzrostu w okresie zimowym a długością poroża. 


\title{
MINIMALNY POZIOM NATĘŻENIA ŚWIATŁA KONIECZNY DO WYWOŁANIA REAKCJI FOTOPERIODYCZNEJ U DANIELI (DAMA DAMA) UTRZYMYWANYCH W WARUNKACH FERMOWYCH
}

Minimal level of illuminance intensity necessary to trigger off photoperiodic reaction of farmed fallow deer (Dama dama)

\author{
Marek Bogdaszewski ${ }^{1}$, Katarzyna Tajchman ${ }^{2}$, Zofia Bogdaszewska $^{1}$ \\ ${ }^{1}$ Instytut Parazytologii PAN, Stacja Badawcza w Kosewie Górnym \\ ${ }^{2}$ Uniwersytet Przyrodniczy w Lublinie, Katedra Etologii i Dobrostanu Zwierząt, Zakład Hodowli Zwierząt Dzikich \\ e-mail: kosewopan@kosewopan.pl
}

Cyklicznie, corocznie powtarzający się proces wytwarzania i zrzucania poroża przez samce jeleniowatych jest unikalnym u ssaków przykładem regeneracji tkanki. Badania dotyczące przebiegu tego procesu są niezwykle istotne $\mathrm{z}$ uwagi na fakt, iż jest on oparty na działaniu mezenchymalnych komórek macierzystych (MSC). Dzięki swoim unikalnym cechom komórki te są postrzegane jako przyszłość medycyny regeneracyjnej. Dotychczas odkryto kilka źródeł efektywnego pozyskiwania komórek MSC, takich jak: szpik kostny, tkanka tłuszczowa, krew pępowinowa, łożysko, miazga zębowa, mięśnie szkieletowe i inne. Rosnące poroże jest, w odróżnieniu od wyżej wymienionych tkanek, usytuowane na zewnątrz organizmu, co znacznie ułatwia prowadzeniu tego typu badań.

Podejmowane są próby modyfikacji cyklu rozwoju poroża poprzez manipulowanie natężeniem i długością oświetlenia w warunkach hodowli fermowej. Nie ulega bowiem wątpliwości, że regulacja tego procesu ma podłoże fotoperiodyczne, a zasadniczym czynnikiem są zmiany długości dnia. W warunkach naturalnych zrzucanie skostniałego poroża następuje wiosną, co związane jest $\mathrm{z}$ wydłużającym się dniem. Poza zmianą tego czynnika istotne jest także określenie minimalnego poziomu natężenia światła, przy którym możliwe jest wywołanie opisanej reakcji organizmu.

Badania zostały przeprowadzone w sezonie zimowym 2015/2016 na terenie fermy jeleniowatych Stacji Badawczej Instytutu Parazytologii Polskiej Akademii Nauk w Kosewie Górnym k. Mrągowa. Do badań wykorzystano 2 grupy po 5 byków danieli w wieku 3-5 lat, utrzymywanych w pomieszczeniach zamkniętych, wyposażonych w okna (stosunek powierzchni okien do powierzchni podłogi wynosił $1: 20$ ) oraz w sztuczne oświetlenie. Grupa I doświetlana była światłem sztucznym o natężeniu 150 luksów, a grupa II o natężeniu 300 luksów. Zastosowano lampy LED o mocy nominalnej $18 \mathrm{~W}$ i deklarowanym strumieniu świetlnym 1850 lumenów. Emitowane światło miało barwę białą zimną (o temperaturze barwowej $6000 \mathrm{~K}$ ). Jako grupę kontrolną wykorzystano byki utrzymywane na wybiegach zewnętrznych. Począwszy od grudnia, rozpoczęto zwiększanie długości dnia w stosunku do oświetlenia naturalnego o 1 godzinę co 2 tygodnie aż do osiągnięcia 16 godzin.

Zaobserwowano, że zwiększenie długości dnia realizowane przy natężeniu oświetlenia na poziomie 150 luksów nie wpłynęło na zmianę przebiegu cyklu poroża w stosunku do grupy kontrolnej, natomiast światło o natężeniu 300 luksów wywołało wyraźną reakcję polegającą na przyspieszeniu wzrostu, wytarciu ze scypułu i zrzuceniu poroża o ok. 2 tygodnie. 


\title{
OCENA WYBRANYCH CECH JAKOŚCIOWYCH MIĘSA DZIKO ŻYJĄCEGO DANIELA EUROPEJSKIEGO (DAMA DAMA)
}

\author{
Assessment of selected meat quality traits from wild fallow deer (Dama dama)
}

\author{
Marta Bykowska
}

\author{
Uniwersytet Przyrodniczy w Poznaniu, Katedra Hodowli Zwierząt i Oceny Surowców, \\ Złotniki, ul. Słoneczna 1, 62-002 Suchy Las \\ e-mail: m.bykowska@gmail.com
}

Daniel europejski jest gatunkiem introdukowanym na terenie naszego kraju. Populacja dziko żyjąca w roku 2016 osiągnęła ponad 21 tys. sztuk. Mięso pozyskane od daniela europejskiego charakteryzuje się dobrą jakością bez sztucznych dodatków, co związane jest z szeroką dostępnością różnorodnego pokarmu i częstym przemieszczaniem się zwierząt. W dzisiejszych czasach konsumenci coraz częściej zwracają uwagę na jakość i naturalność produktów, mięso daniela europejskiego wpisuje się w ten trend. Celem przeprowadzonych badań była ocena wybranych cecha jakościowych mięsa dziko żyjącego daniela europejskiego. Materiał stanowiło 9 łań dziko żyjącego daniela europejskiego w wieku ok. 24 miesięcy o średniej masie ciała 41,88 $\pm 7,58 \mathrm{~kg}$ pozyskanych metodą odstrzału. Po $24 \mathrm{~h}$ od uboju pobrano z tuszy trzy mięśnie $(\mathrm{m}$. $s u$ praspinatus, $m$. longissimus, m. semimembranosus). Analiza $\mathrm{pH}$ została wykonana elektrodą szklanokalomelową (ERH-11X1, SCHOOT, Niemcy) podłączoną do przenośnego pH-metru (Handylab 2, SCHOOT, Niemcy). Kwasowość była analizowana $45 \mathrm{~min}, 24 \mathrm{~h}$ po uboju. Analizę barwy (L*, a*, b*) aparatem Konica Minolta (the Netherlands) $24 \mathrm{~h}$ po uboju. Wykonano analizę chemiczną - zawartość suchej masy (\%) (PN-ISO 1442:2000), białka ogólnego (\%) metodą Kjeldahla (1975), tłuszczu ekstrahowanego (\%) metodą Soxhleta (PN-ISO 1444:2000), wyciek naturalny (\%) metodą Honikela (1998), wyciek termiczny (\%) metodą Honikela (1998), zawartość wody wolnej (\%) metodą Grau-Hamma (1953) w modyfikacji Pohja i Niinivaara (1957) i plastyczność $\left(\mathrm{cm}^{2}\right)$. Analizę statystyczną wykonano przy użyciu pakietu ANOVA oprogramowania SAS ver. 9.4. Stwierdzono istotny wpływ $(\mathrm{P} \leq 0,01)$ mięśnia na $\mathrm{pH}$ analizowane $45 \mathrm{~min}$ i $24 \mathrm{~h}$ po uboju. Najwyższym $\mathrm{pH}_{45 \min }(6,43)$ i $\mathrm{pH}_{24 \mathrm{~h}}(5,83)$ charakteryzował się mięsień supraspinatus w porównaniu z pozostałymi analizowanymi mięśniami ( $m$. longissimus $-\mathrm{pH}_{45 \min }=5,93, \mathrm{pH}_{24 \mathrm{~h}}=5,69 ;$ m. semimembranosus $\left.-\mathrm{pH}_{45 \min }=5,60, \mathrm{pH}_{24 \mathrm{~h}}=5,66\right)$. Analiza barwy wykazała istotny wpływ $(\mathrm{P} \leq 0,05)$ mięśnia na jasność $\left(\mathrm{L}^{*}\right)$ analizowanych mięśni. Mięsień longissimus charakteryzował się najniższym indeksem $\mathrm{L}^{*}$, czerwienie (a*) i żółci (b*) w porównaniu do mięśnia supraspinatus i semimembranosus (L* 35,96 vs. 38,61 vs 39,91; $a^{*} 10,26$ vs. 10,82 vs. 10,71 ; b* 4,63 vs. 5,53 vs. 5,63). Wpływ mięśnia stwierdzono również dla wycieku naturalnego i plastyczności $(P \leq 0,05)$ oraz dla wycieku termicznego i wody wolnej $(P \leq 0,01)$. Najmniejszym wyciekiem naturalnym ( 0,64 vs. 1,08 vs. $0,88 \%)$, wodą wolną $(26,53$ vs. 32,91 vs. $33,23 \%)$ i plastycznością $\left(5,61\right.$ vs. 5,95 vs. $\left.6,44 \mathrm{~cm}^{2}\right)$ charakteryzował się mięsień supraspinatus w porównaniu z m. longissimus i m. semimembranosus, co może być spowodowane wyższym pH końcowym mięśnia. Najniższym wyciekiem termicznym (28,03 vs. 28,60 vs. $31,68 \%)$ cechował się mięsień longissimus w porównaniu z mięśniami supraspinatus i semimembranosus, co może być związane z ich odmienną funkcją i mikrostrukturą. Analiza chemiczna wykazała istotny wpływ $(\mathrm{P} \leq 0,01)$ mięśnia na analizowane cechy. Mięsień longissimus charakteryzował się największą zawartością suchej masy (24,54 vs. 22,86\%), białka (22,77 vs. 20,64\%) i najmniejszą tłuszczu $(0,44$ vs. 0,70\%) w porównaniu z mięśniem supraspinatus. Na podstawie wyników możemy wnioskować o dobrej jakości i przydatności mięsa daniela europejskiego. Mięsień longissimus charakteryzuje się najlepszą jakością spośród analizowanych mięśni. 


\title{
MORFOMETRIA PSA TYPU GREYSTER W ASPEKCIE PRZYSTOSOWANIA DO UŻYTKOWANIA SPORTOWGO
}

Morphometry of the greyster type dog in the aspect of adaptation to sporting use

\author{
Hieronim Frąckowiak, Mateusz Brylewski, Marcin Komosa, Maria Nabzdyk \\ Uniwersytet Przyrodniczy w Poznaniu, Instytut Zoologii, Zakład Anatomii Zwierząt \\ e-mail: hieronim.frackowiak@up.poznan.pl
}

Psy typu greyster powstały w latach ' $80 \mathrm{XX}$ wieku w Norwegii ze skrzyżowania wyżła niemieckiego krótkowłosego z chartem angielskim. Nazwa pochodzi od połączenia angielskich nazw ras wyjściowych „grey” od słowa greyhund (chart angielski), a drugi człon od słowa vorsther (wyżeł). Eksterier tych psów jest najbardziej zbliżony do wyżła niemieckiego krótkowłosego, ponieważ aż $75 \%$ ich puli genowej pochodzi od wyżła, a pozostałe 25\% od greyhunda (Szmurło i Szmurło 2000).

Psy typu greyster potrafią osiągnąć prędkość maksymalną ok. $50 \mathrm{~km} / \mathrm{h}$. Zaprzęgi złożone z tych psów na zawodach pokonują trasę od 5 do $8 \mathrm{~km}$ ze średnią prędkością powyżej $30 \mathrm{~km} / \mathrm{h}$. Są to psy o dużym temperamencie i niskim poziomie agresji. Przedstawiciele psów tego typu $\mathrm{w}$ warunkach domowych potrafią zachowywać spokój i godzinami leżeć, nie wykazując aktywności. Jest to cecha odziedziczona po charcie. Wymagają od właściciela bliskiego kontaktu. Bardzo często tylko w zaprzęgu kierowanym przez swojego właściciela lub osobę im bardzo dobrze znaną potrafią wykazać cały potencjał swoich możliwości. Bieganie dla greysterów jest ogromną pasją, która wytycza im sens egzystencji. Psom tym należy zatem zapewnić intensywny ruch, którego deficyt może wpłynąć na niepożądane zachowanie i zbyt dużą pobudliwość. Psy typu greyster nie są uznane za rasę przez Międzynarodową Federację Kynologiczną, ponieważ nie posiadają określonego wzorca rasy. Wynika to z faktu, że w hodowli tych psów najważniejsza jest użytkowość sportowa. Celem pracy jest analiza morfometryczna budowy i wykazanie przystosowania anatomicznego psa typu greyster do pracy pociągowej.

Obserwacje i pomiary zoometryczne wykonano u psów typu greyster, aktualnie czynnych sportowo, utrzymywanych i użytkowanych przez polskich zawodników i hodowców. Pomiary wykonano ogółem u 28 psów typu greyster obu płci (14 samców i 14 suk) w wieku od 2 do 6 lat. U psów w pozycji stojącej wykonano sześć następujących pomiarów zoometrycznych: obwód klatki piersiowej, długość kończyny przedniej (piersiowej), długość kończyny tylnej (miednicznej), wysokość w kłębie, długość skośna tułowia. Pomiarów dokonano podczas Mistrzostw Europy Federacji ESDRA, które odbyły się w Niemczech w mieście Christianslust w dniach 2-4 listopada 2012 r. Na podstawie dokonanych pomiarów zostały obliczone następujące indeksy (Pruski 2007): indeks formatu (długości tułowia), indeks wysokonożności, indeks eurysomii (obwodu klatki piersiowej).

Na podstawie przeprowadzonych pomiarów oraz ich analizy wykazano, że budowa anatomiczna psów typu greyster wybitnie predysponuje je do pracy w zaprzęgu. Każda z części ciała psów w typie greyster jest przystosowana do efektywnego i szybkiego biegania. Z obserwacji własnych wynika, że oprócz optymalnej budowy ciała psy te posiadają również odpowiedni temperament, który bardzo dobrze sprawdza się w sporcie zaprzęgowym.

\section{Piśmiennictwo}

Szmurło M., Szmurło I. 2000. Husky i inne. Sport Psich Zaprzęgów. Egros, Warszawa. Pruski W. 2007. Hodowla koni. Powszechne Wydawnictwo Rolnicze i Leśne, Warszawa. 


\title{
OCHRONA DZIKICH GATUNKÓW ZWIERZĄT NA PRZYKŁADZIE ŻBIKA I RYSIA
}

Protection of wild animals taking the example of wildcat and lynx

\author{
Paulina Gawryś, Dorota Kołodziejczyk, Stanisław Socha
}

\author{
Uniwersytet Przyrodniczo-Humanistyczny w Siedlcach, Katedra Metod Hodowlanych i Hodowli Drobiu, \\ ul. B. Prusa 12/14, 08-110 Siedlce \\ e-mail: dormark1@wp.pl, socha@uph.edu.pl
}

Celem pracy była analiza ochrony zwierząt na przykładzie żbika i rysia. Dodatkowo zostały poruszone kwestie ochrony przyrody i monitoringu tych gatunków w Polsce. W ramach badań przeprowadzono ankietę, w której przebadano grupę kilkudziesięciu osób pod względem wiedzy przyrodniczej. Ankietę przeprowadzono wśród osób w różnym wieku i różnej płci, uczących się bądź po studiach, mających wiedzę z różnych dziedzin. Grupa badawcza miała charakter międzynarodowy - byli w niej mieszkańcy krajów należących do Unii Europejskiej (Polska, Bułgaria, Szwecja) oraz spoza Unii - z Rosji, Ukrainy i Izraela. W ankiecie poruszono kwestie ochrony przyrody, a także kwestie szczegółowego zapobiegania wymieraniu żbika oraz rysia w różnych krajach. Aby przeanalizować, na czym w poszczególnych krajach koncentrują się działania rządu i jak widzą pracę danego systemu ludzie, zostały zadane pytania odnośnie do ochrony środowiska, a także co dany rząd robi dla środowiska i co promuje poprzez swoje działania. Jeśli nie zmienimy swojego podejścia i nie zaczniemy chronić przyrody, w XXI w. może wymrzeć ogromna liczba gatunków roślin i zwierząt. Przyczynami tego będą: zbyt niska liczba areałów naturalnych i ostoi, skażone środowisko naturalne, duża liczba połowów i odstrzałów, kłusownictwo, kolekcjonerstwo, gromadzenie trofeów, pozyskiwanie afrodyzjaków, pamiątkarstwo, moda na skóry, pióra lub futra [Jakimiuk i Kryt 2012]. W myśl ustawy o ochronie przyrody Skarb Państwa odpowiada za szkody wyrządzone przez gatunki wpisane jako zagrożone (art. 52, pkt 1). Rada Ministrów wydała rozporządzenie 10.09.1997 r. o gatunkach zwierząt chronionych, do których dołączył wilk. Odszkodowania wyrządzone przez te zwierzęta przysługiwały jedynie na terenach, gdzie dany gatunek został objęty ochroną (Wiśniewski 2004).

W Polsce rysie są objęte ścisłą ochroną, ze względu na to, iż jest to gatunek zagrożony wyginięciem. Cała jego populacja nie liczy więcej niż 200 sztuk. Bardzo często zdarza się, że rysie wpadają we wnyki zastawiane przez kłusowników na inną zwierzynę - przez to, że żywią się sarnami, jeleniami, podążają za nimi i wpadają w pułapki. Rysie zamieszkują wielkie terytoria porośnięte lasami, niestety brak ciągłości tych kompleksów sprawia, że wpadają pod koła samochodów czy pociągów. Zagrożeniem dla tego gatunku jest też zbyt intensywna gospodarka łowiecka, powodująca ubożenie gamy pokarmowej dla rysia (Wolfram i Leończuk 2011).

Z kolei naturalnymi wrogami zagrażającymi żbikowi są wilki oraz zdziczałe psy, a jeśli chodzi o młode osobniki to dodatkowym zagrożeniem są ptaki drapieżne i lisy. Niezwykle niska liczebność stwarza olbrzymie zagrożenie $\mathrm{w}$ zmienności genetycznej tej populacji. Istnieje wysokie prawdopodobieństwo, że kot domowy skrzyżował się wielokrotnie ze żbikiem i przez ten precedens w Europie może już nie występować żbik czystej krwi. Dodatkowym zagrożeniem dla żbików są choroby przenoszone przez koty domowe lub mieszańce oraz pasożyty. Wielkim utrudnieniem jest dzielenie kompleksów leśnych, a powstawanie dróg przecinających lasy powoduje zagrożenie dla żbików podczas przemieszczania się za pożywieniem. W przypadku sadzenia monokulturowych lasów pozbawiamy ten gatunek potencjalnych kryjówek, a także zmniejszamy liczbę zasobów pokarmowych. Czasami zdarza się, że omyłkowo zostają odstrzelone, ale też poluje się na nie, mimo iż gatunek ten podlega ścisłej ochronie gatunkowej. Na polskiej czerwonej liście zwierząt zagrożonych i ginących oraz w polskiej czerwonej księdze zwierząt gatunek ten ma status zagrożonego, natomiast na liście dla Karpat to gatunek krytycznie zagrożony (Wolfram i Leończuk 2011). 


\title{
WEGAŃSKA DIETA PSÓW?
}

\author{
Vegan diet of dogs?
}

\author{
Andrzej Gugołek ${ }^{1}$, Tomasz Wyczling ${ }^{2}$, Janusz Strychalski ${ }^{1}$, Anna Czarnecka ${ }^{2}$ \\ ${ }^{1}$ Uniwersytet Warmińsko-Mazurski, Katedra Hodowli Zwierząt Futerkowych i Łowiectwa, \\ ul. Oczapowskiego 5, 10-719 Olsztyn, \\ ${ }^{2}$ PZZ w Kwidzynie, Sp. z o.o., ul. Południowa 14 A, 82-500 Kwidzyn \\ e-mail: gugolek@uwm.edu.pl, tomaszwyczling@pzzkwidzyn.pl
}

Pies domowy (Canis lupus familiaris), podobnie jak uznawany za jego przodka wilk, zaliczany jest do zwierząt mięsożernych. Obecnie jednak wielu naukowców i hodowców psów uważa je za wszystkożerne, tłumacząc to jako efekt udomowienia. Wegetarianizm, czyli dieta bez produktów mięsnych, i weganizm dieta bez produktów pochodzenia zwierzęcego, np. mleka czy jaj, jest coraz popularniejsza wśród ludzi. Wielu z nich stara się swój styl żywienia przełożyć także na swoich podopiecznych - psy. Pomimo że dla wielu taka koncepcja żywieniowa jest dziwna, na rynku paszowym pojawia się coraz więcej pasz tego typu, będących odpowiedzią na zapotrzebowanie. Są to najczęściej produkty importowane, reklamowane jako wpływające pozytywnie na stan zdrowotny zwierząt oraz antyalergiczne. Istnieją także pierwsze badania wskazujące na brak wpływu żywienia wegetariańskiego/wegańskiego na stan zdrowotny psów.

Opozycyjną teorią dotyczącą żywienia psów jest dieta BARF (biologically appropriate raw food). Dieta ta propagowana jest przez zwolenników teorii, że żywienie psów powinno być maksymalnie zbliżone do diety ich dzikich przodków, co oznacza, że w jej skład powinny wchodzić przede wszystkim surowe mięso i kości oraz niewielkie ilości nieprzetworzonych pasz roślinnych: owoców i warzyw.

Paradoksalnie żywienie psów tymi dwoma diametralnie różnymi dietami tłumaczone jest często podobnie, dobrem zwierząt i troską o ich zdrowie. Autorzy mają wrażenie, że psy są antropomorfizowane, a życiowe postawy i światopogląd właścicieli przekładane są na zwierzęta pozostające pod ich opieką. Ponadto wiele informacji dotyczących żywienia psów z różnych przyczyn nie zostało sprawdzonych naukowymi metodami, a propagowane jest za pomocą reklam emitowanych w mass mediach. Celowe jest zatem naukowe poznanie wpływu różnych diet na stan zdrowotny psów. Pracownicy Katedry Hodowli Zwierząt Futerkowych i Łowiectwa UWM w Olsztynie, współpracując z firmą paszową PZZ w Kwidzynie, opracowali i przygotowali 5 wegańskich przeznaczonych dla psów suchych diet granulowanych, różniących się dodanym do nich aromatem. Diety przygotowano ze śrut zbożowych, nasion roślin oleistych i ich produktów ubocznych oraz premiksów mineralno-witaminowych. Zastosowano dodatki aromatyczne o zapachu: łososia, wołowiny, wołowiny gotowanej, kiełbasy i bekonu. Sprawdzono chęć pobierania przygotowanych mieszanek przez psy różnych ras, od różnych właścicieli i utrzymywanych w różnych warunkach. Wykonano także test smakowitości pasz o różnych aromatach.

Stwierdzono, że większość psów z chęcią pobierało pasze wegańskie, jednak zwierzęta utrzymywane w najlepszych warunkach i żywione różnorodnie lub najlepszymi paszami komercyjnymi zjadały jej najmniej. Zmodyfikowany test smakowitości wykazał, że psy preferowały pasze o aromacie łososia.

Opisane powyżej wstępne badania dotyczące pasz wegańskich mają charakter bardziej informacyjny niż naukowy i nie dostarczyły jasnej odpowiedzi, czy dieta pozbawiona zwierzęcego białka jest odpowiednia dla psów. Doniesienie ma charakter dyskusyjny i jest zachętą do dalszych dociekań naukowych. Zagadnienie to pozostaje otwarte i wymaga kolejnych, szczegółowych naukowych badań na psach różniących się rasą, wiekiem i stanem fizjologicznym. 


\title{
HISTORIA I WSPÓŁCZESNE PROBLEMY Z GOSPODAROWANIEM JELENIA SIKA CERVUS NIPPON W REPUBLICE CZESKIEJ
}

History and contemporary problems with the management of sika deer Cervus nippon in Czech Republic

\author{
Vladimir Hanzal ${ }^{1}$, Paweł Janiszewski ${ }^{2}$ \\ ${ }^{1}$ University of Life Sciences in Prague, Department of Game Management and Wildlife Biology \\ ${ }^{2}$ Uniwersytet Warmińsko-Mazurski w Olsztynie, Katedra Hodowli Zwierząt Futerkowych i Łowiectwa \\ e-mail: hanzal@fld.czu.cz,janisz@uwm.edu.pl
}

Początki występowania i hodowli jelenia sika na terenach obecnych Czech sięgają końca XIX w., czyli czasów, w których w Europie modna była hodowla zagrodowa zwierząt dzikich w przypałacowych zwierzyńcach. Pierwsze osobniki jelenia sika japońskiego oraz jelenia sika Dybowskiego zostały sprowadzone do zamkniętej hodowli w okolicach miejscowości Podebrad - w 1890 lub 1891 r. Były tam wypuszczone 3 łanie i jeden byk. W 1902 r. było już tam 70 osobników, a w 1912 - 125. Dodatkowo do tego czasu zostało odłowionych ok. 100 zwierząt. W XIX w. jeleń sika został sprowadzony w okolice miejscowości Plzeń, a na początku XX w. w kilka kolejnych miejsc na Morawach. Początek obecnie występujących dzikich populacji wynikał głównie ze zniszczenia ogrodzeń hodowli zamkniętych (tzw. obór), co miało miejsce w pierwszej połowie XX w., głównie w wyniku działań wojennych. Na początku lat 90. ubiegłego stulecia obecność jelenia sika stwierdzano już na ponad 22\% terenów Czech. Łowieckie czeskie statystyki dotyczące tego gatunku są systematycznie prowadzone od $1966 \mathrm{r}$. Wtedy populacja została oszacowana na 460 osobników. W roku 2011 było ich już 9715, czyli 21 razy więcej. Wzrost liczebności nie odpowiadał jednak wzrostowi pozyskania w analogicznym czasie, który był prawie 40-krotny. Może to sugerować błędne określanie liczebności i duże niedoszacowanie. $Z$ danych liczbowych wynika także, że od kilkunastu lat w Czechach redukcja jelenia sika przewyższa jego szacowaną liczebność, a dodatkowo, że oba te parametry wzrosły w tym czasie dwukrotnie. Pozyskanie jelenia sika w 2016 r. wyniosło ponad 16 tys. osobników. W porównaniu z rokiem 2007 jest to wzrost o $100 \%$. W roku 2016 odstrzał jelenia szlachetnego i daniela wynosił w Czechach odpowiednio: około 26 tys. i około 20 tys., a warto też zaznaczyć, że obszar Czech wynosi w przybliżeniu 1/4 obszaru Polski. Jako inne negatywne zjawisko występowania tego obcego gatunku stwierdza się występowanie krzyżówek pomiędzy jeleniem sika i jeleniem szlachetnym, co wykazano w obu głównych czeskich populacjach. Osobniki powstałe z takich krzyżówek są płodne i wykazują fenotypowo cechy obu gatunków, np. pośrednie rozmiary ciała, szczątkowe nakrapianie sierści itp. Hybrydyzacja uwidacznia się także w wyglądzie i jakości poroża oraz w wymiarach czaszek. 


\title{
ALERGIE U PSÓW Z TRZECH OBSZARÓW POLSKI BADANE ZA POMOCĄ TESTÓW ALERGICZNYCH IN VITRO
}

\author{
In vitro allergy testing in dogs from three areas of Poland
}

\author{
Bartosz Jania $^{1,2}$, Marta Dopierała ${ }^{1}$, Katarzyna Andraszek ${ }^{1}$, Ewa Wójcik ${ }^{1}$ \\ ${ }^{1}$ Uniwersytet Przyrodniczo-Humanistyczny w Siedlcach, Instytut Bioinżynierii i Hodowli Zwierząt, \\ Katedra Genetyki i Hodowli Koni, ul. B. Prusa 14, 08-110 Siedlce \\ ${ }^{2}$ LAB-WET Weterynaryjne Laboratorium Diagnostyczne, ul. Wita Stwosza 30, 02-661 Warszawa \\ e-mail: bartosz.jania@uph.edu.pl; katarzyna.andraszek@uph.edu.pl
}

\begin{abstract}
Alergie to nie tylko dolegliwości dotykające ludzi, ale również zwierzęta, np. psy. Choroby alergiczne są często obserwowane w praktyce weterynaryjnej. Alergeny mogą mieć pochodzenie roślinne, zwierzęce lub mogą być związkami chemicznymi. W zależności od danego alergenu i reakcji organizmu wyróżnia się różne rodzaje nadwrażliwości, które są odpowiedzią immunologiczną organizmu na substancje obce. Powstają wówczas swoiste przeciwciała, które wiążąc się z antygenem, prowadzą do wytworzenia mediatorów odpowiadających za powstanie stanu zapalnego. Późno zdiagnozowane bądź nieleczone alergie mogą doprowadzić do poważnych powikłań zdrowotnych. Na przykład reakcje uczuleniowe powodujące swędzące zmiany skórne mogą być przyczyną wystąpienia otwartych ran w wyniku ciągłego drapania się psa.

Celem pracy było określenie częstotliwości występowania alergii na różne alergeny środowiskowe u psów pochodzących z trzech regionów Polski. Badaniami objęto psy-pacjentów zakładów leczniczych dla zwierząt zlokalizowanych w Polsce północnej (Gdańsk i okolice), w okolicach Warszawy i na terenie Polski południowej (okolice Krakowa, Katowic i Nowego Sącza). Materiał badawczy klasyfikowano według miast, w których wykonywane były analizy. W badaniach wykorzystano panel alergiczny, w którym znajduje się 15 pojedynczych alergenów oraz 5 mieszanek (pyłki: trawa, drzewa, chwasty; roztocza kurzu domowego, roztocza spiżarniane, pleśnie, Malassezia, pchły). Oznaczano stężenie przeciwciał IgE.

Analizując uzyskane wyniki, można potwierdzić hipotezę, że psy wychowujące się w bardziej zanieczyszczonym środowisku, w tym wypadku w południowej części Polski, mają większe skłonności do alergii. Dodatkowo zauważalna jest różnica w liczbie badanych pacjentów i przypadków z odnotowanymi dodatnimi wynikami testu alergicznego między Polską południową, a północną czy centralną. Psów badanych na terenie północnej Polski było znacząco mniej niż tych badanych w Polsce południowej. Jak powszechnie wiadomo południowa część kraju jest bardziej zurbanizowana niż północna, dlatego zanieczyszczenie powietrza na południu jest znacznie większe niż na północy. Dodatkowo Gdańsk to miasto znajdujące się bardzo blisko Morza Bałtyckiego, co szczególnie wpływa na oczyszczanie się powietrza.

Czynników wpływających na występowanie alergii u psów jest bardzo dużo. Jednakże większość badań potwierdza, że to właśnie środowisko jest głównym czynnikiem warunkującym tendencje do występowania reakcji alergicznych u psów. Głównymi alergenami będącymi powodem zmartwień właścicieli zwierząt, nie tylko w Polsce, ale również za granicą, są roztocza. Dlatego ważne jest, aby pies od najwcześniejszych chwil życia miał kontakt $\mathrm{z}$ różnymi zwierzętami oraz żeby był utrzymywany w odpowiednim środowisku, które pozwoli uodpornić układ immunologiczny, tym samym zmniejszając tendencje do występowania reakcji alergicznych.
\end{abstract}




\title{
WARTOŚĆ ODŻYWCZA WYBRANYCH PODROBÓW UZYSKANYCH OD JELENIA SZLACHETNEGO (CERVUS EPLAPHUS) UTRZYMYWANEGO W WARUNKACH FERMOWYCH
}

Nutritional value of selected offal obtained from red deer (Cervus elaphus) kept in farm conditions

\section{Paweł Janiszewski ${ }^{1}$, Agnieszka Dziedzic ${ }^{1}$, Tomasz Daszkiewicz ${ }^{1}$, Marek Bogdaszewski ${ }^{2}$, Żaneta Steiner-Bogdaszewska ${ }^{2}$}

\author{
${ }^{1}$ Uniwersytet Warmińsko-Mazurski, ul. Oczapowskiego 5, 10-719 Olsztyn \\ ${ }^{2}$ Stacja Badawcza Instytutu Parazytologii PAN w Kosewie Górnym, 11-700 Mrągowo \\ e-mail: janisz@uwm.edu.pl, kosewopan@kosewopan.pl
}

W naszym kraju mało popularne jest nie tylko spożywanie mięsa pozyskiwanego od zwierząt dzikich, ale także ich podrobów. Podczas patroszenia narządy wewnętrzne często traktowane są jako produkt uboczny, co spowodowane jest m.in. brakiem świadomości o ich przydatności technologicznej i wartości odżywczej.

W pracy została przeprowadzona analiza wybranych podrobów uzyskanych od jelenia szlachetnego $(C e-$ rvus elaphus) utrzymywanego w chowie fermowym. Wskazane zostały różnice w zawartości składników odżywczych między poszczególnymi podrobami z uwzględnieniem wieku zwierzęcia. Określono także zależność pomiędzy masą ciała jelenia a masą podrobów.

Materiały do pracy zostały zebrane na fermie jeleniowatych należącej do Stacji Badawczej IP PAN w Kosewie Górnym. Analiza fizykochemiczna została wykonana w Laboratorium Katedry Towaroznawstwa i Przetwórstwa Surowców Zwierzęcych na Wydziale Bioinżynierii Zwierząt UWM w Olsztynie. Materiał do badań pobrano od 5 cieląt oraz od 10 byków w wieku 2 lat i 3 lat. Pobrano następujące narządy: nerki, wątrobę, serce i język.

Stwierdzono, że średnia masa serca byków wynosiła $600,9 \mathrm{~g}$, a cieląt $319,8 \mathrm{~g}$. Wątroba zwierząt starszych ważyła średnio 867,4 g, a młodszych 591,6 g. Średnie masy nerek nie różniły się istotnie w obu grupach wiekowych jeleni: byki - 242,7 g, cielęta - 155,8 g. Natomiast masa języka dojrzałych osobników wynosiła 349,8 g, a niespełna rocznych cieląt o ponad połowę mniej - 170,8 g. Porównując procentowy udział narządów obu grup wiekowych, można zauważyć taki sam udział nerek w stosunku do masy ciała zwierząt $0,24 \%$. Udział innych narządów kształtował się następująco: serce byka $-0,59 \%$, cielęcia $-0,50 \%$, wątroby odpowiednio: $0,85 \%$ i $0,92 \%$ oraz języka: $0,34 \%$ i $0,27 \%$. Porównując badane grupy wiekowe pod względem składu chemicznego poszczególnych podrobów, stwierdzono, że zarówno serce byka, jak i cielęcia zawierało podobną ilość suchej masy (ok. 22,5\%), białka (19,1-19,5\%), tłuszczu (1,05-1,2\%) oraz popiołu (0,97-1,0\%). Również zawartość suchej masy, białka i związków mineralnych była podobna w wątrobach obu grup jeleni. Natomiast poziom tłuszczu w wątrobie byczej wynosił $1,5 \%$, a w przypadku cielęcej było to zaledwie $0,5 \%$. Nerki w obu grupach nie różniły się znacznie średnią zawartością suchej masy, białka, tłuszczu i popiołu. Stwierdzono, że w obu grupach wiekowych jeleni najbardziej różnił się skład chemiczny języków. Podroby te pochodzące od dojrzałych samców zawierały 40,1\% suchej masy, 12,9\% białka, 25,9\% tłuszczu oraz $0,7 \%$ popiołu, natomiast cielęce odpowiednio: $30,3 \%$ suchej masy, $22,7 \%$ białka, $14 \%$ tłuszczu i 0,8\% związków mineralnych.

Podsumowując, ze względu na zawartość białka najwyższą wartością odżywczą charakteryzuje się wątroba, zarówno byka, jak i cielęcia. Jest również bogata w związki mineralne. W związku z tym spośród analizowanych podrobów może mieć najszersze zastosowanie w przemyśle mięsnym. 


\title{
DYNAMIKA SZKÓD WYRZĄDZANYCH PRZEZ BOBRA EUROPEJSKIEGO CASTOR FIBER NA TERENIE WOJEWÓDZTWA WARMIŃSKO-MAZURSKIEGO
}

Dynamics of damage caused by the European beaver Castor fiber in the Warmian-Masurian voivodeship

\author{
Paweł Janiszewski ${ }^{1}$, Zuzanna Hermanowska ${ }^{1}$, Andrzej Gugołek ${ }^{1}$, Paweł Janczyk ${ }^{2}$ \\ ${ }^{1}$ Uniwersytet Warmińsko-Mazurski, Wydział Bioinżynierii Zwierząt, ul. Oczapowskiego 5, 10-719 Olsztyn, \\ ${ }^{2}$ Regionalna Dyrekcja Ochrony Środowiska w Olsztynie, ul. Dworcowa 60, 10-437 Olsztyn \\ e-mail: janisz@uwm.edu.pl
}

Obecność bobrów z przyrodniczego punktu widzenia wywiera pozytywny wpływ na cały ekosystem. Jednak biorąc pod uwagę wpływ bobrów na gospodarkę człowieka, działalność tych zwierząt bywa coraz bardziej problematyczna. Celem pracy było zewidencjonowanie i scharakteryzowanie szkód wyrządzonych w latach 2009-2016 przez bobra europejskiego Castor fiber na terenie województwa warmińskomazurskiego. W badaniach przeanalizowano dane pochodzące z protokołów sporządzanych podczas szacowania szkód spowodowanych działalnością bobra europejskiego na ww. terenie. Analiza ta obejmowała lata 2009-2016. Dane zostały udostępnione przez Regionalną Dyrekcję Ochrony Środowiska w Olsztynie. Zawierały informacje dotyczące: miejsca wystąpienia szkody (województwo, powiat, gmina, miejscowość, nr działki), daty zgłoszenia szkody oraz rodzaju szkód.

Stwierdzono, że ilość zgłoszeń dotyczących szkód powodowanych przez bobry do roku 2013 systematycznie wzrastała: od 640 w 2009 r. do 1807 w 2013 r. Może to sugerować wzrost ilości wyrządzanych szkód w woj. warmińsko-mazurskim bądź ewentualnie uświadomienie poszkodowanych właścicieli terenu o możliwości uzyskania odszkodowania finansowego. Natomiast w latach 2014-2016 stwierdzono spadek i stabilizację ilości zgłaszanych szkód, co z kolei może świadczyć o skuteczności wprowadzanych metod zapobiegania konfliktom między bobem a człowiekiem. W woj. warmińsko-mazurskim, jak wynika z przeprowadzonych zestawień w latach 2009-2016, największym problemem związanym ze szkodliwym działaniem bobrów na gospodarkę człowieka były zalania i podtopienia w użytkach zielonych $(52,75 \%)$. W dalszej kolejności szkody polegały na zgryzieniach i ścięciach drzew $(28,41 \%)$ oraz zalaniu drzewostanów $(12,67 \%)$. Najmniej zgłoszeń odnotowano w wyniku strat w zebranych i magazynowanych plonach $(0,03 \%)$. W rejonach wschodnich woj. warmińsko-mazurskiego zauważyć można najintensywniejsze szkody spowodowane działalnością bobrów. Uwidacznia się też tendencja spadkowa wysokości odszkodowań w kierunku rejonów zachodnich województwa. Analizując okres zgłaszania szkód, stwierdzono, że najwięcej zgłoszeń odnotowano w miesiącach wiosennych i letnich: maj (14\%), czerwiec (15\%), lipiec (14\%). W następnej kolejności szkody zgłaszane były w kwietniu (10\%), sierpniu (9\%) oraz wrześniu (9\%). W październiku i listopadzie zaobserwowano spadek ilości zgłaszanych szkód.

Uzyskane informacje mogą być wykorzystane praktycznie podczas planowania metod, terminu i miejsca zastosowania środków zapobiegających powstawaniu szkód wyrządzonych przez bobry. 


\title{
JAKOŚĆ MIĘSA BYKÓW DANIELA EUROPEJSKIEGO (DAMA DAMA) Z OBWODU ŁOWIECKIEGO W ZACHODNIEJ POLSCE
}

The quality of venison of fallow deer (Dama dama) bucks from hunting area in northern Poland

\author{
Agnieszka Ludwiczak ${ }^{1}$, Maciej Skorupski², Piotr Ślósarz ${ }^{1}$, Marta Bykowska ${ }^{1}$, \\ Joanna Składanowska-Baryza ${ }^{1}$, Łukasz Stańczak ${ }^{2}$, Małgorzata Krokowska-Paluszak ${ }^{2}$, \\ Łukasz Sikora ${ }^{1}$, Marek Stanisz ${ }^{1}$
}

\footnotetext{
${ }^{1}$ Uniwersytet Przyrodniczy w Poznaniu, Katedra Hodowli Zwierząt i Oceny Surowców, Złotniki, ul. Słoneczna 1, 62-002 Suchy Las

${ }^{2}$ Uniwersytet Przyrodniczy w Poznaniu, Katedra Łowiectwa i Ochrony Lasu, ul. Wojska Polskiego 28, 60-637 Poznań e-mail: agnieszka.ludwiczak@up.poznan.pl
}

Cechy fizykochemiczne mięsa pochodzącego od zwierząt łownych uwarunkowane są szeregiem czynników genetycznych i środowiskowych. Charakterystyczną cechą dziczyzny jest ciemna barwa, a najważniejszymi czynnikami decydującymi o barwie tkanki mięśniowej są: pH, zawartość oraz forma chemiczna mioglobiny, zawartość wody całkowitej i poszczególnych jej frakcji oraz udział tłuszczu ekstrakcyjnego. Masa ciała zwierząt w znacznym stopniu uzależniona jest od ich wieku, ale na ich rozwój osobniczy wpływ ma wiele czynników środowiskowych. Zmienność dostępności pożywienia, uwarunkowana biologicznym cyklem przyrody, wpływa na przyrosty masy ciała i kondycję zwierząt, może więc także oddziaływać na fizykochemiczne właściwości tkanki mięśniowej. Materiał badawczy stanowiły mięśnie longissimus et lumborum (LTL) z 19 tusz pochodzących od łań daniela europejskiego (Dama dama) odstrzelonych przez myśliwych w lasach zachodniej Polski. Wiek zwierząt wynosił w przybliżeniu 24 miesiące. Odłów zwierzyny miał miejsce w dwóch okresach sezonu łowieckiego 2017-2018: w lipcu pozyskano 9 łań (grupa 1), w grudniu pozostałe 10 (grupa 2). Po odstrzale dokonano pomiaru poubojowej masy ciała. Mięśnie do badań pobrano po 24-godzinnym schłodzeniu tusz. Przeprowadzone analizy fizykochemiczne obejmowały pomiar $\mathrm{pH}$, barwy $\left(\mathrm{L}^{*}, \mathrm{a}^{*}, \mathrm{~b}^{*}, \mathrm{C}^{*}, \mathrm{~h}^{\mathrm{o}}\right)$, udziału wody wolnej metodą ucisku $(\%)$ oraz podstawowego składu chemicznego. Pozyskane dane poddano analizie wariancji w celu oceny wpływu okresu odstrzału (letni i zimowy) na cechy jakościowe mięsa danieli oraz obliczono współczynniki korelacji pomiędzy cechami fizykochemicznymi mięsa. Łanie pozyskane w lipcu ważyły średnio $41,9 \mathrm{~kg}$, i nie różniły się istotnie poubojową masą ciała od tych z odstrzału zimowego, o masie 40,9 kg. Wartość pH mięsa zwierząt z grupy 1 była wyższa od pH mięsa grupy 2 (5,7 vs. do 5,5, $\mathrm{P} \leq 0,01)$. Mięso danieli z grupy 1 charakteryzowało się także wyższą zawartością wody wolnej $(32,9 \%$ vs. $22,8 \%, \mathrm{P} \leq 0,01)$ oraz wody całkowitej $(75,5 \%$ vs. $74,9 \%, \mathrm{P} \leq 0,01)$ od mięsa danieli z grupy 2. Stwierdzono także wpływ okresu odstrzału na różnice barwy mięsa. Mięso zwierząt $\mathrm{z}$ odstrzału zimowego było jaśniejsze od mięsa tych $\mathrm{z}$ odstrzału letniego $\left(\mathrm{L}^{*}=44,1\right.$ vs. $\mathrm{L}^{*}=36,0$, $\mathrm{P} \leq 0,01$ ), charakteryzowało się także niższą wartością a* i wyższym parametrem $\mathrm{b}^{*}$ (odpowiednio o 3,2 i 1,5 jedn., $\mathrm{P} \leq 0,01$ i $\mathrm{P} \leq 0,05)$. Okres pozyskania zwierząt miał także znaczący wpływ na odcień barwy $\left(\mathrm{h}^{\mathrm{o}}\right)$, który w grupie 1 wynosił 23,8, a w grupie 2 był o 17,0 jedn. wyższy $(\mathrm{P} \leq 0,01)$. Zawartość tłuszczu ekstrahowanego była znacznie mniejsza w mięsie łań pozyskanych w lipcu niż w grudniu $(0,4 \%$ vs. 0,9\%, $\mathrm{P} \leq 0,01)$. Wartość $\mathrm{pH}$ zmierzona po 24 godzinach po uboju w LTL była skorelowana $\mathrm{z} \mathrm{L}^{*}(-0,512$, $\mathrm{P} \leq 0,05)$ oraz udziałem wody wolnej $(0,714, \mathrm{P} \leq 0,001)$. Stwierdzono także silne, ujemne zależności pomiędzy udziałem wody wolnej a $\mathrm{L}^{*}(-0,898, \mathrm{P} \leq 0,001) \mathrm{i}^{\mathrm{o}}(-0,948, \mathrm{P} \leq 0,001)$ oraz pomiędzy udziałem wody wolnej a zawartością tłuszczu ekstrahowanego $(-0,896, \mathrm{P} \leq 0,001)$. Tłuszcz ekstrahowany był także ujemnie skorelowany $\mathrm{z} \mathrm{a}^{*}(-0.601, \mathrm{P} \leq 0,01)$ oraz dodatnio $\mathrm{z} \mathrm{L}^{*}(0,797, \mathrm{P} \leq 0,001)$.

Podsumowując, badanie jakości mięsa danieli odstrzelonych przez myśliwych w lasach zachodniej Polski wykazało zróżnicowanie cech fizykochemicznych mięsa w zależności od okresu odstrzału. Ze względu na powyższe można wnioskować o zróżnicowanej jakości technologicznej mięsa danieli wolno żyjących, zależnie od miesiąca pozyskania zwierząt w obwodzie łowieckim. 


\title{
MIKO CZARNY (CALLIMICO GOELDII) - BEHAWIOR OKRESU OKOŁOPORODOWEGO
}

Periparturient behaviour of goeldi's marmoset (Callimico goeldii)

\author{
Jacek Nowicki ${ }^{1}$, Olga Szeleszczuk ${ }^{2}$, Karolina Palka $^{3}$ \\ ${ }^{1}$ Uniwersytet Rolniczy w Krakowie, Zakład Hodowli Trzody Chlewnej i Drobnego Inwentarza, \\ Al. Mickiewicza 24/28, 30-059 Kraków \\ ${ }^{2}$ Uniwersytet Rolniczy w Krakowie, Zakład Anatomii Zwierząt \\ ${ }^{3}$ Śląski Ogród Zoologiczny w Chorzowie \\ e-mail: j.nowicki@urk.edu.pl
}

Miko czarny występuje w południowej Kolumbii, zachodniej Brazylii, wschodnim Peru i północnej Boliwii. Gatunek ten zagrożony jest wyginięciem z powodu utraty siedlisk. Grupy miko czarnego opuszczają swoje rodzime terytoria, poszukując nowych, przede wszystkim przez wycinanie lasów przez człowieka. Wobec tego niezbędna stała się ochrona i rozmnażanie tych cennych zwierząt w ogrodach zoologicznych. Aby działania te były w pełni skuteczne, istotne jest poznanie wszystkich aspektów życia gatunku. Dlatego celem pracy było stworzenie dziennych profili behawioralnych samicy miko czarnego (Callimico goeldii) w okresie okołoporodowym (3 doby), w szczególności uwzględniając jej interakcje w stadzie w warunkach ogrodu zoologicznego. Obserwacje prowadzono w marcu 2016 r. w Śląskim Ogrodzie Zoologicznym w Chorzowie. Monitorowano całodobowo zachowania grupy rodzinnej składającej się z: samicy, samca oraz ich 7 młodych. Obserwacje prowadzono przy pomocy 2 kamer przemysłowych i cyfrowego rejestratora. Obserwacje rozpoczęto od doby porodu. Od godziny 00:00 do 6:00 rano obserwowano ciągły sen samicy. Wspólnie z innymi osobnikami. Interakcje samicy z innymi członkami stada $\mathrm{w}$ godzinach porannych były krótkie i polegały na tym, że samica próbowała iskać innych członków stada. Około godziny 11:00 interakcje z członkami stada wydłużyły się gwałtownie - samica była iskana przez inne osobniki, przewracając się na plecy. Większość czasu odpoczywała, przechodząc tylko czasem w inne miejsce. Od godziny 19 samica poruszała się w kółko, była niespokojna. Prawdopodobnie w tym momencie zaczęła się akcja porodowa. Samica zachowywała się w ten sposób do godziny 19:12. Następnie małpa odpoczywała wraz z grupą, do godziny 22:40, kiedy zaobserwowano jej przejście na półkę znajdującą się pod listwą promiennikową. Od tej pory, aż do zakończenia pierwszej doby obserwacji, zauważono wzmożone czyszczenie się samiczki. Samica często zwijała się, sięgając do okolic podbrzusza. Przypuszczalnie młode najpierw znajdowało się na brzuchu matki, a w takiej pozycji nie jest możliwe stwierdzenie jego obecności i można jedynie przypuszczać, analizując zachowanie matki, że młode się urodziło. W tym dniu na odpoczynek poświęciła ona $37 \%$ czasu doby, sen stanowił $36 \%$ doby, czyszczenie się 5\%, czuwanie zajęło jej $4 \%$, interakcje ze stadem $12 \%$, jedzenie zaledwie 3\% czasu, a przemieszczanie się kolejne 3\% czasu doby. Następnego dnia około godziny 4 rano, gdy samica się przemieszczała po półce, po raz pierwszy zauważono mały czarny kształt na jej plecach. Można więc stwierdzić, że młode przemieściło się na plecy matki. Interakcje polegały na tym, że każdy członek stada wąchał noworodka i przypatrywał się mu znajdującemu się na plecach matki. Samica pozwalała na takie zachowania. Po godzinie 7:00 samica czyściła się już z mniejszą częstotliwością. Widać było jej zdenerwowanie, kiedy inni członkowie stada chcieli iskać młode znajdujące się na plecach. Samica często odganiała ich lub odchodziła w inną część pomieszczenia. Około godziny 18:00 zaobserwowano, że samica pozwalała się już dotykać praktycznie wszystkim osobnikom i iskać swoje młode. Samica mniej czasu spędziła na odpoczynku niż w poprzedniej dobie, bo zaledwie 29\%. Sen zajął jej o $7 \%$ mniej czasu, natomiast czas czyszczenia się nie uległ zmianie. Wydłużył się czas interakcji w stadzie aż o 5\%, przypuszczalnie dzięki pojawieniu się nowego potomka. Aktywność ruchowa samicy wzrosła także o 5\%.

Czuwanie wynosiło $7 \%$, a czas spędzony na jedzeniu $2 \%$ czasu doby. W trzeciej dobie obserwacji wydłużył się czas spędzany na odpoczynku i śnie, odpowiednio do 35 i 38\% czasu doby. 


\section{CHARAKTERYSTYKA PRZYPADKÓW ZWIERZĄT TRAFIAJĄCYCH DO OŚRODKA REHABILITACJI ZWIERZĄT „MARYSIEŃKA”, LASY MIEJSKIE - WARSZAWA}

Characteristics of animals which are referred to the Animal Rehabilitation Center "Marysieńka",
City Forests - Warsaw

Ewa Pacholik, Krzysztof Głowacz, Alicja Abramowicz

Szkoła Główna Gospodarstwa Wiejskiego w Warszawie,

Zakład Higieny i Dobrostanu Zwierząt, ul. Ciszewskiego 8, 02-786 Warszawa

e-mail: krzysztof_glowacz@sggw.pl

Ośrodek Rehabilitacji Zwierząt „Marysieńka” pełni ważną rolę w udzielaniu pomocy dziko żyjącym ssakom, których stan nie pozwala na przeżycie w środowisku naturalnym. Ze względu na zwiększającą się liczbę konfliktów do jakich dochodzi między społeczeństwem a zwierzętami dzikimi, żyjącymi na terenie miasta, ośrodek pełni istotną rolę $\mathrm{w}$ przeprowadzeniu opieki i rekonwalescencji oraz pomaga powrócić tym zwierzętom do ich naturalnego środowiska, przez co przyczynia się do ochrony bioróżnorodności.

Materiał został opracowany na podstawie kart pacjentów oraz ewidencji zwierząt, a także na podstawie danych opublikowanych przez Straż Miejską miasta stołecznego Warszawy. Do warszawskiego Ośrodka Rehabilitacji trafia najwięcej jeży (Erinaceus), w latach 2008-2017 było ich 1509, ssaków z rzędu nietoperzy (Chiroptera) - 1479 oraz wiewiórek pospolitych (Sciurus vulgaris) - 824 osobniki. Dosyć często do placówki trafiają dziki (Sus scorfa) - 310 osobników, sarny europejskie (Caprelous caprelous) - 306 osobników, zające szaraki (Lepus europaeus) - 199 osobników oraz lisy (Vulpes vulpes) - 182. Na tej podstawie można stwierdzić, że do Ośrodka najczęściej przyjmowane są małe ssaki, a także dziki i ssaki kopytne. Do placówki przyjmowane są również małe drapieżniki - lis pospolity, zwierzęta z rodziny łasicowatych (kuna domowa, kuna leśna, tchórz zwyczajny, gronostaj, norka europejska, wydra, łasica łaska) i borsuk. $\mathrm{Z}$ dużych drapieżników tylko raz został przywieziony wilk szary (Canis lupus) wymagający rehabilitacji, który po opatrzeniu i ustabilizowaniu stanu został przewieziony do Ośrodka Rehabilitacji Zwierząt w Olsztynku. Do Ośrodka trafiają także przedstawiciele gatunków niewystępujących naturalnie w Polsce: afrykański jeż pigmejski (Atelerix albiventris) przywieziony do Ośrodka raz w 2016 r., raz w 2017 r. czy kuc (Equus caballus), który znalazł się w Ośrodku w 2016 r. Częściej można spotkać jenota azjatyckiego (Nyctereutes procyonoides), gatunek inwazyjny, który już na stałe zamieszkał w Polskich lasach. Przyjmowanie zwierząt zbiegłych z niewoli (jeż pigmejski, kuc) nie jest statutowym zadaniem Ośrodka, jednak z racji tego, że w granicach miasta stołecznego Warszawy oraz w jego okolicach nie ma innych placówek, do których mogłyby zostać przyjęte, są przywożone do Ośrodka. 


\title{
ANALIZA TEMPA WZROSTU SZCZENIĄT RAS SPANIELI
}

\author{
Analysis of growth rate of spaniel puppies

\begin{abstract}
Magdalena Pieszka, Patrycja Kuś, Jarosław Łuszczyński, Bogusława Długosz, Romana Augustyn, Monika Stefaniuk-Szmukier, Zenon Podstawski
\end{abstract} \\ Uniwersytet Rolniczy im. Hugona Kołłątaja w Krakowie, Instytut Nauk o Zwierzętach, \\ Zakład Hodowli Koni, al. Mickiewicza 24/28, 30-059 Kraków \\ e-mail:mpieszka@ar.krakow.pl
}

Urodzeniowa masa ciała szczeniąt jest bardzo ważnym czynnikiem, który niejednokrotnie decyduje o przeżyciu noworodków. Osobniki o niskim parametrze narażone są na hipotermię oraz hipoglikemię. Mniejsze zwierzęta przegrywają również w momencie rywalizacji o dostęp do sutków matki. Wraz z siarą, dzięki której uzyskują odporność bierną, dostarczane są składniki odżywcze oraz energia niezbędna do spełnienia podstawowych funkcji życiowych. Bardzo ważnym zadaniem hodowcy jest monitorowanie dziennego przyrostu osesków poprzez ważenie. Dopuszczalna jest 10-procentowa utrata masy urodzeniowej w ciągu pierwszej doby życia, natomiast ok. 10 dnia życia masa urodzeniowa powinna się podwoić. Celem pracy była analiza tempa wzrostu masy ciała szczeniąt wybranych ras spanieli w okresie przebywania przy matce w zależności od wieku matki, wieku ojca, liczebności miotu oraz płci osobników.

Informacje nt. masy ciała szczeniąt zostały zaczerpnięte z profesjonalnych hodowli psów wyżej wymienionych ras. Pomiary mas ciała wykonywane były przez hodowców w odstępach siedmiodniowych przez okres pierwszych 28 dni życia. Badaniami objęto łącznie 234 szczenięta (35 szczeniąt pochodzących z 5 miotów clumber spanieli, 110 osesków pochodzących z 16 miotów springer spanieli angielskich, 89 noworodków pochodzących z 15 miotów cocker spanieli angielskich). Następnie przeanalizowano wpływ wieku matki, wieku ojca, liczebności miotu oraz płci na masę ciała szczeniąt w poszczególnych etapach życia oraz na tempo wzrostu tego parametru w ciągu pierwszych 28 dni życia. Przeprowadzona analiza wykazała, że największą urodzeniową masą ciała charakteryzowały się szczenięta clumber spanieli - 392,8 g, a najmniejszą szczenięta cocker spanieli angielskich - 299,3 g, co stanowiło zarówno w jednym, jak i drugim przypadku 1,4\% masy ciała dorosłej nieszczennej suki. Masa urodzeniowa szczeniąt springer spanieli angielskich wynosiła 387,1 g, co stanowiło 2,15\% masy ciała nieszczennej, dorosłej suki. Analiza dynamiki zmian masy ciała szczeniąt wybranych ras spanieli w zależności od wieku suki-matki nie wykazała jednoznacznej zależności. Najczęściej większą masą ciała charakteryzowały się szczenięta pochodzące od suk 5-letnich $\mathrm{z}$ wyjątkiem springer spanieli. Analiza dynamiki zmian masy ciała szczeniąt w zależności od wieku ojca wykazała, że w przypadku badanych ras największą masę ciała osiągają szczenięta po ojcach młodszych, 2-, 3- i 4-letnich. Analiza dynamiki zmian masy ciała szczeniąt ze względu na liczebność miotu nie wykazała jednoznacznej tendencji. Na podstawie przeprowadzonych analiz uwzględniających płeć szczeniąt stwierdzono, że pieski charakteryzowały się większą masą ciała od suczek w niemal każdym badanym okresie. W ciągu pierwszych 28 dni życia najwyższym tempem wzrostu charakteryzowały się szczenięta rasy clumber spaniel $-138,6 \%$, a najniższym springer spanieli angielskich $-113,1 \%$. Tempo wzrostu cocker spanieli angielskich wynosiło $122,8 \%$. Analiza wykazała, że suczki badanych ras charakteryzowały się większym tempem wzrostu niż pieski. Analiza wpływu liczebności miotu oraz wieku matki na tempo wzrostu szczeniąt nie wykazała jednoznacznej zależności. Tempo wzrostu w zależności od wieku ojca nieznacznie malało $\mathrm{z}$ wiekiem reproduktorów.

Badania zostały sfinansowane z dotacji przyznanej przez MNiSW na działalność statutową DS 3257/ZHK/2018. 


\title{
PORÓWNANIE EFEKTYWNOŚCI ZESTAWU 18 STR I 21 STR W CELU PRZEPROWADZANIA BADAŃ KRYMINALISTYCZNYCH Z UDZIAŁEM PSÓW
}

Comparison of the effectiveness of 18 STR and 21 STR panels for forensic DNA analysis of canine

\author{
Anna Radko, Angelika Podbielska, Małgorzata Miszczak
} Instytut Zootechniki - Państwowy Instytut Badawczy, Zakład Biologii Molekularnej Zwierząt, ul. Krakowska 32-083 Balice
e-mail: anna.radko@izoo.krakow.pl

Profilowanie DNA u psów, wykorzystywane rutynowo w ramach kontroli rodowodów, coraz częściej znajduje zastosowanie w badaniach kryminalistycznych.

W prezentowanej pracy porównano przydatność do badań identyfikacyjnych zestawu 18-STR (AHTk211, CXX279, REN169O18, INU055, REN54P11, INRA21, AHT137, REN169D01, AHTh260, AHTk253, INU005, INU030, FH2848, AHT121, FH2054, REN162C04, AHTh171, REN247M23) oraz zestawu 21-STR - zawierającego 3 dodatkowe markery (AHTH130, REN64E19, REN247M23) rekomendowane przez ISAG do badań identyfikacyjnych psów.

Badania przeprowadzono na podstawie danych pochodzących od losowo wybranych 452 psów 9 ras (labrador retriever, golden retriever, owczarek podhalański, owczarek niemiecki, wilczarz irlandzki, yorkshire terrier, yorkshire terrier biewer, buldog francuski, maltańczyk). W celu porównania efektywności badanych zestawów STR dla każdego panelu oszacowano kumulatywne prawdopodobieństwo wykluczenia, w przypadkach gdy znany jest genotyp jednego z rodziców $\left(\mathrm{CPE}_{1}\right)$ i obu rodziców $\left(\mathrm{CPE}_{2}\right)$, siłę dyskryminacji (CPD), teoretyczne prawdopodobieństwo identyczności $\left(\mathrm{CP}_{\mathrm{ID}}\right)$ oraz prawdopodobieństwo przypadkowej zgodności - RMP.

Wyliczone prawdopodobieństwo wykluczenia $\mathrm{CPE}_{1}$ i $\mathrm{CPE}_{2}$ dla 18 loci STR wyniosło odpowiednio 0,9998806 i 0,99999976, a dla 21 loci - 0,9999829 i 0,9999999901. CPD wyliczona dla każdego markera osiągnęła wartości powyżej 0,85 , natomiast łączna wartość siły dyskryminacji dla obu paneli była bliska 1.0. Oszacowane prawdopodobieństwo $\mathrm{CP}_{\mathrm{ID} \text { (theoretical) }}$ dla 18 markerów było na poziomie $4,02 \times 10^{-20}$, a dla 21 markerów $-6,42 \times 10^{-24}$. Przeprowadzono również ocenę praktycznego zastosowania badanych zestawów STR poprzez wyliczenie prawdopodobieństwa przypadkowej zgodności - RMP $\mathrm{w}$ trakcie analizy profilu DNA pozyskanego z próbek materiału dowodowego dostarczonego przez policję $\mathrm{w}$ sprawie karnej $\mathrm{z}$ udziałem psów. Otrzymane prawdopodobieństwo, że przypadkowy pies w populacji będzie miał taki sam profil DNA jak uzyskany w dowodowej próbce, wyniosło $2.85 \times 10^{-22}$ i $1.73 \times 10^{-26}$, odpowiednio dla 18 i 21 STR. 


\title{
WIELKOŚĆ „KOŚCI ŚW. HUBERTA” W SERCACH JELENI I DANIELI FERMOWYCH - WYNIKI WSTĘPNE
}

The size of „,bones of Saint Hubert” in the hearts of farmed red and fallow deer - preliminary results

\author{
Joanna Sadowska, Jagoda Czajkowska, Izabella Czaplejewicz, Anna Baranowska, Paweł Pietuszko \\ Uniwersytet Warmińsko-Mazurski w Olsztynie, Studenckie Naukowe Koło Hodowców Zwierząt Łownych „Hubertus” \\ e-mail: izabellaczaplejewiecz@gmail.com
}

W dzisiejszych czasach najbardziej pożądanym trofeum ze zwierzyny płowej jest poroże samca. W średniowiecznej Polsce często poszukiwano w sercu zwierzęcia specyficznej kości, przyjmującej u dorosłych osobników kształt krzyża (os cordis), przez co nadano jej gwarową nazwę kostki św. Huberta, hubertki lub hubertówki. Obecnie w naszym kraju nie jest to powszechnie znane trofeum łowieckie, natomiast w innych krajach europejskich (np. Czechy, Niemcy) myśliwi tradycyjnie pobierają je i eksponują. W fachowej literaturze łowieckiej, zarówno krajowej, jak i zagranicznej, informacje na temat „kości św. Huberta” u jeleniowatych są znikome. Celem badań było scharakteryzowanie wielkości kości sercowych os cordis pozyskanych z serc jeleni i danieli pochodzących z chowu fermowego. Materiał do badań pochodził z fermy jeleniowatych Stacji Badawczej IP PAN w Kosewie Górnym. Serca uzyskano w trakcie ubojów przeprowadzonych w grudniu 2017 (daniele) i styczniu 2018 roku (jelenie). Wykorzystano materiał pochodzący od 18 cieląt jeleni płci męskiej oraz od łącznie 12 samców jeleni w wieku 2-3 lat. W przypadku danieli serca uzyskano od 32 byków będących wieku 2-3 lat. Po dokładnym usunięciu tkanki mięśniowej z kostki zważono kostkę oraz wykonano pomiary. Analizowano masę serca, masę kostki oraz jej wymiary: długość, szerokość i grubość oraz określono zależności pomiędzy wybranymi cechami.

W trakcie badań wykazano, że kostka występowała w sercu u $28 \%$ cieląt i u $50 \%$ byków jeleni. W przypadku samców danieli stwierdzono ją aż u 94\% analizowanych osobników. Średnia masa kostki w przypadku jeleni wyniosła: cielęta $-0,05 \mathrm{~g}$, byki $-0,08 \mathrm{~g}$, natomiast u samców danieli $-0,13 \mathrm{~g}$, przy średniej masie serca wynoszącej odpowiednio: 357,9 g, 615,5 g oraz 287,3 g. Współczynnik korelacji pomiędzy tymi cechami wynosił: -0,702 (cielęta jelenia), 0,283 (byki jelenia), 0,602 (byki danieli). Kość z serca byków danieli poza największą masą charakteryzowała się także największą długością - 17,10 mm, szerokością $7,57 \mathrm{~mm}$ i grubością - 2,94 mm. W przypadku równowiekowych samców jeleni wartości te były następujące: długość - 12,9 mm, szerokość - 6,68 mm i grubość - 2,53 mm. Natomiast u cieląt jeleni cechy te wyniosły odpowiednio: $6,06 \mathrm{~mm}, 4,56 \mathrm{~mm}$ i $2,36 \mathrm{~mm}$.

$\mathrm{Na}$ podstawie powyższych badań można wyciągnąć wstępne wnioski, że podstawowym czynnikiem wpływającym na wielkość kości sercowej jest gatunek zwierzęcia, a nie masa serca. Należy zaznaczyć, że powyższe badania będą kontynuowane $\mathrm{z}$ uwzględnieniem osobników innych gatunków (sarna europejska i muflon), płci oraz środowiska bytowania (ferma i łowiska naturalne). 


\title{
SEZONOWE ZMIANY STĘŻENIA KORTYZOLU WE KRWI DANIELI EUROPEJSKICH (DAMA DAMA) UTRZYMYWANYCH W WARUNKACH FERMOWYCH
}

\author{
The seasonal changes of cortisol level in blood of farmed fallow deer (Dama dama)
}

\section{Żaneta Steiner-Bogdaszewska ${ }^{1}$, Katarzyna Tajchman ${ }^{2}$, Paweł Bogdaszewski ${ }^{1}$, Marek Bogdaszewski ${ }^{1}$}

\author{
${ }^{1}$ Instytut Parazytologii PAN, Stacja Badawcza w Kosewie Górnym \\ ${ }^{2}$ Uniwersytet Przyrodniczy w Lublinie, Katedra Etologii i Dobrostanu Zwierząt, Zakład Hodowli Zwierząt Dzikich \\ e-mail: kosewopan@kosewopan.pl
}

Bekowisko, czyli okres godowy daniela europejskiego (Dama dama), rozpoczyna się na początku października i charakteryzuje się wzmożoną pobudliwością samców. Podczas wykonywania jesiennych zabiegów zootechnicznych w warunkach fermowych ze względu zarówno na bezpieczeństwo pracowników, jak i zwierząt termin prac ustala się możliwie jak najwcześniej. Równocześnie nie jest możliwe prowadzenie zabiegów na zwierzętach, u których proces wycierania poroża nie zakończył się. Im bardziej w tym okresie zwierzęta są poddane czynnikom stresującym, tym bardziej są pobudzone i istnieje większe ryzyko wzajemnych urazów, szczególnie niebezpiecznych u szpicaków.

Celem pracy było określenie stężenia kortyzolu w surowicy krwi u samców daniela europejskiego w trakcie wzrostu pierwszego poroża, tj. od 11. do 15. miesiąca życia. Doświadczenie przeprowadzono w okresie od 10.05.2017 r. do 20.09.2017 r. w Stacji Badawczej Instytutu Parazytologii Polskiej Akademii Nauk w Kosewie Górnym, w woj. warmińsko-mazurskim. Grupą badawczą było dziewięć samców daniela europejskiego w jednorodnej grupie wiekowej. Grupa badawcza była zróżnicowana pod względem masy ciała, znajdowały się w niej zarówno osobniki słabsze i silniejsze. Byki daniela były przyzwyczajone do obecności człowieka i rutynowych prac zootechnicznych ponieważ przed okresem pastwiskowym przebywały w zadaszonych zimowych pomieszczeniach, w codziennym bliskim kontakcie z obsługą. W trakcie trwania doświadczenia od osobników z grupy badawczej została pobrana krew dwukrotnie, na początku okresu pastwiskowego oraz na końcu. W tym samym czasie zwierzęta zostały również zważone, jesienią zmierzono także długość ich poroża. Stężenie kortyzolu zostało określone przy pomocy chemiluminescencyjnego testu immunoenzymatycznego IMMULITE ${ }^{\circledR} 2000$ Cortisol (BioMaxima, Lublin, Poland).

Średnie stężenie kortyzolu w maju wyniosło $3,29 \pm 1,60 \mathrm{ug} / \mathrm{dl}$, natomiast średnia masa ciała $32,11 \pm 1,92 \mathrm{~kg}$. We wrześniu średnie stężenie kortyzolu było wyższe, bo na poziomie $13,34 \pm 2,61 \mathrm{ug} / \mathrm{dl}$, a średnia masa ciała 43,83 $\pm 2,32 \mathrm{~kg}$. Średnia długość pierwszego poroża wyniosła $12,11 \pm 2,01 \mathrm{~cm}$. Zaobserwowano wzrost stężenia kortyzolu pomiędzy majem a wrześniem średnio o 10,04 $\pm 3,45 \mathrm{ug} / \mathrm{dl}$.

Nie stwierdzono korelacji pomiędzy masą ciała oraz długością poroża a stężeniem kortyzolu, co może świadczyć o braku wpływu rozmiarów ciała i masy zwierzęcia na poziom jego pobudzenia. Podobny poziom pobudzenia zarówno u pozornie niegroźnych osobników o mniejszej masie ciała i krótszym porożu, jak i u większych osobników może sugerować potencjalnie równy poziom agresji, co ma znaczenie dla zachowania bezpieczeństwa podczas rutynowo wykonywanych zabiegów zootechnicznych.

Nie przesądza to jednak o trafności i możliwości uogólnień takich wniosków, gdyż warto mieć na uwadze, że jednakowo wysoki poziom kortyzolu nie musi oznaczać manifestacji tych samych zachowań. Stwierdzono słabą korelację ujemną pomiędzy stężeniem kortyzolu pomiędzy majem a wrześniem $(\mathrm{R}=-0,31)$, jednak niezbędna jest pełna analiza statystyczna wyników uzyskanych na liczniejszej grupie zwierząt.

Przeprowadzone badania są wstępem do dalszej analizy sezonowych zmian stężenia kortyzolu we krwi danieli fermowych. Konieczne jest uzupełnienie badań na liczniejszej grupie zwierząt w różnym wieku. Ponadto należy zwiększyć częstotliwość oznaczania kortyzolu, np. raz w tygodniu, w miarę zbliżania się okresu godowego. 


\title{
ZASTOSOWANIE METODY RZUCANIA PIŁKI PRZED PSEM W NAUCE BIEGANIA NA KOMENDĘ
}

Application of the ball-throwing in front of the dog method in learning to run on command

\author{
Janusz Strychalski ${ }^{1}$, Andrzej Gugołek ${ }^{1}$, Aleksandra Reksa ${ }^{2}$, Aleksandra Kujtkowska ${ }^{2}$, \\ Aleksandra Felke ${ }^{2}$, Piotr Dworak ${ }^{3}$

\footnotetext{
${ }^{1}$ Uniwersytet Warmińsko-Mazurski, Katedra Hodowli Zwierząt Futerkowych i Łowiectwa, ul. Oczapowskiego 5, 10-719 Olsztyn

${ }^{2}$ Studenckie Koło Naukowe Miłośników Psów Użytkowych

${ }^{3}$ Centrum Szkolenia Psów - Wychowany Pies, 10-900 Olsztyn

e-mail: janusz.strychalski@uwm.edu.pl
}

Spośród dyscyplin posłuszeństwa psów najbardziej znanymi w Polsce są: PT (Pies Towarzyszący), BH (Begleithundprüfung), IPO (Internationale Prüfung Ordnung), Rally-o (Rally-obedience) i Obedience. Regulamin Egzaminów i Zawodów Psów Towarzyszących 1, 2, 3 stopnia określa, że jednym z zadań psa w PT1 jest bieganie na komendę zakończone przywołaniem. Na polecenie sędziego przewodnik zaczyna maszerować z psem przy nodze, bez smyczy. Po około 10 krokach daje komendę do odbiegnięcia - pies powinien oddalić się na odległość co najmniej 5 kroków. Przewodnik może wskazać kierunek ręką. Po odbiegnięciu psa, po kilku sekundach na komendę do przywołania pies ma za zadanie wrócić do przewodnika. Istnieje wiele metod nauki psa odbiegania na komendę, takich jak np. ,targetowanie” czy nauka biegania psa do tzw. granicy. Celem niniejszej pracy była weryfikacja skuteczności metody rzucania małej piłki przed psem w nauce biegania na komendę.

W doświadczeniu wzięło udział 10 psów różnych ras oraz mieszańców międzyrasowych, w różnym wieku i różnej płci. Wszystkie psy były wcześniej nauczone gonić i łapać piłkę oraz przynosić ją przewodnikowi. Każdemu psu jego przewodnik rzucał piłkę, która spadała zawsze przed psem - 40 powtórzeń dziennie, w różnych odstępach czasu. Po 20 powtórzeniach przewodnik dodawał do wyrzutu piłki komendę „,biegaj”, a wyrzucenie piłki opóźniał o około 1 sekundę. Jednocześnie co 15 powtórzeń po komendzie „biegaj” nie następowało wyrzucenie piłki, lecz po kilku sekundach przewodnik wydawał komendę na przywołanie psa, a po przybiegnięciu psa kontynuował wydawanie komendy „biegaj” i wyrzucanie piłki. Po 120 powtórzeniach (czyli po trzech dniach od rozpoczęcia nauki biegania na komendę) niezależny obserwator (właściciel szkoły dla psów) ocenił wykonanie ćwiczenia przez każdego psa, przyznając mu jedną z ocen: doskonała, bardzo dobra, dobra, dostateczna, niedostateczna. Wyniki ocen zamieszczono w tabeli 1.

Tabela 1. Oceny psów za ćwiczenie biegania na komendę

\begin{tabular}{|c|c|}
\hline Liczba psów & Ocena \\
\hline 7 & doskonała \\
\hline 2 & bardzo dobra \\
\hline 1 & dobra \\
\hline
\end{tabular}

Uzyskane wyniki wskazują, że zastosowana metoda jest bardzo skuteczna w nauce biegania psa na komendę. Może być z powodzeniem użyta podczas przygotowywania psa do egzaminu PT1. 


\title{
SKUTECZNA METODA NAUKI PSA „SIADU W MARSZU”
}

An effective method of learning a dog "sit in a walk"

\author{
Janusz Strychalski ${ }^{1}$, Magdalena Łęczycka ${ }^{2}$, Marta Dulis ${ }^{3}$, Marta Borowska $^{3}$, Agata Pazyra $^{3}$ \\ ${ }^{1}$ Uniwersytet Warmińsko-Mazurski, Katedra Hodowli Zwierząt Futerkowych i Łowiectwa, ul. Oczapowskiego 5, 10-719 Olsztyn \\ ${ }^{2}$ Szkoła dla Psów Team Spirit Magdalena Łęczycka, 87-100 Toruń \\ ${ }^{3}$ Studenckie Koło Naukowe Miłośników Psów Użytkowych \\ e-mail: janusz.strychalski@uwm.edu.pl
}

Obedience (posłuszeństwo) to w opinii wielu kynologów najtrudniejsza dyscyplina sportowa związana z posłuszeństwem psa. Międzynarodowy Regulamin Zawodów Obedience klas 1, 2 i 3, ustanowiony przez FCI (Fédération Cynologique Internationale - Międzynarodowa Federacja Kynologiczna) przewiduje wykonanie przez psa ćwiczenia „siad w marszu” we wszystkich klasach. Ćwiczenie polega na tym, że przewodnik z psem przy nodze idą po linii prostej tzw. normalnym krokiem. Po przejściu określonego dystansu przewodnik, nie zatrzymując się, wydaje psu komendę ,siad”, którą pies musi niezwłocznie wykonać. Przewodnik natomiast idzie dalej.

Wielu przewodników nie potrafi nauczyć swojego psa ,siadu w marszu”. W niniejszej pracy postanowiono sprawdzić skuteczność metody nauki tego zadania, którą oparto na trzech zasadach: rozpoczynania przez przewodnika marszu lewą nogą, wydawania komendy „,siad” równocześnie z postawieniem lewej nogi przewodnika na podłożu oraz podania nagrody (smakołyka) po wykonaniu ćwiczenia dokładnie w miejscu, w którym powinien zatrzymać się pies.

W badaniu wzięło udział sześć psów, różnych ras i w różnym wieku, oraz ich przewodnicy. Trzy psy stanowiły grupę kontrolną. Przewodnikom psów z tej grupy polecono, aby nauczyli swoje psy „,siadu w marszu", trenując codziennie przez 21 dni. Nie udzielono im żadnych dodatkowych wskazówek. Grupę doświadczalną stanowiły trzy inne psy, które uczono „,siadu w marszu” również przez 21 dni, z zastosowaniem trzech zasad, które podano powyżej. Po upływie 21 dni niezależny obserwator (właściciel szkoły dla psów) oceniał wykonanie ćwiczenia przez każdego psa, przyznając mu ocenę w skali 1-10 (gdzie 1 stanowiło ocenę najgorszą, a 10 najlepszą) . Wyniki ocen zamieszczono w tabeli 1.

Tabela 1. Oceny psów za ćwiczenie ,siad w marszu”

\begin{tabular}{|c|c|c|}
\hline Specyfikacja & \multicolumn{2}{|c|}{ Oceny } \\
\hline Numer psa & grupa kontrolna & grupa doświadczalna \\
\hline 1 & 2 & 6 \\
\hline 2 & 4 & 7 \\
\hline 3 & 4 & 8 \\
\hline Średnia ocen & 3,33 & 7,00 \\
\hline
\end{tabular}

Uzyskane wyniki wskazują, że podana metoda nauki ćwiczenia „siad w marszu” jest skuteczna i może być polecana do stosowania przez przewodników psów. 


\title{
WPŁYW DODATKÓW MINERALNYCH NA ZAWARTOŚĆ MAKROELEMENTÓW W WYBRANYCH TKANKACH DANIELI FERMOWYCH
}

The influence of mineral additives on the contents of macroelements in selected tissue farmed fallow deer

\author{
Katarzyna Tajchman ${ }^{1}$, Marek Bogdaszewski ${ }^{2}$, Edyta Kowalczuk-Vasilev $^{3}$, Leszek Drozd ${ }^{1}$, \\ Żaneta Steiner-Bogdaszewska ${ }^{2}$
}

\footnotetext{
${ }^{1}$ Uniwersytet Przyrodniczy w Lublinie, Katedra Etologii i Dobrostanu Zwierząt, Zakład Hodowli Zwierząt Dzikich

${ }^{2}$ Instytut Parazytologii PAN, Stacja Badawcza w Kosewie Górnym

${ }^{3}$ Uniwersytet Przyrodniczy w Lublinie, Instytut Żywienia Zwierząt i Bromatologii, Zakład Żywienia Zwierząt i Paszoznawstwa e-mail: katarzyna.tajchman@up.lublin.pl
}

Odżywianie jest jednym z trzech głównych czynników wpływających na czynności fizjologiczne, takie jak wzrost czy rozwój poroża u jeleniowatych. Kwestia właściwego karmienia jest szczególnie ważna u młodych zwierząt. Celem badań było wykazanie, czy suplementacja o zwiększonym poziomie wapnia i fosforu będzie miała korzystny wpływ na skład mineralny pierwszego poroża i kości oraz jak wpłynie na zawartość makroelementów w tkance mięśniowej i wątrobie u danieli fermowych (Dama dama). Przeprowadzone analizy statystyczne wykazały pozytywny wpływ suplementacji zwiększoną dawką wapnia i fosforu na masę ciała oraz znaczący średni dodatni współczynnik korelacji $(\mathrm{r}=0.48, \mathrm{p} \leq 0.05)$ pomiędzy poziomem wapnia a długością poroża. Ponadto wykazano silną dodatnią zależność między dawką pokarmową a zawartością sodu $\mathrm{w}$ tkance mięśniowej $(\mathrm{r}=0,67 \mathrm{i} \mathrm{r}=0,57$, odpowiednio dla $\mathrm{P}$ i Ca $\mathrm{w}$ diecie, $\mathrm{p} \leq 0.05)$ oraz bardzo silny, istotny statystycznie ( $\mathrm{r}=0,83$ i $\mathrm{r}=0,86$, odpowiednio dla $\mathrm{P}$ i Ca $\mathrm{w}$ diecie, $\mathrm{p} \leq 0.05$ ) wpływ na zawartość fosforu w wątrobie. Suplementacja wapniem i fosforem diety danieli miała bardzo silny dodatni wpływ na skład mineralny kości i poroża $(\mathrm{r} \sim 0,8-0,9)$. Zwiększenie stężenia $\mathrm{Ca}$ i $\mathrm{P}$ w diecie cieląt danieli fermowych podnosi wyraźnie stężenie makroelementów w kościach, które w przyszłości mogą stanowić rezerwuar do zakładania kolejnych poroży przez zwierzęta, co uchroni je przed okresową osteoporozą. Ponadto suplementacja może wpływać korzystnie na przyrost masy ciała zwierząt. 


\title{
WPŁYW PRZESIEDLEŃ NA STRUKTURĘ GENETYCZNĄ POPULACJI JELENIA SZLACHETNEGO (CERVUS ELAPHUS) W POLSCE
}

Effect of translocations on the genetic structure in populations of the red deer (Cervus elaphus) in Poland

\author{
Katarzyna Tajchman $^{1}$, Monika Król ${ }^{1}$, Wioletta Sawicka-Zugaj ${ }^{2}$, Monika Greguła-Kania ${ }^{3}$, \\ Leszek Drozd $^{1}$, Piotr Czyżowski ${ }^{1}$ \\ ${ }^{1}$ Uniwersytet Przyrodniczy w Lublinie, Katedra Etologii i Dobrostanu Zwierząt, Zakład Hodowli Zwierząt Dzikich \\ ${ }^{2}$ Uniwersytet Przyrodniczy w Lublinie, Instytut Hodowli Zwierząt i Ochrony Bioróżnorodności, \\ Zakład Hodowli i Ochrony Zasobów Genetycznych Bydła \\ ${ }^{3}$ Uniwersytet Przyrodniczy w Lublinie, Instytut Hodowli Zwierząt i Ochrony Bioróżnorodności, \\ Zakład Hodowli Małych Przeżuwaczy i Stacja Badawcza im. prof. T. Efnera \\ e-mail: katarzyna.tajchman@up.lublin.pl
}

Na terenie całej Europy, w tym także Polski, stosowano zabiegi przesiedleń jelenia szlachetnego (Cervus elaphus) mające na celu poprawę jakości lokalnych populacji. Zabiegi te miały charakter zasilenia miejscowych (małych) populacji dodatkowymi osobnikami, a w konsekwencji także odmiennym genotypem. Celem badań było określenie wpływu translokacji poprzez oznaczenie różnic filogenetycznych populacji jeleni z siedmiu regionów Polski: z województwa lubelskiego, warmińsko-mazurskiego, pomorskiego i zachodniopomorskiego, opolskiego i śląskiego oraz z województwa wielkopolskiego na podstawie analiz mikrosatelitarnych DNA. Analizie poddano loci: BMC1009, IDVGA55, INRA121, NVHRT48, CSSM41, BM757. W badanych populacjach średnia wartość (heterozygotyczności obserwowanej) $\mathrm{H}_{\mathrm{o}}$ była na poziomie 0,457, (heterozygotyczność oczekiwana) $\mathrm{H}_{\mathrm{e}}-0,613$, PIC (polymorphism information content) natomiast dla wszystkich grup jeleni był wyższy niż 0,500 , co wskazuje na duże zróżnicowanie genetyczne populacji jeleni w Polsce. Wartość współczynnika Wrighta $\mathrm{F}_{\mathrm{ST}}(0,17)$ była bliska średniej występującej w Europie u tego gatunku $(0,166)$. Jednak wskaźniki pokrewieństwa $\mathrm{F}_{\mathrm{IS}}$ i $\mathrm{F}_{\mathrm{IT}}$ były dosyć wysokie (odpowiednio 0,259 i 0,334), co może wskazywać na istnienie struktur wewnętrznych w poszczególnych subpopulacjach. Ponadto nie udało się wykluczyć efektu bottleneck ze względu na ujemne wartości $\mathrm{F}_{\mathrm{IS}}$ i $\mathrm{F}_{\mathrm{IT}} \mathrm{W}$ locus BMC1009 (odpowiednio $-0,260,-0,071$ ) oraz nadwyżkę $\mathrm{H}_{\mathrm{e}}$ w stosunku do $\mathrm{H}_{\mathrm{eq}}$. 


\title{
CZĘSTOTLIWOŚĆ WYSTĘPOWANIA DYSPLAZJI STAWU BIODROWEGO U PSÓW RASOWYCH
}

\author{
Frequency of hip dysplasia in breed dogs
}

Jacek Zawiślak, Natalia Chełmowska

\begin{abstract}
Uniwersytet Technologiczno-Przyrodniczy w Bydgoszczy, Zakład Hodowli Owiec, Kóz i Zwierząt Futerkowych, ul. Mazowiecka 28, 85-084 Bydgoszcz e-mail: futerka@utp.edu.pl
\end{abstract}

Psy w stanie dzikim rzadziej chorowały niż obecne, które zapadają na wiele chorób, w tym na dysplazję stawu biodrowego. Chorobę tę po raz pierwszy u psów zdiagnozowano w 1935 r. Jest jedną z najczęściej występujących u psów chorób układu kostno-stawowego. Spotykana jest częściej u psów ras olbrzymich i dużych niż u małych, u których także można ją zaobserwować. Jest to choroba dziedziczna i rozwojowa, zależna od wieku zwierzęcia i jego użytkowania.

Celem pracy była analiza częstotliwości występowania dysplazji stawu biodrowego u psów rasowych na przykładzie wybranego gabinetu weterynaryjnego w województwie kujawsko-pomorskim.

Przedmiotem badań było 27 psów różnych ras. Badano predyspozycje rasowe psów do dysplazji stawu biodrowego. Literatura podaje wiele różnych klasyfikacji dysplazji stawu biodrowego, do której zaliczane są poszczególne stadia choroby. W przeprowadzonych badaniach zastosowano następującą klasyfikacją, zgodną z dokumentacją weterynaryjną $\mathrm{w}$ analizowanym gabinecie: $\mathrm{A}$ - lekka dysplazja, B - umiarkowana dysplazja, C - ciężka dysplazja. Analizowano psy ze względu na ich płeć i wiek. Dane do badań uzyskano z wybranego gabinetu weterynaryjnego w Bydgoszczy w latach 2015-2017.

Z przeprowadzonych badań wynika, że rasą psa najczęściej chorującego na dysplazję stawów biodrowych w latach 2015-2017 był owczarek niemiecki. Z 27 psów badanej populacji aż 8 (co stanowi $30 \%)$ z nich to właśnie owczarki niemieckie, które pochodzą z I grupy według FCI. Następna grupa psów z najczęściej występującą dysplazją to grupa II, czyli pinczery, sznaucery i molosy, szwajcarskie psy górskie i psy do bydła. W tej grupie dysplazja miała miejsce u rottweilera czy berneńskiego psa pasterskiego. W obserwowanej populacji psów dysplazja często występowała także w III grupie psów, jaką stanowią teriery. Najrzadziej omawiane schorzenie zaobserwowano w grupie V, w której był tylko jeden pies rasy szpic miniaturowy. Dysplazja w omawianej populacji psów nie występowała w grupach, takich jak jamniki, psy gończe i rasy pokrewne, wyżły oraz charty. Choroba ta była diagnozowana w 70\% u psów, a tylko u 30\% suk.

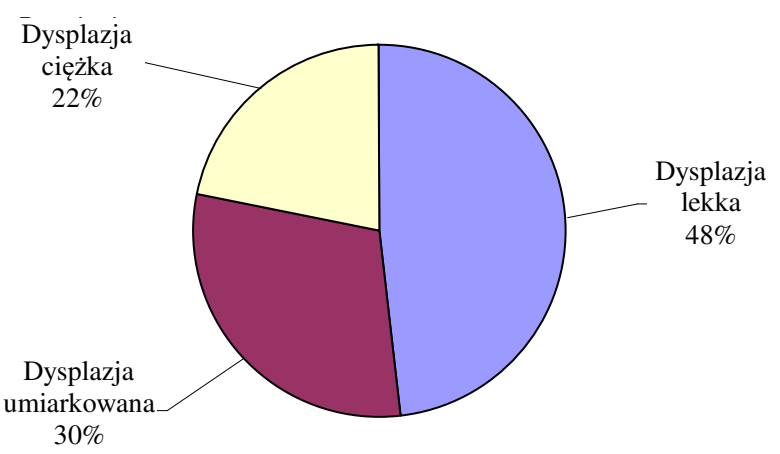

Wykres 1. Udział procentowy poszczególnych stopni dysplazji w wybranym gabinecie weterynaryjnym w latach 2015-2017 Wiek obserwowanych psów był zróżnicowany, a średnia wieku dla całej analizowanej populacji psów ze zdiagnozowaną dysplazją biodrową wynosiła 3-4 lata. Udział procentowy poszczególnych stopni dysplazji w wybranym gabinecie weterynaryjnym w latach 2015-2017 przedstawiono na wykresie 1.

Na podstawie przeprowadzonych badań można stwierdzić, że rasą najbardziej predysponowaną do dysplazji stawu biodrowego był owczarek niemiecki (I gr. wg FCI). Stwierdzono, że dysplazja stawu biodrowego częściej występowała u psów niż u suk. Zaobserwowano, że największą grupę psów (48\%) stanowiły psy z lekką dysplazją stawu biodrowego, a najmniejszą grupa psów z dysplazją ciężką (22\%). 


\title{
DYSPLAZJA STAWÓW BIODROWYCH U PSÓW
}

\author{
Hip dysplasia in dogs
}

\author{
Aleksandra Zienkiewicz, Piotr Baranowski, Katarzyna Pęzińska-Kijak \\ Zachodniopomorski Uniwersytet Technologiczny w Szczecinie, Pracownia Anatomii Zwierząt, \\ ul. Doktora Judyma 14, 71-466 Szczecin \\ e-mail: piotr.baranowski@zut.edu.pl
}

Dysplazja stawu biodrowego jest obecnie powszechnym schorzeniem ortopedycznym występującym u psów. Problem dotyczy głównie psów ras dużych i olbrzymich, ale może ujawnić się u przedstawicieli mniejszych ras. Doniesienia naukowe wskazują na możliwość istnienia predyspozycji rasowych do występowania tego schorzenia, które staje się najczęstszą przyczyną kulawizn kończyny miednicznej u psów. Celem badań była analiza ekspresji dysplazji stawów biodrowych psów z trzech grup i porównanie wyników badań własnych z wynikami zawartymi w piśmiennictwie. Materiałem do badań były 23 zdjęcia radiologiczne udostępnione przez jedną z przychodni weterynaryjnych małych zwierząt. Zdjęcia obejmowały staw biodrowy psów, w wywiadzie ustalono wiek, płeć i masę ciała pacjentów. Radiogramy obejmowały następujące grupy: I - psy w typie labrador retriever $(\mathrm{n}=6)$, II - psy w typie owczarka niemieckiego $(\mathrm{n}=9)$, III - psy wielorasowe, w wieku od 6 do 72 miesięcy. Wyniki umieszczono w bazie programu Statistica v.8 Pl, obliczono wartości średnie kąta Norberga dla stawu lewego i prawego, odchylenie standardowe, wartości minimalne i maksymalne oraz dodatkowo wartości współczynników korelacji cząstkowych, z wyłączeniem płci osobnika, dla masy ciała i kąta Norberga. Nie wykazano istotnego wpływu płci na ekspresję dysplazji stawów biodrowych w żadnej z badanych grup psów oraz wpływu masy ciała na rozchylenie kątów Norberga. Natomiast stwierdzono większe zmiany dysplastyczne u psów w typie golden retrivera w porównaniu z pozostałymi rasami psów. Zwrócono również uwagę na rosnące ryzyko wystąpienia dysplazji wraz ze wzrostem masy ciała psów. 
Sekcja Chowu i Hodowli Trzody Chlewnej 


\title{
JAKOŚĆ EJAKULATÓW KNURÓW W ZALEŻNOŚCI OD WARTOŚCI HODOWLANEJ KNURA
}

\author{
Quality of ejaculates depending on the breeding value of boar
}

\author{
Agnieszka Adamiak ${ }^{1,2}$, Stanisław Kondracki ${ }^{1}$, Anna Wysokińska ${ }^{1}$ \\ ${ }^{1}$ Uniwersytet Przyrodniczo-Humanistyczny w Siedlcach, Katedra Rozrodu i Higieny Zwierząt, ul. Prusa 14, 08-110 Siedlce \\ ${ }^{2}$ Mazowieckie Centrum Hodowli i Rozrodu Zwierząt w Łowiczu, ul. Topolowa 49, 99-400 Łowicz \\ e-mail: agnieszka.adamiak@ mchirz.pl
}

Zależności pomiędzy cechami użytkowości rozrodczej a cechami określającymi zdolności tuczne i mięsność tusz od dawna stanowią przedmiot rozważań i badań naukowych. Uzyskiwane dotychczas wyniki prowadzą jednak do sprzecznych wniosków, co utrudnia podejmowanie decyzji o preferencji określonego modelu użytkowego knurów inseminacyjnych. Celem niniejszej pracy jest określenie, w jaki sposób i w jakim stopniu predyspozycje knurów do użytkowania inseminacyjnego związane są cechami użytkowości tucznej i rzeźnej, szacowanymi w ocenie przyżyciowej.

Określono zależności między wartością hodowlaną knurów inseminacyjnych wyrażoną wynikami oceny przyżyciowej knurów (mięsność, dobowy przyrost masy ciała) a efektami użytkowania rozpłodowego knurów. Dla każdego knura ustalono wartość hodowlaną na podstawie wyników oceny przyżyciowej, uwzględniając: dobowy przyrost masy ciała standaryzowany na wiek 180 dni oraz procent mięsności tuszy standaryzowany na masę ciała $110 \mathrm{~kg}$. Knury podzielono na trzy grupy według kryterium dobowych przyrostów masy ciała i według kryterium mięsności. Do grupy I kwalifikowano knury o małych dobowych przyrostach masy ciała $(710,93 \mathrm{~g})$ i o małej mięsności tusz $(60,30 \%)$. Do grupy II kwalifikowano osobniki o średnich dobowych przyrostach masy ciała $(792,57 \mathrm{~g})$ i o średniej mięsności tusz $(61,39 \%)$. Do grupy III kwalifikowano knury o dużych dobowych przyrostach masy ciała $(858,43 \mathrm{~g})$ i o dużej mięsności tusz $(63,06 \%)$.

Wykazano, że ejakulaty pozyskiwane od knurów o małych przyrostach dobowych masy ciała zawierały o 2,25 mld plemników mniej niż ejakulaty pozyskiwane od knurów o średnich dobowych przyrostach masy ciała $(\mathrm{P} \leq 0,01)$ i o 1,55 mld plemników mniej niż ejakulaty pobierane od knurów o dużych dobowych przyrostach masy ciała $(\mathrm{P} \leq 0,01)$. Ejakulaty pozyskiwane od knurów o małych dobowych przyrostach masy ciała wyróżniały się jednak o 10,93 tys. $/ \mathrm{mm}^{3}$ większą koncentracją plemników niż ejakulaty pobierane od knurów o średnich dobowych przyrostach masy ciała $(\mathrm{P} \leq 0,01)$ i o 20,40 tys. $/ \mathrm{mm}^{3}$ większą koncentracją plemników niż ejakulaty pobierane od knurów o dużych dobowych przyrostach masy ciała $(\mathrm{P} \leq 0,01)$. Z ejakulatów knurów o małych dobowych przyrostach masy ciała (grupa I) sporządzano o co najmniej 0,55 mniej dawek inseminacyjnych niż z ejakulatów pozyskiwanych od knurów o średnich i dużych dobowych przyrostach masy ciała $(\mathrm{P} \leq 0,01)$. Wraz ze wzrostem mięsności knurów zwiększała się także objętość ejakulatu, koncentracja plemników i ogólna liczba plemników w ejakulacie. Z ejakulatów knurów o największej mięsności (63,06\%) sporządzano o 1 dawkę inseminacyjną więcej niż z ejakulatów knurów o średniej mięsności $(61,39 \%)$ $(\mathrm{P} \leq 0,01)$ i o 1,42 dawki inseminacyjnej więcej niż z ejakulatów knurów o małej mięsności $(60,30 \%)$ (P 0,01). Podsumowując, należy stwierdzić, że do inseminacji bardziej nadają się knury, które w ocenie przyżyciowej wykazują się większymi przyrostami masy ciała i uzyskują większą mięsność tusz. Tempo dobowych przyrostów masy ciała i zawartość mięsa w tuszy stwierdzone w ocenie przyżyciowej mają istotny wpływ na jakość ejakulatów pobieranych w czasie użytkowania inseminacyjnego knurów. 


\title{
PORÓWNANIE WARTOŚCI UŻYTKOWEJ I HODOWLANEJ LOSZEK PBZ I WBP ORAZ MIESZAŃCÓW F1
}

\author{
Comparison of performance test results of PL and PLW and F1 gilts
}

\author{
Marta Borsuk, Wanda Milewska \\ Uniwersytet Warmińsko-Mazurski w Olsztynie, Katedra Hodowli Trzody Chlewnej, ul. Oczapowskiego 5, 10-719 Olsztyn \\ e-mail: malwa@uwm.edu.pl
}

Celem pracy było porównanie wartości użytkowej i hodowlanej loszek czystorasowych pbz i wbp oraz mieszańców dwurasowych pbz $\times$ wbp i wbp $\times$ pbz. Dane zebrano w okresie od 1 stycznia do 30 września 2017 r. w gospodarstwie rolno-hodowlanym, zlokalizowanym w województwie kujawsko-pomorskim. Stado podstawowe składało się z 70 loch rasy polskiej białej zwisłouchej i 70 loch rasy wielkiej białej polskiej, od których pozyskiwano materiał hodowlany czystorasowy i loszki mieszańce dwurasowe. W pracy oceniono: liczbę sutków, przyrosty dobowe masy ciała standaryzowane, grubość słoniny w P2 i P4, wysokość oka polędwicy, mięsność, indeks selekcyjny OP. Wyniki przedstawiono w tabeli 1.

Tabela 1. Cechy użytkowe i hodowlane badanych loszek (wartość średnia \pm odchylenie standardowe)

\begin{tabular}{|l|c|c|c|c|}
\hline \multicolumn{1}{|c|}{ Cechy } & pbz & wbp & pbz $\times$ wbp & wbp $\times$ pbz \\
\hline Liczba sutków [szt.] & $14,5^{\mathrm{B}} \pm 0,7$ & $14,8^{\mathrm{b}} \pm 0,8$ & $15,4^{\mathrm{Aa}} \pm 0,8$ & $14,8^{\mathrm{b}} \pm 0,8$ \\
\hline Średnie przyrosty m. c. standaryzowane [g/dz.] & $683 \pm 85,3$ & $628,3^{\mathrm{B}} \pm 70,7$ & $719^{\mathrm{A}} \pm 65,7$ & $641^{\mathrm{B}} \pm 63,3$ \\
\hline Mięsność [\%] & $57,6 \pm 1,7$ & $58,2 \pm 1,8$ & $57,6 \pm 1,2$ & $58,2 \pm 1,8$ \\
\hline Grubość słoniny z dwóch pomiarów [mm] & $10,4 \pm 1,6$ & $10,3 \pm 1,8$ & $10,7 \pm 1,1$ & $10,3 \pm 1,8$ \\
\hline Wysokość oka polędwicy [mm] & $56,3^{\mathrm{b}} \pm 2,0$ & $55,8^{\mathrm{b}} \pm 3,3$ & $58,6^{\mathrm{a}} \pm 2,8$ & $56,4^{\mathrm{b}} \pm 3,5$ \\
\hline Indeks selekcyjny OP [pkt] & $117,4 \pm 11,7$ & $110,5^{\mathrm{B}} \pm 8,9$ & $122,9^{\mathrm{A}} \pm 9,6$ & $112,7^{\mathrm{B}} \pm 7,7$ \\
\hline
\end{tabular}

A, B - różnica potwierdzona statycznie na poziomie $\mathrm{P} \leq 0,01$

$\mathrm{a}, \mathrm{b}$ - różnica potwierdzona statycznie na poziomie $\mathrm{P} \leq 0,05$

Loszki pbz × wbp wykazały się największą liczbą sutków (15,4 szt.). W stosunku do czystorasowych pbz (14,5 szt.) różnica między grupami okazała się wysoko istotna. Podobne relacje stwierdzono w odniesieniu do przyrostów dobowych masy ciała $(\mathrm{P}<0,01)$, wysokości oka polędwicy $(\mathrm{P}<0,05)$ oraz indeksu selekcyjnego $(\mathrm{P} \leq 0,01)$. Najlepszymi parametrami charakteryzowały się loszki pbz $\times$ wbp. Indeks BLUP kształtował się w granicach od 9,77 (pbz) do 9,81 pkt (wbp). Potwierdza to wysoką przydatność loszek obu ras do użytkowania rozpłodowego. Prowadząc ocenę, selekcję oraz odpowiedni dobór zwierząt do rozrodu, można osiągnąć postęp hodowlany w cechach ważnych gospodarczo. 


\title{
ANALIZA UŻYTKOWOŚCI ROZPŁODOWEJ LOCH PIERWIASTEK I WIELORÓDEK PIC W ZALEŻNOŚCI OD KOLEJNEGO CYKLU ROZPŁODOWEGO
}

Analysis of reproduction traits of primiparous and multiparous PIC sows depending on parity number

\author{
Dorota Bugnacka, Martyna Zarzecka
}

\begin{abstract}
Uniwersytet Warmińsko-Mazurski w Olsztynie, Katedra Hodowli Trzody Chlewnej, ul. Oczapowskiego 5, 10-718 Olsztyn e-mail: dorotabu@uwm.edu.pl
\end{abstract}

Cechy użytkowości rozpłodowej loch mają tendencję do zmian wartości w zależności od wieku lochy. Płodność, plenność i mleczność loch rosną wraz z każdym kolejnym cyklem rozpłodowym, osiągając apogeum w 3-5 cyklu. Od tego momentu rozpoczyna się ich powolny spadek, z zastrzeżeniem, że istnieje tu pewne zróżnicowanie indywidulane. Dlatego powinno się stale analizować ich wartość, aby móc podjąć świadomą decyzję o brakowaniu lochy ze stada i nie wyeliminować lochy wysokopłodnej, kierując się tylko numerem cyklu ani też nie pozostawiać w stadzie lochy młodszej, ale niskoprodukcyjnej. Celem badań była analiza porównawcza wartości cech rozpłodowych loch PIC utrzymywanych w warunkach chlewni towarowej w zależności od kolejnego cyklu rozpłodowego.

Analizowano dane pochodzące $\mathrm{z}$ gospodarstwa wielkotowarowego w województwie podlaskim, utrzymującego stado podstawowe 215 loch i prowadzącego chów w cyklu zamkniętym. Dane pochodziły łącznie z 389 miotów: po 84 mioty w cyklach 1., 2. i 3. oraz 71 w 4., 39 w 5., 17 w 6., 5 w 7., 3 w 8. i 2 mioty w cyklu 9. Wszystkie lochy kryto knurami linii PIC-410, utrzymywanymi w tej samej chlewni. Analizowano: długość ciąży, laktacji, okresu jałowienia, cyklu rozpłodowego, liczbę prosiąt urodzonych (ogółem, żywo i martwo), śmiertelność w odchowie, liczbę prosiąt odsadzonych z miotu. Na podstawie uzyskanych danych wyliczono: plenność fizjologiczną i gospodarczą oraz częstotliwość oproszeń. Uzyskane dane opracowano statystycznie (jednoczynnikowa analiza wariancji w układzie nieortogonalnym, test Duncana) w programie STATISTICA 12.0. Uzyskano następujące dane:

\begin{tabular}{|c|c|c|c|c|c|c|c|c|c|c|}
\hline \multirow{2}{*}{ Wyszczególnienie } & \multicolumn{10}{|c|}{ Kolejny cykl rozpłodowy } \\
\hline & 1 & 2 & 3 & 4 & 5 & 6 & 7 & 8 & 9 & średnia \\
\hline Długość ciąży [dni] & 116,0 & 116,2 & 116,0 & 116,2 & 116,0 & 115,4 & 115,2 & 117,0 & 117,5 & 116,2 \\
\hline Długość laktacji [dni] & 27,1 & 26,0 & 27,0 & 27,6 & 28,2 & 28,7 & 30,4 & 29,3 & 27,5 & 27,8 \\
\hline Długość jałowienia [dni] & 6,06 & 5,31 & 6,55 & 7,00 & 7,70 & 5,20 & 5,33 & 5,00 & - & 6,02 \\
\hline $\begin{array}{l}\text { Długość cyklu } \\
\text { rozpłodowego [dni] }\end{array}$ & 148,0 & 148,0 & 150,0 & 151,0 & 151,0 & 150,0 & 151,0 & 150,0 & - & 149,9 \\
\hline Częstotliwość oproszeń & 2,47 & 2,47 & 2,43 & 2,43 & 2,40 & 2,42 & 2,41 & 2,43 & - & 2,43 \\
\hline $\begin{array}{l}\text { Liczba prosiąt urodzonych: } \\
\text { - ogółem [szt.] } \\
\text { - żywo [szt.] } \\
\text { - martwo [szt.] } \\
\text { - odsadzonych [szt.] }\end{array}$ & $\begin{array}{c}13,57 \\
12,92 \\
0,65^{\mathrm{A}} \\
11,32 \\
\end{array}$ & $\begin{array}{c}12,56 \\
11,79^{\mathrm{a}} \\
0,77^{\mathrm{A}} \\
11,27 \\
\end{array}$ & $\begin{array}{c}14,50 \\
13,68^{\mathrm{A}} \\
0,82^{\mathrm{A}} \\
11,27 \\
\end{array}$ & $\begin{array}{c}14,62 \\
13,59^{\mathrm{A}} \\
1,03^{\mathrm{a}} \\
11,06 \\
\end{array}$ & $\begin{array}{c}14,74 \\
13,36^{\mathrm{A}} \\
1,38 \\
10,97 \\
\end{array}$ & $\begin{array}{c}15,06^{\mathrm{a}} \\
14,12^{\mathrm{A}} \\
0,94^{\mathrm{A}} \\
11,06 \\
\end{array}$ & $\begin{array}{c}13,40 \\
12,80^{\mathrm{a}} \\
0,60^{\mathrm{A}} \\
10,60 \\
\end{array}$ & $\begin{array}{c}16,00^{\mathrm{A}} \\
13,67^{\mathrm{A}} \\
2,33^{\mathrm{Bb}} \\
11,33^{2} \\
\end{array}$ & $\begin{array}{c}11,00^{\mathrm{Bb}} \\
9,50^{\mathrm{Bb}} \\
1,50 \\
11,00 \\
\end{array}$ & $\begin{array}{c}13,94 \\
12,83 \\
1,11 \\
11,10 \\
\end{array}$ \\
\hline Śmiertelność [\%] & $4,71 \mathrm{~A}^{\mathrm{d}}$ & $6,03^{\mathrm{A}}$ & $4,93^{\mathrm{Ad}}$ & $6,05^{\mathrm{A}}$ & 8,66 & $6,29^{\mathrm{A}}$ & $3,78^{\mathrm{D}}$ & $15,56^{\mathrm{B}}$ & $13,40^{\mathrm{Cc}}$ & 7,71 \\
\hline Plenność gospodarcza [szt.] & 27,96 & 27,84 & 27,39 & 26,88 & 26,66 & 26,77 & 25,55 & 27,53 & - & 27,07 \\
\hline
\end{tabular}

Stwierdzono bardzo dobre wyniki użytkowania rozpłodowego badanych loch PIC, przy ich średniej płodności rzeczywistej (liczba prosiąt żywo urodzonych) na poziomie 12,83 prosięcia, i plenności gospodarczej na poziomie 27,07. Wykazano, że kolejny cykl rozpłodowy wpłynął istotnie statystycznie na liczbę 
prosiąt urodzonych i śmiertelność w ich odchowie. Lochy w cyklu 6. i 8. rodziły najwięcej prosiąt ogółem, a płodność rzeczywista była najwyższa w cyklach 3-6. Liczba prosiąt martwo urodzonych była z kolei najwyższa w 8. miocie. Najwyższą śmiertelność w odchowie stwierdzono w 8. i 9. miocie.

Biorąc pod uwagę powyższe, stwierdzono, że w badanej chlewni należy użytkować lochy do 7. cyklu rozpłodowego włącznie. Tym samym stwierdzono, że lochy hybrydowe PIC użytkowane w badanym obiekcie utrzymują wysoką wartość cech użytkowości rozpłodowej w dłuższym okresie niż standardowo się przyjmuje (4-5. cykl), przy założeniu, że zwierzęta bytują w bardzo dobrych warunkach i są otoczone prawidłową opieką. 


\title{
PORÓWNANIE WYNIKÓW UŻYTKOWOŚCI ROZPŁODOWEJ LOCH PIERWIASTEK I WIELORÓDEK PIC
}

\author{
Comparison of reproduction traits of primiparous and multiparous PIC sows
}

\author{
Dorota Bugnacka, Martyna Zarzecka
}

\begin{abstract}
Uniwersytet Warmińsko-Mazurski w Olsztynie, Katedra Hodowli Trzody Chlewnej, ul. Oczapowskiego 5, 10-718 Olsztyn e-mail: dorotabu@uwm.edu.pl
\end{abstract}

Wartość cech użytkowości rozpłodowej powinna być dokładnie kontrolowana i stale analizowana, bowiem zależy od nich efektywność produkcji w chlewni. Płodność i plenność loch są warunkowane wieloma czynnikami, zarówno genetycznymi, jak i środowiskowymi, przy czym ze względu na ich niskie współczynniki odziedziczalności czynniki środowiskowe mają zwykle przewagę w ich kształtowaniu. Przy zapewnieniu prawidłowych warunków bytowania zwierząt ujawniają się w pełni ich predyspozycje genetyczne. Biorąc pod uwagę stałe doskonalenie genetyczne świń, w produkcji wykorzystujemy lochy o coraz wyższych parametrach użytkowości rozpłodowej. Znanym faktem jest zależność mówiąca o jej niższej wartości u loch pierwiastek niż u wieloródek, jednakże i te różnice stają się coraz mniejsze, zwłaszcza w przypadku loch linii hybrydowych. Dlatego też celem badań była analiza porównawcza wartości cech rozpłodowych loch pierwiastek i wieloródek PIC utrzymywanych w warunkach chlewni towarowej.

Analizowano dane pochodzące $\mathrm{z}$ gospodarstwa wielkotowarowego położonego w województwie podlaskim, utrzymującego stado podstawowe 215 loch i prowadzącego chów w cyklu zamkniętym. W grupie loch pierwiastek analizowano dane pochodzące z 84 miotów (łącznie 1085 prosiąt), natomiast w grupie wieloródek z 385 miotów (łącznie 3990 prosiąt). Wszystkie lochy kryto knurami linii PIC-410, utrzymywanymi w tej samej chlewni. Analizowano: długość ciąży, okresu jałowienia, cyklu rozpłodowego, liczbę prosiąt urodzonych (ogółem, żywo i martwo), śmiertelność w odchowie, liczbę prosiąt odsadzonych z miotu. Na podstawie uzyskanych danych wyliczono: plenność fizjologiczną i gospodarczą oraz częstotliwość oproszeń. Uzyskane dane opracowano statystycznie (jednoczynnikowa analiza wariancji w układzie nieortogonalnym), wykorzystując program Statistica 12.0. Uzyskano następujące dane:

\begin{tabular}{|l|c|c|}
\hline \multirow{2}{*}{\multicolumn{1}{|c|}{ Wyszczególnienie }} & \multicolumn{2}{c|}{ Grupa loch } \\
\cline { 2 - 3 } & pierwiastki & wieloródki \\
\hline Długość ciąży [dni] & 116,00 & 116,10 \\
\hline Długość laktacji [dni] & 27,10 & 27,20 \\
\hline Długość jałowienia [dni] & 6,06 & 6,20 \\
\hline Długość cyklu rozpłodowego [dni] & 150,00 & 148,00 \\
\hline Liczba prosiąt urodzonych ogółem [szt.] & 13,57 & 14,03 \\
\hline Liczba prosiąt urodzonych żywo [szt.] & 12,92 & 13,08 \\
\hline Liczba prosiąt urodzonych martwo [szt.] & $0,65^{\text {a }}$ & $0,95^{\text {b }}$ \\
\hline Liczba prosiąt odsadzonych [szt.] & 11,32 & 11,16 \\
\hline Śmiertelność prosiąt w odchowie [\%] & 4,71 & 6,19 \\
\hline
\end{tabular}

Na podstawie powyższych danych można stwierdzić, że lochy badanych grup uzyskały bardzo dobre i niezróżnicowane statystycznie wartości analizowanych cech rozpłodowych, takich jak: długość poszczególnych faz cyklu rozpłodowego oraz liczba prosiąt urodzonych ogółem, żywo urodzonych i odsadzonych z miotu, przy bardzo niskim poziomie ich śmiertelności. Istotnie statystycznie zróżnicowana i wyższa w przypadku loch wieloródek była natomiast liczba prosiąt martwo urodzonych. Zaprezentowane dane mogą być traktowane jako potwierdzenie teorii, że lochy hybrydowe, o wysokiej wartości genetycznej, utrzymywane w bardzo dobrych warunkach bytowania mogą rodzić i odchowywać bardzo liczne mioty również w swoim pierwszym cyklu rozpłodowym. 


\title{
WPEYW CZASU PRZECHOWYWANIA W WARUNKACH CHŁODNICZYCH NA STABILNOŚĆ OKSYDACYJNĄ MIĘSA TUCZNIKÓW RASY PUŁAWSKIEJ
}

The influence of cold storage time on oxidative stability of meat of Puławska fatteners

\author{
Piotr Domaradzki ${ }^{1}$, Anna Litwińczuk ${ }^{1}$, Marek Babicz ${ }^{2}$, Piotr Skałecki ${ }^{1}$, Małgorzata Dmoch ${ }^{1}$, Michał \\ Prasow ${ }^{1}$, Małgorzata Ryszkowska-Siwko ${ }^{1}$, Beata Ciupak ${ }^{1}$ \\ ${ }^{1}$ Uniwersytet Przyrodniczy w Lublinie, Katedra Towaroznawstwa i Przetwórstwa Surowców Zwierzęcych, \\ ul. Akademicka 13, 20-950 Lublin \\ ${ }^{2}$ Uniwersytet Przyrodniczy w Lublinie, Instytut Hodowli Zwierząt i Ochrony Bioróżnorodności, Zakład Hodowli \\ Biotechnologii Świń, ul. Akademicka 13, 20-950 Lublin \\ e-mail: piotr.domaradzki@up.lublin.pl
}

Celem pracy była ocena wpływu czasu przechowywania w warunkach chłodniczych na stabilność oksydacyjną dwóch mięśni szkieletowych ( $m$. longissimus dorsi vs. m. semimembranosus) tuczników rasy puławskiej.

Badaniami objęto dwa mięśnie szkieletowe (m. longissimus dorsi - LD vs. m. semimembranosus - SM) pobrane z 6 tusz świń rasy puławskiej. Po wykonaniu rozbioru technologicznego wychłodzone próby mięśni pakowano próżniowo $\mathrm{w}$ worki z folii PA/PE i przechowywano $\mathrm{w}$ temperaturze $4^{\circ} \mathrm{C}$ do momentu wykonania oznaczeń. W pobranych próbach 4. dnia post mortem oznaczono podstawowy skład chemiczny, tj. zawartość wody, związków mineralnych, białka ogólnego metodą Kjeldahla oraz tłuszczu metodą Soxhleta. W celu oznaczenia kwasów tłuszczowych (KT) została przeprowadzona ekstrakcja tłuszczu metodą Folcha i in. [1957], a zawarte w wyekstrahowanym tłuszczu KT przeprowadzono w estry metylowe (EMKT) zgodnie z normą PN-EN ISO 12966-2:2017-05. Rozdział EMKT przeprowadzono techniką chromatografii gazowej wg PN-EN ISO 12966-1:2015-01 przy użyciu chromatografu gazowego Varian CG 3900 z detektorem płomieniowo-jonizacyjnym (FID). Stabilność oksydacyjną lipidów oznaczono w 4., 7., 14. dniu post mortem (p.m.) w oparciu o wartość liczby nadtlenkowej (LN), liczby kwasowej (LK) i wskaźnika TRARS.

Rodzaj mięśnia istotnie $(\mathrm{p} \leq 0,05)$ różnicował zawartość tłuszczu. Jego wyższy poziom stwierdzono w mięśniu najdłuższym grzbietu (LD) w porównaniu z mięśniem półbłoniastym (SM) (2,02 vs. 1,67\%). Mięsień SM charakteryzował się wyższym udziałem kwasów tłuszczowych z grupy PUFA $(14,22 \%$ vs. $9,17 \%$; $\mathrm{p} \leq 0,01), \mathrm{n}-6(13,29$ vs. $8,59 \% ; \mathrm{p} \leq 0,05), \mathrm{n}-3$ (0,67 vs. $0,47 \% ; \mathrm{p}>0,05)$ oraz istotnie niższym SFA $(35,71$ vs. $38,85 \% ; \mathrm{p} \leq 0,01)$ w porównaniu z LD. Podczas 14-dniowego chłodniczego przechowywania badanych mięśni obserwowano postępujące zmiany oksydacyjne i hydrolityczne zawartych w nich lipidów, o czym świadczy wzrost wskaźnika TBARS (z 0,24 w 4. dniu p.m. do 0,52 mg MDA/kg w 14. dniu p.m.) i liczby kwasowej (z 2,11 w 4. dniu p.m. do 3,23\%WKT w 14. dniu p.m.). Pomimo obserwowanych zmian wskaźniki stopnia zjełczenia lipidów (TBARS, LN i LK) były na relatywnie niskim poziomie, co świadczy o dobrej stabilności oksydacyjnej mięsa i ochronnej roli pakowania próżniowego. Mięsień SM odznaczał się większą wartością TBARS (przeciętnie o 0,05 mg MDA/kg) i LK (o 0,36 \% WKT) w porównaniu z LD. Obserwowane międzymięśniowe różnice najprawdopodobniej związane były z różną zawartością tłuszczu i odmiennym profilem kwasów tłuszczowych.

Badania zrealizowano w ramach projektu Biostrateg „Kierunki wykorzystania oraz ochrona zasobów genetycznych zwierząt gospodarskich w warunkach zrównoważonego rozwoju" współfinansowanego przez Narodowe Centrum Badań i Rozwoju w ramach Strategicznego programu badań naukowych i prac rozwojowych „Środowisko naturalne, rolnictwo i leśnictwo” (BIOSTRATEG2/297267/2/NCBR/2016). 


\title{
ZMIANY SKŁADU CHEMICZNEGO MLEKA W KOLEJNYCH DNIACH LAKTACJI U LOCH RAS MATECZNYCH
}

The chemical composition of milk in maternal sow breeds in subsequent days of lactation

\author{
Robert Eckert, Magdalena Szyndler-Nędza
}

Instytut Zootechniki - Państwowy Instytut Badawczy, ul. Krakowska 1, 32 - 083 Balice e-mail: robert.eckert@izoo.krakow.pl

Jakość siary i mleka jest ściśle związana z właściwym żywieniem loch w okresie ciąży i w konsekwencji zdolnością gromadzenia rezerw tłuszczu i białka przed intensywnym okresem ich użytkowania, jakim jest laktacja. A o tym możemy sądzić na podstawie grubości słoniny mierzonej u loch $\mathrm{w}$ dniu porodu. Lochy nie tylko różnią się pod względem ilości produkowanego mleka, ale także zmian jego składu chemicznego. Mając to na uwadze przeprowadzono analizę składu mleka loch rasy wbp (58 szt.) i pbz (65 szt.), które urodziły i odchowały swe potomstwo w pierwszych trzech miotach. Nie uwzględniając czynnika rasowego, lochy podzielono na trzy grupy doświadczalne pod względem grubości słoniny w punkcie P2, mierzonej w dniu porodu. Skład chemiczny mleka w 7., 14. i 21. dniu życia z podziałem na grupy doświadczalne przedstawiono w tabeli 1 . W grupach loch o różnej grubości słoniny nie obserwowano znaczących zmian w suchej masie mleka w kolejnych dniach laktacji. Analizując zmiany zawartości białka, stwierdzono, że jedynie u loch o najcieńszej i najgrubszej słoninie w kolejnych dniach laktacji następowało zwiększenie jego zawartości. W przypadku zawartości tłuszczu w mleku we wszystkich grupach loch jego poziom systematycznie obniżał się w kolejnych dniach laktacji. Nie zauważono natomiast żadnych tendencji, jeśli chodzi o zmiany w zawartości laktozy w mleku. Stwierdzono również, że im większą grubość słoniny grzbietowej miały lochy, tym większą zawartością tłuszczu w 7. dniu laktacji oraz większą zawartością laktozy w 14. i 21. dniu cechowało się ich mleko.

Tabela 1. Zmiany w składzie chemicznym mleka w kolejnych dniach laktacji u loch o różnej grubości słoniny w dniu porodu

\begin{tabular}{|c|c|c|c|}
\hline \multirow{2}{*}{ Wyszczególnienie } & \multicolumn{3}{|c|}{ Grubość słoniny P2 w dniu porodu [mm] } \\
\cline { 2 - 4 } & 14 i mniej & $15-17$ & 18 i więcej \\
\hline Liczba miotów & 136 & 106 & 110 \\
\hline Sucha masa [\%] & & & \\
7. dzień & 17,83 & 18,08 & 17,96 \\
14. dzień & 17,89 & 18,06 & 17,97 \\
21. dzień & 17,87 & 17,56 & 18,09 \\
\hline Białko [\%] & & & \\
7. dzień & 4,62 & 4,52 & 4,60 \\
14. dzień & 4,88 & 4,92 & 4,65 \\
21. dzień & 4,98 & 4,66 & 4,79 \\
\hline Tłuszcz [\%] & & & \\
7. dzień & 7,40 & 7,66 & 7,69 \\
14. dzień & 7,35 & 7,13 & 6,23 \\
21. dzień & 6,98 & 6,70 & \\
\hline Laktoza [\%] & \multicolumn{3}{|c}{} \\
7. dzień & 5,56 & 5,62 & 5,56 \\
14. dzień & 5,54 & 5,61 & 5,71 \\
21. dzień & 5,49 & 5,51 & 5,57 \\
\hline
\end{tabular}

Przedstawione wyniki badań wskazują, że niezależnie od stopnia otłuszczenia loch zawartość podstawowych składników mleka w kolejnych dniach laktacji zmienia się podobnie. Ponadto lochy o większej grubości słoniny grzbietowej produkują mleko o większej zawartości tłuszczu do 7. dnia laktacji, a w 14. i 21 . dniu laktacji o większej zawartości laktozy. 


\title{
WPEYW CZASU PRZECHOWYWANIA NA RUCHLIWOŚĆ, INTEGRALNOŚĆ BŁONY KOMÓRKOWEJ I AKROSOMU ORAZ AKTYWNOŚĆ MITOCHONDRIÓW PLEMNIKÓW KNURA KONSERWOWANYCH W STANIE PŁYNNYM
}

\author{
The influence of storage time on motility, integrity of plasma membrane and acrosome, and mitochondrial \\ activity of boar sperm during preservation in liquid state
}

\author{
Dariusz Gączarzewicz, Ewa Kwita, Jan Udała, Tomasz Stankiewicz, Barbara Błaszczyk, Bogumiła \\ Pilarczyk, Agnieszka Tomza-Marciniak, Małgorzata Bąkowska
}

\author{
Zachodniopomorski Uniwersytet Technologiczny w Szczecinie, Katedra Biotechnologii Rozrodu Zwierząt i Higieny Środowiska \\ e-mail: dariusz.gaczarzewicz@ zut.edu.pl
}

W chowie i hodowli trzody chlewnej wykorzystanie nasienia do zabiegów inseminacyjnych w praktyce ogranicza się do przechowywanego w stanie płynnym. Mając jednak na uwadze podatność plemników knura na utratę właściwości biologicznych, zwłaszcza przy wydłużaniu okresu konserwacji nasienia, w badaniach przeprowadzono analizę wybranych parametrów jakości długoterminowo przechowywanego w stanie płynnym nasienia knurów rasy polskiej białej zwisłouchej (pbz) oraz hybrydowej linii Hypor.

W badaniach wykorzystano ejakulaty 22 użytkowanych rozpłodowo knurów (pbz $=12$, Hypor $=10$ ), które rozrzedzono rozcieńczalnikiem Vitasem LD (Magapor S.L.), a następnie przechowywano przez 10 dni w temperaturze $16^{\circ} \mathrm{C}$. W nasieniu w 1., 3., 6., 8. oraz 10. dniu przechowywania przeprowadzono ocenę ruchliwości plemników za pomocą komputerowego systemu SCA (Sperm Class Analyzer ${ }^{\circledR}$, Microptic S.L.), a także określano procentowy udział plemników żywych z aktywnymi mitochondriami oraz plemników żywych z integralnym akrosomem, stosując metody barwienia fluorescencyjnego, odpowiednio z SYBR-14, PI i JC-1 oraz z SYBR-14, PI i lektyną PNA sprzężoną z Alexa Fluor 594 (Invitrogen ${ }^{\mathrm{TM}}$ ). W technikach fluorescencyjnych wykorzystano mikroskop Olympus BX41 i filtr U-DM-FI/P12 (Olympus). Analizę statystyczną przeprowadzono m.in. na podstawie analizy wariancji powtarzanych pomiarów dla rang Friedmana oraz testów Wilcoxona i U Manna-Whitneya, przyjmując dopuszczalne maksymalne prawdopodobieństwo P błędu pierwszego rodzaju równe 0,05 .

W badaniach stwierdzono istotny wpływ czasu przechowywania nasienia na wszystkie parametry charakteryzujące sposób poruszania się (tj. prędkość i trajektorię ruchu) plemników, skutkujący po 10 dniach konserwacji nasienia istotnym spadkiem średnich wartości m.in. odsetka plemników ruchliwych (z 89\% do 48\%), plemników z ruchem postępowym (z 66\% do 29\%) oraz z ruchem postępowym szybkim (z $47 \%$ do $16 \%)$. Czas przechowywania wpłynął również istotnie ( $<0,001)$ na liczbę plemników żywych $\mathrm{z}$ aktywnymi mitochondriami (z wysokim i obniżonym $\Delta \Psi \mathrm{m}$ ) oraz plemników żywych z prawidłowym akrosomem, których średni udział w 10. dniu konserwacji obniżył się odpowiednio o 51\% (z 67\%) oraz o 13\% (z 77\%). Przeprowadzone badania wykazały ponadto korzystniejsze ogólne, istotne statystycznie w poszczególnych okresach przechowywania, kształtowanie się wskaźników jakości nasienia knurów hybrydowej linii Hypor w odniesieniu do knurów rasy pbz (m.in. parametrów ruchliwości w początkowym okresie konserwacji oraz odsetka plemników żywych z integralnym akrosomem od 5. dnia przechowywania nasienia). Niemniej jednak $\mathrm{w}$ obu grupach genetycznych długoterminowa konserwacja nasienia w rozcieńczalniku Vitasem LD nasilała zmiany związane z utratą prawidłowych funkcji plemników, co z kolei sugeruje, że w celu poprawy wyników płodności należy w miarę możliwości minimalizować okres przechowywania nasienia knurów do momentu wykonania zabiegu inseminacyjnego. 


\title{
PARAMETRY FIZYCZNE EJAKULATU I MORFOLOGIA PLEMNIKÓW ORAZ ZALEŻNOŚCI POMIĘDZY CECHAMI NASIENIA U KNURÓW HYPOR W POSZCZEGÓLNYCH SEZONACH ROKU
}

\author{
Effects of season on semen parameters and relationships between selected semen characteristics \\ in Hypor boars
}

\author{
Krzysztof Górski, Stanisław Kondracki, Anna Wysokińska
}

\begin{abstract}
Uniwersytet Przyrodniczo-Humanistyczny w Siedlcach, Katedra Rozrodu i Higieny Zwierząt, ul. B. Prusa 14, 08-110 Siedlce e-mail: krzysztof.gorski@uph.edu.pl
\end{abstract}

Wpływ pory roku na występowanie zmian w budowie morfologicznej plemników oraz zmienność cech ilościowych ejakulatu samców różnych ras jest zróżnicowana i zależy od ich wrażliwości na działanie czynników sezonowych. W niniejszej pracy podjęto próbę określenia wpływu czynników sezonowych na cechy fizyczne ejakulatu i morfologię plemników knurów Hypor oraz korelacji fenotypowych pomiędzy wybranymi cechami ejakulatów w zależności od pory roku.

Badaniami objęto 114 ejakulatów pobranych od 12 knurów Hypor. Do badań wybrano knury młode, w wieku 7-9 miesięcy. Ejakulaty poddano ocenie, ustalając: objętość ejakulatu, koncentrację plemników, odsetek plemników wykazujących prawidłowy ruch, ogólną liczbę plemników w ejakulacie oraz liczbę dawek inseminacyjnych uzyskanych $\mathrm{z}$ jednego ejakulatu. $\mathrm{Z}$ pobranych próbek ejakulatu wykonano preparaty mikroskopowe. W każdym preparacie oceniono budowę morfologiczną 500 plemników ze wskazaniem liczby plemników o prawidłowej budowie i plemników morfologicznie zmienionych, wyróżniając formy ze zmianami głównymi i podrzędnymi. W każdym preparacie wykonano pomiary morfometryczne 15 losowo wybranych plemników o prawidłowej budowie morfologicznej, ustalając: długość główki plemnika, szerokość główki plemnika, pole powierzchni główki plemnika, obwód główki plemnika, długość witki i łączną długość plemnika. Ejakulaty pogrupowano według sezonu, w którym były pobierane: zima (styczeń, luty, marzec), wiosna (kwiecień, maj, czerwiec), lato (lipiec, sierpień, wrzesień), jesień (październik, listopad, grudzień).

Stwierdzono wyraźny wpływ pory roku na cechy fizyczne ejakulatu i obraz morfologiczny plemników knurów Hypor. Wykazano, że plemniki z ejakulatów pobieranych w sezonie wiosennym mają największe główki. Główki tych plemników były najdłuższe, najszersze i miały największą powierzchnię oraz obwód. Najmniejszą długość i szerokość miały główki plemników z ejakulatów pobieranych w okresie jesiennym. Plemniki z ejakulatów pobieranych w okresie jesiennym miały także główki o najmniejszym obwodzie i o najmniejszej powierzchni. Stwierdzono, że odsetek plemników wykazujących główne zmiany morfologiczne zmieniał się w niewielkim zakresie w zależności od pory roku. Największy odsetek głównych wad plemników obserwowano wiosną $(1,58 \%)$, a najmniejszy jesienią $(0,80 \%)$. Najwięcej plemników z wadami podrzędnymi stwierdzono w ejakulatach pobieranych w okresie letnim $(3,89 \%)$, o 1,37\% więcej niż w ejakulatach pobieranych w okresie jesiennym. Wykazano, że cechy fizyczne ejakulatu knurów Hypor również zależą od pory roku. Najmniejszą objętość mają ejakulaty pobierane wiosną, a ejakulaty pobierane zimą mają największą koncentrację plemników. Najwięcej dawek inseminacyjnych można było sporządzić z ejakulatów pobieranych w okresie zimowym. Najmniej porcji inseminacyjnych wykonywano z ejakulatów pobieranych jesienią. Najmniejszą liczbę plemników w ejakulacie stwierdzono w sezonie jesiennym.

Najmniejszy odsetek plemników o ruchu postępowym stwierdzono w ejakulatach pobieranych jesienią (74,19\%), a największy wiosną $(78,33 \%)$ i latem $(78,09 \%)$. Wykazano wysokie korelacje pomiędzy wymiarami główek plemników a koncentracją plemników i liczbą plemników w ejakulatach pobieranych w sezonie jesiennym $(\mathrm{r}=0,36-0,69)$ i zimowym $(\mathrm{r}=0,29-0,58)$. Stwierdzono także wysokie korelacje $(\mathrm{r}=0,45-0,58)$ pomiędzy długością główki i polem powierzchni główki plemnika, a koncentracją plemników i ogólną liczbą plemników w ejakulatach pobieranych w sezonie letnim. 


\title{
OCENA SKALI STRAT SPOWODOWANYCH NISKĄ MASĄ CIAŁA PROSIĄT PRZY URODZENIU W STADACH ŚWIŃ RASY WBP I PBZ
}

Assessment of scale of losses caused by low body weight at birth of piglets from PLW and PL breed herds

\author{
Aleksandra Hajn ${ }^{1}$, Anna Rekiel $^{1}$, Tadeusz Blicharski ${ }^{2}$, Justyna Więcek ${ }^{1}$, Martyna Snopkiewicz ${ }^{2}$ \\ ${ }^{1}$ Szkoła Główna Gospodarstwa Wiejskiego w Warszawie, Katedra Szczegółowej Hodowli Zwierząt, Pracownia Hodowli Trzody \\ Chlewnej, ul. Ciszewskiego 8, 02-786 Warszawa \\ ${ }^{2}$ Polski Związek Hodowców i Producentów Trzody Chlewnej POLSUS, ul. Ryżowa 90, 02-495 Warszawa \\ e-mail: justyna_wiecek@sggw.pl
}

W wyniku wieloletniej pracy hodowlanej, realizowanych programów selekcyjnych i krzyżowania towarowego uzyskano znaczną poprawę płodności loch. W licznych miotach również częściej występują straty prosiąt. Problemem ostatnich lat jest rodzenie przez bardzo płodne lochy prosiąt o niskiej masie ciała, w tym z syndromem IUGR.

Celem pracy było określenie, w ilu miotach pochodzących od loch rasy wielka biała polska (wbp) i polska biała zwisłoucha (pbz) stwierdzana niska masa ciała (NMC) noworodków stanowi przyczynę padnięć w okresie od urodzenia do 21. dnia odchowu. Skalę problemu oceniono w okresie jednej dekady, tj. w latach 2007-2016. Materiał do analizy stanowiły dane o użytkowości rozpłodowej loch rasy wbp oraz pbz użytkowanych w latach 2007-2016 w stadach zarodowych na terenie całej Polski. Dane do analiz udostępnił Polski Związek Hodowców i Producentów Trzody Chlewnej POLSUS. W stadach hodowlanych przyczyny upadków są kontrolowane, a informacje zapisywane wg klucza 1-7; pozycję 2. stanowią upadki spowodowane NMC. Zebrany materiał opracowano statystycznie. W okresie badawczym liczba miotów podlegających ocenie zmniejszyła się w rasie wbp i pbz odpowiednio 4- i 2-krotnie. Łącznie oceniono dla rasy wbp 30206 miotów, straty spowodowane NMC dotyczyły 3748 miotów $(12,41 \%)$. W rasie pbz skala strat była podobna, oceniono ogółem 66916 miotów, a straty wynikające z NMC prosiąt stwierdzono w 7700 miotach, co stanowiło 11,64\%. Porównano skalę strat spowodowanych NMC dla miotów 1. (pierwszych) i 8. (ósmych oraz dalszych). Ogółem oceniono dla rasy wbp 5960 miotów pierwszych. W 729 miotach $(12,23 \%)$ wystąpiły straty spowodowane NMC noworodków. Miotów ósmych ogółem oceniono prawie 3-krotnie mniej, tj. 2179. Upadki spowodowane NMC stwierdzono w 270 miotach, co stanowiło 12,39\%. Ogółem oceniono też 13986 miotów pierwszych loch pbz. NMC jako przyczyna upadków wystąpiła w 1624 miotach (11,61\%). Miotów ósmych oceniono 5004, z czego w $602(12,03 \%)$ przyczyną strat była NMC prosiąt przy urodzeniu. Straty w stadach zarodowych spowodowane NMC plasują się na pozycji drugiej, przyczyną najważniejszą i dominującą są biegunki. Małe zróżnicowanie skali strat wynikających z NMC prosiąt przy urodzeniu wskazuje, że przyczyn problemu nie należy upatrywać w płodności loch krajowych ras matecznych. Można ją uznać za optymalną w aspekcie kształtowania masy ciała noworodków. Bardziej prawdopodobne wydaje się popełnianie błędów przez hodowców w zakresie żywienia loch prośnych. Wyrównaniu masy ciała prosiąt w miocie oraz optymalizacji ich masy ciała przy urodzeniu sprzyja utrzymanie właściwej kondycji loch m.in. $\mathrm{w}$ drugim miesiącu ciąży. Podawanie lochom w słabej kondycji dodatkowej dawki paszy w tym okresie umożliwia zgromadzenie właściwych rezerw białka i tłuszczu, wpływa też korzystnie na zjawisko miogenezy płodów. Zastosowanie w końcowej fazie ciąży vs do ciąży niskiej, optymalnych dawek mieszanki, bogatszej w energię i składniki pokarmowe, o lepszej strawności, sprzyja zwiększeniu masy ciała intensywnie rosnących w tym okresie płodów oraz ich wyrównaniu. Szkolenie hodowców oraz przestrzeganie wymienionych zasad żywienia powinno w przyszłości sprzyjać zmniejszeniu liczby miotów w których wystąpi NMC prosiąt i upadki z tego tytułu. 


\title{
ANALIZA WARTOŚCI RZEŹNEJ TUCZNIKÓW RASY PUŁAWSKIEJ Z UWZGLĘDNIENIEM ICH POCHODZENIA
}

\author{
Analysis of slaughter value of Puławska breed fatteners in consider to their origin
}

\author{
Marcin Hałabis, Marek Babicz
}

\begin{abstract}
Uniwersytet Przyrodniczy w Lublinie, Instytut Hodowli Zwierząt i Ochrony Bioróżnorodności, Zakład Hodowli i Biotechnologii Świń, ul. Akademicka 13, 20-950 Lublin

e-mail: marcinhalabis@interia.pl
\end{abstract}

Wartość rzeźna jest jednym z podstawowych czynników warunkujących opłacalność produkcji świń. Na jej poziom mogą wpływać czynniki genetyczne, w tym pochodzenie tuczników w odniesieniu do linii knura - ojca i rodziny lochy - matki. Celem pracy było określenie wartości rzeźnej tuczników rodzimej rasy puławskiej z uwzględnieniem linii i rodzin jako czynnika różnicującego. W ramach doświadczenia przeprowadzono odchów i tucz 40 tuczników rasy puławskiej. Zwierzęta pochodziły z rodzin Fuki i Samy oraz linii Wicher i Sam. Uboje tuczników przeprowadzono przy średniej masie ciała $112,8 \mathrm{~kg}( \pm 5,4 \mathrm{~kg})$ w zakładach mięsnych zgodnie $\mathrm{z}$ przepisami obowiązującymi $\mathrm{w}$ zakładzie. W ocenie wartości rzeźnej tuczników uwzględniono: wydajność rzeźną, ciepłą i zimną, grubość słoniny, wysokość oka polędwicy, masę i procentowy udział wyrębów zasadniczych, masę tkanek uzyskanych z dysekcji szczegółowej polędwicy i szynki. Na podstawie masy wyrębów zasadniczych oraz ich ceny rynkowej obliczono wartość handlową tusz, a także ustalono wartość 5 najcenniejszych wyrębów.

Jak wykazano, wydajność rzeźna zimna tuczników z rodziny Samy wynosiła 79,9\% i była wyższa w porównaniu z wydajnością tuczników z rodziny Fuki o 1,8\%. W przypadku linii Wichra i Sama wartości te kształtowały się odpowiednio na poziomie 78,3\% i 80,3\%. Średnia mięsność tuczników rasy puławskiej wynosiła 55,05\% przy grubości słoniny określonej na 19,4 mm. Większym udziałem tkanki mięśniowej charakteryzowały się osobniki z rodziny Fuki $(56,75 \%$, przy grubości słoniny $14,85 \mathrm{~mm})$ i linii Wichra $(56,40 \%$, przy grubości słoniny $15,94 \mathrm{~mm}$ ). Średnia masa szynki w półtuszach badanych osobników wynosiła $10,98 \mathrm{~kg}$, natomiast schabu 4,20 kg. W odniesieniu do pochodzenia tuczników stwierdzono większe wartości w rodzinie Samy oraz linii Sama. Analogiczny rozkład wielkości zaobserwowano w aspekcie udziału tkanki mięśniowej w polędwicy i szynce. Uwzględniając rynkowe ceny poszczególnych wyrębów oraz ich masę, zanotowano, że średnia wartość handlowa półtusz ze świń rasy puławskiej wynosiła 467,17 zł. W przypadku rodzin Fuki i Samy wielkości te wyniosły odpowiednio 420,66 zł i 465,26 zł. Natomiast u linii Sama i Wichra 491,82 zł i 400,81 zł. Sumę wyrębów półtuszy uznawanych powszechnie za najcenniejsze ze względu na zawartość i jakość mięsa, tj. schab, szynka, łopatka, karkówka, boczek, wyceniono średnio na 346,63 zł, co stanowiło 74,2\% wartości całej półtuszy. Dla rodzin Fuki i Samy parametry te kształtowały się na poziomie odpowiednio 319,32 zł i 75,91\% oraz 337,60 zł i 72,56\%. Ocena podstawowych wskaźników wartości rzeźnej wykazała, że ważnym czynnikiem genetycznym wpływającym na ich poziom jest rodzina i linia, z których pochodzą tuczniki rasy puławskiej. Uzyskane dane liczbowe w zakresie umięśnienia i otłuszczenia wykazały wysoką przydatność świń rasy puławskiej do produkcji dobrej jakości materiału rzeźnego.

Badania zrealizowano w ramach projektu Biostrateg „Kierunki wykorzystania oraz ochrona zasobów genetycznych zwierząt gospodarskich w warunkach zrównoważonego rozwoju" współfinansowanego przez Narodowe Centrum Badań i Rozwoju w ramach Strategicznego programu badań naukowych i prac rozwojowych „Środowisko naturalne, rolnictwo i leśnictwo” (BIOSTRATEG2/297267/2/NCBR/2016). 


\title{
ZNACZENIE ODSETKA PLEMNIKÓW O RUCHU POSTEPOWYM DLA FREKWENCJI ZMIAN MORFOLOGICZNYCH I WYMIARÓW PLEMNIKÓW W EJAKULATACH KNURÓW
}

\author{
The importance of sperm morphology on processing for morphological changes and dimensions \\ in the ejections of the boars
}

Maria Iwanina, Stanisław Kondracki, Marcin Mackiewicz

\author{
Uniwersytet Przyrodniczo-Humanistyczny w Siedlcach, Instytut Bioinżynierii i Hodowli Zwierząt, \\ Katedra Rozrodu i Higieny Zwierząt \\ e-mail: radwan@uph.edu.pl
}

Ruchliwość plemników jest ważnym parametrem określającym jakość nasienia. Wskazuje ona na zdolności zapładniające plemników i brana jest pod uwagę przy analizie przeżywalności plemników przed procesem i po procesie zamrażania-rozmrażania nasienia. Badanie morfologii umożliwia ocenę budowy plemników i wnioskowanie o przebiegu procesu spermatogenezy oraz dostarcza informacji o częstości występowania plemników z deformacjami morfologicznymi, które mogą obniżać wskaźnik płodności knura. Zdolność poszczególnych plemników do penetracji komórki jajowej zależy od wymiarów i kształtu plemników. Celem niniejszej pracy jest określenie znaczenia odsetka plemników o ruchu postępowym dla występowania zmian morfologicznych plemników oraz wymiarów plemników w ejakulatach knurów.

Badaniami objęto 393 ejakulaty pobrane od 33 knurów. W świeżo pobranych ejakulatach określono cechy fizyczne (objętość ejakulatu, koncentracja i ruchliwość plemników, liczba plemników w ejakulacie) oraz ustalono liczbę dawek inseminacyjnych sporządzanych z jednego ejakulatu. Ejakulaty pogrupowano na dwie grupy według kryterium odsetka plemników wykazujących ruch postępowy, wyodrębniając: ejakulaty, w których odsetek plemników ruchliwych wynosił 70\% (grupa I), ejakulaty, w których odsetek plemników ruchliwych wynosił $80 \%$ (grupa II). W każdym ejakulacie określono frekwencję zmian morfologicznych plemników oraz wykonano pomiary plemników.

Zaobserwowano, że ejakulaty o większej ruchliwości plemników zawierają więcej plemników $(\mathrm{P} \leq 0,05)$. Ejakulaty o mniejszej ruchliwości plemników (grupa I) miały większy odsetek plemników ze zmianami głównymi niż ejakulaty o większej ruchliwości plemników (grupa II). W ejakulatach z grupy I udział plemników ze zmianami głównymi był istotnie większy niż w ejakulatach z grupy II $(\mathrm{P} \leq 0,05)$. Do najczęściej występujących głównych zmian morfologicznych należały plemniki z kroplą proksymalną i plemniki z wadą Daga. Obie te formy morfologiczne częściej występowały w ejakulatach o mniejszej ruchliwości plemników. Nie udowodniono jednak zależności frekwencji tych zmian od ruchliwości plemników w ejakulacie. Częstość występowania podrzędnych zmian morfologicznych nie wykazywała istotnej zależności od ruchliwości plemników w ejakulacie. Najczęściej występującymi zmianami podrzędnymi były plemniki z pojedynczą pętlą witki (około $2 \%$ plemników), plemniki z distalną kroplą protoplazmy (około 0,6\% plemników) oraz plemniki z główką wolną normalną (około 0,6\% plemników). Plemniki z ejakulatów o większej ruchliwości (grupa II) miały główki o nieco większej szerokości niż plemniki z ejakulatów o mniejszej ruchliwości plemników (grupa I). Długość główek plemników zmniejszała się jednak nieznacznie wraz ze wzrostem ruchliwości plemników w ejakulacie. Plemniki w ejakulatach o większej ruchliwości (grupa II) miały także większe pole powierzchni główki (o 1,07 $\mu \mathrm{m}$ ), co zostało potwierdzone statystycznie $(\mathrm{P} \leq 0,05)$. 


\title{
WPEYW MASY URODZENIOWEJ PROSIĄT NA WYNIKI PRODUKCYJNE
}

The effect of the birth weight of piglets on performance results

\author{
Paweł Jaroś, Justyna Więcek, Anna Rekiel, Martyna Batorska, Arkadiusz Biernacki \\ Szkoła Główna Gospodarstwa Wiejskiego w Warszawie, Katedra Szczegółowej Hodowli Zwierząt, Pracownia Hodowli Trzody \\ Chlewnej, ul. Ciszewskiego 8, 02-786 Warszawa \\ e-mail: justyna_wiecek@sggw.pl
}

Masa ciała w dniu urodzenia ma decydujący wpływ na przeżywalność osesków oraz ich wyniki w okresie odchowu i tuczu. Najlżejsze prosięta pobierają zazwyczaj pokarm matczyny z sutków mało atrakcyjnych pod względem mleczności, narażone są na niedożywienie i przygniecenia. Jeśli przeżyją czas odchowu przy matce, zwykle w dalszych etapach tuczu wolniej rosną i charakteryzują się mniejszą żernością w porównaniu z osobnikami, które w dniu urodzenia miały optymalną (ok. 1,5 kg) lub dużą masę ciała.

Celem pracy było określenie wpływu masy ciała prosiąt $\mathrm{w}$ dniu urodzenia na ich przeżywalność i wyniki produkcyjne.

Badania przeprowadzono na 104 prosiętach pochodzących od 9 loch. Zwierzęta ważono indywidualnie w 1., 21., 28., 60. i 171. dniu życia. Prosięta odchowywano w kojcach porodowych przez pierwsze 28 dni życia, następnie w dwóch kojcach grupowych. Prosięta od 8. dnia życia miały dostęp do paszy ad libitum. W okresie tuczu dwufazowego żywione były zgodnie z zapotrzebowaniem. Na podstawie ważeń wyliczono przyrosty dobowe $\mathrm{w}$ poszczególnych okresach życia, współczynniki korelacji Pearsona między masą ciała prosięcia $\mathrm{w}$ dniu urodzenia a liczebnością miotu oraz między masą ciała $\mathrm{w}$ dniu urodzenia a masą ciała w 21., 28., 60. i 171. dniu życia.

Średnia liczba prosiąt urodzonych i odchowanych w miocie wynosiła odpowiednio 11,5 i 10,7 prosięcia. Różnica między masą ciała najlżejszego i najcięższego oseska w pierwszym dniu życia wynosiła $1,8 \mathrm{~kg}$ (min. 0,5 - max. 2,3 kg) a w 171. dniu $61 \mathrm{~kg}$ (min. 89 - max. $150 \mathrm{~kg}$ ). Do 21. dnia życia przeżyło 99 prosiąt. Upadki stwierdzono w grupie najlżejszych prosiąt (masa poniżej $1 \mathrm{~kg}$ ). W całym okresie obserwacji śmiertelność wyniosła 7\%. Jak wynika z obserwacji własnych i literatury tematu prosięta o małej masie urodzeniowej są bardziej narażone na upadki z uwagi na zwiększone ryzyko zaburzeń układu nerwowego, oddechowego, pokarmowego i krążeniowego (Declerck i in. 2016). Często przyczyną upadków w pierwszych tygodniach życia jest martwicze zapalenie jelit i upośledzenie syntezy argininy (Wu i in. 2004). Wartość współczynnika korelacji między liczebnością miotu a masą urodzeniową prosiąt wynosiła $-0,223(\mathrm{P} \leq 0,05)$. Wartości współczynników korelacji między masą prosięcia w dniu urodzenia a masą w 21., 28., 60. i 171. dniu życia były dodatnie i mieściły się w zakresie od $+0,627(\mathrm{P} \leq 0,01)$ do $+0,709(\mathrm{P} \leq 0,01)$. Zwierzęta o małej masie urodzeniowej (poniżej $1,1 \mathrm{~kg}$ ) przez cały okres tuczu charakteryzowały się mniejszymi przyrostami dobowymi i w rezultacie po 170 dniach życia osiągnęły znacznie mniejszą masę ciała w porównaniu ze świniami o masie urodzeniowej powyżej $1,1 \mathrm{~kg}$.

W badaniach własnych liczebność miotów była przeciętna. Można stwierdzić, że niska masa przy urodzeniu nie była spowodowana dużą płodnością loch. Często przyczyną rodzenia się małych prosiąt w miocie są błędy żywieniowe w stosunku do loch prośnych. Hodowcy i producenci powinni zwrócić szczególną uwagę na żywienie loch w okresie ciąży wysokiej. Niedoborowe żywienie loch w okresie najintensywniejszego zwiększania masy płodów decyduje o niskiej masie urodzeniowej i słabych wynikach produkcyjnych potomstwa. 


\title{
WPEYW CZĘ̧SCIOWEGO ZASTĄPIENIA BIAŁKA POEKSTRAKCYJNEJ ŚRUTY SOJOWEJ BIAEKIEM POCHODZACYM ZE ŚRUTY GUAR (CYAMOPSIS TETRAGONOLOBA) NA EFEKTYWNOŚĆ TUCZU ŚWIŃ
}

The influence of the partial replacement of protein of soybean meal with protein derived from guar meal

(Cyamopsis tetragonoloba) on the effectiveness of the fattening of pigs

\author{
Krzysztof Karpiesiuk, Wojciech Kozera, Dorota Bugnacka, Anna Woźniakowska, Barbara Jarocka
Uniwersytet Warmińsko-Mazurski w Olsztynie, Katedra Hodowli Trzody Chlewnej, ul. Oczapowskiego 5, 10-719 Olsztyn e-mail: krzysztof.karpiesiuk@uwm.edu.pl

Produkcja zwierzęca stoi przed wyzwaniem związanym z dostępnością taniej i jednocześnie wysokiej jakości paszy. Poszukuje się rozwiązań polegających na wprowadzaniu do pasz dodatków, które mogą wpłynąć na poprawę cech smakowych, dietetycznych i jakościowych mięsa. Obecnie żywienie zwierząt monogastrycznych, w tym trzody chlewnej, prowadzone jest głównie w oparciu o zboża oraz poekstrakcyjną śrutę sojową (PŚS) jako główny komponent białkowy.

Celem badań była ocena wpływu zastosowania śruty guar jako komponentu wysokobiałkowego stanowiącego ekwiwalent białka poekstrakcyjnej śruty sojowej w żywieniu tuczników. Doświadczenie przeprowadzono na 64 tucznikach mieszańcach F2 pochodzących z krzyżowania towarowego prostego [ $($ ( $p$ polska biała zwisłoucha $\times \hat{\sigma}$ wielka biała polska) $\times \hat{\sigma}(q$ pietrain $\times \hat{\jmath}$ duroc $)$. Tucz prowadzono od średniej masy ciała $30,1 \mathrm{~kg}$ do $112,2 \mathrm{~kg}$. Zwierzęta z grupy I (kontrolnej) żywione były zbożowo-sojową mieszanką pełnoporcjową, natomiast w mieszankach przeznaczonych dla tuczników z grup doświadczalnych część białka poekstrakcyjnej śruty sojowej zastąpiono białkiem śruty guar w ilościach odpowiednio: 25, 50 i 75\% (II, III, VI).

Tabela 1. Średnie wyniki tuczu zwierząt doświadczalnych

\begin{tabular}{|c|c|c|c|c|c|c|}
\hline \multirow{2}{*}{ Wyszczególnienie } & & \multicolumn{4}{|c|}{ Grupa } & \multirow{2}{*}{ Ogółem } \\
\hline & & $\mathrm{I}$ & II & III & IV & \\
\hline Liczba sztuk & $\mathrm{n}$ & 16 & 16 & 16 & 16 & 64 \\
\hline \multirow{2}{*}{ Długość tuczu [dni] } & $\bar{x}$ & 97 & 98 & 101 & 101 & 99 \\
\hline & $\mathrm{s}$ & 7,2 & 7,5 & 7,5 & 7,5 & 7,6 \\
\hline \multirow{2}{*}{ Początkowa masa ciała $[\mathrm{kg}]$} & $\bar{x}$ & 30 & 30,1 & 30,1 & 30,0 & 30,1 \\
\hline & $\mathrm{s}$ & 4,36 & 3,76 & 4,76 & 3,33 & 3,99 \\
\hline \multirow{2}{*}{ Końcowa masa ciała $[\mathrm{kg}]$} & $\bar{x}$ & $115,3^{\mathrm{a}}$ & $117,0^{\mathrm{a}}$ & $109,8^{\mathrm{b}}$ & $106,8^{\mathrm{b}}$ & 112,2 \\
\hline & $\mathrm{s}$ & 5,78 & 5,95 & 8,5 & 9,43 & 8,48 \\
\hline \multirow{2}{*}{ Przyrosty dobowe $[\mathrm{g}]$} & $\bar{x}$ & $885^{\mathrm{a}}$ & $895^{\mathrm{a}}$ & $792^{b}$ & $762^{b}$ & 833 \\
\hline & $\mathrm{s}$ & 88 & 86 & 111 & 120 & 116 \\
\hline Dzienne spożycie paszy [kg] & $\bar{x}$ & 2,43 & 2,50 & 2,30 & 2,24 & 2,37 \\
\hline Zużycie paszy na kg przyrostu m.c. [kg] & $\bar{x}$ & 2,77 & 2,79 & 2,96 & 3,01 & 2,89 \\
\hline
\end{tabular}

Częściowa (25\%) substytucja białka poekstrakcyjnej śruty sojowej w mieszankach pełnoporcjowych dla tuczników białkiem pochodzącym ze śruty guar nie wpłynęła negatywnie na wyniki produkcyjne badanych świń. Jednakże tego poziomu zastąpienia białka poekstrakcyjnej śruty sojowej białkiem ze śruty guar nie należy przekraczać ze względu na obniżenie efektywności tuczu. Z uwagi na zbyt małą liczbę badań związanych $\mathrm{z}$ wykorzystaniem śruty guar jako alternatywy dla poekstrakcyjnej śruty sojowej należy w dalszym ciągu prowadzić doświadczenia z wykorzystaniem tego surowca. 


\title{
KSZTAŁTOWANIE SIE DOCHODU Z GOSPODARSTWA UTRZYMUJĄCEGO TRZODĘ CHLEWNĄ PO WEJŚCIU POLSKI DO UNI EUROPEJSKIEJ - NA PODSTAWIE DANYCH Z FADN
}

Development of revenue from pig farms after Poland's accession to the European Union on the basis of FADN

\author{
Krzysztof Karpiesiuk, Wojciech Kozera, Dorota Bugnacka, Anna Woźniakowska, Barbara Jarocka
Uniwersytet Warmińsko-Mazurski w Olsztynie, Katedra Hodowli Trzody Chlewnej, ul. Oczapowskiego 5, 10-719 Olsztyn e-mail: krzysztof.karpiesiuk@uwm.edu.pl

Produkcja rolnicza stanowi wypadkową wielu czynników, wynikających zarówno ze specyfiki danego terenu, poziomu rozwoju gospodarczego, sytuacji rynkowej oraz stanu polityki rolnej. Dochód w gospodarstwach rolnych produkcjących żywiec wieprzowy uzależniony jest od wielu czynników. Jednym $\mathrm{z}$ najważniejszych jest poziom cen sprzedaży trzody chlewnej oraz cena pasz stosowanych w żywieniu. W produkcji trzody chlewnej występuje zjawisko tzw. cykli świńskich, czyli cykliczne wahania cen wywołane zmianami podaży żywca wieprzowego

Celem pracy jest analiza zmian, jakie wystąpiły w latach 2004-2016 w dochodach gospodarstw ujętych w systemie FADN utrzymujących trzodę chlewną. Badania przeprowadzono, wykorzystując dane Polskiego FADN pobrane w szeregach czasowych (https://fadn.pl/publikacje/szeregi-czasowe/). Analizie poddano następujące zmienne FADN:

- dochód z rodzinnego gospodarstwa rolnego (zł) - SE 420,

- dochód z rodzinnego gospodarstwa na osobę pełnozatrudnioną rodziny (zł/FWA) - SE 430.

Wykres 1. Zmiana dochodu $\mathrm{z}$ rodzinnego gospodarstwa oraz dochodu $\mathrm{z}$ rodzinnego gospodarstwa na osobę pełnozatrudnioną w gospodarstwach sklasyfikowanych według typu użytkowego specjalizujących się w chowie trzody chlewnej

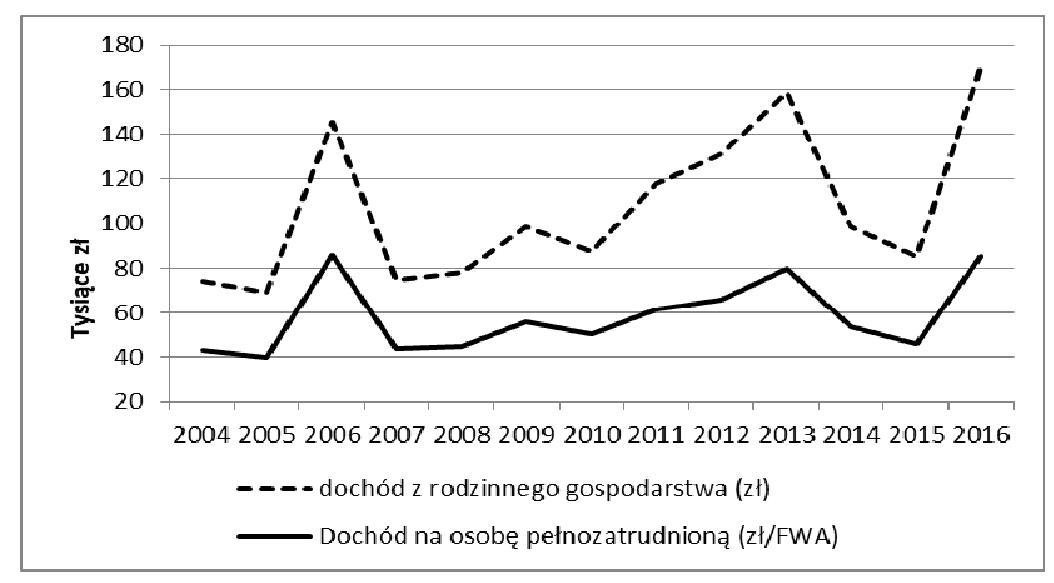

Ze względu na duże zmiany cen żywca wieprzowego w poszczególnych latach następowały wahania związane $\mathrm{z}$ dochodem uzyskiwanym $\mathrm{w}$ tych gospodarstwach. $\mathrm{Z}$ danych przedstawionych na wykresie wynika, że pomimo wahań, jakie następowały w latach 2007-2010, 2014-2015 dochód z rodzinnego gospodarstwa rolnego produkującego trzodę chlewną wzrósł w 2016 r. ponad 2-krotnie w porównaniu z dochodem z roku wstąpienia Polski do Uni Europejskiej. Na podobnym poziomie nastąpiła zmiana dochodu na osobę pełnozatrudnioną w gospodarstwie rodzinnym. Najwyższy dochód $(85621,09$ zf) $\mathrm{z}$ rodzinnego gospodarstwa rolnego na osobę pełnozatrudnioną uzyskały gospodarstwa w 2006 r., natomiast najniższy w 2005 r. (40114,46 zł). 


\title{
PODSTAWOWE PARAMETRY JAKOŚCI MIĘSA TUCZNIKÓW DANBRED NAIMA I RASY PUŁAWSKIEJ
}

\author{
Basic parameters of meat quality of Danbred Naima and Pulawska breed fatteners
}

\author{
Anna Kasprzyk, Marek Babicz \\ Uniwersytet Przyrodniczy w Lublinie, Instytut Hodowli Zwierząt i Ochrony Bioróżnorodności, Zakład Hodowli i Biotechnologii \\ Świń, ul. Akademicka 13, 20-950 Lublin \\ e-mail: anna.kasprzyk@up.lublin.pl
}

Jakość mięsa powinna być pierwszoplanowym celem w produkcji tuczników, w sytuacji bowiem pełnej dostępności rynkowej szerokiego asortymentu produktów i dużej podaży mięsa bardzo istotnym zagadnieniem jest produkcja surowca dobrej jakości, spełniającego w głównej mierze oczekiwania konsumentów. W kraju prawie wszystkie nowoczesne i zmodernizowane fermy prowadzą produkcję tuczników w oparciu o zwierzęta importowane, pochodzące ze stad hodowlanych wykorzystujących odpowiednie programy krzyżowania. Producenci wybierają zwierzęta o wysokiej wartość użytkowej, nie zwracają uwagi na jakość uzyskanego mięsa. W produkcji towarowej nastawionej na maksymalizację zysków czynnikiem, który w sposób zasadniczy wpływa na jakość mięsa, jest genotyp użytkowanych świń.

Celem pracy była ocena jakości mięsa świń rasy puławskiej oraz tuczników pochodzących spośród reprezentatywnej grupy importowanych nowoczesnych mieszańców handlowych wykorzystywanych w krajowej produkcji mięsa. Doświadczeniem objęto 3 grupy tuczników: grupa I (Danbred), grupa II (Naima) i grupa III (rasa puławska). W każdej grupie było po 16 zwierząt (stosunek loszek do wieprzków 1: 1). Tucz świń prowadzono od początkowej masy ciała $30 \mathrm{~kg} \pm 2 \mathrm{~kg}$. Zwierzęta trzymano po $20 \mathrm{szt}$. w kojcu w jednakowych warunkach środowiskowych. Tucz podzielono na 2 okresy. Skład mieszanki pełnoporcjowej: w I okresie tuczu 13,27 MJ/kg energii metabolicznej, 167,9 g/kg surowego białka i $10,8 \mathrm{~g} / \mathrm{kg}$ lizyny; w II okresie tuczu 12,61 MJ/kg energii metabolicznej, 143,8 g/kg surowego białka i 8,6 g/kg lizyny. Zwierzęta żywiono do woli paszą sypką z automatów paszowych, przy stałym dostępie do wody. Po uzyskaniu masy ciała 103-105 kg tuczniki zostały poddane ubojowi w zakładzie mięsnym zgodnie z rutynowymi procedurami. Dokonano pomiaru $\mathrm{pH}_{45}$ i $\mathrm{pH}_{24}$ mięśnia longissimus lumborum (LL) za pomocą cyfrowego miernika CPU Star. Parametry barwy mięsa (CIE L* a* b*) określano za pomocą spektrofotometru sferycznego X-Rite Series 8200. W rozdrobnionych próbkach oznaczano podstawowy skład chemiczny: zawartość wody metodą suszenia wg PN ISO 1442:2000, białka metodą Kjeldahla wg PN 75/A-04018, tłuszczu metodą Soxhleta wg PN ISO 1444:2000 i związków mineralnych w postaci popiołu wg PN-ISO 936:2000. Do analizy statystycznej wykorzystano jednoczynnikową analizę wariancji, a do obliczeń program Statistica 5.0. Istotność różnic pomiędzy grupami obliczono testem Duncana przy $\mathrm{P} \leq 0,05$ i $\mathrm{P} \leq 0,01$. Analizując właściwości technologiczne mięśnia najdłuższego grzbietu, stwierdzono istotnie $(\mathrm{P} \leq 0,01)$ wyższą wartość $\mathrm{pH}_{45}$ u tuczników Naima i Danbred w porównaniu z tucznikami rasy puławskiej. Wartości $\mathrm{pH}_{24}$ badanego surowca były typowe dla mięsa normalnego. Oceniając parametry barwy mięsa, stwierdzono, że tuczniki rasy puławskiej w porównaniu z tucznikami Danbred i Naima miały mięsień ciemniejszy i jednocześnie charakteryzujący się większym udziałem barwy czerwonej. Jednakże różnice te nie były statystycznie istotne. Mięso tuczników rasy puławskiej odznaczało się najmniejszą ilością wody i największą zawartością białka. W odniesieniu do zawartości tłuszczu nie obserwowano różnic statystycznie istotnych pomiędzy analizowanymi grupami. Istotnie wyższy udział popiołu zanotowano w przypadku mięsa tuczników rasy puławskiej w porównaniu z mięsem z pozostałych grup. 


\title{
CHARAKTERYSTYKA PARAMETRÓW FIZYCZNYCH I CHEMICZNYCH NEREK ŚWIŃ RASY POLSKIEJ BIAŁEJ ZWISŁOUCHEJ
}

Characteristics of the physical and chemical parameters of the kidneys of Polish Landrace pigs

\author{
Kinga Kropiwiec-Domańska, Marek Babicz \\ Uniwersytet Przyrodniczy w Lublinie, Instytut Hodowli Zwierząt i Ochrony Bioróżnorodności, Zakład Hodowli i Biotechnologii \\ Świń, ul Akademicka 13, 20-950 Lublin \\ e-mail: kingakropiwiec@gmail.com
}

Nerki wieprzowe to parzysty, jednopłatowy czerwono-brunatny narząd miąższowy o kształcie spłaszczonego ziarna fasoli. W organizmie zwierzęcym pełnią wiele ważnych funkcji, m.in. oczyszczają krew, biorą udział w procesach metabolicznych, a także odgrywają ważną rolę wewnątrzwydzielniczą. W przemyśle spożywczym zaliczane są do grupy jadalnych pubojowych surowców ubocznych. Nerki mogą być przeznaczone do bezpośredniego spożycia w formie potrawy smażonej, stanowią surowiec do produkcji wędlin podrobowych oraz farszów wyrobów garmażeryjnych.

Celem pracy jest ocena jakości technologicznej i konsumpcyjnej nerek pozyskanych z tuczników rasy polskiej białej zwisłouchej.

Badania przeprowadzono na grupie 30 tuczników rasy polskiej białej zwisłouchej. Na pozyskanych nerkach oznaczono: masę, stężenie jonów wodorowych $\left(\mathrm{pH}_{45}, \mathrm{pH}_{24}\right)$, procentowy udział wody luźnej, skład chemiczny (woda, białko, kolagen, tłuszcz, makro- i mikroelementy) oraz kaloryczność $100 \mathrm{~g}$ produktu. Ponadto oznaczono profil kwasów tłuszczowych, wyliczono procentowy udział poszczególnych grup kwasów tłuszczowych, ich wzajemny stosunek oraz wskaźniki dietetyczne: aterogenności (AI) i tombogenności (TI).

$\mathrm{Z}$ przeprowadzonych analiz wynika, iż $\mathrm{pH}_{45}$ nerek tuczników rasy pbz wynosiło 6,29 , a $\mathrm{pH}_{24}$ wzrosło do wartości 6,58. Nerki w porównaniu z mięsem wieprzowym charakteryzowały się większym udziałem wody, mniejszą zawartością białka oraz porównywalną tłuszczu. Nerki wieprzowe zawierały duże ilości kwasów nienasyconych, w tym kwasów omega-3 i omega-6 oraz charakteryzowały się korzystnymi wartościami wskaźnika miażdżycowego - aterogenności (AI) i wskaźnika zakrzepowego - trombogenności (TI). Stwierdzono również, że nerki tuczników rasy pbz są dobrym źródłem manganu, cynku i miedzi. 


\title{
ZALEŻNOŚĆ POMIĘDZY ECHOTEKSTURĄ PRZEKROJU POPRZECZNEGO MIEŚSINIA NAJDŁUŻSZEGO GRZBIETU W PRZYŻYCIOWEJ ORAZ POUBOJOWEJ DIAGNOSTYCE ULTRASONOGRAFICZNEJ ŚWIŃ
}

Relationship between echotexture of musculus longissimus dorsi cross-section after in-vivo or post mortem USG diagnostic of pigs

\author{
Michał Marszałek $^{1}$, Martyna Małopolska ${ }^{1}$, Tomasz Schwarz ${ }^{1}$, Maciej Murawski², \\ Mariola Pabiańczyk ${ }^{1}$, Ryszard Tuz ${ }^{1}$, Jacek Nowicki ${ }^{1}$
${ }^{1}$ Uniwersytet Rolniczy im. Hugona Kołłątaja w Krakowie, Instytut Nauk o Zwierzętach, Zakład Hodowli Trzody Chlewnej i Drobnego Inwentarza
${ }^{2}$ Uniwersytet Rolniczy im. Hugona Kołłątaja w Krakowie, Instytut Nauk o Zwierzętach, Katedra Biotechnologii Zwierząt e-mail:michal.marszalek@student.urk.edu.pl

Techniki wykorzystujące ultradźwięki uważane są za najważniejsze metody diagnostyczne, pozwalające na nieinwazyjny wgląd w strukturę tkankową tuszy. Celem badań było określenie zróżnicowania wartości pikseli pomiędzy przyżyciowym i poubojowym obrazowaniem USG przekroju poprzecznego mięśnia najdłuższego grzbietu świń.

Materiał badawczy stanowiło 49 tuczników rasy pbz pochodzących z doświadczenia żywieniowego prowadzonego w SKURTCh, w Zakładzie Doświadczalnym Instytutu Zootechniki PIB w Chorzelowie. Zwierzęta w tuczu kontrolnym podzielono na cztery grupy doświadczalne o zróżnicowanej $(0,20,40$ i $60 \%)$ zawartości ziarna żyta populacyjnego w mieszance paszowej. Przed ubojem zwierząt przeprowadzono diagnostykę USG przekroju poprzecznego mięśnia najdłuższego grzbietu, którą powtórzono na tuszy po uboju i wytrzewieniu zwierząt, stosując konweksową sondę USG o częstotliwości $5 \mathrm{MHz}$. Uzyskane skany zostały poddane analizie parametrów echo tekstury w programie Image-Pro Premier, pod kątem średniej, odchylenia standardowego, minimalnej oraz maksymalnej intensywności piksela. Uzyskane dane poddano analizie statystycznej w programie Statistica, porównując parametry pikselizacji pomiędzy diagnostyką przyżyciową i poubojową testem $t$-Studenta dla par skorelowanych. Współzależność analityczną skanów określono za pomocą współczynnika korelacji Pearsona.

W diagnostyce przyżyciowej wartość wszystkich parametrów pikselizacji w obrazie USG była mniejsza, a tym samym obraz ciemniejszy niż w badaniu poubojowym. Pomimo nieznacznych różnic numerycznych okazały się one wysoko istotne, co oznacza równomierny rozkład danych w parach skanów (tabela). Współczynnik korelacji pomiędzy diagnostyką przyżyciową i poubojową dla średniej wartości piksela wyniósł 0,436 i był wysoko istotny $(\mathrm{P}<0,01)$, a dla pozostałych parametrów obrazu nie przekraczał wartości 0,2 i był nieistotny ze statystycznego punktu widzenia.

\begin{tabular}{|l|c|c|c|}
\hline \multicolumn{1}{|c|}{ Parametry obrazu } & Diagnostyka przyżyciowa & Diagnostyka poubojowa & Istotność różnic \\
\hline Średnia wartość piksela & $35,86 \pm 6,35$ & $40,90 \pm 7,42$ & $\mathrm{P}<0,001$ \\
\hline Odchylenie piksela & $17,55 \pm 1,69$ & $20,89 \pm 1,88$ & $\mathrm{P}<0,001$ \\
\hline Maksymalna wartość piksela & $122,67 \pm 7,06$ & $127,06 \pm 2,08$ & $\mathrm{P}<0,001$ \\
\hline Minimalna wartość piksela & $0,00 \pm 0,00$ & $0,00 \pm 0,00$ & - \\
\hline Heterogeniczność piksela & $0,13 \pm 0,04$ & $0,21 \pm 0,06$ & $\mathrm{P}<0,001$ \\
\hline
\end{tabular}

Wyniki badań wskazują na wysoki poziom współzależności obrazu pomiędzy przyżyciową i poubojową diagnostyką USG mięśnia najdłuższego grzbietu świń w zakresie najważniejszego parametru, którym jest średnia wartość piksela, odzwierciedlająca twardość tkanki.

Finansowanie: NCBR grant ENERGYFEED umowa nr BIOSTRATEG2/297910/12/NCBR/2016. 


\title{
PORÓWNANIE WYNIKÓW UŻYTKOWOŚCI ROZPŁODOWEJ LOCH CZYSTORASOWYCH Z UŻYTKOWOŚCIĄ ROZPŁODOWĄ LOCH MIESZAŃCÓW
}

Comparison of reproductive performance of purebred Yorkshire with crossbred Yorkshire $\times$ Landrace sows

\author{
Beata Matysiak, Anna Sosnowska, Maria Kawęcka, Anita Kołodziej-Skalska, Anna Dorosińska
}

Zachodniopomorski Uniwersytet Technologiczny w Szczecinie, Katedra Hodowli Trzody Chlewnej, Żywienia Zwierząt i Żywności, ul. Klemensa Janickiego 29, 71- 270 Szczecin

e-mail: anna-sosnowska@zut.edu.pl

Nowoczesny chów i hodowla trzody chlewnej wiąże się bezpośrednio z opłacalnością produkcji, a zatem z bilansem kosztów związanych z otrzymaniem tucznika i ceną, jaką się za niego uzyska, co oznacza umiejscowienie tego procesu w aktualnych warunkach ekonomicznych. Posiadanie zwierząt o wysokiej wartości genetycznej jest elementem zmniejszającym koszty produkcji. Z uwagi na fakt, że cechy użytkowości rozpłodowej loch w znaczącym stopniu decydują o opłacalności produkcji trzody chlewnej, dąży się poprzez selekcję do zwiększania liczby prosiąt urodzonych w miocie.

Celem pracy była analiza wyników użytkowości rozpłodowej loch czystorasowych yorkshire oraz mieszańców danish landrace $\times$ yorkshire, utrzymywanych w fermie wielkotowarowej. Na podstawie dokumentacji oceniono 399 loch czystorasowych i 367 loch mieszańców.

Tabela 1. Użytkowość rozpłodowa loch w 4 kolejnych miotach

\begin{tabular}{|l|r|r|r|r|r|r|r|r|}
\hline \multirow{2}{*}{ Cecha } & \multicolumn{4}{|c|}{ Yorkshire (Y) } & \multicolumn{3}{c|}{ Yorkshire $\times$ Landrace $(\mathrm{Y} \times \mathrm{L})$} \\
\cline { 2 - 9 } & 1 miot & 2. miot & 3. miot & 4 . miot & 1. miot & 2. miot & 3. miot & 4 . miot \\
\hline Liczba prosiąt w miocie: & & & & & & & & \\
- urodzonych ogółem & 12,4 & 14,7 & 15,2 & 14,5 & 14,2 & 15,6 & 15,9 & 16,2 \\
- martwo urodzonych & 1,2 & 0,8 & 1,2 & 1,3 & 0,9 & 1,1 & 1,2 & 1,6 \\
- żywo urodzonych & 11,2 & 13,8 & 14,0 & 13,2 & 13,3 & 14,5 & 14,7 & 14,6 \\
- odsadzonych w 29. dniu życia & 9,7 & 10,3 & 10,3 & 9,2 & 12,4 & 11,6 & 11,2 & 11,5 \\
\hline Straty prosiąt do 29. dnia życia [\%] & 13,7 & 25,3 & 26,9 & 31,0 & 13,0 & 21,8 & 24,8 & 24,3 \\
\hline
\end{tabular}

Zgodnie $\mathrm{z}$ wieloma danymi lochy mieszańce od 1. do 4. miotu rodziły więcej prosiąt żywych w miocie w porównaniu z lochami czystorasowymi. Straty prosiąt do odsadzenia zwiększały się znacząco wraz z liczbą prosiąt urodzonych. Nasuwa się pytanie, czy zwiększanie liczby prosiąt urodzonych w miocie jest uzasadnione fizjologicznie i ekonomicznie, szczególnie że wysoki odsetek upadków prosiąt jest problemem w wielu gospodarstwach. Wraz ze wzrostem liczby prosiąt urodzonych prosięta rodzą się z mniejszą masą ciała i wymagają większej uwagi i dokarmiania droższymi preparatami mlekozastępczymi lub np. sproszkowaną siarą krów czy preparatami jogurtowymi, co generuje wzrost kosztów produkcji. Wyrównanie masy ciała ma kluczowe znaczenie przy odsadzaniu prosiąt, dlatego zmusza do przesadzania ich do loch zastępczych (mamek), tworzenia żłobków. Jest to czasochłonne, wymaga często dodatkowej przestrzeni $\mathrm{w}$ chlewni. Wiele z wymienionych preparatów czy zabiegów stosuje się na fermie, mimo to występuje znaczny procent strat. 


\section{EFEKTYWNOŚĆ PRODUKCJI WARCHLAKÓW NA PRZYKŁADZIE FERMY UTRZYMUJĄCEJ STADO 175 LOCH}

Effectiveness of piglets production in the herd of 175 sows

Wanda Milewska, Damian Jasiński Uniwersytet Warmińsko-Mazurski w Olsztynie, Katedra Hodowli Trzody Chlewnej, ul. Oczapowskiego 5, 10-719 Olsztyn
e-mail: malwa@uwm.edu.pl

Duży import świń z Danii, Holandii oraz Niemiec wymusza poszukiwanie krajowych rozwiązań, które mogą zostać wdrożone do praktyki. Większość polskich tuczarni nie jest jednak przekonana do polskiego wsadu (prosiąt/warchlaków), gdyż jak dotąd nie byliśmy w stanie konkurować z zachodnimi producentami. Jednak dynamiczny rozwój i ciągłe doskonalenie ras czystych i kwalifikowanie jako zwierząt hodowlanych mieszańców dwurasowych zmienia ten pogląd. Celem pracy było określenie efektywności produkcji warchlaków w chlewni utrzymującej stado 175 loch. Badania przeprowadzono w okresie od lipca do września 2017 r. w miejscowości Dąbek, w powiecie mławskim, w województwie mazowieckim. Do najważniejszej infrastruktury należy wybudowana w 2015 r. chlewnia na 175 loch oraz 3 tuczarnie po 500 sztuk każda. Materiał zwierzęcy stanowiło 30 miotów urodzonych przez lochy rasy WBP/PBZ kryte knurami rasy pietrain (Maxter), w tym były: 4 mioty pierwsze, 12 miotów drugich, 8 trzecich, 6 czwartych. Wyniki przedstawiono w poniższej tabeli.

\begin{tabular}{|c|c|c|c|c|c|c|}
\hline \multirow{2}{*}{ Grupa - miot } & \multicolumn{4}{|c|}{ Liczba prosiąt w kolejnych miotach } & \multirow{2}{*}{$\begin{array}{c}\text { Masa ciała } \\
\text { przy urodzeniu } \\
\mathrm{kg} \\
\end{array}$} & \multirow{2}{*}{$\begin{array}{c}\text { Straty prosiąt } \\
\%\end{array}$} \\
\hline & ogółem & żywych & martwych & w 21. dniu & & \\
\hline 1 & 13,75 & $13,75^{\mathrm{b}}$ & 0,00 & 13,00 & $1,34^{\mathrm{a}}$ & 5,11 \\
\hline 2 & 15,83 & $15,58^{\mathrm{c}}$ & 0,08 & 12,50 & $1,16^{\mathrm{b}}$ & 19,52 \\
\hline 3 & 16,00 & $16,00^{\mathrm{a}}$ & 0,00 & 12,25 & $1,13^{\text {bd }}$ & 22,54 \\
\hline 4 & 14,83 & $13,66^{\text {bd }}$ & 1,83 & 11,66 & $1,29^{\mathrm{c}}$ & 13,02 \\
\hline Ogółem & 15,40 & 15,06 & 0,40 & 12,33 & 1,20 & 17,10 \\
\hline
\end{tabular}

Lochy wbp $\times$ pbz kryte knurem rasy pietrain (Maxter) urodziły liczne mioty i dobrze je odchowały. Straty prosiąt do wieku 21. dni w pierwszym miocie były niskie. Masa ciała prosiąt przy urodzeniu miała istotny wpływ $(\mathrm{P}<0,01)$ na kształtowanie się strat prosiąt w odchowie. Uzyskane wyniki nie odbiegają od podawanych przez innych autorów, zarówno krajowych, jak i zagranicznych, co pozwala mieć nadzieję na poprawę sytuacji na rynku produkcji prosiąt/warchlaków do tuczu. Na polskiej wsi należy podtrzymać tradycję produkcji tuczników pochodzących od polskich producentów prosiąt/warchlaków rodzimych ras, by przestać być „tuczarnią Europy” i uniezależnić się od kosztownego importu. 


\title{
PORÓWNANIE UŻYTKOWOŚCI ROZPŁODOWEJ LOCH PIC I WBP × PBZ
}

\author{
Comparison of reproductive performance of PIC and PLW $\times$ PL sows
}

\section{Wanda Milewska, Sandra Szepietowska}

\begin{abstract}
Uniwersytet Warmińsko-Mazurski w Olsztynie, Katedra Hodowli Trzody Chlewnej, ul. Oczapowskiego 5, 10-719 Olsztyn e-mail:malwa@uwm.edu.pl
\end{abstract}

Celem pracy było porównanie użytkowości rozpłodowej loch PIC i mieszańców F1 (wbp × pbz) krytych knurami duroc $\times$ pietrain. Obserwacje przeprowadzono w rodzinnym gospodarstwie rolnohodowlanym, położonym $\mathrm{w}$ województwie podlaskim, w powiecie wysokomazowieckim. Materiał doświadczalny stanowiło 40 loch, które podzielono na dwie grupy: I - PIC (20 szt.), II - F1 (wbp × pbz) (20 szt.). Od loch PIC uzyskano 29 miotów, a od wbp $\times$ pbz -33 . Analizie poddano następujące cechy: liczbę prosiąt żywo urodzonych w miocie, martwych, ogółem, odsadzonych w 28. dniu, straty prosiąt do 28. dnia w szt. i przeżywalność [\%].

\begin{tabular}{|l|c|c|c|}
\hline \multicolumn{1}{|c|}{ Grupa } & PIC & wbp $\times$ pbz & $\bar{x} \pm \mathrm{s}$ \\
\hline $\begin{array}{l}\text { Liczba prosiąt } \\
\text { urodzonych ogółem }\end{array}$ & $14,58 \pm 2,36$ & $14,90 \pm 2,54$ & $14,70 \pm 2,45$ \\
\hline Liczba prosiąt urodzonych żywych & $14,20 \pm 2,28$ & $14,03 \pm 2,7$ & $14,11 \pm 2,5$ \\
\hline Liczba prosiąt urodzonych martwych & $0,27^{\mathrm{B}} \pm 0,64$ & $1,0^{\mathrm{A}} \pm 1,19$ & $0,66 \pm 1,03$ \\
\hline Liczba prosiąt odsadzonych w 28. dniu & $13,27 \pm 1,72$ & $13,09 \pm 1,97$ & $13,17 \pm 1,85$ \\
\hline Straty [szt.] & $0,93 \pm 1,25$ & $0,96 \pm 1,33$ & $0,95 \pm 1,28$ \\
\hline Przeżywalność [\%] & $94,06 \pm 7,92$ & $94,33 \pm 7,57$ & $94,21 \pm 7,68$ \\
\hline
\end{tabular}

Stwierdzono istotne różnice $(\mathrm{P} \leq 0,01)$ w liczbie prosiąt martwo urodzonych. W miotach loch $w b p \times$ pbz było ich więcej. Najwyższą płodność rzeczywistą lochy PIC osiągnęły w 4. cyklu rozpłodowym, a wbp $\times$ pbz już w 2 . Lochy PIC rodziły prosięta lżejsze $(\mathrm{P} \leq 0,01)$. U loch pierwiastek PIC zanotowano wystąpienie przypadków agresji. 


\title{
WYNIKI ODCHOWU PROSIĄT ODSADZONYCH ŻYWIONYCH MIESZANKAMI O SKŁADZIE PROSTYM (SIMPLE) LUB ZŁOŻONYM (SEMI-COMPLEX)
}

\author{
Rearing results of weaned piglets fed mixtures of simple or semi-complex type
}

Wanda Milewska, Patrycja Palińska, Dorota Bugnacka

\begin{abstract}
Uniwersytet Warmińsko-Mazurski w Olsztynie, Katedra Hodowli Trzody Chlewnej, 10-718 Olsztyn, ul. Oczapowskiego 5 e-mail: dorotabu@uwm.edu.pl
\end{abstract}

Okres poodsadzeniowy jest newralgiczny dla dalszych wyników odchowu świń. Wielopoziomowy stres generowany w procesie odsadzenia, związany ze zmianami warunków utrzymania i żywienia prosiąt, może mieć wielorakie konsekwencje. Spadek spożycia paszy, zakłócenia w procesach trawiennych, aż do wystąpienia chorób układu pokarmowego, są przyczyną obniżenia tempa wzrostu, a nawet spadku masy ciała prosiąt w pierwszych dniach po odsadzeniu. Aby temu zapobiec, ważne jest nie tylko wczesne dokarmianie prosiąt ssących, co w połączeniu ze stosowaniem dodatków stabilizujących funkcjonowanie układu pokarmowego wpływa na większe spożycie paszy po odsadzeniu, ale też używanie mieszanek o składzie dostosowanym do potrzeb prosiąt. Przede wszystkim zawierających komponenty łatwostrawne, o wysokiej jakości białka, najlepiej z udziałem białka pochodzenia zwierzęcego. Celem badań było porównanie wyników odchowu prosiąt żywionych mieszankami o składzie prostym (typu prestarter) lub złożonym (semi-complex), ze zróżnicowaną zawartością (ilość i źródła) białka pochodzenia zwierzęcego.

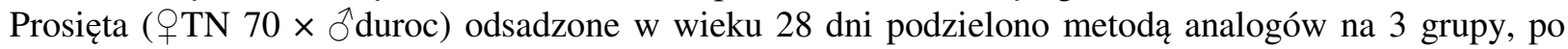
30 prosiąt w każdej. Doświadczenie trwało 14 dni, podczas których prosięta żywiono mieszankami.

\begin{tabular}{|l|c|c|c|}
\hline \multicolumn{1}{|c|}{ Skład i wartość pokarmowa mieszanek } & 1 & 2 & 3 \\
\hline Śruta pszenna & 30,00 & 18,00 & 30,30 \\
\hline Śruta jęczmienna & 26,50 & 25,00 & 30,70 \\
\hline Zakwaszacz & 0,50 & 0,50 & 0,50 \\
\hline Koncentrat białkowy [MPU 40\%] & 40,00 & 47,50 & 12,50 \\
\hline Premix [MPU] & - & 2,50 & 5,00 \\
\hline Olej sojowy & 0,50 & 1,50 & - \\
\hline Olej rzepakowy & - & - & 2,00 \\
\hline Preparat mlekozastępczy & - & 5,00 & - \\
\hline Mączka rybna & - & - & 5,00 \\
\hline Glukoza & 2,50 & - & - \\
\hline Laktoza 30\% & - & - & 4,00 \\
\hline Serwatka & - & - & 10,00 \\
\hline Energia metaboliczna (kalkulowana) [MJ/kg] & 14,06 & 14,10 & 14,10 \\
Zawartość białka ogólnego [g/kg] & 195,40 & 199,00 & 180,00 \\
\hline
\end{tabular}

Po trwającym 14 dni doświadczeniu uzyskano następujące wyniki:

\begin{tabular}{|l|c|c|c|}
\hline \multicolumn{1}{|c|}{ Wyszczególnienie } & 1 & 2 & 3 \\
\hline Początkowa masa ciała prosiąt [kg] & 7,61 & 7,92 & 7,81 \\
\hline Średnie dzienne przyrosty masy ciała $[\mathrm{g}]$ & 388 & 296 & 298 \\
\hline Średnie dzienne pobranie paszy $[\mathrm{kg}]$ & 0,48 & 0,40 & 0,44 \\
\hline Średnie dzienne wykorzystanie paszy $[\mathrm{kg} / \mathrm{kg}]$ & 1,24 & 1,35 & 1,48 \\
\hline
\end{tabular}


Żywienie prosiąt odsadzonych mieszankami o składzie wzbogaconym o komponenty pochodzenia zwierzęcego (preparat mlekozastępczy w mieszance 2 lub mączka rybna, laktoza i serwatka w mieszance 3) nie przyniosło poprawy wyników odchowu prosiąt. Biorąc pod uwagę spożycie i wykorzystanie paszy oraz średnie dzienne przyrosty prosiąt, najlepsze rezultaty przyniosło stosowanie $\mathrm{w}$ żywieniu standardowej mieszanki pełnoporcjowej typu prestarter (mieszanka 1). Ponadto zróżnicowanie poziomu białka w dietach (mieszanki 2 i 3) nie wpłynęło na zróżnicowanie wyników odchowu badanych prosiąt. Wskazuje to, że stosowanie w okresie poodsadzeniowym mieszanek o obniżonej zawartości białka nie wpływa ujemnie na przyrosty dzienne i wykorzystanie paszy przez prosięta. 


\title{
EFEKTYWNOŚĆ STOSOWANIA FITOBIOTYKÓW W ŻYWIENIU TUCZNIKÓW
}

The efficacy of fitobiotics in fattening nutrition

\author{
Piotr Mordaka, Martyna Batorska, Justyna Więcek, Anna Rekiel, Arkadiusz Biernacki \\ Szkoła Główna Gospodarstwa Wiejskiego w Warszawie, Katedra Szczegółowej Hodowli Zwierząt, Pracownia Hodowli \\ Trzody Chlewnej, ul. Ciszewskiego 8, 02-786 Warszawa \\ e-mail: martyna_batorska@sggw.pl
}

Fitobiotyki należą do dodatków paszowych coraz częściej stosowanych w żywieniu zwierząt ze względu na swoje liczne funkcje. Substancje czynne pochodzące z ziół zwiększają pobranie paszy poprzez zwiększenie apetytu, wpływają korzystnie na perystaltykę jelit, optymalizują wchłanianie składników pokarmowych z paszy, zwiększają sekrecję enzymów trawiennych, stabilizują mikroflorę jelitową oraz pozytywnie wpływają na system immunologiczny (Kasprowicz 2006, Grela i in. 2013).

Celem doświadczenia była ocena wpływu nowego dodatku ziołowego stosowanego w paszy na wyniki tuczne i rzeźne tuczników oraz efektywność ekonomiczną tuczu.

Przeprowadzono doświadczenie na 278 warchlakach obu płci importowanych z Danii, które przydzielono na podstawie masy ciała do grupy kontrolnej (K) i grupy doświadczalnej (D), otrzymującej mieszankę pełnoporcjową z dodatkiem fitobiotyków. Mieszanki pełnoporcjowe wyprodukowano w gospodarstwie na bazie śrut zbożowych (jęczmień, pszenica, pszenżyto i owies), które uzupełniono poekstrakcyjną śrutą sojową i premiksem. Dodatkowo mieszanki natłuszczano olejem rzepakowym w ilości 2\%. Tucz trwający 87 dni podzielono na dwa okresy tuczu: I - od 39,0 do $80 \mathrm{~kg}$ i II - od $80 \mathrm{~kg}$ do masy ubojowej ok. $125 \mathrm{~kg}$. Mieszanki zawierały 13,1 MJ EM/kg i 16,8\% oraz 16,0\% białka ogólnego odpowiednio w I i II okresie tuczu. W mieszankach doświadczalnych zastosowano dodatek mikronizowanych ziół w ilości $200 \mathrm{~g} / \mathrm{t}$ paszy: ostra papryka (Capsicum annuum), gorczyca biała (Sinapis alba), mydlnica (Saponalia officinalis), tatarak (Acorus calamus) oraz kurkuma (Curcuma longa). Świnie utrzymywano na ruszcie betonowym w 5 kojcach grupowych chlewni, każdy o powierzchni $60 \mathrm{~m}^{2}$. Zastosowano żywienie ad libitum ze stałym dostępem świń do wody w poidłach smoczkowych. W celu kontroli przyrostów masy ciała, pobrania i zużycia paszy, 40 świń (po 20 sztuk z każdej grupy) zakolczykowano i ważono indywidualnie co 2 tygodnie. Monitorowano warunki mikroklimatyczne chlewni i status zdrowotny zwierząt. Po uboju określono mięsność tuczników według klasyfikacji EUROP oraz przeprowadzono uproszczoną kalkulację ekonomiczną. Uzyskane wyniki tuczne i rzeźne opracowano w programie IBM SPSS Statistic 24.

Średnie przyrosty masy ciała tuczników doświadczalnych wynosiły $1066 \mathrm{~g}$, o $73 \mathrm{~g}$ więcej niż kontrolnych. Od 57. dnia tuczu świnie doświadczalne rosły szybciej i były cięższe niż kontrolne, istotną różnicę $(\mathrm{P} \leq 0,05)$ stwierdzono między grupami w 87 . dniu tuczu. Zużycie paszy wynosiło $2,56 \mathrm{~kg} / \mathrm{kg}$ w grupie $\mathrm{D}$ i $2,61 \mathrm{~kg} / \mathrm{kg} \mathrm{w}$ grupie $\mathrm{K}$, ale w wyniku zastosowania dodatku fitobiotyków pobranie paszy doświadczalnej było większe o $11,5 \mathrm{~kg} / \mathrm{szt}$. ( $\mathrm{P} \geq 0,05)$. Mięsność tuczników była wyrównana w obu grupach i wynosiła $58,3-58,4 \%$. Nie stwierdzono istotnego wpływu płci tuczników na wyniki produkcyjne. Tuczniki doświadczalne cechowała większa masa tusz $(\mathrm{P} \leq 0,01)$ niż kontrolne, nie stwierdzono istotnych różnic między grupami w wysokości oka polędwicy i w grubości słoniny.

Uproszczona kalkulacja ekonomiczna tuczu świń wykazała, że pomimo droższej paszy doświadczalnej (o 7,00 zł/szt.) dochód z jednego tucznika był o 12,00 zł większy w grupie doświadczalnej niż w kontrolnej, w żywieniu której nie zastosowano dodatku fitobiotyków, co uzasadnia ich stosowanie w żywieniu rosnących świń. 


\title{
STEREOTYPIE BEHAWIORALNE I ZACHOWANIA AGONISTYCZNE TUCZNIKÓW ŻYWIONYCH MIESZANKAMI Z RÓŻNYM UDZIAŁEM ŻYTA
}

Behavioural stereotypies and agonistic behaviour in fatteners fed mixtures with rye share

\author{
Jacek Nowicki, Mariola Pabiańczyk, Tomasz Schwarz, Ryszard Tuz, Martyna Małopolska
}

Uniwersytet Rolniczy w Krakowie, Zakład Hodowli Trzody Chlewnej i Drobnego Inwentarza, al. Mickiewicza 24/28, 30-059 Kraków

e-mail: j.nowicki@urk.edu.pl

Informacje ze strony producentów trzody chlewnej oraz naukowe, jednak wciąż tylko pilotażowe, opracowania brytyjskie wskazują na pozytywny wpływ stosowania żyta w mieszankach dla świń na zachowanie tych zwierząt (KWS UK, 2017). Producenci i hodowcy, którzy stosując się do obowiązujących regulacji w zakresie dobrostanu (Dyrektywa 2008/120/WE i Zalecenie 336/2016 do ww. Dyrektywy), chcą jeszcze bardziej zredukować ilość i czas trwania zachowań niepożądanych u świń, zmuszeni są do poszukiwania dodatkowych rozwiązań. EFSA (2007) wśród czynników wywołujących gryzienie ogonów przez świnie za najłatwiejszą metodę uznaje optymalizację żywienia. Dlatego celem pracy było określenie wpływu żywienia świń rosnących mieszankami z różnym udziałem żyta na występowanie stereotypii behawioralnych i innych zachowań niepożądanych. Materiał doświadczalny stanowiło 36 tuczników podzielonych na 3 grupy, po 12 sztuk: I - 0\% żyta (grupa kontrolna), II - 40\% żyta w mieszance i III 60\% żyta w mieszance. 24-godzinne obserwacje prowadzono raz w tygodniu przez 7 kolejnych tygodni od stwierdzenia, że hierarchia jest już stabilna (7 doba od zestawienia grup). Stwierdzono, że czas spędzany na walkach w grupach I i III był zbliżony, jednak istotnie dłuższy niż w grupie II (tab. 1).

Tabela 1. Zachowania agonistyczne, stereotypie behawioralne i zachowania nietypowe tuczników żywionych mieszankami z różnym udziałem żyta $(24 \mathrm{~h}=100 \%)$

\begin{tabular}{|c|c|c|c|}
\hline Zachowanie & $\begin{array}{l}\text { I - } 0 \% \text { żyta } \\
\quad(\mathrm{n}=12)\end{array}$ & $\begin{array}{l}\text { II }-40 \% \text { żyta } \\
\quad(\mathrm{n}=12)\end{array}$ & $\begin{array}{l}\text { III - 60\% żyta } \\
\quad(\mathrm{n}=12)\end{array}$ \\
\hline Walki & $\begin{array}{l}0,53 \mathrm{a} \\
\pm 0,18\end{array}$ & $\begin{array}{l}0,16 \mathrm{~b} \\
\pm 0,03\end{array}$ & $\begin{array}{l}0,48 \mathrm{a} \\
\pm 0,26\end{array}$ \\
\hline $\begin{array}{l}\text { Stereotypie behawioralne } \\
\text { i zachowania patologiczne, w tym: }\end{array}$ & $\begin{array}{l}4,20 \mathrm{aA} \\
\pm 1,73\end{array}$ & $\begin{array}{l}2,02 \mathrm{~b} \\
\pm 0,67\end{array}$ & $\begin{array}{l}0,91 \mathrm{cB} \\
\pm 0,42\end{array}$ \\
\hline Belly nosing & $\begin{array}{c}3,04 \mathrm{aA} \\
\pm 1,40\end{array}$ & $\begin{array}{l}1,64 \mathrm{~b} \\
\pm 0,61\end{array}$ & $\begin{array}{c}0,20 \mathrm{cB} \\
\pm 0,14\end{array}$ \\
\hline Żucie uszu & $\begin{array}{l}1,09 \mathrm{a} \\
\pm 0,31\end{array}$ & $\begin{array}{l}0,31 \mathrm{~b} \\
\pm 0,26\end{array}$ & $\begin{array}{l}0,57 \mathrm{~b} \\
\pm 0,22\end{array}$ \\
\hline Gryzienie ogonów & $\begin{array}{c}0,07 \\
\pm 0,01\end{array}$ & $\begin{array}{c}0,07 \\
\pm 0,12\end{array}$ & $\begin{array}{c}0,14 \\
\pm 0,05\end{array}$ \\
\hline
\end{tabular}

Najdłuższy czas trwania stereotypii odnotowano w grupie I, w grupie II był on dwukrotnie krótszy, natomiast w III zanotowano wysoko istotnie $(\mathrm{P}<0,01)$ krótszy czas tego zachowania niż w grupie I. W grupie I zanotowano najdłuższy czas spędzany na zachowaniu belly-nosing oraz najdłuższy czas gryzienia uszu $(\mathrm{P}<0,05)$. Natomiast czas spędzany na gryzieniu ogonów nie różnił się statystycznie między grupami. Można zatem stwierdzić, że udział żyta w mieszankach dla świń rosnących wpływa znacząco na ograniczenie występowania zachowań agonistycznych, stereotypii i innych zachowań niepożądanych, przy czym najbardziej efektywny jest $60 \%$ udział tego zboża w mieszance, szczególnie w odniesieniu do stereotypii określanej jako belly-nosing. 


\title{
ZNACZENIE ZIÓ£ W ŻYWIENIU TRZODY CHLEWNEJ
}

The importance of herbs in feeding pigs

\author{
Aleksandra Paskudska, Dorota Kołodziejczyk, Stanisław Socha \\ Uniwersytet Przyrodniczo-Humanistyczny w Siedlcach, Instytut Bioinżynierii i Hodowli Zwierzą, \\ Katedra Metod Hodowlanych i Hodowli Drobiu, ul. B. Prusa 12/14, 08-110 Siedlce \\ e-mail: socha@uph.edu.pl, dormark1@wp.pl
}

Korzystne działanie ziół na zdrowie zwierząt wykorzystuje się również w żywieniu świń. W tym przypadku preparaty immunostymulujące mają ogromne znaczenie w okresie neonatalnym, gdy prosięta szczególnie narażone są na choroby wywołane przez drobnoustroje. Celem pracy było przedstawienie roślin leczniczych i ziół stosowanych jako dodatki w żywieniu trzody chlewnej w oparciu o badania wybranych autorów.

Wykorzystanie ziół jest ważne w żywieniu prosiąt, gdyż są narażone na liczne schorzenia. Układ odpornościowy i jego prawidłowe działanie ma wpływ na ochronę organizmu przed zakażeniami grzybiczymi, bakteryjnymi i wirusowymi. Brak odporności lub czynników środowiskowych jest powodem dużej śmiertelności i zachorowalności noworodków w czasie od urodzenia do odsadzenia. $\mathrm{Z}$ tego względu przeprowadza się bardzo wiele badań nad odpornością młodych zwierząt gospodarskich. Powstało wiele preparatów na bazie ziół leczniczych, które mają zadanie immunomodelujące, antystresowe czy adaptogenne (Markowska-Daniel 1993). Liczne badania wykazały wpływ ziół na rozrodczość świń. Koper włoski, kminek, jałowiec czy pokrzywa pozytywnie wpływa na poprawę mleczności loch i parametry rozrodu. Powodują także zwiększenie apetytu i działają korzystnie na przemianę materii u loch w okresach okołoporodowych. Rumianek działa przeciwzapalnie, co również wpływa na zdrowotność miotu i poród. Podawanie kminku lochom wysokoprośnym skutecznie przeciwdziała bezmleczności, która często występuje po porodzie. Połączenie w mieszance kozieradki, kopru, bazylii, nagietka i rumianku lochom w czasie okołoporodowym wpływa na masę i żywotność prosiąt w czasie odsadzenia. Dzięki użyciu w paszach dodatków detoksykacyjnych ekstraktów ziołowych można dłużej stosować jedną mieszankę bez konsekwencji, które związane są z pogorszeniem dostępności mikroelementów i witamin. Ekstrakt ma korzystny wpływ nie tylko na odporność, smakowitość i apetyt, ale także zwiększa i chroni dostępność witamin i składników mineralnych. Ziół używa się także jako naturalnych dezodorantów w celu poprawy w chlewniach mikroklimatu, gdyż powodują zmniejszenie emisji amoniaku. Do tego używa się rośliny Yuccaa schidigera, które pochodzi z Meksyku i Stanów Zjednoczonych (Soszka 2013). Stwierdzono, że perz, pokrzywa oraz czosnek zwiększają pobieranie paszy, co ważne jest szczególnie przy odsadzeniu prosiąt. W wyniku tego poprawiła się strawność paszy i jej poszczególnych składników. Wykazano również polepszenie procesów metabolicznych (Turyk i Osek 2010) w badaniach na prosiętach z niedowagą przy urodzeniu. Charakteryzowały się słabą odpornością z powodu zaburzeń laktacyjnych u loch. Preparat ziołowy sporządzony z bazylii, kozieradki, nagietka, kopru i rumianku poprawił aktywność fagocytarną oraz spowodował wzrost przyrostów masy ciała (Kołacz i in. 1997). Podawanie natomiast lochom prośnym mieszanek ziołowych, które zawierają przewrotnik, pokrzywę i koper, spowodowało, że prosięta były bardziej żywotne i charakteryzowały się większą masę ciała (Grela i Fritz 1995). Suszone ekstrakty z melisy, szałwii i jeżówki przyniosły poprawę dobowych przyrostów masy ciała tuczników. Melisa jako dodatek do paszy w żywieniu poprawiła mięsność o ponad 2\%, a szałwia i jeżówka zwiększyły o 3\% powierzchnię oka polędwicy (Hanczakowska 2004). Wyciąg z lukrecji, czosnku, tymianku i kminku zwiększył u tuczników o 6\% przyrosty dobowe masy ciała. Nastąpiła też poprawa mięsności w $3 \%$.

Należy jednak pamiętać, że zastępowanie antybiotyków ziołami czy dodawanie ich do pasz w celu polepszenia wyników w odchowie należy traktować kompleksowo. Trzeba zwierzętom zapewnić odpowiednie warunki żywieniowe z zastosowaniem dodatków paszowych, odpowiedzialną profilaktykę weterynaryjną i - co najważniejsze - odpowiednie warunki utrzymania. 


\title{
OPRACOWANIE OPTYMALNEGO INDEKSU SELEKCYJNEGO STOSOWANEGO W OCENIE PRZYŻYCIOWEJ KNURÓW I LOSZEK HODOWLANYCH
}

Development of optimal selective index used in performance tested for boars and gilts

\author{
Piotr Polok ${ }^{1}$, Grzegorz Żak ${ }^{2}$, Aurelia Mucha ${ }^{2}$ \\ ${ }^{1}$ Polski Związek Hodowców i Producentów Trzody Chlewnej POLSUS, ul. Ryżowa 1, 02-496 Warszawa, \\ ${ }^{2}$ Instytut Zootechniki - Państwowy Instytut Badawczy, Zakład Hodowli Trzody Chlewnej, ul. Sarego 2, 31-047 Kraków \\ e-mail: aurelia.mucha@izoo.krakow.pl
}

W krajowej hodowli świń procentowa zawartość mięsa w tuszy i przyrost dzienny masy ciała są wykorzystywane do wyliczania indeksu selekcyjnego, którego wartość decyduje o podjęciu decyzji hodowlanej dotyczącej pozostawienia bądź wybrakowania ze stada ocenianego zwierzęcia. Analiza zmian przyrostów dziennych masy ciała i zawartości mięsa w tuszy loszek i knurów rasy pbz na tle założeń krajowego programu hodowlanego wykazała osiągnięcie $\mathrm{w}$ przypadku knurów oraz przekroczenie u loszek procentowej zawartości mięsa w tuszy. Natomiast w przypadku przyrostów dziennych stwierdzono konieczność doskonalenia tej cechy u knurów i loszek. Celem pracy było opracowanie optymalnego indeksu selekcyjnego stosowanego w ocenie przyżyciowej knurów i loszek hodowlanych, tak aby zrealizowane zostały założenia krajowego programu hodowlanego.

Badania prowadzono z wykorzystaniem wyników cech tucznych i rzeźnych ocenianych przyżyciowo według aktualnie obowiązującej metodyki. Z 13403 knurów rasy pbz do analiz wybrano knury spełniające kryteria: a) ocenione knury wybrane zostały na remont stad zarodowych lub zakupione do stacji inseminacji, b) oceniono po nich minimum 5 sztuk czystorasowego potomstwa jednej płci, pochodzącego z co najmniej 2 miotów. Na tej podstawie wyodrębniono 222 knury posiadające ocenione czystorasowe potomstwo męskie i 427 knurów posiadających czystorasowe potomstwo żeńskie. Dla zwierząt objętych badaniami opracowano 5 indeksów selekcyjnych zróżnicowanych pod względem ważności cech - standaryzowanego przyrostu dziennego (PD) i standaryzowanej procentowej zawartości mięsa w tuszy (ZM): indeks 1 - PD 90\%, ZM 10\%; indeks 2 - PD 70\%, ZM 30\%; indeks 3 - PD 50\%, ZM 50\%; indeks 4 - PD 30\%, ZM 70\%; indeks 5 PD 10\%, ZM 90\%. Knury stadne (ojcowie potomstwa) podzielono na grupy według wartości indeksu selekcyjnego oraz przyrostów dziennych i procentowej zawartości mięsa w tuszy standaryzowanych na 180 . dzień życia. W obrębie każdej grupy wyodrębniono podgrupy: A - 5\% najlepszych knurów; B - 10\% najlepszych knurów; C - 15\% najlepszych knurów; D - 20\% najlepszych knurów; E - 25\% najlepszych knurów. Efektywność selekcji w oparciu o 5 indeksów selekcyjnych, jak również wartość standaryzowanego przyrostu dziennego i standaryzowanej procentowej zawartości mięsa w tuszy badano na podstawie użytkowości potomstwa analizowanych knurów, które było ocenione przyżyciowo. Analizy dokonano na podstawie korelacji i trendów w obrębie badanych cech w zależności od podgrupy, z której pochodzili ojcowie.

$\mathrm{Na}$ podstawie przeprowadzonych obliczeń i analiz wybrano optymalne indeksy selekcyjne zapewniające osiągnięcie takiego poziomu cech tucznych i rzeźnych doskonalonego pogłowia, aby możliwa była realizacja założeń krajowego programu hodowlanego. Optymalnym wariantem doskonalenia przyrostów dziennych i ustabilizowania procentowej zawartości mięsa w tuszy u potomstwa męskiego jest zastosowanie indeksu 2, w którym ważność cechy ,przyrost dzienny” wynosi 70\%, a ,zawartość mięsa w tuszy” 30\%, przy uwzględnieniu wyboru ojców spośród 5\% najlepszych osobników pod względem wielkości indeksu selekcyjnego. Dla potomstwa żeńskiego indeksem selekcyjnym, który pozwoli na jednoczesne doskonalenie przyrostów dziennych i powstrzymanie wzrostu procentowej zawartości mięsa w tuszy, jest również indeks 2 , jednak wyboru ojców loszek można dokonać spośród grupy 15\% najlepszych osobników pod względem indeksu. 


\title{
JAKOŚĆ MIĘSA TUCZNIKÓW PO KNURACH RAS DANAVL DUROC I PUŁAWSKA
}

Meat quality of fatteners after boars of DanAvl Duroc and Pulawska breeds

\author{
Artur Rybarczyk $^{1}$, Robert Moroch $^{1}$, Daniel Polasik $^{2}$, Krzysztof Sameluk $^{1}$ \\ ${ }^{1}$ Zachodniopomorski Uniwersytet Technologiczny w Szczecinie, Pracownia Towaroznawstwa Produktów Spożywczych, \\ al. Piastów 45, 70-310, Szczecin \\ ${ }^{2}$ Zachodniopomorski Uniwersytet Technologiczny w Szczecinie, Katedra Genetyki i Ogólnej Hodowli Zwierząt \\ e-mail: artur.rybarczyk@ zut.edu.pl
}

Celem badań było określenie właściwości fizyczno-chemicznych i sensorycznych $m$. longissimus lumborum tuczników DanAvl Hybrid (landrace-yorkshire) i pochodzących od loch DanAvl Hybrid po czystorasowych knurach DanAvl duroc i puławska z uwzględniem polimorfizmu genu wrażliwości na stres (RYRl). Wszystkie tuczniki do badań były utrzymywane w zbliżonych warunkach środowiskowych i żywione zbilansowaną mieszanką paszową ad libitum. Po osiągnięciu masy ciała około $112 \mathrm{~kg}$, po 60 tuczników z każdej z grup, były przewożone w temp. $22-24^{\circ} \mathrm{C}$ do Zakładów Mięsnych, gdzie zostały poddane trwającemu $15 \mathrm{~h}$ odpoczynkowi przedubojowemu przy zachowaniu 24 h głodówki do uboju. W trakcie uboju wykonano pomiar mięsności aparatem AutoFom (SFK Technology, Dania) oraz ustalono płeć i masę ciepła tusz. Na podstawie tych dwóch ostatnich z każdej grupy wybrano po 30 tusz, wyrównanych pod względem masy i zbliżonym udziałem loszek i wieprzków. W trakcie wychładzania na prawych tuszach, $w$ m. longissimus lumborum (LL), wykonano pomiary $\mathrm{pH}$ (40 min, 3 i $24 \mathrm{~h}$ post mortem - p.m.) przy użyciu pH-metru CP-411 firmy Elmetron i przewodności elektrycznej (EC: 2 i 24 h p.m.), stosując konduktometr LF-Star (Ingenieurbüro Matthäus). W laboratorium na pobranych próbach mięśnia LL określono $\mathrm{pH}$ (48 i $96 \mathrm{~h}$ p.m.), cechy barwy (L*, a*, b*, C*; 24 i 48 h p.m.) przy użyciu HunterLab Mini Scan XE Plus 45/0 źródło światła D65 i obserwator $10^{\circ}$, określono wyciek swobodny (24-48 h i 24-96 h p.m.) i oznaczono podstawowy skład chemiczny. Na mięśniu LL, uprzednio zamrożonym na okres jednego miesiąca, określono wyciek rozmrażalniczy i termiczny, oceniono wyróżniki sensoryczne oraz wykonano pomiar siły cięcia za pomocą szerometru Warnera-Bratzlera. Ponadto, wykorzystując próbki mięśnia LL, wyizolowano DNA przy użyciu zestawu GeneMATRIX Tissue DNA Purification Kit (EURx), a polimorfizm genu RYRl określono, wykorzystując metodę PCR-RFLP. W analizowanych grupach tuczników mieszańców stwierdziliśmy tylko osobniki heterozygotyczne $(C T)$ względem genu RYRl u tuczników z udziałem rasy Puławska (6,7\%). Pozostałe grupy tuczników były wolne od allelu $T$ względem locus $R Y R 1$. W związku z tym w analizie mięsności tusz i jakości mięsa wykorzystano wyniki tylko dla osobników o genotypie $C C / R Y R 1$. Tuczniki pochodzące po knurach DanAvl duroc cechowały się lepszą jakością mięsa w stosunku do tuczników DanAvl Hybrid i ich mieszańców z rasą puławską, o czym świadczy wyższe pH w czasie 24 - 96 h p.m., wyższa ocena sensoryczna soczystości, kruchości i smakowitości oraz niższa siła cięcia przy jednocześnie mniejszej zawartości białka ogólnego i większej zawartości tłuszczu śródmięśniowego. Natomiast tuczniki DanAvl Hybrid w porównaniu z tucznikami po knurach DanAvl duroc i puławska charakteryzowały się gorszą jakością mięsa, tj. większa jasność ( $\mathrm{L}^{*}$ ) barwy i większy wyciek swobodny zarówno z mięsa świeżego, jak i rozmrażanego. Mięso tuczników po rasie puławska charakteryzowało się największą czerwonością (a*), a tuczników po rasie DanAvl duroc najmniejszą żółtością (b*) i nasyceniem $\left(\mathrm{C}^{*}\right)$ barwy. 


\title{
EFEKTYWNOŚĆ PRODUKCYJNA ZWIĘKSZONEGO UROZMAICENIA ŹRÓDEŁ ENERGII PASZOWEJ DLA ŚWIŃ ROSNĄCYCH
}

\author{
Production efficiency of increased energy sources diversity for growing pigs
}

\author{
Tomasz Schwarz ${ }^{1}$, Ryszard Tuz ${ }^{1}$, Artur Turek ${ }^{2}$, Karol Włodarczyk $^{3}$, Jan Wujczak ${ }^{4}$, Jacek Nowicki ${ }^{1}$ \\ ${ }^{1}$ Uniwersytet Rolniczy w Krakowie, Instytut Nauk o Zwierzętach, Zakład Hodowli Trzody Chlewnej i Drobnego Inwentarza \\ ${ }^{2}$ Blattin Polska Sp. z o.o., ${ }^{3}$ KWS Lochow Polska Sp. z o.o., ${ }^{4}$ Gospodarstwo Rolne Jan Wujczak \\ e-mail: rzschwar@cyf-kr.edu.pl
}

Jednym z kluczowych czynników intensyfikacji wskaźników produkcyjnych świń rosnących jest poprawa wartości biologicznej składników odżywczych. Spośród metod umożliwiających osiągnięcie tego efektu najprostsze wydaje się zwiększenie urozmaicenia mieszanek poprzez wzrost liczby surowców paszowych. W zakresie źródeł energii paszowej zwykle mieszanki optymalizowane są w oparciu o 2 standardowe składniki, jakimi są pszenica i jęczmień. Badania uwzględniające dodatek 3. składnika zwykle pokazują wzrost efektywności produkcji. Celem badań było określenie efektywności produkcyjnej tuczu świń z zastosowaniem mieszanek zawierających 4 zbożowe surowce paszowe. Badania przeprowadzono w komercyjnej fermie na 500 świniach DanBred, porównując wskaźniki użytkowości tucznej i rzeźnej zwierząt żywionych mieszankami zawierającymi 3 (pszenica + jęczmień + żyto) lub 4 (pszenica + jęczmień + żyto + kukurydza) składniki zbożowe. Wskaźniki użytkowości tucznej (przyrost masy ciała i FCR) uległy istotnej poprawie przy zastosowaniu mieszanek o większym urozmaiceniu surowcowym. Parametry rzeźne (wydajność rzeźna, grubość polędwicy, mięsność) okazały się nieznacznie obniżone (tabela).

\begin{tabular}{|l|c|c|c|}
\hline \multicolumn{1}{|c|}{ Parametr } & Gr. 4 składniki & Gr. 3 składniki & $\begin{array}{c}\text { Poziom istotności } \\
\text { /różnica [\%] }\end{array}$ \\
\hline Przyrost m.c. grower [g/d] & $1160 \pm 160$ & $1139 \pm 158$ & 0,119 \\
\hline Przyrost m.c. finiszer [g/d] & $1116 \pm 135$ & $1071 \pm 111$ & 0,001 \\
\hline Przyrost m.c. całość [g/d] & $1134 \pm 114$ & $1103 \pm 101$ & 0,005 \\
\hline FCR grower & 2,34 & 2,43 & $-3,85 \%$ \\
\hline FCR finiszer & 2,71 & 3,01 & $-11,07 \%$ \\
\hline FCR całość & 2,50 & 2,69 & $-7,60 \%$ \\
\hline Masa żywca [kg] & $130,94 \pm 11,58$ & $128,50 \pm 10,51$ & 0,023 \\
\hline Masa tuszy [kg] & $103,93 \pm 10,04$ & $102,26 \pm 8,40$ & 0,054 \\
\hline Wydajność rzeźna [\%] & $79,35 \pm 2,45$ & $79,64 \pm 3,34$ & 0,163 \\
\hline Grubość słoniny [mm] & $14,77 \pm 3,58$ & $14,49 \pm 3,83$ & 0,238 \\
\hline Grubość polędwicy [mm] & $61,54 \pm 4,87$ & $62,21 \pm 4,83$ & 0,1001 \\
\hline Mięsność [\%] & $57,88 \pm 2,73$ & $58,25 \pm 2,92$ & 0,107 \\
\hline
\end{tabular}

Podsumowując, zastosowanie bardziej urozmaiconych mieszanek paszowych, zawierających 4 składniki zbożowe zamiast 3, pozwala na istotną poprawę kluczowych wskaźników tucznych przy nieznacznym negatywnym wpływie na wskaźniki rzeźne. Konieczne jest kontynuowanie analiz w celu określenia opłacalności produkcji i jakości surowców dla przemysłu mięsnego.

Finansowanie: NCBR, ENERGYFEED umowa BIOSTRATEG2/297910/12/NCBR/2016. 


\title{
WYKORZYSTANIE MIĘSA ŚWIŃ RASY PUŁAWSKIEJ DO PRODUKCJI WĘDZONEK WYSOKIEJ JAKOŚCI
}

The use of meat of Puławska breed pig for the production of high-quality smoked meat

\author{
Piotr Skałecki ${ }^{1}$, Marek Babicz ${ }^{2}$, Piotr Domaradzki ${ }^{1}$, Anna Litwińczuk ${ }^{1}$, Michał Prasow ${ }^{1}$, \\ Marcin Hałabis ${ }^{2}$
${ }^{1}$ Uniwersytet Przyrodniczy w Lublinie, Katedra Towaroznawstwa i Przetwórstwa Surowców Zwierzęcych
${ }^{2}$ Uniwersytet Przyrodniczy w Lublinie, Instytut Hodowli Zwierząt i Ochrony Bioróżnorodności, Zakład Hodowli i Biotechnologii Świń, e-mail: skalka_p@op.pl

Celem pracy była ocena jakości wędzonek wyprodukowanych z mięsa świń rasy puławskiej. Materiał do badań stanowiły 2 mięśnie szkieletowe, tj. półbłoniasty i najdłuższy grzbietu, pobrane z 10 tusz tuczników rasy puławskiej. $\mathrm{Z}$ pobranych mięśni wyprodukowano wędzonki. $\mathrm{W}$ surowcu oraz w produktach oznaczono zawartość podstawowych składników chemicznych, soli i kolagenu metodami referencyjnymi oraz wyróżniki barwy CIE L*a*b* za pomocą miernika Minolta CR-310. Test szerometryczny wykonano w produktach, wykorzystując maszynę wytrzymałościową Zwick/RoellProline BDO-FB0.5TS, rejestrując siłę (N) i pracę (J) cięcia. Dodatkowo produkty poddano ocenie konsumenckiej. Wykorzystany do produkcji wędzonek określony mięsień istotnie różnicował barwę ocenianych produktów. Istotnie większą wartość jasności L* i barwy czerwonej a* oraz mniejszą barwy żółtej b* stwierdzono w wędzonkach z mięśnia najdłuższego grzbietu. Rodzaj mięśnia wpływał również istotnie na parametry kruchości ocenianych produktów. Wędzonki z mięśnia najdłuższego grzbietu w porównaniu z produktami z mięśnia półbłoniastego charakteryzowały się mniejszymi wartościami siły cięcia $(22,98$ vs. $38,90 \mathrm{~N})$. Nie stwierdzono istotnego wpływu rodzaju mięśnia na skład chemiczny ocenianych produktów, choć większy udział tłuszczu, o 2,79 punktu procentowego, stwierdzono w wędzonkach ze schabu. Nie wykazano również istotnego wpływu mięśnia na udział kolagenu w wędzonkach, którego średni udział wynosił od $0,65 \%$ w wędzonkach z szynki do 0,97\% w wędzonkach ze schabu. Średnia zawartość soli w ocenianych produktach wyniosła $2,18 \%$. Wyróżniki jakości organoleptycznej produktów, tj. barwa, kruchość, soczystość, smak i zapach, zostały ocenione bardzo wysoko. Średnia ocena ogólna wędzonek z szynki wyniosła 4,70, a ze schabu 4,85 .

Badania zrealizowano w ramach projektu Biostrateg „Kierunki wykorzystania oraz ochrona zasobów genetycznych zwierząt gospodarskich w warunkach zrównoważonego rozwoju" współfinansowanego przez Narodowe Centrum Badań i Rozwoju w ramach Strategicznego programu badań naukowych i prac rozwojowych „Środowisko naturalne, rolnictwo i leśnictwo” (BIOSTRATEG2/297267/2/NCBR/2016). 


\title{
DŁUGOWIECZNOŚĆ LOCH RASY RODZIMEJ
}

\author{
Sows longevity native breed
}

\author{
Ewa Skrzypczak, Karolina Szulc, Piotr Luciński, Karolina Popiela \\ Uniwersytet Przyrodniczy w Poznaniu, Katedra Hodowli Zwierząt i Oceny Surowców, Złotniki, ul. Słoneczna 1, 62-002 Suchy Las \\ e-mail: ewa.skrzypczak@up.poznan.pl
}

Długowieczność loch jest tematem często poruszanym w badaniach ze względu na znaczenie dla ekonomiki produkcji i dobrostanu zwierząt.

Przodek świni domowej, którym jest dzik europejski, w naturalnym środowisku osiąga wiek 20-25 lat. Jednak w produkcji trzody chlewnej lochy często są brakowane już po 3. miocie ze względu na problemy z płodnością i niedostatecznymi wynikami produkcyjnymi (Tart i in. 2013). Wpływ na taki stan rzeczy ma zaawansowana selekcja w kierunku poprawy cech produkcyjnych i uzyskanie loch o niskim otłuszczeniu w idealnej kondycji, o wysokiej wydajności rozrodczej i niskim zużyciu paszy.

Celem pracy była analiza wieku wybrakowania loch ze stada ze względu na wybrane cechy użytkowe. Badanie przeprowadzono na populacji świń rasy złotnickiej białej (złb) w Rolniczym Gospodarstwie Doświadczalnym Uniwersytetu Przyrodniczego. Badaniami objęto okres od 2001 do 2017 r. na populacji $\mathrm{N}=406$ loch.

W przeprowadzonych badaniach dowiedziono, że lochy, które były brakowane w wieku powyżej 1601 . dnia życia (powyżej 4 lat) charakteryzowały się największą średnią liczbą prosiąt urodzonych w miocie 10 sztuk, jednak lochy te generowały największe straty w stadzie, na poziomie prawie $11 \%$. Analizując wiek wybrakowania lochy i liczbę prosiąt odsadzonych z miotu, dowiedziono, że matki w wieku od 1201 do 1600 dni życia odchowywały największą liczbę prosiąt $(9,13$ szt. $\pm 0,93)$. Lochy o najkrótszym okresie użytkowania w stadzie (do 2 lat) charakteryzowały się najdłuższym cyklem produkcyjnym, który wynosił średnio 211 dni. Samice o najmniejszej zawartości mięsa w tuszy 45,68\% $\pm 5,28$ były zwierzętami najdłużej użytkowanymi w badanym stadzie (powyżej 5. roku życia). Wiek wybrakowania ze stada okazał się czynnikiem, który miał statystycznie wysoko istotny wpływ na cechy użytkowości rozpłodowej badanej populacji loch. W analizowanym gospodarstwie najwięcej loch - 169 szt. - odchowało od 6 do 8 miotów, co stanowiło prawie $42 \%$ wszystkich samic. Wraz z wiekiem udział loch w kolejnych miotach malał, 7 loch doczekało się 11. i 12. miotu, a najmniej loch miało 13 miotów - 2 szt. Ponad $56 \%$ loch ze stada brakowano w wieku do 1200 dni życia (3 lata i 3 miesiące).

W badanym stadzie nie brakowano loch ze względu na podeszły wiek, lecz dominującą przyczyną brakowania były problemy z rozrodem, głównie nieskuteczność zapłodnień, powtarzanie rui, niezadowalające wyniki reprodukcyjne. Lochy najszybciej brakowane ze stada ze względu na problemy z rozrodem kumulowały najwięcej dni nieprodukcyjnych. 


\section{WPŁYW ŹRÓDŁA BIAŁKA ROŚLINNEGO I DODATKU ENZYMÓW PASZOWYCH DO MIESZANEK NA METABOLIZM AZOTU U TUCZNIKÓW}

Effect of source plant protein and addition of feed enzymes on mixtures on nitrogen metabolism in growing-finishing pigs

Wiesław Sobotka, Elwira Fiedorowicz-Szatkowska

Uniwersytet Warmińsko-Mazurski w Olsztynie, Katedra Żywienia Zwierząt i Paszoznawstwa e-mail: sobotkawieslaw64@gmail.com

W ostatnich latach poszukiwane są alternatywne źródła białka roślinnego w żywieniu zwierząt monogastrycznych do genetycznie modyfikowanej poekstrakcyjnej śruty sojowej. Jednym z nich mogą być nasiona roślin bobowatych czy też DDGS kukurydziany. Zwiększenie efektywności wykorzystania wysokobiałkowych komponentów paszowych można uzyskać poprzez zastosowanie egzogennych enzymów paszowych, takich jak celulaza, $\beta$-glukanaza i ksylanaza. Celem przeprowadzonych badań było określenie wpływu zastosowania w żywieniu tuczników mieszanek paszowych z udziałem łubinu żółtego odmiany Taper i DDGS z kukurydzy, z dodatkiem lub bez dodatku enzymów paszowych, na metabolizm azotu u tuczników. Przeprowadzono badania strawnościowo-bilansowe na 16 tucznikach DanBred, utrzymywanych pojedynczo w kojcach metabolicznych według schematu przedstawionego w tabeli 1.

Tabela 1. Schemat badań

\begin{tabular}{|c|c|c|c|}
\hline Grupy doświadczalne & Liczba zwierząt & $\begin{array}{c}\text { Źródło białka roślinnego (ŹB) } \\
(100 \% \text { substytucja białka sojowego) }\end{array}$ & Enzymy paszowe (E) \\
\hline $\mathrm{R}+\mathrm{E}$ & 4 & PŚR „00” + łubin żółty odm. Taper & - \\
\hline $\mathrm{R}+\mathrm{E}+\mathrm{E}$ & 4 & PŚR „00” + łubin żółty odm. Taper & + \\
\hline $\mathrm{R}+\mathrm{D}$ & 4 & PŚR „,00” + DDGS kukurydziany & - \\
\hline $\mathrm{R}+\mathrm{D}+\mathrm{E}$ & 4 & PŚR „,00” + DDGS kukurydziany & + \\
\hline
\end{tabular}

${ }^{1} \mathrm{R}$ - poekstrakcyjna śruta rzepakowa „,00” (PŚR), Ł - łubin żółty odm. Taper, D - DDGS kukurydziany, E - enzymy paszowe

W ww. badaniach oceniano strawność białka, retencje azotu i jego wykorzystanie w mieszankach grower/finiszer dla tuczników w zależności od zastosowanych czynników doświadczalnych.

Wykazano, że źródło białka roślinnego (ŹB) oraz dodatek enzymów paszowych (E) nie miały istotnego wpływu na strawność białka ocenianych mieszanek doświadczalnych. W mieszankach grower istotnie wyższą retencję azotu odnotowano u tuczników żywionych dawkami pokarmowymi z łubinem żółtym (Ł) w stosunku do DDGS kukurydzianego (D). Wykorzystanie azotu zatrzymanego do strawionego było istotnie większe w grupach $€$ aniżeli w D. W drugim okresie tuczu źródło białka roślinnego nie wpłynęło istotnie zarówno na strawność białka ogólnego, jak i wykorzystanie azotu. Nie odnotowano korzystnego wpływu wzbogacenia mieszanek doświadczalnych grower i finiszer preparatem enzymatycznym zawierającym celulazę, $\beta$-glukanazę i ksylanazę na analizowane wskaźniki metabolizmu azotu. 


\title{
ANALIZA ZMIAN STRUKTURY POLIMORFIZMU GENÓW W ZALEŻNOŚCI OD ZINBREDOWANIA LOCH RAS RODZIMYCH
}

Analysis of changes in gene polymorphism structure depending on inbreeding level of native breed sows

\author{
Magdalena Szyndler-Nędza ${ }^{1}$, Robert Eckert ${ }^{1}$, Katarzyna Ropka-Molik ${ }^{2}$, Karolina Szulc ${ }^{3}$, \\ Ewa Skrzypczak ${ }^{3}$, Marek Babicz ${ }^{4}$
}

\footnotetext{
${ }^{1}$ Instytut Zootechniki - Państwowy Instytut Badawczy, Zakład Hodowli Trzody Chlewnej, ul. Krakowska 1, 32-083 Balice ${ }^{2}$ Instytut Zootechniki - Państwowy Instytut Badawczy, Zakład Biologii Molekularnej Zwierząt, ul. Krakowska 1, 32-083 Balice

${ }^{3}$ Uniwersytet Przyrodniczy w Poznaniu, Katedra Hodowli Zwierząt i Oceny Surowców, ul. Słoneczna 1, 62-002 Suchy Las

${ }^{4}$ Uniwersytet Przyrodniczy w Lublinie, Instytut Hodowli Zwierząt i Ochrony Bioróżnorodności, Zakład Hodowli i Biotechnologii Świń, ul. Akademicka 13, 20-950 Lublin e-mail: magdalena.szyndler@izoo.krakow.pl
}

Celem przeprowadzonych badań było określenie struktury genetycznej w każdej z trzech ras rodzimych, w zależności od stopnia ich zinbredowania. Do badań wytypowano geny uznawane za potencjalne markery cech tucznych, rzeźnych będących jednocześnie markerami jakości mięsa, cech rozpłodowych oraz odporności na stres i choroby, czyli cech, w których rasy rodzime odróżniają się od ras popularnie hodowanych.

Badaniami objęto populacje świń ras puławskiej, złotnickiej białej i złotnickiej pstrej utrzymywanych w latach 2015-2016. Przeprowadzono analizę rodowodową, która dała podstawę do podziału tych populacji na pięć grup pod względem poziomu zinbredowania ( $\mathrm{F}<0,008(1) ; 0,008 \leq \mathrm{F}<0,0313(2) ; 0,0313 \leq \mathrm{F}<0,0625$ (3); $0,0625 \leq \mathrm{F}<0,098$ (4); F $\geq 0,098$ (5)). Od loch w każdej grupie pobrano cebulki włosowe. Ogółem pobrano materiał biologiczny od 131 loch rasy puławskiej, 101 loch rasy złotnickiej pstrej i 127 loch rasy złotnickiej białej. Z cebulek włosowych wyizolowano DNA oraz przeprowadzono optymalizację metody PCR-RFLP, umożliwiającej oznaczenie frekwencji alleli i genotypów wybranych genów.

Na podstawie szczegółowej analizy zmian frekwencji genotypów genów związanych z rozrodem w poszczególnych grupach inbredu, wykazano, że w rasie puławskiej wzrost inbredu związany był przede wszystkim ze zwiększeniem ilości osobników o genotypie $F S T^{B B}$, w rasie złotnickiej białej o genotypie $E S R^{A A}$, w rasie złotnickiej pstrej o genotypie PRL ${ }^{\text {Del/Del }}$. W przypadku genów kodujących produkty uczestniczące w procesach wzrostu i rozwoju wskazano, że w każdej z analizowanych ras wzrastające zinbredowanie loch łączyło się ze zmianą struktury genotypów w obrębie przede wszystkim genu MYF4. W rasie puławskiej wzrastała ilość osobników z allelem $M Y F 4^{B}$, w rasie złotnickiej białej i pstrej zwiększała się frekwencja osobników obu form homozygotycznych $A A$ i $B B$. Ponadto w rasie złotnickiej białej od wartości inbredu $\mathrm{F} \geq 0,0625$ stwierdzono zwiększenie ilości osobników posiadających allel $G$ genu $S C I$, allel $D$ genu $H A F A B P / H a e l l$ i allel $h$ genu HAFABP/HinfI, a w rasie złotnickiej pstrej przede wszystkim allel $A$ genu $M C 4 R$. Analizując polimorfizm genów związanych ze zdrowotnością świń, stwierdzono jedynie w rasie puławskiej zmniejszenie frekwencji osobników homozygotycznych $C O X 2^{22}$ i $C R P^{G G}$ w grupie o najwyższej wartości inbredu. Należy zaznaczyć, że w przypadku niektórych polimorfizmów genów (w rasie puławskiej MYF4, HFABP/Haell, HFABP/Hpall, i SCI, w rasie złotnickiej białej - DGAT1, SCI, MC4R i HFABP/HinfI i w rasie zł pstrej - MC4R) wzrost wartości inbredu powyżej $\mathrm{F} \geq 0,0625$ (puławska, zł biała) i F $\geq 0,098$ (zł pstra) łączył się (wbrew oczekiwaniom) ze zwiększeniem ilości osobników heterozygotycznych. 


\title{
EFEKTYWNOŚĆ EKONOMICZNA ZWIĘKSZONEGO UROZMAICENIA ŹRÓDEŁ ENERGII PASZOWEJ DLA ŚWIŃ ROSNĄCYCH
}

Economic efficiency of increased energy sources diversity for growing pigs

\author{
Ryszard Tuz ${ }^{1}$, Tomasz Schwarz ${ }^{1}$, Artur Turek ${ }^{2}$, Karol Włodarczyk $^{3}$, Jan Wujczak ${ }^{4}$, Jacek Nowicki ${ }^{1}$ \\ ${ }^{1}$ Uniwersytet Rolniczy w Krakowie, Instytut Nauk o Zwierzętach, Zakład Hodowli Trzody Chlewnej i Drobnego Inwentarza \\ ${ }^{2}$ Blattin Polska Sp. z o.o., ${ }^{3}$ KWS Lochow Polska Sp. z o.o., ${ }^{4}$ Gospodarstwo Rolne Jan Wujczak \\ e-mail: rztuz@cyf-kr.edu.pl
}

Ekonomiczna efektywność produkcji świń uzależniona jest od wielu czynników działających synergistycznie lub antagonistycznie. Do najważniejszych działań synergistycznych należy powiązanie potencjału genetycznego zwierząt i żywienia. Żywienie jest czynnikiem kluczowym, generuje około 70\% kosztów, a jego działanie w zakresie ekonomii jest związane ze zmianą relacji kosztów do przychodów. Może to polegać na obniżaniu kosztów paszy przy zachowaniu parametrów produkcyjnych, a także na poprawie wskaźników produkcyjnych przy zachowanych lub nieznacznie podniesionych kosztach. Celem pracy było określenie efektywności ekonomicznej tuczu świń z zastosowaniem droższych, ale bardziej urozmaiconych i tym samym potencjalnie bardziej efektywnych produkcyjnie pasz. Badania przeprowadzono w komercyjnej fermie na 500 świniach DanBred, porównując wskaźniki ekonomicznej efektywności tuczu mieszankami komponowanymi w oparciu o 3 (pszenica + jęczmień + żyto) lub 4 (pszenica + jęczmień + żyto + kukurydza) składniki zbożowe. Analizom poddano koszty przyrostu masy ciała oraz przychody ze sprzedaży tusz, obliczając wartość nadwyżki bezpośredniej jako parametru określającego opłacalność produkcji. Ceny mieszanek typu grower nie różniły się znacząco pomiędzy grupami, jednak w przypadku mieszanek typu finiszer różnica była już wyraźna. Ze względu na poprawę wskaźników produkcyjnych świń żywionych paszami bardziej zróżnicowanymi koszt przyrostu masy ciała w tej grupie w okresie tuczu wstępnego był niższy, jednak znaczące obniżenie cen mieszanek trójskładnikowych w okresie tuczu końcowego spowodowało istotne obniżenie całkowitego kosztu tuczu w tej grupie. Pomimo większej wartości sprzedaży tusz świń żywionych bardziej urozmaiconymi mieszankami podwyższone koszty tuczu spowodowały znaczące obniżenie opłacalności produkcji w tej grupie (tabela).

\begin{tabular}{|l|c|c|c|}
\hline \multicolumn{1}{|c|}{ Parametr } & Gr. 4 składniki & Gr. 3 składniki & Poziom istotności/różnica [\%] \\
\hline Cena growera [zł] & 984,22 & 974,12 & $1,03 \%$ \\
Cena finiszera [zł] & 963,22 & 918,47 & $4,65 \%$ \\
Koszt 1 kg p.m.c. grower [zł] & $2,30 \pm 0,32$ & $2,37 \pm 0,31$ & 0,000001 \\
Koszt 1 kg p.m.c. finiszer [zł] & $2,61 \pm 0,58$ & $2,25 \pm 0,32$ & 0,000001 \\
Koszt 1 kg p.m.c. całość [zł] & $2,43 \pm 0,29$ & $2,30 \pm 0,29$ & 0,00011 \\
Koszt paszy/szt. [zł] & 250,25 & 233,38 & $6,74 \%$ \\
Koszt warchlaka [zł] & $320,50 \pm 57,87$ & $322,35 \pm 48,52$ & 0,38 \\
Koszt bezpośredni [zł] & 570,75 & 555,73 & $2,63 \%$ \\
Cena 1 kg tuszy [zł] & $6,25 \pm 0,15$ & $6,26 \pm 0,17$ & 0,334 \\
Cena tuszy [zł] & $648,95 \pm 60,43$ & $639,22 \pm 50,64$ & 0,0608 \\
Nadwyżka bezpośrednia/szt. [zł] & 78,20 & 83,49 & $-6,76 \%$ \\
\hline
\end{tabular}

Finansowanie: NCBR, ENERGYFEED, umowa BIOSTRATEG2/297910/12/NCBR/2016. 


\title{
WPŁYW KONSYSTENCJI PASZY NA DOBOWE PRZYROSTY MASY CIAŁA PROSIĄT
}

Comparison of the growth rate of piglet's fed with liquid and dry feed

\author{
Ryszard Tuz ${ }^{1}$, Paweł Sztafiński ${ }^{1}$, Martyna Małopolska ${ }^{2}$, Tomasz Schwarz ${ }^{1}$, Jacek Nowicki ${ }^{1}$ \\ ${ }^{1}$ Uniwersytet Rolniczy w Krakowie, Instytut Nauk o Zwierzętach, Zakład Hodowli Trzody Chlewnej i Drobnego Inwentarza \\ ${ }^{2}$ Instytut Zootechniki - Państwowy Instytut Badawczy, Zakład Hodowli Trzody Chlewnej \\ e-mail: rztuz@cyf-kr.edu.pl
}

Dobra jakość prosiąt odsadzonych jest podstawą do uzyskania satysfakcjonujących wyników produkcyjnych w późniejszym okresie. Jednym z ważniejszych elementów odchowu prosiąt jest żywienie przy maciorze. W pierwszych dniach życia jedynym pokarmem osesków jest siara, a następnie mleko. Aby przygotować organizm prosięcia do trawienia pokarmów stałych, układ pokarmowy musi przejść tzw. trening enzymatyczny, który pozwoli na trawienie węglowodanów. Rozpoczyna się on wraz z zadawaniem niewielkiej ilości paszy stałej od około 6-7 dnia życia prosiąt. Od tego, ile paszy przyswoją prosięta, zależy ich zdolność do pobierania pasz stałych, przyrosty masy ciała oraz masa odsadzeniowa.

Celem badania była analiza przyrostów masy ciała prosiąt w zależności od konsystencji paszy.

Badania przeprowadzono w gospodarstwie rodzinnym zlokalizowanym w województwie śląskim. Materiał badawczy stanowiło 46 prosiąt mieszańców, pochodzących z czterech miotów loch pbz $\times$ wbp inseminowanych knurami pietrain. Doświadczenie prowadzono w okresie od 1 do 43 dnia życia prosiąt. Zwierzęta

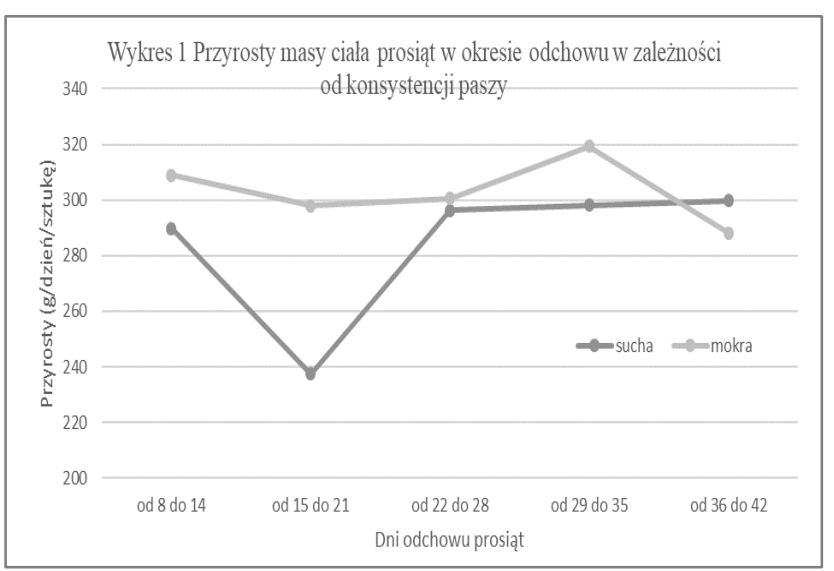
losowo podzielono na dwie grupy: I - dokarmiana suchą paszą typu prestarter oraz II - tą samą paszą, zwilżoną wodą, podawaną $w$ formie papki. Dokarmianie rozpoczęto w 7 dniu życia prosiąt. Zwierzęta ważono w $1,8,15,22,29,36$ oraz 43 dniu życia. Ponadto ważono paszę, która była zadawana dwa razy dziennie, a przed podaniem paszy usuwano i ważono niedojady.

Średnie dobowe przyrosty masy ciała prosiąt od urodzenia do odsadzenia oscylują w zakresie od 180 do $240 \mathrm{~g}$ (Sowizdrzał 2013). W badaniach własnych uzyskano wartości wynoszące średnio $277,14 \mathrm{~g}$ dla prosiąt dokarmianych suchą mieszanką i 292,99 g dla zwierząt pobierających prestarter $\mathrm{z}$ dodatkiem wody. Na podstawie analizowanych danych stwierdzono, ze prosięta dokarmiane w okresie odchowu paszą o konsystencji papki pobrały średnio 178,90 g paszy dziennie, co stanowiło większe o 12,32 g pobranie paszy w stosunku do prosiąt dokarmianych paszą suchą. W konsekwencji większego pobrania paszy i większych przyrostów masy ciała $\mathrm{w}$ okresie odchowu prosięta dokarmiane paszą z dodatkiem wody uzyskały średnio o 0,66 kg większą masę ciała w dniu odsadzenia.

Badania finansowane z DS. 3236. 


\title{
RUCH PLEMNIKÓW OCENIANY METODĄ TRADYCYJNĄ I SYSTEMEM CASA W CZASIE PRZECHOWYWANIA NASIENIA KNURÓW W STANIE PŁYNNYM
}

\author{
Sperm movement assessed by traditional method and CASA system during storage of boar semen \\ in liquid state
}

\author{
Jan Udała, Dariusz Gączarzewicz, Ewa Kwita, Tomasz Stankiewicz, Barbara Błaszczyk, \\ Bogumiła Pilarczyk, Agnieszka Tomza-Marciniak, Małgorzata Bąkowska, \\ Aleksandra Balicka-Ramisz, Karolina Procak
}

\begin{abstract}
Zachodniopomorski Uniwersytet Technologiczny w Szczecinie, Katedra Biotechnologii Rozrodu Zwierząt i Higieny Środowiska e-mail: jan.udala@zut.edu.pl
\end{abstract}

Ruchliwość jest podstawową właściwością plemników, objawem żywotności i integralności strukturalnej, decydującą o ich zdolności zapładniającej. W praktyce inseminacyjnej ocena ruchu postępowego plemników jest najczęściej stosowanym testem do określania jakości nasienia. Wykonywana w tym celu ocena mikroskopowa jest oceną subiektywną, uwarunkowaną wpływem wielu czynników zewnętrznych. W ostatnich latach coraz szersze zastosowanie w praktyce znajduje komputerowy systemu analizy nasienia (CASA), pozwalający na szczegółową charakterystykę ruchu plemników. Dlatego też głównym celem niniejszych badań było porównanie kształtowania się ruchu postępowego plemników ocenianego metodą tradycyjną i CASA w kolejnych dniach przechowywania konserwowanego nasienia knurów w stanie płynnym.

Badania zostały przeprowadzone na nasieniu pobranym od 20 knurów Maximus i WBP, w wieku 13-25 miesięcy, utrzymywanych $w$ jednym $z$ zakładów unasienniania zwierząt na Pomorzu Zachodnim. Nasienie rozrzedzano rozcieńczalnikiem Gedil, a następnie przechowywano w $16^{\circ} \mathrm{C}$, monitorując zmiany ruchu plemników w 1., 3., 5., 8. i 10. dniu. Ruchliwość nasienia metodą tradycyjną (mikroskopową) wykonano na stoliku Bloma, w kontraście fazowym, przy powiększeniu 100-krotnym w warstwie $5 \mu \mathrm{m}$. Ocenę komputerową przeprowadzono, wykorzystując Sperm Class Analyzer® (Microptic S.L), współdziałającym z mikroskopem Nicon Eclipse E-200z, wyposażonym w kamerę cyfrową. Analizę obrazu przeprowadzano

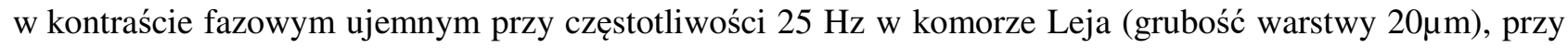
powiększeniu 100-krotnym.

Wykazano, że udział plemników o ruchu postępowym oceniany na stoliku Bloma i systemem CASA w 1 . dniu badania wynosił odpowiednio $71,8 \pm 12,6 \%$ i $65,2 \pm 16,3 \%$, natomiast w ostatnim dniu $26,5 \pm 12,9 \%$ i $31,5 \pm 12,4 \%$. Między obiema metodami oceny tego ruchu wystąpiła wysoko istotna zależność $(\mathrm{r}=0,922$, $\mathrm{P}=0,01$ ). Ruch całkowity plemników (oceniany CASA) wyniósł $87,0 \pm 9,3 \%$. i 50,0 $\pm 12,5 \%$, odpowiednio 1. i 10. dnia badania. W kolejnych dniach obserwowano stopniowy spadek ruchliwości, przy czym niewielki jeszcze w 3. dniu, natomiast już wyraźny w następnych dniach procesu konserwacji nasienia. Między ejakulatami występowała duża zmienność, a w wielu próbach w ostatnim dniu przechowywania stwierdzano ponad 70\% plemników o ruchu postępowym. Średnio ruchem szybkim w 1. dniu poruszało się 43,3 $\pm 15,9 \%$, a w ostatnim dniu $17,2 \pm 10,3 \%$ plemników, ruchem średnim odpowiednio $29,6 \pm 8,6 \%$ i $16,4 \pm 6,3 \%$, a ruchem wolnym $14,3 \pm 8,1 \%$ i $16,3 \pm 7,3 \%$ plemników.

Reasumując, stwierdzono dużą zgodność między metodami w ocenie ruchliwości plemników, co wskazuje na wystarczającą możliwość wykorzystania tradycyjnej metody mikroskopowej w podstawowej kontroli zmian jakości nasienia knura podczas długoterminowego przechowywania w stanie płynnym. 


\section{REFERATY}




\title{
HODOWLA ŚWIŃ RASY PUŁAWSKIEJ W WARUNKACH ROLNICTWA ZRÓWNOWAŻONEGO
}

Breeding of Pulawska swine in the sustainable agriculture conditions

\author{
Marek Babicz ${ }^{1}$, Marcin Hałabis ${ }^{1}$, Anna Litwińczuk $^{2}$, Piotr Domaradzki ${ }^{2}$, Piotr Skałecki ${ }^{2}$ \\ ${ }^{1}$ Uniwersytet Przyrodniczy w Lublinie, Instytut Hodowli Zwierząt i Ochrony Bioróżnorodności, Zakład Hodowli i Biotechnologii \\ Trzody Chlewnej, ul. Akademicka 13, 20-950 Lublin \\ ${ }^{2}$ Uniwersytet Przyrodniczy w Lublinie, Katedra Towaroznawstwa i Przetwórstwa Surowców Zwierzęcych, \\ ul. Akademicka 13, 20-950 Lublin \\ e-mail: marek.babicz@up.lublin.pl
}

Z pojęciem zrównoważonego rolnictwa jest związana ochrona zasobów genetycznych zwierząt gospodarskich jako element zachowania krajobrazu wiejskiego. W tym aspekcie jest to proces gospodarowania zasobami genetycznymi zwierząt w taki sposób, aby można było zaspokoić aspiracje rozwojowe obecnego pokolenia, a jednocześnie aby przyszłe pokolenie mogło czerpać porównywalne korzyści. Zrównoważony rozwój obejmuje trzy zasadnicze wymiary - społeczny, ekonomiczny i ekologiczny - ściśle skorelowane z hodowlą zachowawczą zwierząt gospodarskich, w tym świń rasy puławskiej (Borecka 2016, Harasim 2008).

W wymiarze społecznym zrównoważonego rozwoju świnie rasy puławskiej stanowią stały, historyczny element regionu Lubelszczyzny, z którego się wywodzą. Tradycje hodowli tej rasy świń sięgają 1926 r., kiedy podjęto planowe prace hodowlane zmierzające do uzyskania pierwszej krajowej rasy świń. Do roku 1936 wytworzono populację świń w typie tłuszczowo-mięsnym (Zabielski 1939). Ten typ świni krajowej określono mianem ,świni gołębskiej”, której to nazwy używano do 1951 r., kiedy dokonano zmiany na „rasę puławską". Do lat 80 . XX w. rasa puławska była bardzo popularna w chowie masowym, utrzymywano ją nie tylko na Lubelszczyźnie, ale również w Polsce centralnej i południowej. Na przełomie lat 80. i 90. XX w. nastąpił gwałtowny spadek zainteresowania wykorzystaniem tej rasy w masowej produkcji tuczników, czego główną przyczyną była znacznie niższa mięsność w porównaniu z rasami importowanymi: duroc, hampshire, pietrain (Walkiewicz i in. 2017). Do utrzymania hodowli rasy puławskiej na Lubelszczyźnie przyczyniły się działania, jakie podjęli naukowcy, hodowcy i przedstawiciele instytucji hodowlanych z regionu. W myśl uchwały z dnia 29 sierpnia 1996 r. Rady Hodowlanej ds. Hodowli Trzody Chlewnej przy Centralnej Stacji Hodowli Zwierząt w Warszawie rasę puławską objęto ochroną jako rezerwę genetyczną (Bajda 2000).

W wymiarze ekonomicznym rolnictwa zrównoważonego rodzime rasy świń powinny być traktowane jako źródło dochodu w gospodarstwach rodzinnych zapewniających optymalny poziom dobrostanu, co pozwala na wytworzenie produktu o wysokiej jakości etycznej. $Z$ uwagi na konieczność konkurowania z dużymi fermami należy dążyć do maksymalnego wykorzystania charakterystycznych cech użytkowych świń rasy puławskiej, co umożliwia podniesienie opłacalności produkcji. Poziom cech użytkowych świń rasy puławskiej spełnia kryteria standardu hodowlanego komponentu matecznego (Babicz i in. 2013, 2016, Kasprzyk $\mathrm{i}$ in. 2013). Obecnie rasa prezentuje typ przejściowy między tłuszczowo-mięsnym a mięsnym (Florowski i in. 2006, 2007). W tym aspekcie coraz częściej zwraca się uwagę na możliwość wykorzystania ras rodzimych do produkcji wyrobów regionalnych i tradycyjnych, o wysokiej jakości oraz niepowtarzalnej recepturze i technologii wytwarzania (Krupiński 2006).

Podstawę do wykorzystania rasy puławskiej w produkcji wyrobów tego typu daje wpisanie świni rasy puławskiej w dniu 28 maja 2009 r. na prowadzoną przez Ministra Rolnictwa i Rozwoju Wsi Listę Produktów Tradycyjnych, będącą częścią strategii identyfikacji i promocji produktów regionalnych.

W produkcji wyrobów tradycyjnych istotne znaczenie ma jakość surowca wieprzowego, która rzutuje na końcową ocenę konsumentów. Podstawowymi wskaźnikami jakości technologicznej i konsumpcyjnej wie- 
przowiny są właściwości fizyczne i skład chemiczny. Jak wynika z przeprowadzonych badań (Babicz i in. 2013, Kasprzyk i in. 2013), parametry te przyjmowały wartości charakterystyczne dla mięsa normalnej jakości, typu RFN, najbardziej pożądanego przez konsumentów.

Ochrona zasobów genetycznych świń w wymiarze ekologicznym zrównoważonego rozwoju jest coraz częściej postrzegana jako podstawowy element związany z utrzymaniem ras rodzimych (Szulc 2011). Większość populacji świń rasy puławskiej objętej hodowlą zachowawczą jest utrzymywana w gospodarstwach rodzinnych. Mniejsza skala produkcji sprzyja utrzymaniu optymalnych warunków dobrostanu oraz wdrażaniu zasad dobrej praktyki rolniczej, co przynosi wymierne korzyści dla środowiska. Ponadto świnie rasy puławskiej utrzymywane są przede wszystkim w systemie ściółkowym, co pozwala na ograniczenie zagrożeń związanych z zanieczyszczeniem środowiska szkodliwymi gazami (amoniak, siarkowodór, dwutlenek węgla), odorami i azotem.

Wymiar ekologiczny użytkowania świń rasy puławskiej w warunkach rolnictwa zrównoważonego ma istotne znaczenie $\mathrm{w}$ aspekcie preferencji konsumentów, którzy coraz częściej poszukują surowca kulinarnego i wyrobów wyprodukowanych zgodnie z tymi zasadami.

Hodowla świń rasy puławskiej prowadzona w warunkach rolnictwa zrównoważonego pozwoli nie tylko na zachowanie rasy dla przyszłych pokoleń, ale również na jej trwałe umiejscowienie w krajowej produkcji wieprzowiny.

Badania zrealizowano w ramach projektu Biostrateg „Kierunki wykorzystania oraz ochrona zasobów genetycznych zwierząt gospodarskich w warunkach zrównoważonego rozwoju” współfinansowanego przez Narodowe Centrum Badań i Rozwoju w ramach Strategicznego programu badań naukowych i prac rozwojowych „Środowisko naturalne, rolnictwo i leśnictwo” (BIOSTRATEG2/297267/2/NCBR/2016).

\section{Piśmiennictwo}

Babicz M., Kropiwiec K., Kasprzak K., Skrzypczak E., Hałabis M. 2013. Analysis of the quality pork obtained from carcasses fatteners of Polish Landrace and Pulawska breed. Annales UMCS, sec. EE, 31(4), 1-7.

Babicz M., Szyndler-Nędza M., Skrzypczak E., Kasprzyk A. 2016. Reproductive performance of native Pulawska and high productivity Polish landrace sows in the context of stress during the period of early pregnancy. Repr. Dom. Anim. 51(1), 91-97.

Bajda Z. 2000. Ocena fenotypowej i genetycznej zmienności w populacji rasowej świni puławskiej utrzymywanej w hodowli zachowawczej. Praca doktorska, AR Lublin.

Borecka A. 2016. Produkcja żywca wieprzowego w gospodarstwach rodzinnych w warunkach zrównoważonego rozwoju. Rocz. Nauk. SERiA 18(6), 17-21.

Florowski T., Pisula A., Adamczak L., Buczyński J.T., Orzechowska B. 2006. Technological parameters of meat in pigs of two Polish local breeds - Zlotnicka Spotted and Pulawska. Anim. Sci. Pap. Rep. 24(3), 217-224.

Florowski T., Pisula A., Rola M., Adamczak L. 2007. Wpływ krzyżowania towarowego świń rasy puławskiej z rasami wbp i pbz na jakość kulinarną mięsa. Rocz. IPMiT 45(1), 25-34.

Kasprzyk A., Babicz M., Kamyk-Kamieński P., Lechowski J. 2013. Slaughter value and meat quality of Pulawska and Polish Landrace breeds fatteners. Annales UMCS, sec. EE, 31(3), 1-9.

Krupiński J. 2006. Polskie rasy zachowawcze. Atlas zwierząt gospodarskich objętych programem ochrony w Polsce. IZ, Kraków.

Szulc K. 2011. Ochrona zasobów zwierząt gospodarskich w kontekście zrównoważonego rozwoju. Probl. Ekoroz. 6 (2), $141-146$.

Walkiewicz A., Babicz M., Kasprzyk A., Kondracki S., Blicharski T., Bajda Z., Różycki M., Szyndler-Nędza M., Jaszczyńska M. 2017. Program hodowlany ochrony zasobów genetycznych świń rasy puławskiej (tekst jednolity).

Zabielski Z. 1939. Studia nad świnią gołębską. Cz. II. Pam. PINGW Puł. 17, 224-277. 


\title{
ŚWINIE RASY WIELKIEJ BIAŁEJ POLSKIEJ - HISTORIA, TERAŹNIEJSZOŚĆ, PRZYSZŁOŚĆ
}

Polish large white pigs - history, present, future

\author{
Tadeusz Blicharski ${ }^{1}$, Grzegorz Żak ${ }^{2}$, Anna Hammermeister ${ }^{1}$, Piotr Polok ${ }^{1}$, Robert Kaźmierczak ${ }^{1}$, \\ Jakub Borkowski ${ }^{1}$

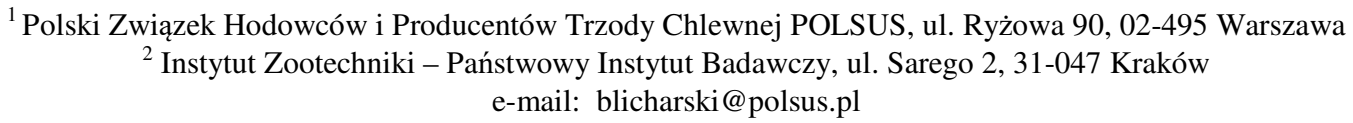

Hodowla świń rasy wielkiej białej polskiej ma w naszym kraju długoletnią tradycję. Rasa ta na przestrzeni szeregu lat uległa znaczącym przeobrażeniom w zakresie cech użytkowych. Jest to efektem prowadzenia prac hodowlanych wynikających z założeń realizowanego programu hodowlanego, ukierunkowanych na poprawę cech tucznych, rzeźnych, a od 10 lat również cech użytkowości rozpłodowej. Prace te prowadzone głównie w oparciu o materiał krajowy, ale również importowany z innych krajów Europy Zachodniej, doprowadziły do momentu, w którym należałoby podjąć decyzję, co należy uczynić, aby w pełni wykorzystać potencjał świń rasy wbp. Szczegółowa analiza aktualnego poziomu użytkowości świń tej rasy, zarówno w odniesieniu do całej populacji aktywnej, jak i wybranych linii knurów i ich potomstwa skłania do zastanowienia się nad przyszłością rasy wbp i ewentualnego podjęcia decyzji wynikających z wniosków, jakie nasuwają się po przeanalizowaniu wyników użytkowości i wartości hodowlanej.

\section{Historia rasy wbp}

Proces kształtowania się rasy wielkiej białej polskiej rozpoczął się we wczesnych latach XX w. w wyniku krzyżowania ras miejscowych z rasami wielką i średnią białą angielską oraz niemiecką białą szlachetną. Ośrodki hodowli świń angielskich zlokalizowane były w centralnej i wschodniej Polsce, natomiast świń niemieckich w zachodnich rejonach Polski. Proces ten zdecydowanie nabrał tempa po II wojnie światowej, kiedy to krzyżowanie wypierające $\mathrm{z}$ zastosowaniem rasy wielkiej białej angielskiej oraz prace hodowlane doprowadziły do wyrównania obu populacji. W wyniku znacznego dolewu krwi świń rasy wielkiej białej angielskiej oraz świadomej pracy selekcyjnej polskich hodowców typ użytkowy miejscowej rasy białej ostrouchej z tłuszczowo-mięsnego został stopniowo przekształcony w mięsny. W związku z tym już w 1951 r. na konferencji w Krakowie, której uczestnikami byli przedstawiciele Ministerstwa Rolnictwa i Instytutu Zootechniki, podjęto uchwałę o połączeniu obu ras pod nazwą wielka biała polska. Jednak dopiero na mocy rozporządzenia Ministra Rolnictwa z 2 sierpnia 1956 r. (Dziennik Ustaw z 1956 r. Nr 49 poz. 218) świnie rasy białej ostrouchej ujęto łącznie $\mathrm{z}$ wielką białą angielską pod wspólną nazwą rasy wielkiej białej. Nazwa rasy - wielka biała spotkała się ze sprzeciwem zarówno hodowców, jak i środowiska naukowego, ponieważ nie obejmowała ona określenia ,polska”. Uważano, że pogłowie świń rasy wielkiej białej angielskiej hodowane w Polsce, a zwłaszcza białej ostrouchej, to wynik prac hodowlanych i wysiłku polskich hodowców. Nazwa wielka biała polska wskazywałaby na odrębne pochodzenie tej rasy i nie identyfikowałaby się z wielką białą angielską. Dopiero rozporządzeniem Ministra Rolnictwa z 27 grudnia 1962 r. wprowadzono nazwę wielka biała polska (Dz.U. z 1963 r. Nr 6 poz. 38). 


\section{Rola świń rasy wbp w Krajowym Programie Hodowlanym}

Świnie rasy wbp zgodnie z założeniami Krajowego Programu Hodowlanego obowiązującego od 2010 r. stanowią komponent matczyny i w tym kierunku powinny być doskonalone. Zgodnie z zapisami Programu prace hodowlane prowadzone w obrębie ras matczynych zmierzają do uzyskania:

- wysokiego poziomu cech związanych z użytkowością rozrodczą (liczba prosiąt żywo urodzonych, liczba prosiąt w 21. dniu, wiek pierwszego oproszenia, plenność, liczba sutków, długość okresu międzymiotu),

- odpowiedniego tempa wzrostu,

- niskiego zużycia paszy na $1 \mathrm{~kg}$ przyrostu masy ciała,

- mięsności tusz na poziomie: 58\% dla loszek, 60\% dla knurków,

- uwolnienia ras należących do komponentu matecznego genu wrażliwości na stres RYR1T.

Tabela 1. Założenia Krajowego Programu Hodowlanego dla poszczególnych cech podlegających doskonaleniu na drodze prac hodowlanych

\begin{tabular}{|l|c|c|}
\hline \multicolumn{1}{|c|}{ Cecha } & Cel hodowlany & Średnie wartości w 2017 r. \\
\hline Liczba prosiąt żywo urodzonych & 13 szt. & $12,30 \mathrm{szt}$. \\
\hline Liczba prosiąt w 21. dniu & $12 \mathrm{szt}$. & $11,37 \mathrm{szt}$. \\
\hline Wiek pierwszego oproszenia & $340 \mathrm{dni}$ & $360 \mathrm{dni}$ \\
\hline Plenność & $27 \mathrm{szt}$. & b.d. \\
\hline Liczba sutków (dopuszcza się asymetrię 1 sutka) & $16 \mathrm{szt}$. & $14,82 \mathrm{szt}$. \\
\hline Długość okresu międzymiotu & $160 \mathrm{dni}$ & $653 \mathrm{~g}$ loszki \\
\hline Wielkość przyrostu dobowego masy ciała & $680 \mathrm{~g}$ loszki & $748 \mathrm{~g}$ knurki \\
\hline Mięsność & $800 \mathrm{~g}$ knurki & $59,2 \%$ loszki \\
\hline Gen $R Y R 1 T$ & $58 \%$ loszki & $60,6 \%$ knurki \\
\hline
\end{tabular}

\section{Użytkowość świń rasy wbp}

Poziom cech użytkowych świń rasy wbp uległ znaczącym zmianom na przestrzeni lat. Jest to efektem prowadzonych prac hodowlanych zmierzających w początkowych latach głównie do zwiększania zawartości mięsa w tuszy i poprawy cech tucznych. Działania te dały efekt w postaci wyraźnego wzrostu poziomu tych cech. Od 10 lat (od roku 2008) doskonaleniu na drodze genetycznej podlegają również cechy użytkowości rozpłodowej, co jest niezmiernie istotne w przypadku rasy zaliczanej do komponentu matczynego. Zamiany poziomu cech tucznych i rzeźnych na przestrzeni 20 lat zamieszczono w tabeli 2.

Tabela 2. Użytkowość tuczna i rzeźna świń rasy wbp w latach 1996-2017

\begin{tabular}{|c|c|c|c|c|}
\hline \multirow{2}{*}{ Rok } & \multicolumn{2}{|c|}{ Przyrost dzienny $(\mathrm{g})$} & \multicolumn{2}{c|}{ Procentowa zawartość mięsa } \\
\cline { 2 - 5 } & knury & loszki & 55,9 & loszki \\
\hline 1996 & 621 & 564 & 58,3 & 55,2 \\
\hline 2001 & 632 & 585 & 59,0 & 57,3 \\
\hline 2006 & 679 & 624 & 60,0 & 57,2 \\
\hline 2011 & 698 & 638 & 60,5 & 58,7 \\
\hline 2016 & 727 & 648 & 60,6 & 59,2 \\
\hline 2017 & 748 & 653 & & 59,2 \\
\hline
\end{tabular}


Przeprowadzona szczegółowa analiza użytkowości tucznej i rzeźnej świń rasy wbp wykazała poza wysokim poziomem mięsności, zarówno loszek jak i knurów, również dość dużą zmienność w obrębie tych cech. Ponadto analizy wykazały, że w obrębie cech rzeźnych następuje widoczne przesunięcie ich poziomu w kierunku powyżej średniej dla całej populacji. Średnie wyniki użytkowości tucznej i rzeźnej dla 59905 młodych knurów rasy wbp ocenionych przyżyciowo w latach 1996-2016 przedstawiono w tabeli 3.

Tabela 3. Użytkowość tuczna i rzeźna populacji knurów rasy wbp ocenionych w latach 1996-2016

\begin{tabular}{|l|c|c|c|c|c|}
\hline \multicolumn{1}{|c|}{ Parametr } & $\begin{array}{c}\text { Przyrost dzienny } \\
{[\mathrm{g}]}\end{array}$ & $\begin{array}{c}\text { Grubość słoniny P2 } \\
{[\mathrm{mm}]}\end{array}$ & $\begin{array}{c}\text { Grubość słoniny P4 } \\
{[\mathrm{mm}]}\end{array}$ & $\begin{array}{c}\text { Wysokość oka } \\
\text { polędwicy [mm] }\end{array}$ & $\begin{array}{c}\text { Zawartość mięsa } \\
\text { w tuszy [\%] }\end{array}$ \\
\hline Wartość średnia & 697,8 & 9,04 & 8,98 & 55,52 & 59,6 \\
\hline SD & 84,1 & 1,79 & 1,74 & 4,82 & 2,14 \\
\hline $\begin{array}{l}\text { Współczynnik } \\
\text { zmienności [\%] }\end{array}$ & 12,06 & 19,85 & 19,37 & 8,68 & 3,58 \\
\hline
\end{tabular}

Jak wskazują wyniki przedstawione w tabeli 3, istnieje duża zmienność w obrębie grubości słoniny oraz przyrostów dziennych. Jest to informacja, że w populacji można znaleźć osobniki znacząco różniące się od siebie pod względem tych cech, a zatem istnieje możliwość efektywnego doskonalenia tych cech w pożądanym kierunku przez zastosowanie odpowiednich narzędzi i podjęcie określonych decyzji. Nieco mniejszą zmiennością cechuje się procentowa zawartość mięsa w tuszy, co można tłumaczyć tym, że przez wiele lat ten parametr był traktowany priorytetowo przez hodowców. Należy także wyraźnie zaznaczyć, że w 2017 r., co pokazano w tabeli 2, wartość tego parametru przekracza już próg zapisany w Krajowym Programie Hodowlanym i to zarówno w przypadku knurów, jak i loszek. Dlatego też dokonano szczegółowej analizy tej cechy w celu stwierdzenia, ile osobników reprezentuje poszczególne przedziały mięsności, gdy badaną populację ocenioną w latach 1996-2016 podzieli się na grupy wyznaczone przez $+1,+2 \mathrm{i}+3$ oraz $-1,-2$ i -3 odchylenia standardowe od średniej zarówno w kierunku dodatnim, jak i ujemnym. Wyniki przedstawia wykres 1.

\section{Zawartość mięsa, \%}

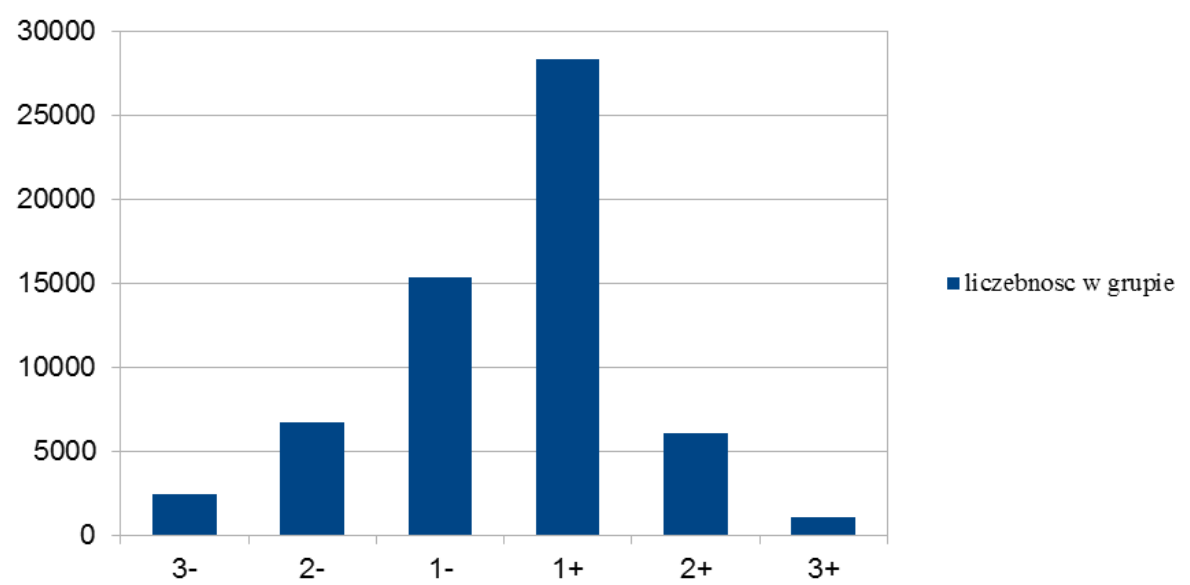

Wykres 1. Liczba knurów w poszczególnych przedziałach mięsności w zależności od odchylenia od średniej

Jak wynika z danych przedstawionych na wykresie 1, najwięcej knurów znajduje się w przedziale 1+, czyli wyznaczonym przez wartość 1 odchylenia standardowego od średniej procentowej zawartości mięsa w tuszy. Jest to przedział, w którym mięsność mieści się w granicach od 59,62\% do 61,76\%, a jego liczebność wynosi 28323 osobniki w analizowanym okresie. Co istotne i godne podkreślenia, w przedziale 2+, czyli w tym, w którym mięsność knurów wbp wynosiła od 61,77\% do 63,90\%, znalazły się 6034 osobniki, zaś w przedziale $3+$ skupiającym knury o mięsności powyżej 63,90\% znajdowało się 1062 szt. Można zatem 
stwierdzić, że ponad 7 tys. knurów z populacji aktywnej ocenionych przyżyciowo spełniło pod względem mięsności warunki, jakie stawia się rasom ojcowskim. Podobne zależności jak dla procentowej zawartości mięsa w tuszy stwierdzono dla wysokości oka polędwicy. Należy także dodać, że identyczne analizy wykonano także dla loszek i stwierdzono tendencje w zakresie rozkładu badanych cech zbliżone do knurów.

Podczas analiz danych zaobserwowano także inne interesujące zjawisko. A mianowicie stwierdzono, że niektóre linie knurów i ich potomstwo charakteryzują się mięsnością znacząco odbiegającą od średniej wyliczonej dla całej populacji aktywnej. W powiązaniu do prezentowanych wyżej wyników dało to podstawy do podjęcia rozważań i prób planowania działań dotyczących przyjęcia strategii na przyszłość w odniesieniu do świń rasy wbp.

\section{Plany na przyszłość w świetle dokonanych analiz wyników oraz aktualnej sytuacji w chowie i hodowli świń}

Współczesna produkcja towarowa świń powraca w coraz większym stopniu do wykorzystywania ras czystych. Hybrydowe rozpłodniki w dużym stopniu utraciły popularność ze względu na dość znaczną zmienność użytkowości rzeźnej potomstwa, czyli uzyskiwanych mieszańców towarowych. W większości krajów jako ostateczny knur terminalny najpowszechniejszą jest rasa pietrain. Tymczasem jest to rasa niosąca, owszem ogromny potencjał w zakresie mięsności, ale jednocześnie nie jest szybko rosnącą i ma nie najlepsze opinie w odniesieniu do jakości mięsa. Nawet po uwolnieniu od niekorzystnej mutacji genu wrażliwości na stres wykazuje się mięsem o gorszej jakości w porównaniu z innymi rasami.

Krajowy rynek oczekuje nowej propozycji w zakresie oferty rasowej. Spośród utrzymywanych w kraju ras uwagę zwraca omawiana w niniejszej pracy rasa wielka biała polska. Jako rasa mateczna nie odbiega znacząco wynikami użytkowości rozpłodowej od rasy polskiej białej zwisłouchej, jednak w stosunku do niej okazuje się być bardziej plastyczna. Niemal we wszystkich krajach jest wykorzystywana jako komponent do krzyżowania towarowego z rasą pbz lub jej odpowiednikami do uzyskiwania wysoko produkcyjnych loszek $\mathrm{F}_{1}$. Jednocześnie zauważa się duży potencjał rasy wbp do szybkiego wzrostu i odkładania mięsa, co wykazały analizy, których wyniki zaprezentowano w pierwszej części referatu. Była to z resztą pierwsza nowoczesna, europejska rasa o dużym potencjale wzrostu. Użytkowość rozpłodowa była cechą selekcjonowaną u świń wbp znacznie później. Ze względu na fakt, że świnie rasy wbp wykazują duży potencjał szybkiego wzrostu i odkładania białka, w niektórych krajach w obrębie tej rasy wyodrębniono populacje zwierząt, które w programach krzyżowania są traktowane jako rasa lub linia ojcowska.

W warunkach krajowej hodowli, o czym już wcześniej wspomniano, istnieją stada obejmujące rozpłodniki charakteryzujące się bardzo wysokim tempem wzrostu oraz mięsnością na poziomie ras ojcowskich. Są to zwykle stada, w których selekcję opierano w znaczącym stopniu na wynikach oceny w SKURTCh. Dla potwierdzenia tej tezy poniżej przedstawiono wyniki użytkowości tucznej i rzeźnej knurów z kilku wybranych stad rasy wbp:

stado 1: 06501-0600/17 - przyrost dzienny 863 g; mięsność 64,8\%

stado 2: 06501-0054/18 - przyrost dzienny 826 g; mięsność 65,3\%

stado 3: 20199-0667/17 - przyrost dzienny 869 g; mięsność 63,3\%

stado 4: 02473-0550/17 - przyrost dzienny 806 g; mięsność 66,2\%

stado 5: 22727-0558/16 - przyrost dzienny 804 g; mięsność 63,8\%

stado 6: 26613-0649/16 - przyrost dzienny 856 g; mięsność 63,1\%

Jak widać, stada o tak wysokiej użytkowości tucznej i rzeźnej można znaleźć w różnych rejonach kraju i są to knury działające aktualnie w hodowli.

Biorąc pod uwagę szereg przesłanek, w tym w szczególności te, które przedstawiono w tezach prezentowanej publikacji, planowane jest wyodrębnienie nowej rasy spośród populacji świń rasy wbp. Wyodrębniona populacja będzie doskonalona wg nowego programu hodowlanego, którego założenia będą określały jej charakter jako komponent ojcowski. Świnie nowo tworzonej rasy wielkiej białej ojcowskiej będą zwierzętami szybko rosnącymi, późno dojrzewającymi o białym umaszczeniu, relatywnie dużymi, uzyskującymi masę ciała $350-400 \mathrm{~kg}$. Istotną ich cechą jest harmonijna budowa ciała z kłodą o dużych rozmiarach, osadzoną na mocnych nogach. Sylwetka będzie charakteryzowała się prostym, równym i dość szerokim grzbietem, mocnym 
zadem, z wyraźnie lub wybitnie wysklepioną szynką. Głowa o lekko wklęsłym profilu, uszy stojące ostro zakończone. Umięśnienie zwłaszcza szynek i łopatek będzie wyraźnie widoczne. Świnie nowo tworzonej rasy będą charakteryzowały się dobrą jakością mięsa (ocena w SKURTCh) oraz niskim zużyciem paszy na $1 \mathrm{~kg}$ przyrostu masy ciała. Zwierzęta tej rasy muszą być wolne od recesywnego genu RYR1 ${ }^{\mathrm{T}}$. Ze względu na ww. cechy będą używane jako ostateczny męski komponent terminalny do produkcji tuczników.

Jak już wcześniej wspomniano, zwłaszcza w stadach, w których ocenia się knury na podstawie potomstwa w SKURTCh, występują osobniki o wybitnych parametrach w zakresie tempa wzrostu i mięsności, charakterystycznych dla ras ojcowskich. Przykładem są przytoczone wyżej wyniki użytkowości tucznej i rzeźnej kilku knurów rasy wbp.

\section{Planowane założenia programu hodowlanego dla rasy wielkiej białej ojcowskiej (wbo)}

Intensywne i skuteczne doskonalenie cech tucznych i rzeźnych tuszy oraz selekcja w kierunku poprawy cech jakości mięsa powinny doprowadzić do uzyskania następujących celów hodowlanych:
a. procentowa zawartość mięsa w tuszy loszek $62,0 \%$
b. procentowa zawartość mięsa w tuszy knurków
$63,5 \%$
c. wielkość przyrostu dobowego masy ciała loszek
$725 \mathrm{~g}$
d. wielkość przyrostu dobowego masy ciała knurków
$825 \mathrm{~g}$
e. zużycie paszy na $1 \mathrm{~kg}$ przyrostu masy ciała
f. wolne od mutacji genu RYR $1^{\mathrm{T}}$
$2,5 \mathrm{~kg}$
g. liczba sutków genotyp RYR1 ${ }^{\mathrm{CC}}$ 14 szt.

\section{Metody hodowlane}

1. Ocena:

a. budowy, wzrostu i rozwoju oraz kondycji zwierząt,

b. wartości użytkowej - fermowa,

c. stacyjna (SKURTCh),

d. wartości hodowlanej metodą BLUP - model zwierzęcia,

e. genotypu metodami genetyki molekularnej, w tym identyfikacja polimorfizmu genu wrażliwości na stres (RYR1).

2. Selekcja - praca w stadzie $\mathrm{z}$ wykorzystaniem poniższych parametrów:

a. wyniki oceny fermowej, przyżyciowej dla:

- loszek,

- knurków,

b. indeksy oceny stacyjnej:

- indeks knura,

- indeks kojarzenia,

c. parametry jakości mięsa: $\mathrm{pH}, \mathrm{WHC}$, barwa L*a*b*, IMF,

d. indeksy BLUP.

3. Dobór do kojarzeń - indywidualny dobór do kojarzeń za pomocą specjalistycznego programu komputerowego.

Dane o użytkowości dostępnych rozpłodników wskazują, że na ich podstawie można będzie wyprowadzić nową rasę o wybitnych walorach tucznych i rzeźnych. Funkcjonująca ocena w stacjach SKURTCh powinna być podstawowym i nieodzownym źródłem wyników obiektywnej oceny cech tucznych, rzeźnych oraz jakości mięsa i powinna wspomagać w zasadniczym stopniu selekcję w kierunkach założonych w nowo opracowywanym programie hodowlanym. 
Sesja Młodych Naukowców 


\title{
BARWA SKORUPY JAKO CZYNNIK DETERMINUJĄCY JAKOŚĆ JAJ PRZEPIÓRKI JAPOŃSKIEJ
}

The color of shell as a factor determining the quality of Japanese quail eggs

\author{
Patrycja Chabroszewska ${ }^{1}$, Angelika Gryta ${ }^{1}$, Damian Spustek $^{1}$, Ewelina Misiec ${ }^{1}$, \\ Justyna Batkowska
}

\author{
${ }^{1}$ Uniwersytet Przyrodniczy w Lublinie, Sekcja Hodowli Drobiu SKN Biologów i Hodowców Zwierząt \\ ${ }^{2}$ Uniwersytet Przyrodniczy w Lublinie, Instytut Biologicznych Podstaw Produkcji Zwierzęcej, ul. Akademicka 13, 20-950 Lublin \\ e-mail: p.chabroszewska@gmail.com
}

Barwa skorupy ptasiej uwarunkowana jest genetycznie. Wiele gatunków ptaków znosi jaja o barwnej lub nakrapianej skorupie. Także w przypadku przepiórki japońskiej pozyskane jaja mają na ogół charakterystyczny plamiasty wzór na skorupie. Układ tych plam jest cechą indywidualną dla każdej samicy, pozwalającą na rozróżnienie poszczególnych osobników. Jednak wśród standardowo zabarwionych jaj zdarzają się jaja o skorupie jednolitej, o barwie od białej do seledynowej, pozbawione plam. Konsument na ogół nie ma preferencji w tym zakresie, niewielki rozmiar oraz smak jaja w pełni go satysfakcjonuje. Jednak wśród hodowców panuje przekonanie, że jaja te mogą być gorszej jakości, zarówno jako konsumpcyjne, jak i wylęgowe.

Celem pracy była ocena jakości jaj przepiórki japońskiej w zależności od barwy skorupy.

Materiał do badań stanowiło 150 jaj przepiórki japońskiej pozyskanych od stada utrzymywanego w Stacji Dydaktyczno-Badawczej Zwierząt Drobnych im. Laury Kaufman. Jaja podzielono na 2 równoliczne grupy: I - o standardowej, nakrapianej skorupie, II - o jednolitej, seledynowej skorupie. Jaja zebrano tego samego dnia i indywidualnie ponumerowano. Oceniano: indeks jaj, masę oraz masę właściwą jaja, cechy skorupy (wytrzymałość, masę, grubość, gęstość) oraz treści (wysokość białka, liczbę jednostek Haugha, barwę, masę i indeks żółtka).

Wykazano, że jaja o seledynowej barwie skorupy były istotnie mniejsze od jaj plamiastych, charakteryzowały się gorszą wytrzymałością skorupy, mniejszym i bardziej kulistym żółtkiem, a jednocześnie większą wysokością białka gęstego i liczbą jednostek Haugha. Jaja te odznaczały się większym udziałem białka, a mniejszym żółtka niż jaja o standardowej skorupie. Nie stwierdzono jednak różnic w gęstości czy grubości skorupy. Interesującą obserwację poczyniono w aspekcie obecności plam mięsnych w jajach. W grupie o nakrapianej skorupie stwierdzono plamy mięsne w 6,6\% jaj, zaś w grupie o skorupie jednobarwnej aż w 24,6\%, zależność potwierdzono statystycznie.

$\mathrm{Na}$ podstawie przeprowadzonych badań nie wydaje się, by jaja przepiórcze o jednolitej skorupie były gorszej jakości niż te o skorupie nakrapianej, jeśli przeznaczone są do konsumpcji. Jednak stwierdzone zróżnicowanie daję podstawę do podjęcia dalszych badań w kierunku oceny tych jaj jako wylęgowych. 


\title{
THE IMPACT OF THE USE OF BIOCIDAL PAINT ON THE MICROBIOLOGICAL QUALITY OF POULTRY LITTER
}

Wpływ zastosowania farby o właściwościach biobójczych na jakość mikrobiologiczną ściółki w kurnikach

\author{
Sara Dzik ${ }^{1}$, Tomasz Mituniewicz ${ }^{1}$, Bogumił Torłop ${ }^{2}$ \\ ${ }^{1}$ Uniwersytet Warmińsko-Mazurski w Olsztynie, Katedra Higieny Zwierząt i Środowiska, ul. Oczapowskiego 5, 10-719 Olsztyn \\ ${ }^{2}$ KLEIB Ltd. company, ul. Kolejowa 15-17, 87-880 Brześć Kujawski \\ e-mail: sara-dzik@wp.pl
}

One of the most important elements conditioning of chickens welfare is appropriate microclimate in the poultry houses. Microbiological contamination has an important role. A significant number of microorganisms are found in the litter. Microflora of litter has a specific dynamics of change. Therefore, its quantitative and qualitative composition depends on environmental conditions. One of the most threatening pathogens is mold, which has become a major problem in poultry production. In contrast to mammals, birds rarely get dermatomycoses. However, a significant problem is fungal infections of the respiratory system caused by Aspergillus sp. and yeast infections of the gastrointestinal tract. The birds have air sacculitis of very large capacity, which are in the respiratory system. These air sacculitis are a very good environment for fungal growth. It promotes the occurrence of fungal infections of the respiratory system.

The analysis of available literature indicates that so many problems regarding the reduction of pathogenic microorganisms from chickens' habitat have not been explained, especially in large-scale production. The issue of the effectiveness of methods of disinfection of livestock buildings available on the market is also unresolved.

It was assumed that the use of innovative disinfectant in the poultry houses (in the form of a paint for livestock buildings) containing two repellents: chemical (permethrin) and optical (mixture of ultramarine with violet 23) will reduce the number of pathogenic microorganisms in the poultry bedding and improve the physical properties of the litter.

The research material comprised two poultry houses with the maximum broiler chicken stocking density (22.000 birds). Birds were reared for 42 days. In the experimental building, an innovative biocidal paint for animal houses was applied, as a disinfection method. However, in the control building the building's interior was painted with limewash. After positive tests in laboratory conditions, the evaluation of the effectiveness of the paint was carried out in production conditions. The evaluation of the quality of poultry litter was based on: a) the physical parameters - 0,21 st and 42 nd day of broiler chickens rearing, temperature and relative humidity of the surface layer of the straw bedding were measured; b) microbiological contamination - the number of bacteria, the number of yeasts and molds as well as identification in the presence of fungi: Aspergillus fumigatus, Candida albicans, Fusarium spp.

Based on the results of the research it was found that in the experimental building in the initial period of chickens rearing the number of microorganisms in the poultry bedding increased sharply. Whereas in the further phase of birds exploitation it stabilized. In contrast, in the control building with the growth of the chickens the number of bacteria and yeast and molds in the litter increased all the time. Fluffy fungi in the litter were identified in both poultry houses. 


\title{
THE INBREEDING LEVEL IN POPULATION OF HORSE FAMILY KEPT IN ZOOLOGICAL GARDENS
}

Poziom zinbredowania populacji z rodziny koniowatych utrzymywanych w ogrodach zoologicznych

\author{
Patrycja Grzybek $^{1}$, Piotr Ćwiertnia ${ }^{2,3}$, Tomasz Szwaczkowski ${ }^{1}$ \\ ${ }^{1}$ Uniwersytet Przyrodniczy w Poznaniu, Katedra Genetyki i Podstaw Hodowli Zwierząt \\ ${ }^{2}$ Miejski Ogród Zoologiczny w Płocku, \\ ${ }^{3}$ Ogród Zoologiczny w Poznaniu \\ e-mail: patrycja.grzybek92@gmail.com
}

The situation of wild animals is currently very complicated. Recently, many initiatives are taken to protect biodiversity. On the other hand, there is a growing degradation of the natural environment, especially in the Third World. This situation largely concerns equidae species (Equidae). One of the main ways to protect endangered species is the in-vivo ex-situ method used in zoological gardens. Effective husbandry requires pedigree information, especially when molecular methods cannot be used.

The aim of the study was to assess the completeness of pedigree data, as well as to estimate the level of inbreeding and survival for three species of zebras kept in zoological gardens.

Based on the information contained in the Species360 internet database, a total of 9.454 individuals living in the years 1834-2017 were analyzed. Inbreeding coefficients were estimated on the basis of additive relationship matrix. The calculations were performed using the CFC package program.

The smallest population size was recorded in the Hartmann's Mountain zebra population (1206 individuals). The numbers of the two other species were as follows: 3032 individuals (Grevy's zebra), 5216 individuals (Plain zebra, not covered by the protection program). The species covered by the genetic conservation program - Grevy's zebra (92.12\%) and Hartmann's zebra (92.14) - were clearly characterized by a greater completeness of pedigrees - in contrast to the Plain zebra (76.29\%).

Compared to the other two species (Hartmann's zebra - 134, Grevy's zebra - 273). Plain zebra population is derived from the largest number of founders (702). The lowest inbreeding level is estimated for the Grevy's zebra population (1.59\%) in the entire population, and $12.46 \%$ in the inbred group), next one is Hartmann's zebra (3.02\%) for the whole population and $13.75 \%$ for inbred animals), and as last is Plain zebra $(2.36 \%)$ for the whole population and for inbred up to $18.73 \%$.

In all three species, a high level of premature mortality was observed. About $26 \%$ of individuals died in the first year of life, of which more than half in the first day. In general, a relatively low inbreeding level was estimated in all three populations. It should be remembered, however, that the precision of estimates is determined by the pedigree completeness. 


\title{
WPEYW ZAKAŻENIA WYMIENIA KRÓW MLECZNYCH GRONKOWCAMI KOAGULAZODODATNIMI LUB KOAGULAZOUJEMNYMI NA EKSPRESJE GENÓW ALFA-S1-KAZEINY I KAPPA-KAZEINY ORAZ NA ZAWARTOŚĆ SKŁADNIKÓW MLEKA
}

The influence of dairy cow udder infection with coagulase-positive or coagulase-negative staphylococci on the expression of alpha S1-casein and kappa-casein genes and the milk component contents

\author{
Ewelina Kawecka ${ }^{1,2}$, Magdalena Zalewska ${ }^{1}$, Daria Reczyńska ${ }^{1}$, Paulina Brodowska ${ }^{1}$, \\ Danuta Słoniewska ${ }^{1}$, Sławomir Petrykowski ${ }^{3}$, Sylwester Marczak ${ }^{3}$, Emilia Bagnicka $^{1}$

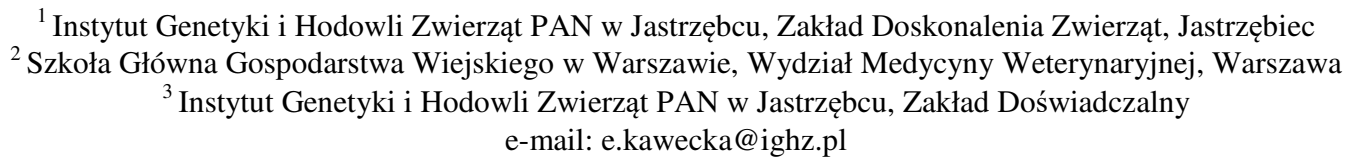

Stan zapalny wymienia jest jedną z głównych chorób krów mlecznych i może być powodowany m.in. przez gronkowce koagulazododatnie (CoPS) lub koagulazoujemne (CoNS). Zapalenie gruczołu mlekowego powoduje zmiany składu mikrobiologicznego oraz cech chemicznych i fizycznych mleka. Najczęściej jest to wzrost liczby komórek somatycznych (LKS), wzrost zawartości białek serwatkowych przy obniżonej zawartości kazein i spadek zawartości laktozy. Zapalenie przyjmuje dwie formy: kliniczną lub podkliniczną. Kliniczne zapalenie wymienia charakteryzują widoczne zmiany w wyglądzie mleka (kolor, zapach, konsystencja), ale także widoczne zmiany stanu wymienia (twardość, zaczerwienienie, podwyższona ciepłota). $\mathrm{W}$ przypadku podklinicznego zapalenia wymienia charakterystyczne objawy nie są widoczne, dlatego podkliniczne stany pozostają niezauważone przez hodowcę, co prowadzi do zakażania kolejnych krów poprzez kubki udojowe. Głównymi białkami mleka wpływającymi na jakość/wydajność wytwarzanych serów są kazeiny. Celem badań była analiza wpływu zakażeń gronkowcami CoPS lub CoNS na ekspresję genów (alfa-S1-kazeina i kappa-kazeina), związanych z parametrami technologicznymi mleka oraz na wydajność i cechy fizykochemiczne mleka (zawartość procentowa tłuszczu, białka ogólnego, laktozy i suchej masy, zawartość mocznika, LKS).

Badania przeprowadzono na 40 krowach mlecznych rasy polskiej holsztyńsko-fryzyjskiej, odmiany czarno-białej. Zwierzęta te cierpiały na chroniczne i nawracające stany zapalne gruczołu mlekowego lub brakowane były z powodu problemów z rozpłodem. Stan zdrowia wymienia określono na podstawie analizy mikrobiologicznej mleka ćwiartkowego, pobranego sterylnie na 2 dni przed ubojem zwierząt. Użyto podłoża agar Columbia uzupełnionego o 5\% krwi owczej oraz agar MacConkeya (BioMérieux, Francja). Następnie przygotowane posiewy inkubowano w $37^{\circ} \mathrm{C}$ przez $24-36 \mathrm{~h}$. Bakterie identyfikowano $\mathrm{z}$ wykorzystaniem testów na obecność enzymu koagulazy oraz testów API. Próby parenchymy gruczołu sutkowego pobierano natychmiast po uboju, płukano w PBS i natychmiast mrożono w ciekłym azocie. Próby do dalszych analiz przechowywano $\mathrm{w}$ temperaturze $-80^{\circ} \mathrm{C}$. Do badań wybrano 58 prób parenchymy z ćwiartek wymienia, z których 28 było zakażonych gronkowcami CoPS, 15 gronkowcami CoNS, natomiast 15 było wolnych od bakterii $(\mathrm{H})$. Próby z grupy $\mathrm{H}$ pochodziły od krów, u których nie stwierdzono obecności bakterii w żadnej z ćwiartek wymienia. Całkowite RNA izolowano za pomocą komercyjnego kitu RNeasy Mini Kit (Qiagen), a następnie analizowano ekspresję genów, wykorzystując technikę qPCR (quantitative polymerase chain reaction) (LightCycler480, Roche). Jako gen referencyjny stosowano gen GAPDH (dehydrogenaza aldehydu 3-fosfo-glicerynowego). Ponadto przeanalizowano wpływ bakterii z grupy CoPS i CoNS na cechy fizykochemiczne mleka. Skład mleka z całego wymienia ustalono z wykorzystaniem aparatu MilkoScan FT2, natomiast LKS z użyciem aparatu Fossomatic 90 (FOSS). LKS transformowano za pomocą logarytmu naturalnego (lnLKS). 
W wyniku przeprowadzonych badań wykazano obniżoną ekspresję obu badanych genów w ćwiartkach wymienia zakażonych bakteriami z grupy CoPS w porównaniu z H $(\mathrm{p} \leq 05)$.

W przypadku genu kappa-kazeiny odnotowano również niższą ekspresję tego genu w tkankach grupy CoNS niż $\mathrm{H}$, jednak na poziomie trendu: $0,1>\mathrm{p}>0,05$. Alfa-S1-kazeina jest głównym białkiem mleka, od zawartości której zależy wydajność sera. Kappa-kazeina natomiast wpływa na stabilizację i powstawanie miceli kazeinowych (duże, stabilne cząsteczki koloidalne) i zapobiega precypitacji kazein w mleku, jest więc markerem jakości technologicznej mleka. Zatem podczas stanu zapalnego gruczołu mlekowego powodowanego przez gronkowce koagulazododatnie parametry technologiczne mleka prawdopodobnie ulegają pogorszeniu ze względu na obniżoną ekspresję genów kazein.

Ponadto wykazano wyższy poziom wydajności mleka krów zakażonych CoPS w stosunku do krów z grupy CoNS ( $<$ 0,05) (29,9 vs. 26,1 kg), przy pośrednim poziomie wydajności krów z grupy H $(27,9 \mathrm{~kg})$. W przypadku procentowej zawartości tłuszczu i białka odnotowano wyższy procent tłuszczu i białka w grupach CoPS i CoNS w stosunku do H $(\mathrm{p}<0,01)$. Analogiczne wyniki zaobserwowano w przypadku procentowej zawartości suchej masy oraz lnLKS. Nie stwierdzono natomiast różnic w zawartości laktozy pomiędzy badanymi grupami. Wyższy poziom mocznika zaobserwowano zarówno w grupie CoPS w stosunku do $\mathrm{H}$ $(\mathrm{p}<0,05)$, jak i w grupie CoPS w stosunku do CoNS $(\mathrm{p}<0,05)$, jednak ten poziom we wszystkich grupach zawierał się w wartościach referencyjnych (odpowiednio: 205, 177, $175 \mathrm{mg} / \mathrm{l}$ ).

Na podstawie uzyskanych wyników wykazano, że zakażenie gruczołu mlekowego zarówno gronkowcami z grupy CoPS, jak i CoNS obniża ekspresję genów kazein, od poziomu których zależy jakość technologiczna mleka. Jak oczekiwano, zapalenie wymienia, nawet pojedynczej ćwiartki, powoduje wzrost poziomu LKS w mleku całościowym, zdojonym z całego wymienia, gdyż leukocyty napływają w zwiększonej ilości nie tylko do ćwiartki zakażonej bakteriami, ale również do sąsiednich ćwiartek, wolnych od bakterii. Ponadto w badanej grupie zwierząt najwyższą wydajnością mleka oraz zawartością białka ogólnego i tłuszczu charakteryzowały się krowy z grupy CoPS. Wzrost zawartości białka w mleku krów z grupy CoPS i CoNS mógł wynikać ze wzrostu zawartości białek serwatkowych, zwłaszcza w zakażonej ćwiartce, jednak może to również świadczyć o tym, że pozostałe ćwiartki wymienia funkcjonują prawidłowo i zakażenie sąsiedniej ćwiartki nie tylko nie wpływa ujemnie ani na wydajność mleka, ani na jego zawartość, ale pozostałe ćwiartki wręcz kompensują pracę tej objętej stanem zapalnym. Wynika to prawdopodobnie z faktu, że obecność bakterii stwierdzano w pojedynczych ćwiartkach wymienia, a więc stanem zapalnym nie było objęte całe wymię. O ile analizę ekspresji genów prowadzono na tkankach pobranych z zakażonych ćwiartek wymienia, to analizę wydajności mleka i jego zawartości przeprowadzono na mleku całościowym - zdojonym z całego wymienia. Zatem w celu ustalenia rzeczywistego związku między obecnością patogennych bakterii a wydajnością mleka i jego jakością do badań należy pobierać mleko ćwiartkowe. Grupę kontrolną powinny stanowić krowy, których wszystkie ćwiartki wymienia są wolne od patogenów. 


\title{
WYKORZYSTANIE WIELORASOWEGO KRZYŻOWANIA KRÓLIKÓW RAS ŚREDNICH DO PRODUKCJI BROJLERÓW TOWAROWYCH W CHOWIE TRADYCYJNYM
}

Use of multi-breed crossbreds rabbits medium race on the broilers production in traditional breeding

\author{
Michał Kmiecik, Sylwia Pałka, Konrad Kozioł, Łukasz Migdał, Józef Bieniek \\ Uniwersytet Rolniczy im. H. Kołłątaja w Krakowie, Katedra Genetyki i Metod Doskonalenia Zwierząt, \\ al. Mickiewicza 24/28, 30-059 Kraków \\ e-mail: michal.kmiecik@urk.edu.pl
}

Celem pracy było określenie wielkości heterozji będącej wynikiem różnych wariantów krzyżowań międzyrasowych rodziców oraz ocena skutków hodowlanych zastosowanych krzyżowań.

Doświadczenie prowadzono w Stacji Doświadczalnej Katedry Genetyki i Metod Doskonalenia Zwierząt w Przegorzałach. Pokolenie wyjściowe stanowiły króliki czystych ras: popielniańskiej białej (†16 i §12), termondzkiej białej ( 18 i $\precsim 15$ ), nowozelandzkiej białej ( 16 i $\precsim 10$ ) oraz kalifornijskiej, odmiany czarnej

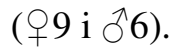

Z kojarzeń zwierząt czystorasowych uzyskano 240 szt. potomstwa królików rasy popielniańskiej białej, 256 królików rasy termondzkiej białej, 121 królików rasy nowozelandzkiej białej oraz 95 królików rasy kalifornijskiej, odmiany czarnej. Na potrzeby doświadczenia utworzono 2 linie doświadczalne. W pierwszej linii obustronnie krzyżowano rasę nowozelandzką białą $(\mathrm{Nb})$ z popielniańską białą $(\mathrm{Pb})$, uzyskując 72 szt. potomstwa $\mathrm{Pb} / \mathrm{Nb}$ oraz 50 szt. potomstwa $\mathrm{Nb} / \mathrm{Pb}$. W drugiej linii obustronnie skrzyżowano rasę termondzką białą $(\mathrm{Tb})$ z kalifornijską, odmianą czarną $(\mathrm{Kc})$, uzyskując 51 szt. potomstwa $\mathrm{Tb} / \mathrm{Kc}$ oraz 58 szt. potomstwa $\mathrm{Kc} / \mathrm{Tb}$. Na podstawie ocenionych cech przyżyciowych do kolejnego etapu krzyżowania wykorzystano samice mieszańców dwurasowych, tj. rasy nowozelandzkiej białej i popielniańskiej białej $(\mathrm{Nb} / \mathrm{Pb})$, kojarzone z samcami rasy kalifornijskiej, odmiany czarnej $(\mathrm{Kc})$, oraz samice rasy termondzkiej białej i kalifornijskiej, odmiany czarnej, $(\mathrm{Tb} / \mathrm{Kc})$ kojarzone z samcami rasy popielniańskiej białej $(\mathrm{Pb})$, otrzymując 83 szt. potomstwa trójrasowego $\mathrm{Pb} / \mathrm{Nb} / \mathrm{Kc}$ oraz 204 szt. potomstwa trójrasowego $\mathrm{Tb} / \mathrm{Kc} / \mathrm{Pb}$.

$\mathrm{Z}$ analizy statystycznej wynika, że grupa genetyczna królików ma istotny wpływ na cechy reprodukcyjne, takie jak wielkość miotu oraz liczba odsadzonych i odchowanych królicząt. Stwierdzono, że króliki z grupy genetycznej $\mathrm{Tb} / \mathrm{Kc} / \mathrm{Pb}$ cechują się największymi wartościami wymienionych parametrów, natomiast najmniejsze wartości zanotowano dla królików z grupy genetycznej $\mathrm{Nb} / \mathrm{Nb}$. Największą masę urodzeniową wykazują króliki z grupy genetycznej Tb/Tb (70 g), a najmniejszą króliki z grupy genetycznej $\mathrm{Nb} / \mathrm{Nb}(59 \mathrm{~g})$. Średnia masa ciała przy odsadzeniu (35. d.ż.) była największa u królików z grupy genetycznej $\mathrm{Pb} / \mathrm{Pb}(830 \mathrm{~g})$, natomiast najmniejszą stwierdzono u królików z grupy genetycznej $\mathrm{Nb} / \mathrm{Nb}(670 \mathrm{~g})$. Największą masą w 84. d.ż. cechowały się króliki z grupy $\mathrm{Pb} / \mathrm{Pb}$ oraz $(\mathrm{Tb} / \mathrm{Kc}) / \mathrm{Pb}$, odpowiednio 2629 i 2626 g, natomiast najmniejszą masę wykazały króliki z grupy $\mathrm{Nb} / \mathrm{Nb}(2161 \mathrm{~g})$.

Podsumowując, krzyżowanie wielorasowe wpływa na skrócenie okresu odchowu oraz poprawę wyników produkcyjnych zwierząt. 


\title{
WPEYW HYDROTERAPII NA POWIERZCHNIOWA TEMPERATURE KONI PO WYSIŁKU PODCZAS CIEPŁEJ I CHŁODNEJ POGODY W PORZE LETNIEJ
}

\author{
Effect of hydrotherapy on superficial temperature in horses after effort during warm \\ and cold weather in summer
}

\author{
Marta Liss, Kostiantyn Vasiukov, Iwona Janczarek, Izabela Wilk, Sylwester Tkaczyk \\ Uniwersytet Przyrodniczy w Lublinie, Katedra Hodowli i Użytkowania Koni, ul. Akademicka 13, 20-950 Lublin \\ e-mail: iwona.janczarek@up.lublin.pl
}

W pracy założono, że zakres koniecznego wspomagania procesu termoregulacji organizmu podczas wysiłku jest zależny od czynników atmosferycznych. W związku z tym założeniem celem pracy było porównanie wpływu różnych wariantów hydroterapii na powierzchniową temperaturę ciała koni po wysiłku w warunkach atmosferycznych różniących się temperaturą powietrza. Badaniami objęto 16 dorosłych wałachów rekreacyjnych. Podczas ciepłej, a następnie chłodnej pogody w porze letniej przeprowadzono czterokrotnie powtarzane doświadczenie. W trakcie każdego powtórzenia konie były poddane znormalizowanemu wysiłkowi (trening) pod jeźdźcem. Po wysiłku przeprowadzono 4 warianty 30-minutowego wspomagania procesu termoregulacji: oprowadzanie bez siodła po zacienionym miejscu oraz oprowadzanie połączone z trzykrotnie powtarzaną zimną hydroterapią w wariancie: chłodzenie dolnych części ciała, górnych części ciała i całego ciała. Pomiary temperatury powierzchniowej wykonano za pomocą kamery termowizyjnej Thermal Imagers Ti9 FLUKE, a następnie analizowano w programie SmartView 4.1. Analizie poddano średnią temperaturę siedem części lewej i prawej strony ciała koni. Pomiary wykonano przed każdym powtórzeniem hydroterapii oraz po $10 \mathrm{~min}$ od trzeciego jej powtórzenia. Wykonano wieloczynnikową analizę wariancji (Repeated Measures Analysis of Variance) dla danych z powtarzanymi pomiarami i testy T-Tukeya. Stwierdzono, że po treningu podczas ciepłej pogody proces odprowadzania ciepła może być zaburzony, co jest najprawdopodobniej spowodowane za małą różnicą między temperaturą powierzchniową ciała a temperaturą powietrza. Można sugerować, że termoregulacja powinna być wówczas wspomagana za pomocą zimnej hydroterapii. Jednakże zabieg ten powinien być ograniczony jedynie do dolnych części ciała. Hydroterapia górnych części ciała może być mało skuteczna, a efekt hydroterapii całego ciała opóźniony. Po wysiłku podczas chłodnej pogody zabieg nie powinien być natomiast stosowany, gdyż może doprowadzić do nadmiernego wychłodzenia organizmu. Uzyskane w pracy wyniki rzucają zatem nowe światło na praktykowane dotychczas metody odprowadzania ciepła z ciała koni po wysiłku. 


\title{
PREFERENCJE SMAKOWE WARCHLAKÓW ŻYWIONYCH MIESZANKAMI Z RÓŻNYM UDZIAŁEM ŻYTA HYBRYDOWEGO I POPULACYJNEGO
}

Taste preferences of weaners fed mixtures with hybrid and population rye

\author{
Mariola Pabiańczyk ${ }^{1}$, Jacek Nowicki ${ }^{1}$, Tomasz Schwarz ${ }^{1}$, Ryszard Tuz ${ }^{1}$, Michał Marszałek ${ }^{1}$, \\ Martyna Małopolska

\footnotetext{
${ }^{1}$ Uniwersytet Rolniczy w Krakowie, Instytut Nauk o Zwierzętach, Zakład Hodowli Trzody Chlewnej i Drobnego Inwentarza

${ }^{2}$ Instytut Zootechniki - Państwowy Instytut Badawczy, Zakład Hodowli Trzody Chlewnej e-mail: mariola.pabianczyk@urk.edu.pl
}

Najważniejszym elementem decydującym o sukcesie ekonomicznym produkcji zwierzęcej jest żywienie, które powinno być efektywne, tanie i bezpieczne, przy czym bezpieczeństwo należy rozumieć przede wszystkim w kontekście zdrowia zwierząt, wysokiego poziomu ich dobrostanu i wynikającej z tego efektywności produkcji. Jęczmień i pszenica stanowią główny komponent mieszanek paszowych. W ostatnich latach bardzo dynamicznie wzrasta wykorzystanie ziarna kukurydzy w żywieniu świń, a w niektórych rejonach kraju także pszenżyta. Żyto w Polsce wciąż jest postrzegane jako surowiec o słabej jakości. Stosowane jest rzadko i w niewielkich ilościach. Producenci i hodowcy uważają, że żyto jest niechętnie pobierane przez świnie. Dlatego celem badań było określenie preferencji smakowych świń rosnących w odniesieniu do mieszanek zawierających zarówno składniki standardowe, jak i żyto populacyjne i hybrydowe.

Badania przeprowadzono na 12 tucznikach podzielonych na 2 niezależne grupy po 6 szt. Świnie w każdej z grup miały do dyspozycji 3 automaty paszowe z 3 różnymi mieszankami. W grupie I automaty zawierały następujące mieszanki: automat A - $40 \%$ jęczmienia i $40 \%$ pszenicy, B - $40 \%$ żyta populacyjnego i C $60 \%$ żyta populacyjnego. W grupie II zastosowano automaty z następującymi mieszankami: A - $40 \%$ jęczmienia i $40 \%$ pszenicy, D - 40\% żyta hybrydowego i E - 60\% żyta hybrydowego. Świnie karmiono ad libitum. Całodobowe obserwacje behawioralne prowadzono przez 4 dni wybrane z 4 kolejnych tygodni tuczu. Obserwacje wykonano za pomocą kamer CCD z oświetlaczami IR i cyfrowymi rejestratorami poklatkowymi. Obliczono średni czas przebywania zwierząt przy każdym z automatów w obu niezależnych grupach. Istotność różnic pomiędzy średnimi dotyczącymi czasu przebywania przy poszczególnych automatach określono za pomocą analizy wariancji i testu Duncana.

W grupie I najdłuższy średni czas spędzony przy automacie przez jedną świnię stwierdzono w odniesieniu do automatu A (75,66 min). Statystycznie istotnie niższe wartości $(\mathrm{P}<0,05)$ uzyskano w przypadku automatów B i C (odpowiednio 38,08 i 36,58 min). Testy preferencji wykazały, że w grupie I najbardziej atrakcyjna była mieszanina zawierająca $40 \%$ jęczmienia i $40 \%$ pszenicy, jednak warto zauważyć, że poziom udziału żyta nie miał wpływu na preferencje świń, gdy oceniano je na podstawie czasu spędzanego przy automacie. W grupie II wyniki kształtowały się odmiennie. Preferowany był automat zawierający mieszankę z $60 \%$ udziałem żyta hybrydowego (E) - 77,97 min. Statystycznie istotnie (P < 0,05) krótszy czas zanotowano w przypadku automatu zawierającego $40 \%$ żyta hybrydowego w mieszance (25,65 min). Wartość pośrednią zanotowano w przypadku automatu zawierającego mieszankę kontrolną (A) - 40,62 min.

Podsumowując, można stwierdzić, że w sytuacji gdy świnie miały możliwość wyboru mieszanki kontrolnej lub mieszanki zawierającej żyto populacyjne, preferowały mieszankę kontrolną. Natomiast gdy oprócz mieszanki kontrolnej dostępne było żyto hybrydowe, wybierały paszę z największym udziałem żyta hybrydowego, a dopiero w dalszej kolejności mieszankę kontrolną. Najmniej były zainteresowane mieszanką zawierającą $40 \%$ żyta hybrydowego. 


\title{
WPEYW SUPLEMENTACJI MIESZANINA EKSTRAKTU ROZMARYNU I KURKUMY NA EKSPRESJĘ GENÓW UKŁADU IMMUNOLOGICZNEGO W WĄTROBIE KOZIOŁKÓW RASY POLSKIEJ BIAŁEJ USZLACHETNIONEJ
}

The influence of mixture of rosemary and turmeric extracts on the gene expression of immune system in the liver of the Polish White Improved goat kids

\author{
Daria Reczyńska ${ }^{1}$, Ewelina Kawecka ${ }^{1,2}$, Paulina Brodowska ${ }^{1}$, Magdalena Zalewska ${ }^{1}$, \\ Danuta Słoniewska ${ }^{1}$, Sławomir Petrykowski ${ }^{3}$, Karina Horbańczuk ${ }^{3}$, Emilia Bagnicka ${ }^{1}$

\footnotetext{
${ }^{1}$ Instytut Genetyki i Hodowli Zwierząt PAN w Jastrzębcu, Zakład Doskonalenia Zwierząt

${ }^{2}$ Szkoła Główna Gospodarstwa Wiejskiego w Warszawie, Wydział Medycyny Weterynaryjnej

${ }^{3}$ Instytut Genetyki i Hodowli Zwierząt PAN w Jastrzębcu, Zakład Doświadczalny e-mail: d.reczynska@ighz.pl
}

Organizmy narażone są na kontakt z patogenami (wirusy, bakterie, grzyby), pasożytami oraz związkami toksycznymi, z którymi musi radzić sobie ich układ odpornościowy. Cytokiny są jedną z grup białek biorących udział w odpowiedzi immunologicznej (humoralnej i komórkowej), wpływając na procesy zapalne, m.in. poprzez aktywację i proliferację komórek odpornościowych (neutrofili, makrofagów, komórek tucznych) oraz syntezę białek ostrej fazy i prostaglandyn. Ponadto mogą wykazywać działanie zarówno na komórki je wytwarzające, położone w pobliżu oraz oddalone od miejsca ich uwalniania za pośrednictwem układu krwionośnego. Cytokiny umożliwiają komunikację pomiędzy leukocytami (interleukiny), które są pobudzane przez chemokiny, mogą wpływać na różnicowanie się komórek szlaku krwiotwórczego (cytokiny hemopoetyczne) oraz brać udział w obronie przeciwwirusowej (interferony).

W utrzymaniu zdrowia zwierząt bardzo ważne jest wzmacnianie ich układu immunologicznego poprzez odpowiednią suplementację diety. Naturalnym antyoksydantem i chemoprewentem są zawarte m.in. w ziołach polifenole. Związki te wykazują działanie przeciwzapalne oraz wysoką aktywność w chorobach metabolicznych.

Celem pracy była analiza wpływu suplementacji diety koziołków rasy polskiej białej uszlachetnionej mieszaniną ekstraktów rozmarynu i kurkumy na ekspresję genów cytokin w wątrobie.

Badania przeprowadzono na koziołkach $(\mathrm{N}=20)$ rasy polskiej białej uszlachetnionej, wolnych od zakażenia lentiwirusem małych przeżuwaczy (SRLV). Zwierzęta podzielono na 2 grupy: kontrolną, żywioną dietą podstawową, zgodną z normami systemu INRA (Francja), oraz eksperymentalną, żywioną dietą wzbogaconą o mieszaninę ekstraktów rozmarynu i kurkumy w stosunku $896: 19$. Koziołki otrzymywały ekstrakt w ilości 1,6 g/dzień/szt., podawany indywidualnie w kapsułkach skrobiowych przed rannym zadaniem paszy. Po 90 dniach od rozpoczęcia doświadczenia koziołki ubito i bezpośrednio po uboju pobrano fragmenty wątroby, które natychmiast mrożono w ciekłym azocie, a następnie izolowono całkowite RNA za pomocą zestawu RNasy Mini Kit (Qiagen, Niemcy). W celu określenia poziomu transkryptów badanych genów przeprowadzono reakcję real-time PCR zgodnie z protokołem producenta użytego zestawu LightCycler® 480 SYBR Green I Master (Roche, Szwajcaria). W badaniach wykorzystano sekwencje starterów genów wybranych na podstawie danych literaturowych.

Badano poziom transkryptów genów interleukin prozapalnych: 1-alfa $(I L-1 \alpha), 1$-beta $(I L-1 \beta), 2$ (Il-2), $6(I L-6), 8(I L-8), 12$ (IL-12), 16 (IL-16), 18 (IL-18), interferonu alfa (INF- $\alpha)$, gamma $(I N F-\gamma)$ oraz ligandu chemokiny 4 (CCL4), a także przeciwzapalnych: interleukiny 4 (IL-4) i 10 (IL-10) oraz interferonu beta $(I N F-\beta)$ i czynnika martwicy nowotworu alfa $(T N F-\alpha)$. Jako gen referencyjny zastosowano cyklofilinę A (PPIA). 
W grupie koźląt z dietą suplementowaną mieszaniną ekstraktów ziołowych odnotowano niższą ekspresję $I L-12 \mathrm{w}$ porównaniu $\mathrm{z}$ grupą kontrolną $(\mathrm{p} \leq 0,05)$ oraz tendencję do wyższej ekspresji $I L-18$ i $I N F-\gamma$ $(0,05<\mathrm{p}<0,1)$.

Według obecnego stanu wiedzy $I L-18$ pod nieobecność $I L-12$, IL-15 i IL-23 może powodować polaryzację immunologiczną w kierunku limfocytów pomocniczych Th2, co może świadczyć o patologicznej roli tej cytokiny w reakcjach alergicznych, zwłaszcza że $I L-18$ jest wytwarzana również przez komórki nabłonkowe jelit. Niski poziom ekspresji $I L-12$ oraz tendencja do wyższego poziomu mRNA $I L-18 \mathrm{w}$ prezentowanych badaniach może zatem świadczyć o odczynie alergicznym powstałym w wyniku suplementacji diety zbyt wysoką dawką suplementu. Natomiast podwyższona ekspresja $I F N-\gamma$ mogła być spowodowana zwiększoną ekspresją $I L-18$. Wyższy poziom transkryptów $I F N-\gamma$ w wątrobie koziołków grupy doświadczalnej może więc świadczyć o immunosupresyjnym działaniu zbyt wysokiej dawki suplementu. Zatem suplementacja ekstraktami ziołowymi wymaga precyzyjnego określenia ilości stosowanego dodatku.

Finansowanie: PRELUDIUM 11 NCN2016/21/N/NZ9/01508 i POIG.01.01.02-14-090/09 „Biożywność - innowacyjne, funkcjonalne produkty pochodzenia zwierzęcego". 


\title{
PROJEKT OCENY STOPNIA NATĘŻENIA WYSIŁKU KONI WYŚCIGOWYCH NA PODSTAWIE PARAMETRÓW HRV
}

\author{
Project of assessment of effort intensity in racehorses based on HRV parameters
}

\author{
Sylwester Tkaczyk, Marta Liss, Izabela Wilk
}

Uniwersytet Przyrodniczy w Lublinie, Katedra Hodowli i Użytkowania Koni e-mail: sylwester.tkaczyk@up.lublin.pl

Przez zmienność rytmu zatokowego (heart rate variability, HRV) rozumie się powtarzające się cyklicznie występowanie różnic odstępów RR w badaniu EKG, które zależy od oddziaływania mechanizmów kontrolujących aktywność węzła zatokowo-przedsionkowego. Zmienność ta jest odzwierciedleniem stanu czynnościowego układu autonomicznego serca, co powoduje, że może być wykorzystywana jako metoda oceny wydolności fizycznej organizmów trenowanych i nietrenowanych. Jej popularność jest spowodowana nieinwazyjnością, co pozwala na bezpieczną kontrolę funkcji układu krążenia, poziomu emocjonalności oraz reakcji na wysiłek fizyczny. W stosunku do badań nad człowiekiem metoda ta zaczęła być stosowana w badaniach hipologicznych ze znacznym opóźnieniem. W pracy przyjęto założenie, że parametry zmienności rytmu zatokowego są wystarczająco czułym wyznacznikiem w porównawczej ocenie wydolności organizmu podczas wysiłku o nieznacznie różniącym się natężeniu. Weryfikacja tego założenia spowodowała, iż celem pracy była ocena możliwości zastosowania parametrów HRV w ocenie stopnia wysiłku koni wyścigowych określonego na podstawie tempa ruchu podczas galopu treningowego. Badaniami objęto po 15 ogierów i klaczy arabskich czystej krwi i pełnej krwi angielskiej podczas pierwszego sezonu wyścigowego. Wysiłek (kenter lub galop), jakiemu konie były poddawane na torze treningowym, pogrupowano według tempa ruchu (pomiar urządzeniem GPS) oraz obowiązującej nomenklatury wyścigowej. Podczas każdego rodzaju wysiłku przebadano 6 parametrów opisujących zmienność rytmu zatokowego koni (pomiar urządzeniem Polar RS800CX). Następnie ustalono procedury oceny stopnia wysiłku koni wyścigowych w oparciu o wspomniane parametry HRV. Na podstawie uzyskanych wyników stwierdzono, że parametry HRV mogą być wykorzystywane w ocenie stopnia wysiłku koni wyścigowych. Tego typu ocenę najlepiej przeprowadzać na podstawie analizy parametrów opisujących reakcję obydwu składowych układu autonomicznego. Klacze wyścigowe charakteryzuje wzmożona aktywność części współczulnej tego układu, co oznacza, iż przygotowania do startu w gonitwach powodują w ich przypadku o wiele większe generowanie wysiłku niż u ogierów. Trening klaczy powinien zatem zasadniczo różnić się od treningu ogierów. W przypadku klaczy można zasugerować skrócenie sezonu wyścigowego lub znaczące ograniczenie maksymalnej liczby startów w gonitwach. 


\title{
COMPARISON OF POTENTIAL EFFECTS ON THE PROFITABILITY OF THE US MPP APPLICATION ON DAIRY STABLES IN VENETO AND WIELKOPOLSKA
}

Porównanie potencjalnych efektów zastosowania amerykańskiego systemu ubezpieczeń producentów mleka na stabilność rynku w Wenecji Euganejskiej i w Wielkopolsce

\author{
Federico Vaona $^{1,3}$, Cristian Bolzonella ${ }^{2}$, Martino Cassandro ${ }^{1}$, Tomasz Szwaczkowski ${ }^{3}$ \\ ${ }^{1}$ University of Padova, Department of Agronomy, Food, Natural Resources, Animals and Environment, Legnaro, Padova, Italy \\ ${ }^{2}$ University of Padova, Department of Land, Environment, Agriculture and Forestry, Legnaro, Padova, Italy \\ ${ }^{3}$ Poznan University of Life Sciences, Department of Genetics and Animal Breeding, Poznań, Poland \\ e-mail: federico.vaona@studenti.unipd.it
}

The American agricultural policy has introduced a form of insurance to guarantee the specific income for dairy producers called the Dairy Margin Protection Program (DMPP). The program aims to protect farmers from the volatility of prices of both milk and production, without having distorting effects on the market. The DMPP program started in August 2014 and will end on 31 December 2018. Membership is voluntary but with the obligation to remain in the insurance system until the end of the program. The program ensures a share of the perceived income, chosen annually by the producer, of a quantity of reference milk assigned to the individual producer on a historical basis.

The insurable theoretical income is defined monthly by the difference between the average milk price and the feed cost index calculated on the basis of a standard ration.

Farmers who are members of the DMPP program are entitled to compensation when the theoretical milk income is below the level of income coverage chosen by the producer for a two-month period.

The methodology is based on monthly average price (in 2007-2017 years) of: milk, corn, soybean meal and alfalfa hay (in Veneto) and milk, corn, soybean meal and meadow hay in Wielkopolska as well as calculation of the IOFC (Income Over Feed Cost), assessment of the margin ( $€ / \mathrm{kg}$ of milk) - for small , medium and large farm (no MPP, 0.07 protection level and 90\% of historical production, 0.15 protection level and $25 \%$ of historical production, 0.15 protection level and $90 \%$ of historical production). Assessment of the risk reduction by coverage level was included as well. A comparison was made between the costs actually incurred by the Community Agricultural Policy (CAP) in support of the milk sector and what would have cost a potential application of the MPP.

It was concluded that application the U.S. levels of coverage the risk reduction of margin is higher in Wiekopolska than Veneto because the Wielkopolska's IOFC is lower. The comparison between CAP subsides and the potential compensation produced by MPP in Veneto are aligned for the large farms instead are higher for medium and small farms. 


\title{
WHEN DO HORSES DIE?
}

\author{
Kiedy konie umierają? \\ Izabela Wilk $^{1}$, Marcjanna Wiśniewska ${ }^{2}$ \\ ${ }^{1}$ Uniwersytet Przyrodniczy w Lublinie, Katedra Hodowli i Użytkowania Koni \\ ${ }^{2}$ Uniwersytet Technologiczno-Przyrodniczy im. J.J. Śniadeckich w Bydgoszczy, Katedra Nauk o Zwierzętach, \\ Zakład Hodowli Trzody Chlewnej i Koni \\ e-mail: izabela.wilk@up.lublin.pl
}

Health problems associated with advanced age incline to detailed control of the condition, particularly to monitor Heart Rate Variability (HRV). The HRV basis is the physiological variability of the heart sinus rhythm illustrated by differences in time of successive heart cycles. These differences are often difficult to notice when the routine ECG registration at rest is visually analysed. The HRV is a natural phenomenon caused by rhythmical activity of both parts of autonomic nervous system (ANS): sympathetic and parasympathetic, with the vagus nerve activity, respiratory cycle as well as changes in the activity of neurohumoral factors released to circulation of blood. The analysis of heart rate variability has been assumed as a method of prognosticating death risk caused by heart-vessels reasons. In organisms being at risk of death, HRV profile is specifically deformed: the total HRV power and its parts are reduced, the participation of the vagus nerve in heart rhythm regulation is lowered and the rhythm is random. During the aging process, the heart rhythm is more and more random. A disturbance in autonomic equilibrium, particularly a decline in parasympathetic component, is the main mortality indicator. In human medicine, studies are conducted on determining 24-hour HRV changes in old people in order to save the body in so-called critical hours in day and night. In hipology, such studies have not been performed until now. In the present study, we have assumed that HRV activity, mainly considering the parasympathetic system, is lowering with age and this activity depends on the 24-hour rhythm. The aim of the study has been to compare some heart rate variability parameters in the 24-hour rhythm. The material included six 4-6 year and six 22-30 year old horses. Using telemetric Polar RS800CX device, 24-hour HRV measurements were performed. Then, the measurements were analysed with the use of Kubios HRV software. Six successive 4-hour intervals were distinguished. The first interval began at 12:00. During each interval, three HRV parameters were analysed: total HRV power (mHRV), sympathetic component activity (LF) and parasympathetic component activity (HF) of ANS. A multifactorial analysis of variance for repeated measures and T-Tukey test have been performed. The results showed the influence of the horse's age on mHRV and HF. Both parameters were significantly lower in old horses than in young horses. The lowest levels occurred after midnight which was assumed as hypothetic death hours of old horses. There were no differences associated with the horse age in the 8:00-12:00 interval. A highest level of parameters analysed was found in this interval in old horses. Differences in HRV were low in old horses, which enabled to initially elaborate the 24-hour rhythm. In the case of young horses, such attempt was not possible to realize.

Badania zrealizowano w ramach projektu NCN Miniatura 1 „Dobowa aktywność komponentów autonomicznego układu nerwowego koni” 2017/01/X/NZ9/00472. 